

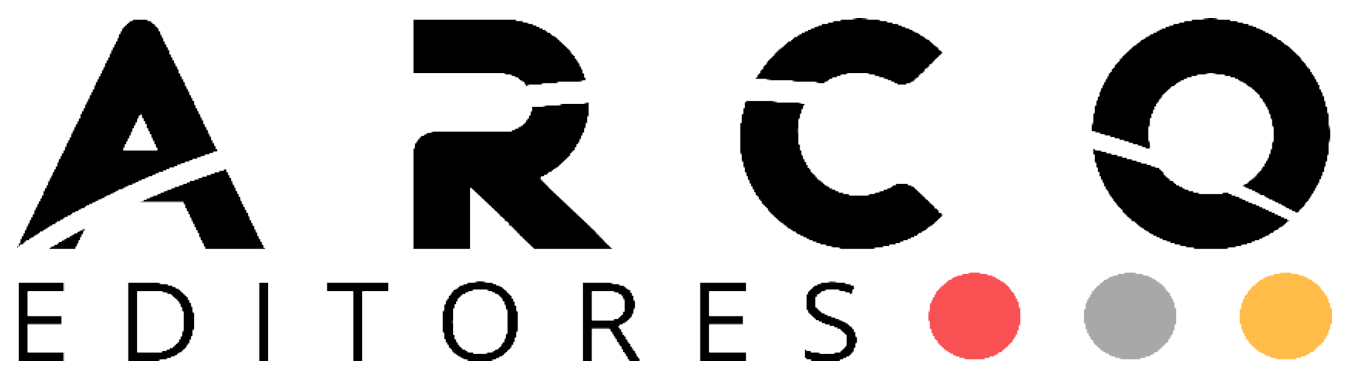

\title{
DIREITO À EDUCAÇÃO NO BRASIL: DISPUTAS IDEOLÓGICAS NA CONSTITUIÇÃO DE 1988
}

\author{
VIVIANE MERLIM MORAES
}




\section{FICHA CATALOGRÁFICA}

Dados Internacionais de Catalogação na Publicação (CIP) (Câmara Brasileira do Livro, SP, Brasil)

Moraes, Viviane Merlim

Direito a educação no Brasil : disputas ideológicas na constituição de 1988 [livro eletrônico] / Viviane Merlim Moraes. -- 1. ed. -Santa Maria, RS : Arco Editores, 2021.

PDF

ISBN $978-65-89949-04-6$

1. Direito à educação 2. Direito à educação Brasil I. Título.

$21-71238$ CDU-34:37.014.1 (81)

Índices para catálogo sistemático:

1. Brasil : Direito à educação 34:37.014.1(81)

Aline Graziele Benitez - Bibliotecária - CRB-1/3129

10.48209/978-65-89949-04-6

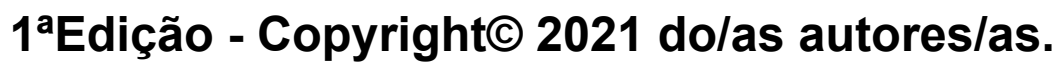


Arco Editores.

\section{DIAGRAMAÇÃO E PROJETO GRÁFICO}

Arco Editores.

\section{REVISÃO}

Dos/as Autores/as.

\section{CONSELHO EDITORIAL}

Prof. Dr. Adilson Tadeu Basquerot e Silva - UNIDAVI/SC

http://lattes.cnpq.br/8318350738705473

Profa. Msc. Jesica Wendy Beltrán UFCE- Colômbia

http://lattes.cnpq.br/0048679279914457

Profa. Dra Fabiane dos Santos Ramos UFSM- Santa Maria/RS

http://lattes.cnpq.br/0003382878348789

Dr. João Riél Manuel Nunes Vieira de Oliveira Brito UAL - Lisboa- Portugal.

http://lattes.cnpq.br/1347367542944960

Profa. Dra. Alessandra Regina Müller Germani UFFS- Passo Fundo/RS http://lattes.cnpq.br/7956662371295912

Prof. Dr. Everton Bandeira Martins UFFS - Chapecó/SC

http://lattes.cnpq.br/9818548065077031

Prof. Dr. Erick Kader Callegaro Corrêa UFN- Santa Maria/RS

http://lattes.cnpq.br/2363988112549627

Prof. Dr. Pedro Henrique Witchs UFES - Vitória/ES

http://lattes.cnpq.br/3913436849859138

Prof. Dr.Thiago Ribeiro Rafagnin UFOB

http://lattes.cnpq.br/3377502960363268
Prof. Dr. Mateus Henrique Köhler UFSM- Santa Maria/RS http://lattes.cnpq.br/5754140057757003

Profa. Dra. Liziany Müller Medeiros UFSM- Santa Maria/RS

http://lattes.cnpq.br/1486004582806497

Prof. Dr. Camilo Darsie de Souza UNISC- Santa Cruz do Sul/RS

http://lattes.cnpq.br/4407126331414

Prof. Dr. Dioni Paulo Pastorio UFRGS - Porto Alegre/RS http://lattes.cnpq.br/7823646075456872

Prof. Dr. Leonardo Bigolin Jantsch -

UFSM- Palmeira das Missões/RS http://lattes.cnpq.br/0639803965762459

Prof. Dr. Leandro Antônio dos Santos -UFU- Uberlândia/MG

http://lattes.cnpq.br/4649031713685124

Dr. Rafael Nogueira Furtado UFJF- Juiz de Fora/MG http://lattes.cnpq.br/9761786872182217

Profa. Dra. Angelita Zimmermann UFSM- Santa Maria/RS

http://lattes.cnpq.br/7548796037921237

Profa. Dra. Francielle Benini Agne Tybusch UFN- Santa Maria/RS http://lattes.cnpq.br/4400702817251869 


\section{AGRADECIMENTOS}

A Deus, pela existência terrena;

À minha família, em especial aos meus pais, pela paciência, pelo apoio, pela compreensão e pelo amor que nos une;

Aos meus filhos, Gabriel e Rafael, por compreenderem minha ausência e pela parceria na vida e nas demandas cotidianas;

À escola pública, por me ensinar a ser a profissional que hoje eu sou, e por me encorajar a sempre buscar novos desafios;

Aos professores do PPGE, PPGCP e PPGH da UFF, pelas relevantes contribuições à minha formação;

Aos colegas do GRUPPE - Grupo de Pesquisa de Políticas Públicas de Educação - pelas relevantes contribuições a este trabalho e pela parceria em todos os momentos;

Aos professores participantes do exame de qualificação e da banca final, pela disponibilidade e auxílio no encaminhamento da presente pesquisa, especialmente ao Prof. Waldeck Carneiro, orientador e amigo;

Às amigas que se disponibilizaram a ler o presente texto, com muito carinho e atenção - Augusta e Elma;

Aos companheiros da Rede Municipal de Educação de Niterói, em especial aos colegas da Escola Municipal Professor Dario de Souza Castello, pelo convívio diário e fraterno, à época da pesquisa;

Aos amigos de jornada, aqui representados na figura da querida Lucy Teixeira, com os quais compartilhei conhecimentos, livros, dúvidas e angústias nesse processo solitário que é o doutoramento. 
O trabalho produtivo (não o trabalho simulado) deve contar como alicerce da formação e desenvolvimento da personalidade. O homo faber deve usar as mãos, o corpo, a inteligência para produzir de modo real. O mesmo deve-se dizer das artes e dos esportes. Eles devem formar mentes e corações. Sobre esse fundamento é que deve crescer o ensino intelectual propriamente dito, de "formação do intelecto". Essa parte do ensino precisa ser diferenciada, rica e intensiva, mas balanceada com as outras e tendo como protótipo a "descoberta do mundo", o uso ativo da inteligência criadora e do modelo experimental de amadurecimento da razão [...] O objetivo último da educação escolarizada não está em "fazer a cabeça do estudante". Mas em inventar e reinventar a civilização sem barbárie (FERNANDES, 1989, p. 263-264). 


\section{SUMÁRIO}

PREFÁCIO .8

1. INTRODUÇÃO 11

2. O DIREITO À EDUCAÇÃO COMO CAMPO DE DISPUTAS DAS POLÍTICAS PÚBLICAS NO BRASIL

2.1 A IMPORTÂNCIA DO MANIFESTO DOS PIONEIROS DA EDUCAÇÃO NOVA NO CONTEXTO NACIONAL DOS ANOS DE 1930 A 1945

2.2 A CONSTITUIÇÃO DE 1946, O MANIFESTO DE 1959 E A CAMPANHA NACIONAL EM DEFESA DA ESCOLA PÚBLICA: LONGOS ANOS DE DISCUSSÃO PARA A ELABORAÇÃO DE UMA LEI DE DIRETRIZES E BASES PARA A EDUCAÇÃO NACIONAL

2.3 A DITADURA EMPRESARIAL-MILITAR, A REDEMOCRATIZAÇÃO, OS DEBATES EM TORNO DE NOVOS ORDENAMENTOS LEGAIS E SEU LEGADO À EDUCAÇÃO BRASILEIRA

3. A ASSEMBLEIA NACIONAL CONSTITUINTE COMO CAMPO POLÍTICO: AgENTES EM DISPUTA PELO DIREITO À EDUCAÇÃO..

3.1 O TRABALHO NA SUBCOMISSÃO 8A - AGENTES, PARTIDOS, ASPECTOS GERAIS E DA EDUCAÇÃO

3.2 O TRABALHO NA COMISSÃO 8 - AGENTES, PARTIDOS, ASPECTOS GERAIS E DA EDUCAÇÃO......

3.3. O TRABALHO NA COMISSÃO DE SISTEMATIZAÇÃO - AGENTES, PARTIDOS, ASPECTOS GERAIS E DA EDUCAÇÃO.

4. DEMOCRATIZAÇÃO DAS OPORTUNIDADES EDUCACIONAIS E LIBERDADE DE ENSINO NAS DISCUSSÕES DO PROCESSO CONSTITUINTE: DIREITO PARA QUEM?

4.1 CONCEPÇÃO DE DEMOCRATIZAÇÃO DAS OPORTUNIDADES EDUCACIONAIS NO TEXTO CONSTITUCIONAL DE 1988

4.1.1 A democratização das oportunidades educacionais: do texto da Comissão dos Notáveis à aprovação da CF de 1988

4.2. CONCEPÇÃO DE LIBERDADE DE ENSINO NO TEXTO CONSTITUCIONAL DE 1988

4.2.1 A liberdade de ensino: do texto da Comissão dos Notáveis à aprovação da CF de 1988

5. CONSIDERAÇÕES FINAIS 


\section{PREFÁCIO}

É um prazer, um privilégio e um orgulho prefaciar este primeiro livro autoral da professora, pedagoga e pesquisadora Viviane Merlim Moraes. Em primeiro lugar, porque conheço e acompanho a trajetória da autora há muitos anos: como aluna e orientanda, como profissional da educação e diretora de escola pública, como gestora em uma secretaria municipal de educação, como pesquisadora e como colega no corpo docente da Faculdade de Educação da Universidade Federal Fluminense (FEUFF), na qual ingressou após aprovação, em primeiro lugar, em concurso público recente. Em todos esses lugares e funções, a autora sempre se destacou pela competência e rigorosidade acadêmicas, pela disciplina para o estudo, pela inteligência e sagacidade nas análises e pela capacidade de trabalhar em equipe.

Todas essas características se manifestam, de alguma forma, na presente obra, oriunda da tese de doutorado que defendeu, com brilhantismo, no Programa de Pós-Graduação em Educação da FEUFF, em fevereiro de 2018. Esta é a segunda razão pela qual me orgulho de assinar este prefácio, pois fui o orientador da tese e, nessa condição, pude observar, desde um lugar privilegiado, a evolução da pesquisa e da pesquisadora: o processo meticuloso de construção do objeto, o aprofundamento denso e gradual dos fundamentos teórico-metodológicos do estudo, a realização do trabalho empírico, a minudente pesquisa documental, o diálogo incessante com a literatura. Todo o artesanato da pesquisa, como diria Wright Mills, me permitiu estabelecer vários momentos de diálogo com a autora: dúvidas sobre enfoques, conceitos, análises, leituras. Lembro-me bem, por exemplo, de uma das últimas sugestões de leitura que fiz à então doutoranda, quando embarcava para uma viagem ao exterior: deparei, na livraria do aeroporto, com um livro que me parecia importante para a tese. Comprei a obra, li no avião e lhe fiz de imediato a sugestão. Quando retornei, poucas semanas depois, Viviane Merlim Moraes já tinha comprado o seu exemplar, que já estava lido e com o conteúdo devidamente incorporado ao trabalho, de forma adequada.

Em terceiro lugar, ressalto, ainda, nossa afinidade teórica com o meu mestre Pierre Bourdieu, que dá régua e compasso ao quadro conceitual elaborado pela autora para fazer as análises sociológicas do fenômeno investigado. Com efeito, durante anos, compartilhamos, no âmbito do nosso coletivo de pesquisa, o Grupo de Pesquisa em Políticas Públicas de Educação (GRUPPE/FEUFF), inúmeras leituras e incontáveis discussões sobre o pensamento e a obra daquele que considero o maior sociólogo do século XX. A propósito, a pesquisa que deu origem ao presente livro foi várias vezes apresentada e discutida, no 
contex to do GRUPPE, com os demais pesquisadores, professores, doutorandos e mestrandos que o integram. Nessas ocasiões, Viviane Merlim Moraes, demonstrando genuíno espírito científico, ouvia, ponderava, anotava, enfim, levava em conta as contribuições emanadas daquela construção coletiva. A propósito, exatos vinte anos depois da fundação do GRUPPE, cujas primeiras reuniões tiveram lugar no mês de agosto de 2001, Viviane Merlim Moraes hoje é sua coordenadora-adjunta, dividindo comigo orientações acadêmicas de mestrandos e doutorandos.

Sua apropriação da "artilharia sociológica" de Pierre Bourdieu, notadamente os conceitos de campo, habitus, capital, agente e estratégia, permitiu o estabelecimento de uma competente articulação entre teoria e empiria, grande desafio em qualquer pesquisa, reconhecida pela qualificadíssima banca examinadora da tese, inclusive por um de seus membros, notável conhecedor e divulgador da sociologia bourdieusiana no campo da educação brasileira, a saber, o meu grande mestre no Brasil, Luiz Antônio Cunha.

Mas a tese e, agora, o livro de Viviane Merlim Moraes também se inscrevem no campo da sociologia política. Afinal, o foco de seu trabalho é o direito à educação, direito constitucional e humano, historicamente negado pelas elites brasileiras aos filhos das classes populares, como parte de sua estratégia de dominação. Ademais, o microcosmo social sobre o qual a autora se debruçou para fazer a investigação foi nada mais nada menos que a Assembleia Nacional Constituinte, que elaborou e promulgou a Carta Magna de 1988, outrora chamada de "Constituição Cidadã". Ora, por um lado, Viviane Merlim Moraes formula questionamentos de natureza sociológica e emprega conceitos da sociologia para buscar respondê-los. Por outro lado, a autora está inequivocamente implicada, dada a especificidade de seu objeto, no campo das disputas políticas e ideológicas mais centrais.

Nesse sentido, ganham destaque nas análises da autora as contribuições de Florestan Fernandes, referência inapagável da sociologia política brasileira e autor que integra o regime de leituras de Viviane Merlim Moraes, de forma mais sistemática, desde a época em que cursava o mestrado em educação.

Em quarto lugar, apraz-me prefaciar este livro pela afinidade de concepções e posições que me aproximam de sua autora, em especial no tocante à luta pela efetiva democratização do direito à educação no Brasil. Mais ainda nestes tempos soturnos, marcados por retrocessos e ameaças constantes à democracia, suas instituições e direitos a ela inerentes, entre eles, muito especialmente, o direito à educação. As sucessivas tentativas de amordaçamento da escola, de criminalização ou de desqualificação do magistério, de banimento do pensamento crítico do ambiente escolar tornam o livro de Viviane Merlim 
Moraes ainda mais importante. As mensagens de ódio, intolerância e violência que subjazem ao discurso protofascista que tenta se afirmar no Brasil contemporâneo podem ser neutralizadas pelo protagonismo da escola republicana. Mas por uma escola pública que seja realmente democrática: nas condições objetivas e subjetivas de acesso, permanência e desenvolvimento, em especial para os filhos da pobreza, dos territórios de favela, das famílias historicamente excluídas do direito aos bens materiais e culturais, produzidos coletivamente, de modo que aqueles sujeitos sejam respeitados na sua diversidade e que tenham o repertório de saberes que carregam valorizado pelo currículo escolar. Para conter o obscurantismo, é preciso uma escola pública que seja democrática também na sua gestão: aberta à participação de profissionais da educação, estudantes e famílias, transparente, dialógica, representativa das posições manifestadas pela maioria da comunidade escolar. Enfim, para barrar o pensamento reacionário, necessitamos de uma escola pública que seja democrática também pelo conteúdo das posições que difunde, como parte do processo de formação e de socialização de crianças, adolescentes e jovens: respeito à diversidade, valorização da pluralidade de ideias e promoção de valores altruístas, humanistas e democráticos.

A jovem professora da rede municipal de Niterói, que conheci à porta de minha sala de aula na FEUFF, quando ela ainda iniciava o mestrado, e que postulava à época a possibilidade de uma licença para estudos, abordando-me devido à minha condição de dublê de professor e secretário de educação de Niterói, fez um verdadeiro percurso de combatente, mas sua caminhada foi exitosa. A tal ponto, que hoje ela coloca à disposição do campo educacional brasileiro uma obra de fôlego, cuja leitura é indispensável, seja para quem se interessa pelos temas do direito à educação e da política educacional, seja para quem busca se aprofundar no emprego de referenciais da sociologia da educação e da sociologia política com o fito de estudar o fenômeno educativo.

Rio de Janeiro, 29 de junho de 2021

(Viva São Pedro! Salve, Xangô!)

\section{WALDECK CARNEIRO}

Professor da FEUFF e do Programa de PG em Educação da UFF

Coordenador do GRUPPE

Doutor em Sociologia da Educação (Univ. Paris V / Sorbonne) 


\section{INTRODUÇÃO}

A problematização de conceitos gerais vulgarmente aplicados ao campo educacional tornou-se uma espécie de compulsão desde o ingresso na Faculdade de Educação da Universidade Federal Fluminense (FEUFF) em 1996, ainda no curso de graduação em Pedagogia. Compreender as representações sociais da disciplina entre professores ${ }^{1}$; discutir o conceito de intelectual aplicado à formação do pedagogo ${ }^{2}$; perceber os limites e possibilidades da formação para a cidadania, apresentada como responsabilidade do(s) sistema(s) de ensino ${ }^{3}$, foram caminhos que me levaram à Academia com o objetivo de buscar respostas para questionamentos que me permitem melhor dialogar com meu cotidiano profissional - a educação básica, em especial, o ensino fundamental.

A mesma motivação me trouxe novamente ao Programa de Pós-Graduação em Educação da FEUFF, neste momento para analisar a inserção da pauta do direito à educação no cenário brasileiro. Tema deveras amplo, com muitas variáveis e inúmeras possibilidades de abordagem e encaminhamento. Contudo, estabelecer um recorte é fundamental, tendo em vista as urgências que o processo de doutoramento nos coloca, bem como os limites de um relatório de pesquisa.

Desta forma, o presente trabalho tem como eixo central a discussão sobre o direito à educação na história brasileira, por meio da hipótese que não existe um único significado, mas diferentes sentidos assumidos por tal conceito a partir das disputas travadas no campo político, que redundaram na publicação de determinadas leis gerais, que regulam e organizam o Estado - como as Constituições Federais (CF), e que definem os ordenamentos gerais da educação no país - como as Leis de Diretrizes e Bases da Educação Nacional (LDBEN).

Ajustar o foco da análise significa a aproximação com o objeto que se deseja estudar. Para tanto, são colocadas tarefas subsidiárias, mas não menos importantes, que envolvem o conhecimento do terreno político, social e econômico do país a partir do período conhecido como "Era Vargas" à publicação da última Constituição Federal (1988), bem como a análise de documentos relevantes produzidos por educadores ou grupos de pensadores que vieram a disputar espaço nas orientações que posteriormente se materializaram nas Constituições

1 VILLELA, Viviane Merlim Moraes. As representações sociais da disciplina entre professores das escolas públicas e privadas de São Gonçalo/R.J. Monografia (Graduação em Pedagogia) - Universidade Federal Fluminense; Orientadora: Adonia Antunes Prado; 2000.

2 VILLELA, Viviane Merlim Moraes. A formação de educadores / intelectuais no curso de pedagogia da Faculdade de Educação da Universidade Federal Fluminense. Monografia (Aperfeiçoamento/Especialização em Educação Superior no Brasil) - Universidade Federal Fluminense; Orientador: Giovanni Semeraro; 2003.

3 VILLELA, Viviane Merlim Moraes. O conceito de cidadania na definição de políticas públicas educacionais: debates e impasses na elaboração do Plano Municipal de Educação de Niterói/ RJ. Dissertação (Pós-Graduação em Educação) Universidade Federal Fluminense; Orientadora: Adonia Antunes Prado; 2008. 
Federais, especificamente na acima citada. Tal demarcação é ainda mais significativa quando pensamos que no ano que se inicia a carta magna completará trinta anos.

Desta forma, ao buscarmos compreender o sentido de direito à educação que se buscou elaborar no Brasil, temos em mente que tal processo não ocorreu instantaneamente, quando o país, ainda colônia, passou a ser explorado pelos portugueses vindos da metrópole, tampouco após a independência ou a proclamação da república. Resgatamos, a título de contextualização, as disputas ideológicas ocorridas entre diferentes grupos que buscavam a hegemonia política, econômica e social, nomeadamente em dois momentos históricos, a saber:

$\checkmark$ Os anos de 1930, tendo como principal referência o Manifesto dos pioneiros da educação nova, que foi apresentado em 1932 e cuja discussão influenciou na temática educacional constante na CF de 1934. Os debates iniciados são desencorajados por um período de supressão das liberdades, que, inclusive, fez nascer uma nova carta magna (1937), sendo somente retomado com a redemocratização e com a promulgação de uma nova Constituição, em 1946. Na ocasião se reacende as discussões em torno da LDBEN que vinha sendo elaborada (e mais tarde se tornou a Lei ${ }^{\circ} 4.024 / 1961$ ), que originou a publicação do Manifesto dos educadores novamente convocados e da Campanha nacional em defesa da escola pública, nos anos finais da década de 1950 e início de 1960;

$\checkmark$ Os anos que sucederam a publicação de uma lei geral para a educação, profundamente marcados por uma ditadura empresarial-militar ${ }^{4}$, que aprovou uma nova CF, em 1967, para suspender suas prerrogativas logo no ano seguinte. No contexto geral deste período, foram publicadas duas grandes reformas do ensino - Leis $\mathrm{n}^{\circ}$ 5.540/1968 e $\mathrm{n}^{\mathrm{o}} 5.692 / 1971$. Os debates travados na Assembléia Nacional Constituinte (ANC) sobre a temática educacional na Constituição Federal a ser elaborada nos anos de redemocratização são o principal foco do presente trabalho.

Ainda assim, se pensamos no volume de material produzido nos períodos acima descritos para análise, percebemos a inviabilidade da pesquisa. Isto posto, optamos por trabalhar com a periodização exposta apenas como um cenário no qual detalharemos as

$4 \quad$ Em evento recente na FEUFF, na ocasião da fundação do Movimento Educação Democrática (realizado no dia 29/06/2017, na sala 318), o Professor Luiz Antônio Cunha afirmou que prefere utilizar a expressão "ditadura empresarial-militar", posto que a expressão civil-militar é muito abrangente, uma vez que são considerados civis todas as pessoas que não são militares, e, portanto, não destaca a importante influência dos empresários neste momento histórico. Nesta tese adotaremos tal nomenclatura. 
disputas ideológicas entre os diferentes grupos que buscaram a hegemonia no campo político, ao elaborarem uma nova Constituição, no âmbito dos trabalhos da ANC, especificamente no que é pertinente à ideia de direito à educação.

Ao pensarmos o objeto específico desta tese, porém, não podemos desconsiderar alguns componentes basilares que nos permitem construir o arcabouço teórico-metodológico no qual se ancoram suas definições principais. Partimos, pois, do conceito de educação em sua totalidade. Tomamos por embasamento a perspectiva dialética, que nos apresenta a educação de forma orgânica, a partir do entendimento de que este conceito foi elaborado historicamente - sendo, portanto, necessário recuperar sua trajetória e o espaço-tempo onde se desenvolveu, para que viesse a atender e expressar os interesses de uma classe social ou de grupos que disputam vantagens em um determinado campo e período definidos.

Desenvolver a trajetória do conceito de educação demandaria outra tese. Necessitaríamos passar por Sócrates, Rousseau, Kant, Hegel, Weber, Marx e tantos outros que contribuíram com a compreensão do homem em sua relação com o mundo. Limitamonos a pensar a educação como o processo de humanização do ser biológico dentro da e na sociedade. Esta, portanto, abrange todos os processos formativos que se dão ao longo da vida, agindo, como afirma Anísio Teixeira (1934, p.120), como um “[...] processo de contínua reorganização e reconstrução da experiência".

No livro Escola e Democracia, Saviani (2006) afirma que a concepção de educação varia de acordo com a vinculação social de um determinado grupo, que pode ser expressa de duas formas: por meio de teorias que objetivam explicá-la como instrumento de equalização social e, portanto, de superação da marginalidade; ou como fator de discriminação social, contribuindo para reforçar a marginalização. Cabe, portanto, entender a realidade social, histórica, econômica e política de um Estado para compreender o conceito de educação que este defende e em qual teoria se embasa.

Ao pensarmos o método histórico dialético como caminho a ser percorrido pela pesquisa, ressaltamos uma forma de percepção do real, por meio de sua historicidade, em concordância com Demo (2012), no que se refere à mobilidade da história, que é, ao mesmo tempo, objetiva e subjetiva, como "produção imorredoura de conteúdos novos" (IDEM, p. 121). Neste sentido, destacamos ainda que:

[...] o método histórico consiste em investigar acontecimentos, processos e instituições do passado para verificar a sua influência na sociedade de hoje, pois as instituições alcançaram sua forma atual através de alterações de suas partes componentes, ao longo do tempo, influenciadas pelo contexto cultural particular de cada época (MARCONI e LAKATOS, 2010, p.89). 
O alinhavo da perspectiva histórica à dialética também está profundamente marcado por algumas categorias que lhes são fundantes, a saber: o pressuposto do conflito social, no qual há uma clara percepção da história como historicamente condicionada (DEMO, 2012, p.90), a partir de suas teses, antíteses e sínteses; a totalidade dialética, que resgata a dinâmica do real por meio de suas polarizações, que não deve, por sua vez, permitir a confusão entre casualidade e causalidade (IDEM, p. 93); as condições objetivas e subjetivas, que permitem aproximações com o que é dependente e com o que independe da ação humana, assim como as dimensões quantitativa e qualitativa da realidade social; a unidade de contrários, no qual se resgata a importância do diálogo como fala entre contrários, sendo oportuno estabelecer a distinção entre contrário - componente essencial da totalidade histórica - e contraditório - termo excludente (IBIDEM, p.98); e, por fim, a teoria e a prática, que nos leva a compreender a história que temos como "o caminho concreto que a realidade construiu" (DEMO, 2012, p. 101).

O conceito de história, como vemos, não é simples. Partimos do entendimento desta não como um retrato, estático, inexorável, mas como síntese possível de ações empreendidas no tempo-espaço pelos homens, ou, com o auxílio de Cunha (1984, p.9), como “[...] produto da atividade do sujeito que conhece - o historiador - sobre o passado, atividade essa na qual ele faz intervir suas preferências, opções pessoais e os condicionamentos sociais que sobre ele atuam".

Não nos cabe, neste sentido, trazer a história como olhar retrospectivo, um mero depósito de fatos passados, mas buscar criar nexos que tornem possíveis as reflexões que ultrapassam a relação linear existente entre o passado, o presente e o futuro, reequacionando os significados que um mesmo fato pode apresentar quando visto por diferentes olhares e narrado por diferentes vozes. Concordamos com Ferreira (2000, p. 7) quando afirma que

O aprofundamento das discussões acerca das relações entre passado e presente na história, e o rompimento com a ideia que identificava objeto histórico e passado, definido como algo totalmente morto e incapaz de ser reinterpretado em função do presente, abriram novos caminhos para o estudo da história do século XX [...] Essa perspectiva que explora as relações entre memória e história, ao romper com uma visão determinista que elimina a liberdade dos homens, coloca em evidência a construção dos atores de sua própria identidade e reequaciona as relações entre passado e presente, reconhecendo que o passado é construído segundo as necessidades do presente e chamando a atenção para os usos políticos do passado.

Tal relação vai exigir de nós um olhar mais cuidadoso e distante da díade causa e efeito. Recorremos a Le Goff, em seu livro História e memória (1990), no qual recoloca 
o problema por considerá-lo fundamental à consciência e ciência históricas. Assim, para além de demarcar o presente histórico por meio da definição do período contemporâneo tal como explicitado tradicionalmente nos programas escolares (LE GOFF, 1990, p. 203), ele destaca a complexidade do passado, que é apreendido e vivido de formas distintas entre os diferentes povos e sujeitos, na formação de suas identidades coletivas. A demarcação entre tais períodos, seria, pois, ideológica.

Na busca pela ruptura com um passado mitificado, no qual "os hábitos de periodização histórica levam, assim, a privilegiar as revoluções, as guerras, as mudanças de regime político, isto é, a história dos acontecimentos" (IDEM, p. 204), encontramos a denominação história do tempo presente, estabelecida a partir de uma nova conjugação temporal.

Antes, porém, Le Goff (IBIDEM, p. 213) resgata a complexidade e a diversidade do entendimento espaço-tempo, com base em algumas análises: primeiramente na oposição passado/presente na psicologia, sobretudo a partir de Freud; na relação entre passado/ presente à luz da linguística, destacando a dificuldade de apreensão dos conceitos de simultaneidade, posterioridade e anterioridade; no contexto do passado/presente no pensamento selvagem, que pode ser disjuntiva e conjuntiva em relação ao presente; por meio de reflexões gerais sobre o passado/presente na consciência histórica, evocando Eric Hobsbawm, na compreensão do passado como "período anterior aos acontecimentos que um indivíduo se lembra diretamente"; por meio da evolução da relação passado/ presente no pensamento europeu da Antiguidade grega ao século XIX, período de intensas transformações, refletidas no Cristianismo, na marcação cronológica do tempo, dentre outros aspectos; para finalmente abordar o século XX entre a vivência do passado, a história do presente e o fascínio do futuro, no qual novas relações temporais são estabelecidas, sobretudo pautadas na compreensão de que o passado é algo reconstruído com base no presente, por meio da elaboração de memórias e de um patrimônio. O autor conclui afirmando ser "necessário fazer nascer uma verdadeira história contemporânea, uma história do presente que pressupõe que não haja apenas história do passado, que acabe uma história que assenta num corte nítido do presente e do passado" (LE GOFF, 1990, p. 224-225).

Ao analisar o livro Batismo de sangue de Frei Betto, do ano de 1984, Fernandes (1986, p. 229-230) afirma que alguns livros "fazem história", enquanto outros apenas "a documentam". Aborda o compromisso com o resgate da memória, bem como a responsabilidade do historiador/narrador em descobrir diferentes versões da história, a fim de construir novos nexos na relação passado-presente, para além do que é comumente apresentado como verdade. Desta forma, extrapola a visão da história como ocorrência, afirmando-a em um sentido revolucionário, como 
[...] a paixão dos seres humanos, homens e mulheres, que percorrem até o fim e até ao fundo os rumores de sua existência, os conflitos da sociedade na qual vivem, os valores nos quais acreditam, a luta revolucionária contra as pequenas e as grandes iniquidades, os caminhos que levam à igualdade e à liberdade, ou seja, a liberdade com igualdade. Se ela separa grandes blocos humanos, lançando uns contra os outros, também une a imensa maioria que luta para abolir a degradação da pobreza, a exploração do trabalhador assalariado e a dominação dos poderosos.

Diante do exposto, percebe-se "uma alteração na forma de experimentação da temporalidade" a partir das mudanças ocorridas no "próprio debate teórico produzido pelos historiadores envolvidos com o estudo do chamado tempo presente" (MARCELINO, 2014, p. 164).

Ainda refletindo sobre formas de experimentar a temporalidade, Mattos (1987), na apresentação do livro O tempo Saquarema, explicita que o recorte daquela pesquisa extrapola o tempo cronológico por ela abrangido - "dos últimos anos do período regencial até o denominado 'renascer liberal' dos anos sessenta" (MATTOS, 1987, p. 2). Reconstitui, pois, o período estudado a partir da ação dos Saquaremas, compreendendo-os como produto e produtores da história. Desta forma, os conceitos discutidos são pensados, não como uma realidade anterior, mas como resultante da intervenção daquele grupo no período evidenciado. Parte da ideia principal "que não podemos modificar o passado mas podemos modificar o conhecimento que dele possuímos a partir de interrogações diversas, e a de que um trabalho de tese é menos um tema em busca de um autor, e sim uma ou mais questões requerendo soluções" (IDEM, p. 3).

Outro enfoque trazido à baila por Fico (2012, p. 44) é a importância do testemunho, que permite o confronto entre o conhecimento histórico produzido e as narrativas dos agentes que vivenciaram o período estudado, já que não se trata mais o passado com um grande distanciamento temporal. Esse aspecto, inclusive, é de fundamental relevância à presente pesquisa, uma vez que, como veremos mais adiante, as entrevistas propostas serão realizadas com agentes que protagonizaram os movimentos do período demarcado por este relatório. Tal perspectiva torna-se ainda mais interessante na medida em que nos propomos a estudar as políticas públicas, campo diretamente ligado à história do tempo presente, sobre o qual Fico (IDEM. p. 45) estabelece a seguinte reflexão:

De fato, a marca central da História do Tempo Presente - sua imbricação com a política - decorre da circunstância de estarmos, sujeito e objeto, mergulhados em uma mesma temporalidade, que, por assim dizer, "não terminou". Isso traz importantes consequências epistemológicas para o conhecimento que se deseja construir. 
Na perspectiva de fazer dialogar passado e presente, distante da concepção que só há objetividade quando o pesquisador se encontra distante dos acontecimentos pesquisados, a retomada do conceito de política pública é indispensável para recompor os caminhos percorridos pelo Estado brasileiro na inclusão do direito à educação como parte de suas preocupações, assim como as concepções que o embasam e as ações que decorrem de tal novidade. Neste sentido, a problematização de Cruz (2012, p. 70) em seu texto "Estado regulador e políticas públicas", ressalta a importância de se perceber a questão da garantia da educação à população como uma "[...] ação $0^{5}$ pública ou do Estado, na medida em que ela expressa um movimento do Estado de dar conta de uma situação ou de um problema, reconhecendo a centralidade do seu papel".

Souza (2006, p. 22), em sua revisão da literatura sobre as políticas públicas, afirma que estas se constituem no terceiro caminho da ciência política norte-americana, no que é pertinente ao estudo da vida pública. Os outros dois seriam o estudo das instituições e das organizações locais. As policy analysis foram apresentadas por Laswell (apud SOUZA, 2006, p.23) “[...] como forma de conciliar conhecimento científico/acadêmico com a produção empírica dos governos e também como forma de estabelecer o diálogo entre cientistas sociais, grupos de interesse e governo". Na atualidade, segundo a mesma autora, o conceito de política pública pode ser assim definido:

[...] campo do conhecimento que busca, ao mesmo tempo, colocar o governo em ação $^{6}$ e/ou analisar esta ação (variável independente) e, quando necessário, propor mudanças no rumo ou curso dessas ações (variável dependente). A formulação de políticas públicas constitui-se no estágio em que os governos democráticos traduzem seus propósitos e plataformas eleitorais em programas e ações que produzirão resultados ou mudanças no mundo real (IDEM, p.26).

Faria (2003, p. 21) nos chama a atenção para os "momentos" do estudo das políticas públicas como subárea da Ciência Política. Afirma que, primeiramente, houve uma ênfase na própria formação das políticas, para que, em um segundo momento, nos anos 1950, estas fossem concebidas por si mesmas como foco de análise. O terceiro e atual momento, a partir das décadas de 1980-1990, trazem a diversificação e complexificação dos processos sociais por meio da inserção de novos agentes no cenário político tradicional.

Neste sentido, estudar a educação como política pública é buscar entender as ações dos governos como expressão das demandas, dos debates e embates que se produzem na política. Ou, como afirma Azevedo (2001, p. 60)

[...] para se ter uma aproximação dos determinantes que envolvem a política educacional, deve-se considerar que a mesma articula-se ao projeto de sociedade 
que se pretende implantar, ou que está em curso, em cada momento histórico, ou em cada conjuntura, projeto este que corresponde [...] ao referencial normativo global de uma política. Tal projeto de sociedade, por sua vez, é construído pelas forças sociais que tem poder de voz de decisão e que, por isto, fazem chegar seus interesses até o Estado e à máquina governamental, influenciando na formulação e implementação de políticas ou dos programas de ação.

O presente estudo pode contribuir para instigar um novo olhar acerca das políticas públicas educacionais. O que se objetiva é a complexificação desta questão, ou seja, a análise das políticas públicas pelo seu teor jurídico, como ação pública que precisa ser compreendida a partir da identificação das suas fases, sequenciais e interrelacionais, na produção de uma política (RUA, 2009, p.37). Tal análise é importante na medida em que visa à interpretação das causas e consequências da ação do(s) governo(s) na vida pública (IDEM, p.20-23) e no tempo presente, entendida dialeticamente, posto que estes são oriundos de grupos sociais, com interesses que lhes são próprios e que acabam por representar e defender.

Sem a pretensão positivista da neutralidade e da imparcialidade, conjugaremos a pesquisa documental - forma principal de análise do material empírico - com os testemunhos, buscando trazer ao debate educacional brasileiro elementos que sejam instrumentalizadores de múltiplas e originais interpretações para a realidade estudada.

Ainda com o objetivo de melhor definir as questões que serão aqui problematizadas de forma subsidiária, trazemos Piletti (2002) e suas definições didáticas que nos permitem diferenciar os conceitos de sistema, sistema de educação, sistema de ensino e sistema escolar. Sistema seria definido, pois, como um conjunto de elementos materiais e não materiais, que dependem reciprocamente uns dos outros de maneira a formar um todo organizado. $\mathrm{O}$ autor destaca três ideias centrais que não podem faltar na caracterização de um sistema. São elas: conjunto de elementos; dependência recíproca entre tais elementos; e todo organizado. A partir de tal concepção organiza, por nível de abrangência, os demais conceitos: o sistema de educação teria um sentido mais amplo, confundindo-se com a sociedade que educa em seus diferentes espaços; o sistema de ensino, de abrangência intermediária, contém as escolas e demais instituições que se dedicam sistematicamente à atividade de ensino; por fim, destaca o sistema escolar, que compreende uma rede de escolas, apresentando-se em um grau de abrangência mais restrito do que os demais. Trabalharemos neste texto com os dois primeiros sistemas apresentados, ou seja, a educação e o ensino serão recorrentemente mencionados.

Podemos perceber nessa explicação que os conceitos mais amplos de educação e 
história apresentados anteriormente, levam-nos também a uma ampliação do conceito de ensino, entendido por Saviani (2008), grosso modo, como produção de saber, de forma que os atores envolvidos no processo sejam sujeitos de suas aprendizagens, que absorvem, ressignificam e transformam o meio no qual vivem.

De forma a definir o contorno que unificará o nosso quadro teórico-metodológico, para analisar o momento histórico delimitado, Pierre Bourdieu se torna referência importante por oferecer elementos para a compreensão de diversas dimensões da realidade social. Neste sentido, o real é percebido como fonte inesgotável de saber e os agentes são os sujeitos que vão tentar superar a ideia unívoca de verdade.

O referencial teórico bourdiesiano nos permite discutir os limites e as possibilidades da formação de uma agenda política, assim como os embates entre os agentes formuladores desta, por meio do conceito de campo, compreendido como resultado de processos de diferenciação social, da forma de ser e do conhecimento do mundo (ARAUJO, 2009, p. 36) que dá suporte às relações de força entre os agentes e as instituições que lutam pela hegemonia (monopólio da autoridade). Gostaríamos de evidenciar a importância da categoria campo, com inspiração em Pierre Bourdieu, para o entendimento de tal relação:

Todas as lutas internas ao campo envolvem a distribuição e posse de um capital específico. A luta ocorre entre aqueles que pretendem assumir posições e aqueles que pretendem mantê-las. Em geral, novatos disputam, dentro das regras estabelecidas, o lugar daqueles que ocupam posições dominantes [...] É como um jogo que pressupõe que se reconheçam as suas regras como legítimas e que, fundamentalmente, existam pessoas dispostas a jogar (IDEM, 2009, p. 36).

Neste sentido, considera-se a noção de campo como elemento articulador do período acima delimitado, favorável à ruptura com uma determinação automática das relações, uma vez que se considera que são nas pressões e nas disputas entre os agentes neste espaço que se firma um ambiente de negociação e composição de ações para a resolução de problemas previamente determinados (BOURDIEU, 2004).

Diante do exposto, o referencial discutido nos limites deste trabalho apresenta vários fatores que irão interferir na agenda elaborada pelos formuladores das políticas públicas, nos momentos históricos previamente definidos. Em última análise, estes agentes, oriundos de um campo político, portadores de habitus e capital específicos, serão os responsáveis pela produção e reprodução das condições favoráveis aos grupos que representam ou de sua transformação, uma vez que não há um caminho único na dinâmica da sociedade. Apesar deste trabalho não se dedicar ao estudo do conceito de habitus e de capital, 
traçaremos brevemente a relação entre eles no sentido de favorecer a compreensão da categoria articuladora desta tese. Ter clareza da complexa teia que liga a história e estrutura a realidade, assim como compreender o campo de forças e de lutas que produzem a política é fundamental para perceber a educação como síntese da realidade que a cerca. Daí a ligação entre todos os contextos que até agora elencamos.

Cabe aqui uma advertência para que possamos distinguir a perspectiva de Marx, que dá suporte ao conceito de história que apresentamos acima, e a de Bourdieu, que ora passamos a discutir. Conquanto tenhamos clareza que ambos estão engajados em desvelar a dominação sobre os sujeitos, destacamos que o primeiro chama a atenção para o lado econômico dessa dominação, enquanto Bourdieu o faz para o lado simbólico. Assim sendo, embora a principal diferença entre as concepções de dominação provenha das visões da classe dominante, Marx trabalha com ela dentro da estrutura, enquanto Bourdieu o faz dentro da superestrutura.

Desta maneira, ao apresentar o que considera fundamental à sua obra, no livro Razões práticas, Bourdieu (1996) traz dois aspectos: a filosofia da ciência concebida como relacional - que atribui primazia às relações - e a filosofia prática disposicional. Neste sentido, considera que a filosofia da ciência raramente é aplicada às ciências sociais por se opor às relações objetivas, que define como " [...] as que não podemos mostrar ou tocar e que precisamos conquistar, construir e validar por meio do trabalho científico". Afirma, pois, que esta se vincula a realidades, grupos, indivíduos, "substanciais", ou seja, concretos. No que é pertinente à filosofia da ação, esta seria disposicional por se referir aos agentes e suas relações, especificamente nas situações em que atuam, na realidade. Lahire (2005, p.16-17) busca ampliar a discussão sobre as disposições, por meio do entendimento de sua gênese e da diferenciação entre as disposições para agir e as disposições para crer - as crenças:

Se a sociologia pretende continuar a ser uma sociologia disposicional, em vez de se pôr ao lado das abordagens a-históricas e des-socializantes do mundo social (reduzido a uma gramática ou a uma lógica de acção presente, a sistemas de acção, à ordem presente da interacção, ...), ela deve ultrapassar a simples invocação ritual do passado incorporado, tomando por objecto a constituição social e as modalidades de actualização desse passado.

Desta forma, retomamos a perspectiva de Bourdieu (1996, p.10) sobre a filosofia da prática, que seria o suporte de diferentes conceitos por ele produzidos, os quais estruturam toda sua obra: 
[...] habitus, campo, capital - e que tem como ponto central a relação, de mão dupla, entre as estruturas objetivas (dos campos sociais) e as estruturas incorporadas (do habitus), opõe-se radicalmente aos pressupostos antropológicos inscritos na linguagem, na qual comumente se fiam os agentes sociais, particularmente os intelectuais, para dar conta da prática (especialmente quando, em nome de um racionalismo estreito, consideram irracional qualquer ação ou representação que não seja engendrada pelas razões explicitamente dadas de um indivíduo autônomo, plenamente consciente de suas motivações).

Falaremos um pouco sobre eles por considerarmos de extrema relevância a advertência de Thiry-Cherques (2006, p. 33), quando afirma que as teorias de habitus e campo são entrelaçadas, uma se apresentando como consequência da outra. Daí, mais uma vez, julgarmos significativo explicitar brevemente cada um desses conceitos, embora as análises a serem realizadas nos próximos capítulos retomem, apenas, este último.

No livro O poder simbólico (2004, p. 61), Bourdieu historiciza a gênese do habitus, a partir de uma crítica à antropologia - sobretudo à noção de inconsciente de Lévi-Strauss $^{7}$ - e ao conceito de agente apresentado pelos althusserianos ${ }^{8}$, aproximandose do conceito de gramática generativa de Chomsky, ou seja, como algo que "permite aos falantes proficientes de uma dada língua produzir impensadamente atos de discurso corretos de acordo com regras partilhadas de um modo inventivo mas, não obstante, previsível” (WACQUANT, 2007, p.66). O autor define, portanto, o habitus como “[...] um conhecimento adquirido e também um haver, um capital [...] indica a disposição incorporada, quase postural" (BOURDIEU, 2004, p.61); ou, como define Thiry-Cherques (2006, p. 34) "[...] rotinas corporais e mentais inconscientes, que nos permitem agir sem pensar". Diferente da perspectiva de Chomsky, o conceito de habitus se concentra em uma aptidão social, variável - devido às condições espaço-temporais que a realidade social e as distribuições do poder impõem - duradouro, mas não eterno, apesar de apresentar certa inércia em determinados períodos (WACQUANT, 2007, p.66).

No mesmo sentido do conceito de habitus, emerge o de campo na obra bourdiesiana. Como caminho para estudo da sociedade, dos agentes e suas relações, campo

[...] serviria como um instrumento de pensamento assim elaborado para descobrir, aplicando-o a domínios diferentes, não só as propriedades específicas de

$7 \quad$ Para Lévi-Strauss o inconsciente pode ser concebido como a própria atividade simbólica. Para uma leitura mais aprofundada sobre o tema: IELGESKI, F. O olhar de Claude Lévi-Strauss sobre as ciências. Disponível em: http://www.sbhc.org.br/resources/anais/10/1345086010_ARQUIVO_O olhardeClaudeLevi.pdf Acesso em: 8fev 2014.

8 Para Althusser (1998) o conceito de agente estava intrinsecamente ligado ao de estrutura e, portanto, com o sujeito que reproduz a dominação característica da sociedade capitalista. 
cada campo - alta costura, literatura, filosofia, política, etc. - mas também as invariantes reveladas pela comparação dos diferentes universos tratados como casos particulares do possível (BOURDIEU, 2004, p.66).

Antes de continuar a aprofundar a definição de campo, cabe retomar o conceito de espaço social. O capítulo VI do livro O poder simbólico (2004, p.133) é iniciado a partir de uma crítica à teoria marxista, vista por Bourdieu como “[...] ilusão intelectualista que leva a considerar a classe teórica, construída pelo cientista como classe real [...] que leva a reduzir o campo social, espaço multidimensional, unicamente ao campo econômico, às relações de produção econômica". Apresenta desta forma, a sociologia como topologia social, e o mundo social como espaço. Neste espaço a diferenciação seria considerada a partir das posições ocupadas pelos grupos de agentes, que seriam detentores das propriedades que existem neste local. Diferente do conceito de classes apresentado por Marx, considerada por Bourdieu como dotadas de uma existência "virtual" (1996, p. 26), o conceito de espaço social valoriza a posição relativa ocupada por cada agente, que pode ser, portanto, mutável. Não ambiciona uma categorização estrutural como a classe faz na obra marxista, mas dela se aproxima na medida em que "organiza as práticas e as representações dos agentes" (IDEM, p. 24) e "define uma potencialidade objetiva de unidade" (IBIDEM, p.25).

Retomamos aqui a observação de Braga na apresentação do livro $O$ marxismo encontra Bourdieu, de Burawoy (2010, p.9). Ele afirma que o pensamento de Bourdieu atrai a atenção dos estudiosos de Marx por ser sensível às classes sociais e ao imenso abismo que separa as classes trabalhadoras dos detentores de capital. Desta forma, rompe com a ideia de que existem apenas duas classes dicotômicas: proletariado e burguesia, reconhecendo a existência de "[...] conjuntos de agentes que ocupam posições análogas no espaço social, possuem quantidades similares de capital, oportunidades semelhantes de sucesso e disposições muito próximas" (VALLE, 2007, p.123).

O espaço seria, portanto, uma concepção relacional do mundo social (BOURDIEU, 1996,p.48), onde os indivíduos e grupos existem na e pela diferença, uma vezque representam diferentes papéis no cotidiano. É mais simples para estes agentes se reconhecerem em um mesmo projeto de acordo com a proximidade em que se encontram neste espaço social; “[...] é a realidade primeira e última já que comanda até as representações que os agentes sociais podem ter dele" (IDEM, p.27).

Ampliando a concepção marxista de capital, Bourdieu agrega a esse conceito não apenas o acúmulo de bens e riquezas econômicas, mas todo recurso ou poder que se manifesta em uma atividade social. Assim, além do capital econômico, é decisiva a 
compreensão do capital cultural (saberes e conhecimentos expressos em títulos e diplomas) e do capital social (relações sociais convertidas em recursos de dominação). Refere-se, de uma forma geral, a um capital simbólico que confere um distintivo de prestígio ou honra e que permite identificar os agentes no espaço social. Desta forma, desigualdades sociais não decorreriam somente de desigualdades econômicas, mas também dos entraves causados, por exemplo, pelo déficit de capital cultural no acesso a bens simbólicos.

Podemos então refletir sobre a importância do conceito de capital econômico e cultural na construção do espaço social, posto que

[...] o espaço social organiza-se de acordo com três dimensões fundamentais: na primeira dimensão, os agentes se distribuem de acordo com o volume global do capital possuído, aí inclusos todos os tipos; na segunda, de acordo com a estrutura desse capital, isto é, de acordo com o peso relativo do capital econômico e do capital cultural no conjunto de seu patrimônio; na terceira, de acordo com a evolução, no tempo, do volume e da estrutura de seu capital. Dada a correspondência que se estabelece entre o espaço de posições ocupadas no espaço social e o espaço de disposições (ou de habitus) de seus ocupantes e também, por intermediações dessas últimas, o espaço de tomada de posição, o modelo funciona como princípio de classificação adequado: as classes que podemos produzir recortando as regiões do espaço social agrupam agentes tão homogêneos quanto possível, não apenas do ponto de vista de suas práticas culturais, de consumo, de suas opiniões políticas, etc. (BOURDIEU, 1996, p. 30).

Para além do acesso aos bens simbólicos, outro princípio de diferenciação seria a apropriação privada de bens e serviços públicos. Esta apropriação seria garantida por outra espécie de capital - o capital político. Diferentemente deste, o capital escolar - que tem a instituição escolar como locus principal de disseminação - contribui para reproduzir a distribuição do capital cultural e, por fim, a própria estrutura do espaço social.

Araujo (2009, p.38) afirma que os conceitos de habitus e campo buscam ressignificar os papéis comumente atribuídos pela sociologia tradicional aos agentes e às estruturas na relação entre indivíduo e sociedade. Neste sentido, apesar da conduta do agente poder ser previsível a partir da ideia de habitus, não se pode desconsiderar a perspectiva de espaço social e das posições nele ocupadas, que rompem com uma visão determinista de sociedade, por meio da introdução de elementos como capital e sua distribuição no campo.

Compreender a multidimensionalidade de processos sociais nos quais são gestadas visões de homem e mundo, sobretudo por meio da educação, implica contemplar a dimensão micro e macro das relações políticas, que, inclusive, dão origem às próprias formulações das políticas públicas para esta área. 
Em estudo sobre os partidos políticos no Brasil, Assumpção e Kerbauy (2011) resgatam a interação social dos indivíduos como elemento fundamental ao funcionamento das organizações políticas de uma forma geral. Para tanto, trazem reflexões pautadas em Bourdieu e nas categorias capital político e campo político. Tais conceitos se constituiriam, segundo os autores, como ferramentas importantes na compreensão da forma de produção e acesso aos recursos políticos, posto que baseados no reconhecimento, entre um determinado grupo, das suas lideranças. Concluem que, no caso brasileiro, o campo político é constituído por aspectos que influenciam a acumulação do capital político necessário para exercer tal liderança. Cabe, pois, definir melhor estes conceitos:

O campo político, entendido ao mesmo tempo como campo de forças e como campo de lutas que tem em vista transformar a relação de forças que confere a este campo a sua estrutura em dado momento, não é um império: os efeitos das necessidades externas fazem-se sentir nele por intermédio sobretudo da relação que os mandantes, em consequência da sua distância diferencial em relação aos instrumentos de produção política, mantém com os seus mandatários e da relação que estes últimos, em consequência das suas atitudes, mantém com suas organizações. O que faz com que a vida política possa ser descrita na lógica da oferta e da procura é a desigual distribuição dos instrumentos de produção de uma representação do mundo social explicitamente formulada. $\mathrm{O}$ campo político é o lugar em que se geram, na concorrência entre os agentes que nele se acham envolvidos, produtos políticos, problemas, programas, análises, comentários, conceitos, acontecimentos, entre os quais os cidadãos comuns, reduzidos ao status de $<$ consumidores $>$, devem escolher, com probabilidades de mal-entendido tanto maiores quanto mais afastados estão do lugar de produção (BOURDIEU, 2004, p. 164).

Local de conflitos e competição permanente entre os envolvidos na busca pelo poder, o campo político é tensionado e permeado por disputas entre sujeitos (e propostas) que possuem maior rede de vínculos, compromissos e lealdades que são construídas em outros espaços, e "importadas" como uma espécie de capital simbólico, que agregará valor ao agente que possuir maiores contatos. Desta forma, os interesses pessoais interferem em tal jogo tanto quanto os coletivos, posto que ambos dialogam nesta complexa rede de relações que é tecida no espaço social. A história da educação brasileira é profundamente marcada por tais interesses, como veremos nos capítulos seguintes, especificamente no objeto central desta tese - a discussão sobre a ideia de direito à educação na Assembleia Nacional Constituinte de 1987 e em seu produto final, a Constituição Federal que dela decorreu.

De forma a buscar padronizar as nomenclaturas que utilizaremos doravante neste estudo em consonância com os conceitos que lhes são estruturantes, resgatamos a distinção 
entre indivíduo - sujeito - agente, proposta por Bourdieu e apresentada por Thiry-Cherques (2006, p. 34) da forma seguinte:

Todo agente, indivíduo ou grupo, para subsistir socialmente, deve participar de um jogo que lhe impõe sacrifícios. Neste jogo, alguns de nós nos cremos livres, outros determinados. Mas, para Bourdieu, não somos nem uma coisa nem outra. Somos o produto de estruturas profundas. Temos, inscritos em nós, os princípios geradores e organizadores das nossas práticas e representações, das nossas ações e pensamentos. Por este motivo Bourdieu não trabalha com o conceito de sujeito. Prefere o de agente. Os indivíduos são agentes à medida que atuam e que sabem, que são dotados de um senso prático, um sistema adquirido de preferências, de classificações, de percepção [...]

Destaca-se que a ideia de percepção apresentada acima não nos remeteria ao conceito estrutural de classe como afirmou Marx, mas a uma perspectiva superestrutural, onde o agente e não o sujeito tenderia a expressar suas visões de mundo de acordo com as posições relacionais que o mesmo ocupa em um determinado campo. Bourdieu, ao utilizar o termo agente, rompe com o pressuposto da liberdade racional do sujeito, para resgatar a ideia de sua ação.

As relações estruturadas pelos grupos que são reconhecidos como referências em um determinado espaço social vão, por conseguinte, indicar a posição - de maior ou menor destaque - que os agentes ocuparão neste campo. Daí ser tão importante o reconhecimento dos pares para o sucesso de uma proposta colocada, uma vez que são essas relações que definem o poder posicional do agente no campo em que atua, aumentando ou diminuindo os seus recursos políticos e seu poder decisório. O processo de gestação das leis gerais e das leis pertinentes à educação são exemplos claros das influências dos agentes no poder de decisão e, como consequência, no produto final alcançado por elas. Diante desta premissa, nossa pesquisa documental apontou caminhos para a análise dos principais agentes que protagonizaram a discussão de direito à educação na $\mathrm{ANC}$, que explicitaremos mais à frente.

Ao apresentar o campo político como monopólio dos profissionais, Bourdieu (2004, p. 164-165) traz elementos como competência social e técnica, tempo livre e capital cultural para abordar as relações que se estabelecem no jogo político. Afirma que "[...] o campo político exerce de fato um efeito de censura", uma vez que os instrumentos de percepção e expressão do mundo social, assim como as opiniões que circulam em um dado grupo vão depender, em grande parte, do acesso que tais grupos possuem aos produtos oferecidos pelo campo, ou seja, aos referidos instrumentos. Desta forma, ao não acessar o discurso 
elaborado por "profissionais", limita-se à própria compreensão dos "não iniciados" à linguagem política, elaborada e disseminada no campo político. Como resultado, legitimase o discurso político como um discurso técnico, cabendo aos diferentes grupos delegar seu poder decisório e colocar-se em uma posição autor/ator frente aos projetos políticos então definidos.

Com vistas a oferecer aos possíveis leitores deste texto um roteiro que facilite seu entendimento, passaremos a apresentar sua organização. O segundo capítulo consistirá em uma apresentação sobre a vinculação da educação ao direito, compreendendo-a, como afirma Bobbio (2004), no âmbito de um sistema normativo. Cury (2002, p. 247) nos auxilia a pensar a efetivação deste direito na realidade brasileira, quando destaca que

[...] em muitos casos, a realização dessas expectativas e do próprio sentido expresso da lei entra em choque com as adversas condições sociais de funcionamento da sociedade em face dos estatutos de igualdade política por ela reconhecidos. É inegável também a dificuldade de, diante da desigualdade social, instaurar um regime em que a igualdade política aconteça no sentido de diminuir as discriminações. Além disso, muitos governos proclamam sua incapacidade administrativa de expansão da oferta perante a obrigação jurídica expressa.

Assim, pensar no direito à educação no solo brasileiro é partir de uma reflexão que não desconsidere nossa origem de país colonizado, patriarcal e escravocrata, marcado por profundas desigualdades sociais, uma vez que tais características muito influenciaram e ainda hoje influenciam no que se oferece aos sujeitos do nosso sistema educacional, sobretudo à população mais pobre, que tardiamente teve acesso à instituição escolar e ao capital por ela socializado (SOUZA, 2017). Este capítulo discutirá um amplo período da historiografia brasileira - faremos uma breve passagem pela colônia e pelo império, focando nossa discussão a partir do final da república velha e o início da era Vargas, em 1930, por compreendermos este período como catalisador de mudanças mais significativas na educação brasileira. Esta é a principal razão, inclusive, pela qual se optou pelo recorte temporal estabelecido.

Este conturbado período é também considerado um marco na historiografia, pois delimita as esferas econômica e educacional, onde o Estado começou a intervir nas questões da educação, combatendo mais diretamente o analfabetismo. A educação passou a ser vista como fator de progresso, em meio a mudanças na estrutura econômica, uma vez que a industrialização ganhou importância devido às dificuldades enfrentadas pelo modelo agrário exportador. 
Passear entre as diferentes concepções e propostas de educação elaboradas para a população brasileira, bem como as distintas forças que se apresentaram em disputa pela preponderância de sua concepção, não será uma tarefa fácil, posto que nos exigirá grande esforço analítico, de maneira que possamos distinguir quais lograram maior êxito consubstanciando o que Antonio Gramsci definiu como guerra de movimento e de posição, ao analisar as relações entre o Estado e a sociedade civil no que chamou de oriente e ocidente, na efetivação da "dominação" e da "direção intelectual e moral" na disputa pela hegemonia de uma classe sobre a outra (GRAMSCI, 2004) ou de determinados agentes no espaço social - materializando-se em ordenações legais, ou seja, nas Constituições Federais.

Após uma incursão na história recente da política e da educação brasileira no segundo capítulo, julgamos ser pertinente aprofundar o processo de abertura política e redemocratização, que se iniciou com a anistia, no ano de 1979, e se estendeu pelos anos de 1980, com o movimento pelas eleições diretas e a posterior instalação de uma Assembleia Nacional Constituinte, que, com todas as contradições, expressou o anseio por novos tempos a partir de um aparato legal.

Desta forma o terceiro capítulo visa apresentar as discussões que circundaram este momento histórico, trazendo a movimentação dos diferentes agentes e partidos políticos no Congresso Nacional e na sociedade em geral, sobretudo nas etapas que constituíram a ANC, especificamente os debates que se deram nas comissões e subcomissões.

Na mesma direção, buscaremos empreender um esforço no sentido de apresentar a polissemia que assumiu a ideia de direito à educação dentre os grupos que disputaram e lograram posições no campo político e, consequentemente, no campo educacional no período em destaque. Diante das leituras exploratórias já realizadas, foi possível esmiuçar a categoria central deste trabalho - direito à educação, em categorias analíticas mais específicas, mas não menos importantes. Tais instrumentos auxiliarão nas novas reflexões advindas da pesquisa documental, baseada em fontes escritas, primárias, sobretudo nos seguintes documentos:

\footnotetext{
$\checkmark$ Anteprojeto "Afonso Arinos" ou da "Comissão dos Notáveis";

$\checkmark$ Atas da Assembleia Nacional Constituinte:

. Comissão 8 - Comissão da Família, da Educação, Cultura, Esportes, da Ciência, de Tecnologia e da Comunicação;

. Subcomissão 8a - Subcomissão de Educação, Cultura e Esportes;

. Comissão 9 - Comissão de Sistematização;

$\checkmark$ Versões preliminares do texto constitucional;

$\checkmark$ Texto final da Constituição Federal de 1988.
} 
Partimos da compreensão de documento como "produto de uma sociedade [...] que manifesta o jogo de força dos que detêm o poder. Não são, portanto, produções isentas, ingênuas; traduzem leituras e modos de interpretação do vivido por um determinado grupo de pessoas em um dado tempo e espaço" (SILVA, 2016b, p. 4556). Neste sentido, optamos pelas versões preliminares e final da CF que sustenta o período delimitado pela pesquisa, assim como as discussões das etapas concernentes ao seu processo de elaboração, que trouxeram à tona diferentes concepções de direito à educação, bem como as subcategorias delimitadas, que melhor explicaremos no parágrafo seguinte.

As concepções que analisaremos serão agrupadas em duas categorias, com o intuito de favorecer o estudo: democratização das oportunidades educacionais, entendida, grosso modo, como ações que objetivaram a ampliação do acesso ao sistema educacional e aos sistemas de ensino por um maior número de pessoas; e liberdade de ensino, que abrange tanto a natureza (forma) do ensino oferecido no sistema educacional brasileiro e o ente por ele responsável, quanto o conteúdo ministrado no mesmo. Concordamos com Sá-Silva (2009, p. 12), quando afirma que

[...] que as categorias devem antes de tudo refletir os propósitos da pesquisa. Eles apontam alguns critérios que podem auxiliar o investigador a avaliar com mais segurança as categorias que foram originadas do material documental: a homogeneidade interna, a heterogeneidade externa, inclusividade, coerência e plausibilidade.

As categorias ora apresentadas são esquemáticas, posto que, em muitos momentos, acabam por se entrecruzarem. Não serão desenvolvidas a partir de um único autor, uma vez que aliaremos a pesquisa bibliográfica, com base em fontes secundárias, à pesquisa documental. Cinco autores serão fundamentais para alinhavá-las aos períodos históricos delimitados nos capítulos subsequentes, a saber: Anísio Teixeira, Florestan Fernandes, Dermeval Saviani, Luiz Antônio Cunha e Carlos Roberto Jamil Cury. Como esses autores estarão presentes nas discussões ao longo do texto, não cabe, neste momento, salientar uma obra apenas, tendo em vista que nos basearemos em vários materiais e publicações por eles produzidos.

Em continuidade à exposição dos temas a serem abordados no quarto capítulo, trabalharemos as categorias anteriormente elencadas, com o intuito de desenvolver uma argumentação baseada em diferentes autores sobre as diferenças de concepção, os avanços (e também sobre os possíveis recuos) da educação no contexto nacional. O pensamento de Anísio Teixeira e sua experiência à frente da gestão do ensino na Bahia e no Rio de Janeiro, 
que clamava pela ruptura da educação como privilégio de um grupo (TEIXEIRA, 1957); o fecundo e instigante pensamento socialista de Florestan Fernandes, sua experiência na Campanha Nacional em Defesa da Escola Pública, em 1960, assim como sua atuação parlamentar no processo constituinte do final dos anos de 1980; as profícuas contribuições de Dermeval Saviani sobre a legislação educacional brasileira; entre outras discussões possíveis, comporão a análise de cada uma das categorias propostas, buscando o(s) sentido(s) a elas atribuídos e preponderantes nos diferentes espaços-tempos e etapas da ANC. Por sua vez, buscaremos cotejar as discussões advindas da revisão bibliográfica com os dados pertinentes ao momento histórico, com vistas a ilustrar, problematizar e construir análises qualitativas que possam vir a enriquecer o painel que se pretende desenhar.

Para elucidar questões específicas referentes a determinados momentos e processos históricos, auxiliando no diagnóstico ou na complexificação das análises, acreditamos que as entrevistas podem se apresentar como uma técnica importante. De acordo com Marconi e Lakatos (2010, p. 170), as entrevistas apresentam os seguintes objetivos: averiguar fatos; determinar as opiniões sobre os fatos; determinar sentimentos; descobrir planos de ação; inferir condutas atuais ou do passado; e descobrir motivos conscientes para opiniões, sentimentos, sistemas ou condutas. Podem, também, ser classificadas em diferentes tipos: entrevistas padronizadas ou estruturadas; entrevistas semi-estruturadas; e entrevistas despadronizadas ou não estruturadas. No caso desta pesquisa, as semi-estruturadas são mais indicadas por combinarem perguntas fechadas e abertas, nas quais o entrevistado tem a possibilidade de discorrer sobre o tema proposto de forma mais livre, sem respostas ou condições previamente fixadas pelo pesquisador (MINAYO, 1996). Cumpre destacar que muitos agentes que participaram das disputas aqui problematizadas estão vivos, podendo trazer seus testemunhos da história por eles também construída e/ou pesquisada. Julgamos pertinente realizar cinco entrevistas, com dois grupos de interlocutores: o primeiro, composto por intelectuais ligados ao campo educacional, que participaram ativamente do processo de elaboração da CF de 1988. O segundo, composto por dois deputados constituintes, que participaram do trabalho legislativo nas comissões já apresentadas anteriormente. Segue, pois, a identificação dos entrevistados e respectivos objetivos das entrevistas, que transcrevemos respeitando a fala dos agentes, sem nenhuma alteração de nossa parte:

GRUPO 1:

Carlos Roberto Jamil Cury - ressaltar aspectos do direito à educação no Brasil, tendo em vista a larga experiência no tema e sua atuação como membro do Conselho Nacional de Educação (CNE) na Câmara de Educação Básica (CEB), da qual foi presidente por duas vezes, entre os anos de 1996 e 2004. Foi ouvido na subcomissão 
8a na ANC, como representante da CAPES (Coordenação de Aperfeiçoamento de Pessoal de Nível Superior), na 13ª reunião, no dia 23 de abril de 1987. A entrevista foi realizada no dia 24/02/2016, em Campinas/SP;

$\checkmark$ Luiz Antônio Cunha - elucidar aspectos do período abrangido por esta pesquisa, tendo em vista sua relevante contribuição ao estudo da educação no Brasil, com destaque para a perspectiva de democratização do país e liberdade de ensino, discussões que muito nos interessa, sobretudo, no terceiro e quarto capítulos da pesquisa realizada. Participou da ANC como representante da SBPC (Sociedade Brasileira para o Progresso da Ciência), na 12 $2^{\mathrm{a}}$ reunião, no dia 23 de abril de 1987. A entrevista foi realizada no dia 12/09/2016, no escritório do professor no Rio de Janeiro; Osmar Fávero - compreender o espaço ocupado pela matéria educacional nas constituições brasileiras, devido à sua relevante militância no campo educacional. Participou da ANC como presidente da Associação Nacional de Pós-Graduação e Pesquisa em Educação (ANPEd) na $15^{\mathrm{a}}$ reunião, realizada em 28 de abril de 1987. A entrevista foi realizada no dia 13/09/2016, no gabinete do professor, na Universidade Federal Fluminense.

\section{GRUPO 2:}

Deputado Arolde de Oliveira - discutir a dinâmica do trabalho constituinte nas subcomissões e comissões, bem como as posições que observou e adotou no tocante ao direito à educação. Na ANC protagonizou algumas discussões na Comissão 8, objeto de nosso estudo. Foi entrevistado no dia 23/01/2017 em seu escritório no Rio de Janeiro. Foi escolhido para a entrevista por ter sido Deputado Federal Constituinte oriundo do Rio de Janeiro, identificado com o campo conservador. Na ocasião foi eleito pelo PFL - Partido da Frente Liberal;

Deputado Paulo Ramos - discutir a dinâmica do trabalho constituinte nas subcomissões e comissões, bem como as posições que observou e adotou no tocante ao direito à educação. Foi Deputado Federal Constituinte (1986/1990) pelo PMDB - Partido do Movimento Democrático Brasileiro, fazendo parte da Comissão de Sistematização como titular (Comissão 9). Foi entrevistado no dia 01/02/2017 em seu gabinete na ALERJ (Assembleia Legislativa do Estado do Rio de Janeiro). Foi escolhido para a entrevista devido ao fato de ser oriundo do Rio de Janeiro, identificado com o campo progressista. 
Passemos aos pontos específicos de cada uma das categorias deste trabalho. Ao abordarmos a democratização das oportunidades educacionais, baseamo-nos primeiramente em um aspecto fundamental do Manifesto dos Pioneiros da Educação Nova, datado de 1932, no qual um grupo de intelectuais reclamava, em meio a um contexto político conturbado, a organização, por parte do Estado, de um plano geral de educação com a bandeira de uma escola única, pública, laica, obrigatória e gratuita. Tal questão emergiu, sobretudo, devido a oportunidade de acesso e a qualidade do ensino brasileiro se configurarem como privilégio de apenas uma pequena classe dominante em detrimento de grande parcela da população. $\mathrm{O}$ acesso seria, pois, a palavra-chave para buscarmos as concepções de intelectuais e documentos oriundos dos diferentes períodos contextualizados por este estudo.

Não obstante o ponto de partida para a reflexão que ora se coloca seja o mesmo, veremos distintas defesas sobre o acesso à escola. De perspectivas liberais que definem a importância da abertura do sistema educacional para todos, como forma de propiciar as mesmas oportunidades à população, passamos por especificações que consideram a legitimidade de conceber os iguais de forma diferenciada, em uma perspectiva de equidade ${ }^{9}$, a considerações mais radicais, na qual a verdadeira universalização da educação só se percebe mediante a existência de uma escola que ultrapasse

[...] a cultura cívica [que] era a cultura de uma sociedade de democracia restrita, inoperante, na relação da minoria poderosa e dominante com a massa da sociedade. Essa massa era a gentinha; e, para ser a gentinha, a educação seria como uma pérola, que não deveria ser lançada aos porcos (ou então, seria uma espécie de ersatz, uma coisa elementar, rudimentar, que ajudaria a preparar máquinas humanas para o trabalho) (FERNANDES, 1989, p. 162).

Ao propor a revolução educacional como ponto de partida para qualquer outra revolução, pretendia-se evidenciar o caráter universal que a escola deveria assumir, preparando para o real exercício da cidadania e, por conseguinte, de uma nova hegemonia ideológica pela classe subalterna (OLIVEIRA, 2010, p.98). É justamente neste aspecto que Florestan teceu uma crítica à pedagogia de Paulo Freire, uma vez que afirmou não bastar uma Pedagogia do Oprimido, mas uma pedagogia da desopressão, na qual os "de baixo" possam deixar o estado de alienação em busca de uma formação que os tornem dirigentes, tal como mencionamos no início desse texto e como afirma Oliveira (2010, p. 100):

Não se trata, indica Florestan, de educar as massas populares apenas para o uso de técnicas rudimentares de nossa civilização letrada e industrial. A ideia é por em

9 Consideramos que o conceito de equidade é mais apropriado do que o de igualdade, uma vez que o critério da justiça e imparcialidade deve ser observado em cada caso, para que se possa superar as desigualdades e injustiças. 
prática uma filosofia educacional democrática, adequada aos valores fundamentais de uma civilização que dignifique o trabalho, aspire à distribuição equitativa dos direitos e das obrigações sociais e consagre teórica e praticamente o saber racional fornecido pela ciência e pela tecnologia - possibilitando, assim, a interação social como fonte de aperfeiçoamento moral da pessoa e da sociedade, fazendo de todo o ser humano um real "agente criador da cultura", com capacidade de exercer, de maneira crítica e sustentável, o domínio "sobre as condições naturais e artificiais do ambiente" (FERNANDES, 1971, p. 177). Nessa perspectiva, abarcando política e ciência, a pedagogia socialista de Florestan mostra-se coadunada com o projeto gramsciano de colaborar para que os "condenados da terra" tornem-se "dirigentes" de seu mundo.

Tanto Gramsci quanto Florestan, resguardadas as especificidades do terreno e tempo histórico em que militaram, exigiram da escola a responsabilidade para com a socialização do capital cultural, do conhecimento acumulado para as novas gerações, sem discriminálas em classes sociais distintas. Para tanto, muito mais do que a escola única, proposta em 1932, exigiam uma escola que garantisse a universalização da capacidade intelectual, derivando daí a importância do papel docente na ação pedagógica.

Trataremos também da liberdade de ensino, que abrange tanto a natureza (forma) do ensino oferecido no sistema educacional brasileiro e o ente por ele responsável, quanto o conteúdo ministrado no mesmo. Razão principal da letargia do processo de tramitação da primeira LDBEN, posto que colocava em esferas antagônicas o ensino público e o privado.

Os recursos destinados à educação também constituíram elementos de enfrentamento entre os grupos signatários dos Manifestos de 1932 e 1959 e setores que representavam as escolas confessionais e privadas. Estes últimos propugnavam a liberdade de ensino como possibilidade de escolha da família, sem considerar que os recursos provenientes do Estado deveriam ser destinados exclusivamente às escolas públicas. Fica a pergunta de Florestan Fernandes (1989, p. 235) como norte para discutir essa categoria multifacetada: “A liberdade é do professor, a liberdade é da escola, a liberdade é da família?”.

O estudo realizado nos oferece um instrumental para lançar algumas "pistas" sobre a discussão educacional apresentada no tempo presente. De acordo com Chinelli (2005, p. 74) o pensamento de Florestan Fernandes, um dos principais intelectuais da Campanha, objetivava "[...] colocar os trabalhadores, os excluídos e os oprimidos - os incultos ou semicultos - nas malhas da rede escolar" (FERNANDES, 1989, p.9). Seria esta uma utopia que se materializou na promulgação da Constituição Cidadã? Teríamos nos reconciliado com nossa dívida às classes despossuídas, com os grupos subalternos ou, como define 
Souza, com a ralé10? Estas são algumas das provocações que o trabalho pretende fazer, em suas considerações finais, trazendo alguns elementos da história para iluminar a reflexão sobre o tempo presente e suscitar o interesse para possíveis desdobramentos desta pesquisa.

Todavia, discutir uma questão no momento histórico em que ela ocorre se mostrou um desafio adicional. Os dilemas do pesquisador, a necessidade do distanciamento - que embora saibamos ser impossível, uma vez que a nossa forma de ver, interpretar e agir no mundo nunca é neutra - apareceram com total vigor. Rompe-se, despretensiosamente, com o pressuposto de que para se fazer história científica é preciso se distanciar dos problemas do tempo presente, de maneira a conferir objetividade ao trabalho acadêmico (FERREIRA, 2000 , p. 2), posto que há uma nova apreensão do estudo do político e, consequentemente, do estudo do contemporâneo. Sem o objetivo de lançar certezas, tais reflexões buscam demarcar que o campo educacional é um espaço em constante movimento, com disputas que produzem ora avanços e ora recuos.

Apesar de o tema escolhido não ser exclusivo à presente pesquisa, uma vez que vários autores se dedicaram a estudar as Constituições - inclusive alguns que serão muito relevantes ao presente trabalho, já citados nesta introdução - acreditamos que sua originalidade reside nas escolhas realizadas, que estabelecem o diálogo entre categorias de análise mais amplas (direito à educação e campo político), com categorias mais restritas (democratização do acesso e liberdade de ensino) para a compreensão do período delimitado para o estudo. A mesma relação se processa com os documentos a serem analisados e com os interlocutores selecionados para a entrevista.

Encontramos alguns resultados ${ }^{11}$ próximos ao nosso objeto após uma pesquisa no SciELO (Scientific Electronic Library Online), em consulta a artigos e revistas de educação; e também na ferramenta google acadêmico, na qual utilizamos como filtro as seguintes expressões:

Direito à educação nas Constituições Federais - foram encontrados 13 artigos, porém nenhum deles propunha o recorte delimitado no presente relatório, ou seja, o tensionamento entre as leis aprovadas e as disputas que as precederam, a partir da conceituação de campo político;

$\overline{10}$ Jessé Souza (2011) chama de ralé uma classe inteira que é desprovida dos meios econômicos, sociais, culturais e morais, uma vez que se encontra em situação de total abandono social e político, naturalizado por toda a sociedade.

11 A lista dos artigos pode ser encontrada na Bibliografia, ao final do trabalho. 
$\checkmark$ Direito à educação no Brasil de 1930 à 1988 - foram encontrados 30 textos, dentre artigos da área jurídica e do campo educacional, com ênfase em um ou outro aspecto da problemática proposta neste estudo, não contemplando o recorte aqui proposto;

$\checkmark$ Caminhos do direito à educação no campo político brasileiro: Disputas ideológicas nas constituições federais - apenas 1 texto, também pertinente a uma pesquisa de doutorado, da Universidade Federal do Rio Grande do Sul, que aborda o percurso das políticas públicas educacionais no Brasil, por meio de um resgate histórico que tem como ponto de partida a década de 1930, chegando até o ano de 2007. Todavia, não aborda a ideia de direito à educação, lançando seu foco sobre a tramitação de leis e de programas educacionais.

Feitas as considerações introdutórias apresentadas neste capítulo, passaremos à discussão que dará suporte a todo trabalho de pesquisa. Assim sendo, no próximo capítulo apresentaremos a gênese da educação como direito no Brasil, evidenciando os conflitos, os grupos e as disputas postas no momento histórico por nós delimitado. Ressaltamos que trata-se de um capítulo longo, que busca reconstituir aspectos históricos fundamentais ao entendimento do período em questão, assim como articula questões de natureza política com as pertinentes ao campo educacional. Arriscaremo-nos, ainda, a tecer algumas sínteses sobre as distintas concepções de direito à educação, que, na metodologia dialética, originarão novas teses e antíteses, a serem problematizadas nos capítulos subsequentes. 


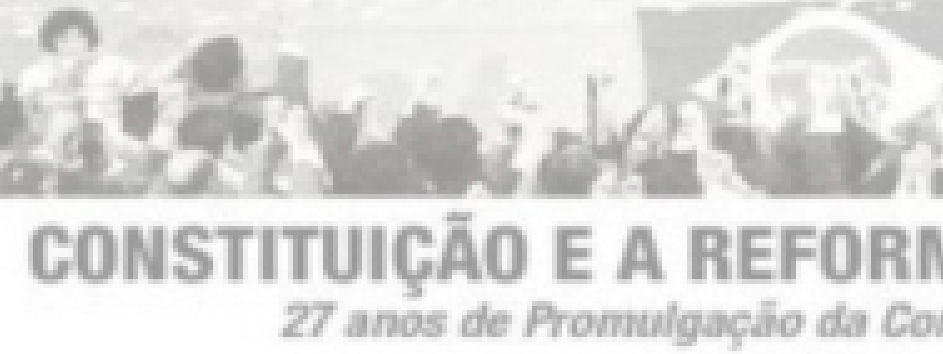

\section{O DIREITO À EDUCAÇÃO COMO CAMPO DE DISPUTAS DAS POLÍTICAS PÚBLICAS NO BRASIL}

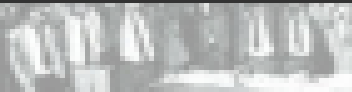


Ao analisarmos os diversos aspectos componentes de uma realidade, deparamo-nos com agentes que são determinados por uma concepção histórica de educação ao mesmo tempo em que a reelaboram, por meio de suas práticas. Sendo assim, não é possível analisar a realidade nacional sem antes entender como algumas concepções se forjaram no cenário mundial.

Se, na Antiguidade, prevalecia a ideia de que o homem é um ser político, que se encontra inserido em uma relação social na qual o todo se sobrepõe às partes, na modernidade o Estado passou a ser concebido como resultado da associação de indivíduos livres e autônomos, por meio de um contrato social, em que estes pudessem deixar o estado de natureza e fugir da barbárie. Tosi (2000, p.44) afirma que tais concepções foram construídas entre os séculos XVII e XVIII, quando a burguesia intentou se constituir como classe dirigente e reivindicou um maior espaço de ação, o que até então não era permitido pela nobreza e pelo clero. Serviram ainda de base para formar a pauta das declarações de direitos do homem, que seguiram as revoluções liberais após a dissolução do mundo feudal. Desta forma, a Convenção Nacional Francesa, em 1793, em seu Art. XXII, assegurava que "A instrução é a necessidade de todos. A sociedade deve favorecer com todo o seu poder o progresso da inteligência pública e colocar a instrução ao alcance de todos os cidadãos".

Para a consolidação do ideário burguês, a educação se tornou um instrumento essencial para a difusão dos valores culturais para todos. Em linhas gerais, podemos dizer que as revoluções burguesas operaram uma inversão na lógica até então construída no mundo ocidental, uma vez que apresentaram, primeiramente, a perspectiva de cidadania ligada aos ideais burgueses (liberdade, igualdade e propriedade) para colocar então a educação como instrumentalizadora do cidadão, baseando-se no discurso da imaturidade popular para as decisões políticas. Nessa perspectiva, rompeu-se com a construção antiga de cidadania fundamentada nas práticas políticas de decisão dos cidadãos, sendo também a educação construída nesse fazer, para revestir-lhe do caráter de produto do processo educativo, posto que dele "...se espera o milagre de configurar o novo homem livre para o novo mercado econômico, social e político" (ARROYO, 1987, p.37).

A passagem da educação como um dos direitos oriundos da cidadania a promotora desta deu-se justamente a partir da ressignificação do conceito, quando foi repassada à escola a tarefa de civilização do povo, de acordo com o projeto de sociedade urbanoindustrial em desenvolvimento, identificando o cidadão aos interesses da nação: 
[...] as transformações na produção da vida material provocaram transformações na organização política, na formação do Estado moderno, colocaram os homens em novas relações com a natureza - a ciência moderna - e trouxeram alterações na organização do saber - a escola moderna. Entretanto, a vinculação determinante no pensamento político e pedagógico inverte essa concepção da história e passa a privilegiar a educação escolar e os processos educativos mais amplos como constituintes das transformações na produção da vida material, e, sobretudo, como constituintes da ordem política, das formas de participação na história e no convívio social (ARROYO, 1987, p. 34-35).

Dias (2014, p.442) afirma que a temática do direito à educação sempre esteve intimamente relacionada à própria evolução da perspectiva dos direitos humanos, tendo se aprimorado ao longo dos anos até ser apresentada em uma versão mais atualizada: a Declaração Universal dos Direitos do Homem, adotada pela Assembleia Geral da Organização das Nações Unidas (ONU), em 10 de dezembro de 1948, que reafirmou, no seu artigo XXVI:

Toda pessoa tem direito à instrução. A instrução será gratuita, pelo menos nos graus elementares e fundamentais. A instrução elementar será obrigatória. A instrução técnico-profissional será acessível a todos, bem como a instrução superior, esta baseada no mérito.

Foi a constituição das sociedades burguesas que trouxe consigo a necessidade da escolarização universal e obrigatória. Dessa forma, para que se pudesse participar da vida da cidade, isto é, para ser cidadão, era necessário ser escolarizado e dispor dos instrumentos oferecidos pela escola para a decodificação do mundo. Concordamos com Saviani (1997, p. 3), quando afirma que:

[.... no âmbito da sociedade moderna que a educação se converte, de forma generalizada, numa questão de interesse público a ser, portanto, implementada pelos órgãos públicos, isto é, pelo Estado o qual é instado a provê-la através da abertura e manutenção de escolas.

A razão se tornou, portanto, o instrumento fundamental para que se pudesse participar livremente das tomadas de decisões, ou seja, para ser cidadão. Jamil Cury (2002, p. 251) afirma que para ser proprietário, "livre", era necessário ser dono de tal faculdade. Seria esta a principal justificativa sobre a qual muitos países fizeram da educação primária uma condição para o exercício dos direitos políticos, em especial, o sufrágio. 
Desse modo, mesmo o liberalismo pregando a não intervenção do Estado, que deveria ser regulado pela "mão invisível do mercado", percebeu a necessidade deste na promoção da educação, tendo em vista que se tratava de uma matéria de interesse geral (SMITH, 1983). Em sendo um tema de interesse da nação, caberia a ele a elaboração de regras gerais para organizá-la, de modo a se constituir como um direito.

Bobbio historiciza, em A Era dos Direitos (2004, p.9), a crítica que faz aos jusnaturalistas, que tratavam o direito como algo irrefutável, comum à natureza humana, passando pela elaboração dos direitos humanos e dos direitos de segunda (instrução e assistência, por exemplo) e terceira geração (ecologia). Afirma, pois, que os direitos não nasceram todos ao mesmo tempo; foram elaborados quando "devem ou podem nascer". Desta forma, na introdução do livro, aborda o conceito de direito, partindo dos termos que são comumente abordados neste campo teórico e buscando uma solução possível para as distinções que lhes são atribuídas:

Na distinção entre moral rights e legal rights, o critério é o fundamento; na distinção entre "direitos naturais" e "direitos positivos", é a origem. Mas, em todos os quatro casos, a palavra "direito", no sentido de direito subjetivo (uma precisão supérflua em inglês, porque right tem somente o sentido de direito subjetivo) faz referência a um sistema normativo, seja ele chamado de moral ou natural, jurídico ou positivo. Assim como não é concebível um direito natural fora do sistema das leis naturais, também não há outro modo de conceber o significado de moral rights a não ser referindo-os a um conjunto ou sistema de leis que costumam ser chamadas de morais, ainda que nunca fique claro qual é o seu estatuto (do mesmo modo como, de resto, nunca ficou claro qual é o estatuto das leis naturais). Estou de acordo com os que consideram o "direito" como uma figura deôntica, que tem um sentido preciso somente na linguagem normativa. Não há direito sem obrigação; e não há nem direito nem obrigação sem uma norma de conduta [...] (IDEM, p. 10).

Retomamos o texto Direito à educação: direito à igualdade, direito à diferença, de Jamil Cury (2002), uma vez que ele parte do mesmo princípio anunciado por Bobbio. Segundo o autor, não é possível falar de direito se ele não é reconhecido. E não basta o reconhecimento social do mesmo. Urge que ele esteja inscrito em leis de caráter nacional, como na Constituição Federal, por exemplo, uma vez que é ela quem vai direcionar o cotidiano das pessoas que vivem em um determinado território. Desta forma caminha o direito à educação, que a duras penas foi se tornando uma exigência, sendo incluído nas legislações de nosso país na medida em que se aprofundavam as disputas que colocavam tal tema no cerne do debate nacional. 
Tudo isso possui enorme impacto no cotidiano das pessoas, mesmo que nem sempre elas estejam conscientes de todas as suas implicações e consequências [...] É inegável também a dificuldade de, diante da desigualdade social, instaurar um regime em que a igualdade política aconteça no sentido de diminuir as discriminações. Além disso, muitos governos proclamam sua incapacidade administrativa de expansão da oferta perante a obrigação jurídica expressa. É por essas razões que a importância da lei não é identificada e reconhecida como um instrumento linear ou mecânico de realização de direitos sociais. Ela acompanha o desenvolvimento contextualizado da cidadania em todos os países. A sua importância nasce do caráter contraditório que a acompanha: nela sempre reside uma dimensão de luta. Luta por inscrições mais democráticas, por efetivações mais realistas, contra descaracterizações mutiladoras, por sonhos de justiça. Todo o avanço da educação escolar além do ensino primário foi fruto de lutas conduzidas por uma concepção democrática da sociedade em que se postula ou a igualdade de oportunidades ou mesmo a igualdade de condições sociais (CURY, 2002, p. 246-247).

E foi neste processo não linear, de idas e vindas, que se inscreveu o direito à educação na história brasileira. De forma geral, pode-se inferir que pouco se avançou no aspecto educacional nos anos compreendidos entre o período colonial e a primeira república. Durante o Brasil Colônia, a educação era destinada a uma pequena parcela da população: somente aos filhos homens que não eram os primogênitos dos senhores de terra, não havendo preocupação com a educação primária. A formação era enciclopédica, voltada para as letras, evidenciando um grande abismo em relação à realidade social, reforçado pela ação dos jesuítas. Não se discutiam as relações locais, nem os problemas do Brasil. A escolástica, método utilizado por estes interlocutores, visava formar o homem educado nos moldes europeus. Mesmo após a expulsão deste grupo religioso no século XVIII pelo Marquês de Pombal, as marcas de sua educação elitista permaneceram diferenciando as classes sociais (ROMANELLI, 2003).

Após a expulsão dos jesuítas, por meio de um alvará datado de 1759, foram instituídas as aulas régias, com professores nomeados pelo governo, cujo objetivo era preparar uma elite necessária para fins econômicos e políticos. Na virada do século XVIII para o século XIX, tornou-se muito comum a elite local da colônia do Brasil enviar seus filhos para a cidade de Coimbra, em Portugal, com o intuito de completarem a sua formação. A influência do iluminismo foi muito notória neste momento, posto que a evolução da educação impunha a condição de que os padres fossem retirados do cenário educacional, já que a manutenção de religiosos no controle das escolas significaria uma dificuldade de libertação do obscurantismo, com vistas à elevação da razão. Essa nova sociedade deveria 
ser baseada na Revolução Francesa, sendo uma das medidas propostas a formulação da instrução pública.

Em sua dissertação, Santos (2012) $)^{12}$ faz uma análise da experiência do Seminário de Olinda, instituição inaugurada ainda no período colonial, em 1800, mas que se alimentava da perspectiva iluminista por ser pautada em um arrojado plano político e educacional para a época. Tal característica lançaria as bases do que mais tarde seria o primeiro curso jurídico de Olinda, já após a Independência, em 1827. Cabe destacar, todavia, que essa não era a regra para a educação naquele período.

Em Educação é um Direito, Anísio Teixeira (1968, p.35) resgata o processo de constituição dos Estados nacionais e da produção da riqueza das nações, trazendo autores como Adam Smith e Rousseau. Desta forma, o indivíduo que neste contexto emergiu como "peça da engrenagem" tinha na educação um processo limitado, uma vez que às massas se destinava o treino e às elites uma realidade diferenciada. A ideia do saber como direito do individuo e como necessidade social, com vistas ao desenvolvimento do homem racional, independente e democrático, ganhou força nos séculos XVIII e XIX na Europa, mas, no Brasil, tal perspectiva demorou um pouco mais para se efetivar. Essa mudança na estrutura social fica evidente na seguinte passagem:

Pode-se agora perceber quanto é público o novo interesse, a nova necessidade da educação. Haverá, por certo, educação privada. Será mesmo conveniente que desapareça de todo um esforço, que somará ao Estado, na grande experimentação educacional do presente e do próximo futuro. Mas o empreendimento se irá fazer tão dispendioso e tão amplo, que em sua maior parte será inevitavelmente público. Público, por esse motivo do custo, e público porque representará cada vez mais um interesse público. É a sociedade, como um todo, que, mais do que qualquer outro grupo, estará interessada na formação do cidadão, do membro desse corpo social extremamente complexo e plural em que ela se transformou.

Sobre o Brasil, Teixeira, ao refinar sua análise para o nosso contexto, afirmou que “[...] o país nascia em estado de dissolução”(IDEM, p. 59), pois nem o novo - o espírito de liberdade, nem o velho - a religião, conseguiram configurar a nova ordem social que viria a se instituir com a separação oficial de Portugal, em 1822. Desta forma, o brasileiro era fruto de uma ordem patriarcal dividida entre proprietários - a elite, e a população em geral. O próprio processo de independência, para além das versões romantizadas da

12 SANTOS, Daniella Miranda. Memória, Igreja e Educação: Dom Azeredo Coutinho e o Seminário de Olinda como precursor dos Cursos Jurídicos no Brasil. Dissertação (Mestrado em Memória: Linguagem e Sociedade da Universidade Estadual do Sudoeste da Bahia - UESB). Orientadora: Professora Dra. Ana Palmira Bittencourt Santos Casimiro; 2012. 
história oficial, inseriu-se em um processo de separação gradual de Portugal, que não rompeu com a estrutura de dominação aqui posta. Tal processo teve início com a elevação do Brasil à categoria de Reino Unido de Portugal, em 1815. O retorno da família real à metrópole, em 1821; a revolução constitucionalista - revolução liberal portuguesa de 1820, que culminou no descontentamento dos representantes brasileiros na elaboração da Constituinte Portuguesa, que não aceitaram as propostas recolonizadoras para o Brasil, foram os passos seguintes. Desta forma, em janeiro de 1822, por meio do "Dia do Fico", D. Pedro informalmente decretou a separação de Portugal, oficializada apenas no dia sete de setembro daquele mesmo ano.

Assim sendo, a primeira menção legal sobre a educação se fez na Constituição Brasileira outorgada em 1824, logo após a proclamação da independência. Esta apresentou no inciso 32 o ensino primário como gratuito a todos os cidadãos, excluindo formalmente os escravos deste processo.

O golpe militar liderado pelo Marechal Deodoro da Fonseca, em 1889, deu início à nossa história republicana, fruto do desgaste da monarquia com diferentes setores, a saber: a elite agrária, os proprietários de escravos (revoltados após a abolição da escravatura, um dos últimos sustentáculos do Império), as classes médias e profissionais liberais, os militares, o movimento republicano que se fortalecia nas grandes cidades do Sudeste, entre outras situações.

Em 1891, a segunda Constituição, a primeira denominada de Constituição Federal inspirada no modelo norte-americano da liberal-democracia (Constituição Estadunidense de 1787) e nos princípios dos direitos humanos - reservou ao governo da União a responsabilidade não exclusiva pela criação de instituições de ensino superior e secundário nos estados (DAVIES, 2004, p.16). Cabe destacar que esta carta constitucional não faz menção às responsabilidades dos governos locais para com a educação elementar, nem mesmo os proíbe de criar instituições de ensino secundário e superior. Por esta omissão podemos avaliar o quanto a educação popular não era tida como uma preocupação, um problema estrutural, mas apenas como uma contingência que era preciso remediar (TEIXEIRA, 1957, p. 93).

Em Que tipo de república?, Fernandes cita Costa para descrever a história do Brasil até então, afirmando que esta "[...] se tornou nacional antes de livrar-se de sua condição colonial" (1986, p. 164). Destaca, pois, que a tradição de concentração do poder no "tope" 
criou uma ausência de "cultura cívica" em nosso país, na medida em que as instituições existentes absorveram os "costumes políticos" que trazem à baila a seguinte lógica: "o que é bom para os donos do poder é bom para a coletividade como um todo" (1986, p. 68). Já em O desafio educacional (1989, p. 127), ratifica o pensamento exposto ao afirmar que "[...] a República foi traída pelos republicanos, que aceitaram um acordo com os fazendeiros e não levaram à frente um sistema republicano de educação". Diante o exposto, resgata-se em Teixeira (1968, p. 59) a estrutura educacional do período: para a elite composta pelos filhos dos antigos proprietários rurais e pela classe comercial que começara a se estruturar era oferecida a escola secundária (sem caráter profissional) e o ensino superior. Para parcela da população em geral, a escola primária e as escolas técnico-profissionais - a escola de artes e ofícios e a escola normal, como é exemplificado pelo autor em outra obra (1957, p. 161):

No Brasil, a escola primária, embora ainda para poucos, passou por duas fases. Primeiro, organizou-se, segundo o modelo então reinante na Europa, como um sistema de educação paralelo ao propriamente preparatório para a escola superior e formador da elite dominante. O seu curso compreendia sete ou oito anos de estudos, completados os quais o aluno encerrava a sua vida escolar, ou continuava nas escolas chamadas vocacionais. Reproduzia-se o dualismo educacional corrente na Europa e, sobretudo, na França, onde se buscara inspiração. A escola primária, a escola normal e as escolas de artes e ofícios constituíam o sistema da classe média, então pequena e reduzida; o ginásio e a escola superior, o sistema escolar da elite dominante.

Até os anos de 1920-1930 a estrutura social, política e educacional foi profundamente marcada pela exclusão de muitos. Apesar de legalmente não mais existir a escravidão, a relação de subordinação e subalternidade da maior parte da população permaneceu inalterada e, certamente, a educação cumpriu um papel importante neste quadro, separando a elite do povo em um sistema dual de ensino. Seria, pois, a educação "[...] um privilégio e, como tal, tende a transformar-se numa formalidade ou simulação" (TEIXEIRA, 1968, p. $68)$.

O período também foi marcado pela tentativa de restauração católica no Brasil, abalada desde a proclamação da república, na qual formalizara-se a separação entre Estado e Igreja. Alguns congressos foram realizados no período, nos quais se destacava a orientação da Igreja na atuação política

[...] Essa opção implica a colaboração com o Estado, em termos de parceria e de garantia do status quo. Nesse sentido, a Igreja mobiliza seus intelectuais, por 
meio, entre outras organizações, do Centro D. Vital e o cardeal D. Sebastião Leme; funda, no Rio de Janeiro, a Liga Eleitoral Católica. A Constituição de 1934 registra alguns resultados dessa ofensiva, tal como a instituição do ensino religioso nas escolas públicas, a presença de capelães militares nas Forças Armadas e a subvenção estatal para as atividades assistenciais ligadas à Igreja (AZEVEDO, 2004, p.112).

As décadas de 1920 a 1930 trouxeram também os embates concernentes ao voto secreto e livre, que estendeu sua influência na área da educação, sobretudo pela mobilização de uma vanguarda dos educadores brasileiros, que vinha realizando conferências desde o final dos anos de 1920. Em 1924 tais educadores se reuniram no Rio de Janeiro, criando a Associação Brasileira de Educação (ABE). Segundo Prado (2010, p. 35), a iniciativa representou um compromisso dos intelectuais brasileiros com a educação nacional, congregando dois aspectos importantes:

[...] por um lado, os principais representantes desse movimento, também conhecido como "renovadores", já vinham discutindo novas ideias sobre ensino e educação, ideias essas que se encontravam em voga na Europa e nos Estados Unidos e que questionavam a chamada "educação tradicional"; além disso alguns desses educadores já vinham realizando reformas educacionais em seus estados de origem conforme orientações de política pedagógica renovada, de acordo com as linhas de pensamento que defendiam.

Foi um período de grandes iniciativas, conhecido como a década das reformas educacionais. Não havia ainda um sistema organizado de educação pública, porém, influenciados pelos ideais da Escola Nova, alguns estados brasileiros começaram a propor mudanças, a começar por São Paulo, onde, em 1920, Sampaio Dória realizou a primeira das reformas regionais do ensino, bastante significativa, uma vez que promoveu a reforma radical do ensino primário de forma que o mesmo contemplasse todas as crianças, atendendo às prerrogativas de um estado que estava em adiantado processo de industrialização ${ }^{13}$. $\mathrm{Na}$ sequência, entre os anos de 1922 e 1923, Lourenço Filho seguiu a mesma perspectiva no Ceará; em 1924, Anísio Teixeira foi convidado para assumir a Diretoria de Instrução Pública da Bahia; entre 1925 e 1928, José Augusto Bezerra de Menezes, no Rio Grande do

13 Anísio Teixeira resgata que um dos eixos da reforma foi a diminuição do curso primário para 2 anos, depois novamente alterado para 4 anos (na cidade), e para 3 anos (na zona rural). Tal postura, junto à reorganização do curso normal, visava à adoção de "[...] uma política de educação popular reduzida, com professores também de preparo reduzido" (1957, p. 122). 
Norte, deu continuidade ao movimento das reformas; já nos anos de 1927 e 1928, Lisímaco Costa iniciou as reformas do Paraná; em período idêntico Francisco Campos iniciou o trabalho no estado de Minas Gerais; por fim, no Rio de Janeiro, que era o Distrito Federal à época, as mudanças na estrutura educacional se deram por Fernando de Azevedo, nos anos compreendidos entre 1927 e 1930 (CPDOC, 2015a).

Para apresentar o cenário educacional brasileiro, tomamos como referência a “Revolução de 1930”, que significou, segundo Fausto (1988), uma nova conciliação entre a classe dirigente do país e as classes médias, provocando a aceleração nas mudanças sociais e políticas do Brasil. Segundo o autor, o termo revolução aplicado ao contexto brasileiro de 1930 é questionado, pois tal movimento não contou com uma participação popular que pudesse legitimar seu propósito, nem mesmo se pode afirmar que o poder foi tomado por outra classe, mas por um grupo heterogêneo que se uniu contra o mesmo adversário, formalizando uma troca de elites no poder, sem grandes rupturas.

A insatisfação com a República Velha nos anos de 1920 a 1930 foi materializada em alguns movimentos, como o movimento tenentista, que abrangeu a Revolta dos 18 do Forte de Copacabana (1922), a Revolta Paulista de 1924, a Comuna de Manaus (Amazonas, 1924) e a Coluna Prestes (1925-1927). Estas revoltas tinham em comum a insatisfação com a oligarquia que se mantinha no poder e a crise econômica, agravada pela crise da bolsa de valores de Nova Iorque, em 1929, que atingiu o Brasil e a produção do café.

Assim, em linhas gerais, a Revolução de 1930 foi o movimento armado, liderado pelos estados de Minas Gerais, Paraíba e Rio Grande do Sul, por meio da formação da Aliança Liberal, que culminou no golpe de Estado, o golpe de 1930, que depôs o presidente da república Washington Luís em 24 de outubro, impediu a posse do presidente eleito Júlio Prestes e pôs fim à República Velha, conhecida como política do "café-com-leite"14. Getúlio Vargas tornou-se chefe do governo provisório com amplos poderes, revogando a Constituição de 1891 e passando a governar por decretos. Nomeou interventores para todos os governos estaduais, com exceção de Minas Gerais. Tal nomeação, que era de tenentes inexperientes em sua maioria, redundou na Revolução de 1932, conhecida como

14 Em 1929, lideranças da oligarquia paulistana romperam a aliança com os mineiros, conhecida como política do "café-com-leite", e indicaram o paulista Júlio Prestes como candidato à presidência da república. Em reação, o governador de Minas Gerais, Antônio Carlos Ribeiro de Andrada apoiou a candidatura oposicionista do gaúcho Getúlio Vargas. Em $1^{\circ}$ de março de 1930, foram realizadas as eleições para presidente da república que deram a vitória ao candidato governista, que era o governador do estado de São Paulo, Júlio Prestes. Porém, ele não tomou posse, em virtude do golpe de estado desencadeado a 3 de outubro de 1930, e foi exilado. 
revolução constitucionalista. Foi a primeira reação ao governo centralizador de Getúlio Vargas (FAUSTO, 1997).

Destacamos este período da história brasileira como marco da presente tese por este significar, sob a ótica de diferentes autores, um período de integração política da nação, com uma participação crescente de diferentes grupos sociais no organismo nacional. Tal perspectiva ganhou materialidade no campo educacional com a criação do Ministério da Educação e Saúde, em 1930, logo após o triunfo da "revolução", o que reflete o reconhecimento desta área no "plano institucional, como uma questão nacional" (SAVIANI, 1997, p. 6). Segundo Teixeira (1968, p. 61) este momento:

Trata-se de alteração independente da sua estrutura de classes, pois não as destrói, significando antes a identificação em nível mais alto de todos os brasileiros. A manifestação consciente deste processo integrativo é o chamado nacionalismo que, sob tal aspecto, constitui aqui o mesmo fenômeno que acompanha no século

XIX o desenvolvimento político de todas as nações hoje consideradas desenvolvidas.

O caso brasileiro, fruto de análises a respeito do seu capitalismo tardio, de sua revolução burguesa, da estrutura de representação de interesses, e do Estado orgânicocomunitarista, apresenta-se de maneira distinta dos países da Europa, por exemplo, ou mesmo dos Estados Unidos da América. As análises de Vianna e Carvalho (2000, p.11) apresentam o cerne da questão:

Resulta daí um problema de natureza empírica: as sociedades retardatárias, objetos de processos de modernização conduzidos pela ação coercitiva do Estado e caracterizadas pela ausência de um estatuto de liberdade e de igualdade comum a todos os seus indivíduos, quando institucionalizam os modernos institutos da democracia política, o fazem desencontradas de uma cultura cívica que possa ancorá-la.

Draibe (1985), em seu livro Rumos e Metamorfoses: Estado e industrialização no Brasil - 1930-1960, desenvolve a ideia de que somente uma análise globalizante da realidade - que envolva os aspectos econômicos, políticos e sociais - pode ser fundamental e decisiva para a compreensão das relações Estado/industrialização no Brasil. Para tanto, desenvolve o conceito de revolução burguesa de Florestan Fernandes, uma vez que o considera fundamental por permitir a compreensão da especificidade do processo de transformação 
capitalista ocorrido no Brasil. Assim, de acordo com tal autor, a revolução burguesa no Brasil compreenderia um conjunto de transformações econômicas, tecnológicas, sociais, psicoculturais e políticas que não se realizam de uma única vez, mas ao longo de um período de 30 anos, e só se completaram quando o desenvolvimento capitalista no Brasil atingiu sua base industrial.

De acordo com tal perspectiva, não se pode dizer que os anos de 1930 consolidaram este processo, ao contrário, que ele se estendeu até os anos de 1960, diferentemente das revoluções burguesas clássicas, apresentando-se como um processo de transformação continuada, em que, ao mesmo tempo, tanto se construiu a estrutura econômico-industrial, como se formaram e se diferenciaram as classes sociais e as estruturas políticas do próprio Estado.

Já Teixeira (1968, p. 60) define que a Revolução de 1930 marca o período de integração política do Brasil, que vai se consumar em 1945-1946, com a publicação de uma nova carta constitucional, democrática, e com a conquista do sufrágio universal. Segundo o autor, somente neste período se rompe com a representação homogênea da elite no poder institucional. Em ambas as perspectivas, porém, tal período inaugura um novo debate, que traz a educação para um patamar diferenciado, como direito de uma cidadania ainda embrionária.

\subsection{A IMPORTÂNCIA DO MANIFESTO DOS PIONEIROS DA EDUCAÇÃO NOVA NO CONTEXTO NACIONAL DOS ANOS DE 1930 A 1945}

Como vimos anteriormente, o desenvolvimento da racionalidade, da capacidade cognitiva é um imperativo humano, portanto, universal. As condições de sua realização, entretanto, são historicamente datadas e dependem das concepções de homem, mundo e sociedade, bem como dos espaços criados em determinados períodos para sua realização. Concordamos com Cury (2002, p. 253) quando afirma que:

$\mathrm{O}$ direito à educação, como direito declarado em lei, é recente e remonta ao final do século XIX e início do século XX. Mas seria pouco realista considerálo independente do jogo das forças sociais em conflito. Tanto a ampliação dos direitos civis e políticos como a inserção de direitos sociais não são apenas uma estratégia das classes dirigentes que aí teriam descoberto, na solução coletiva, diversas vantagens [...] são também um produto dos processos sociais levados adiante pelos segmentos da classe trabalhadora, que viram nele um meio de participação na vida econômica, social e política. 
A educação pública se constituiu, no bojo das mudanças advindas das revoluções burguesas, como necessidade de todos e não mais como bem a ser usufruído somente por uma pequena parcela da população - a elite, vista por si própria como superior. Ao contrário, "[...] deveria transformar-se na agência de educação dos trabalhadores comuns, dos trabalhadores qualificados, dos trabalhadores especializados em técnicas de toda ordem e dos trabalhadores da ciência" (TEIXEIRA, 1957, p. 45). Todavia, este não foi o caminho trilhado pelos países colonizados, devido às fragilidades e heterogeneidade de sua classe operária e da forte dualidade do ensino até então em curso.

No Brasil, como vimos anteriormente, a educação primária foi privilégio de poucos, excluindo-se deste grupo as classes populares e, formalmente, por muitas décadas, os negros, os índios e as mulheres. $\mathrm{O}$ avanço na discussão dos direitos - primeiro instituídos no âmbito dos Estados-Nações, como fruto da constituição da cidadania, depois como direitos universais, de um Estado que não tem mais fronteiras - incorporou os antes excluídos. Desta forma, concordamos com Bobbio (2004, p. 19), quando ele coloca que

A Declaração Universal contém em germe a síntese de um movimento dialético,
que começa pela universalidade abstrata dos direitos naturais, transfigura-se na
particularidade concreta dos direitos positivos, e termina na universalidade não
mais abstrata, mas também ela concreta, dos direitos positivos universais.

Tal movimento dialético volta a especificar o direito, passando a considerar aspectos antes escamoteados, mas que vão se tornando uma exigência social até se converterem em um direito positivo (CURY, 2002, p. 260). Cabe ressaltar a importância do Manifesto dos Pioneiros da Educação Nova, publicado em 1932, como expressão deste processo no campo do direito à educação em nosso país. Ele se propunha, grosso modo, a responder à pergunta de Anísio Teixeira expressa no livro Educação Progressiva (1934, p. 139): “Que dizer, pois, de preparar a escola - a escola para todos - pondo-a em eficiência, integrada na mesma finalidade?".

O surgimento da escola se deu com o aparecimento da escrita e o enriquecimento da tradição oral por meio desta nova forma de memória coletiva. Surgiu, pois, como instituição de preparação do letrado (sacerdote, filósofo, pensador, erudito, profissional, artista, cientista). Não visava substituir a influência direta da sociedade, mas sim atuar como uma "instituição específica para a formação de especialistas da tradição escrita, a 
latere, e sem prejuízo daquela influência social direta quanto a participação e integração de todos na comunidade" (TEIXEIRA, 1956, p.116). Residia aí a necessidade de substituição dessa escola de caráter intelectual e livresco por uma educação nova, do trabalho, ativa ou progressiva, com base na "[...] formação de todos os homens" que não poderia obedecer “[...] aos métodos de formação de uma classe especial de estudiosos, eruditos, intelectuais ou cientistas" (IDEM, p. 87).

Desta forma, o Manifesto buscou a superação do "empirismo grosseiro" que governava o sistema educacional brasileiro (MEC, 2010, p. 34). Tal documento, assinado por diversos educadores alinhados com a perspectiva liberal, dentre eles, Anísio Teixeira e Fernando de Azevedo, propunha a reforma educacional por etapas, que viesse a proporcionar a evolução contínua motivada por forças organizadas oriundas da cultura e da educação, conduzindo a sociedade "à grande reforma" (IDEM, p.38-40). O direito à educação foi apresentado como uma reação à educação tradicional, ou seja,

[...] deixa de constituir um privilégio determinado pela condição econômica e social do indivíduo, para assumir um "caráter biológico", com que ela se organiza para a coletividade em geral, reconhecendo a todo o indivíduo o direito a ser educado até onde o permitiam suas aptidões naturais, independente de razões de ordem econômica e social. A educação nova, alargando sua finalidade para além dos limites das classes, assume, com uma feição mais humana, sua verdadeira função social, preparando-se para formar "a hierarquia democrática" pela "hierarquia das capacidades", recrutadas em todos os grupos sociais, a que se abrem as mesmas oportunidades de educação. Ela tem, por objeto, organizar e desenvolver os meios de ação durável, com o fim de "dirigir o desenvolvimento natural e integral do ser humano em cada uma das etapas de seu crescimento", de acordo com uma certa concepção do mundo.

Ao apresentar o Estado em face da educação, o texto defendeu sua função pública por meio da instituição de escolas oficiais, definindo os princípios da gratuidade, obrigatoriedade e laicidade do ensino, admitindo, contudo, a coexistência com o ensino privado. Ao estabelecer o direito biológico de cada indivíduo à sua educação (MEC, 2010, p. 44), defendeu a escola única, para todos, que rompesse com a existência de escolas distintas para classes sociais diferentes, sobretudo a "[...] quem a estrutura social do país mantém em condições de inferioridade econômica para obter o máximo de desenvolvimento de acordo com suas aptidões vitais" (IDEM, p. 44).

Florestan Fernandes (1989, p.127) considera, sobre este ponto, que os Pioneiros nutriram a ilusão de promover no Brasil a revolução burguesa por dentro da educação, 
desconsiderando que o movimento de transformação do ideal em direito positivo (em leis, portanto) ficaria subjugado às disputas presentes entre os diferentes agentes atuantes no campo político daquele período histórico, sobretudo nas mãos dos representantes das instituições católicas de ensino e dos mantenedores das escolas privadas.

No que se refere ao conteúdo a ser desenvolvido na escola única, destaca-se a unidade entre o fazer escolar e o desenvolvimento integral do indivíduo, o desenvolvimento da autonomia por meio da atividade espontânea, entre outras questões que deveriam, em última análise, conduzir à construção de uma sociedade democrática, na qual se cultivasse e perpetuasse a identidade da consciência nacional em comunhão com a consciência humana (MEC, 2010, p. 65). Essa "grande reforma" somente seria viabilizada por intermédio de um plano de reconstrução nacional, com base no progresso da ciência, traduzida no “[...] impulso de arrastar a burguesia a decisões políticas propriamente revolucionárias" (FERNANDES, 1989, p. 34), que promovessem a articulação entre as etapas e níveis educacionais, rompendo com sistemas paralelos e duais, que reforçam a estratificação social. $\mathrm{Na}$ introdução ao texto do Manifesto, redigida por Fernando de Azevedo, evidenciaram-se algumas passagens nas quais uma crítica ao conteúdo da educação destinada à população se fincou:

Toda a cultura superior, no Brasil, nunca ultrapassou os limites das ambições profissionais. Mas, organizada exclusivamente para a formação profissional, sem qualquer aparelhamento de cultura livre e desinteressada, ela constituiu, no Império e na República, o único sistema de instrução superior, cujas deficiências em vão se procurava suprir com os esforços raramente compensadores da autodidaxia e de viagens de estudos que acabavam frequentemente em viagens de recreio (MEC, 2010, p. 19).

A nossa educação, estranha às realidades nacionais e tradicionalmente baseada no humanismo, correspondia à política educativa do Império, em que, emperrada na escola secundária, de tipo clássico, estritamente literário, o problema da educação nacional, nos seus dois aspectos fundamentais, das universidades e da educação popular, nunca se desprendeu de aspirações e fórmulas vagas (IDEM, p.20).

Ainda no que é pertinente à introdução do Manifesto, destacamos que o documento fez uma ressalva à atuação dos debates parlamentares, que deveriam se centrar nos problemas nacionais, e não apenas em torno do poder, buscando mais do que uma declaração de direitos; uma declaração de deveres (IBIDEM, p. 22). Trouxe a importância dos intelectuais signatários e de sua geração, vistos como "[...] representantes mais altos do seu espírito, a primeira que reagiu contra esses defeitos e inscreveu, no seu programa de ação, as reformas econômicas, sociais e pedagógicas, radicais e profundas" (MEC, 2010, p. 20) e 
da campanha pela educação nacional como "a grande obra, e a de maior alcance, realizada por homens dessa geração, em cujo grupo sólido vieram incorporar-se, identificadas pelos mesmos ideais, outras figuras eminentes" (IDEM, p. 22).

Ainda sobre a influência da vanguarda que dirigiu tal movimento, destacou que a educação pública não se trata apenas de

[...] uma bandeira revolucionária, cuja empunhadura foi feita para as mãos dos verdadeiros reformadores, capazes de sacrificar pelos ideais comuns sua tranquilidade, sua energia e sua própria vida; e um código em que se inscreveu, com as teorias da nova educação infletidas para um pragmatismo reformador, um programa completo de reconstrução educacional, que será mais cedo ou mais tarde a tarefa gigantesca das elites coordenadoras das forças históricas e sociais do povo, no seu período crítico de evolução (MEC, 2010, p. 24).

Assim, considerando-se as instituições pedagógicas e as ideias como produtos possíveis da realidade social e política “[...] Era preciso, pois, examinar os problemas de educação do ponto de vista não de uma estética social [...], mas de uma sociedade em movimento; não dos interesses da classe dirigente, mas dos interesses gerais" (IBIDEM, p. 27). Cabe-nos, pois, destacar a influência de renomados intelectuais na redação e difusão deste documento, agentes deste período.

Fernando de Azevedo apresentou uma visão otimista dos anos de 1930 e do papel da educação neste contexto. O desafio que se colocara naquele momento era o de fazer o governo provisório de Getúlio Vargas romper com a perspectiva modernizadora pautada nas elites e dialogar com tais aspirações. A experiência de Anísio Teixeira à frente da educação nos estados da Bahia (entre 1924 - 1928) e no Distrito Federal (entre 1931 - 1935), o levou a perceber o direito à educação para além de uma esfera formalista, com vistas a uma ruptura efetiva com o sistema dual de ensino.

Estas são as premissas que embasam o Manifesto. Sob o título de "A reconstrução educacional no Brasil. Ao povo e ao governo", os Pioneiros começaram a alinhavar as bases do que julgavam ser os principais problemas da educação nacional - a falta de preparo das forças culturais, o campo educacional como um sistema fragmentado e desarticulado, a falta de determinação dos fins da educação e da aplicação do método científico. Ressaltam que a mudança no cenário educacional brasileiro começou a ocorrer nos anos de 1920 (como mencionamos anteriormente), por meio das reformas em diferentes estados, como evidencia-se a seguir: 
Não tardaram a surgir, no Distrito Federal e em três ou quatro Estados as reformas e, com elas, as realizações, com espírito científico, e inspiradas por um ideal que, modelado à imagem da vida, já lhe refletia a complexidade. Contra ou a favor, todo o mundo se agitou. Esse movimento é hoje uma ideia em marcha, apoiandose sobre duas forças que se completam: a força das ideias e a irradiação dos fatos (MEC, 2010, p. 36).

Colocou-se como problema central a concretização de "uma nova política educacional, que nos preparará, por etapas, a grande reforma" (IDEM, p. 38), que seria a formação da "hierarquia democrática" por intermédio da "hierarquia das capacidades", reconhecendo a todos "o direito de ser educado até onde o permitam suas aptidões naturais", rompendo, enfim, "com a velha estrutura do serviço educacional" (IBIDEM, p.40), que por si somente definia quem nele avançava e quem dele saía.

No que é pertinente ao papel do Estado na garantia do direito à educação, o Manifesto $\mathrm{o}$ apresentou como seu promotor principal, junto à família, na sua variedade de graus e manifestações. Tal formação se daria preponderantemente em uma escola única, pública, laica, gratuita, autônoma (entendendo uniformidade como multiplicidade), descentralizada, contínua, articulada, mediatizada pelo trabalho, científica e obrigatória, pelo menos da faixa etária dos 7 aos 15 anos de idade (MEC, 2010, p. 43-51). Apesar de estabelecer uma faixa etária básica para a aplicação do preceito legal da obrigatoriedade, articulou a educação primária, a educação secundária e a superior de forma orgânica, sem hierarquizá-las em um conjunto estático de valores que desconsideram a dinâmica do real e sua principal característica - a de um organismo maleável e vivo (IDEM, p. 61).

Os princípios ora anunciados foram os pomos da discórdia com alguns grupos, como, por exemplo, o que era constituído por intelectuais e representantes da Igreja Católica, os mantenedores das escolas privadas e os educadores que defendiam uma perspectiva de centralização nas políticas oriundas da esfera federal de governo. Desta forma, a tarefa principal que se colocava os Pioneiros era a de incumbir o Estado de um dever que

[...] exige maior capacidade de dedicação e justifica maior soma de sacrifícios; aquele com que não é possível transigir sem a perda irreparável de algumas gerações; aquele em cujo cumprimento os erros praticados se projetam mais longe nas suas consequências, agravando-se à medida que recuam no tempo; o dever mais alto, mais penoso e mais grave é, decerto, o da educação que, dando ao povo a consciência de si mesmo e de seus destinos e a força para afirmar-se e realizá-los, entretém, cultiva e perpetua a identidade da consciência nacional, na sua comunhão íntima com a consciência humana (IBIDEM, p.65). 
Cabe destacar que a publicação do Manifesto foi precedida pela realização, em Niterói, da IV Conferência Nacional de Educação, organizada pela Associação Brasileira de Educação (ABE), que tinha, entre seus objetivos, a elaboração de uma política educacional, consubstanciada em um plano de educação nacional para a Constituição que viria a ser discutida. Nessa ocasião, foram elaborados um anteprojeto do capítulo da educação para a nova Constituição e um esboço de um plano nacional (FNE, 2011, p.4; PRADO, 2010, p. $34)$.

Eleita uma Assembleia Nacional Constituinte, em 1933, esta recebeu como tarefa adequar a legislação nacional ao novo momento histórico vivido. Florestan Fernandes destaca que destarte a "paz social edificada e garantida pela ditadura Vargas" (1989, p. 35), os Pioneiros alcançaram êxito no que se referia à incorporação de alguns de seus pleitos à carta magna aprovada. Assim, a Constituição de $1934^{15}$, em seu artigo 149, apresentou a educação como direito de todos, devendo ser ministrada pela família e pelos poderes públicos aos nativos e aos estrangeiros aqui residentes, de modo que desenvolvesse o espírito brasileiro e a consciência da solidariedade humana. Fixou a competência da União para traçar "diretrizes" para a educação nacional, estabelecendo um sistema nacional de educação, a ser organizado por meio do Plano Nacional de Educação (PNE), com vistas à busca de soluções para os problemas brasileiros.

Para além do que se refere ao aspecto educacional, introduziu o voto secreto e o voto feminino, criou a justiça do trabalho e as leis trabalhistas - com destaque para a introdução da jornada de 8 horas diárias de trabalho, repouso semanal e férias remuneradas. Percebese, pois, a inspiração na doutrina dos direitos humanos e a influência do Manifesto de 1932, mas a ausência de mecanismos claros para a consolidação do direito proclamado.

A CF de 1934, ao instituir os sistemas de ensino e os conselhos de educação, apresentou uma tarefa ao Conselho Nacional de Educação (CNE): a competência para elaborar um PNE, inspirado nos seguintes princípios:

Art 150 - Compete à União:

a) fixar o plano nacional de educação, compreensivo do ensino de todos os graus e ramos, comuns e especializados; e coordenar e fiscalizar a sua execução, em todo o território do País;

b) (...) Parágrafo único - O plano nacional de educação constante de lei federal, 
nos termos dos arts. $5^{\circ}, \mathrm{n}^{\circ} \mathrm{XIV}$, e $39, \mathrm{n}^{\circ} 8$, letras a e e, só se poderá renovar em prazos determinados, e obedecerá às seguintes normas:

a) ensino primário integral gratuito e de freqüência obrigatória extensivo aos adultos;

b) tendência à gratuidade do ensino educativo ulterior ao primário, a fim de o tornar mais acessível;

c) liberdade de ensino em todos os graus e ramos, observadas as prescrições da legislação federal e da estadual;

d) ensino, nos estabelecimentos particulares, ministrado no idioma pátrio, salvo o de línguas estrangeiras;

e) limitação da matrícula à capacidade didática do estabelecimento e seleção por meio de provas de inteligência e aproveitamento, ou por processos objetivos apropriados à finalidade do curso;

f) reconhecimento dos estabelecimentos particulares de ensino somente quando assegurarem a seus professores a estabilidade, enquanto bem servirem, e uma remuneração condigna.

Ressaltamos que as inquietações dos Pioneiros, no que se refere à necessidade de organização de um PNE que viesse a organizar a educação nacional, tomou corpo neste dispositivo constitucional. Desta forma, o referido Plano foi elaborado no período de 17 de fevereiro a 17 de maio em 50 reuniões plenárias do $\mathrm{CNE}$, resultante de um processo de pesquisa e consulta a diferentes órgãos, instituições, sindicatos, entre outros, além de profícuo debate. O material elaborado veio a constituir “ [...] um código rígido, com 504 artigos, com detalhamento de cursos, currículos, exames e toda a rotina da gestão escolar" (FNE, 2011, p.6).

Contudo, apesar de enviado por mensagem do ministro Gustavo Capanema ao presidente da república, em maio de 1937, o contexto político e social do país que se encontrava em efervescência desde a assunção de Vargas, teve como culminância um golpe de Estado.

Com uma duração bastante limitada, a Constituição Federal de 1934 teve suas garantias suspensas no ano seguinte, com base na lei de segurança nacional promulgada em 4 de abril de 1935, que definia crimes contra a ordem política e social. Sua principal finalidade era transferir para uma legislação especial os crimes contra a segurança do Estado, submetendo-os a um regime mais rigoroso, com o abandono das garantias processuais. Tal 
lei foi acionada como resposta ao que se acreditava ser uma ameaça comunista no país, expressa sobretudo com a criação da ANL - Aliança Nacional Libertadora ${ }^{16}$, com a revolta comunista de 1935, conhecida pejorativamente como Intentona Comunista ${ }^{17}$, e com o suposto plano Cohen, divulgado pela "voz do Brasil", no dia 30 de setembro de 1937. A despeito do fracasso da revolta comunista, esta forneceu elementos para o fechamento do regime por Vargas. Depois de novembro de 1935, o Congresso passou a aprovar uma série de medidas que cerceavam seu próprio poder, enquanto o executivo ganhava poderes de repressão praticamente ilimitados. Esse processo culminou, após a divulgação do referido plano Cohen ${ }^{18}$, com o golpe de Estado de 10 de novembro de 1937, que fechou o Congresso, cancelou eleições e manteve o então presidente no poder. Instituiu-se o chamado Estado Novo, que se estendeu até 1945.

No contexto de retirada dos direitos políticos por uma ditadura, uma nova carta constitucional foi elaborada em 1937. Cabe ressaltar que a lei geral ora promulgada retirou a expressão "direito à educação", apresentando outra perspectiva, como "[...] o dever de solidariedade dos menos para com os mais necessitados". É notória a desresponsabilização do Estado com a garantia da educação pública, gratuita e obrigatória, consagrando a educação privada e, consequentemente, secundarizando a presença estatal, colocada de forma meramente supletiva. Com um caráter altamente centralizador, adequado ao momento histórico de supressão das liberdades individuais do Estado Novo, inviabilizou o Plano Nacional de Educação (PNE) que estava sendo gestado e elaborou as Leis Orgânicas de Ensino, também conhecidas como "Reforma Capanema", implantadas por uma série de decretos-leis baixados entre 1942 e 1946.

Antes, porém, em 1941, por intermédio do Decreto $n^{\circ} 6788$, foi convocada a realização da primeira conferência de educação, na qual Capanema objetivou elaborar um código da educação nacional, que não chegou a termo devido à declaração de guerra à Itália e à Alemanha, em 1942. Seriam, pois, os objetivos do referido código:

a) Iniciar o estudo das bases de organização de um programa nacional de educação, síntese dos objetivos da educação nacional e sistema dos meios de atingi-los pelo esforço comum da ação oficial e da iniciativa privada;

b) Estudar as linhas gerais de organização dos sistemas educativos regionais, inclusive a estrutura e o processo de sua administração; 
c) Examinar, de modo especial, a situação do ensino primário e do normal no país, não só para que possam fixar as diretrizes gerais de organização dessas duas modalidades de ensino, mas ainda para o estabelecimento de medidas de ordem administrativa e financeira tendentes à sua difusão e melhoria;

d) Examinar a situação em que se encontra no país o ensino profissional e técnico, de todos os ramos (industrial, agrícola, comercial, etc), para o fim de ser estabelecido o processo de sua coordenação sob uma só direção, de seu desenvolvimento e de sua adequação às necessidades nacionais;

e) Assentar as medidas de ordem administrativa que possibilitem a imediata organização da Juventude Brasileira em todas as escolas do país (FNE, 2011, p.7).

Diante dos fatos expostos, segundo Ribeiro (2003), a regulamentação do ensino foi levada a efeito a partir de 1942, com a denominação de Leis Orgânicas do Ensino, tal como apresentado nos parágrafos precedentes. Em linhas gerais, cabe destacar que ela estruturou o ensino industrial, reformou o ensino comercial e criou o Serviço Nacional de Aprendizagem Industrial - SENAI, como também trouxe mudanças no ensino secundário, por intermédio dos decretos-lei que se seguem:

$\checkmark \mathrm{n}^{\mathrm{o}} 4.073$, de 30 de janeiro de 1942 - organizou o ensino industrial;

$\checkmark \mathrm{n}^{\circ} 4.048$, de 22 de janeiro de 1942 - instituiu o SENAI;

$\checkmark \mathrm{n}^{\mathrm{o}} 4.244$ de 9 de abril de 1942 - organizou o ensino secundário em dois ciclos: o ginasial, com quatro anos, e o colegial, com três anos;

$\checkmark \mathrm{n}^{\mathrm{o}}$ 6.141, de 28 de dezembro de 1943 - reformou o ensino comercial.

Após a queda do Estado Novo e a assunção provisória da presidência por José Linhares, então presidente do Supremo Tribunal Federal, em outubro de 1945, foi apresentada a Lei Orgânica do Ensino Primário, que organizou esse nível de ensino com diretrizes gerais, a saber: este continuou a ser de responsabilidade dos estados; organizou o ensino primário supletivo, com duração de dois anos, destinado a adolescentes a partir dos 13 anos e adultos; organizou também o ensino normal e o ensino agrícola; e criou o Serviço Nacional de Aprendizagem Comercial - SENAC. Nesse momento o Ministério da Educação estava a cargo de Raul Leitão da Cunha. Foram criados os seguintes DecretosLei:
$\checkmark \quad \mathrm{n}^{\mathrm{o}} 8.529$, de 02 de janeiro de 1946 - organizou o ensino primário a nível nacional;


$\begin{array}{ll}\checkmark & \mathrm{n}^{\mathrm{o}} 8.530, \text { de } 02 \text { de janeiro de } 1946 \text { - organizou o ensino normal; } \\ \checkmark & \mathrm{n}^{\mathrm{o}} 8.621 \text { e } 8.622 \text {, de } 10 \text { de janeiro de } 1946 \text { - criaram o SENAC; } \\ \checkmark & \mathrm{n}^{\mathrm{o}} 9.613 \text { de } 20 \text { de agosto de } 1946 \text { - organizou o ensino agrícola. }\end{array}$

A criação da Associação de Educação Católica do Brasil também foi um dado relevante do período. AAEC se apresentou como forma de resistência das escolas católicas, tão influentes à época, ao que consideravam ser o processo de estatização do ensino. Desta forma, colocou em relevo a importância da tarefa da família para com a educação, secundarizando o papel do Estado:

O contexto político da fundação da AEC indicava o principal adversário a ser enfrentado pelos católicos: a concepção liberal de uma educação escolar ordenada e ministrada pelo Estado laico. O Ministério da Educação tornou-se o símbolo da presença e da interferência estatal na vida das escolas privadas. Ao longo da obra, são inúmeras as críticas à ação do Estado, representado pela "força invasiva" do Ministério da Educação, e a afirmação de que o direito de educar cabe às famílias, que devem escolher a forma mais adequada aos seus filhos, em reação a processos “uniformizantes" impostos pelo Estado (SENRA, 2017, p. 3).

A AEC buscou agregar os fiéis à Igreja por meio da mobilização política e jurídica, estabelecendo alianças para evitar o avanço do papel do Estado na educação escolar e, ao mesmo tempo, garantir condições privilegiadas para a sobrevivência da rede escolar católica. Assim, foi estratégica a sua fundação ter se realizado no momento de redemocratização do país, na medida em que ajudaria a influenciar na elaboração dos dispositivos legais que deveriam ser criados - a nova CF e, por conseguinte, a primeira LDBEN do Brasil. A entidade atacou de frente os intelectuais que assinaram o Manifesto, por meio de um trabalho vigoroso de perseguição e difamação dos mesmos, a exemplo do que aconteceu com Anísio Teixeira.

Após a convocação de novas eleições, assumiu a presidência o candidato vitorioso nas eleições, o general Eurico Gaspar Dutra, dando início à República Nova. A necessidade da elaboração de "diretrizes" e "bases" para a educação nacional somente reapareceu no texto constitucional de $1946^{19}$, que desencadeou a discussão da primeira LDBEN. Fernandes (1989, p. 35-36), ao analisar este período, destaca que

A efêmera constituição [1934] somente descortinou essas esperanças. Elas reapareceram mais tarde nos debates que cercaram a elaboração da carta 19 Disponível em: http://www.planalto.gov.br/ccivil_03/constituicao/constituicao46.htm. Acesso em: 06 ago. 2014. 
constitucional de 1946, na qual há um recuo, embora o projeto de democratização do ensino continuasse a brilhar e o dispositivo sobre a competência da União de legislar sobre as diretrizes e bases da educação nacional se mantivesse (cf. art. $\left.5^{\circ}, \mathrm{XV}, \mathrm{c}\right)$. Nesse ínterim, o ambiente se modificara substancialmente. Os pensadores e os educadores católicos se lançaram à luta contra os pioneiros da educação nova. Os liberais revelaram temor de que os ganhos na descentralização não fossem suficientemente compensados pelas ameaças da intervenção do Estado na organização do ensino [...] Os proprietários de escolas a pagamento entraram decididamente na liça [...] Os educadores sustentaram suas posições com ardor. Mas não podiam fazer face aos ataques que vinham de várias direções.

\subsection{A CONSTITUIÇÃO DE 1946, O MANIFESTO DE 1959 E A CAMPANHA NACIONAL EM DEFESA DA ESCOLA PÚBLICA: LONGOS ANOS DE DISCUSSÃO PARA A ELABORAÇÃO DE UMA LEI DE DIRETRIZES E BASES PARA A EDUCAÇÃO NACIONAL}

A organização dos setores educacionais no processo de elaboração da primeira LDBEN devia-se ao entendimento de que a formulação de leis não poderia estar atrelada apenas aos interesses dos grupos que operam o executivo, posto que estes, por vezes, encontram-se comprometidos com outros pendores que não são os que de fato dizem respeito à preocupação com a matéria educacional. Com base em uma perspectiva de grande política, entendendo esta como "movimentos orgânicos (relativamente permanentes)" que devem ser diferenciados "dos movimentos que podem ser chamados de conjuntura (e que se apresentam como ocasionais, imediatos, quase acidentais)" (GRAMSCI, 2004, p.36, Caderno 13, §17), percebem a necessidade de não fragmentar a análise da realidade por meio da supervalorização da educação, tampouco pela subvalorização da mesma, mas respeitando a complexidade das relações que se estabelecem neste campo, que se coloca como estratégico para a formação da hegemonia - pelos grupos dominantes - ou da contrahegemonia - pelos grupos dominados.

O processo de tramitação da primeira LDBEN, aprovada em 1961 (Lei no 4.024), após um longo debate em que interesses de grupos antagônicos disputavam a hegemonia do espaço social é, grosso modo, o resultado da disputa de dois grandes projetos de educação: o dos defensores do sistema educacional privado e do sistema público. Os primeiros viam a família como responsável pela educação de seus filhos, sendo esse discurso, na verdade, uma estratégia para que o Estado viesse a se desresponsabilizar de seu papel 
de provedor de políticas públicas e continuasse concedendo verbas ou subsídios para as escolas particulares, principalmente as católicas, que possuíam a maioria das escolas de grau secundário e que tinham fortes lobistas, como Carlos Lacerda.

A segunda perspectiva era a dos defensores do sistema oficial de ensino, público e laico, que percebiam a democratização do ensino como caminho para a democratização da sociedade. Esta não era somente a disputa por uma visão de educação; era, sobretudo, a definição de uma questão política, que buscava a conciliação entre a burguesia nacional e as classes mais tradicionais, ligadas ao capital internacional. Carvalho e Vianna (2000, p. 26) descrevem o período da discussão da LDBEN, que se iniciou na segunda metade dos anos de 1940, como a retomada da perspectiva liberal, porém com uma nova roupagem:

No âmbito da ordem de 1946, que retomou o ideário liberal combinando-o com a ordem corporativa anterior, à medida que se ampliavam as liberdades, as instituições daquele sistema passaram a abrigar processos tendentes a uma efetiva autonomização da vida associativa, inclusive do mundo do trabalho, favorecendo uma concepção de república orientada por valores comunitários, em que o indivíduo, apesar de reconhecido como ente dotado de autonomia e portador de direitos próprios, se via envolvido com a ideia de bem comum. Assim, na ordem de 46, procurou-se harmonizar os pressupostos do indivíduo com os direitos de grupos sociais, dando origem a uma ideologia particular de setores majoritários das elites - o liberal-comunitarismo. A ideia predominante de república ganhou, então, um contorno mais largo e impreciso, dependente de uma crescente mobilização e participação sociais em nome do bem comum, que pressupunha a erradicação do patrimonialismo.

Neste contexto, a publicação de uma nova Constituição após um grande intervalo nas discussões inauguradas pelos Pioneiros, trouxe novamente a organização dos Sistemas Estaduais de Ensino (SEE), no artigo 169, assim como definiu como competência da União a elaboração das diretrizes e bases da educação nacional - artigo $5^{\circ}$, inciso XV, alínea $\mathrm{d}$ (DAVIES, 2004, p. 23-25).

Faria e Souza (2003, p. 49) informam que a polêmica centralização/ descentralização continuou presente neste período, pois em seu texto final, a CF de 1946 expressou a responsabilidade da União na forma de uma ação supletiva, que deveria ser instaurada somente quando as administrações locais não apresentassem condições de cumprirem com suas metas administrativas. Outro fato que merece destaque é a ressalva feita pelo legislador no inciso II, artigo 168, que versava sobre o direito à gratuidade do ensino secundário, que somente poderia ser acionado pelos que pudessem comprovar insuficiência de recursos. Assim, ainda no que se refere ao direito à educação, resgatamos o texto da lei, como forma 
de melhor nos auxiliar nesta reflexão ${ }^{20}$ :

Art 166 - A educação é direito de todos e será dada no lar e na escola. Deve inspirar-se nos princípios de liberdade e nos ideais de solidariedade humana. Art 167 - O ensino dos diferentes ramos será ministrado pelos Poderes Públicos e é livre à iniciativa particular, respeitadas as leis que o regulem.

Art 168 - A legislação do ensino adotará os seguintes princípios: I - o ensino primário é obrigatório e só será dado na língua nacional; II - o ensino primário oficial é gratuito para todos; o ensino oficial ulterior ao primário sê-lo-á para quantos provarem falta ou insuficiência de recursos; III - as empresas industriais, comerciais e agrícolas, em que trabalhem mais de cem pessoas, são obrigadas a manter ensino primário gratuito para os seus servidores e os filhos destes; IV as empresas industrias e comerciais são obrigadas a ministrar, em cooperação, aprendizagem aos seus trabalhadores menores, pela forma que a lei estabelecer, respeitados os direitos dos professores; V - o ensino religioso constitui disciplina dos horários das escolas oficiais, é de matrícula facultativa e será ministrado de acordo com a confissão religiosa do aluno, manifestada por ele, se for capaz, ou pelo seu representante legal ou responsável;VI - para o provimento das cátedras, no ensino secundário oficial e no superior oficial ou livre, exigir-se-á concurso de títulos e provas. Aos professores, admitidos por concurso de títulos e provas, será assegurada a vitaliciedade; VII - é garantida a liberdade de cátedra.

Anísio Teixeira (1968, p. 69), ao analisar a nova lei, parte da ideia de educação como direito que nela se expressa. Direito individual à escola para todos os brasileiros, sendo obrigatória a frequência no ensino primário, que, por sua vez, também é encargo do Estado. Sua crítica se baseia no fato da lei impor a participação de todos os brasileiros no ensino primário sem, no entanto, oferecer caminhos para o estímulo e a promoção deste direito. A Constituição prevê a destinação de recursos para cada ente com a finalidade de garantir que os mesmos possam dispor dos recursos necessários para as despesas que lhe são vinculadas ordinariamente. Desta forma, a ênfase é no ensino primário. Os demais níveis de ensino, por não terem o caráter de obrigatoriedade, só poderiam ser financiados após o atendimento constitucional a este. Argumenta ainda sobre o dever solidário entre os entes federados para o cumprimento do que se encontra disposto na $\mathrm{CF}$.

No que se refere à importância da participação familiar na educação, percebese que tal instituição precede à escolar. Anísio Teixeira então afirma que a vinculação à família objetiva priorizar o meio local como importante agente socializador e educador do indivíduo. Caberia, portanto, à escola primária “[...] inserir-se no meio local, devolvendo a criança por intermédio deste seu meio, a fim de que as experiências de ensino tenham raízes e o indispensável caráter integrativo que as deve marcar" (1968, p. 72). Nota-se a influência de Dewey na análise do autor, que objetiva claramente romper com o que chama 20 Disponível em http://www.planalto.gov.br/ccivil_03/Constituicao/Constituicao46.htm. Acesso em 08.dez. 2015 
de "caráter de transplantação" da nossa evolução como sociedade, que enraizou a escola de caráter civilizatório em nossa realidade, como entidade superior, forma de promover a aculturação.

O mote da família viabilizou que a proposta da AEC, pautada nas orientações do Vaticano, ganhasse peso nas discussões do campo educacional. A primazia da educação familiar sobre a escolar objetivava o resgate de valores morais em contrapartida à liberdade do Estado e aos demais elementos trazidos pela modernidade. Assim, a educação era percebida como uma forma avançada e importante de anunciação do evangelho cristão, capaz de arregimentar "almas" para a Igreja. Desta forma, buscaram-se alianças para, dentre outras ações, influenciar parlamentares na defesa de tais propostas no processo de elaboração da LDBEN. Nas palavras do primeiro presidente da AEC:

Uma das grandes bandeiras, do início deste período, era a defesa do pluralismo, da liberdade e da democratização do ensino. A educação católica, praticamente, hegemônica até o final do período do padroado, deparava-se agora, com a expansão do ensino público, laico e liberal, o fortalecimento do marxismo e o avanço da educação protestante, em várias capitais e grandes cidades brasileiras. Tudo isso criava exigências e dificuldades para a escola católica e levava a AEC, seguindo as orientações da Igreja, a: combater o monopólio estatal no campo da educação, que esbarrava de frente com a liberdade de ensino, e, portanto, com o ensino particular confessional; [...] ajudar a Igreja a resgatar a confiança de que gozara junto ao governo, em outras circunstâncias da história brasileira, além de: encontrar aliados na defesa dos valores humanistas e cristãos, no campo da educação (CRUZ, 1966, p. 82).

Neste sentido, concordamos com Montalvão (2013, p. 296), quando afirmou que uma das maiores batalhas travadas pela AEC como entidade representativa das escolas católicas no cenário nacional foi a defesa da manutenção da educação escolar como prolongamento dos valores " $[. .$.$] pregados no culto dominical, no catecismo e demais encontros paroquiais,$ originando elites capazes de influenciar a convivência política e ideológica, de enfrentar os efeitos perversos da modernização econômica e da secularização da cultura, em curso na metade do século XX”. Caberia, portanto, à família a tarefa precípua na formação das novas gerações, sendo do Estado o ente de apoio à instituição familiar.

No bojo de um debate ideológico acerca da relação entre educação e desenvolvimento, os anos de 1950 a 1960 testemunharam o nascimento de um grande movimento em defesa da escola pública, protagonizado, em grande medida, por Florestan Fernandes. Assim, podese afirmar que a Campanha em Defesa da Escola Pública foi um movimento "[...] liderado por educadores da velha geração dos "pioneiros", com a participação de profissionais de 
outros ramos, intelectuais, estudantes e líderes sindicais" (SILVA, 2005, p.83).

Tal como dito anteriormente, a etapa final de discussão da Lei Federal n ${ }^{\circ}$ 4.024/1961 - a primeira LDBEN - envolveu interesses distintos e se acirrou com a apresentação do "substitutivo Lacerda", em 1958, após um longo processo iniciado em 1948, sob o número 605, ano em que Clemente Mariani, então ministro da Educação e da Saúde, encaminhou o projeto inicial ao presidente Eurico Gaspar Dutra (SAVIANI, 2008, p. 32). Com a intenção que a LDBEN desencadeasse uma "revolução" educacional, o projeto logo gerou a mobilização do deputado Gustavo Capanema, que considerou o mesmo uma atitude política antigetulista, e não apenas um texto educacional, em parecer emitido no ano seguinte. Arquivado, desarquivado em 1951, com extensos períodos de tramitação na Comissão de Educação e Cultura da Câmara dos Deputados - cinco anos e meio - somente em 1957 chegou ao plenário daquela Casa, consideravelmente emendado. Não foi votado na ocasião, sendo arbitrariamente retirado da ordem do dia devido à apresentação do texto de Carlos Lacerda, identificado a partir de então pelo $\mathrm{n}^{\circ}$ 2.222/1957.

No plano nacional vários fatos importantes já haviam se desenrolado: o retorno de Getúlio Vargas à presidência, por meio de eleições diretas, em 1950; a criação da Petrobrás, fruto de tendências nacionalistas no pensamento político e econômico; entre outros. Também ocorreram uma série de denúncias sobre grupos ligados a Getúlio, o que fez grande parte da opinião pública se voltar contra quem já fora conhecido como o pai dos pobres. A vinculação de seu nome a episódios de corrupção; a tentativa de assassinato a Carlos Lacerda por membros de sua guarda pessoal, por exemplo, desencadearam uma grave crise que o levou ao suicídio em agosto de 1954, logo depois de sua última reunião ministerial, na qual fora aconselhado por seus ministros a se licenciar da presidência. Este ato trouxe à cadeira presidencial o então vice-presidente João Fernandes Campos Café Filho.

Em 1955, Juscelino Kubitschek foi eleito presidente, tomando posse em janeiro de 1956. Cabe ressaltar que desde o lançamento de sua candidatura teve início uma movimentação que solicitava a intervenção militar no país, já que Juscelino era visto como elemento ligado às forças getulistas. Uma vez eleito, setores da União Democrática Nacional (UDN) pregaram a deflagração de um regime militar por meio da inviabilização das eleições, liderados por Carlos Lacerda. Tendo o presidente Café Filho adoecido neste conturbado período, travou-se uma disputa sobre sua sucessão. Carlos Luz, presidente da Câmara foi declarado impedido pelo Congresso Nacional, apresentando-se a nomeação de 
Nereu Ramos.

Tendo garantido seu direito de posse, o governo de Juscelino Kubitschek se caracterizou pelo chamado desenvolvimentismo, doutrina que se detinha nos avanços técnicos e industriais como suposta evidência de um avanço geral do país. Seu lema foi 50 anos em 5: rompeu com o Fundo Monetário Internacional (FMI), devido às condições por ele oferecidas; herdou de seus predecessores uma economia instável e com inflação crescente, optando por se abrir ao capital estrangeiro como forma de conter a inflação, inclusive com a possibilidade de reatar relações com a antiga URSS (União das Repúblicas Socialistas Soviéticas). Porém, novamente rompeu relações com o FMI. Cabe ressaltar que mesmo diante do cenário conturbado em 1960, Kubitschek inaugurou Brasília, a nova capital do Brasil, e a Universidade de Brasília, tendo transmitido a seu sucessor, o presidente eleito Jânio Quadros, um país com enormes contradições.

Voltemos ao terreno educacional. Destaca-se que o "substitutivo Lacerda" incorporou as conclusões do III Congresso Nacional dos Estabelecimentos Privados de Ensino, que teve lugar em 1948. Saviani (2008, p.38-39) ressalta que ao final de 1956 se recrudesceu a oposição dos defensores da iniciativa privada, expressa fervorosamente nos discursos do deputado padre Fonseca e Silva, como nos relata o autor:

[...] ele se insurge contra a orientação filosófica do INEP, que era dirigido por Anísio Teixeira, além de atacar também o I Congresso Estadual de Educação Primária [...] acusa Anísio Teixeira de comunista e aproxima o pragmatismo de Dewey do marxismo [...] Desencadeia-se, assim, o conflito entre escola pública e escola particular que irá polarizar a opinião pública do país até 1961.

Segundo Montalvão (2013, p. 298), o padre e deputado levava à tribuna sua preocupação com a relação entre pragmatismo e marxismo, que levaria às escolas e às novas gerações o perigo do distanciamento com a Igreja. Desta forma, considerava que a vontade de democratizar a educação coincidia com o ataque ao trabalho das instituições confessionais católicas, consideradas um empecilho para que a ação estatal ocorresse sem constrangimentos. Atacar Anísio, grande difusor das ideias de Dewey no Brasil, era afrontar a ameaça liberal e "comunista", de forma que "A missão apostólica seria evitar que a sociedade cristã brasileira - especialmente os mais fracos, crianças, jovens e mulheres caíssem na pregação revolucionária" (IDEM, p. 301). Destacou-se, ainda no ano de 1958, a realização da Conferência dos Religiosos do Brasil, órgão ligado à Igreja católica, que, inspirada nas encíclicas papais, objetivava ganhar espaço na discussão política e educacional do país, lançando em sua revista periódica um apelo público aos católicos no sentido de 
alertá-los quanto às concepções filosófico-educacionais de Anísio Teixeira.

Com a defesa explícita das escolas privadas e confessionais, o referido texto legal definia a educação como "[...] formação integral da personalidade [...], respeitando os direitos fundamentais e a liberdade do homem, sempre orientada para o bem comum" (SAVIANI, 2008, p. 55), a ser viabilizada pela família, cabendo ao Estado oferecer recursos para que esta se desobrigasse do encargo educacional, por meio das escolas de iniciativa particular ou pelo ensino oficial (conforme expresso no artigo $4^{\circ}$ e $5^{\circ}$ ). Tal perspectiva ficou bastante evidenciada em diversos trechos, em que ficava vedado ao Estado exercer o monopólio do ensino (artigo $6^{\circ}$ ); em que a igualdade de condições entre as escolas oficiais e privadas foi defendida, quer seja por meio da representação nos órgãos competentes, quer seja pela distribuição de verbas de maneira proporcional, ou mesmo pelo reconhecimento dos estudos realizados nos estabelecimentos privados (artigo $7^{\circ}$ ). No que se refere às competências do Estado, o mesmo não teria autonomia para fiscalizar as escolas, fazendo esse trabalho apenas quando solicitado (artigo 10). Por fim, os recursos públicos deveriam ser distribuídos sob a forma de "cooperação financeira" entre a União e o ensino privado em todos os níveis (artigo 70).

E foi em reação à ideia de "educação livre", defendida no texto de Lacerda - livre da fiscalização do Estado, mas remunerada pelos cofres públicos - que se contrapuseram alguns educadores brasileiros que tornaram a publicar um manifesto - o Manifesto dos educadores mais uma vez convocados, datado de 1 de julho de 1959 e redigido, novamente, por Fernando de Azevedo. Baseado na concepção de liberdade disciplinada pelo Estado, que difere da perspectiva do monopólio da educação pelo mesmo, mas que também não coaduna com a de "educação livre" acima exposta, o Manifesto de 1959 defendia a escola pública, fundada sob a inspiração dos ideais democráticos, ou seja, da escola pública, da educação liberal e democrática, voltada para o trabalho (MEC, 2010, p. 87). Concordamos com Vianna e Carvalho (2000, p. 26) quando afirmam que:

\footnotetext{
Naquele contexto, para os portadores da questão igualitária, ampliar a cidadania e democratizar a República reclamavam uma participação e uma mobilização crescentes, na medida em que as instituições careciam de procedimentos democráticos por onde pudessem transitar os temas substantivos da democratização social do país.
}

Outro aspecto que é necessário destacar relaciona-se ao direito à educação, mote principal do documento em questão. Partindo da crítica às instituições de ensino privadas 
que, em muitos casos, assemelhavam-se a "balcões de comércio" (MEC, 2010, p. 87), o Manifesto de 1959 defendia, como vimos, a liberdade de ensino disciplinada pelo Estado, pela via liberal e democrática, com vistas à ampliação da oferta educacional por parte dos Estados modernos. Dessa forma, sustentou-se a necessidade da escola pública, universal, gratuita, obrigatória e integral (IDEM, p. 90), assentada sobre os princípios do respeito à pessoa humana, à disciplina consciente, aos princípios morais, cívicos e solidários, à educação para o trabalho e desenvolvimento econômico e para a transformação do homem e de seu universo, o que se evidencia na seguinte observação:

$\mathrm{Na}$ educação formal, universalização, obrigatoriedade e gratuidade formam parte de um único processo. A obrigatoriedade e a gratuidade da educação representam, simultaneamente, a garantia da universalidade do acesso à educação, ao tempo em que asseguram o direito do homem à educação (DIAS, 2014, p. 449).

Pasinato (2013) afirma que a principal diferença entre o texto produzido em 1932 e o de 1959 é que o primeiro motivou as discussões que deram origem à Constituição Federal de 1934, que, por sua vez, já apresentava a necessidade de elaboração de diretrizes para a educação nacional. O segundo, de forma distinta, foi resultado das disputas de posição em um embate ideológico sobre a concepção na qual se assentaria a escola brasileira. $\mathrm{O}$ autor traz ainda o significado de público no pensamento de três intelectuais signatários do Manifesto de 1959: Anísio Teixeira, Paschoal Lemme e Florestan Fernandes.

Segundo Pasinato (2013, p.4), Anísio Teixeira estabeleceu uma crítica à educação privada católica, que estimulava o espaço de formação doutrinária em detrimento de um conhecimento acessível a todos. Tal conhecimento, portanto, é de interesse público, posto que dele depende o desenvolvimento da sociedade. Paschoal Lemme (IDEM, p.9), por sua vez, promoveu uma discussão a respeito da subvenção estatal aos estabelecimentos privados de ensino, assim como ao ensino confessional, em contrapartida ao ensino laico. Por fim, afirma que, para Florestan Fernandes (IBIDEM, p.6), um país somente poderia ser democrático quando promovesse a democratização do ensino, uma vez que é a escola pública a instituição responsável pela democratização da sociedade em geral. Neste sentido, combateu o argumento de que o Estado democrático não deve incentivar a distinção entre esfera pública e privada, uma vez que esta concepção de vida social restringe o uso da educação por uma elite, mantendo privilégios de classe. Esta é a linha originária da já mencionada Campanha em Defesa da Escola Pública.

Santos (2010, p. 3), em seu estudo sobre a atuação de Florestan na referida Campanha, ratifica que, para o intelectual ora apresentado, a educação no Brasil nunca fora vista como 
incômodo, como um "problema social" e que, portanto, prescindia de preocupação e de empenho coletivo na busca por sua melhoria. Tornou-se estratégico, pois, trazer a educação para o centro do debate acerca da modernização e do desenvolvimento do país, pautando a discussão educacional na perspectiva da necessidade de superação do atraso brasileiro nesta questão, por meio da democratização do acesso de todos à educação pública. Buscouse romper com uma política "coronelista", traço marcante na política brasileira, pelo viés da resolução dos problemas educacionais, de natureza tanto quantitativa quanto qualitativa.

Destarte a movimentação causada entre diferentes setores nacionais, em 29 de setembro de 1959 foi apresentada uma nova redação ao substitutivo que então se encontrava em tramitação na Câmara, tendo esta sido aprovada em 10 de dezembro. Tal versão manteve “[...] a estrutura do projeto original, enxertou-lhe um conteúdo que contrariava a orientação de fundo que presidira a formulação do primeiro projeto" (SAVIANI, 2008, p. 42).

Em meio à mobilização da Igreja, da imprensa, da União Nacional dos Estudantes (UNE), do Ministério da Guerra, dentre outros grupos/setores, que se fizeram representar nas acaloradas discussões por meio de manifestos, moções e sugestões, em maio de 1960, na I Conferência Estadual de Defesa da Escola Pública, realizada em São Paulo, Florestan Fernandes proferiu uma palestra intitulada $A$ democratização do ensino. Cabe ressaltar que muitos esforços foram por ele empreendidos no sentido de discutir a educação como objeto científico e como campo de intervenção prática, posto que o sociólogo não poupou esforços para apresentar trabalhos a respeito da temática, buscando forjar um bloco contrahegemônico, por meio da mobilização da opinião pública contra a aprovação do projeto de lei defendido pelos privatistas e pelos grupos ligados à Igreja. No dia 30 de janeiro de 1960, iniciou a publicação de uma série de três artigos intitulados Em defesa da escola pública, no qual demonstrou que a aprovação do projeto na Câmara era um verdadeiro ataque dos grupos privados contra o Estado democrático em seus alicerces, para conduzir o governo aos modelos fornecidos pelo autoritarismo e pelo corporativismo.

A Campanha em Defesa da Escola Pública eclodiu, praticamente, a partir da indignação provocada, em quase todos os círculos da sociedade brasileira, pelo projeto de lei aprovado na Câmara dos Deputados. O repúdio partiu de todos os meios responsáveis para exigir a rejeição do projeto de lei. As entidades e setores mobilizados em torno da questão pressionaram o Senado Federal através de inúmeras manifestações. Na verdade, o projeto de lei aprovado pela Câmara dos Deputados lançou à nação o desafio de problematizar as posições adotadas pelos círculos reacionários e obscurantistas, que se opuseram de todas as maneiras à reconstrução educacional. Apresentaram-se, assim, os princípios da Campanha: 
Em primeiro lugar, o nosso objetivo central é a qualidade e a eficácia do ensino. Se defendemos a Escola Pública, fazemo-lo porque ela oferece condições mais propícias, num país, de produzir "bom ensino" e de proporcioná-lo, sem restrições econômicas, ideológicas, raciais, sociais ou religiosas, a qualquer indivíduo e a todas as camadas da população.[...] Em segundo lugar, pretendemos impedir que o Estado Democrático continue prisioneiro de interesses particularistas na esfera da educação, com perda maior ou menor de sua autonomia para a realização das tarefas educacionais que lhe competem administrativamente e politicamente, e com a devastação improdutiva dos recursos oficiais destinados à educação. (...) Em terceiro lugar, pretendemos esclarecer e alertar as opiniões para que todos os cidadãos patriotas e responsáveis, independentemente do seu saber e prestígio, venham a preocupar-se com os problemas educacionais brasileiros e com sua solução, colocando-se, assim, em condições de influenciar, pelos mecanismos normais do regime democrático, as decisões e orientações dos partidos e do governo nesse campo (FERNANDES, 1960, p.186).

Com as pressões advindas da Campanha e após a apresentação à Câmara dos Deputados de um novo substitutivo de caráter conciliatório pelo deputado Celso Brant (1959), em fevereiro de 1960, foi aprovado por aquela casa legislativa, sendo encaminhado ao Senado, onde recebeu mais algumas emendas. Finalmente aprovada em 1961, como “uma 'solução de compromisso' entre as principais correntes em disputa" (SAVIANI, 2008, p. 46), acionou-se "[...] o pacto das elites (conciliação pelo alto) através do qual se torna possível preservar os interesses dos grupos privilegiados [...] adiando-se para um futuro indefinido a realização das aspirações das massas populares" (IDEM, p.47). À lei aprovada, Florestan Fernandes teceu severas críticas, dentre as quais destacamos a seguinte:

Em suma, as limitações fundamentais do projeto de Diretrizes e Bases derivam da maneira pela qual o legislador se vinculou, subjetiva e politicamente, com a ordem social existente. Na situação histórico-social do Brasil, um projeto dessa natureza teria de conter, forçosamente, normas que ajustassem os diferentes tipos de ensino, isoladamente, e o sistema nacional de ensino, como um todo, aos processos que estão transformando a sociedade brasileira em uma sociedade de classes, de economia capitalista e de regime político democrático. Seria preciso remover todos os resíduos do antigo regime, que obstruem nossa capacidade de progresso educacional (FERNANDES, 1966, p. 363).

Ao Estado fez a acusação de "coveiro de suas próprias escolas" (OLIVEIRA, 2010, p. 50), posto que a vitória da LDBEN representava a força da Igreja católica e dos setores empresariais que se dedicavam à tarefa educacional, assim como a resistência das elites brasileiras à proposta de mudanças sociais mais profundas e, consequentemente, a perda de poder nos campos político e econômico. Afirmou que há um rancor das elites aos princípios socialistas e, ainda, às próprias concepções liberais das reformas educacionais, uma vez 
que no Brasil a educação não era pensada para as massas.

Apesar de socialista, Florestan destacou a importância dessas reformas na criação de homens que viessem a atender às demandas do tempo histórico, mesmo que para alimentar, em um primeiro momento, à ordem burguesa, onde a educação tivesse o claro papel de desenvolver seu raciocínio abstrato e a sua capacidade de formulação, para então, em um momento posterior, promover uma verdadeira revolução educacional e social. Porém, é importante destacar que os conceitos de democracia e socialismo estão profundamente vinculados, como afirma Semeraro (2002, p. 31-32) e como acreditava Florestan Fernandes:

Se entendemos democracia como um processo, como socialização crescente da política no rumo da socialização do poder, como uma conquista efetiva não só de regras do jogo (e é claro que somos a favor de regras do jogo, regras do jogo que mudam, se aprofundam, se transformam) mas também de igualdade substantiva, então é preciso dizer com clareza que essa democracia é claramente incompatível com o modelo político, econômico e social que está sendo implementado no país [...] Se entendermos por socialismo a criação de condições para que a igualdade seja efetiva não só no plano econômico-social, mas também no plano político para que, ao lado da socialização dos meios de produção, haja também socialização de poder-, então devemos ter claro que não há democracia plenamente realizada sem socialismo.

O clima de tensão vivenciado pela educação não estava descolado da vida do país. Elegeu-se, em 1960, Jânio Quadros para a sucessão de Juscelino Kubitschek com uma votação expressiva. O novo presidente combinou promessas ousadas - "varrer" a corrupção, acabar com a inflação, combater a burocracia e as formas arcaicas de governo - com medidas de pequenas dimensões - proibiu o uso de maiôs e biquínis nos concursos de miss, a realização de rinhas de galo e o uso de lança perfumes, por exemplo. Fomentou muitas polêmicas, dentre as quais algumas das mais graves foram a condecoração de Ernesto "Che" Guevara; a criação da PEI - Política Externa Independente; as medidas de austeridade na política interna; e o combate aos movimentos esquerdistas. Em agosto de 1961 renunciou motivado por "forças terríveis".

Devido à sua renúncia, caberia a faixa presidencial ao vice-presidente, identificado como simpatizante do comunismo, o que causou grande movimentação nos bastidores da política. Na ocasião, inclusive, o mesmo se encontrava em visita à Singapura. Com a adoção do regime parlamentarista, e consequente redução dos poderes presidenciais, finalmente os militares aceitaram que João Goulart assumisse seu mandato. O primeiro ministro do Brasil foi Tancredo Neves. Apesar da tentativa de ampliação de sua base governista, a aproximação com grupos à esquerda sempre causou preocupação nos setores mais reacionários. 
Diante do retorno ao presidencialismo - em 1963, de uma grave crise econômicofinanceira e diversos descontentamentos no campo político, “[...] a agitação contra Goulart recrudesceu, unificando contra seu governo proprietários de terras, interesses norteamericanos que conspiravam através da Embaixada, e a maioria das forças armadas" (CPDOC, 2015c, p.4). Estavam dadas, pois, as condições para a instalação de um governo militar, por meio do golpe deflagrado em 31 de março de 1964.

\subsection{A DITADURA EMPRESARIAL-MILITAR, A REDEMOCRATIZAÇÃO E O INÍCIO DOS DEBATES EM TORNO DE NOVOS ORDENAMENTOS LEGAIS.}

Reis (2014, p. 14) descreve a primeira metade dos anos 1960 como "o período mais quente da história republicana". Trata-se do capítulo introdutório do livro Ditadura e democracia no Brasil, que objetiva revisitar, 50 anos depois, a história de um dos períodos mais difíceis e conturbados da história brasileira.

Para reconstituir o período, o autor aborda os anos do governo de João Goulart, que já nasceu contestado por segmentos das elites dominantes brasileiras, como vimos anteriormente. Em 1962, no contexto de manifestações e greves, Jango anunciou o programa de reformas de base, que englobava a reforma agrária, urbana, bancária, eleitoral, do estatuto do capital estrangeiro e da reforma universitária, como forma de atender às necessidades sociais e nacionais, agregado à antecipação do pleito que pôs fim ao parlamentarismo, em 1963, e o plano trienal que objetivava incentivar o desenvolvimento e controlar a inflação. Neste ponto, Daniel Aarão Reis (2014, p. 36) afirma que "para os de baixo, [o plano trienal] era pouco. Para os de cima, demais". A crise se acirrou e, aliada a ela, o temor da emergência das lideranças populares e da "ameaça vermelha" - o comunismo.

Com o avanço da reforma proposta por João Goulart, por meio da organização de comícios com vistas ao aumento da pressão popular, desencadeou-se a contrarreforma. A primeira Marcha da família com Deus pela liberdade aconteceu em São Paulo e uniu os grupos da direita, em março de 1964. A crise instaurada na Marinha do Brasil, que desestabilizava os preceitos militares de hierarquia e disciplina, foi agravada pelo então presidente em seu último discurso, no centro do Rio. No dia 30 de março de 1964 foi, portanto, ordenada a ação militar para depor João Goulart, que, sem exitar “[...] saiu da história pela fronteira com o Uruguai, asilando-se em Montevidéu” (IDEM, p.45).

Com a instauração de outra ditadura, que a princípio se definiu como defensora da democracia e das prerrogativas constitucionais, desordenou-se mais uma vez o processo 
de democratização em curso, por meio da censura e da repressão aos grupos contrários ao regime; e desmantelou-se, novamente, as tentativas de organização de grupos oriundos da classe subalterna. Assim, mesmo com a roupagem democrática, posto que a Constituição de 1946 continuava vigente, constituiu-se uma junta militar, com chefes das três forças, que formaram o Comando Supremo da Revolução (IBIDEM, p. 51). Consumado o golpe em nome da democracia e da civilização ocidental e cristã, foi definido o prazo para novas eleições (1965 e 1966) e publicado o Ato Institucional número I, que permitia cassar quem se impusesse contra o regime. Desta forma, foi eleito o general Castello Branco para presidente, por um Congresso Nacional onde algumas cassações já haviam mudado sua composição.

Os quinze anos seguintes foram o período, nas palavras de Coutinho (2006, p. 185) "de onde" e "para onde" a crise do Estado de tradições nacional-estadistas brasileiro transitou. Buscou-se modernizar, mesmo que de forma conservadora, a economia do Brasil. Para o autor, a intervenção militar ocorrida em 1964 não pode ser chamada de fascista, pois tal forma política totalitária só teria espaço em países que dispunham de uma grande organização da sociedade civil, o que não era o caso brasileiro. Em contraste com o fascismo, a ditadura objetivou desmobilizar as massas, por meio de uma "ideologia da nãoideologia" (IDEM, p. 186). Na mesma linha de argumentação caminha Saviani, ao analisar a tramitação das reformas produzidas na $\operatorname{LDBEN~}^{\circ} 4.024 / 1961$, que tomaram forma neste período - a Lei $n^{0} 5.540 / 1968$ e a Lei $n^{\circ} 5.692 / 1971$, que analisaremos mais adiante. Para Saviani (2008, p. 5), embasado em Debrun (1983), os eixos da política nesses anos foram o autoritarismo desmobilizador e o autoritarismo mobilizador ou, como preferiu denominar, autoritarismo triunfante (SAVIANI, 2008, p. 7). Estes seriam sustentados politicamente por uma democracia excludente, ou seja, como “[...] um regime que deliberada e sistematicamente exclui da participação política amplos setores da sociedade civil, entre eles, as chamadas "elites dissidentes"” (IDEM, p. 8).

Iniciamos este capítulo com o termo ditadura empresarial-militar por considerarmos que apesar dos militares serem os protagonistas do processo, a base de sustentação do período se deu em distintas forças, movimentos e lideranças civis (termo abrangente, já explicitado na introdução deste trabalho) e empresariais que intentavam não perder espaço no campo político (REIS, 2014, p. 58-62). Tal perspectiva também se evidencia em Fernandes (1986, p. 168), quando o sociólogo analisou a processo de abertura política:

[...] os governantes que assaltaram o Estado brasileiro e o amoldaram a seus fins políticos, engendraram um forma policial-militar de ditadura burguesa que pode oscilar "endurecendo" ou "liberalizando-se" de acordo com a conjuntura 
econômica, social e política e com o volume de pressões contra a ordem ilegal estabelecida como "institucional" e "revolucionária". Essa oscilação é intrínseca aos dinamismos "normais" da república institucional e é rematada loucura atribuirlhe qualquer eficácia política para gerar o seu contrário, um regime republicano democrático-burguês. De outro lado, fica igualmente claro que o caminho da democracia será sempre bloqueado pela ditadura, enquanto ela não for reduzida à impotência. $\mathrm{O}$ cano do fuzil que a alimenta e reproduz, em cumplicidade com uma vasta teia de interesses da grande burguesia nacional e estrangeira, ainda se mantém voltado contra o coração da Pátria.

O mandato do presidente Castello Branco foi prorrogado até março de 1967, por meio de uma emenda constitucional aprovada ainda em 1964. Alguns movimentos descontentes com o regime começaram a despontar, dentre os quais os estudantes universitários se destacaram (REIS, 2014, p. 59). Outro Ato Institucional (AI) foi publicado (AI n ${ }^{\circ}$ ), desta vez dissolvendo os partidos políticos existentes e criando o bipartidarismo; introduzindo as eleições indiretas para a presidência da república; e depondo os governadores legalmente eleitos. Outros duros ataques aos direitos civis foram realizados por meio dos AI, sendo o mais severo o AI n⿳5 5, de 1968, que eliminou a liberdade de opinião, de reunião, controlou os partidos políticos e sindicatos, proibiu as greves e o direito de defesa. Foram realizadas muitas prisões arbitrárias, a justiça militar passou a encarregar-se do julgamento de crimes civis, a inviolabilidade da correspondência e do lar deixaram de existir e o próprio direito à integridade física - prerrogativa máxima dos direitos humanos - passou a ser desprezado, com as frequentes sessões de tortura e os assassinatos tão denunciados pelos grupos contrários ao regime. Era "[...] um golpe dentro do golpe. A ditadura sem disfarces, escancarada" (REIS, 2014, p.73). A esta altura, o novo presidente era Arthur da Costa e Silva.

O presidente supracitado apostou na retomada do desenvolvimento, abandonado por seu antecessor, o presidente Castello Branco. Começam os "anos de ouro e de chumbo" (REIS, 2014, p. 74), nos quais o crescimento do país se acelerou, mas também se intensificaram os atos de resistência ao regime, por meio, sobretudo, de três grandes grupos: os moderados do MDB (Movimento Democrático Brasileiro - partido de oposição ao regime), o movimento estudantil já mencionando anteriormente, e as organizações revolucionárias clandestinas. Intensificou-se, também a repressão.

O período desenvolvimentista (1930 - 1989), quando houve uma aceleração no processo capitalista no Brasil, é caracterizado por alguns autores ${ }^{21}$ como o período em que os direitos de cidadania foram sendo ampliados, de forma segmentada, de maneira a

21 Lúcia Neves (2005, p. 88) menciona esta característica da cultura política brasileira, usando, inclusive o conceito de revolução passiva, que toma de Werneck Vianna e Carlos Nelson Coutinho. 
"humanizar" as relações de exploração do capital e assim conter a organização autônoma de frações da classe dirigida, posto que algumas de suas reivindicações estariam sendo atendidas, mesmo que de maneira ainda precária. Desta forma, os direitos sociais voltaram a ser incrementados, agora com a inclusão dos trabalhadores rurais aos benefícios da previdência social através do FUNRURAL ${ }^{22}$, além da extensão destes às empregadas e aos autônomos. Criou-se também neste período o FGTS (Fundo de Garantia por Tempo de Serviço), que substituiu o sistema de estabilidade do governo, que se processava por meio do pagamento de indenizações em caso de dispensa (SANTOS, 1979), e o BNH (Banco Nacional de Habitação). O milagre econômico do país governado pelo General Emílio Garrastazu Médici, beneficiou de forma desigual diversos setores da população de forma muito rápida, gerando uma sensação de melhoria nas condições de vida de apenas uma parcela da população: a classe média. A concentração de riqueza e poder, que sempre marcou a realidade do país, formou uma pirâmide social ainda mais distorcida.

No que se refere ao aparato legal construído no período da ditadura, temos uma nova Constituição aprovada em 1967 e duas leis da educação, que objetivaram reformar a LDBEN em vigor. São elas: a Lei no 5.540/1968 - conhecida como reforma universitária, que reorganizou o ensino superior no país, buscando a "modernização" deste nível segundo os padrões norte-americanos; e a Lei $n^{\circ} 5.692 / 1971$, que versava sobre a reforma do ensino de $1^{\circ}$ e $2^{\circ}$ graus. Além das leis, foram criados Planos Nacionais de Desenvolvimento (PND), nos quais o binômio segurança/ desenvolvimento "[...] definiam as diretrizes e metas nacionais gerais e para cada área, que eram detalhadas nos respectivos Planos Setoriais" (FNE, 2011, p. 13). Desta forma, a educação compunha o Plano Setorial de Educação e Cultura. Não nos deteremos nos referidos planos $^{23}$, uma vez que estes não constituem nosso objetivo central.

A Constituição de 1967, aprovada no período acima exposto, mostrou-se como uma espécie de reflexo da conjuntura da "guerra fria", na qual sobressaiu a "teoria da segurança nacional", cujo objetivo principal era combater os inimigos internos, rotulados

22 Fundo de Assistência e Previdência do Trabalhador Rural, instituído pela lei $\mathrm{n}^{\circ}$ 4.214/63. Foi extinto em 1977, com sua incorporação ao Sistema Nacional de Previdência e Assistência Social - SINPAES. Para mais informações acessar www.faemg.org.br/arquivos acesso em 11/01/07.

23 Segundo o documento O planejamento educacional no Brasil, do Fórum Nacional de Educação (2011), foram elaborados quatro Planos Nacionais de Desenvolvimento: o I PND, dos anos de 1972 a 1974; o II PND, de 1975 a 1979; o III PND, de 1980 a 1985; e o I PND da nova república, de 1986 a 1989. Este último não previa planos setoriais, uma vez que o próprio plano contemplava, em seus capítulos, os temas pertinentes ao desenvolvimento do país. Neste, a discussão da educação era abordada com a tarefa de "Universalizar o ensino de $1^{\circ}$ grau; melhorar e ampliar o $2^{\circ}$ grau; redimensionar as modalidades supletiva e especial de ensino; estabelecer padrões mais elevados de desempenho acadêmico; integrar a educação física e o desporto no processo educacional; utilizar recursos tecnológicos para fins educativos e, finalmente; redefinir as competências institucionais no exercício dos encargos públicos constituem objetivos básicos das ações que integram as linhas programáticas da educação" (I PND/NR apud FNE, 2011, p.16). 
de subversivos. No que é pertinente à regulamentação da matéria educacional, abordou a necessidade de a União estabelecer e executar planos nacionais de educação e saúde, em seu artigo $8^{\circ}$, inciso XIV. A garantia da educação como direito foi apresentada no título IV, artigo 168, que contou inicialmente com a seguinte redação: “A educação é direito de todos e será dada no lar e na escola; assegurada a igualdade de oportunidade, deve inspirar-se no princípio da unidade nacional e nos ideais de liberdade e solidariedade humana" (DAVIES, 2004, p. 28). A Emenda Constitucional (EC) n 1 de 1969 alterou sua redação, incluindo a responsabilidade do Estado para com a sua garantia. A CF de 1967 pautava, ainda, a gratuidade e a obrigatoriedade do ensino nos estabelecimentos oficias entre 7 e 14 anos, apresentando a possibilidade de apoio técnico e financeiro à iniciativa particular, inclusive por meio de bolsas de estudo. Já no ensino secundário e superior, havia uma preponderância na concessão de bolsas de estudo sobre a gratuidade, o que ficou evidenciado no artigo 176, incisos III e IV.

Na sequência, a lei da reforma universitária (Lei $n^{\circ} 5.540 / 1968$ ), buscou inserir a universidade na lógica racionalizadora do capital, por meio da garantia de sua eficiência, modernização e flexibilidade administrativa (SAVIANI, 2008, p. 70), sendo resultante dos estudos desenvolvidos por um grupo de trabalho nomeado no governo do presidente Arthur da Costa e Silva, do qual a representação estudantil, apesar de nomeada, recusouse a fazer parte. Com o objetivo de adequar a universidade aos novos padrões do modelo econômico adotado, que passava do nacional-desenvolvimentismo ao capitalismo de mercado, teve como base a obediência aos acordos MEC-USAID, orientados pela doutrina de interdependência. Segundo Florestan Fernandes (1989, p. 140), tais acordos

[...] traçaram uma rota a um tempo regressiva e diferenciadora, no âmbito das aspirações e das promessas ou ilusões pedagógicas que fermentavam o Brasil. E impunham uma especialização dentro do "mundo global" da indústria da cultura: o capitalismo monopolista da era atual não deixa muitos espaços às nações dependentes e periféricas quanto ao uso de suas potencialidades criativas. Elas são nações capitalistas secundárias e devem cumprir seu papel em harmonia com o pioneirismo, a hegemonia e o esplendor do núcleo imperial.

Desta forma, os acordos visavam instrumentalizar a juventude brasileira às exigências do capitalismo, transformando o ensino superior em "mercadoria no sistema de circulação capitalista mundial” (IDEM, p. 141). A tramitação da lei da reforma universitária no Congresso Nacional foi abordada por Saviani no livro Política e Educação no Brasil: o papel do Congresso Nacional na legislação de ensino (2008, p. 75-81). Nele o autor 
transcreve as falas que se apresentaram contrárias à sua aprovação, porém destaca que estas não influenciaram o resultado final. Tratava-se, pois, de uma oposição consentida, já que o Congresso se encontrava depurado, após as inúmeras cassações promovidas pelos AI.

Por conseguinte, a construção do sistema departamental, a instituição da carreira docente devido ao fim da cátedra vitalícia, o sistema de créditos com o propósito de desarticular o movimento estudantil, a generalização da pós-graduação e especialização dos professores, enfim, todas estas características são decorrência da modernização da universidade brasileira conforme os padrões norte-americanos, implantados no Brasil principalmente na década de 1970 e acentuados nas décadas de 1980 e 1990 (SGUISSARD, 2000). Segundo Saviani (2008, p. 83) a lei aprovada em 1968 "traduziu a opção pelo ajustamento da ideologia política ao modelo econômico", evidenciando que as decisões pertinentes ao campo educacional não competiam aos educadores, mas sim aos técnicos. Florestan Fernandes (1975, p. 203-204) tece a seguinte crítica à lei:

É preciso que fique bem claro, de antemão, que entendemos a reforma universitária consentida como uma manifestação da tutelagem política e como mera panacéia. Não podemos aceitá-la porque ela não flui de nossa vontade, não responde aos anseios que animam as nossas lutas pela reconstrução da universidade e não possui fundamentos democráticos legítimos. Complemento de dois decretos-leis de um Governo militar autoritário e expressão perfeita do poder que engendrou a constituição outorgada à Nação em janeiro de 1967, ela representa uma contrafração de nossos ideais e de nossas esperanças. A ela devemos opor a autêntica reforma universitária, que nasce dos escombros de nossas escolas e da ruína de nossas vidas, mas carrega consigo a vocação de liberdade, de igualdade e de independência do povo brasileiro.

No que se refere à Lei $\mathrm{n}^{0}$ 5.692/1971, a mesma dinâmica adotada em 1968 foi utilizada: um grupo de trabalho foi formado por ordem do presidente Emílio Garrastazu Médici, em 1970, com o objetivo de "estudar, planejar e propor medidas para a atualização e expansão do Ensino Fundamental e do Colegial" (SAVIANI, 2008, p. 107). Cumprido o prazo estabelecido pelo presidente, o projeto elaborado pelo grupo deu entrada no Congresso Nacional também em regime de urgência, recebendo emendas que buscavam apenas aperfeiçoar o texto, sem efetuar mudanças significativas na estrutura das propostas. Percebese claramente a inexistência de resistências, até mesmo porque a comissão encarregada de apreciar tal proposta contava com um número muito superior de parlamentares da Aliança Renovadora Nacional - a ARENA - partido do regime (dez senadores e oito deputados) do que do MDB (um senador e três deputados). 
De uma forma geral, podemos afirmar que a tendência liberalista expressa na LDBEN de 1961 foi substituída no texto da reforma de $1^{\circ}$ e $2^{\circ}$ graus por uma tendência tecnicista. Apesar de manter a orientação da organização escolar brasileira previamente delineada, a Lei $n^{\circ}$ 5.692/1971 reestruturou a forma de operar o ensino nestes níveis (IDEM, p. 123). Uma das suas principais características foi instituir a profissionalização compulsória no ensino médio, que cumpria, segundo os legisladores, a função de descaracterizar formalmente o sistema dual de ensino vigente no Brasil. Todavia, o que de fato aconteceu foi um reforço a tal prerrogativa, posto que aos estudantes oriundos de grupos pertencentes à elite dominante ficava reservado o acesso ao $2^{\circ}$ grau com uma formação ampliada, e, conseqüentemente, ao ensino superior. Aos grupos que compunham as classes subalternas, quando muito, restava a terminalidade do processo de escolarização formal no $2^{\circ}$ grau, ou mesmo a terminalidade específica, de acordo com suas necessidades (ROMANELLI, 2003). Mais tarde, em 1982, o mecanismo de profissionalização compulsória viria a ser revogado pela Lei $n^{\circ} 7.044$.

Ao comparar o processo de aprovação das duas reformas, que alteraram em tempos distintos a primeira LDBEN, Saviani (2008, p. 123-124) afirma que a principal diferença entre elas foi a vinculação da aprovação das leis aos tempos vividos: enquanto a lei da reforma universitária buscava desmobilizar o movimento dos estudantes e professores, a lei da reforma do $1^{\circ}$ e $2^{\circ}$ graus foi anunciada como a salvação da educação brasileira, como forma de construção de um projeto nacional de desenvolvimento para o país.

Com a crise do chamado milagre econômico, em meados da década de 1970, houve um desgaste nesta prática autoritária, sendo ela obrigada a se abrir, pelo e para o bem do desenvolvimento do capitalismo, de forma "lenta, gradativa e segura" (REIS, 2014, p. 99). A esta altura (1974) já tínhamos o último presidente-general da ditadura, Ernesto Geisel. Aos aspectos econômicos podemos aliar os movimentos organizados, dentre eles o movimento estudantil, já mencionado, e o de grupos intelectuais (professores e artistas) merecem destaque, posto que cresceram e se constituíram como elemento de oposição aberta ao regime. Mesmo com o fracasso da guerrilha nesta mesma década, as organizações de origem civil e religiosa ${ }^{24}$ tomaram corpo na luta contra a ditadura. Em 1978 lideranças sindicais deflagraram greves, no qual o nome de Luiz Inácio Lula da Silva apareceu, no

24 Um segmento da Igreja Católica mobilizou-se por meio da Teologia da Libertação, contando com o envolvimento de religiosos na defesa dos direitos humanos, ocasionando, inclusive, a prisão e o desaparecimento de muitos deles. As associações de profissionais, como a OAB (Ordem dos Advogados do Brasil), a ABI (Associação Brasileira de Imprensa) e o SBPC (Sociedade Brasileira para o Progresso da Ciência) buscaram deixar claro seu antagonismo e repúdio ao regime, embora, em um primeiro momento, a $\mathrm{OAB}$ e a $\mathrm{ABI}$, além da $\mathrm{CNBB}$ (Conferência Nacional dos Bispos do Brasil) tenham demonstrado apoio aos militares, conforme afirma Reis (2014, p. 62). O elemento comum entre os movimentos civis e religiosos se caracterizou pela busca de um contato direto com a população, conforme afirma José Murilo de Carvalho (2001, p.183). 
comando do Sindicato dos Metalúrgicos de São Bernardo do Campo. Em 1979, caíram os AI, a censura política, e foi revogado o estado de exceção. Estavam dadas as condições para a transição democrática, com o general João Baptista Figueiredo.

A década de 1980 tornou-se significativa por abarcar os momentos de abertura política e de redemocratização do país. Conhecida como a "década perdida" da economia da América Latina (MARANGONI, 2012), os movimentos que se articularam pela retomada da democracia no Brasil foram um marco que precisa ser mencionado. A fundação do PT - Partido dos Trabalhadores, em 1980, por um grupo heterogêneo, formado por militantes de oposição à ditadura, sindicalistas, intelectuais, artistas e católicos ligados à teologia da libertação; a criação da CUT (Central Única dos Trabalhadores), em 1983; o Movimento dos Trabalhadores Rurais sem Terra (MST), no Paraná, em 1984, são alguns exemplos de articulações que vieram a influenciar toda a organização política a partir de então.

Em 1982 aconteceram eleições municipais e estaduais, das quais puderam participar os anistiados contemplados pela lei de anistia, publicada por João Figueiredo em agosto de 1979. O ano de 1984 foi considerado o auge do movimento popular, onde os principais símbolos nacionais - o hino e a bandeira - foram reapropriados pelo povo em campanhas pelas eleições diretas, que ficaram amplamente conhecidas por Diretas Já. Tal movimento foi desencadeado após a apresentação da Proposta de Emenda Constitucional (PEC) $n^{\circ}$ 05/1983 pelo Deputado Federal Dante de Oliveira (PMDB), que tinha por objetivo reinstaurar as eleições diretas para presidente da república no Brasil, posto que a tradição democrática havia sido interrompida no país pelo golpe de 1964, sendo considerado o maior movimento político da história da república (REIS, 2014, p. 144). Foram realizadas várias manifestações públicas, que demonstravam a importância da aprovação de tal dispositivo para significativas parcelas da população brasileira. Dois comícios marcaram a campanha, dias antes da mesma ser votada - um no Rio de Janeiro, no dia 10 de abril de 1984, e outro no dia 16 de abril, em São Paulo.

Apesar das movimentações, a PEC foi rejeitada pela Câmara dos Deputados no dia 25 de abril de 1984. Por sua natureza, era necessário contar com votos favoráveis de dois terços da Casa (320 deputados) para que a mesma seguisse ao Senado. O resultado da votação foi, todavia, desfavorável: 298 deputados a favor; 65 contra; 3 abstenções e 113 ausências ao plenário. Com a rejeição da emenda, a eleição para presidente da república de 1985 foi novamente indireta. Desta forma, o candidato governista indicado foi Paulo Maluf, do PDS - Partido Democrático Social. 
Entretanto, algumas articulações, em especial do PMDB, dividiram a base governista, que era maioria no Congresso Nacional, formando a Aliança Democrática e um novo partido, dissidente do PDS - o PFL (Partido da Frente Liberal), com lideranças civis que tradicionalmente apoiaram a ditadura, capitaneadas por José Sarney. Tal dinâmica ocasionou a escolha do oposicionista Tancredo Neves (PMDB) como presidente da república e José Sarney, como vice. Encerrou-se assim um ciclo de cinco presidentes militares, iniciado em 1964. Tancredo, porém, nunca veio a tomar posse, falecendo por sérios problemas de saúde no dia 21 de abril de $1985^{25}$. Seu vice, José Sarney, tomou posse em 15 de março daquele mesmo ano, sendo também um dos responsáveis pelo processo de redemocratização do país, mesmo tendo apoiado os militares por vinte anos. Mudou-se o regime sem que ele mudasse efetivamente de mãos.

Sobre o processo que se iniciou com a transição democrática, que inviabilizou as eleições diretas e que originou o processo constituinte, Fernandes fez várias críticas, em diferentes momentos, das quais destacamos as seguintes:

Poder-se-ia dizer que, ao escusar-se do pacto social oferecido pela Aliança Democrática, pela "Nova República" e sacramentado por Tancredo Neves os trabalhadores expuseram-se ao pior, deixando de ser parte de um processo no qual acabaram se tornando objeto de barganha dos de cima. Estes iriam revelarse compassivos, até, se não por condescendência ou generosidade, por temor da “explosão social”, que não se afasta da imaginação perversa dos poderosos. Ora,

na verdade, tudo o que foi feito - mesmo aquilo de interesse direto ou indireto para os proletários e a massa popular - visava salvar o capital de uma catástrofe econômica e a ordem política de uma comoção violenta, de consequências imprevisíveis (1986, p. 27).

Antes, a "transição lenta, gradual e segura" estava incubada no governo ditatorial. Agora, a tutela militar está incubada na "transição democrática", sem tirar nem pôr. A retaguarda militar é o poder, não por trás do trono, mas através dele! (1986, p.35).

A chamada "conciliação conservadora" tinha por objetivo uma estratégia clara, de natureza político-militar: fecha os horizontes que a crise da República institucional abria para a eclosão das forças populares na cena histórica (2014, p. 27).

$O$ pacto social que se quer engendrar, na hora mesma em que está prestes a reunirse um Congresso Constituinte (!), é um embuste gigantesco, infelizmente com muitos precedentes em nossa história de "conciliações e reformas" desse jaez (2014, p. 48).

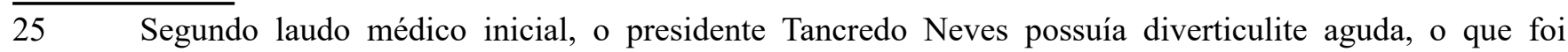
questionado no livro O Paciente. O caso Tancredo Neves, de Luis Mir (2010). Há ainda versões que apontam uma teoria da conspiração, não comprovada: http://averdadenomundo.blogspot.com.br/2011/06/morte-de-tancredoneves.html; http://www.istoe.com.br/reportagens/34410_MORTE+SUSPEITA; http://amp-mg.jusbrasil.com.br/ noticias /3015988/filho-de-tancredo-neves-vai-a-justica-para-esclarecer-sua-morte; http://noticias.terra.com.br/ brasil/ noticias/0,OI515280-EI306,00-Medico+admite+ter+falsificado+laudo+de+Tancredo.html 
Esse politicismo vazio, pernicioso e visceralmente atrasado (ele nos reverte às ditas "velhas oligarquias" e às suas práticas políticas, embora, ao mesmo tempo, esteja enraizado no jogo de forças do atual capitalismo monopolista dependente e nas irradiações globais da cidade de São Paulo como a megalópole que sateliza os dinamismos internos do desenvolvimento desigual) é em si e por si mesmo, o modo pelo qual uma burguesia impotente corrói os dinamismos políticos do desenvolvimento capitalista e, por essa via indireta, debilita a luta das classes trabalhadoras e das massas populares (2014, p. 17).

Para o sociólogo, então deputado pelo PT, toda a reação conservadora que marcou o momento teria um único objetivo: afastar a população do poder, inviabilizando uma real democratização do mesmo, colocando-a a margem das mudanças, em um processo de tutela, ou de "conciliação pelo alto" (1986, p. 88), com características "prussianas" (COUTINHO, 2006, p. 190), considerada uma estratégia comum e eficaz na realidade histórica brasileira:

Excluído, este mantém aparente condição passiva de comparsa surdo, mudo impassível. Falou-se que foi assim que o povo "assistiu" a todos os acontecimentos de nossa história, que não era a história dele. Mas nem isso é verdadeiro. Ele nunca foi agente ativo, porque sempre esteve privado da condição de agente histórico (FERNANDES, 2014, p. 25).

É uma tradição que conduz, sempre, a um mesmo resultado: manter as rédeas presas, para que a massa popular e as classes trabalhadoras sejam perenemente banidas do exercício do poder [...] as esquerdas do PMDB ou que dele emergiram, empenhadas na defesa da legalidade recém-conquistada, curvam-se ao oficialismo do PMDB e à sua vocação de preferir o poder à defesa ousada da revolução democrática [...] o Brasil deve escolher entre a transição conservadora e a revolução democrática (IDEM, p. 44-47).

São parte dos "costumes políticos" e viciam as instituições ditas "modernas"[...] o que é bom para os donos do poder é bom para a coletividade como um todo (IBIDEM, p.68).

Os que enterraram a campanha pelas eleições diretas temem a democracia, pelo que ela significa na presente conjuntura econômica e política [...] ela não possui um pólo dinâmico burguês. Está imantada de fome, miséria, desemprego, desespero (IBIDEM, p. 164).

Quinze dias antes da morte de Tancredo Neves, Fernandes analisou sua eleição como uma "manobra bem-sucedida para sair por dentro do movimento e pôr-lhe um bridão conservador" (1986, p. 125). Após sua morte, afirmou que esta fechou "de modo nefasto, um circuito perfeito" (IDEM, p. 114), pois colocou no centro das discussões o culto à 
morte de um presidente que não chegou a tomar posse e retirou da ordem do dia toda a articulação política que objetivava a continuidade do poder em mãos análogas.

No próximo capítulo analisaremos a estrutura da Assembleia Nacional Constituinte, os grupos que nela se formaram a partir da posição dos diversos agentes que nela transitaram. Tal análise será possível a partir do estudo das atas disponíveis na página eletrônica do Senado Federal, documentos fundamentais ao trabalho que se pretende desenvolver. 


\section{A ASSEMBLEIA NACIONAL CONSTITUINTE COMO CAMPO POLÍTICO: AGENTES EM DISPUTA PELO DIREITO À EDUCAÇÃO.}


No capítulo anterior vimos que a transição democrática foi mais lenta e gradual do que a população realmente desejava, ou, de acordo com Reis, “[...] já não havia ditadura, mas ainda não existia uma democracia" (2014, p.125). No cenário que se definia nos anos da chamada abertura política - que na historiografia brasileira começou a se delinear no ano de 1979 e início dos anos de 1980 - o sindicalismo ganhava força no Brasil, juntamente com a tradição das esquerdas brasileiras, que, segundo, Daniel Aarão Reis (2014, p. 130), era o trabalhismo e o comunismo. As instituições que antes apoiavam o golpe começaram a se posicionar com discursos democráticos, tentando se distanciar do que fora imputado agora como culpa exclusiva dos militares. A lei da anistia, o fim do bipartidarismo com a reestruturação do campo conservador - que antes se concentrava na $\mathrm{ARENA}^{26}$ - e das esquerdas em outros partidos ${ }^{27}$, começou a complexificar a estrutura política da época.

As eleições de 1982 foram um exercício de voto direto para a eleição de governadores, prefeitos, deputados e vereadores, que não exprimiu o desejo da população por uma bancada mais alinhada com a esquerda (IDEM, p. 140). Como já descrito anteriormente, a campanha das Diretas Já foi um movimento importantíssimo, cujo desfecho amortizou um pouco do clamor por novos tempos. Com a rejeição da emenda Dante de Oliveira ${ }^{28}$ e a eleição indireta para a presidência da república, restava a esperança de uma nova Constituição para materializar os anseios democráticos. Sarney, ao tornar-se o primeiro presidente civil após a ditadura, não conseguiu de imediato se desvincular das ligações que tinha com os militares e toda a estrutura que dera sustentação ao regime, mesmo não sendo mais da ARENA e tendo migrado primeiramente para o PFL - Partido da Frente Liberal e, num segundo momento, para o PMDB, para consolidar a aliança com a chapa de Tancredo Neves.

Após a aprovação do retorno das eleições diretas em 1985, por meio da $\mathrm{EC} \mathrm{n}^{\mathrm{o}} 25$, da possibilidade de formação de novos partidos políticos e da legalização dos partidos comunistas $^{29}$, em novembro de 1986, com a EC n 26 , foram realizadas eleições, nas quais, inclusive, foram eleitos os parlamentares que viriam a compor a Assembleia Nacional

26 PDS - Partido Democrático Social; PP - Partido Popular, mais moderado, ao centro.

27 O MDB se converteu em PMDB (Partido do Movimento Democrático Brasileiro); o PTB (Partido Trabalhista Brasileiro) oriundo do campo do trabalhismo, assim como o PDT - Partido Democrático Trabalhista. O PT foi fundado logo depois, como apresentado no capítulo anterior.

28 A emenda teve 298 votos a favor, 65 votos contra, 3 abstenções e um número grande de parlamentares que faltaram à sua votação - 113. Por tal motivo, apesar da maioria dos votos, não teve o quórum necessário para ser aprovada.

29 PCB - Partido Comunista Brasileiro e PC do B - Partido Comunista do Brasil. 
Constituinte, no ano seguinte. Tal fato foi possível devido à vitória da proposta governista, que propunha que se formasse um Congresso Constituinte, e não uma Constituinte exclusiva para gestar a nova carta magna. Sobre esta questão, o jurista Flávio Bierrenbach, então deputado federal pelo PMDB na legislatura de 1982-1986 fora convidado para ser relator da emenda. Em entrevista (CARVALHO, 2017, p. 136-137), contou que não soube a razão de ter sido escolhido para tal tarefa por Ulysses Guimarães, mas que foi destituído da função por não redigir um texto que correspondesse aos interesses políticos do período:

Eu sustentava, e continuo sustentando, que naquele momento o Brasil vivia sem
Constituição [...] Então eu sempre achei que era preciso ter uma nova Constituição
para o Brasil. E que quem teria legitimidade para fazer uma nova Constituição para
o país seria uma Assembleia Nacional Constituinte, livre, soberana e exclusiva
[...] Sempre achei, antes, durante e depois, que o Congresso não é um poder
constituinte. O Congresso é um poder constituído [...] Fui na casa do dr. Ulysses,
dois dias antes, numa reunião ampla. E sustentei que iria propor um plebiscito
para que o povo decidisse que Constituinte queria, entre outras coisas. [Disseram]
que era inviável, que não tinha clima, que os militares não iam gostar, por aí...
Quando chegou no momento crucial - votar o meu relatório -, a solução política
foi me destituir. E aí já tinha um outro relator e um outro relatório prontos.

Na mesma perspectiva da exposição acima, em entrevista realizada para esta pesquisa, o deputado federal Arolde de Oliveira afirmou que o modelo adotado para a Constituinte afetou decisivamente o seu curso e o produto que dela resultou, posto que os parlamentares estavam presos aos seus vínculos eleitorais, como observamos no trecho seguinte

Foi convocada uma Constituinte, não foi também convocada uma Constituinte - que aí eu acho que deveria ter sido convocada - uma Constituinte exclusiva, para se reunir, rever e fazer uma nova Constituição e se dissolver. Pelo contrário, foi feita uma Constituinte Congressual, quer dizer, os deputados eleitos em 1986 que tomaram posse em 1987, por dois anos, nos dois primeiros anos do mandato eles foram Constituintes. Então nós fomos constituintes nesse período. E no restante dos outros dois anos, voltaram a ser parlamentares como sempre foram. Quais são as implicações, disso? Primeiro, o constituinte congressual, ele tem o comportamento parlamentar, de deputado. Então, ele trata dos assuntos com foco nas suas amarras político, político-eleitorais, dos seus interesses e convicções legítimos, nada que não seja legítimo, mas ele sendo um parlamentar ele tem essas representações parlamentares, e age como um parlamentar na abordagem das diferentes matérias, como, qual a implicação disso no meu entendimento.

Além dos senadores e deputados eleitos no pleito de 1986, também fariam parte da ANC os senadores eleitos anteriormente, em 1982, cujos mandatos continuavam em 
vigência. Nesse contexto uma nova Constituição se tornava indispensável para finalmente enterrar os anos de chumbo no Brasil e seu "entulho autoritário" (CARVALHO, 2017, p. 152), ou seja, uma Constituição consideravelmente emendada que não mais refletia a realidade do país.

Para a organização das demandas educacionais no processo de elaboração da $\mathrm{CF}$, Florestan Fernandes (1989, p. 131) destacou que "não se pode fazer um projeto ou um anteprojeto na área da educação sem perguntar quais são as tarefas educacionais na situação brasileira e qual é a posição que a Assembleia Nacional Constituinte deve ter diante dessas tarefas". Assim sendo, apresentou a relevância de três prioridades básicas, a saber:

Em meu entender, são três os conjuntos de prioridades pedagógicas básicas, que
deveriam ser a fonte de normas constitucionais vivas. Primeiro, a Constituição
deve garantir a todos a igualdade efetiva das oportunidades educacionais [...]
Segundo, a Constituição deve tomar a si uma orientação firme na formalização
de valores que não foram incorporados do exterior com a difusão das instituições
escolares. A escola é o principal "laboratório" de uma sociedade civil (isto é, uma
sociedade burguesa) civilizadora, pluralista e democrática [...] Terceiro, é urgente
que assumamos o caminho de nossa auto-emancipação pedagógica em escala
nacional (IDEM, p. 133 - 134).

Antes, porém, em 18 de julho de 1985, por determinação do presidente Sarney expressa no Decreto ${ }^{\circ}$ 91.450, formou-se a Comissão Provisória de Estudos Constitucionais, um grupo de cinquenta integrantes, conhecida também como Comissão dos Notáveis ou Comissão Afonso Arinos - seu presidente, cuja tarefa era a elaboração de um anteprojeto de Constituição. No ato de instalação da referida comissão, foram palavras do presidente:

A Comissão não substituirá o Congresso nem substituirá o povo. Será, na verdade, uma ponte de alguns meses entre a gente brasileira e os representantes que ela elegerá. Servirá como uma área de discussão livre e informal das razões nacionais, submetendo ao debate público teses básicas quanto ao Estado, à sociedade e à nação (CÂMARA, 2017, p.2).

Tendo trabalhado até setembro 1986, a comissão entregou seu texto final com 436 artigos, além dos 32 artigos que compunha as disposições transitórias, que tinha por objetivo oferecer o pilar para as discussões que se iniciariam com a ANC. No texto de apresentação, Afonso Arinos assim definiu o trabalho que ora vinha a público:

Nós, representantes do Povo Brasileiro, reunidos sob a proteção de Deus em Assembléia Nacional Constituinte, proclamamos a necessidade de oferecer ao nosso País uma Constituição que, ao termo do primeiro século do regime republicano, 
supere as causas das suas experiências negativas e assegure à Nação uma era contínua de Paz, Liberdade, Segurança Pessoal, Bem-Estar e Desenvolvimento, decorrentes da aplicação de princípios políticos, econômicos e sociais adequados à nossa formação nacional $\mathrm{e}$, como estes, historicamente em evolução progressista (CÂMARA, 2017, p. 4).

No que se refere especificamente à discussão educacional, o anteprojeto apresentou no artigo 75, inciso XV, o direito à educação, cultura, ensino e desportos como competência da União e dos Estados. Mais adiante, no artigo 128, inciso VI, colocou a educação como direito metropolitano; o título IV (Da Ordem Social), trouxe no inciso XI o direito à educação como forma de realização da justiça social. Já o título V tratou "Da educação, da cultura, da comunicação social, da ciência e da tecnologia", com o capítulo I direcionado exclusivamente à educação, abarcando os artigos 384 a 394. Iniciou-se o capítulo com o conceito, objetivo e diretrizes da educação:

Art. 384 - A educação, direito de todos e dever do Estado, visa ao pleno desenvolvimento da pessoa e à formação do cidadão, para o aprimoramento da democracia, dos direitos humanos, da convivência solidária a serviço de uma sociedade justa e livre.

Parágrafo único - A educação é inseparável dos princípios da igualdade entre o homem e a mulher, do repúdio a todas as formas de racismo e de discriminação, do respeito à natureza e aos valores do trabalho, dos imperativos do desenvolvimento nacional, da convivência com todos os povos, da afirmação das características mestiças e do pluralismo cultural do povo brasileiro.

Art. 385 - O sistema de educação obedece às seguintes diretrizes:

I - democratização do acesso de toda coletividade aos benefícios da educação;

II - pluralismo de idéias e de instituições públicas e privadas;

III - descentralização da educação pública, cabendo, prioritariamente, aos Estados e Municípios o ensino básico obrigatório, nos termos do art. 387 deste Capítulo [...] (IDEM, p. 52).

O artigo 386 apresentou a educação primeiramente como dever dos pais e, em seguida, como responsabilidade do Estado. $\mathrm{O}$ artigo seguinte tratou da obrigatoriedade - abrangida na faixa etária dos 6 aos 16 anos. A destinação dos recursos foi tema dos artigos 388, 389, 390 e 391. Destaca-se a reafirmação da coexistência de instituições públicas e privadas; a gratuidade do ensino em estabelecimentos públicos de todos os níveis, porém, a admissão em tais estabelecimentos se daria mediante comprovação de carência e, inclusive, pelo mecanismo de bolsas de estudo. Além disso, previa a transferência de recursos públicos para instituições de ensino privado. Por fim, o artigo 393 apresentou o ensino religioso de matrícula facultativa e de oferecimento obrigatório por parte do Estado. 
De acordo com grande parte da literatura que retrata os acontecimentos do período, foi devido à repercussão negativa que o anteprojeto teve no meio sócio-político que o presidente Sarney optou por não o encaminhar à ANC, que logo em seguida iniciaria seus trabalhos. Todavia, em entrevista que compõe o livro de Luiz Maklouf Carvalho (2017, p. 49), Sarney afirmou que

O Ulysses me disse que não aceitaria nem esse, nem nenhum outro projeto de Constituição. Se eu mandasse pra ele, ele devolveria. No fundo era porque o Ulysses queria fazer, com a Constituição, como realmente ele tentou fazer e fez, uma campanha já de sua candidatura.

Por outro lado, diferentes setores do meio educacional começaram a se organizar para participar do processo de elaboração da nova Constituição. Cabe ressaltar que esse processo não se iniciou especificamente para este debate; ele teve início com o "cruzamento entre o movimento sindical dos professores" e a "difusão da crítica acadêmica da educação", nos anos de 1970 e, sobretudo, com a anistia (CUNHA, 2009, p.92). As reuniões da SBPC, a criação da ANPEd e da CEDES em 1978, e da ANDE, em 1979, são exemplos da representatividade que o campo educacional começava a conferir na discussão das políticas públicas no Brasil.

Luiz Antônio Cunha, em seu livro "Educação, Estado e democracia no Brasil", apresenta um capítulo sobre as conferências de educadores e a relevância delas para o momento histórico. Entre 1980 e 1988 aconteceram cinco Conferências Brasileiras de Educação, bienalmente, em diferentes capitais. Ressalta-se a importância da IV Conferência, realizada no ano de 1986, em Goiânia, pois dela resultou a Carta de Goiânia, documento que norteou muitos dos debates que futuramente se apresentariam na ANC.

Sobre a Carta de Goiânia é importante dizer que ao mesmo tempo em que se propunha a fazer um diagnóstico da situação da educação no país ${ }^{30}$ e uma análise da conjuntura a partir dos desdobramentos da abertura política no campo educacional - especificamente após as eleições de 1982 e das eleições indiretas de 1984 - oferecia algumas recomendações à nova Constituição, as quais destacaremos as pertinentes ao direito à educação:

$30 \quad$ Apresentam alguns dados do período, tais como: “[...] mais de 50\% de alunos repetentes ou excluídos ao longo da $1^{\mathrm{a}}$ série do ensino de $1^{\circ}$ grau; cerca de $30 \%$ de crianças e jovens na faixa dos 7 aos 14 anos fora da escola; $30 \%$ de analfabetos adultos e numeroso contingente de jovens e adultos sem acesso à escolarização básica; $22 \%$ de professores leigos; precária formação e aperfeiçoamento profissional de professores de todo país; salários aviltados em todos os graus de ensino" (CEDES, 1986, p. 6). 
1. A educação é um direito de todos os brasileiros e será gratuita e laica nos estabelecimentos públicos, em todos os níveis de ensino.

2. Todos os brasileiros têm direito à educação pública, básica comum, gratuita e de igual qualidade, independentemente de sexo, cor, idade, confissão religiosa e filiação política, assim como da classe social ou da riqueza regional, estadual ou local.

3. O ensino fundamental com 8 anos de duração é obrigatório para todos os brasileiros, sendo permitida a matrícula a partir dos 6 anos de idade.

4. O Estado deverá prover os recursos necessários para assegurar as condições objetivas ao cumprimento dessa obrigatoriedade [...]

5. É obrigação do Estado oferecer vagas em creches e pré-escolas de 0 a 6 anos e 11 meses de idade [...]

7. É dever do Estado prover o ensino fundamental, público e gratuito, de igual qualidade, para todos os jovens e adultos que foram excluídos da escola [...]

9. O ensino de $2^{\circ}$ grau, com 3 anos de duração, constitui a $2^{\mathrm{a}}$ etapa do ensino básico e é direito de todos [...]

15. Os recursos públicos destinados à educação serão aplicados exclusivamente nos sistemas de ensino criados e mantidos pela União, estados e municípios [...]

18. É permitida a existência de estabelecimentos de ensino privado, desde que atendam às exigências legais e não necessitem de recursos públicos para sua manutenção [...] (CEDES, 1986, p. 8-11).

Diante do exposto, os elementos que viriam a conduzir a maior parte dos debates doravante se concentravam em torno de dois eixos, a saber: a laicidade do ensino - que vamos agrupar na subcategoria liberdade do ensino, e a destinação dos recursos públicos exclusivamente para instituições públicas de ensino, que será agrupada nas duas subcategorias que iremos analisar, uma vez que compreende tanto a democratização das oportunidades educacionais, como a liberdade do ensino, como discutiremos no capítulo 4.

Por iniciativa dos professores da UnB (Universidade de Brasília) foi realizado pela ANDES, em 1986, um novo evento para discutir a Carta de Goiânia. Superadas algumas discordâncias de posição, as entidades participantes deste momento se juntaram às signatárias da Carta para que pudessem definir uma posição única que fosse encaminhada à ANC. Foi, então, criado o Fórum Nacional em Defesa da Escola Pública - FNDEP agregando, inicialmente (com a denominação de Fórum da Educação na Constituinte em Defesa do Ensino Público e Gratuito) algumas entidades ${ }^{31}$, todas engajadas no processo 31 São elas: CUT, CGT (Comando Geral dos Trabalhadores), OAB, ANPEd (Associação Nacional de Pós-Graduação e Pesquisa em Educação), SBPC (Sociedade Brasileira pata o Progresso da Ciência), SEAE (Secretaria de Acompanhamento Econômico), CEDES (Centro de Estudos de Direito Econômico e Social), ANDES (Sindicato Nacional dos Docentes das Instituições de Ensino Superior), ANDE (Associação Nacional de Desporto para Deficientes), CPB (Casa Publicadora Brasileira), FENOE (Federação Nacional de Orientadores Educacionais), FASUBRA (Federação de Sindicatos de Trabalhadores TécnicoAdministrativos em Instituições de Ensino Superior Públicas do Brasil), ANPAE, UNE (União Nacional dos Estudantes) e UBES (União Brasileira dos Estudantes Secundaristas). 
de redemocratização do País. O FNDEP foi lançado oficialmente, já no ano de 1987, com o Manifesto em Defesa da Escola Pública e Gratuita. Segundo Prado (2010, p. 44-45), os princípios que fundamentaram o referido documento foram “[...] a defesa do ensino público, laico e gratuito sem nenhum tipo de discriminação econômica, política ou religiosa, a democratização do acesso, permanência e gestão da educação; a qualidade do ensino e o pluralismo de escolas públicas e particulares".

Pinheiro (2005, p.260) resgata as articulações dos grupos vinculados ao setor da educação privada brasileira. Dois grandes grupos destacaram-se no período: o das escolas não-confessionais e o das escolas católicas e comunitárias. O primeiro teve a FENEN Federação Nacional dos Estabelecimentos de Ensino como porta-voz, que trazia, sobretudo, a ideia da liberdade da família na escolha do gênero de educação de seus responsabilizados, que se consubstanciaria na oferta de bolsas de estudo pelo Estado. Já o segundo grupo obteve apoio de suas entidades representativas, a saber: AEC - Associação de Educação Católica do Brasil, ABESC (Associação Brasileira de Escolas Superiores Católicas) e a CNEC - Campanha Nacional de Escolas de Comunidade. Neste caso, apesar de cada qual defender nas suas propostas os seus interesses específicos, elas buscavam de igual modo aproximar-se do setor público e diferenciar-se das escolas privadas não-confessionais, por meio de sua autodefinição como instituições públicas não-estatais, ou como instituições sem fins lucrativos, ou ainda por sua relevante contribuição à sociedade, com qualidade superior às escolas não-confessionais.

Ainda na obra citada, Luiz Antônio Cunha (2009, p. 38-45) apresenta a matéria educacional constante nos programas dos partidos dos parlamentares que compuseram a Câmara dos Deputados em 1986, parlamentares estes que se tornaram, também, constituintes. Destaca, pois, os partidos que ocuparam mais de dez cadeiras naquele espaço, que foram os que seguem: PMDB, PFL, PDS, PDT, PTB, PT e PL. Julgamos pertinente este breve resgate, pois nos auxiliará a compreender a coerência (ou não) da proposição destes agentes para compor o capítulo da educação na nova $\mathrm{CF}$, especificamente no que concerne à noção de direito.

O programa do PMDB defendia a ampliação da aplicação de recursos na educação popular, resultado da ação dos governos militares. Assim, indica a obrigatoriedade e a gratuidade do ensino básico de oito anos, a gratuidade da educação pré-escolar a partir dos dois anos, opõe-se à comercialização do ensino em todos os níveis, e à utilização de verbas públicas exclusivamente no ensino público - sobre a qual existiam algumas discordâncias internas, como vemos a seguir: 
Enquanto o Simpósio de 1982 reivindicava que os $13 \%$ da receita de impostos do governo federal e os $25 \%$ dos governos estaduais e municipais deveriam ser empregados exclusivamente no ensino público, o congresso de 1986 concluiu que se deveria priorizar a manutenção e o desenvolvimento do ensino público [...] Apesar dessas incongruências, o texto produzido pelo congresso do PMDB enfrentou a ideologia neoliberal que pretendia dissolver o lema "recursos públicos para o ensino público", pela suposição de serem públicas as escolas privadas, já que prestariam um "serviço público" (IDEM, p.41).

$\mathrm{Na}$ mesma obra, Cunha ressalta que o texto do congresso não apresentou uma proposta de redação para a Constituição, devido às discordâncias internas pertinentes ao seu conteúdo progressista, sobretudo do setor privatista. Contudo, essa mesma divergência foi capaz de capilarizar o partido no país, por meio de gestões que se estabeleceram após o pleito de 1986. Este resultado forneceu meios para que se pudesse oferecer propostas de governo imediatas, conferindo certa "vantagem" ao partido em detrimento dos demais.

O PTB não fez registros significativos sobre o tema, enquanto o PDT defendeu a gratuidade do ensino por meio de uma reforma educacional que pudesse assegurá-la. Já o PT apresentou a educação como direito do povo e a ser definida por sua base, ou seja, os trabalhadores; criticou a privatização do ensino em todos os níveis, embora, sob este aspecto houvesse discordância com os setores religiosos do partido. Ressalta-se que houve a substituição dos termos público por livre, considerando como serviço público os que são executados também fora da órbita do Estado, assim como fez o PMDB. Todavia, cabe destacar a proposta majoritária, que foi apresentada pelo partido à Constituição:

[...] "o ensino é dever do poder público, devendo ser prestado de forma gratuita em todos os níveis". Sobre o ensino privado, o projeto previa sua extinção após um período de transição de dez anos [...] Assim, durante os dez anos de transição, o ensino privado somente seria ministrado por entidades sem fins lucrativos, sem auxílios ou subsídios públicos. Depois disso, todo o ensino seria ministrado pelos poderes públicos [...] (IDEM, p. 43).

$\mathrm{Na}$ contramão da proposta acima, o PDS apoiou o ensino privado, a partir da perspectiva da família como instituição primeira responsável pela garantia do direito e dever de educar. No que se refere às escolas, defende a atuação subsidiada das instituições privadas, ao passo que estabelece como dever do Estado a garantia do ensino de $1^{\circ}$ grau e do $2^{\circ}$ grau para os estudantes sem recursos. Cunha destaca ainda que o Partido da Frente Liberal foi constituído por membros dissidentes do PDS, que incorporaram além das ideias liberais, algumas perspectivas oriundas do campo católico. Desta junção resultou a prerrogativa de que a família é livre para escolher a educação que deseja fornecer aos 
seus responsabilizados, por meio de subsídios públicos, quer seja na escola pública, ou na particular, por meio das bolsas de estudos.

O Deputado Arolde de Oliveira, ao relembrar a atuação dos partidos que mais participaram do processo constituinte, acabou por ratificar a análise de Cunha, ao citar todos os partidos acima descritos, com exceção do PL. Apontou, ainda, a implicação da configuração do Congresso à época para a formação do Centrão, assunto ao qual voltaremos oportunamente.

Os partidos na época mais fortes eram o PMDB, o PFL, o PTB, o PDT, o PT, basicamente esses partidos mais fortes. O PSDB acabou surgindo depois daquele período, o PMDB [...] congregava várias ideologias naquele tempo, tanto que desovou o PSDB, que era mais à esquerda. Tivemos nesse bolo todo aqui o que nós chamamos de Centrão [...]

Em meio a toda a efervescência de debates que aconteciam na sociedade brasileira, instalou-se a Assembleia Nacional Constituinte (ANC) em $1^{\circ}$ de fevereiro de 1987, com 559 parlamentares - 487 deputados e 72 senadores, sendo que dentre estes últimos, 23 foram eleitos em 1982. Cabe uma ressalva para a situação do senador Fábio Lucena, do PMDB do Amazonas, que mesmo eleito em 1982, foi novamente à votação em 1986, sendo reeleito com um número ainda maior de votos. Apesar da polêmica sobre a validação dos votos destes senadores ter se instalado logo na abertura dos trabalhos constituintes, a mesma não se desdobrou, posto que já resolvida quando da convocação para a ANC, conforme salienta Carvalho (2017, p. 21).

A primeira grande batalha da Constituinte se deu logo na votação do seu regimento interno, relatado por Fernando Henrique Cardoso, então senador pelo PMDB de São Paulo. Segundo o próprio, foi escolhido para tal relatoria "[...] autoritariamente pelo Ulysses. Ele me informou que seria eu, pouco antes de a Constituinte começar. O Ulysses era assim" (IDEM, p.111). Desta forma, após um debate que durou aproximadamente dois meses, foi apresentado um substitutivo que objetivou dirimir os conflitos.

Nessa mesma linha do que afirmou Luiz Antônio Cunha anteriormente sobre as divergências internas do PMDB, Carvalho (IBIDEM) resgatou, nas diferentes entrevistas constantes em seu livro, o relato dessas disputas, notadamente entre o presidente da república, José Sarney, o presidente da ANC, o deputado Ulysses Guimarães, e o senador Mário Covas, líder do partido na Constituinte. O resultado de tal disputa afetou significativamente momentos relevantes da $\mathrm{ANC}$, a começar pela própria eleição deste último para o lugar que 
ocupou no partido, devido ao apoio que lhe foi dado por Sarney para que pudesse desbancar o candidato apadrinhado por Ulysses, o então deputado Luiz Henrique da Silveira. Tal situação confirma-se no relato seguinte do próprio ex-presidente:

[...] Eu até gostava do Luiz Henrique. Mas me colocaram o seguinte argumento: Ulysses já é presidente da Constituinte, do PMDB e da Câmara. Nós entregarmos mais a liderança do PMDB, o Ulysses fica dono de tudo. Então, é melhor que a gente tenha um contraponto, porque o Covas tem uma autoridade grande etc. e tal. Aí eu realmente ajudei o Covas. Quem elegeu o Covas fui eu (IBIDEM, p.54).

Ainda sobre as disputas internas ao PMDB, resgatamos a entrevista realizada com o deputado estadual Paulo Ramos - à época deputado federal constituinte pelo PMDB especificamente quando o mesmo destaca as rusgas existentes entre o presidente Sarney e o deputado Ulysses Guimarães, que antecederam, inclusive, segundo sua argumentação, a posse do mesmo quando da impossibilidade da assunção do cargo pelo presidente eleito indiretamente, Tancredo Neves:

Houve um parecer jurídico do Sepúlveda Pertence, com quem convivi e respeito, mas na verdade, o deputado Ulysses Guimarães somente concordou com o Sarney, com a posse do Sarney, porque ele nunca imaginou que o Tancredo Neves fosse morrer, que não era uma cirurgia de alta complexidade, ao contrário, diverticulite, uma coisa no intestino, uma coisa que tinha um grau de simplicidade muito grande. Me lembro até que eu fui eleito para a Assembléia Nacional Constituinte pelo PMDB. E um dia no gabinete do Dr. Ulysses, era uma pessoa pela qual a gente tinha muito respeito, eu cobrei dele numa discussão muito acirrada e eu cobrei dele porque, e foi a única vez que eu vi Dr. Ulysses falar um pequeno palavrão. Ele falou com raiva, ele estava indignado, ele falou: "Porra, como é que eu ia imaginar que ele ia morrer". Quer dizer, ele não quis contribuir, porque a resistência na transição ao Ulysses Guimarães era muito maior. E se ele assumisse numa situação de continuidade, aí teria que haver eleição. E ele preferiu não complicar o processo, mas acreditando que o Tancredo Neves ia, tanto que a constituição foi elaborada sempre com enfrentamentos entre Ulysses Guimarães e o presidente Sarney, durante a elaboração. Tanto que no período que antecedeu a promulgação da constituição, o presidente Sarney utilizou a rede de rádio e televisão como presidente da república, para dizer que a Constituição ia deixar o país ingovernável. E Ulysses Guimarães exigiu, eu estava no gabinete dele quando ele telefonou: "eu vou entrar na rede de rádio e televisão". Não foi assim um pedido ao presidente da república, não. Foi uma exigência. E foi aquela frase que ele disse "a constituição será a guardiã da governabilidade", respondendo à intervenção do José Sarney. 
No que se refere ao senador Mario Covas, existem algumas divergências entre os atores que estudamos com relação a sua atuação. Na apresentação do seu livro, Carvalho (2017, p.15) afirma que "Se os leitores quiserem escolher o cristo do livro, Covas é um forte candidato". Tal alegação foi feita pelo motivo dos entrevistados de sua obra lhe imputarem a responsabilidade por ter desencadeado as principais discussões que dificultaram o entendimento entre os personagens que atuaram no Congresso: o parlamentarismo e os cinco anos do mandato do presidente Sarney. Todavia, Paulo Ramos destacou o papel assumido por Mario Covas na tentativa de conferir um caráter mais à esquerda com a indicação dos relatores das diferentes comissões e na estruturação da comissão de sistematização, quando da escolha dos seus membros:

Porque o senador Mario Covas, a comissão de sistematização tinha um perfil considerado muito mais progressista do que o conjunto da constituinte. E quando as subcomissões e comissões foram organizadas, o senador Mario Covas que coordenou a estruturação das comissões em função do regimento, ele já colocou presidente de comissão, de subcomissão coordenadores de bancada, ele foi caminhando para que, para que na comissão de sistematização o perfil fosse mais avançado.

Sobre a comissão de sistematização é importante destacar que apesar do senador Fernando Henrique Cardoso ser o principal candidato à relatoria, o senador Bernardo Cabral acabou por ocupar aquele lugar. A seu respeito também existem argumentos controversos: de articulador que buscava o apoio irrestrito de diferentes agentes, que contava com a "simpatia transformada em apoio" pelo presidente Sarney (CARVALHO, 2017, p. 54), ao habilidoso relator que conseguiu conduzir o processo $^{32}$, o trabalho desta comissão foi fundamental para o desfecho do que se configurou a ANC.

As divergências entre os constituintes filiados ao PMDB era tão grande, assim como as fissuras ideológicas internas ao partido, que se constituiu um subgrupo que veio a se articular junto aos partidos de esquerda para buscar uma maioria na proposição e votação de emendas. O deputado Paulo Ramos assim caracterizou o MUP - Movimento de Unidade Progressista:

[...] a esquerda do PMDB construiu o chamado movimento de unidade progressista. O setor progressista do PMDB tinha mais constituintes que PT, PDT, PSB, PCB

32 Conforme fala do deputado Paulo Ramos: "Render também homenagens ao relator, Bernardo Cabral, teve muita habilidade para se conduzir". 
e PCdoB somados. Então, houve um movimento de unidade. Então, a esquerda do PMDB mais esses partidos se transformaram na constituinte numa espécie de partido político. E uma coisa tão importante e que as pessoas normalmente não sabem, é que os períodos a partir de uma determinada fase de elaboração da constituição, o chamado MUP, a gente chamava se consolidou, um constituinte não podia apresentar 50 emendas. Administrativamente era deferido ao constituinte apresentar 4 emendas. Então a gente só podia apresentar 4. Imagina um texto com 200 artigos, só 4 emendas. E aí o que aconteceu. Aí eu tenho que falar do Plínio de Arruda Sampaio, Plínio era do PT, mas Plínio teve a compreensão também, e aí o MUP reunia os constituintes do MUP e era assim: eu tenho direito a 4 emendas; eu só vou poder fazer 1. Essas outras três eu coloco no banco de emendas, e então somava os deputados e senadores do MUP, multiplicava por 3 e estava lá, nós podíamos apresentar tantas emendas. O MUP era também dividido por comissões, cada comissão elaborava a emenda, até o número tal, para poder ter o aproveitamento para tal, e depois cada um assinava como titular de emenda só para efeito administrativo, quer dizer, eu assinei, por exemplo, uma emenda que eu mesmo elaborei, mas assinei outras 3 do banco. Mas todo mundo assinava junto. Mas, para efeito administrativo a emenda era registrada em nome... Isso representou uma possibilidade muito grande de influir, além, obviamente, desse bloco.

Ao resgatarmos alguns textos sobre o MUP, encontramos uma entrevista do Jornal O Globo do dia 25 de julho de 1987, na qual Miguel Arraes condena a estruturação de grupos para a defesa de posições sem a busca de amplos acordos. Chamou ainda as posições progressistas adotadas pelo grupo de ultrapassadas. No jornal O Estado de São Paulo, de 09 de dezembro de 1987, os parlamentares do MUP são chamados de xiitas. A radicalização das posições internas do PMDB redundou na gênese do PSDB, no ano seguinte, tal como apresentou o deputado Arolde de Oliveira, em trecho de sua entrevista destacado anteriormente. Ressaltamos também a entrevista do vice-líder do PMDB na ANC, Antônio Britto (CARVALHO, 2017, p. 177), quando cita a existência de pelo menos três PMDB à época:

Um, primeiro, que não tinha histórico de resistência à ditadura, e que era uma área extremamente conservadora, que acabou criando uma antítese ao Covas e se aliando muito mais ao Zé Lourenço, líder do PFL. Na outra ponta você tinha a dissidência do MUP, com pessoas que tinham vindo de movimentos sociais organizados [...] E um PMDB que estava em torno de São Paulo, em torno do Covas, visivelmente incomodado com o caminho que o Sarney tinha tomado. E essa história do PSDB tinha muito de uma rebelião paulista. 
A partir da aprovação do regimento interno, a ANC estabeleceu sua metodologia de trabalho, que abarcava discussões por comissões temáticas (no total de oito) ${ }^{33}$, sendo que cada qual teria três subcomissões ${ }^{34}$, de forma que as conclusões delas oriundas fossem encaminhadas à comissão de sistematização, cuja meta era a preparação de uma proposta preliminar para discussão e votação no plenário, em dois turnos. A perspectiva inicial era que o texto final estivesse finalizado em novembro de 1987. Todavia, não foi o que aconteceu. A discussão se estendeu por aproximadamente 20 meses, com muita movimentação de representantes de importantes setores da sociedade civil, para coleta de depoimentos nas subcomissões e, posteriormente, com muitos acordos e disputas, na fase de finalização dos textos pelas comissões, e, principalmente, na comissão de sistematização.

Cabe ressaltar que o regimento aprovado logo no início dos trabalhos causou uma grande instabilidade no processo constituinte, quando se tentava elaborar um texto único, com as contribuições advindas das comissões temáticas. Percebe-se, nesta etapa, que a metodologia adotada privilegiava as proposições iniciais, ou seja, as que foram realizadas nas subcomissões, comissões temáticas e na sistematização, em detrimento das mudanças que se objetivasse fazer na comissão de redação, antes da votação em plenário. Tal dinâmica é bem explicitada por Nelson Jobim, deputado pelo PMDB do Rio Grande do Sul à época, que auxiliou na elaboração do regimento interno da ANC:

Nós tínhamos 559 constituintes. Tiramos os seis membros da mesa, ficaram 553. Aí o dr. Ulysses disse "Os líderes, os cardeais, os caras que tem autoridade vão ser membros da Comissão de Sistematização", que eu já tinha desenhado. Escolhemos 49 nomes para essa comissão. Sobraram 504. Eu tinha feito oito comissões, correspondentes aos oito títulos da Constituição. Cada comissão se subdividiu em três subcomissões. Cada comissão ficou com 63, 21 em cada subcomissão. As subcomissões também tinham quórum. Tudo tinha que ser aprovado por maioria absoluta, por onze votos [...] o problema é que não tinha saída, não tinha como fazer de outro jeito. Os dois jeitos eram: um projeto do governo, que o Sarney não

33 São as seguintes: 1. da Soberania e dos Direitos e Garantias do Homem e da Mulher; 2. da Organização do Estado; 3. da Organização dos Poderes e Sistema de Governo; 4. da Organização Eleitoral, Partidária e Garantia das Instituições; 5. do Sistema Tributário, Orçamento e Finanças; 6. da Ordem Econômica; 7. da Ordem Social; 8. da Família, da Educação, Cultura e Esportes, da Ciência e Tecnologia e da Comunicação.

34 Subcomissões: 1a. da Nacionalidade, da Soberania e das Relações Internacionais; 1b. dos Direitos Políticos, dos Direitos Coletivos e Garantias; 1c. dos Direitos e Garantias Individuais; 2a. da União, Distrito Federal e Territórios; 2b. dos Estados; 2c. dos Municípios e Regiões; 3a. do Poder Legislativo; 3b. do Poder Executivo; 3c. do Poder Judiciário e do Ministério Público; 4a. do Sistema Eleitoral e Partidos Políticos; 4b. de Defesa do Estado, da Sociedade e de sua Segurança; 4c. de Garantia da Constituição, Reformas e Emendas; 5a. de Tributos, Participação e Distribuição de Receitas; 5b. de Orçamentos e Fiscalização Financeira; 5c. do Sistema Financeiro; 6a. de Princípios Gerais, Intervenção do Estado, Regime da Propriedade do Subsolo e da Atividade Econômica; 6 b. da Questão Urbana e Transporte; 6c. da Política Agrícola e Fundiária e da Reforma Agrária; 7a. dos Direitos dos Trabalhadores e Servidores Públicos; 7b. de Saúde, Seguridade e do Meio Ambiente; 7c. dos Negros, Populações Indígenas, Pessoas Deficientes e Minorias; 8a. da Educação, Cultura e Esportes; 8b. da Ciência e Tecnologia e da Comunicação; 8c. da Família, do Menor e do Idoso. 
podia mandar; e a grande comissão, para elaborar o anteprojeto, que também já tinha dado confusão. A saída foi entregar o papel em branco para cada constituinte. Todo mundo disse que era uma grande abertura democrática, mas aquilo, na verdade, é que não tinha outra forma de fazer (CARVALHO, 2017, p. 204).

Ou seja, após a aprovação do texto na comissão de sistematização, seria necessário contar com a maioria absoluta de aproximadamente 280 votos para rejeitar o que a sistematização aprovara com, no máximo, 93 votos. Destacamos a fala do ex-presidente Sarney sobre o regimento:

Eles fizeram um regimento com o qual acreditavam que iam fazer a Constituição só com aquela Comissão de Sistematização, que consagrava uma minoria, e o plenário não ia ter a decisão final. Isso deve ter alimentado muito a campanha dos quatro anos. Porque eles tinham certeza que ganhariam na comissão e o Plenário teria enorme dificuldade de alterar aquele projeto. Precisava de maioria absoluta para rejeitar - uma copia inversa. [O regimento] foi feito com esperteza destinada a manipular. Isso incentivou muito essa Comissão de Sistematização (CARVALHO, 2017, p. 49-50).

O trecho acima nos remete a dois aspectos sobre os quais precisamos também fazer uma breve incursão: a discussão do número de anos de mandato do presidente Sarney e o regime de governo - parlamentarismo ou presidencialismo - e a composição do chamado Centrão, que viabilizou a mudança do regimento e alterou significativamente os rumos da Constituinte. Voltaremos a estas questões mais adiante.

No que é pertinente à indicação dos presidentes e relatores das comissões e subcomissões, é importante destacar que o PMDB e o PFL, partidos majoritários, foram também os que ocuparam as principais cadeiras no processo constituinte, a saber:

$\checkmark$ O PMDB ocupou a relatoria das nove comissões estabelecidas;

$\checkmark$ O PFL ocupou a presidência de oito das nove comissões. Uma única foi ocupada pelo PDS;

$\checkmark$ O PMDB ocupou a presidência de 15 subcomissões e a relatoria de 13;

$\checkmark$ O PFL ocupou a presidência de cinco subcomissões e a relatoria de 4;

$\checkmark$ O PDT ocupou a presidência de duas subcomissões e a relatoria de apenas 1;

$\checkmark$ O PDS ocupou a presidência de uma subcomissão e duas relatorias;

$\checkmark$ O PTB ocupou a presidência de uma subcomissão e uma relatoria;

$\checkmark$ O PFL, o PDC e o PT ocuparam cada um a relatoria de uma subcomissão. 
A ocupação dos lugares de presidente e relator nas comissões e subcomissões eram fundamentais para que se pudesse imprimir nos debates o ritmo e a metodologia a ser adotada nas discussões. Cada lugar ocupado tinha total significado na rede de poderes estabelecidos na ANC, que certamente iria interferir em seu resultado final. Tal perspectiva se evidencia na seguinte observação:

Assim, o fato de o campo político ser autônomo e ter sua lógica própria, lógica que
está no princípio dos posicionamentos daqueles que nele estão envolvidos, implica
que existe um interesse político específico, não automaticamente redutível aos
interesses dos outorgantes do mandato. Há interesses que se definem na relação
com as pessoas do mesmo partido ou contra as pessoas dos outros partidos. O
funcionamento do campo produz uma espécie de fechamento (BOURDIEU, 2011,
p. 199).

Desta forma, esboçou-se um primeiro desenho dos grupos que viriam a ser preponderantes nestes espaços. Porém, a partir dos desdobramentos de cada um deles, a dinâmica inicial adotada foi tomando caminhos próprios, a partir, sobretudo, do primeiro momento de debates, no qual o Congresso foi tomado por representações de diferentes organismos da sociedade civil. A etapa das subcomissões teve início no dia 07 de abril de 1987, com exceção das subcomissões 5a, 5 b e 5c, que se iniciaram no dia seguinte. De acordo com o parágrafo $4^{\circ}$ do artigo 17 do regimento interno, aprovado por meio da resolução n² de 1987 (CÂMARA, 2017a, p. 4), a subcomissão teria um prazo de 45 dias a partir da sua constituição para elaborar um anteprojeto para encaminhamento à sua respectiva comissão.

Assim sendo, o trabalho das subcomissões se estendeu até o final do mês de maio do mesmo ano, com base em um amplo processo de escuta e recebimento de propostas de diferentes naturezas, como podemos observar nas passagens seguintes:

A constituinte mobilizou, quer dizer, o processo constituinte, a elaboração da constituição não se deu sem a participação da sociedade, na participação efetiva no dia a dia dos debates. O Congresso Nacional vivia lotado de representações de todo país. Quer dizer, o processo constituinte foi acompanhado de perto pela sociedade (deputado Paulo Ramos, em entrevista).

A participação da sociedade civil no processo constituinte foi prevista de três maneiras: $1^{\mathrm{a}}$. através das Sugestões Populares, enviadas ao Senado Federal antes das eleições da Constituinte; $2^{\mathrm{a}}$, por intermédio das Audiências Públicas, presença das entidades da sociedade civil em sessões das Subcomissões; $3^{\mathrm{a}}$. através da apresentação de Emendas Populares, encaminhadas à Comissão de Sistematização [...] (PINHEIRO, 2005, pp. 267-268). 
Em sua primeira fase, a Constituinte foi uma festa cívica. As comissões temáticas ouviram, em audiências públicas, perto de mil depoentes: de ministros a índios (muitos índios); de governadores a representantes de minorias organizadas (dezenas deles); de sindicalistas a intelectuais da academia. Algumas das subcomissões mandaram comitivas a diversas regiões do Brasil. E todas elas, de muitos rincões socialmente organizados, encheram a Constituinte de povo - cada segmento levando e querendo garantir a inclusão de suas reivindicações (CARVALHO, 2017, p. 22).

A ideia era deixar a discussão rolar nas comissões subtemáticas, consideradas um "teatro" pela crítica conservadora, afunilar para as temáticas e amarrar um projeto na Comissão de Sistematização, que, na prática, teria poucas chances de mudar em plenário (REIS, 2014, p.154).

Esse processo de incorporação das demandas populares, comemorado como grande ganho do processo democrático por todos os setores e agentes presentes e representados na $\mathrm{ANC}$, foi definido por José Lourenço, líder da bancada do PFL à época, como algo que "ninguém deu muita importância", sendo apenas "uma concessão ao povo para satisfazer egos" (CARVALHO, 2017, p.194).

As comissões temáticas foram instaladas no dia 01 de abril de 1987, com a devida eleição de presidentes e relatores, sendo suas sessões retomadas, em sua maioria, no final do mês de maio ${ }^{35}$. De posse dos documentos produzidos nas subcomissões que as compunham, regimentalmente estes espaços dispunham de 65 dias para conclusão de seu trabalho conforme o parágrafo $3^{\circ}$ do artigo 14 . No caso de não conseguirem efetivar um relatório final para encaminhamento à próxima etapa da ANC - a comissão de sistematização caberia ao relator desta sua produção. Tal fato só aconteceu na comissão 8 , que é um dos nossos objetos de estudo.

“As primeiras batalhas - algumas no sentido literal - ocorreram, entre abril e 26 de junho, nas comissões e subcomissões", segundo Luiz Maklouf Carvalho (2017, p.22). Uma das "batalhas” é narrada nesta obra por José Lourenço (IDEM, p.182), líder do PFL à época, de forma bastante significativa, mostrando como o poder se estabelecia não somente de forma simbólica, na busca por consenso. Era também pela força, como mostra uma passagem que teria acontecido na comissão 6, com base nas discussões advindas da

$35 \quad$ As comissões 1 e 6 realizaram mais uma sessão no mês de abril e retomaram as reuniões no dia 26/05/1987; a comissão 2 realizou duas sessões no mês de abril, retomando-as em 26/05/1987; a comissão 3 retomou as sessões em 06/05/1987; as comissões 4 e 5 retomaram os encontros em 26/05/1987; e as comissões 7 e 8 retornaram aos trabalhos em 25/05/1987. 
subcomissão 6c, que tratava da política agrícola e fundiária e da reforma agrária, grande gargalo das questões sociais do Brasil, até os dias atuais:

No dia de uma votação importante eles estavam sem maioria, porque um tinha faltado. Como eu tinha um suplente do PFL, mandei que ele assinasse o livro e ficasse apto para votar. Eles vieram em cima: "Não pode!" O Saldanha Derzi estava com um revólver $38 \mathrm{~mm}$, e me passou.

Diante de tantos desafios a serem vencidos, caberia à relatoria da comissão de sistematização o próximo passo: produzir um primeiro anteprojeto para ser apreciado. Bernardo Cabral assim o fez, tendo produzido um "Frankenstein" (IBIDEM, p. 23) de 501 artigos. Cabe ressaltar que a composição desta comissão, que teve as mãos do senador Mario Covas, como já mencionado anteriormente, contou com um perfil mais à esquerda. Sobre esta questão, José Lourenço afirmou em entrevista que foi reclamar com o presidente Sarney e solicitar que providências fossem tomadas (IBIDEM, p. 186).

Diante o exposto, a primeira versão foi apresentada à comissão de sistematização em junho de 1987 (REIS, 2014, p. 154). A avaliação feita na ocasião entre os conservadores era que o documento tinha tendências socializantes, e não caminhava na direção "global", ou seja, de acordo com o liberalismo renovado, ou neoliberalismo, que se afirmava no mundo.

Travou-se, pois, uma disputa que colocava em lados opostos os setores reacionários e as esquerdas representadas pelo PDT, PT, PSB, PCB, PCdoB e parte progressista do PMDB. Dos debates realizados resultou um texto com 496 artigos, que foi encaminhado ao plenário em primeiro turno, em julho de 1987. Na ocasião 20.791 emendas de naturezas distintas foram apresentadas, retornando tal projeto à comissão de sistematização no mês seguinte. Sobre tal metodologia, Fernandes (2014, p. 306-308) teceu a seguinte crítica:

A mesa diretora da ANC diluiu o processo de elaboração da constituição, tomando como ponto de referência e como padrão o funcionamento da Câmara e do Senado, introduzindo uma cunha insuperável entre os momentos ou etapas daquele processo e o trabalho contínuo da ANC. Esta se viu anulada [...] por uma calculada supressão de elos entre o órgão central (o plenário) e os organismos intermediários (as subcomissões, as comissões temáticas e a comissão de sistematização) [...] Essa moldura parlamentar facilitou as manobras de entidades e organizações patronais, contrárias às reformas que a situação histórica aponta como imperativas

e, ao mesmo tempo, ofereceu um vasto campo de manobras para interferências indébitas e arrasadoras do Executivo, do Judiciário, das Forças Armadas, dos "lobbies" e grupos de interesses e pressão. 
Ao estudar a sociedade civil no Brasil contemporâneo, Fontes (2006, p. 226) destaca a participação do empresariado brasileiro e os embates no interior das entidades patronais, que, segundo a autora, foram "agressivas" ao longo do processo constituinte, de maneira a tentar impedir, ou mesmo reduzir, os avanços sociais dos trabalhadores na nova Constituição. Os detentores do capital político e econômico não desejavam, pois, perder espaço com possíveis ganhos constitucionais dos grupos oriundos das classes trabalhadoras, ali representados pelos sindicatos de classe, por exemplo. O relato do vicepresidente de relações institucionais da Rede Brasil Sul - afiliada da Rede Globo, Fernando Ernesto Corrêa ao livro do Carvalho (2017, p. 16) confirma, inclusive, a atuação desta, tanto como veículo da mídia, quanto como grande empresa, que objetiva garantir seus interesses privados no campo político.

Daniel Aarão Reis (2014, p. 158) destacou ainda que antes da votação do relatório nesta comissão, “[...] o Congresso tornara-se objeto de pressões e contrapressões em que se disputavam os votos dos parlamentares”. As vinculações políticas dos deputados e senadores com grupos que lhe ofereciam sustentação evidenciaram-se, redundando em persuasão e barganha de votos.

De setembro a novembro aconteceram 535 votações na comissão de sistematização, sendo entregue ao presidente da Constituinte o Projeto A, composto por 335 artigos e com aproximadamente 1.800 dispositivos legais (REIS, 2014, p. 158-159). Desta forma, "Dois projetos e muita confusão depois, e sob os holofotes de toda a mídia, a Comissão de Sistematização encerrou as votações em 18 de novembro" (IDEM, p.23). O documento que tramitou nesta comissão continha um grau de detalhamento pouco desejado para uma Constituição e que se afastava tanto dos princípios liberais clássicos quanto dos neoliberais, flertando com teses nacional-estatistas e com bandeiras advindas dos movimentos populares. Além do exposto, indicava o parlamentarismo como forma de governo e baixava de seis para quatro anos o mandato presidencial. Tal projeto gerou muita insatisfação entre líderes conservadores de diferentes partidos, que resultou na formação de um grupo autodenominado Centro Democrático, que ficou conhecido como Centrão. Em janeiro de 1988 este grupo aprovou uma mudança regimental, alterando a dinâmica das discussões, favorecendo a aprovação de seus interesses.

A articulação conservadora voltou-se contra o regimento que, como explicitamos anteriormente, inviabilizava a mudança dos dispositivos que haviam sido introduzidos no 
texto da comissão de sistematização por exigir, para sua alteração, um número muito maior do que recebeu para que entrasse na redação. Desta forma, por meio da inversão do ônus do quórum, seria possível aprovar pautas que iam ao encontro dos interesses do governo. Várias entrevistas realizadas por Carvalho (2017, p.25) com diferentes agentes do processo confirmam que Sarney fora o principal responsável por tal manobra, valendo-se, inclusive, da compra de votos dos parlamentares, sobretudo por meio da concessão de canais de rádio e televisão.

O novo texto foi encaminhado à discussão do plenário em janeiro de 1988 , sendo aprovado em julho de 1988, em primeiro turno. O texto final fora apresentado no dia 22 de setembro, sendo votado e aprovado. Questões de grande interesse do governo conseguiram manter unidos os parlamentares do Centrão, que trouxeram de volta o presidencialismo e conseguiram definir os cinco anos de mandato do presidente, bandeiras tão caras à gestão naquele momento. Carvalho (IDEM, p. 24) afirma que apesar da aliança conservadora ter conseguido articular tais vitórias, o que predominou nas votações foram os "buracos negros", ou seja, a dificuldade de definir uma matéria. Tal fato exigia que se buscasse, por meio de "conchavos e negociações", acordos. Festas, jantares, futebol, favores de diferentes naturezas. Várias estratégias são narradas nas entrevistas constantes no livro de Carvalho (2017, p.251) como formas de angariar votos. Diz-se, inclusive, que muito do que foi aprovado no capítulo pertinente à educação foi tecido nas festas promovidas na casa do empresário João Carlos Di Genio, dono grupo Objetivo ${ }^{36}$, como podemos ver na entrevista de Oscar Corrêa Júnior, deputado pelo PFL e presidente da comissão 3.

Para tentar articular a maioria em torno da votação de um artigo, Nelson Jobim, deputado e vice-líder do PMDB na ocasião, relatou que sempre era chamado para redigir os textos, de forma a torná-los mais ambíguos, pois “o jogo era esse [...] quando não se conseguia o acordo, e não tinha solução num texto ambíguo, eu usava a técnica de jogar para a lei complementar ou lei ordinária [...]" (IDEM, p. 210). Cita ainda como eram feitos os entendimentos para que se pudesse concluir o processo de votação:

Eram acordos de lideranças. Havia entendimentos na casa do dr. Ulysses e reuniões dos líderes, com o Covas. Depois dessas discussões preliminares, ia-se para o Colégio de Líderes. Para os temas complexos havia debates ou entendimentos paralelos, ou na casa do dr. Ulysses, ou com as próprias lideranças. Eu circulava por tudo, porque fiquei amigo de todo mundo (IBIDEM, p. 211).

36 Um dos maiores empreendimentos educacionais privados do Brasil formado pelas instituições de ensino: UNIP - Universidade Paulista, Curso Objetivo e Colégio Objetivo. 
Sobre as manobras estabelecidas pelo Centrão na etapa final de discussão do projeto da Constituição, Fernandes estabeleceu severas críticas:

O "Centrão" é um conglomerado de políticos unidos pelos interesses do capital e pela necessidade que eles impõem de defesa da ordem existente (2014, p.186).

[...] realiza uma regressão do processo constituinte, que emergia com grandes dificuldades e debilidades graças aos movimentos de iniciativa e da participação populares (IDEM, p. 202).

[...] ele articula, apesar de sua heterogeneidade, o grande capital nacional com as multinacionais e o sistema capitalista mundial de poder; e agrega todos os tipos de privilégios, arcaicos e modernos, típicos de nosso desenvolvimento desigual (IBIDEM, p. 230).

O que se assistiu é de estarrecer e define como os donos do poder percebem e manipulam a ANC. Não há respeito por esta entidade e a própria Constituição é concebida como um meio para definir e defender interesses particularistas [...] Não se produzia uma carta magna. Tentava-se dividir um bolo, entre famintos de poder, de dinheiro e de influência [...] A ANC finalmente revelava a face que lhe impunha o capitalismo selvagem: uma casa de negociatas, na qual se vendia a retalhos uma constituição no ato de ser elaborada (IBIDEM, p. 112-113).

Apesar de se reconhecerem em campos distintos no processo de elaboração da CF de 1988, os dois deputados por nós entrevistados foram consensuais nas razões que levaram à criação do Centrão:

A constituição que saiu da comissão de sistematização primeiro era parlamentarista; segundo, 4 anos para o Sarney; e aí o que aconteceu, pelo regimento interno, pelo regimento interno, o que saiu da comissão de sistematização para ser modificado precisava da metade mais um dos votos. E aí surgiu o chamado Centrão. A revolta do setor conservador, com o apoio do presidente Sarney, contudo, conseguiu ser virtuosa e fazer o contrário: para aprovar é que tem que ter metade mais um, não para modificar. E aí, naquela ebulição, a Constituição se transformou em presidencialista e Sarney conquistou o $5^{\circ}$ ano de mandato (deputado Paulo Ramos, em entrevista).

Tivemos nesse bolo todo aqui o que nós chamamos de Centrão. Centrão era um grupo de deputados do centro, como diz aqui, porque a esquerda era muito forte. A esquerda, a esquerda entendida ideologicamente era muito forte, era tão forte que nós tínhamos que, por exemplo, no meu setor de telecomunicações, nós tínhamos a prestação desses serviços por empresas estatais, né [...]. Tem que recordar aqui. Então, esse era um grupo muito forte que queria levar esse negócio para 
outro lugar. O Artur da Távola, embora o Artur da Távola, ele tivesse um viés de esquerda, ele era um viés de esquerda intelectual. Tipo o PSDB. O PSDB na origem é esquerda, só que o DNA do PT e do PSDB, e até de outros partidos, o PCdoB, o DNA é o mesmo, nessa, isso não é ruim nem é bom, é a realidade histórica, né. Então, nós tivemos essa situação que equilibrou, e o PSDB sempre teve uma posição intelectualmente mais no centro, né, mais ao centro. Então, ele está contido no PMDB nesta época, né. O Mário Covas era o grande líder, na época era o Mário Covas que encabeçava, levava esse PMDB, era enorme o PMDB digase de passagem, levou mais para o centro. E uma parte desse PMDB e a maioria desses outros partidos formaram esse Centrão, então nós conseguimos equilibrar muitas dessas coisas, muitos desses temas nesses debates, que eram, eles viravam a madrugada, passavam a noite toda discutindo para resultado nenhum, não tinha como votar, não tinha como anular, foi uma guerra (deputado Arolde de Oliveira, em entrevista).

O então deputado José Serra, que também foi relator da comissão 5, defende que "O Centrão não era a direita conservadora, o Centrão era o atraso. A esquerda também." Neste sentido, afirma que Sarney "jogou pesado na luta pelos cinco anos” (CARVALHO, 2017, p. 166), ou seja, fez uso da máquina pública de forma ostensiva sob a forma da distribuição de rádios e televisões - com o apoio do então ministro das Comunicações, Antônio Carlos Magalhães. Destaca-se também a fala do vice-líder do PMDB, Antônio Britto, na qual ele afirma que Sarney se envolveu no processo da pior forma, fazendo como que "o mundo real vai [fosse] para a Constituinte, e esse mundo real sempre tem relação com o poder" (IDEM, p. 176). Explicou ainda a forma de pressão exercida pelos empresários junto aos parlamentares, traço marcante da política brasileira, a saber:

Se é a Casa Civil que fala com o cara da FIESP, ou se é o cara da FIESP que vai sozinho, o que importa é que o constituinte levou a pressão da FIESP. Se é o Antônio Carlos que aciona a Globo, ou se a Globo iria para lá sem o Antônio Carlos, é mais matéria arqueológica do que a pressão. Quando os interesses econômicos entram em jogo - impostos, papel do capital estrangeiro, concessão de rádio e TV -, o romantismo foi embora.

O relator Bernardo Cabral explica o surgimento do Centrão como uma espécie de reação à forma que o projeto foi apresentado, ou seja, em uma perspectiva mais progressista. Todavia, seu relato diz entender que se deu uma solução de compromisso, que se deve ao fato de existir 
[...] o medo de que a Constituinte pudesse caminhar para o lado comunista [...] nenhuma dessas correntes tinha força para impor seus desejos na Constituinte. Nem a esquerda, nem a direita. E aí se caminhou para um acordo, para as composições (CARVALHO, 2017, p. 102).

Na mesma obra, José Sarney afirma que o relator Bernardo Cabral "aceitou todas as pressões", por negociar tanto com ele quanto com Ulysses Guimarães e que foram feitas intervenções no texto constitucional relacionadas "à governabilidade do país, como o negócio da previdência, dos gastos, da parte econômica" (IDEM, p.52). Defendeu-se ainda sobre sua responsabilidade para com a articulação que viabilizou a mudança regimental, que, segundo suas palavras "para me desmoralizar, eles botaram o nome de Centrão, quando na realidade era um grupo para lutar por uma Constituinte que fosse legítima, aprovada pela maioria dos constituintes" (IBIDEM, p. 50).

José Lourenço arroga para si a responsabilidade para com a articulação do grupo, após a apresentação do primeiro projeto da comissão de sistematização:

[...] eu comecei a formar o Centro, a falar com os deputados do PMDB e do PDS [...] Meu grande parceiro chama-se Roberto Cardoso Alves. Grande deputado de São Paulo. Foi injustiçado pela imprensa com aquela história do "É dando que se recebe" [...] O Centro nasceu de uma visão concreta: ou nós corrigíamos aquele processo, que privilegiava uma minoria, ou era inviável continuar na Constituinte e apoiar qualquer coisa. Nós tínhamos que reagir. E reagimos quando tínhamos tropa para reagir - os 319 votos que conseguiram aprovar outro regimento (CARVALHO, 2017, p. 186-187).

A entrevista do à época senador Fernando Henrique Cardoso é reveladora também das articulações presentes na comissão de redação, da qual fez parte. Em seu entendimento o lobby é um processo normal do jogo político que envolvia "[...] os setores organizados da sociedade, que tinham um nível mais elevado, entravam em tudo" (CARVALHO, 2017, p.127), citando como exemplo as pressões advindas da "polícia militar, juízes, Supremo, militares".

Reis (2014, p. 160-161) avalia que apesar de alguns recuos, a CF aprovada resgatou os princípios orientadores do estado de bem-estar social, com um "viés favorável às demandas dos trabalhadores e das chamadas classes populares". Todavia, alguns grupos mais 
radicais, como os quadros oriundos do PT - dentre eles o interlocutor principal que usamos para análise do período, Florestan Fernandes - criticaram duramente a desaprovação de propostas fundamentais às causas populares, que foram subjugadas em favor de disposições formuladas ainda no período da ditadura, como, por exemplo, a centralização do poder no Executivo; a representação desproporcional a favor das áreas rurais e pequenos estados, no que tange à eleição de deputados; a questão da reforma agrária, entre outras. Tanto que, em um primeiro momento, houve uma resistência do partido em assinar a lei que ora se aprovara.

De forma geral, pode-se dizer que a Constituição Cidadã - como a lei fundamental de nosso Estado passou a ser conhecida, sobretudo a partir de sua apresentação no dia 05 de outubro de 1988 por Ulysses Guimarães, eliminou a restrição ao voto dos analfabetos, incluiu o voto para maiores de dezesseis anos, tornando-o facultativo em ambos os casos e deixando apenas uma restrição à universalização dos direitos políticos: o voto dos recrutados para o serviço militar. Restabeleceu os direitos civis, que foram suprimidos pelo regime militar, estabeleceu a igualdade entre homens e mulheres, o racismo como crime inafiançável e a defesa das terras indígenas. Foi também a que mais ampliou os direitos sociais $^{37}$, colocando a educação como fator de destaque para a efetivação da cidadania.

A educação, definida como um dos direitos sociais do brasileiro, foi apresentada no capítulo III, seção I, artigo 205 da Constituição Federal, como "direito de todos e dever do Estado e da família, será promovida e incentivada com a colaboração da sociedade, visando o pleno desenvolvimento da pessoa, seu preparo para o exercício da cidadania e qualificação para o trabalho". Observa-se, pois, a educação como instrumento e a obrigatoriedade da escolarização como forma de potencializar a formação do indivíduo social, do patriota, do cidadão nacional. A CF introduziu, ainda, características interessantes e merecedoras de destaque, como a descentralização do ensino ${ }^{38}$, que, embora já tenha sido mencionada em outros momentos históricos, aqui é plenamente delimitada: aos estados caberia o ensino médio e fundamental, e aos municípios caberia o ensino fundamental e a educação infantil, prioritariamente. Para a consecução deste objetivo foi, inclusive, criado o FUNDEF (Fundo

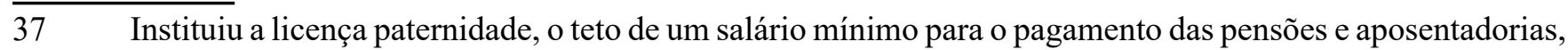
além do pagamento de um salário mínimo aos deficientes físicos e maiores de 65 anos, mesmo não havendo uma contribuição prévia ao INPS (Instituto Nacional de Previdência Social).

38 O conceito de descentralização empregado nos anos 1990, no bojo das políticas de orientação neoliberal, é aplicado como desconcentração, desresponsabilização do Estado para com as questões educacionais e os serviços públicos de uma forma geral (SOUZA e FARIA, 2003, p.55). Difere, portanto, da ótica do ideal democrático, onde descentralização identifica-se com a criação de estratégias para ampliar o espaço de participação dos cidadãos nas decisões públicas. 
de Manutenção e Desenvolvimento do Ensino Fundamental), por meio de uma EC ( $n^{\circ} 14$, de 12/09/1996). Vale ressaltar que este fundo veio a atender somente o ensino fundamental, não englobando a educação infantil, a educação de jovens e adultos e o ensino médio, o que somente aconteceu em $2006^{39}$. Estudaremos de uma forma mais aprofundada o capítulo da educação mais adiante.

Com a eleição de Fernando Collor de Mello, em 1989 - considerado por Daniel Aarão Reis (2014, p. 168) como uma cópia de Jânio Quadros, por seus "trejeitos parecidos, iguais tendências autoritárias e semelhante isolamento político-partidário" - seu posterior impeachment e o início do governo de Fernando Henrique Cardoso, em 1994, a política de orientação neoliberal ${ }^{40}$ - consequência da mundialização e da globalização das relações de produção ${ }^{41}$ - tardou, mas não deixou de ser implementada no Brasil (COUTINHO, 2006, p. 190). Os anos 1990 continuaram pondo em xeque o processo de redemocratização do país, visto que retrocederam em diversos pontos que a Constituição já havia garantido como direitos de cidadania. Sobre esse aspecto, o deputado Paulo Ramos fez uma análise interessante, aqui transcrita, na qual ele relembra a importância da pressão popular no início do processo da ANC, destacando que a inviabilização de vários artigos se deu por sua não regulamentação e pelo esgotamento da participação da população, que não se manteve após a aprovação da carta magna.

[...] o processo constituinte foi acompanhado de perto pela sociedade. Então, lamentavelmente, se houve um esforço de participação e acompanhamento, promulgada a constituição, a impressão que ficou foi a seguinte da sociedade brasileira: já cumprimos com o nosso dever. Como se as coisas, como se a constituição fosse ser implementada e cumprida sem que a sociedade continuasse

pressionando. Digo isso, por que, porque a constituição praticamente, em muitos dos seus pontos, um percentual grande da constituição não entrou em vigor. Não entrou em vigor porque sequer foi regulamentado [...] Então, o que aconteceu, a constituição foi promulgada em 05 de outubro de 1988 e a partir de 05 de outubro

39 Hoje não mais contamos com o FUNDEF, mas com um fundo semelhante, o FUNDEB - Fundo de Manutenção e Desenvolvimento da Educação Básica (EC nº 53, de 19/12/2006), que reproduz a mesma perspectiva redistributiva dos recursos da educação entre os entes federados, só que passando a englobar os níveis que anteriormente não eram contemplados (DAVIES, 2007).

40 Esta política sinaliza uma volta ao liberalismo conservador, onde o mercado é o padrão e a medida de todas as coisas. Ao mesmo tempo em que trabalha com a ideia de "Estado mínimo", este mínimo se refere aos direitos sociais, pois no que tange ao controle e à fiscalização das instituições, o Estado continua "forte", "máximo". Os direitos conquistados pela organização da sociedade civil (saúde, educação, previdência,...) vão sendo destruídos e passam a serem regidos pela lei do mercado (NEVES, 1999).

41 Lea Durante (2000, p. 86) faz uma diferenciação entre mundialização e globalização, definindo o primeiro processo como a fase de expansão transnacional da economia, e o segundo como a dimensão ideológica que oferece sustentação a transferência dos poderes e hegemonia dos Estados para organismos privados que objetivam a acumulação de capital. 
de 1993 ela poderia ser modificada. E aí o que aconteceu, na primeira eleição direta para presidente da república, com uma constituição nova, o povo elegeu Collor de Mello. Que era um quadro da ditadura, liberal, porque veio com um discurso de quanto menos Estado, melhor. Ele veio com um discurso de Estado mínimo; a constituição apontava num sentido, reservando para a soberania nacional o controle de alguns setores [...] Então, o Collor assume na primeira eleição direta para presidente da república e o povo brasileiro elege alguém na contramão do que estava na constituição. E aí ele começou com as privatizações que o Sarney não tinha conseguido, Collor e Itamar. Itamar Franco ao assumir teve, Itamar Franco tinha sido constituinte. O Itamar Franco teve um arroubo, que eu chamo assim, nacionalista ou de apego à Constituição, mas logo depois ele deu continuidade às privatizações. Mas, não podia privatizar o que estava protegido na Constituição. E aí o povo elegeu Fernando Henrique Cardoso. Um homem que vinha da luta contra a ditadura, um progressista. Ao ser eleito, "rasguem tudo que eu escrevi". E aí, para dar curso, né, ao modelo liberal do Estado mínimo [...] No $1^{\circ}$ ano de governo ele acabou com tudo que a constituição protegia: monopólio estatal do petróleo, monopólio das comunicações, foi privatizando. Aí entregou as bacias sedimentares, petróleo, entregou tudo, Vale do Rio Doce...

Desta forma, como reflexo desta política, assistimos ao enfraquecimento da oferta dos serviços públicos e das políticas sociais, dentre elas a educação. É importante ressaltar que o sucateamento dos serviços públicos não começou com o advento do neoliberalismo no Brasil. Este contribuiu para agravar a falta de investimentos neste setor que, como pudemos observar ao longo da história do país, constitui um traço de nossa cultura política. Os efeitos das políticas de orientação neoliberal foram sentidos em menor grau pelos países onde havia estruturado um estado de bem-estar social ${ }^{42}$. No caso brasileiro, onde nunca se consolidou de fato tal modelo e os avanços na área social foram sendo outorgados prioritariamente por políticas de cunho paternalista, tivemos, ao final do século XX, um desenho desordenado de degradação dos direitos de cidadania.

Nogueira (2000) afirma que o processo de desenvolvimento brasileiro aconteceu de forma mais passiva do que ativa, uma vez que se deu em profunda conexão com um longo período de supressão dos direitos. Desta forma, acredita que evoluímos no plano econômico, mas não no político, apesar do grande esforço dos grupos que se articulavam na sociedade civil. Percebe-se que os interesses públicos foram sempre sendo colocados em segundo plano em relação aos interesses privados, resultando assim em um afastamento no que se refere à compreensão da relação existente entre este espaço e o Estado.

$42 \quad$ O estado de bem-estar social, ou welfare state, foi edificado no período pós-guerra unindo esforços para a reconstrução econômica, social e política, com o objetivo de humanização do capitalismo contra a ascensão e a ameaça do socialismo (SPOSATI, 1998, p.23). 
A mudança se fez sem que se eliminassem práticas, estruturas e relações típicas de anteriores fases da vida societal. Em outros termos, fomos nos tornando modernos sem que se tivesse organizado um sistema de representação de interesses dotado de vigor político, poder de absorção e capacidade de processamento de demandas e pressões. Ao invés de se impor aos interesses privados, o poder público continuou reduzido a objeto desses interesses (NOGUEIRA, 2000, p. $122-123$ ).

Tal autor segue sua linha analítica, afirmando que o descrédito da população brasileira nas esferas governamentais se deve ao encaminhamento das questões políticas posteriormente ao período autoritário da ditadura empresarial-militar. Após longos anos de afastamento dos rumos decisórios, esta população não se sentiu contemplada pelo regime democrático que tanto ansiava ver se constituir, muito por decorrência das questões que acima expusemos. Assim, com pouca confiança nos políticos, vendo o Estado como espaço onde agentes representantes de determinados grupos se digladiam para garantir seus interesses pessoais, percebendo a soberania do país ameaçada pela sua subjugação aos ditames dos organismos internacionais - que buscam ampliar o domínio do capital por meio da tão propalada globalização - uma parcela da população começa a se articular e passa a dar vida a uma rede de organizações privadas que buscam disputar o Estado por meio da sociedade civil. Esta, por sua vez, apresentava-se como um espaço propenso para as disputas entre diferentes agentes e frações de classes (FONTES, 2006, p. 233).

Antes, porém, ao longo da década de 1980, devido às mudanças que ocorreram na composição dos agentes responsáveis pela implementação e fiscalização das políticas públicas, o surgimento das grandes centrais sindicais e o aparecimento de entidades aglutinadoras dos movimentos sociais, especialmente as organizações não governamentais - as ONG, os movimentos sociais começaram também a se alterar. Esses fatores, entre outros, contribuíram para a descrença nos movimentos reivindicativos e a consequente perda de sua capacidade mobilizadora das massas. Na década seguinte tivemos o auge das ONG, e a sua transformação em protagonistas do movimento popular, deixando o lugar antes ocupado, que se referia à intermediação e financiamento dos mesmos. Fontes (2006, p. 234) afirma que a ampliação dessas organizações auxiliou na diluição do engajamento social e da percepção das lutas que se pretendia travar, indo ao encontro da afirmação do deputado Paulo Ramos, transcrita anteriormente. 
Para fins deste estudo, centraremos nossas análises nas discussões realizadas nos seguintes espaços: comissão 8 , subcomissão $8 \mathrm{a}$ e comissão de sistematização, especificamente nos trechos em que são discutidos aspectos pertinentes à educação. Para tanto, valemo-nos das leituras das atas das sessões e recorreremos à análise das vinculações políticas dos principais agentes participantes de cada um desses diferentes espaços e objetivamos explicar os rumos e as escolhas adotadas para a caracterização do direito à educação tal como foi apresentado no produto final de todo o processo da ANC.

Neste capítulo não nos dedicaremos às discussões da comissão de redação, posto que, como vimos anteriormente, as mesmas foram dedicadas a melhor compor um texto que já fora aprovado no plenário da comissão de sistematização, após as manobras do Centrão. Destacamos, neste sentido, a argumentação de Cunha (2009, p. 440) que ilustra bem a ruptura entre o processo instaurado até o início dos trabalhos da comissão de sistematização e o produto que dela resultou:

No capítulo sobre a educação, a comissão de sistematização repôs, no geral, o texto do relator da comissão temática, atenuando expressões e suprimindo uma importante condição para que as escolas privadas fossem destinatárias dos recursos públicos: a de serem administradas, em regime de participação, pelos integrantes do processo educacional e pela "comunidade". Como o texto montado pela comissão de sistematização incorporava no todo ou em parte importantes elementos da pauta de reivindicações dos trabalhadores e das forças políticas progressistas, o bloco majoritário dos senadores e deputados reacionários ou conservadores, eufemisticamente autodenominados de "centrão", atuaram reativamente e mudaram o regimento da Assembleia Nacional Constituinte. Pretendiam, com isso, apresentar emendas substitutivas de partes inteiras do projeto constitucional.

\subsection{O TRABALHO NA SUBCOMISSÃO 8A - AGENTES, PARTIDOS, ASPECTOS GERAIS E DA EDUCAÇÃO}

A primeira reunião da subcomissão $8 \mathrm{a}$ - Subcomissão de Educação, Cultura e Esportes, aconteceu no dia 07 de abril de 1987, tendo como presidente eventual o deputado Florestan Fernandes, designado pelo presidente da Comissão 8, Marcondes Gadelha. Nesta ocasião foi apresentado o acordo de lideranças que indicou os nomes dos constituintes Hermes Zaneti (PMDB) para presidente; Aécio de Borba (PDS), para $1^{\circ}$ vice-presidente; e Pedro Canedo (PFL) para $2^{\circ}$ vice-presidente. Tal apresentação foi consolidada por meio de votação - dos vinte votos válidos, 19 garantiram a vitória de Hermes Zaneti, sendo apenas 1 voto em branco. 
Após tomar posse, o presidente designou João Calmon, do PMDB, para a relatoria da subcomissão, lugar este que, como afirmamos anteriormente, foi amplamente ocupado por parlamentares dos maiores partidos na ANC. Na ocasião ocupavam as galerias educadores participantes do XXI CONEP - Congresso Nacional dos Estabelecimentos Particulares de Ensino.

Cabe ressaltar, segundo Pinheiro (2005, p.269) que foi com base em um acordo de lideranças que tal configuração se fez possível. Segundo seu levantamento, 52\% dos constituintes eram do PMDB, 24\% do PFL, e 24\% de outros partidos. Destes, 52\% tinham suas posições ideológicas mais identificadas como as de centro, $29 \%$ consideravam-se de esquerda (ou progressistas) e 19\% de centro-esquerda, fato este comum também nas outras subcomissões.

Foram realizadas trinta e cinco reuniões, entre a instalação da subcomissão e o encerramento de seus trabalhos, em 25 de maio de 1987. Antes de passarmos ao estudo das temáticas abordadas - dentre elas a questão público-privado, incluída entre as questões de mérito - falaremos brevemente sobre os parlamentares envolvidos na condução dos trabalhos que tomaram este espaço.

Hermes Zaneti, presidente, natural do Rio Grande do Sul, professor e advogado, iniciou sua carreira política no MDB em 1964, migrando, em seguida, para o PMDB. Presidente do Centro de Professores do Rio Grande do Sul entre 1975 e 1979, presidiu depois a Confederação dos Professores do Brasil. Foi eleito deputado federal em 1982, tendo votado a favor da emenda Dante de Oliveira. Apoiou a eleição de Tancredo Neves e sempre votou a favor das pautas pertinentes aos professores. Também foi contra os cinco anos de mandato do presidente Sarney, pauta conturbada da constituinte, como vimos anteriormente (CPDOC, 2017a).

Aécio de Borba Vasconcelos, $1^{\mathrm{o}}$ vice-presidente, nascido em Fortaleza, era proveniente de uma família que já estava imersa na vida política - seu pai, inclusive, foi deputado constituinte de 1934 e 1946. Advogado, foi filiado à UDN, prefeito de Fortaleza, deputado estadual, secretário, tendo sido eleito deputado federal pelo PDS, em 1982, e reeleito, em 1986, para a ANC. Algumas considerações são relevantes, para que melhor possamos compreender a atuação política do deputado, conforme dados do Centro de 
Pesquisa e Documentação de História Contemporânea do Brasil, da Fundação Getúlio Vargas (CPDOC, 2017b). Em 1984 o deputado esteve ausente da votação da emenda Dante de Oliveira; no colégio eleitoral, em 1985, votou em Paulo Maluf, candidato a presidente do PDS, que foi derrotado por Tancredo Neves; foi também membro do Centrão.

Pedro Chaves Canedo (CPDOC, 2017c), $2^{\circ}$ vice-presidente, de família tradicional na política goiana, médico, ingressou na vida política como deputado estadual pelo PDS, em 1982. Com a cisão do PDS e criação do PFL, filiou-se ao novo partido no qual foi eleito para deputado federal, em 1986. Votou contra o mandato de cinco anos do presidente Sarney e a favor do presidencialismo.

O relator João de Medeiros Calmon (CPDOC, 2017d) nasceu no Espírito Santo, tendo um familiar também na vida pública. Cursou direito, no Rio de Janeiro, mas trabalhou como repórter, tendo, inclusive, adquirido empresas de jornais e estações de radiodifusão em diversas cidades do Norte e do Nordeste do país. Foi eleito deputado federal pelo Espírito Santo na legenda do Partido Social Democrático (PSD), em 1962. Foi também presidente da Associação Brasileira de Emissoras de Rádio e Televisão (ABERT), entidade que congregava as empresas de radiodifusão e de televisão no Brasil. Em fevereiro de 1964 teve seu nome homologado na convenção nacional do Partido Social Progressista (PSP), como candidato à vice-presidência da república, nas eleições que deveriam ocorrer em outubro de 1965, compondo a chapa com Ademar de Barros, então governador de São Paulo. Em 1965 filiou-se à ARENA, tornando-se presidente da seção estadual do Espírito Santo. Em 1970 foi eleito senador, depois de alguns mandatos como deputado. Com a extinção do bipartidarismo, foi para o PDS. Cabe ainda ressaltar que foi autor de uma emenda que objetivava estipular uma vinculação orçamentária ${ }^{43}$ de cada ente federado ao desenvolvimento do ensino. Conhecida como emenda Calmon, foi um grande destaque nas discussões da ANC de 1987. Em 1984 deixou o PDS e migrou para o PMDB, para apoiar a candidatura de Tancredo Neves. Na constituinte, votou a favor do presidencialismo e do mandato de cinco anos para o então presidente Sarney.

43 "Em julho de 1976, em Brasília, uma comissão mista do Congresso aprovou por unanimidade uma emenda ao texto constitucional que propunha o restabelecimento da vinculação de percentual da receita tributária da União $(12 \%)$ e dos estados, Distrito Federal e municípios (24\% de cada um) à expansão e ao aprimoramento do ensino. A chamada emenda Calmon foi discutida no plenário do Congresso em setembro e rejeitada por decurso de prazo" (CPDOC, 2017d). 
Outros vinte e sete parlamentares ${ }^{44}$ apareceram efetivamente na discussão da matéria educacional nesse espaço. Fizemos também um levantamento biográfico de cada um deles, porém, utilizaremos os dados aí coletados apenas quando forem relevantes para a contextualização de alguma posição por eles adotada.

A segunda reunião da subcomissão ocorreu no dia 09/04/1987, tendo como pauta principal a solicitação de nomes de educadores e instituições relevantes para o cenário educacional, que pudessem ser ouvidos pelos parlamentares. Foi também sugerido pelo parlamentar Chico Humberto a inclusão da discussão sobre lazer, turismo e jogo naquele espaço. No mesmo dia, à noite, foi realizada nova reunião, na qual se definiram as datas em que a discussão sobre a educação teria lugar: seriam em 23, 28, 29 e 30 de abril. A definição do cronograma dos debates se apresentava como elemento fundamental para o cumprimento dos prazos estipulados pelo presidente da ANC.

Nos dias que se seguiram, três reuniões foram suspensas por falta de quórum, conforme versa o artigo 35 da resolução $n^{\circ} 2$ de 1987. Na sétima sessão, realizada na noite do dia 14/04 daquele ano, foram apresentadas as entidades a serem ouvidas pela subcomissão e as respectivas datas, conforme lista seguinte ${ }^{45}$ :

$\checkmark$ 23/04/1987:

ANDE - Associação Nacional de Educação;

ANDES - Sindicato Nacional dos Docentes das Instituições de Ensino Superior; FBAPEF - Federação Brasileira das Associações de Professores de Educação Física; ANPAE - Associação Nacional de Profissionais de Administração da Educação; SBPC - Sociedade Brasileira para o Progresso da Ciência; SEAF - Sociedade de Estudos e Atividades Filosóficas;

$\checkmark$ 28/04/1987:

CPB - Confederação de Professores do Brasil;

FASUBRA - Federação de Sindicatos de Trabalhadores Técnico-Administrativos em Instituições de Ensino Superior Públicas do Brasil;

$44 \quad$ São eles: Florestan Fernandes (PT), Marcondes Gadelha (PFL), Artur da Távola (PMDB), Octávio Elísio (PMDB), Louremberg Nunes (PMDB), Virgílio Távora (PDS), João de Deus (PDT), Antonio de Jesus (PMDB), Eliel Rodrigues (PMDB), Álvaro Valle (PL), Ubiratan Aguiar (PMDB), Gumercindo Milhomem (PT), Eunice Micheles (PFL), Sólon Borges (PTB), Chico Humberto (PDT), Átila Lira (PFL), José Moura (PFL), Tadeu França (PMDB), Bezerra de Melo (PMDB), Jorge Arbage (PDS), Antonio Salim Curiati (PDS), José Fernandes (PDT), Carlos Virgílio (PDS), Roberto Freire (PCB), Augusto Carvalho (PCB), Fernando Santana (PCB) e Márcia Kubitschek (PMDB).

45 A lista que consta nas atas estudadas está com a nomenclatura desatualizada das instituições. Optamos por utilizar aqui a forma como estas são conhecidas nos dias atuais. 
UBES - União Brasileira dos Estudantes Secundaristas;

ANPEd - Associação Nacional de Pós-Graduação e Pesquisa em Educação;

CEDES - Centro de Estudos Educação e Sociedade;

CRUB - Conselho de Reitores Universitários do Brasil.

$\checkmark$ 29/04/1987:

CTI - Centro de Trabalho Indigenista;

ABESC - Associação Brasileira de Escolas Superiores Católicas;

CNEC - Campanha Nacional de Escolas da Comunidade;

FENEN - Federação Nacional dos Estabelecimentos de Ensino;

UNE - União Nacional dos Estudantes;

AEC - Associação de Educação Católica do Brasil;

Na mesma reunião, o constituinte Octávio Elísio solicitou que se realizasse uma sessão extraordinária no dia 23 de abril para que se pudesse receber representantes do Conselho Federal de Educação, do Fórum Nacional de Secretários de Educação e do Grupo de Trabalho Educação e Constituinte do MEC. Apresentou-se ainda uma lista de instituições inscritas para as próximas datas de debate, sobre as quais a subcomissão viria a decidir sobre a participação na sessão do dia 22. Eram as seguintes: Comissão Pró-Índio do Acre; Conferência Nacional dos Bispos do Brasil (CNBB); Sindicatos dos Professores de Estabelecimentos Particulares; MEB - Movimento de Educação de Base; Guiomar Namo de Melo - a ser ouvida como personalidade; CIMI - Conselho Indigenista Missionário; Núcleo de Cultura Indígena; União das Nações Indígenas; Comissão Pró-Índio de São Paulo; e Associação Brasileira de Antropologia. Devido ao grande número de instituições vinculadas à questão indígena, foi feita a proposta de que apenas uma instituição falasse na presença das outras, devido ao fato de não haver tempo para a efetiva participação de todas.

Falou-se ainda sobre algumas situações vividas no país, como a greve de alguns setores; questões práticas, como o horário de início das sessões, o quórum, a necessidade das instituições ouvidas apresentarem suas propostas datilografadas, assim como o calendário a ser adotado nos trabalhos da subcomissão.

Tendo mais uma sessão não existido por falta de quórum, após o feriado de Páscoa, no dia 21 de abril, os constituintes retornaram aos debates, tendo como pauta o início da apresentação das propostas que pretendiam defender. Mencionaremos, de forma bastante resumida, a preocupação dos parlamentares com relação à educação. Todavia, deixaremos para o próximo capítulo a análise sobre a perspectiva de direito à educação nas propostas de texto legal, especificamente com base nas subcategorias que optamos por estudar. 
O deputado Álvaro Valle apresentou a questão da aposentadoria especial para os professores e professoras, a obrigatoriedade do ensino dos 5 aos 14 anos, e o pré-escolar como forma de democratização da educação brasileira, mais ainda do que a educação universitária. O parlamentar também defendeu que não se fizesse distinção na destinação dos recursos entre escolas públicas e privadas, até porque disse acreditar na ineficiência da primeira, mesmo diante do alto investimento que recebe. O constituinte Louremberg Nunes também apresentou tal tema, que foi recorrente tanto nas discussões desta subcomissão, quanto na comissão 8 - a preocupação com os recursos destinados à educação. $\mathrm{Na}$ mesma perspectiva, Chico Humberto abordou a necessidade dos recursos públicos serem exclusivamente destinados às escolas públicas, já que o ensino privado oneraria duas vezes mais os cofres públicos, e também a obrigatoriedade do ensino público dos 5 aos 16 anos, alargando as oportunidades dos jovens e também dos adultos.

O presidente solicitou ao parlamentar Antonio de Jesus indicações de entidades evangélicas que pudessem contribuir com os trabalhos. O vice-presidente Aécio de Borba retomou a questão da destinação dos recursos, já mencionada anteriormente. Pedro Canedo abordou a necessidade das verbas públicas serem exclusivas ao ensino público, enquanto o relator sugeriu que não fosse abordada a questão do jogo na subcomissão. Tal proposta foi acatada pelos parlamentares. Antonio de Jesus sugeriu que as entidades fossem agrupadas e distribuídas no dia da apresentação por temática de debate. Como em outro momento histórico, João Calmon falou da necessidade da vinculação orçamentária; Ubiratan Aguiar defendeu a alfabetização aos seis anos de idade e também a destinação dos recursos públicos exclusivamente às escolas públicas. Florestan destacou o conteúdo e o tamanho que deveria ter uma $\mathrm{CF}$, com a observação de que em países como o nosso, com poucos avanços, a carta magna não deveria ser apenas um documento sem "alma": seria preciso que oferecesse alternativas e que impusesse obrigações.

O deputado Átila Lira colocou a educação dos 0 aos 4 anos como função social do Estado, e não como função educativa; abordou também a municipalização do ensino que não deveria se reduzir apenas à prefeiturização. Sólon Borges não defendeu a antecipação do processo de alfabetização, pois disse valorizar a vivência pré-escolar; abordou como necessária a aplicação de recursos públicos em instituições públicas, embora compreendesse a necessidade da existência do ensino privado.

Aécio de Borba abordou a questão do concurso público para o magistério. Pedro Canedo e Chico Humberto, ambos médicos, trataram da necessidade de discutir a saúde dos educandos. O primeiro disse acreditar que as crianças deveriam ter acesso a exames médicos antes de ingressarem na escola; já o segundo destacou a necessidade de toda a 
população ter acesso aos exames, via saúde pública. Defenderam também a exclusividade do uso dos recursos públicos nas escolas públicas, assim como Ubiratan Aguiar. Neste ponto, Pedro Canedo divergiu do líder do seu partido, Álvaro Valle. Chico Humberto também propôs a criação de auxílio suplementar aos estudantes de escolas públicas.

Foi ainda recolocado nesta sessão o prazo de entrega do relatório da subcomissão: dia $06 / 05$, com destaque para o fato do mesmo ter sido prorrogado, já que, inicialmente, era em 23/04/1987.

$\mathrm{Na}$ sessão seguinte, realizada em 21/04/1987, foram debatidos alguns temas anunciados anteriormente. Cabe um destaque à fala de Florestan Fernandes sobre os seguintes assuntos: o problema do analfabetismo no Brasil; a organização do ensino por meio do arcabouço legal, que deve ser estabelecido pela LDBEN e PNE; a necessidade de recuperação da escola, por meio da descentralização, da democratização e dos conselhos escolares. Sugeriu, pois, o nome do pensador e educador Paulo Freire para discutir essas questões na subcomissão.

$\mathrm{Na} 11^{\mathrm{a}}$ sessão os debates continuaram, com a participação de Louremberg Nunes, que defendeu a possibilidade de existência de diferentes critérios para a transferência de recursos para instituições de ensino públicas ou privadas. A expressão liberdade de ensino - objeto de nossa discussão no quarto capítulo - foi criticada por Octávio Elísio, por não considerá-la como justificativa para concessão de apoio financeiro às escolas particulares ou ao aluno por meio de bolsas de estudo. Florestan Fernandes, mais uma vez, retomou a história da educação brasileira, desde o Manifesto dos Pioneiros da Educação Nova para fazer uma crítica ao seu caráter elitista, característico de uma sociedade capitalista. Átila Lira se colocou a favor da exclusividade da aplicação dos recursos públicos na escola pública; Chico Humberto, por sua vez, abordou as condições de igualdade, sobre o que José Moura complementou, afirmando que a prioridade deveria ser para a merenda e a saúde, no que se refere à aplicação dos recursos da educação. Sobre este aspecto, Octávio Elísio retrucou, reconhecendo a urgência da merenda escolar, posto a precariedade das condições de vida de parcela significativa da população, porém, criticando o fato de tais recursos saírem da rubrica da educação. Ao final da reunião, foram indicadas mais algumas personalidades do campo educacional para serem ouvidas: Heitor Virgulino de Souza, Guiomar Namo de Melo (que já havia solicitado sua participação, conforme relato anterior), e Neidson Rodrigues. 
O dia 23 de abril teve início com o relato do presidente da subcomissão, apresentando o resultado da conversa com o ministro da Educação, que aceitou receber a ANDES para tratar da greve em curso naquele momento. Feitos os esclarecimentos devidos, passou-se à escuta das primeiras entidades convidadas. A ANDE, apresentou proposta baseada na Carta de Goiânia, já mencionada no capítulo anterior. Em toda a apresentação das propostas da associação, ficou evidente a defesa do "[...] direito à educação não [como] o direito de apenas estar na escola, mas é o direito que as pessoas têm de terem acesso a um patrimônio cultural comum" (CÂMARA, 2017b, p.46). Desta forma, falou da exclusividade da aplicação de verbas públicas na educação pública, assim como do compromisso do Estado e da necessidade de atendimento de todos, sem discriminação de idade, sexo, condição social e deficiência. Octávio Elísio tomou parte na discussão, defendendo a importância não somente do acesso, mas da permanência do aluno na escola, com garantia da educação que nela será oferecida. Abordou ainda a questão da descentralização do ensino e do compartilhamento das responsabilidades. Por fim, Tadeu França trouxe questões sobre as escolas comunitárias, sobre as quais teceu críticas.

A ANDES passou a apresentar suas propostas, a partir da vinculação da educação com a ciência e a tecnologia. Partiu do pressuposto que “[...] a educação é um direito de todo cidadão, sendo dever do Estado oferecer ensino público gratuito e laico para todos e em todos os níveis" (IDEM, p. 51). Trouxe a discussão de um padrão de qualidade, tanto para as universidades públicas quanto para as privadas, que viesse a validar o seu tripé, ou seja, o ensino, a pesquisa e a extensão, rompendo com a perspectiva da educação como mercadoria. Desta forma, os recursos públicos deveriam ser de uso exclusivo das instituições públicas. Bezerra de Melo, padre, então reitor da Universidade de Mogi das Cruzes, fez a defesa da liberdade de ensino, aqui entendida num sentido diametralmente oposto ao apontado por Octávio Elísio em encontros anteriores. Cabe ressaltar que ambos eram parlamentares do PMDB. Além da liberdade para ele ser a opção de escolha da família sobre qual o ente que deve gerenciar a escola de seu responsabilizado, colocou-se também contra a laicidade do ensino. Miriam Limoeiro, uma das representantes da ANDES, respondeu reafirmando as posições da associação:

A escola particular deve existir sendo que tudo necessário em termos da sua existência, economicamente, financeiramente deve ser sustentado por aqueles que estão ligados a ela. O Estado não tem nada a ver com isso. As verbas públicas são só para as escolas públicas [...] O que vemos é que a escola particular serve como mecanismo de discriminação a mais, nesta sociedade, que é uma sociedade profundamente marcada pela diferenciação, pela divisão, pela dominação. Com 
o que não podemos concordar é que a educação seja um veículo a tornar mais forte essa dominação. É por isso que defendemos a escola pública. Não é que a escola particular não possa existir. Ela pode existir. Não temos nada contra, que ela exista. No que somos contra é que as parcas verbas destinadas à educação neste País sejam de alguma maneira canalizadas para o ensino particular, que é um ensino elitizante, um ensino que serve àqueles que são os dominadores (IBIDEM, p. 53).

Ainda sobre a destinação das verbas, Sólon Borges falou que a prioridade deveria ser da educação básica, a respeito do que a expositora se contrapôs, ressaltando a importância de todos os níveis de ensino. Novamente Chico Humberto defendeu a assistência ao educando, inclusive mediante a distribuição de livros didáticos.

As demais organizações ouvidas na presente sessão foram apresentadas: a Federação Brasileira das Associações de Professores de Educação Física, a ANPAE e a SBPC. Sobre esta última, destacamos que o seu representante foi por nós entrevistado para esta pesquisa: o professor Luiz Antônio Cunha. A SEAF não compareceu (na sessão seguinte o grupo teria uma discussão a respeito da confusão de horários, remarcando-a para o dia 28/04/1987).

É importante destacar que a FBAPEF apresentou os princípios da educação física escolar; a ANPAE abordou a necessidade da democratização da gestão da educação e do saber específico da administração escolar, arraigados na defesa da escola pública, gratuita, laica e de qualidade em todos os níveis e modalidades, na mesma direção do que é preconizado pelo Fórum Nacional em Defesa da Escola Pública. A SBPC contextualizou a situação da escolarização do brasileiro historicamente, abordando, inclusive, a participação de proprietários de escolas no CFE/CNE. Comprometeu-se com o apoio aos princípios oriundos do FNDEP. O deputado Octávio Elísio solicitou dados comparativos de gastos com a escola pública e privada no Brasil. Hermes Zaneti angariou o apoio das organizações ali presentes na solicitação do aumento de gastos da União para com a educação, para além do que era previsto pela emenda Calmon (13\%). Bezerra de Melo defendeu o ensino religioso com a condenação do ensino laico. Sobre esse ponto, Luiz Antônio Cunha retomou a Campanha Nacional em Defesa da Escola Pública, dos anos de 1960, para explicar o temor das escolas católicas no que consideravam ser o desejo da estatização do ensino. Neste ponto, Antonio de Jesus fez a defesa do ensino religioso, de forma que a representante da ANPAE - Maria Beatriz Moreira Lucy, viesse a relembrar que a família deveria ser a instituição responsável por abordar a discussão da religião. 
Louremberg Nunes relativizou a importância do ensino público, provocando no representante da SBPC uma nova fala sobre a questão do público e privado na história da educação brasileira, objeto de estudos deste interlocutor até os dias atuais. Átila Lira provocou Luiz Antônio Cunha no sentido de problematizar a autonomia universitária.

Cabe ressaltar que ao final da ata desta sessão se encontram anexados os documentos apresentados pelas instituições participantes daquele dia de debates, assim como outros documentos que lhes ofereceram suporte, como, por exemplo, a Carta de Goiânia. No próximo capítulo abordaremos com mais detalhes tais propostas, agrupando-as com base em nossas categorias específicas de análise.

Ao passarmos para a sessão extraordinária do dia 23 de abril, encontramos os representantes do Conselho Federal de Educação, do Fórum Nacional de Secretários de Educação e do Grupo de Trabalho, Educação e Constituinte do MEC. Este último foi apresentado da seguinte forma pelo presidente Hermes Zaneti (IBIDEM, p. 76-77):

O Dr. Oswaldo Della Giustina é Chefe de Gabinete do Ministro da Educação, Dr. Jorge Bornhausen; temos também a presença de Emólio Marques, Secretário de Articulação e Estudos de Planejamento do MEC; Ernâni Bayer, Secretário da Educação Superior do MEC; Júlio Fernando Pessoa Correia, Secretário de Educação Básica; Zeli Izabel Ressler, Secretária de Ensino do $2^{\circ} \mathrm{Grau}$; Júlio César, Secretário de Educação Física e Desportos; Pedro Demo, Diretor-Geral do Instituto Nacional de Estudos e Pesquisas Educacionais - INEP; Carlos Roberto Jamil Cury, representante do Comitê de Especialistas da Coordenação do Aperfeiçoamento de Pessoal de Nível Superior - CAPES; Maria Beatriz Moreira Luci, representante das Associações de Profissionais de Administração da Educação, ANPAE, que já prestou seu depoimento hoje pela manhã; Maria Mirtes Cordeiro Rodrigues, Secretária Municipal da cidade do Cabo, Pernambuco; Gilda Poli Rocha Loures, representante do Fórum Nacional de Secretarias Estaduais de Educação.

O chefe do gabinete do ministro deu início à sua exposição com a afirmação de que o grupo que coordenava não era um lobby, mas sim um esforço para subsidiar as discussões da ANC, sobretudo em pontos mais problemáticos e que arregimentavam discordâncias entre diferentes setores. Eram eles: o financiamento da educação, a dicotomia entre a esfera pública e privada, a questão do acesso à escola, entre outros temas.

Já o Presidente do CFE fez uma abordagem a respeito da tradição constitucional de outros países e do Brasil, para justificar que era necessário definir o "[...] conteúdo do direito à educação e do dever do Estado" (IBIDEM, p. 79). Por fim, a representante do Fórum, Gilda Poli, saudou os constituintes que já fizeram parte do mesmo ${ }^{46}$, explicando 
a sua composição e o apresentando como órgão governamental. Em sua exposição, abordou o ensino público laico, que não seria um ensino ateu; a preocupação com o acesso e permanência na escola; e a emenda Calmon, sobre a qual propôs uma vinculação de recursos pela União de, no mínimo, 18\%. Sobre esse aspecto, o representante do CFE disse acreditar que tal recurso deveria priorizar o ensino fundamental. A sessão foi finalizada com algumas questões problematizadas por Artur da Távola, que foram respondidas pelos participantes. Seu questionamento se dirigia ao direito do cidadão à educação e ao dever do Estado em educar, e também à questão da natureza dos recursos a serem aplicados nas escolas públicas e privadas.

A próxima sessão a receber as entidades que apresentariam suas propostas foi realizada em 28/04/1987. Na ocasião estiveram presentes a Confederação de Professores do Brasil, o CRUB (Conselho de Reitores do Brasil) e a SEAF. O constituinte Octávio Elísio solicitou a inclusão da FASUBRA na pauta do dia, de forma que a instituição pudesse apresentar a situação da negociação da greve que se encontrava em curso.

A Confederação deu início às apresentações, tendo como ponto alto a apresentação de dados sobre o acesso (ou a precariedade dele) à escola. Em seguida, a FASUBRA abordou o papel da constituinte, defendeu o ensino público e gratuito e condenou a existência da lógica mercantil e do lucro no sistema educacional. Propôs a reformulação do ensino de $1^{\circ}$ grau e, por fim, defendeu a elaboração da consciência democrática por intermédio do movimento sindical. A SEAF trouxe as reflexões do FNDEP, agregando às suas proposições a luta pelo retorno da filosofia aos cursos de $2^{\circ}$ grau. Defendeu ainda a prioridade do ensino de $1^{\circ}$ grau e a exclusividade das verbas públicas para o ensino público. O CRUB abordou a necessidade de se pensar um plano educacional e defendeu

[...] que o direito à Educação é de todos, e o Estado tem esse dever: a obrigatoriedade do ensino de $1^{\circ}$ Grau ou de, pelo menos, 8 anos de escolarização, mas aumentando a faixa de 6 aos 16 anos, já que estamos convivendo e conviveremos muito tempo com a evasão e a repetência. Há necessidade, também, de que, assegurada a liberdade de ensino, possamos e tenhamos, no $1^{\circ}$ Grau, o ensino de Língua Portuguesa, mas garantindo o direito de as sociedades indígenas optarem pela sua língua nativa. Reafirmamos, ainda, a necessidade de que a universidade goze de ampla autonomia. É evidente que isso não significa soberania, porque a avaliação por parte da sociedade e a participação da comunidade são essenciais para o desenvolvimento da própria universidade [...] (CÂMARA, 2017b, p.111-112).

Florestan Fernandes, após as considerações feitas pelas instituições na sessão, propôs a criação de um conselho nacional de desenvolvimento da educação, que vinculasse as 
políticas governamentais ao planejamento democrático. Ressaltou que a educação deveria ser pensada como um problema político, posto que “[...] o ensino, no Brasil, não tem sido um instrumento de consciência crítica: ele tem sido um instrumento de dominação cultural e também de exclusão dos oprimidos" (IDEM, p. 112).

Na continuação do debate, o constituinte Ubiratan Aguiar fez a apresentação de um exemplar do jornal "Correio Braziliense", no qual havia uma nota de autoria de vários estabelecimentos privados de ensino de Brasília em protesto contra a subcomissão e sua posição em defesa da escola pública. Informou ainda que tais publicações estavam se espalhando em outros estados e que estas distorciam o trabalho dos constituintes.

Louremberg Nunes fez uma crítica aos debates que, segundo ele, não vinham acompanhados de dados e que se colocavam contra o Estado, desconsiderando que o Estado seriam todos que nele estão. Diante do exposto, o representante da SEAF apresentou algumas considerações, a saber: defendeu a escola única, por meio da implementação de um currículo nacional; propôs a criação de um piso salarial nacional e, também, fez uma crítica à municipalização do ensino de $1^{\circ}$ grau.

O presidente do CRUB retomou o debate que abordava a transferência de recursos para instituições públicas e privadas, defendendo que instituições como a PUC - Pontifícia Universidade Católica - pudessem receber os recursos públicos. $\mathrm{Na}$ mesma linha argumentativa, Antonio de Jesus propôs que instituições com fins não mercantis também fizessem jus a esse recebimento. Bezerra de Melo teceu as mesmas críticas, afirmando que

Mas a minha surpresa maior é a colocação que se faz da escola pública em verdadeiro confronto com a escola particular, com a escola privada. É uma filosofia maniqueísta, em que nós estamos querendo salvar a escola pública, em que nós estaremos querendo valorizar a escola pública, e para isto eu dou todo o meu apoio, porque a escola pública realmente precisa ser priorizada, precisa ser valorizada, num país democrático e numa democracia em que vivemos; mas não podemos simplesmente fazer da escola particular uma caricatura como se a escola particular não fosse também um serviço público a serviço da comunidade. Observo, na proposta educacional, para a Constituição, das diversas entidades aqui já citadas, que se de um lado se dão todos os direitos à escola pública, por outro lado, a escola privada e isto me parece um absurdo (IBIDEM, p. 120).

Em resposta ao constituinte, Octávio Elísio afirmou que existe uma diferença entre defender o uso exclusivo de recursos públicos para a educação pública e condenar as instituições privadas. Em seu contraponto, argumentou que "[...] queremos e desejamos que haja escola particular de boa qualidade; é indispensável que se caracterize, entretanto, 
que a liberdade de ensino só ocorrerá neste país se for dado a todos a oportunidade do acesso a uma escola pública de boa qualidade" (IBIDEM, p. 121). Até o final da sessão as discussões se centraram na problemática de que nem tudo que recebia a nomenclatura de prestação de serviço público seria efetivamente público, em um sentido mais amplo. Cabe melhor contextualizar a origem e posição dos constituintes que participaram do debate daquela sessão, de maneira que possamos melhor compreender se suas posições visaram (ou não) atender aos grupos que auxiliaram na sua eleição.

Desta forma, comecemos por Ubiratan Aguiar (CPDOC, 2017e): advogado, era da ARENA e migrou para o PMDB, vindo a compor o Centrão. Louremberg Nunes (CPDOC, 2017f), também advogado, era da ARENA, tendo migrado para o PMDB. Antonio de Jesus (CPDOC, 2017g), psicólogo formado pela PUC de Goiânia, também da ARENA, passou ao PDS, tornando-se pastor após deixar a vida pública. Bezerra de Melo (CPDOC, 2017h) era sacerdote católico, cursou filosofia e história na Faculdade de Filosofia da Pontifícia Universidade Católica do Rio Grande do Sul e psicologia pela PUC do Rio de Janeiro, sendo ainda um dos fundadores da Universidade de Moji das Cruzes (UMC) ${ }^{47}$, filiado à ARENA e, posteriormente, ao PDS. Octávio Elísio (CPDOC, 2017i), engenheiro formado pela UFOP, era do PMDB, fazendo parte do grupo que posteriormente ingressou no PSDB. Assim sendo, as posições de todos os constituintes que se pronunciaram, com exceção do último, tinham uma história ligada à ditadura empresarial-militar e ao campo religioso, que, como vimos no capítulo anterior, sempre disputou o campo educacional, por ver a educação como mercado e local de doutrinação.

A sessão foi reiniciada à tarde com a presença do Núcleo de Política Científica e tecnológica da UnB, com o seu Centro de Estudos e Acompanhamento à Constituição. Ainda estiveram presentes a ANPEd, tendo como representante o Professor Osmar Fávero - entrevistado para esta pesquisa -; a CEES e a UBES. Alguns constituintes encaminharam suas falas no sentido de pontuar a situação de greve em alguns lugares do país, como Gumercindo Milhomen ao citar a greve de São Paulo e a demissão de servidores.

Assim, a UBES iniciou seu pronunciamento com a leitura de suas propostas, encaminhadas na direção do previsto pelo FNDEP, sobretudo no que era pertinente à garantia do ensino público, laico e gratuito para todos, em todos os níveis, da pré-escola à universidade. Ao criticar o favorecimento histórico da rede privada de ensino no Brasil,

$47 \quad$ Em 1970 aconteceu um episódio de fraude no exame vestibular do curso de medicina que ocasionou, inclusive, a prisão do constituinte. Outros 2 episódios como este novamente ocorreram, em 1976 e 1979. 
sugeriu a exclusão de escolas militares e das subordinadas a outros ministérios da alçada da educação e, portanto, da distribuição de verbas destinadas a este fim. Por fim, apresentou o que seria uma escola democrática: aquela que garantisse "[...] o acesso, a permanência, a distribuição do conhecimento e sua gestão" (CÂMARA, 2017b, p.131).

A ANPEd contextualizou sua atuação numericamente: alcançava, à época, 33 programas de pós-graduação e aproximadamente 600 professores. Trouxe também a influência que teve na elaboração da Carta de Goiânia, na IV Conferência de Educação, assim como a ideia de educação como direito de todos e da democratização da sociedade:

\begin{abstract}
Queremos marcar muito bem que esses dois princípios, que pedimos sejam escritos na Constituição: da obrigação do Estado de atender ao direito de todos os cidadãos, passa, obrigatoriamente, por uma revisão fundamental na forma que está distribuída a educação, na forma como são organizados os sistemas de ensino, o que vai mexer com coisas que não estão apenas na esfera da educação. Uma das coisas é que a demarcação da sociedade exige a democratização do ensino e, evidentemente, já foi bastante discutido de manhã, não é a democratização do ensino que vai garantir a democratização da sociedade, mas passa por ela. Essa possibilidade de acesso, de permanência das crianças em idade escolar, de atendimento daqueles que estão fora da faixa escolar precisa ser redefinida numa linguagem bastante clara para que não caia no vazio (IDEM, p. 132).
\end{abstract}

Osmar Fávero, orador designado para a representação da ANPEd, abordou também o descompromisso do MEC para com a educação pública e o favorecimento das instituições privadas. Para tanto, colocou em planos opostos o direito à educação e a concessão de bolsas de estudo. Esta questão voltou à tona na entrevista que realizamos com o professor para esta pesquisa, quando ele abordou o privatismo que sempre disputou o campo das políticas públicas de educação no Brasil:

O privatismo sempre achou que a educação é primeiro dever da família, depois, por concessão da família, é o Estado. Essa inversão não é acidental, não, essa inversão é proposital mesmo. É o privatismo. Não só a Igreja [...] Nessa história da primazia da família escolher a escola que quer, eventualmente até de bolsa para colocar em uma escola paga com bolsa do Estado [...] e tal, está na linha da liberdade de escolha que a família tem [...] Na relação público/privado, o privado teria privatismo sobre, não teria uma escola obrigatoriamente pública. Essa é a grande discussão da educação no privatismo. Claro, liderado pela Igreja católica, mas não somente, o empresariado também [...] Você tem liberdade de oferecer a escola que você achar que é melhor para os seus filhos, entendido? Eventualmente você tem também a escola pública. 
O Centro de Estudos Educação e Sociedade, representado pela Professora Elizabeth Camargo, passou a conduzir suas proposições. Partindo também da Carta de Goiânia e da defesa da escola democrática, entendida como “[...] liberdade de expressão, da soberania nacional e do respeito aos direitos humanos, como um dos agentes de desenvolvimento, da capacidade de elaboração e reflexão crítica da realidade, visando à preparação para o trabalho e sustentação da vida" (CÂMARA, 2017b, p. 134), trouxe o artigo segundo do documento do FNDEP que evidenciava sua posição perante a CF que se pretendia elaborar: a defesa do ensino público, gratuito e laico em todos os níveis. Neste sentido, afirmou que só existiria possibilidade de cumprimento do dispositivo legal do direito à educação quando houvesse a democratização das oportunidades educacionais. Portanto, não existiria escola pública não estatal.

Sobre esta questão, o constituinte Louremberg Nunes, questionou se famílias abastadas deveriam fazer jus ao ensino público. A esse respeito, a representante da CEDES respondeu que "[...] o Estado tem que assumir a questão educacional porque pagamos a educação através de impostos e de outras formas. Então esse ensino é público justamente por isso: porque ele já está pago" (IDEM, p. 138). Ainda sobre esse assunto, o representante da UBES declarou que o "bolo", ou seja, os recursos destinados à educação deveriam ser divididos após a elaboração de uma Plano Nacional de Educação, de forma que todos tivessem acesso à educação pública em todos os níveis. Destacou ainda, com relação a questão público-privada que "[...] se a classe dominante tiver como opção colocar seus filhos na escola particular, que o faça. Mas a escola pública vai ser garantida para todo mundo" (IBIDEM, p. 138).

O debate continuou, no sentido de enfatizar que toda expansão do sistema escolar foi uma conquista de movimentos sociais, posto que as classes dominantes no Brasil sempre tiveram um papel conservador muito grande, no sentido da garantia de seus privilégios, como muito discutimos no capítulo 2, com base em diferentes autores, como, por exemplo, Anísio Teixeira e o próprio Florestan Fernandes, do qual resgatamos um texto, datado de 1986: "É de baixo que vem a exigência histórica de uma República democrática a serviço de todos - como instrumento da extinção da fome, da miséria, da ignorância, da violência institucionalizada, alicerces dos privilégios daquela mínima minoria" (FERNANDES, $1989^{48}$, p. 52).

$48 \quad$ Este mesmo texto, intitulado Congresso Constituinte sem sonhos, publicado no pasquim de São Paulo em dezembro de 1986, está reunido também na obra Florestan Fernandes na constituinte. Leituras para a reforma política, do Cadernos Perseu, publicado em 2014 (p.37-38). 
Diante dos pontos defendidos pelas instituições presentes, o constituinte Bezerra de Melo colocou o seguinte questionamento:

[...] se o Estado não cumpre com a sua obrigação, se a escola pública está em crise, se a escola privada, também em crise, mas está ocupando seu espaço, porque, querer de alguma maneira, de certo modo pelo que entendi, descartar a contribuição que a escola privada vem dando à educação como complementação a todas estas falhas do Estado? (CÂMARA, 2017b, p. 140).

Uma das respostas a tal questionamento veio por parte do professor Jaques Veloso, que também representava a ANPEd. Afirmou que "qualquer recurso desviado dos cofres públicos para o ensino privado significa uma redução correspondente de vagas na escola pública" (IDEM, p. 141). Para tanto, sugeriu que se trabalhasse com duas categorias de escolas privadas: as mercantis e as sem fins lucrativos - filantrópicas. Outra, veio do representante da UBES, Rovilson Robbi Brito, que estabeleceu uma crítica contundente à transferência de recursos públicos às escolas privadas:

Só quem não se engana, a nosso ver, são os dirigentes da educação, porque eles estão conseguindo cumprir o papel que lhes está determinado, que é exatamente de fazer a escola pública enfraquecer, porque a escola pública não serve mais às classes dominantes, não cumpre mais o papel sequer de dar os conhecimentos para os trabalhadores poderem fazer crescer seus lucros [...] O que acontece hoje é que a burguesia, as classes dominantes não têm interesse na rede pública de ensino. É por isso que a escola privada está cumprindo, de certa forma, o seu papel. Então, nós estamos aqui querendo discutir o porquê dos setores populares estarem alijados da educação. Não é fortalecendo essa elitização que nós vamos resolver o problema da educação em nosso País [...] e se for para se discutir educação como mercadoria, eu, inclusive, oriento os companheiros constituintes, para chamar aqui um dono de supermercado, porque eu não vou discutir essa questão. A questão para mim é a educação, enquanto fator social, e não como um produto que se vai vender, enquanto mercadoria. É isso que predomina na regra, na questão dessas escolas. Então, vamos tratar o que fortalece. Se se quer a escola pública funcionando, como podemos nos dar ao prazer de destinar verbas para outra rede de ensino. Acho que não é possível. Antes de mais nada devemos cuidar do que serve para os amplos setores da sociedade. E, já encerrando, isso para nós é reforçar a escola pública (IBIDEM, p. 141).

Seguem anexas à ata deste dia de discussão todas as propostas entregues por escrito à subcomissão. Todas as suas linhas gerais se encontram traçadas nos parágrafos anteriores. Todavia, no capítulo seguinte, retomaremos alguns trechos que focalizam especificamente a democratização das oportunidades educacionais e a liberdade de ensino. 
A $16^{a}$ sessão da subcomissão 8a contou com a presença de alguns representantes da causa indígena ${ }^{49}$, conforme foi acordado no início dos trabalhos, já que havia a solicitação de vários grupos que discutiam uma mesma temática. No início da sessão, o presidente destacou a dinâmica adotada para que se pudesse ouvir todas as instituições que enviaram representação: uma mesma sessão teria início às nove horas da manhã, seria suspensa ao meio dia e retomada às 17 horas.

Sobre a discussão indígena e suas propostas para a ANC, destacou-se a necessidade de criação de "[...] um espaço democrático a todos os brasileiros, rompendo, desta forma, com a discriminação que historicamente vem atingindo índios, negros e outros grupos sociais minoritários" (CÂMARA, 2017b, p. 167). Assim sendo, a questão do índio foi contextualizada, com ênfase no resgate do Brasil como um país pluriétnico e plurilíngue, ao qual caberia oferecer uma educação que contemplasse tal diversidade, de forma inclusiva, ou seja, sem confundir inclusão com homogeneização. Desta forma, alinhava-se as propostas à constituinte com a Declaração de Princípios da ONU, definida em Genebra, em julho de 1985, quando afirmava que “ [...] as nações e povos indígenas têm direito a receber educação e a negociar com os Estados nas suas próprias línguas, e a criar suas próprias instituições educativas" (IDEM, p.167).

Estiveram também presentes os representantes da ABESC - Associação Brasileira de Escolas Superiores Católicas, CNEC, FENEN, UNE e AEC, cujas observações passaremos a analisar. Cabe ressaltar que a sessão foi uma das mais intensas, posto que instituições com visões contrárias estiveram presentes, movimentando bastante, inclusive a população que se fazia presente nas galerias.

Waldemar Valle Martins, representante da ABESC, informou que a associação contava com 16 universidades católicas, e 32 instituições isoladas à época. Após uma breve contextualização da atuação das instituições católicas na educação brasileira, apresentou os pontos por elas defendido na ANC:

$1^{\circ}$ Somos favoráveis à liberdade de ensino, que é condição e decorrência do regime democrático; $2^{\circ}$ entendemos que o interesse maior da família brasileira é o acesso à educação de qualidade; $3^{\circ}$ reafirmamos a prioridade, a obrigatoriedade e a gratuidade do ensino de $1^{\circ}$ grau para todos, cabendo ao Estado oferecer as

49 Destacamos o trecho da ata que nomeia as instituições e representantes presentes na sessão: "Por esse critério de sorteio de dia e de ordem de seqüência, temos hoje o Centro de Trabalho Indigenista, que fará sua apresentação através da Assessora para Assuntos de Educação, Marina Kahn Villas-Boas. A Professora Marina Kahn Villas-Boas vem acompanhada por: Nieta Lindberg Monte, da Comissão Pró-Índio; Ruth Monteserrat, da Associação Brasileira de Antropologia; Lucinda Ferreira Brito, da Associação Brasileira de Lingüística e Comissão para a Defesa dos Direitos dos Surdos; e Professora Elisabeth Rondon Amarante, da Operação Anchieta e Conselho Indigenista Missionário. Além disto, esta Subcomissão decidiu que ouvirá, pelo espaço de 10 minutos, que corresponde ao Centro de Trabalhos Indigenista, através do Sr. Airton Krenac, porque esta Comissão recebeu a informação de que lhe corresponderia focalizar a questão sob o ponto de vista do índio" (CÂMARA, 2017b, p. 166). 
condições e meios necessários para isso; $4^{\circ}$ com relação ao $2^{\circ}$ e $3^{\circ}$ graus, afirmamos o dever do Estado de garantir o acesso a instituições desses níveis aos cidadãos capacitados, mas carentes de recursos; $5^{\circ}$ com relação à destinação dos recursos públicos, entendemos que o Estado, além de manter as escolas de sua criação e responsabilidade, deverá também subvencionar as instituições que, pela sua atividade, contribuam relevantemente para a cultura, o ensino ou a pesquisa no País, na forma regulamentada por lei (IBIDEM, p. 168).

Ante o exposto, ficou evidente a perspectiva da liberdade de ensino, que conduziu os demais pontos, entendida como a possibilidade da família escolher qual a instituição que receberia seus filhos. Desta forma, toda a política educacional deveria se organizar de forma a garantir tal liberdade, por meio do oferecimento de educação de qualidade em escolas públicas e privadas, sendo que essas últimas deveriam receber, inclusive, subsídios governamentais por auxiliar o Estado nesta oferta. Trouxe dados no sentido de afirmar que, historicamente, os recursos investidos nas universidades privadas não foram tão significativos como dizem os que defendiam a exclusividade de recursos públicos para as instituições públicas.

Após tais considerações, passou-se à próxima instituição: a Campanha Nacional de Escolas da Comunidade, cujo representante presente era Felipe Thiago Gomes, então presidente. Iniciou sua apresentação tratando da importância da Campanha em locais onde a presença do Estado era precária ou inexistente. Desta forma, afirmou que sua posição não era “[...] a favor nem contra a escola pública e a escola particular" (IBIDEM, p. 169). Concluiu afirmando que as escolas que compunham a CNEC estariam mais para a alcunha de públicas do que de privadas, posto que não tinham compromisso com o lucro.

Passou-se, pois, à primeira etapa de debates, que foi iniciada com uma observação do constituinte Bezerra de Melo, que afirmou

[...] estamos muitos felizes, muito alegres mesmo por sentir a presença da escola privada nesta subcomissão, presença esta que até agora se tinha notado muito pequena. Tivemos aqui a audiência de várias entidades ligadas ao ensino público, numa defesa intransigente do ensino público gratuito e laico. Tivemos oportunidade de falar durante e após essas exposições, e discordar de alguns pontos de vista daquelas entidades, sempre tendo como prioridade para nós, apesar de sermos da escola particular, que a educação é um direito de todos e um dever do Estado, que a educação pública, o ensino público deve ser realmente priorizado no país, principalmente no que se refere à educação fundamental - a educação de $1^{\circ}$ grau (IBIDEM, p. 170). 
Sobre os argumentos apontados, Octávio Elísio disse não compreender a estranheza do colega com a presença das instituições particulares apenas naquela reunião, uma vez que a ordem das apresentações fora definida por sorteio. Em seguida, defendeu a liberdade de ensino, só que em uma perspectiva distinta, ou seja, quando a escola de qualidade não fosse prerrogativa apenas das classes privilegiadas, mas de todas, via escola pública.

Sobre tal questão, o representante da ABESC retrucou, afirmando que as instituições privadas de ensino seriam prerrogativa do regime democrático. Na mesma linha, o reitor da PUC Rio complementou a fala do colega, dizendo que as instituições comunitárias não visavam o lucro, tendo uma função proeminentemente social, e não mercadológica. Ainda nessa perspectiva, a representação da CNEC afirmou que não possuía clientes, mas sócios, e que tal sociedade se configuraria da seguinte forma: "O aluno mais rico contribui com mais e o aluno pobre, com menos. Não é possível que o aluno receba gratuitamente as aulas" (CÂMARA, 2017b, p. 174).

Foi ouvido também o representante da União das Nações Indígenas, que apontou a questão da diversidade de tribos, culturas e línguas, com ênfase na ideia de catequese, considerada como "[...] expectativa que um tem de fazer o pensamento dele se sobrepor ao pensamento do outro" (IDEM, p. 174).

Retornando à questão público-privada e à destinação de recursos, a ABESC afirmou que o dualismo colocado na subcomissão não resolveria o problema, e que o grupo deveria avançar na direção já traçada pela escola comunitária, que seria considerada pública, mas não necessariamente estatal.

O relator da subcomissão, João Calmon, encerrou os debates, colocando que a discussão sobre a destinação de recursos seria realizada em momento oportuno. Contudo, suas colocações deixaram transparecer uma visão mais conciliatória da situação, como vemos a seguir:

Como não estamos aqui dominados por nenhum tipo de radicalismo ou de preconceito, tenho a impressão de que esta subcomissão vai discutir, no momento oportuno, a definição sobre a exclusividade da destinação de verbas públicas para escolas públicas ou, então, a manutenção do sistema atual, dependendo, naturalmente, da lei complementar ou da lei ordinária que vai regulamentar o inciso da Carta Magna, a continuação da ajuda ao ensino privado, desde que satisfaça às exigências mínimas que deverão constar de legislação ordinária. Até agora as nossas Constituições, desde a primeira até a atual, a Constituição vigente, que nem merece o nome de Constituição, porque, na realidade, é uma colcha de retalhos, todas têm definido a destinação de recursos públicos para a manutenção e o desenvolvimento do ensino, sem adjetivar o ensino, sem determinar que esse ensino deve ser exclusivamente público, com exclusão de qualquer verba para um 
ensino particular de nível, realmente, comprovadamente, elevado. Essa execução poderá ser introduzida, obviamente, pela Constituinte que ora se reúne. Aqui, na subcomissão, somos apenas o nível mais modesto das várias comissões (IBIDEM, p. 177).

No início da segunda parte dos debates daquela sessão, foi passada a palavra ao constituinte Octávio Elísio, que fez uma denúncia quanto à repressão sofrida por um grupo do Distrito Federal que objetivava fazer uma caminhada até a ANC. Desta maneira, solicitou que a subcomissão se pronunciasse a respeito, uma vez que caberia ao espaço da ANC aspirar pela construção dos caminhos de uma nova sociedade. Acatada a solicitação pelo presidente em exercício, o mesmo explicitou que passaria a palavra à Secretaria de Assuntos Constituintes da Organização Nacional de Entidades de Deficientes Físicos, então presente. Assim sendo, o representante da Secretaria falou dos desafios vividos pelos deficientes e do compromisso da educação e da cultura para com sua inclusão social.

Após as considerações feitas, os convidados da segunda parte da reunião passaram a ser ouvidos. Primeiramente, o da FENEN, Roberto Dornas. Este iniciou sua preleção com o número de instituições agregadas pela Federação: cerca de 35 mil, que envolveriam as de diferentes credos, tamanhos e regiões. Destacou o que acreditava ser a diferença entre educar - tarefa da família - e instruir - tarefa da escola. Avançou, atacando a defesa pela escola pública, até então apresentada na maioria das exposições feitas:

E como se golpeia a democracia de amanhã é golpeando a educação na sua base, é formando a criança pela vontade do Estado, do Estado que impõe. A preocupação da escola particular é que a sociedade futura do Brasil não seja um Chile, não seja um Paraguai, não seja uma Alemanha de Hitler, não seja uma Itália de Mussolini, não seja a Nicarágua, porque lá não vemos este Parlamento, lá não vemos esta diversidade. Transcendente, se quer democracia, temos que ter uma escola, essencialmente plural [...] É preciso garantir à família o direito de escolha. Por que o rico paga imposto e teria o direito na sua escola pública, mas, como ele tem outra condição, ele escolhe a escola batista ou católica de sua preferência, e o pobre é discriminado, porque ele só tem a escola pública, ele não pode ser batista, ele não pode ser leigo, ele não pode ser nazista, ele não pode ser marxista, ele não pode ser católico. Só resta-lhe esta condição. Não reivindicamos nenhum tipo de verbas para a escola particular, a verba é pública e deve ser pública, mas pública para atingir a família, para dar ao pobre também o direito de escolher a escola conforme as suas convicções. Ele escolha a escola, conforme suas crenças e suas convicções, o governo pague por ele (IBIDEM, p.180).

Sua proposta apresentou diferentes questões já sinalizadas: liberdade de ensino entendida como liberdade de escolha da família; democratização do ensino como pluralidade 
e coexistência de instituições públicas e privadas; verbas públicas que deveriam remunerar quem a família escolhesse para prestar o serviço que desejasse adquirir. Por fim, chamou a escola pública de escola sectária, que deveria, segundo sua visão, nos encaminhar forçadamente a uma sociedade socialista.

Após suas considerações, a presidenta da UNE passou a ser ouvida. Iniciou a defesa das instituições públicas, por meio da abordagem a respeito do sucateamento do ensino superior público e do alinhamento das propostas da UNE com relação ao FNDEP. Neste sentido, em seu discurso, a liberdade de ensino assumiu outra conotação, posto que considerou só existir liberdade quando há condição de todos exercê-la, o que historicamente não aconteceu no Brasil, devido ao acesso restrito das camadas populares à educação. A liberdade, pois, seria a possibilidade de "[...] todas as correntes religiosas, as correntes filosóficas que quiserem ter uma escola, sendo sustentada pelas próprias correntes, isto deve ser garantido" (IBIDEM, p. 181).

Passou-se à audição da AEC, representada pelo Padre Agostinho Castejon. Contextualizou a existência e a finalidade da Associação a partir das seguintes considerações, diferenciando-a da FENEN e da ABESC:

É uma associação que existe no Brasil inteiro, em todos os Estados e territórios, tem 42 anos de existência, se pretende como espaço de consciência crítica, de estudo sério da educação, como espaço de debate da educação, e se entende como espaço onde os educadores de escolas públicas, de escolas particulares e de escolas católicas, inspirados a partir do Evangelho, pensam, criticam e analisam a situação educacional. E, em sintonia com a Conferência Nacional dos Bispos do Brasil, com as diretrizes da Conferência, a partir de uma opção preferencial pelos pobres, colocando-se numa perspectiva de busca de uma transformação social, tenta ajudar os educadores católicos das escolas públicas ou particulares a repensar a sua educação (CÂMARA, 2017b, p. 182).

Colocou-se contra o monopólio da escola pública e da estatização da educação, que seria, pelo viés da AEC, antidemocrático. Desta forma, defendeu uma sociedade plural e participativa, onde a opção das pessoas fosse respeitada. Destacou, pois, os primeiros artigos da proposição que representava, a saber: educação de qualidade, para a qual devem ser destinados recursos públicos, com prioridade, para a educação fundamental. Neste sentido, disse que a contraposição entre o ensino público e privado era arcaica, ultrapassada, pois remontava à década de 1940. Defendiam uma escola pública e gratuita, porém, não estatal, ou seja, que não objetivasse o lucro, mas que possibilitasse a opção de escolha por parte das famílias. 
Ao encaminhar o momento dos debates, o presidente Hermes Zaneti franqueou a palavra ao constituinte Louremberg Nunes, que defendeu o pagamento de taxas pelas famílias que possuíssem melhores condições financeiras. Em resposta à provocação do constituinte, Roberto Dornas explicou que não há poucos recursos, mas recursos mal utilizados, posto que a máquina pública é ineficiente e consome parte deles na manutenção de sua burocracia. Já o representante da AEC afirmou que não se deve cobrar taxa alguma na escola pública, mas na renda; por sua vez, a presidenta da UNE voltou a caracterizar o que consistiria verdadeiramente a democratização do ensino e o direito à educação como a possibilidade de “[...] ampliar a rede pública, como forma de corrigir essa grande distorção que tem ocorrido na história da educação em nosso País" (IDEM, p. 184).

O constituinte Antônio de Jesus novamente trouxe o entendimento da democratização das oportunidades educacionais para o campo da escolha individual, caracterizando-a como a possibilidade da família selecionar em qual escola iria matricular seu filho. Na mesma linha, o representante da FENEN transitou, ao colocar também a liberdade de escolha. Já Gisela Moulin, da UNE, reafirmou o caráter social da educação para além da visão mercantil de prestação de serviços. Octávio Elísio destinou suas observações a Dornas, ao problematizar a questão do custo do aluno nas escolas públicas e privadas, afirmando que nem sempre a educação mais barata é a melhor. Bezerra de Melo abordou a necessidade de regularizar o ensino, por meio de algum instrumento que não permitisse que os ricos estudassem nas escolas públicas, tirando vagas da população de baixa renda. Como solução Roberto Dornas ofereceu

[...] se criar um "ticket" de educação, que se dê àquele aluno comprovadamente carente um documento em que ele se matricule onde quiser, e aquele que receber a matrícula vai receber do poder público, ou através da própria empresa, ela financia e depois deduz dos impostos que tem a pagar. É simples questão de mecanismo. A distribuição da renda, realmente, sem as peias burocráticas, de modo geral, conduz a tráfico de influência ou outras coisas (IBIDEM, p. 187).

$\mathrm{Na}$ mesma perspectiva, seguiram os debates, com considerações dos participantes e manifestação da população nas galerias, sempre que a defesa de um ou de outro grupo se mostrava mais contundente. Mudando um pouco o foco das discussões, o constituinte Tadeu França - professor, do PMDB - questionou sobre o piso docente em instituições públicas e privadas e solicitou esclarecimentos quanto a diferença entre a concepção de instituição pública estatal e não estatal. Respondeu o padre Castejon que

A escola pública seria pública, porque o acesso seria em igualdade de condições para todos; seria gratuita, porque não seria cobrada qualquer anuidade aos alunos, na medida em que a escola recebesse os recursos necessários do Estado. Essa disposição teria que ser implementada em lei complementar [...] A Constituição 
teria que manter apenas aberta a possibilidade da existência de escolas públicas não estatais e gratuitas (IBIDEM, p. 188).

Sobre a questão do piso, disse ser de difícil definição para as instituições privadas pelo fato destas não poderem prever de forma correta suas receitas. Já a representante da UNE afirmou que esta nunca foi uma preocupação dos empresários do ensino, mas sim o fruto das lutas do magistério e de seus sindicatos de classe. Outro tema foi abordado por Pedro Canedo, que trouxe o acesso ao ensino superior por meio do vestibular. Sobre essa questão, Gisela Moulin colocou que o vestibular é apenas a culminância de todo um processo de exclusão sofrido pelas classes populares; assim sendo, haveria que pensar a educação em todos os níveis de forma orgânica e, estrategicamente, a entrada no ensino superior.

Artur da Távola, em uma perspectiva conciliatória, fez uma pergunta para cada um dos representantes presentes, sobre a destinação de recursos - se esta deveria ser somente para as instituições públicas estatais ou também para as não estatais, solicitando a visão de cada um deles sobre o fato. A AEC, por intermédio de seu representante, colocou que seria preciso melhor entender o que poderia ser considerado como instituições públicas não estatais, ou seja, defini-las como as que não se beneficiam de lucros. Assim sendo, acreditava que também deveriam receber recursos. A UNE defendeu que não, posto que a escola a ser beneficiada com recursos públicos deveria ser pública, gratuita e laica, o que excluiria os grupos religiosos. Por sua vez, a FENEN afirmou que buscava romper com tais caracterizações, posto que todo ensino seria público, por atender à população em geral, assim como toda verba, que por ser resultante da arrecadação dos impostos, deveria financiar toda a educação.

O relator passou a fazer considerações sobre mecanismos de controle e fiscalização do ensino no país, por meio do MEC e da criação de Conselhos Municipais de Educação. Sugeriu também a realização de amplo diagnóstico, de forma que se pudesse aplicar o dinheiro público efetivamente nas áreas que dele carecem. As entidades presentes se pronunciaram a respeito, abordando a necessidade de se combater as más instituições de ensino, e a UNE sugeriu, por fim, a completa reestruturação do CFE.

Ao final da ata foram anexados os documentos recebidos pela subcomissão naquela ocasião, a saber: quatro documentos pertinentes à questão indígena, um da PUC de Campinas, um da PUC do Rio Grande do Sul, da CNEC, da FENEN, UNE, AEC, e de uma entidade não ouvida nos trabalhos da subcomissão, a COPADIS - Comissão Paulista para Defesa dos Direitos do Surdo. 
A $17^{\mathrm{a}}$ sessão, realizada no dia 30 de abril de 1987 teve início com a leitura da justificativa de ausência do presidente do Conselho Diretor Nacional do MEB - Movimento Educação de Base. Desta forma, concluiu-se que a audição desta instituição estaria contemplada na medida em que o padre Castejon era seu secretário, e foi ouvido na sessão anterior. Retirou-se também da listagem dos que ainda faltavam expor seus depoimentos o Fórum Nacional das Pessoas Portadoras de Deficiência e a Comissão Parlamentar da Organização de Entidades de Deficientes Físicos.

Assim sendo, estavam presentes representantes do Sindicato dos Professores de Estabelecimentos Particulares de três organizações distintas: Sindicato de Professores do Estado de Minas Gerais, Federação dos Trabalhadores em Estabelecimentos de Ensino da Região Sul, Rio Grande do Sul, Santa Catarina e Paraná - FETEE SUL -, e Federação Interestadual dos Trabalhadores em Estabelecimentos de Ensino (FITEE). Desta forma, para cumprir os critérios adotados anteriormente, quando da audição das propostas dos grupos ligados à causa indígena, a presidência optou por destinar tempo de fala apenas às federações.

O deputado Sólon Borges dos Reis - constituinte do PTB, antes filiado ao PDC e depois à ARENA, foi eleito com base eleitoral ligada ao magistério público (CPDOC, 2017o) - sugeriu a inclusão da UDEMO (Sindicato de Especialistas de Educação do Magistério Oficial do Estado de São Paulo) nas apresentações do dia, pedido aceito pelo grupo. Foi também apresentado pelo constituinte Chico Humberto o convite da Câmara dos Vereadores de Uberlândia para o comparecimento de membros da subcomissão àquela cidade. O parlamentar informou que, em contato com a Aeronáutica, foi informado que um avião poderia ser cedido para este fim. A questão foi problematizada por Florestan Fernandes, que questionou se a subcomissão poderia atender todos os convites da mesma natureza que porventura fossem feitos. Desta forma, algumas considerações foram feitas e a visita foi aprovada.

Passou-se à apresentação das propostas das instituições presentes. Francisco Antonio Poli, em nome da UDEMO, apresentou um breve diagnóstico da educação brasileira, e afirmou que a única solução para seus problemas seria a garantia da educação pública e gratuita em todos os níveis. Apesar de definir como necessária a atuação das instituições privadas, defendeu que a lógica educacional prevalecesse sobre a mercantil, e que os recursos públicos não fossem a elas destinado. Apresentou ainda como avanço, em São Paulo, o provimento do cargo de diretor via concurso público. 
No que é pertinente à proposta da FETEE Sul, foi evidenciada de forma bem sucinta a garantia da educação gratuita para todos. Ampliando esta primeira indicação, a FITEE defendeu a emancipação da maioria da população trabalhadora por meio das políticas sociais. Desta forma,

É necessário levar em consideração também o fato de que a solução dos problemas educacionais não se esgota em si mesma, mas está indissoluvelmente ligada à necessidade de distribuição de renda e à melhoria das condições de vida da população nas várias áreas sociais, como saúde, habitação, lazer, cultura, transportes, etc. Nós entendemos que a solução desses problemas exige um novo projeto nacional voltado para o atendimento das necessidades das mais amplas parcelas marginalizadas de nossa população que limite e controle a ação do grande capital internacional em nosso país (CÂMARA, 2017b, p. 225).

Com uma perspectiva bastante crítica, a FITEE abordou a necessidade de expansão da rede pública de ensino e o investimento do poder público em sua manutenção como formas de superação dos problemas educacionais brasileiros. Trataram ainda da diferença entre ensino laico e antirreligioso, posto que o ensino de apenas uma religião descaracterizaria a democracia que deveria predominar no espaço escolar. Ainda sobre a questão da democratização, abordou a necessidade de se pensá-la nas escolas privadas e na estrutura dos Conselhos.

Outras três representações foram ouvidas, trazendo, cada qual, reflexões bem específicas ao debate da matéria educacional na CF. O Conselho Federal de Farmácia reclamou da dificuldade de realizar pesquisas e ensino na área; o Centro de Estudos Afro Brasileiros e o Conselho da Comunidade Negra ofereceram contribuições para que se pudesse pensar sobre o papel do negro na estrutura social, comumente desvalorizado e baseado no padrão colonizador que ainda perdurava no país. Desta forma, seria preciso repensar os valores e conteúdos do ensino, de forma a permitir mudanças de paradigmas.

No debate posterior às apresentações, tanto a UDEMO quanto a FITEE ratificaram suas posições quanto à exclusividade da aplicação de recursos públicos em instituições públicas. Já a FETEE Sul abordou a falta de liberdade dos profissionais de ensino da rede privada, totalmente prejudicial ao processo pedagógico.

O constituinte Sólon Borges afirmou que o nó de estrangulamento da discussão da educação no Brasil não seria a questão público-privada, mas a falta de filosofia da educação na definição dos projetos escolares, bem como a atualização da rede física. Já Antonio de Jesus apresentou o seu conceito de educação como o desenvolvimento integral do homem. 
Retomou, mais uma vez, a ideia de que toda educação seria pública, posto que destinada ao público, desconsiderando toda a polêmica que envolvia a realidade e a discussão públicoprivada. O constituinte Átila Lira, administrador de empresas e economista, apresentou visão favorável à exclusividade da aplicação dos recursos públicos em instituições públicas. Já Florestan Fernandes abordou a importância pedagógica da eleição de diretores, diferentemente da perspectiva de concurso público destinado ao provimento deste cargo. Tadeu França abordou a questão curricular, citando como exemplo a necessidade de se estudar a história da África e outras línguas estrangeiras, para além da língua inglesa. Louremberg Nunes fez uma reflexão, afirmando que todas as falas convergiam para a culpabilização das instituições privadas, por sua ineficiência; disse que caberia uma reflexão sobre os problemas das instituições públicas também. Sobre esta questão, Francisco Poli disse acreditar não ter explicitado com clareza sua posição: não acreditava que o problema da educação pública seria das instituições privadas, mas sim do governo.

A segunda parte da reunião teve início com o chamamento de mais um grupo de representantes, a saber: Comissão PróFederação Nacional de Arte-educadores, representada pela Professora Laís Aderne, da Universidade de Brasília; Associação Nacional dos Professores de Prática de Trabalho, com a Professora Mary Icléa, presidenta; a OCB, Organização das Cooperativas Brasileiras, representada pelo Dr. Guntolf Von Kaick, vicepresidente. E, por fim, a associação das escolas evangélicas, na figura de Ulysses Panisset.

A Comissão foi a primeira a ter espaço para uso da palavra, e defendeu a arte como forma de propiciar o desenvolvimento integral do ser humano, por meio de diferentes linguagens. Nessa mesma perspectiva caminhou a proposta apresentada por Mary Icléa, ou seja, na linha do resgate do trabalho como forma de humanização do homem; também defendeu a exclusividade da aplicação dos recursos públicos em instituições públicas e o caráter laico do ensino, sendo que tal questão deveria ser problematizada pela comunidade escolar, e não pela $\mathrm{CF}$.

No que se refere a OCB, a perspectiva defendida era do desenvolvimento de uma lógica de autoajuda, por meio de uma educação cooperativista. Já as instituições evangélicas partiram do histórico da atuação destas na educação brasileira, campo homogeneizado pela Igreja católica, para então abordar a defesa da educação privada, destacando que ela responderia por um número significativo das matrículas no Brasil. Considerou que uma instituição deveria ser denominada de pública devido à natureza do trabalho educacional desenvolvido e disse ser pouco democrática a falta de opção de escolha quanto à escola em que os pais iriam matricular seus filhos. 
Destacamos também nesta sessão a colocação de Pedro Canedo, que afirmou não ser defensor da aplicação dos recursos públicos exclusivamente nas instituições públicas, e que tal polêmica seria mais conceitual do que prática.

Esta foi a última sessão das audiências públicas destinadas à matéria educacional. Ao final da ata, além dos documentos apresentados pelas instituições ouvidas, agregou-se o do Sindicato dos Professores do Estado de Minas Gerais, que se utilizou das propostas integrais do FNDEP.

Sobre a sessão extraordinária de 04 de maio é importante destacar alguns pontos, com destaque para a necessidade de criação de uma figura jurídica semelhante ao mandato de segurança, de forma a garantir a ação popular contra o poder público, no caso do não cumprimento de suas obrigações constitucionais. Tal problemática, levantada por Louremberg Nunes, ficaria conhecida como mandato de injunção.

João Calmon propôs, ainda, a mudança do sistema de governo, do presidencialismo para o parlamentarismo. Lembramos que tal discussão ocupou por muito tempo as preocupações que desencadearam na configuração do Centrão, como vimos na abertura deste capítulo.

As sessões seguintes ${ }^{50}$ foram dedicadas ao debate dos outros temas abrigados na subcomissão 8a: cultura, esporte e o papel dos editores de livros, entre outras temáticas mais específicas. Como não constituem nosso objeto, não analisaremos as discussões que se desenvolveram nesses momentos. Fazemos um destaque apenas à $19^{a}$ sessão, na qual foram apresentadas considerações sobre a educação religiosa, além da subcomissão ter recebido naquela oportunidade o documento da $\mathrm{CNBB}$, com o tema "O ensino religioso na escola oficial".

Retomamos as atas a partir da $23^{\mathrm{a}}$ sessão, quando o relator apresentou seu relatório, no dia 11 de maio de 1987, após a rica e exaustiva fase das audiências públicas. Destacou, pois, que buscou sintetizar 333 propostas, sendo que no último dia recebeu 305 delas. Ressaltou que ainda não acontecera a reunião com o ministro da educação e que, por conseguinte, o texto ora apresentado se tratava de um documento parcial.

Passou então João Calmon à leitura da introdução do relatório, no qual procedeu um diagnóstico do volume da matéria educacional nos textos constitucionais precedentes, constatando que o mesmo se avolumou nas últimas Constituições. O segundo aspecto

$5011^{a}$ sessão, realizada em $05 / 05 / 1987 ; 20^{a}$ sessão, realizada em $06 / 05 / 1987 ; 21^{\text {a }}$ sessão, realizada em 07/05/1987; e 22a sessão, realizada em 08/05/1987. 
abordado foi a dinâmica da ANC, especificamente no que tange ao trabalho adotado nas subcomissões e comissões temáticas. Exemplificou também os pontos frágeis deste processo: alguns problemas constantes no regimento, assim como lacunas na infraestrutura, sobretudo o tempo exíguo e o acúmulo de trabalho para a produção dos relatórios. Sobre as principais propostas apresentadas pelo relator, cumpre destacar:

$\checkmark$ a vinculação de recursos orçamentários para a educação;

$\checkmark$ a elevação dos percentuais de vinculação;

$\checkmark$ o ensino universal e gratuito nas escolas públicas, tema sobre o qual o relator se mostrou inclinado ao entendimento do serviço público prestado por instituições privadas;

$\checkmark$ a fiscalização do ensino pela comunidade;

$\checkmark$ a aposentadoria especial para profissionais da área do ensino;

$\checkmark$ a intervenção federal nos estados que não viessem a cumprir a determinação constitucional;

$\checkmark$ o papel e a competência da justiça desportiva.

O relator da comissão 8, Artur da Távola, afirmou que do total das propostas recebidas, a maior parte delas se destinava à legislação complementar e ordinária, e não deveriam ser colocadas na carta magna. Seguiu explicando que as discussões coletadas nas audiências foram agrupadas em temas afins, da forma seguinte:

Educação, Princípios, Objetivos e Diretrizes: refere-se à educação como direito de todos os brasileiros. Cabe ressaltar que além desse eixo principal, alguns constituintes - 3 deles - destacaram o direito dos pais e da família em educar seus filhos. Apareceu também a educação para os jovens e adultos, o mandato de injunção, entre outros instrumentos de garantia de direitos para todos. Como princípios, foram destacados os seguintes: unidade nacional, liberdade, solidariedade humana, responsabilidade social e cívica com os objetivos do pleno desenvolvimento da pessoa a serviço de uma sociedade justa e livre, assim como a igualdade e a eliminação de todo tipo de discriminação e preconceito;

$\checkmark$ Obrigatoriedade escolar: a proposta predominante foi a manutenção da obrigatoriedade do ensino fundamental, com a duração de oito anos, sendo permitido o ingresso do aluno na escola já a partir de seis anos, sem limite de idade para a sua conclusão e com a responsabilidade do Estado para com a universalização da educação; 
$\checkmark$ Liberdade e iniciativa: com exceção de apenas uma sugestão das apresentadas sobre este tópico, que deixou o ensino fundamental obrigatório a cargo exclusivo do Estado, todas as sugestões afirmaram o princípio de que a iniciativa privada deveria atuar livremente no ensino. Foram feitas duas propostas de apoio financeiro às famílias para que elas pudessem escolher as escolas que desejassem. Cabe também destacar que vinte entidades apresentaram propostas para o tema, tendo-se destacado como principal reivindicação a exclusividade da aplicação dos recursos públicos no ensino público. Como alternativas, aparecem as seguintes propostas: atuação complementar das instituições privadas e públicas em respeito ao pluralismo da sociedade; estatização do ensino fundamental obrigatório; estatização do ensino em todos os níveis - primeiro, segundo e terceiro graus;

Ensino religioso: foram seis propostas apresentadas; a maioria, ou seja, quatro delas, concordou com a administração desse ensino como disciplina nas escolas públicas de primeiro e segundo graus, enquanto duas delas se opuseram por motivos diversos. A tendência geral foi a de aliar a conotação laica ao ensino público, exceto na proposta oriunda da AEC;

$\checkmark$ Pré-escolas e creches: partem da afirmação da obrigatoriedade do Estado para com a educação de todos a partir do nascimento. Há algumas propostas distintas em relação à idade em que tal obrigação começaria a vigorar. Foram propostas algumas alternativas para a pré-escola: parte constituinte do dever do Estado para com a educação de todos; dever do Estado, sendo obrigatória para todos; a pré-escola com início aos três anos de idade; com início aos quatro anos, estendendo-se até aos seis; com início aos cinco anos, estendendo-se até aos seis; como dever do Estado, de 0 a 6 anos;

$\checkmark$ Auxílio suplementar ao educando: trata das questões pertinentes à alimentação, ao transporte, ao vestuário, ao material escolar e aos serviços médico e odontológico. Destacamos que a maioria das propostas se detém ao ensino fundamental. A proposta do FNDEP era bastante interessante, pois retirava da rubrica da educação estes auxílios, colocando-os com orçamentos próprios;

Educação especial: o atendimento aos alunos com necessidades educacionais especiais apareceu como dever do Estado em todas as propostas feitas;

$\checkmark$ Idiomas do ensino: em sua ampla maioria, as propostas convergiram para a defesa do ensino da língua portuguesa, com ressalvas apenas para o ensino da língua para as comunidades indígenas; 
$\checkmark$ Magistério: a valorização do magistério em todos os níveis apareceu na defesa das propostas apresentadas por todos os constituintes, com garantia fixada em lei, estabelecidas condições condignas de trabalho e padrões mínimos de remuneração. Houve também a defesa do provimento de cargos exclusivamente por meio de concurso público, assim como a definição de uma carreira nacional;

$\checkmark$ O ensino superior: vários aspectos deste nível de ensino foram objeto de considerações dos constituintes, dentre eles, a questão do financiamento, da autonomia universitária, do vestibular ou sua substituição por outro critério de seleção, critérios para a criação de novas instituições e processo de escolha de dirigentes;

$\checkmark$ Educação e trabalho: notou-se uma preocupação com a necessidade de habilitação para exercício de uma profissão, quer seja a nível de ensino fundamental ou médio; todavia, percebemos cautela devido à experiência recente com a profissionalização compulsória, estabelecida pela Lei 5.692/1971 e revogada pela Lei 7.044/1982. Houve propostas que indicavam a criação de escolas técnicas de acordo com as demandas regionais. Tratou-se, ainda, do aumento da idade mínima para o trabalho - de 12 para 14 anos de idade;

$\checkmark$ A organização do sistema de ensino: neste item foram agrupadas as discussões pertinentes à distribuição das competências entre os entes federados. Tratou-se ainda das perspectivas favoráveis e contrárias ao processo de municipalização do ensino; da criação de Conselhos Municipais de Educação (CME); de planos decenais articulados, como o PNE, por exemplo; e da gestão democrática do ensino;

$\checkmark$ Financiamento da educação: tema de grande preocupação dos constituintes, posto que trouxe a necessidade de se assegurar recursos suficientes para o cumprimento da obrigatoriedade escolar; destacou a urgência da previsão orçamentária dos recursos para garantir o cumprimento das obrigações educacionais das diversas esferas de governo. Desta forma, tratou da vinculação de percentuais mínimos e/ou de percentuais sobre receitas de impostos. Novamente apareceu a questão da natureza dos recursos que chegam às instituições públicas e privadas.

Após algumas considerações feitas pelo relator sobre a dinâmica de escrita do texto, diante dos prazos curtos estabelecidos pela mesa diretora da $\mathrm{ANC}$, assim como as reuniões que ainda aconteceriam na subcomissão, passou-se à leitura do anteprojeto. O constituinte Bezerra de Melo, do PMDB, fez uma observação a respeito de suas sugestões não terem sido incluídas no relatório. Da mesma forma, Sólon Borges fez outras considerações a respeito do financiamento, que deveriam ser incluídas. Sobre tais questionamentos, o 
relator informou que optou por inserir em anexo ao seu relatório algumas propostas na íntegra, que era o caso do último constituinte que o questionara, por exemplo, e de um texto elaborado pelo PT.

No que se refere ao anteprojeto, acordou-se que na sessão em curso o grupo iria apresentar o texto referente à educação e, na seguinte, o das demais áreas estudadas pela subcomissão. Voltemos, pois, ao conteúdo do relatório. $\mathrm{O}$ artigo primeiro apresentou a educação, entendida como

[...] direito de todos e dever do Estado, será promovida e incentivada por todos os meios, com a colaboração da família e da comunidade, visando ao pleno desenvolvimento da pessoa e ao compromisso do ensino com os princípios da liberdade, da democracia, do bem comum e do repúdio a todas as formas de preconceito e de discriminação (CÂMARA, 2017b, p. 415).

Entendida primeiramente como dever do Estado, a educação tem a família como instituição de atuação complementar. Especificando sua abrangência, delimitou-se as diretrizes nas quais esta se ancoraria, a saber:

$1^{\circ}$ - Democratização do acesso e da continuidade dos estudos. $2^{\circ}$ - Pluralismo de idéias e de instituições de ensino públicas e privadas. $3^{\circ}$ - Liberdade de pesquisa e de comunicação no exercício do Magistério. $4^{\circ}$ - Adequação aos valores e às condições regionais e locais. $5^{\circ}$ - Descentralização da Educação pública, cabendo prioritariamente aos Estados e Municípios o ensino fundamental obrigatório. $6^{\circ}-$ Garantia de ensino fundamental, regular ou supletivo para todos. $7^{\circ}$ - Valorização do Magistério em todos os níveis, com estruturação das respectivas carreiras e garantias de condições condignas para a eficácia do trabalho, inclusive padrões mínimos de remuneração fixados em lei federal. $8^{\circ}$ - Participação adequada, na forma da lei, de todos os integrantes do processo educacional nas suas decisões. $9^{\circ}$ - Superação progressiva das disparidades regionais e sociais (IDEM, p. 415).

Os eixos mais problemáticos do debate que se instaurara até aquele momento, que diziam respeito à distribuição dos recursos entre o serviço público e as instituições privadas, assim como o que se entendia por liberdade de ensino, apareceram no texto elaborado pela subcomissão 8a. Partindo da coexistência das entidades públicas e privadas, o relator privilegiou o entendimento da possibilidade de divisão dos recursos, desconsiderando que a maior parte dos grupos até então ouvidos nesta esfera diziam o oposto. Ficou, pois, assim a proposta do anteprojeto:

Art. - A lei regulará a transferência de recursos públicos a instituições educacionais privadas que prestem relevantes serviços públicos. Parágrafo único: As instituições, 
a que se referem o caput deste artigo, serão organizadas por comunidades e grupos de caráter social, religioso e cultural. b) comprovada a não - distribuição de lucros, a reaplicação de eventuais excedentes em educação e apresentarão contabilidade aberta e verificável pela comunidade e pelo Poder Público (IBIDEM, p. 416).

Ao finalizar a sessão, o presidente já convocara a próxima, para o dia seguinte. Todavia, abordaremos a $25^{\mathrm{a}}$ reunião, que se iniciou no dia 13 de maio de 1987 , com a presença do então ministro da educação, Jorge Bornhausen, senador afastado. Cabe ressaltar que após essa fase da ANC, ele retomou seu mandato, participando da votação do segundo turno, já na comissão de sistematização. Tal fato aconteceu com outros seis ministros, que deixaram suas respectivas pastas para voltar à constituinte e garantir votos para as pautas a favor do governo. Sobre sua participação no processo como ministro, o próprio fez o seguinte registro:

Eu dei depoimentos sobre o que ocorria nessa área e defendi que a educação tivesse um percentual estabelecido no orçamento - o que ainda é necessário no Brasil, porque se não for obrigatória acaba não ocorrendo. Infelizmente. Mostrei também que nós estávamos com a pirâmide invertida: o gasto no ensino superior era muito maior do que no ensino fundamental. E depois eu entrei com uma emenda garantindo a gratuidade da universidade pública para os que não podiam pagar e tinham um efetivo aproveitamento curricular. Essa emenda foi rejeitada. Mas, eu consegui negociar, nas disposições transitórias, um artigo que diz que a gratuidade é para quem tem a contribuição preponderante do poder público. Com isso, as nossas faculdades continuaram podendo cobrar as mensalidades como fazem até hoje (CARVALHO, 2017, p. 369).

$\mathrm{Na}$ ocasião, o ministro apresentou algumas questões que julgava ser fundamental à $\mathrm{ANC}$ e às propostas que nela se elaboravam. Iniciou sua fala, portanto, a partir da explicação dos projetos destinados à educação básica, embora reconhecesse a obrigação do Estado para com a educação como um todo. Assim sendo, abordou o programa Educação para Todos, que objetivava "zerar" o déficit escolar, incluindo no sistema os alunos que estivessem fora dele. Abordou ainda a melhoria da qualidade da educação, que tinha como foco principal o investimento no docente; o repasse de recursos aos municípios; o problema do analfabetismo, da evasão e da repetência; a reorganização do ensino de $2^{\circ}$ grau, que deveria deixar de ser algo "[...] espremido entre a obrigação constitucional do $1^{\circ}$ grau e a forca do $3^{\circ}$ grau pela qualidade da comunidade universitária" (CÂMARA, 2017b, p. 438).

O ensino técnico; o GERES - Grupo Executivo para Reformulação do Ensino Superior; o Programa Nova Universidade; o crédito educativo; a pós-graduação e a pesquisa; a educação especial; o salário educação; o ensino religioso não obrigatório; a prioridade 
do ensino básico, compreendido como "alicerce" (IDEM, p. 445); a descentralização dos recursos e das responsabilidades, com vistas a eficiência e ao enxugamento do MEC; enfim, vários foram os pontos apresentados por Jorge Bornhausen. Sobre a prioridade de recursos estar expressa na CF para um determinado nível de ensino, o ministro concordou integralmente que não pode haver um dispositivo legal para isso, posto que tal previsão deve ser elencada a cada governo.

Diante a exposição do ministro, o constituinte Florestan Fernandes o chamou de liberal e destacou que o mesmo não apresentou propostas viáveis para a solução dos problemas apresentados; teceu críticas ao GERES e à falta de posicionamento claro do senador licenciado, na medida em que

\begin{abstract}
Ora, na área da educação vivemos esses dilemas porque não basta lamentar o analfabetismo, é preciso ter planos para eliminá-lo num determinado prazo. Não basta dizer que temos recursos escassos, é preciso criar órgãos de planejamento, de descentralização, que permitam resolver os principais problemas educacionais brasileiros. V. Ex. ${ }^{\text {a }}$, melhor do que ninguém, sabe o que está por traz disso (IBIDEM, p. 447).
\end{abstract}

Rebatendo ao deputado, o ministro afirmou que o Estado tem que atuar com as entidades comunitárias, embora, prioritariamente, isso deva se processar com as instituições públicas. Sobre tal situação, o constituinte Louremberg Nunes colocou sua posição, na qual a delimitação da gratuidade do ensino de $2^{\circ}$ e $3^{\circ}$ graus deveria se dar de acordo com o filtro econômico. Acreditava, pois, que tal situação deveria ser definida em legislação própria, e não na CF. Ainda no transcurso deste debate, o constituinte Bezerra de Melo colocou sua posição a respeito do uso público das verbas públicas, que não deveria se esgotar nas escolas públicas, mas sim, no respeito à liberdade. Observou-se mais uma vez o uso da palavra liberdade para justificar o uso de recursos públicos por instituições privadas.

A $26^{\mathrm{a}}$ reunião objetivou a apresentação do texto geral entregue pelo relator, após a incorporação das últimas contribuições. Foi destacado que outra versão ainda seria elaborada, com um conteúdo mais completo. O constituinte Florestan Fernandes teceu uma crítica ao documento que naquele momento tinha em mãos, informando que

[...] infelizmente o relatório é extremamente pobre e pouco dignificante para a nossa Subcomissão. Com todo o respeito que tenho por V. Ex. ${ }^{\text {a }}$, fiquei extremamente decepcionado com o conjunto da realização, e acho que mesmo essa parte geral exigia um tratamento de uma qualidade diferente (CÂMARA, 2017b, p.460). 
O relator passou a apresentar a proposta de encaminhamento dos trabalhos finais da subcomissão, destacando que necessitaria alterar algumas datas antes previstas, para que pudesse proceder a distribuição dos avulsos para discussão e votação do texto. Todavia, considerou que apesar das alterações internas à dinâmica de funcionamento da subcomissão, os prazos não iriam interferir na entrega do texto à ANC. O constituinte Octávio Elísio ponderou no sentido de observar as considerações do relator, mas buscando manter o compromisso da subcomissão com a entrega de um trabalho coerente, que absorvesse, de fato, as principais discussões propostas naquele espaço, mesmo que tal prática custasse um pequeno alargamento no prazo, que, inclusive, estava previsto pela mesa diretora.

Cabe ainda destacar a justificativa do relator que, ao responder à crítica do deputado Florestan Fernandes, informou que incorporou ao relatório, sob a forma de anexo, três contribuições na íntegra, de autoria de três constituintes, a saber: do próprio Florestan, do Octávio Elísio e de Sólon Borges dos Reis, por considerá-las completas e dignas de uma melhor leitura e discussão pelos membros da subcomissão.

Ainda nesta sessão, o presidente informou que após o início dos trabalhos da subcomissão recebeu um ofício do presidente da ANC remetendo mais nomes para compor o grupo, alterando de 21 para 25 o número de membros. Passaram a compor a subcomissão 8a os seguintes constituintes: França Teixeira e Flávio Palmier da Veiga, ambos do PMDB. E também Agripino Lima e Dionísio Hage, pelo PFL. Desta forma, foram feitas algumas considerações, sobretudo por Octávio Elísio, de que Ulysses Guimarães deveria ser questionado sobre as indicações, sobretudo porque os mesmos não participaram de nenhuma sessão até aquele momento, desconhecendo o conteúdo dos debates e não tendo, portanto, esclarecimento suficiente para votar.

Passou-se, pois, à leitura do anteprojeto pelo relator João Calmon. Após a discussão sobre a censura e sobre a tradição constitucional da vinculação de recursos da educação, o presidente falou sobre o fato do educador Paulo Freire ter se voluntariado para participar de uma sessão de trabalhos, e que o mesmo o teria convidado para ser ouvido pela subcomissão no dia dezoito de maio, o que foi acatado pelos membros presentes.

No registro das atas, passamos da $26^{\mathrm{a}}$ sessão, que acabamos de apresentar, realizada no dia 14/05/1987, para a $30^{a}$ sessão especial, realizada em 18/05/1987. Desta forma, não foi possível entender a razão de quatro sessões não terem seus registros reproduzidos, já que a sequência vai seguir, até chegar à $35^{\text {a }}$ reunião - a última realizada pela subcomissão $8 \mathrm{a}$ - na qual o presidente e relator da comissão 8 receberam o texto final, fruto dos trabalhos 
realizados até aquela data, ou seja, o dia vinte e cinco de maio. Desta forma, ao iniciar a sessão especial, Hermes Zaneti explicou aos convidados - Moacir Gadotti e Paulo Freire, a dinâmica em curso, que vale destacar:

Esta subcomissão recebeu aqui em oito reuniões plenárias, que é o número máximo que o Regimento permite, quase cem entidades a prestarem os seus depoimentos, desde a cultura e a educação indigenista, passando pelas entidades católicas e por um número expressivo de entidades que defendem o ensino público. $\mathrm{Na}$ área do Esporte, na área da Cultura e na área da Educação, todas as entidades mais expressivas aqui compareceram trazendo a sua contribuição. Ouvimos também o Sr. Ministro da Educação e o Sr. Ministro da Cultura. Terminou agora o prazo que essas entidades poderiam ser ouvidas. E o Senador João Calmon, que é o nosso relator, já apresentou o seu relatório e o seu anteprojeto. Tivemos a partir de ontem e até quinta-feira desta semana, o período para a apresentação das emendas ao anteprojeto que os nossos convidados estão recebendo neste momento. Sexta-feira, o Senador João Calmon, nosso relator, dará o parecer das emendas que forem apresentadas. Sábado e domingo, estaremos trabalhando no debate e votação. E, na segunda-feira, estaremos entregando já, no final da tarde, o Relatório e o anteprojeto, resultantes do trabalho desta subcomissão à Comissão de Sistematização ${ }^{51}$, cujo Relator-Geral é o eminente Constituinte Artur da Távola, que está presente nesta tarde também. A partir daí, haverá o trabalho em cada uma das oito Comissões Temáticas. Ao término desse trabalho, será conduzido à Comissão de Sistematização que elaborará, o que podemos chamar de anteprojeto da Constituição. Publicado este anteprojeto, haverá um novo prazo para emendas em plenário. E final, aquele processo normal de discussão, votação, emendas em plenário de onde haverá de resultar - esperamos até meados do mês de dezembro deste ano - a nova Constituição do País (IDEM, p. 483).

Pelo trecho em destaque, subentende-se que no dia anterior teve início o processo de elaboração de emendas, ou seja, no dia 17. Ao observarmos o calendário do ano de 1987, vimos que o dia 15/05/1987 foi uma sexta-feira. Não sabemos, pois, se houve ou não sessões entre esses dias, que justifiquem o "salto" nas datas apresentadas nos documentos que analisamos.

Passemos à sessão que contou com a presença de Paulo Freire. Após longas e muitas deferências de constituintes, Moacir Gadotti foi o primeiro a ter seu tempo para exposição. Nele, aproveitou para discorrer sobre a inovação que foi receber segmentos da sociedade para serem ouvidos na subcomissão, além de ter afirmado que algumas de suas sugestões estariam contempladas no texto apresentado pela ANPEd. Desta forma, corroborou a defesa da escola pública em todos os níveis, para todos, com prioridade para os que nela estudam desde os anos iniciais. Outro ponto abordado foi a questão dos conselhos populares

Acreditamos que há um erro do constituinte ao expor o trâmite. 
e participativos, capazes de garantir a gestão democrática da escola. Por fim, abordou a questão da alfabetização, transitando entre a ideia da obrigatoriedade, suplência e direito, visto que acreditava que a educação não deveria limitar-se à idade obrigatória.

O educador Paulo Freire iniciou sua participação retomando um pouco de seu trabalho com a alfabetização, no período da ditadura, o período do exílio, e chegando a reafirmar algumas posições suas amplamente difundidas. Definiu que a "educação não é a alavanca da transformação social, mas é fundamental a essa transformação" (IBIDEM, p. 488), ao abordar a negação do direito a ela, que se processa diariamente, toda vez que uma criança ou jovem é alijado da possibilidade de frequentar a escola. Desta forma, afirmou que

[...] esse não é um fenômeno a ser resolvido pela pedagogia, mas pela política. E a decisão política é exatamente a decisão que faz a pedagogia entrar. E educação não decide. Como ato político ela precisa de um ato político que decida o seu uso, o seu emprego. Evidentemente que podemos fazer na sociedade civil milhares de coisas; eu faço todo mundo faz, você deu uma contribuição enorme. Agora, o que é preciso é fiscalizar o uso desse negócio que você fez, para saber como é que estão chegando essas verbas (CÂMARA, 2017b, p. 488).

Devido ao horário, a sessão foi encerrada não havendo debates. No dia seguinte, a $31^{\mathrm{a}}$ reunião teve início, com o objetivo de discutir e votar o anteprojeto. O relator iniciou sua argumentação, apresentando um histórico sobre a vinculação do percentual mínimo dos orçamentos públicos a serem aplicados na educação. Voltou à Constituição de 1934, que, pela primeira vez estabeleceu tal proposta; apresentou a CF de 1967, que a retirou, e abordou as tentativas realizadas para que a vinculação voltasse ao cenário legal brasileiro, apenas se efetivando no ano de 1983. Cabe ressaltar que várias estratégias foram tentadas para que a votação da conhecida emenda Calmon tivesse espaço no Congresso, pois, nas palavras do senador, havia "desinteresse da maioria dos representantes do povo em relação à aprovação de emendas em favor da educação" (IDEM, p. 490).

No que é pertinente à questão da possibilidade de aplicação de recursos públicos em entidades outras que não as públicas, o relator apresentou sua preocupação com o texto legal deixar de contemplar, por exemplo, as universidades confessionais e estas entrarem em "colapso". Desta forma, explicou que nunca antes houvera tal preocupação e que ele tentara, em seu anteprojeto, contemplar de forma mais rígida a preocupação de alguns constituintes. Cabe, pois, salientar todo o trecho em que o relator destaca a questão: 
Eu fiz estudos, em relação a Constituições anteriores, em 34 e 46 também não houve nenhuma objeção em relação a esse texto, manutenção e desenvolvimento do ensino. Na atual Constituinte que pode tudo, e inclusive reimplantar no Brasil a monarquia e acabar com o sistema federativo, vários Deputados e Senadores propuseram uma alteração desse texto que vem desde 1934, inclusive na época em que alguns dos mais notáveis educadores da História desse País, como Anísio Teixeira, Azevedo e tantos outros, não fizeram nenhuma objeção em relação ao texto que foi aprovado em 1934 e 46. Na Assembléia Nacional Constituinte atual, várias propostas têm o objetivo de acrescentar, depois de "manutenção e desenvolvimento do ensino..." o adjetivo, "público", e a explicação é óbvia, os parlamentares autores dessas propostas temem que se não houver o acréscimo desse adjetivo, "público", que os recursos para a educação vão sofrer um grave desfalque, um desvio deplorável, e esta é a explicação que estou procurando dar aos nobres colegas desta Assembléia Nacional Constituinte. Há um artigo, no meu anteprojeto, que estabelece condições muito rígidas para que qualquer entidade, fora do setor público, receba qualquer ajuda financeira do Governo nos três níveis, Federal, Estadual e Municipal. Nas Constituições anteriores não foi tomada esta precaução. Na Assembléia Nacional Constituinte, na hipótese de ser aprovada a proposta de minha autoria, o recebimento de dinheiro público por entidades não pertencentes ao setor público se torna extremamente difícil. $\mathrm{O}$ art. 15 estabelece o princípio: Art. 15. A lei regulará a transferência de recursos públicos a instituições educacionais privadas que prestem relevantes serviços públicos à comunidade. Parágrafo único: As instituições a que se refere o caput deste artigo: a) serão organizadas por comunidades e grupos de caráter social, religioso e cultural; b) comprovarão a não distribuição de lucros, a replicação de eventuais excedentes em educação e apresentarão contabilidade aberta e verificável pela comunidade e pelo Poder Público (IBIDEM, p. 490).

Outra preocupação exposta pelo relator para a não aprovação da exclusividade da aplicação de recursos públicos em instituições públicas foi a possibilidade de aumento do número de matrículas nas universidades públicas, o que ocasionaria um deslocamento dos recursos da educação básica para o ensino superior e, assim sendo, inviabilizaria a garantia do direito à educação neste nível de ensino. Destacamos, pois, que muitas das entidades ouvidas solicitaram a garantia do direito à educação pública, gratuita e laica em todos os níveis de ensino, o que já anularia a razão da preocupação do relator.

Sobre estas questões, o constituinte Sólon Borges dos Reis fez uma colocação que abordou exatamente as preocupações expostas pelo relator, colocando em xeque seus argumentos com as próprias possibilidades apresentadas no texto legal:

Quanto à destinação de recursos, que foi objeto do relatório do Relator, há dois temores. Se houver exclusividade de recursos públicos para a escola pública, ele teme duas coisas. Primeiro, o colapso de algumas escolas, talvez as confessionais (?), não as empresariais. Porque ocorreria esse colapso? Elas não cobram as mensalidades, as matrículas, as anuidades, como as demais? E se elas não visam 
lucros, então elas são muito mal administradas. Elas pagam mais aos professores do que as escolas não-confessionais (?) ou comunitárias? Eu não entendo bem a razão desse colapso. O outro temor do Constituinte João Calmon é um argumento favorável à tese do dinheiro público para a escola pública, porque ele teme que 50 ou 60 mil remanescentes das escolas que não tiverem auxílio oficial, são as escolas confessionais, passarão para as universidades estatais. Isso não é um bem? Mas, não haverá recursos. Como não haverá recursos? E aqueles recursos que eram destinados a essas escolas? Para onde vão? E os 5\% a mais que estão previstos na proposta do Relator? Não são $13 \%$. São $5 \%$ a mais. São $18 \%$. Temos que partir para um regime que gaste mais, mas que também gaste melhor (CÂMARA, 2017b, p. 492).

Seguiu sua argumentação, fazendo a defesa da liberdade do ensino particular, entendendo esta como a não regulamentação do Estado das regras que devem ser operadas pelo mercado, "fruto do entendimento entre a clientela escolar e a manutenção da escola" (IDEM, p. 492), já que a educação privada se trata de uma forma de serviço.

O debate foi retomado após a leitura de um ofício resposta do presidente Ulysses Guimarães ao presidente Hermes Zaneti, quanto a uma consulta sobre a possibilidade de rejeição do texto integral proposto pelo relator. Assim sendo, em não havendo consenso sobre o relatório apresentado, novo documento deveria ser produzido para votação na subcomissão. Ao retornar aos debates, Florestan Fernandes destacou a fala do constituinte Sólon de Borges quanto as habilidades do relator João Calmon e fez uma observação ácida, quando abordou o critério da escolha de presidentes e relatores das comissões e subcomissões:

A escolha democrática foi feita segundo critérios de democracia autoritária, mas ainda assim, teria sido possível eliminar o nome de um Relator que qualificássemos como não estando à altura, pelo fato de endossarmos a indicação, isso significa que nós reconhecemos essa competência e estávamos dispostos a ver no Constituinte João Calmon uma pessoa que poderia ser porta-voz de nossas esperanças na elaboração desta Constituição (IBIDEM, p. 493).

Cabe também destacar a colocação do deputado do PT com relação a destinação dos recursos, tema que movimentou todo o trabalho na subcomissão, que voltaremos a problematizar no capítulo seguinte. Destacamos que esta discussão não tomou assento somente na ANC de 1987, mas foi objeto de debates que muito contribuíram para a demora na discussão para a elaboração da primeira LDBEN, que, como vimos no capítulo anterior, teve início com a aprovação da CF de 1946 e somente foi aprovada em 1961. Florestan Fernandes, que já protagonizara movimentos contrários ao uso dos recursos públicos para 
manutenção de escolas privadas - tanto as não-confessionais quanto as confessionais, novamente trouxe algumas considerações ao debate, neste momento não apenas como sociólogo, mas como constituinte:

Estou envolvido numa cruzada diferente, de que os recursos públicos sejam investidos, não prioritariamente, mas exclusivamente no sistema público de ensino e isso porque, de um lado, a empresa e ensino enquanto operação industrial e mercantil, como se qualificaria no passado, ela própria deve prover os lucros da sua dinâmica interna e é lamentável, que no Brasil, o Ministério da Educação tenha intervido, de uma forma reiterada, no sentido de impedir que essa dinâmica funcione adequadamente. O que se deve recriminar no Ministério da Educação, em primeiro lugar, não é de que ele abriu a bolsa aqui e ali para a escola privada, que chamamos mercantilizada; é o fato de que o Ministério da Educação não foi sensível à questão de que a educação escolarizada, se ela é colocada como mercadoria, ela é cara, é cara no sistema público de ensino e é igualmente cara no sistema particular de ensino, se for uma boa educação. Então, o Ministério da Educação não deveria fazer gentileza com o chapéu dos outros; quem escolhe uma escola privada para seus filhos, uma escola-pagamento, está sujeito a pagar o valor daquele ensino [...] O Ministério da Educação jamais deveria ter feito isso; se ele reconhece a liberdade de existência do ensino privado, ele deve reconhecer que o ensino privado tem que seguir critérios próprios e determinação do seu valor intrínseco. De onde a escola vai retirar os recursos? E é preciso educar professores, estudantes, funcionários, todos, para entenderem isso [...] Com referência ao ensino confessional o problema é ainda mais complexo, porque aí nós tivemos pessoas que saíram - aí, a sua expressão "campo de batalha" - ao campo de batalha para dizer que a democracia dá alguém que pertença a uma comunidade religiosa o direito de pleitear recursos públicos para aquele tipo de ensino, porque existiria, então a escola pública não oficial, e o cidadão que freqüentasse uma escola particular confessional, tivesse de pagar anuidade, taxa escolar, que ele estaria sujeito a um duplo pagamento, porque ele estaria pagando Imposto de Renda e estaria pagando o ensino. Ora, quando nós estamos pagando o Imposto de Renda ao Estado nós não estamos comprando mercadorias, nós estamos cumprindo um dever cívico (CÂMARA, 2017b, p. 493-494).

Desta forma, defendeu que o uso dos recursos públicos exclusivamente na educação pública seria uma questão de princípios. Citou ainda o documento Por uma nova ordem constitucional, da CNBB, afirmando que esta sempre colocou sua clara opção pelos pobres, mas que apresentou alguns problemas na redação da parte destinada à educação, posto que acreditava que a expansão da escola pública pressuporia a morte da escola privada. Neste sentido, existia uma clara divergência no entendimento do que viria a ser liberdade de ensino: enquanto para a CNBB esta se referia à opção de escolha dos pais, para o constituinte e muitos outros defensores do ensino público, esta seria a garantia de uma vaga para cada criança na escola pública, gratuita e laica. Por fim, explicitou que o anteprojeto não contemplou a necessidade de elaboração do que chamou de um Plano Nacional de 
Educação Plurianual e de uma nova LDBEN, que deveria ser aprovada em um ano, a partir da publicação da CF.

A reunião foi finalizada com a fala do relator, na qual afirmou que a hipocrisia recorrente nas legislações brasileiras deveria ser superada pela nova Constituição, de maneira que deixasse de aparecer no texto a obrigatoriedade do ensino público e gratuito apenas no $1^{\circ}$ grau e se passasse a explicitar, de fato, quais níveis atingiriam a gratuidade e a obrigatoriedade do ensino. Foram anexados à ata desta sessão documentos que buscavam contribuir para o debate, a partir do anteprojeto apresentado, a saber: texto do constituinte Átila Lira, no qual apresentava a coexistência de instituições públicas e privadas e a possibilidade de uso de recursos públicos pelas entidades filantrópicas; texto enviado pela ANPEd, no qual a entidade mostrava a posição do Fórum com relação ao texto, apresentando satisfação em alguns pontos e algumas ressalvas, especificamente no que tange a omissão da gratuidade para além da escolaridade obrigatória. Ressaltou ainda que apenas a AEC, o CRUB e o CNEG defendiam a aplicação de recursos em entidades filantrópicas. Outro ponto que mereceu destaque foi a questão da laicidade, que segundo o documento, não deveria ser confundida com ateísmo.

Pinheiro (2005, p. 270), ao discutir o anteprojeto apresentado pelo relator, afirmou que o mesmo incorporou predominantemente as reivindicações dos setores privatistas, o que redundou na manifestação das instituições que apresentamos no parágrafo anterior. As críticas se baseavam na ideia que o documento deveria retratar as posições majoritárias na subcomissão, o que não aconteceu. Assim sendo, ao apresentar um texto substitutivo, João Calmon buscou incorporar algumas reivindicações do FNDEP, inclusive a exclusividade da aplicação de recursos públicos no ensino público, mesmo mantendo as escolas confessionais e filantrópicas.

A sessão seguinte foi a de número trinta e dois ${ }^{52}$, e se iniciou com a discussão do relatório. Bezerra de Melo se opôs à proposta dos constituintes Florestan Fernandes e Pedro Canedo, que se dispuseram a passar seu tempo regimental para o Professor Juan Tedesco, diretor do escritório da UNESCO, que estava presente naquela ocasião. Assim sendo, iniciou sua fala a partir do debate da destinação de recursos, tema que não havia sido esgotado no dia anterior. Desta forma, disse que acreditava ser impossível desconsiderar o relevante papel de instituições privadas, sobretudo as filantrópicas, dentre elas a PUC, e que a extinção da subvenção governamental viria a inviabilizar o funcionamento de tais instituições, sobretudo no que se refere à pesquisa e extensão universitária. 
Após a exposição do constituinte, passou-se a palavra ao representante da UNESCO. Em linhas bem gerais, sua fala se dedicou à defesa de três pontos básicos: a necessidade de erradicação do analfabetismo; o tempo da escolaridade obrigatória; e a qualidade do ensino. Tadeu França e Aécio de Borba, que presidia a sessão, debateram sobre a carreira docente e aposentadoria, assunto sobre o qual também falou Florestan Fernandes. Logo após, alguns constituintes passaram a discutir a justiça desportiva, que era objeto da subcomissão, mas não de nosso estudo. Por fim, o constituinte Aldo Arantes, passou à leitura do documento enviado pela UNE, que apresentava os princípios já defendidos pelo FNDEP, em resposta ao anteprojeto. Foi relembrado aos participantes que o dia seguinte seria o prazo final para entrega das emendas e que a próxima sessão seria após dois dias, data na qual o relator apresentaria as mudanças feitas no anteprojeto, e se passaria à discussão e votação.

A $33^{a}$ sessão teve início com um debate sobre a inversão da ordem de leitura do anteprojeto, visto que os constituintes ainda não haviam recebido um exemplar do mesmo para avaliação e apresentação de emendas. Como houve discordância no plenário, o presidente optou por suspender a sessão até que o mesmo chegasse às mãos dos deputados e senadores. Desta forma, vinte e cinco minutos depois, o relator passou à leitura do anteprojeto. Levou-se um tempo para a explicação da dinâmica da votação, que abarcava a aprovação do texto substitutivo, o levantamento de destaques e a votação das emendas. Ressaltou-se que toda vez que uma matéria fosse objeto de destaque, já não seria mais votada. O processo foi resumido pelo presidente da seguinte forma:

Ao iniciar-se a sessão de votação, esta Presidência declarará que estão sobre a mesa requerimentos para destaque e votação, separado de tais artigos - correto? Deferido o pedido de destaque, vamos iniciar o processo de votação. Admitamos que V. Ex. ${ }^{a}$ fez um pedido para votar em separado, cujo requerimento do destaque já foi deferido ao início da sessão - o art. $3^{\circ}$ Então, se V. Ex. ${ }^{a}$ quer votar em separado o art. $3^{\circ}$, para aprovar a Emenda $\mathrm{n}^{\mathrm{o}} 137$, nós votaremos de uma parte a Emenda ${ }^{\circ} 137$, que V. Ex. ${ }^{a}$ propõe a votação em separado. Se aprovada a Emenda $n^{\circ} 137$, que V. Ex. a propôs, na votação em separado, cairá o texto do substitutivo e em seu lugar entrará a matéria que foi objeto de votação em separado (IDEM, p. 516).

O constituinte Octávio Elísio disse sentir falta de um parecer do relator justificando os motivos que o levaram a aceitar uma ou outra emenda, de maneira a tornar o processo mais transparente. Fez uma análise e disse que não houve mudanças significativas em relação ao texto anterior, citando, inclusive, o exemplo da destinação dos recursos. Citou ainda alguns pontos em que a mudança foi mais significativa. Propôs a aprovação do texto, 
mas devendo ele ser melhor estudado na etapa posterior, ou seja, pela comissão temática. Não nos deteremos agora nestes pontos, pois serão analisados no próximo capítulo.

A sessão $34^{\mathrm{a}}$ aconteceu no mesmo dia vinte e três de maio, à tarde. Concordamos com Pinheiro (2005, p. 270), quando afirmou que nesta data a subcomissão se encontrava tensa, com opiniões divididas e com os constituintes muito confiantes nas bases sociais que os apoiavam e que estavam presentes nas galerias, pressionando os demais parlamentares em seus votos. Diante de tal cenário, o presidente deu início à mesma, informando aos constituintes que o quórum para votação continuaria sendo de onze constituintes, pois até aquele momento não tinha obtido resposta do presidente da ANC sobre a inclusão de novos membros. É importante observar que esta sessão foi atravessada pela leitura dos destaques, a apresentação de elementos a favor e contra os mesmos. Como afirmamos anteriormente, não nos deteremos nas observações dos parlamentares neste momento, já que estas serão objeto de análise futuramente.

Os parlamentares que mais se destacaram nesta sessão foram Florestan Fernandes (PT), Sólon Borges dos Reis (PMDB), Louremberg Nunes (PMDB), Eliel Rodrigues (PMDB) - que fez uma proposta de inserção do ensino da teoria criacionista em todos os níveis escolares - Pedro Canedo (PFL), João de Deus (PDT), Antônio de Jesus (PMDB), João Calmon (PMDB) e Octávio Elísio (PMDB). Destaca-se que o tema que mereceu maior tempo de debate foi, como de costume em todas as outras sessões, a destinação dos recursos públicos. Outras discussões foram a questão da descentralização do ensino; a extensão da obrigatoriedade do ensino para além do ensino fundamental; o mandato de injunção; a alfabetização das comunidades indígenas; o ensino religioso; o plano de carreira; a responsabilidade dos entes federados e os sistemas de ensino; as universidades; a vinculação constitucional dos recursos para a educação. Por fim, foram abordados os temas pertinentes à cultura e ao desporto. Ressaltamos que esta reunião foi encerrada às $23 \mathrm{~h} 25 \mathrm{~min}$, dada a complexidade dos temas e das posições adotadas.

A última sessão aconteceu no dia 25/05/1987, e contou com a presença do presidente e do relator da comissão 8, os parlamentares Marcondes Gadelha (PFL) e Artur da Távola (PMDB), respectivamente. Destaca-se um trecho da fala do presidente da comissão, ao abordar a relevância do papel ocupado pelas subcomissões na elaboração do texto da CF: "A Subcomissão é entendida como um contato preliminar e original com a sociedade, um contato mais direto, e supõe-se que o trabalho da Subcomissão retrata o sentimento geral do povo brasileiro" (IBIDEM, p. 562). 
Cunha (2009, p. 437) analisa o texto aprovado nesta etapa como "uma expressiva vitória das forças progressistas no campo educacional". Desta forma, o inovador mandato de injunção foi acatado pelo relator João Calmon, de forma a criar um instrumento jurídico para obrigar o Estado a garantir o direito à educação, ao mesmo tempo em que outros temas do campo conservador se mantiveram, como, por exemplo, o ensino religioso obrigatório ao Estado e facultativo aos alunos; e a possibilidade de as instituições comunitárias e filantrópicas acessarem os recursos públicos destinados à educação. Pinheiro ressaltou a influência que a participação da sociedade civil teve no voto dos constituintes com posição mais ao centro, que acabaram influenciados pelas entidades mais representativas. Arriscamo-nos a dizer que um texto constitucional mais alinhado às posições progressistas foi encaminhado à comissão 8 , mas não encontrou nela o mesmo campo profícuo para se desenvolver.

Com inspiração no diagrama constante no livro A distinção, de Pierre Bourdieu (2007, p. 423), arriscaremos fazer um esquema para distribuir no campo estudado as disposições dos constituintes no que tange à defesa do direito à educação no texto da Constituição que começou a ser elaborado. Enquanto naquela obra o esquema proposto se baseava na competência estética de pessoas de diferentes grupos sociais para afirmar a distinção de seus gostos a partir de sua origem de classe, aqui nos pautaremos na proximidade dos constituintes com posturas e concepções mais ou menos progressistas ou conservadoras, no que se refere ao direito à educação. Concordamos com Souza (2012, p. 19), quando ele afirma que a sociologia disposicionalista de Bourdieu é "[...] a tentativa mais consequente e sofisticada de perceber os fios invisíveis que constroem a trama de simpatias e preconceitos que pré-decidem, a partir do pertencimento de classe, toda luta social por todo tipo de bem ou recurso escasso, seja ele material ou ideal".

Assim sendo, de uma forma muito rudimentar, utilizamos a divisão esquerda e direita para representar as diferenças de posições adotadas por cada constituinte, como progressistas ou conservadoras, respectivamente. Para melhor exemplificar o que entendemos por tais termos, resgatamos uma discussão contemporânea do livro "Direita e esquerda. Razões e significados de uma distinção política”, de Bobbio (1995, p.33-34):

\footnotetext{
"Esquerda" e "direita" indicam programas contrapostos com relação a diversos problemas cuja solução pertence habitualmente à ação política, contrastes não só de ideias, mas de interesses e de valorações [valutazions] a respeito da direção a ser seguida pela sociedade, contrastes que existem em toda sociedade e que não vejo como possam simplesmente desaparecer [...] Recentemente chegou-se mesmo a afirmar que [...] a velha dupla poderia ser substituída por outra: progressistasconservadores. Mas houve também quem, de modo ainda mais radical, rejeitou toda e qualquer visão dicotômica [...] ditas em politiquês, das quais devemos nos
} 
libertar para formarmos, de agora em diante, novas agregações, com base não em posições, mas em problemas.

Ao buscar romper com a discussão antitética oriunda da Revolução Francesa, em que coloca em polos opostos e estanques as duas posições, o autor pretende reestruturar os conceitos para além de sua tradução no plano ideológico, combinando-os com o novo espectro transversal da política, devido aos novos problemas colocados na atualidade. Desta forma, seria possível se pensar em várias posições intermediárias entre tais extremos, denotando a complexidade da análise das posições dos agentes estudados no campo da ANC. Posturas de extrema esquerda ou extrema direita, assim como posições mais centrais podem ser assumidas, dependendo do problema discutido em um determinado momento. É importante observar que dentro de um mesmo partido - como é o caso do PMDB e do PFL, existem posições bastante divergentes, como ficou muito claro nos debates reconstituídos até aqui.

QUADRO I - Espaço da Subcomissão 8a

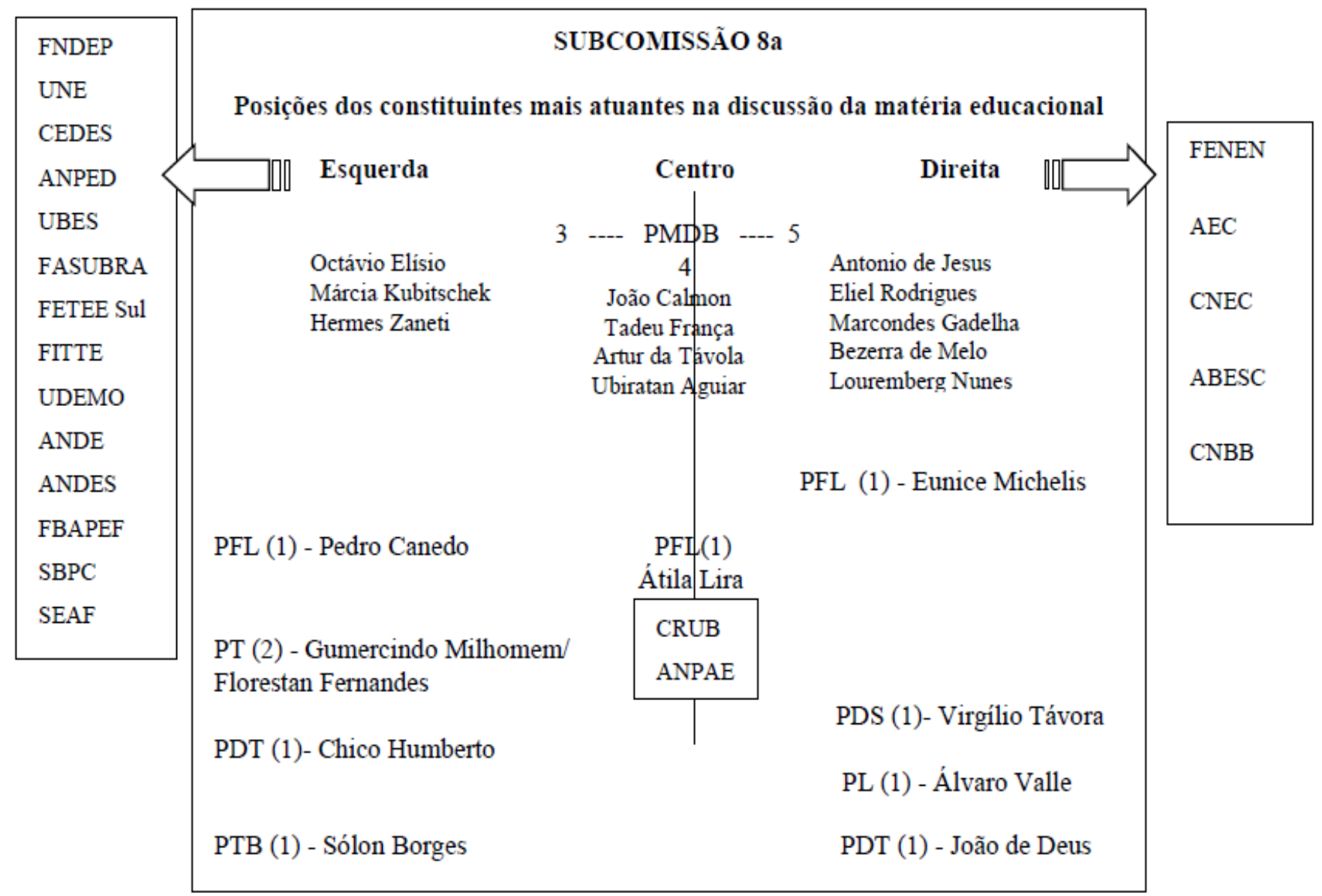




\subsection{O TRABALHO NA COMISSÃO 8 - AGENTES, PARTIDOS, ASPECTOS GERAIS E DA EDUCAÇÃO}

Os encontros da Comissão da Família, da Educação, Cultura e Esportes, da Ciência e Tecnologia e da Comunicação - a comissão 8 - ou vulgarmente conhecida como comissão do fim do mundo ${ }^{53}$, reiniciou seus trabalhos no dia 25 de maio de 1987, imediatamente após a entrega do documento das subcomissões a ela subordinadas: subcomissão 8a, da Educação, Cultura e Esportes; subcomissão 8b, da Ciência e Tecnologia e da Comunicação; subcomissão 8c, da Família, do Menor e do Idoso. Tal dinâmica já foi apresentada no início deste capítulo.

Lembramos quea primeira sessão ocorreuantes do início do trabalho nas subcomissões, ainda no dia primeiro de abril de 1987, e que nela, além da instalação dos trabalhos, presidida por Florestan Fernandes, deu-se a eleição dos candidatos pré-escolhidos, como salientou o próprio constituinte, na ocasião, respondendo a Hermes Zaneti, que questionara se havia alguma indicação de parlamentares para ocupar os cargos de presidente e relator da comissão: "circulam rumores, que considero antidemocrático, de que os candidatos já são pré-escolhidos" (CÂMARA, 2017c, p. 1). Na sequência, o constituinte Antonio Brito (um dos vice-líderes do PMDB), explicou qual teria sido o encaminhamento adotado para a escolha dos mesmos, a saber:

Inicialmente, Sr. Presidente, saúdo os companheiros de todos os Partidos aqui, presentes, no momento em que se instala uma das Comissões que, pela abrangência, pela importância dos temas, haverá de ser claramente definidora do rumo que o País haverá de tomar e do tipo de Constituição que haveremos de construir e elaborar. Ao longo dos últimos dias, nesta Casa, estabeleceram-se negociações entre todos os Partidos, de modo a que, conforme praxe, de um lado, e especial necessidade de conveniência num momento constituinte, pudessem, todos os Partidos ter a participação necessária no trabalho constituinte. Estes acordos prosperaram ao longo dos últimos dois dias e permitiram que, pela unanimidade, todos os Partidos com assento na Assembléia Nacional Constituinte chegassem a um entendimento, e, baseados nas negociações havidas, nos critérios estabelecidos pelo Regimento, indicaram a participação de cada um nas Comissões que hoje se instalam. Em nome da Liderança do PMDB, e dando curso aos entendimentos havidos nesta Casa, comunico, Sr. Presidente, que foi elaborada uma chapa de entendimento entre todos os Partidos, prevendo como candidato desse entendimento de todos os partidos à Presidência o Senador Marcondes Gadelha, do PFL Para a $1^{\text {a }}$-VicePresidência, o companheiro Constituinte José Elias Murad [depois corrigiu o sobrenome para Moreira]; para a $2^{\text {a }}$-Vice-Presidência o companheiro Osvaldo Sobrinho (IDEM, p.1).

A comissão foi assim apelidada por congregar temas complexos e de difícil acordo entre os constituintes. 
Sobre os acordos para a indicação dos representantes desta comissão, o constituinte Mendes Ribeiro, também do PMDB, que desejava pleitear uma das vagas, teceu a seguinte crítica:

Sr. Presidente, sei que a essência da democracia pode até ser a negociação, mas a negociação que nasça no seio da Bancada. Eu votaria, com inenarrável prazer, na figura carismática da Constituinte Cristina Tavares. Eu votaria no Companheiro Artur da Távola, votaria no Companheiro Hermes Zaneti, votaria em qualquer um, votaria no Constituinte Marcondes Gadelha, com muita honra, se eu tivesse sido consultado, e se não tivesse sido posto como o foi para toda esta Comissão, o prato pronto (IBIDEM, p. 2).

Após os debates que se desencadearam pela situação colocada, passou-se à eleição. Para além da chapa de entendimento apresentada, Mendes Ribeiro apresentou seu nome à presidência, tendo recebido nove votos, contra cinquenta do indicado. Para $1^{\circ}$ vicepresidente, José Elias Moreira foi votado por 47 dos presentes, sendo que Artur da Távola obteve apenas um único voto. Somaram-se ainda 12 votos brancos. Para $2^{\circ}$ presidente não houve candidatos além de Osvaldo Sobrinho, que contou com 50 votos e 10 votos brancos. De posse do resultado, o presidente recém empossado designou Artur da Távola como relator, passando, em seguida, à divisão das subcomissões.

Foram realizadas vinte e quatro sessões, entre os dias 01/04/1987 e 14/06/1987, quando o prazo para o trabalho da comissão se esgotou sem a mesma ter elaborado um texto final, que representasse o consenso do grupo ali reunido. Antes de passarmos à dinâmica das reuniões, faremos um breve panorama dos agentes de destaque neste espaço, indicados para a presidência e relatoria, conforme descrito anteriormente.

Marcondes Iran Benevides Gadelha, membro da tradicional família Gadelha da cidade de Sousa, localizada no sertão paraibano, era médico e filho de deputado federal. Elegeu-se também deputado federal pela Paraíba, como seu pai, na legenda do Movimento Democrático Brasileiro, obtendo a maior votação de seu partido no estado. Ao final dos anos de 1970, após a reformulação dos partidos, migrou para o PMDB e, em 1982, para o PDS, partido de apoio ao regime militar. Segundo a biografia do constituinte no CPDOC (2017j), o senador votou contra a emenda Dante de Oliveira em 1984 e, com a disputa para as eleições indiretas internas ao partido, quando o mesmo optou pela indicação de Paulo Maluf, o PDS de dividiu e Gadelha migrou para a Frente Liberal - que mais tarde deu origem ao PFL - tendo, por conseguinte, apoiado Tancredo Neves. Votou ainda a favor do presidencialismo e pelos cinco anos de mandato do presidente José Sarney, tendo se tornado líder da bancada do PFL em 1988, oferecendo sustentação ao governo. 
Nascido em Poços de Caldas, o $1^{\circ}$ vice-presidente José Elias Moreira (CPDOC, 20171) era engenheiro agrônomo e iniciou sua vida política na ARENA. Após a extinção do bipartidarismo, filiou-se ao PDS, trocando a sigla para o PTB em 1986, quando concorreu à vaga de deputado federal, tornando-se constituinte. Sua eleição contou com amplo apoio da União Democrática Ruralista (UDR), da qual foi fundador, posto que além de empresário, era também fazendeiro e proprietário de um canal de televisão. Algumas de suas posições são significativas para a compreensão de sua atuação na ANC: votou contra a nacionalização do subsolo, a criação de um fundo de apoio à reforma agrária e à estatização do sistema financeiro. Por outro lado, foi favorável ao presidencialismo e aos cinco anos de mandato para Sarney.

Osvaldo Roberto Sobrinho (CPDOC, 2017m) nasceu em São Paulo. Formado economista, atuou como docente e delegado do MEC, assento para o qual foi indicado por Louremberg Nunes. Foi deputado estadual pela ARENA, em 1976, tendo migrado para o PP em 1980. Com a incorporação do PP ao Partido do Movimento Democrático Brasileiro, filiou-se a esta agremiação em 1981. Eleito deputado federal em 1986, votou a favor do presidencialismo, do mandato de 5 anos para José Sarney e foi contra a desapropriação da propriedade privada. Foi um dos membros do Centrão, tendo se filiado, ao final dos trabalhos constituintes, ao Partido Trabalhista Brasileiro (PTB).

O relator, Artur da Távola (CPDOC, 2017n), cujo nome civil era Paulo Alberto Moretzsohn Monteiro de Barros, nasceu no Rio de Janeiro em 1936. Bacharel em direito, elegeu-se deputado estadual constituinte no recém-criado estado da Guanabara, na legenda do Partido Trabalhista Nacional (PTN). Em 1962, obteve novo mandato de deputado estadual, ingressando então no PTB. Nesse período, marcou sua atuação parlamentar pela oposição ao governador Carlos Lacerda, da União Democrática Nacional. Com a emergência do golpe empresarial-militar, foi para o exílio, retornando ao Brasil apenas em 1968, quando passou a assinar as colunas no jornal Última Hora sob o pseudônimo de Artur da Távola. Em 1976 filou-se ao MDB, tendo migrado para o PMDB ao final dos anos de 1970. Nos anos de 1980 e 1981 foi primeiro vice-presidente da Associação Brasileira de Imprensa (ABI), sendo eleito deputado constituinte pelo PMDB, do qual se tornou vice-líder. Na Constituinte, defendeu alterações na legislação pertinente às concessões de canais de TV, por acreditar que estas deveriam deixar de ser uma prerrogativa exclusiva do poder executivo, passando a ser de responsabilidade de um conselho de comunicação, o que foi, porém, rejeitado pelos parlamentares do Centrão. Foi a favor do parlamentarismo 
e do mandato de 4 anos para o então presidente José Sarney. Por fim, cumpre destacar que era parte do grupo de constituintes que saíram do PMDB e formaram o PSDB, em 1988.

É pertinente também resgatar um pouco da história do constituinte Mendes Ribeiro, visto que o mesmo disputou a presidência da comissão, mesmo com a indicação de outro colega de partido. Jorge Alberto Mendes Ribeiro (CPDOC, 2017t), bacharel em ciências jurídicas, também jornalista e formado em filosofia, disputou sua primeira eleição em 1958, pela UDN. Em 1962, foi eleito vereador em Porto Alegre pelo Movimento Trabalhista Renovador, mandato ao qual renunciou com o início da ditadura. Esteve afastado da vida pública até 1985, atuando como professor e apresentando programas de rádio e televisão neste período. Nas eleições de 1986, já filiado ao PMDB, assumiu a vaga de deputado constituinte, votando contra o presidencialismo, o mandato de 5 anos para Sarney e a criação de um fundo de apoio à reforma agrária.

Procedimento semelhante ao realizado na análise da subcomissão 8 a foi aqui também adotado. Levantou-se os constituintes que mais participaram das discussões concernentes à matéria educacional, e deles buscamos alguns dados biográficos para sustentar algumas de nossas sínteses. Quarenta e três parlamentares ${ }^{54}$, contando com os que acima apresentamos, foram por nós destacados, sendo que destes, dezoito também participaram efetivamente da subcomissão que estudamos.

Voltemos, pois, à sessão do dia 25/05/1987. Nela foi deliberada a necessidade da comissão proceder a escuta de movimentos sociais ligados à educação, além de figuras ilustres do campo. Desta forma, foram sugeridos os nomes de Paulo Freire - que já se fizera presente na subcomissão -; Cristovam Buarque, Darcy Ribeiro e Laércio Moura. Antes, porém, o presidente deu início à sessão, abordando a importância do trabalho que se desenvolveria naquele espaço e também destacou a ausência do texto oriundo da subcomissão 8a. Tal fato foi decorrência do descompasso entre os horários das sessões:

$54 \quad$ São eles: Florestan Fernandes (PT), Marcondes Gadelha (PFL), Artur da Távola (PMDB), Octávio Elísio (PMDB), Louremberg Nunes (PMDB), Virgílio Távora (PDS), João de Deus (PDT), Antonio de Jesus (PMDB), Eliel Rodrigues (PMDB), Álvaro Valle (PL), Ubiratan Aguiar (PMDB), Gumercindo Milhomem (PT), Eunice Micheles (PFL), Sólon Borges (PTB), Hermes Zaneti (PMDB), Antonio Brito (PMDB), José Elias (PTB), Osvaldo Sobrinho (PMDB), Mendes Ribeiro (PMDB), Mário Covas (PMDB), João Calmon ((PMDB), Nelson Aguiar (PMDB), Pedro Canedo (PFL), Nelson Seixas (PDT), Pompeu de Sousa (PMDB), Angelo Magalhães (PFL), Aécio de Borba (PDS), Abigail Feitosa (PMDB), Fausto Rocha (PFL), Olívio Dutra (PT), José Mendonça de Moraes (PMDB), Cristina Tavares (PMDB), Joaci Góes (PMDB), Arolde de Oliveira (PFL), Jorge Hage (PMDB), José Lourenço (PFL), Aldo Arantes (PCdoB), Carlos Alberto Caó (PDT), Eraldo Tinoco (PFL), Rita Furtado (PFL), Haroldo Lima (PCdoB), Brandão Monteiro (PDT) e Fábio Lucena (PMDB). 
enquanto a comissão se reuniu às 11 horas, a subcomissão teve sua $35^{\mathrm{a}}$ e última sessão iniciada às 15 horas.

Srs. Constituintes, iniciamos hoje uma nova etapa no processo de elaboração constitucional, etapa importante, de extraordinária significação, de revisão e integração dos textos oriundos das Subcomissões, culminando com a apresentação de uma proposta da Comissão Temática, na forma de um anteprojeto a ser redigido pelo eminente Relator e que será, afinal, encaminhado à Comissão de Sistematização. A partir deste momento, as três Subcomissões formam um só corpo deliberativo. Quero dar as boas-vindas a todos, saudar a participação e elogiar o trabalho até aqui desenvolvido a nível de Subcomissões. Recebemos os textos da Subcomissão da Ciência e Tecnologia, da Comunicação e da Subcomissão da Família, do Menor e do Idoso. Infelizmente, até este momento, não chegou até esta Presidência o texto da Subcomissão da Educação, Cultura e Esportes. Aquela Subcomissão tem, entretanto, o prazo até meia noite para proceder à entrega. Neste momento, seus membros devem estar reunidos, elaborando a redação final do anteprojeto daquela Subcomissão. Nada impede que iniciemos os nossos trabalhos com uma visão preliminar de prazos e com uma visão, também, da matéria substantiva que haveremos de discutir (CÂMARA, 2017c, p. 9).

Na sequência, o presidente esclareceu os presentes sobre a dinâmica desta nova fase da elaboração da constituinte, citando os prazos constantes no regimento interno, especificamente no parágrafo terceiro do artigo 14, que vale ser transcrito para um melhor entendimento do desafio que se apresentava aos constituintes:

As Comissões, a partir de sua constituição, terão prazo de 65 (sessenta e cinco) dias para concluir seu trabalho, findo os quais o encaminharão à Comissão de Sistematização que, por sua vez, deverá, dentro de 30 (trinta) dias, apresentar à Mesa o Projeto de Constituição (CÂMARA, 2017a, p.4).

Isso posto, caberia à comissão um prazo de vinte dias para a elaboração de um novo anteprojeto, visto que a subcomissão teve 45 dias para a execução de sua tarefa. Sabemos que as grandes divergências de opinião sobre pontos sensíveis das subcomissões seriam maximizadas neste momento, o que geraria muitos debates e poucos consensos. No caso da subcomissão da Ciência e Tecnologia, da Comunicação, um ponto nevrálgico seria a discussão da censura e da concessão de canais de televisão e rádio; já no caso do debate educacional, a destinação dos recursos públicos e a conceituação de liberdade de ensino seriam os principais eixos de disputa.

Com a apresentação dos prazos, o presidente também colocou a urgência em revisar os textos oriundos das subcomissões, de maneira a estipular um mesmo padrão de redação 
para todos, viabilizando uma coerência ao novo texto. Ao final da sessão o constituinte Hermes Zaneti prestou esclarecimentos quanto a entrega do relatório final da subcomissão 8a, conforme já antecipamos nas linhas acima.

Nos dois dias seguintes aconteceram a terceira e quarta sessões, com a apresentação das normas de funcionamento interno do trabalho desta etapa da ANC, tendo como base a resolução $\mathrm{n}^{\circ} 2$ de 1987, assim como a definição do calendário de funcionamento. Todo o tempo foi dedicado ao estudo e discussão da metodologia adotada para as demais reuniões, com a preocupação do presidente de que "a democraticidade não venha a prejudicar a fluidez dos trabalhos" (CÂMARA, 2017c, p.17). Ao final da $4^{\mathrm{a}}$ sessão, Hermes Zaneti solicitou que o presidente fizesse chegar às mãos dos constituintes uma proposta de calendário com sugestões de pessoas/instituições relevantes, que fossem auxiliar na realização do trabalho da comissão.

A quinta sessão teve início com a distribuição dos anteprojetos oriundos de cada uma das subcomissões subordinadas à comissão 8 , assim como informes a respeito do funcionamento das sessões ordinárias e extraordinárias. Cabe ressaltar que a apresentação de emendas aos anteprojetos se iniciou também nesta data, por meio do preenchimento de formulário próprio, no qual constavam informações da subcomissão de origem. Após alguns esclarecimentos e reclamações de situações vividas em outras subcomissões, passou-se à leitura do anteprojeto da subcomissão 8a. João Calmon, então relator daquela subcomissão, deu início à discussão do mesmo, destacando o artigo que introduzia a obrigatoriedade de destinação de $50 \%$ dos recursos públicos para a garantia do ensino fundamental para todos. Outros aspectos que julgou relevante destacar foram: a garantia da gratuidade em todos os níveis de ensino; a vinculação constitucional de receitas, que aumentou de 13 para 18\%, no que é concernente aos impostos federais; a criação de um Conselho Nacional de Desenvolvimento da Educação; e, obviamente, a questão da destinação exclusiva dos recursos públicos para a educação pública. Sobre este tópico, o relator João Calmon informou à comissão que houvera um impasse que foi deixado para ser resolvido neste espaço, como vemos no trecho seguinte:

Foi o texto do art. 15 quenão chegounem sequer a ser votado na Subcomissão, através de um acordo de cavalheiros, - que muito honra nossos colegas que integraram esta Subcomissão - tinha o seguinte texto: Art. 15. A lei regulará a transferência de recursos públicos a instituições educacionais privadas, que prestam relevantes serviços públicos. Parágrafo único: As instituições a que se refere o caput deste artigo: a) serão organizadas por comunidades e grupos de caráter social, religioso e cultural. b) comprovarão a não distribuição de lucros, a reaplicação de eventuais excedentes em educação, e apresentarão contabilidade aberta e verificável pela comunidade e pelo poder público. Através de um acordo de cavalheiros não foi 
nem sequer votado esse artigo, porque a Subcomissão, através desse acordo, que a nível de Comissão Temática ou de Comissão de Sistematização seria apresentado uma proposta introduzindo o artigo nas disposições transitórias, contemplando por algum tempo, não ainda especificados, 5, 10, ou 15 anos, estas poucas entidades, do setor privado [...] (IDEM, p. 44-15).

Diante as observações iniciais, os demais constituintes, que também participaram das sessões na subcomissão 8a, passaram à defesa de suas propostas. Louremberg Nunes, abordou a obrigatoriedade da destinação de $50 \%$ de todas as verbas da educação para o ensino obrigatório que, à época, era a faixa etária de 7 aos 14 anos. Defendeu que esse nível era o que deveria contar com mais recursos, e não o nível superior, como já acontecera, segundo sua argumentação, em algumas execuções orçamentárias. Defendeu também que a destinação de recursos públicos exclusivamente para instituições públicas acabaria com as escolas comunitárias e confessionais que não tivessem objetivo de lucro. Nesse ponto propõe uma distinção entre o que chamou de escolas mercantis e as escolas sem fins lucrativos. Octávio Elísio e Hermes Zaneti adotaram a mesma linha propositiva que Louremberg.

Artur da Távola levantou a questão do mandato de injunção e do que ele representa em termos jurídicos, como garantia da efetivação do direito à educação e do dever do Estado de educar, ou seja, "para obrigar ao organismo público que cumpra aquilo que a lei determina" (IBIDEM, p. 44). Sobre a vinculação orçamentária, foi defendida como única forma de melhoria das condições educacionais no Brasil, nas palavras do constituinte Louremberg Nunes.

Nelson Aguiar propôs uma análise do artigo primeiro, que trouxe a concepção de educação, vista como direito de todos e responsabilidade da família. Teceu uma crítica ao fato da família ser responsabilizada pela educação das crianças e adolescentes, quando muitas estariam em condição de abandono. Assim sendo, afirmou que o artigo precisava ser melhorado, para que pudesse abarcar a complexidade da situação brasileira, tal como a proposta seguinte:

Educação é direito do cidadão e dever do Estado, e é de todos e será promovida e incentivada por todos os meios, com a colaboração da família e da comunidade, visando ao pleno desenvolvimento da pessoa e ao compromisso do ensino, com o princípio da liberdade, acrescento, da igualdade, da democracia, da justiça e do bem comum (IBIDEM, p. 45). 
Louremberg Nunes voltou a falar sobre o mandato de injunção para a garantia do acesso à educação, assim como dos dois princípios fundamentais à convivência humana: igualdade e justiça. O parlamentar João de Deus, após parabenizar o relator da subcomissão, teceu uma crítica ao texto pertinente à cultura, defendendo a necessidade da existência da censura. Octávio Elísio destacou alguns pontos que considerou fortes no anteprojeto, tais como a necessidade de valorização do magistério; a garantia da continuidade da obrigação do Estado com o ensino médio; a liberdade da atuação da iniciativa privada no campo educacional, porém, sem verbas públicas; o ensino universitário; a existência de sistemas de ensino; e a necessidade de elaboração de uma nova LDBEN no período de até dez meses - o que não ocorreu, haja visto que a CF foi promulgada em 1988 e a nova lei da educação apenas em 1996.

A $6^{\text {a }}$ reunião ordinária aconteceu no final da tarde do dia 18 de maio de 1987, destinando-se à discussão do anteprojeto da subcomissão 8a, como na anterior. Discutiuse, basicamente, as questões do ingresso no magistério; o salário-educação e a garantia do direito à cultura. Sobre as comunicações, houve um debate sobre a contribuição que a fala do ministro das Comunicações - à época, Antonio Carlos Magalhães - poderia ou não trazer à comissão. Mesmo, não sendo o escopo de nossa análise, esse debate é relevante, tendo em vista que esta personalidade foi citada muitas vezes no início do capítulo, como um dos articuladores do lobby do presidente Sarney na Constituinte, para conseguir aprovar os cinco anos de mandato por meio da distribuição de concessões de canais de rádio e televisão aos deputados e senadores.

A sessão do dia seguinte teve por objetivo a discussão do relatório da subcomissão da Ciência e Tecnologia e da Comunicação, que não iremos detalhar. A do dia primeiro de junho, executada em caráter extraordinário, dedicou-se à leitura e análise do relatório da subcomissão 8c, que dispunha sobre a família, o menor e o idoso. Destacou-se que houve uma participação expressiva da população, que enviou 12.500 sugestões, além da realização de oito sessões de debates, que auxiliaram na definição do conceito de família, e trouxeram uma preocupação com a criança e o idoso, que nunca fora apresentada. Neste sentido, Nelson Aguiar destacou que fora a primeira vez que um texto constitucional se preocupou em individualizar o direito da criança. Sendo suspensa no início da tarde, a sessão foi retomada à noite, dedicando-se à assuntos como aposentadoria e adoção.

A sétima sessão ordinária teve início no dia dois de junho, e o presidente abordou a dificuldade de votar, por falta de quórum, o calendário com as sugestões de personalidades a serem ouvidas no âmbito da comissão. Assim sendo, solicitou autonomia para que ele e o relator agissem neste sentido, de forma a evitar atrasos nos trabalhos. Apresentou a 
data para a comissão ouvir o ministro das Comunicações. Feito isso, a palavra foi passada ao constituinte Nelson Seixas, que disse se preocupar com o relatório da subcomissão 8a, identificando-se como "pai de retardado" (CÂMARA, 2017c, p.75). Sua preocupação seria em decorrência do relatório indicar que somente as instituições públicas deveriam ser destinatárias dos recursos públicos, o que dificultaria a existência, por exemplo, da APAE Associação de Pais e Amigos de Excepcionais - e da Associação Pestalozzi. Neste sentido, o presidente da comissão também fez um apelo aos constituintes para que reexaminassem melhor essa questão, posto que estaria recebendo a visita de muitos representantes de instituições religiosas, que objetivavam reverter tal concepção no texto constitucional. Sobre a Pestalozzi, inclusive, Nelson Seixas destacou que o senador Pompeu de Sousa, do PDT, deveria estar atento à questão uma vez que sua mulher seria representante daquela associação em Brasília. O constituinte Ângelo Magalhães (PFL) fez uma observação após a leitura do artigo 15 do anteprojeto, afirmando que as universidades católicas iriam fechar por falta de recursos e que a rede pública não dispunha de número de vagas suficiente para suprir a demanda.

Ainda sobre a destinação dos recursos, Aécio de Borba afirmou que apenas uma minoria defendia a exclusividade da aplicação dos recursos na educação pública, e que a subcomissão já havia formado um certo consenso sobre este aspecto, tanto que deixou o debate para ser refinado neste espaço. Destacamos o trecho em que o constituinte fez essa análise:

$\mathrm{O}$ art. 15, que seria votado, foi considerado prejudicado, em virtude da emenda adicionada ao art. $7^{\circ}$. Posso informar à Casa e aos companheiros de Comissão que todo o texto do art. 15 foi agora proposto como substitutivo exatamente ao art. $7^{\circ}$. A despeito de pequena parcela que defende intransigentemente que os recursos públicos sejam exclusivamente destinados à escola pública, há certo consenso dentro da Comissão de que devam ser ressalvadas aquelas entidades que realmente têm até hoje prestado significativa contribuição ao ensino, mas que não são de ordem pública (IDEM, p. 76).

O constituinte Antonio de Jesus falou sobre o grande número de instituições privadas existentes no Brasil e que, caso estas deixassem de receber recursos públicos, não haveria quem recebesse os alunos que delas sairiam. Em nenhum momento o mesmo colocou que deveria ser um compromisso do Estado a abertura de escolas públicas em número suficiente para atender a tal demanda. Ressaltou ainda que o ensino público seria muito oneroso aos cofres do Estado, que a família deveria ser livre e respeitada em suas opções, sob o risco do Estado se tornar ditatorial. Cabe transcrever todo o trecho: 
Por tudo isso, percebi que há necessidade de que alguém clame, nesta hora, e não sou proprietário de nenhuma escola, mas minha consciência me determina que, dentro de assunto tão significativo, devemo-nos pronunciar também, devemos respeitar a iniciativa privada. Sou de pleno parecer de que esta Constituição seja justa, venha a respeitar a iniciativa privada, a liberdade - não adianta pregar justiça social sem se dar liberdade de escolha. A família deve ter liberdade, deve poder optar pela escola filantrópica, pela mercantilista ou pela pública ou estatal. Não podemos, de maneira alguma, querer simplesmente estatizar o estudo, achando que seja a solução para o Brasil. Simplesmente ditatorial tudo para o Estado dentro de termos educacionais, acredito não seja suficiente para resolver os problemas. Se o assunto é democrático, deixem, então, todas as linhas de ação educacional existir e se tenha também o senhor Estado como protetor de todas (IBIDEM, p. 77).

$\mathrm{Na}$ mesma linha, Fausto Rocha (PFL) fez suas considerações em nome dos constituintes evangélicos. Afirmou defender a separação entre Igreja e Estado, e que, portanto, as escolas confessionais deveriam ser livres do jugo estatal. Todavia, não via prejuízo na passagem de recursos públicos para estas escolas, por meio da concessão de bolsas de estudo, uma vez que também considerava que, neste caso, influía a liberdade dos pais, que deveriam e poderiam escolher quais as melhores escolas para matricularem seus filhos. Sobre este aspecto, Antonio de Jesus também reafirmou a separação entre Igreja e Estado, dizendo que não poderia o Estado repassar verbas às igrejas, diretamente. Porém, seria possível fazer essa passagem de recursos às suas obras educacionais, de assistência social e de saúde, por exemplo.

Sobre essa tensão entre público, privado e a laicidade do ensino, resgatamos a entrevista a nós concedida pelo professor Luiz Antônio Cunha. Nela, ele apresenta um pressuposto da democracia, que é a laicidade da escola pública, que apesar de aprovado no texto final da $\mathrm{CF}$, efetivamente não acontece na realidade, nos dias atuais. Por outro lado, acaba por acontecer o oposto do que o constituinte Fausto Rocha apresentou, ou seja, não existe liberdade de escolha na escola pública - onde todos os alunos acabam, na prática, tendo aula de ensino religioso, e, o que é pior, de uma religião que não necessariamente a sua família escolheu. $\mathrm{Na}$ escola particular, os responsáveis conseguem matricular seus filhos em escolas confessionais ou laicas, por quererem ou não que o conteúdo religioso seja ensinado como parte do currículo escolar:

[...] muitas escolas que eu frequentei eu perguntava para a diretora, "escuta, aqui tem prática de religião?" e diziam "não, não tem, porque a escola é laica", mas encontrava em todo lugar sinos, professor rezando antes da aula de matemática, sabe, coisas desse tipo. Então a compulsoriedade religiosa, o que significa a exclusão, não só de algumas religiões, como de não crenças religiosas, o que a Constituição garante [..] Hoje você pode ter acesso, nesse aspecto, se você colocar 
seu filho em uma escola privada que não tenha ensino religioso. Só no setor privado que você tem essa liberdade de escolha. Numa escola pública você não tem, na escola pública você tem o ensino religioso obrigatório, imposto, sob o poder dos diretores e professores, eles que tem o poder [...] É grave. O pai comum de aluno de escola pública, ele não tem as condições psicológicas e políticas de dizer, de encarar um diretor de escola e dizer "eu não quero que meu filho tenha ensino religioso". Não tem. Mesmo no município do Rio de Janeiro, onde a lei manda que tenha cartaz dizendo que é optativo.

Voltaremos a essa discussão no capítulo seguinte e nas considerações finais deste trabalho. Ainda no que é pertinente a destinação dos recursos públicos, Nelson Aguiar se colocou contra a formulação presente no texto do anteprojeto, pois acreditava que a fonte da receita do Estado era o povo e que ele, como proprietário dos recursos, poderia escolher onde e como aplicá-los. Portanto, conceder bolsas de estudo para que as famílias escolhessem onde seus filhos deveriam ou não estudar, assim como oferecer subsídios às escolas privadas, seria fazer justiça e garantir a liberdade. Seguiu, ainda, dizendo não compreender como os constituintes poderiam ter essa espécie de valor em uma sociedade capitalista:

Que caretice é esta, numa sociedade capitalista? Então, vamos ter coragem de sair às ruas e dizer: queremos socializar tudo. Vamos ter coragem de defender isto. Vamos parar com essa caretice. Se queremos somente a presença do Estado na área da educação, para que o ensino seja garantido a todos, desde o primário até à universidade, vamos ter coragem de lutar pela socialização do estudo [...] Por que na área da educação é que vamos - desculpem-me a expressão - utilizar um expediente tão estreito? Paciência... Lembro-me que os desbravadores deste País, na área de educação, provieram da iniciativa particular [...] De modo que estou aqui para defender muito mais que isto, o direito e a obrigação do Estado subsidiar essas escolas. Agora, lucro não. Não gostaria de ver essas instituições servindo para enriquecer alguns, como de resto está acontecendo. O Estado tem que intervir neste setor, para corrigir (CÂMARA, 2017c, p. 78).

Fazendo a defesa de um caminho intermediário entre as propostas, Olívio Dutra, líder da bancada do PT, afirmou que o ensino público seria garantido para quem precisasse, ou seja, para quem não dispusesse de recursos. Quem pudesse, portanto, deveria pagar por ele. Desta forma, percebemos a desarticulação da ideia de direito, prevalecendo a perspectiva de educação como assistência. Nessa linha, Nelson Aguiar propôs uma diferenciação entre ensino gratuito e ensino estatizado. Defender o ensino gratuito, em sua concepção, não seria dizer que todo o ensino deva ser estatizado. Assim, acreditava que a coexistência de instituições públicas e privadas seria salutar. Sua maior preocupação se dirigia ao ensino 
superior, uma vez que acreditava que a universidade pública acabava por servir ao público oriundo das escolas privadas e que, portanto, teria condições de pagar. Desta forma, a universidade consistiria em uma espécie de desperdício de dinheiro público, posto que os dela egressos não reverteriam o seu trabalho em prol do Estado, mas de empresas privadas ${ }^{55}$.

Olívio Dutra, por outro lado, trouxe outra contribuição para se repensar o debate, ampliando a ideia de educação assistencial apresentada primeiramente, na direção da elaboração de uma educação democrática e para todos:

Entendemos que o ensino é um direito de todos e um dever do Estado. Entendemos que a escola confessional, dessa ou daquela religião, numa sociedade democrática, deve ter todo o direito de existir. A escola privada, empresarial, também deve existir - afinal de contas é uma sociedade capitalista, desigual, e que vai encontrar pessoas com condições econômicas para pagar a escola privada, e vai também atender o interesse ideológico de pessoas que querem ter uma educação dirigida no sentido desse ou daquele credo religioso. Por outro lado, é fundamental que o Estado garanta o ensino público e gratuito em todos os níveis para o universo geral da sociedade. A escola pública tem que ser a tarefa principal do Estado, têla espalhada territorialmente, tê-la democratizada, no sentido de que não seja o Estado a empurrar o tipo de ensino que a comunidade quer, mas a comunidade podendo definir o ensino que queira; com uma escola pública democratizada, no sentido da sua própria administração - as direções devem ser eleitas pelos círculos de pais e mestres, pelos alunos, pelos trabalhadores de tais instituições; o curriculum deve ser definido em conjunto com a comunidade. Enfim, a escola pública precisa ser valorizada neste país. É preciso que os recursos públicos sejam investidos nas escolas públicas. Entendemos que a escola confessional, a escola particular, a escola privada, têm historicamente e terão ainda, no nosso país, muito espaço e muita tarefa pela frente (IDEM, p. 79).

Evidenciou-se uma divergência clara nas posições dos dois constituintes. Nelson Aguiar defendia que a fonte dos recursos era o povo e que, sendo assim, tanto a escola estatal quanto a privada seriam escolas públicas. No que se refere ao nível superior, entendia que não deveria ser prioridade do Estado, pois a maior parte da população a ele não ascendia. Cabe, pois, destacar novamente o discurso de Olívio Dutra sobre a garantia do ensino público em todos os níveis como forma de elaboração de uma sociedade democrática. Ele afirmou, inclusive, que esta seria a posição do seu partido sobre o tema educacional:

Temos que valorizar o ensino, criar o ensino fundamental, valorizar o primário e o secundário e possibilitar que haja o ensino público gratuito em todos os níveis para o universo da sociedade, sem eliminação da escola confessional ou

55 Também voltaremos à esta discussão nas considerações finais, quando traçaremos um breve paralelo entre este estudo e os dias atuais. 
da escola privada. Quer dizer, defender a escola pública hoje, a sua valorização, o encaminhamento de verbas preferencialmente para ela. Não como os companheiros e eu sentimos no discurso do companheiro Nelson Aguiar, se contrapor ou tentar eliminar a escola privada. Não, não é necessariamente isto. A questão não é ser comunista estatizante, ou ser capitalista privatizante. Não. Temos que construir uma sociedade que não possa ficar nesse maniqueísmo. Queremos - e esta é uma posição nossa, enquanto trabalhadores do $\mathrm{PT}$ - um Estado democrático, permeado pela sociedade civil, um Estado que não seja técnico-burocrático-militar, um privilégio das castas e das elites brasileiras, um Estado que possa ter uma estrutura organizada permanentemente fiscalizada pela sociedade, através das suas instâncias organizadas. Este Estado democrático tem compromissos sociais inadiáveis e um desses compromissos é com a educação pública. É este Estado que defendemos, que deva efetivamente tratar de distribuir recursos e riquezas, porque é um papel dele, também, democratizar recursos e oportunidades, preferencialmente os recursos públicos para as escolas públicas (IBIDEM, p. 80).

O presidente da comissão, por sua vez, disse que precisava estar esclarecido quanto ao tratamento diferenciado que era dado aos temas que dela faziam parte - educação, cultura, esporte, comunicação, tecnologia, pesquisa - no que se refere à destinação dos recursos públicos. Questionou como poderiam permitir o repasse de recursos públicos para todas as áreas, menos para a educação. Sobre este aspecto, Olívio Dutra fez algumas considerações sobre a necessidade de ampliação do investimento em educação pública, com destaque para o trecho seguinte:

Efetivamente, não podemos retirar recursos do Ministério da Educação, que têm
que ser canalizados para a escola pública, para que a iniciativa particular monte
uma escola no interior do Município de Bossoroca, no Rio Grande do Sul. Se
a iniciativa particular, usando esses recursos, pode montar a escola, por que o
Estado não pode fazer também? Por que não? Então, o Estado só tem o recurso e
repassa para lá? A não ser que seja para uma instituição efetivamente filantrópica,
que não vise lucros, o Estado, neste caso, pode e deve atender com recursos. Não
podemos, de forma alguma, retirar recursos das escolas públicas, do setor público
de ensino, para repassar para o setor privado do ensino (IBIDEM, p. 81).

Olívio Dutra retornou à discussão do ensino religioso, afirmando que a obrigatoriedade deste na escola pública se constituiria em um "atentado" ao Estado laico, posto que não seria possível dialogar na escola com toda a diversidade de religiões existentes em um país como o nosso, e que, consequentemente, acabaria se priorizando uma religião em detrimento da outra. Ante o exposto, defendeu a neutralidade da escola pública neste campo, posto que 
A escola pública é exatamente na direção de que o Estado não tem que estar a serviço de nenhuma seita, ou grupo religioso. O Estado é independente da igreja. Então, defendemos que o ensino religioso seja feito nas escolas confessionais, nas escolas particulares, privadas. $O$ ensino religioso não cabe na escola pública (CÂMARA, 2017c, p. 81).

José Mendonça de Morais, em resposta à colocação do colega, disse acreditar ser possível o Estado cumprir o seu dever com o serviço de terceiros, ou seja, das instituições privadas. Argumentou, com base em supostos dados do governo, que o ensino público seria muito mais oneroso aos cofres públicos do que o ensino privado, como vemos no trecho seguinte:

Uma das questões que me tem chamado a atenção na análise do custo operacional da educação de um cidadão brasileiro e que me trouxe ao microfone para o aparte a V. Ex. ${ }^{a}$ Se V. Ex. a analisar, através dos dados estatísticos oferecidos pelo próprio Governo, quanto fica um produto acabado, chamado o homem no nível superior, desde o primeiro dia de escola pública até o último, V. Ex. ${ }^{a}$ verificará que o Estado gasta uma fortuna exorbitante para colocar na cabeça de um cidadão aquilo que gostaria de ter colocado, mas não o fez, se o Estado usasse a vigésima parte do recurso que gastou com um cidadão - sou fruto de uma escola pública federal, onde me formei, se o Estado gastasse $20 \%$ apenas, portanto a quinta parte, através de repasse à escola privada, do primeiro dia até o último, estaria tendo cinco vezes mais produtos acabados em termos de educação - coloco bastante malícia nisso, o homem não seria mais o sujeito, mas sim o produto do Estado (IDEM, p. 81).

Por fim, após defender a destinação dos recursos públicos às escolas privadas, por estas formarem "produtos" mais baratos para o mercado, o constituinte defendeu, sobre o ensino religioso, que as comunidades escolares deveriam decidir pela existência ou não desta disciplina em seus currículos. Sobre este último posicionamento, Octávio Elísio demonstrou estar em concordância.

$\mathrm{O}$ presidente passou à discussão do anteprojeto oriundo da subcomissão 8b, especificamente sobre a questão da censura e, logo após, suspendeu a sessão, retomando-a no final da tarde. O mesmo tema permaneceu, pois, em uma extensa discussão, na qual o constituinte Eliel Rodrigues defendeu o estabelecimento de parâmetros da moral cristã e evangélica para a censura. Esse fato é digno de destaque, visto que corrobora a discussão travada anteriormente, na qual Octávio Elísio defendia a laicidade do Estado. Na sessão seguinte, realizada no dia 03/06/1987, outro tema polêmico foi trazido no debate entre os constituintes Arolde de Oliveira - que entrevistamos para a realização deste trabalho Cristina Tavares e Florestan Fernandes, sobre o papel da direita e da esquerda em um país 
como o Brasil. Tal assunto emergiu quando da discussão sobre a necessidade de criação de um Conselho Nacional de Comunicação Social, momento em que Arolde de Oliveira fez uma crítica ao posicionamento de alguns constituintes, que chamou de "radicais" (IBIDEM, p. 103). Resgatamos, inclusive, um trecho da entrevista em que o deputado relembrou esse debate na ANC:

A tendência da esquerda, obviamente, sempre é para uma economia estatal mesmo. E, a predominância a partir daquela época era para economia mais liberais, mais para o capitalismo, mais liberais, etc. Mais engessado. Isso só veio se reformar depois dos anos 1990. Na área de telecomunicações eu participei intensamente desse período. Mas, enfim, mas tudo isso por trás. Mas, como a esquerda era muito forte, né, e tem uma visão muito clara ideologicamente de como tem que se organizar o setor educacional, a área cultural, etc., por razões que não cabe aqui nós discutirmos, faz parte do processo, né, então, evidentemente, essas questões foram muito debatidas, né, e algumas delas incluídas na Constituição. Algumas delas foram incluídas na Constituição, por exemplo, a liberdade, a liberdade de ensino, foi incluído, né. Foram feitos capítulos específicos sobre o assunto, muito analíticos, mas descritivos, bem claros, na Constituição algumas coisas vieram a ser revistas e até introduzidas depois já com emendas [...] Mas, o que veio de lá, veio dentro desses padrões e com esse viés. Era tão significativo isso para a esquerda na época, que os debates, eles ficavam focados, eu me lembro que na minha comissão nós tínhamos lá na ala à esquerda Cristina Tavares, era uma deputada, deputada do Maranhão, do Maranhão, de Pernambuco, muito preparada e muito aguerrida.

A discussão rendeu longas laudas das atas da comissão 8 , nas quais não nos deteremos. Com a retomada da sessão ao final da tarde, o presidente fez alguns informes sobre as próximas tarefas da comissão e o relator da subcomissão 8a, João Calmon, mais uma vez trouxe a público sua preocupação com a vinculação orçamentária para a educação. A partir da preocupação do constituinte, Hermes Zaneti historicizou todo o processo de luta para a vinculação de receitas nas Constituições, de forma a garantir a aplicação mínima de recursos no campo educacional.

Algumas personalidades estiveram presentes naquela sessão, como Dercy Fontoura, da SBPC, Israel Roizemberg, que abordou assuntos ligados à genética e embriologia, e Vanilda Paiva, secretária da SBPC, convidada a falar sobre o conceito de entidade pública, privada, e comunitária, a fim de auxiliar os constituintes a melhor formularem o texto pertinente à destinação dos recursos públicos. Desta forma, a professora se colocou na defesa da escola pública como escola oficial, posto que o Estado seria o único ente capaz de universalizar o acesso ao ensino de $1^{\circ}$ e $2^{\circ}$ graus e democratizar o mesmo para 
o nível superior. Afirmou ainda que o argumento de que todo serviço prestado é público, objetivava a privatização do sentido da coisa pública. Apresentou questionamentos sobre a efetivação da municipalização do ensino que, segundo suas análises, não seria o melhor caminho devido à situação vivida por muitos municípios brasileiros, que não conseguiam se sustentar, quiçá elaborar e prover um sistema próprio de ensino.

Questionada por Nelson Aguiar sobre as possibilidades de co-gestão oferecidas pelas escolas comunitárias, afirmou que esta pode também ocorrer em escolas públicas, mediante a democratização do aparelho estatal. Ainda no debate dos constituintes com a especialista convidada, Florestan Fernandes lembrou do processo de elaboração da LDBEN de 1961, e de todo o trabalho realizado na ocasião para promoção da privatização do espaço público, por meio dos discursos veiculados, que redundaram na aprovação do texto legal. Hermes Zaneti refletiu sobre a possibilidade de instituições privadas e comunitárias não terem objetivo de lucro, sobre o que Vanilda respondeu que não acredita, posto que todas elas oferecem um serviço em troca de uma remuneração.

A sessão seguinte $(04 / 06 / 1987)$ foi destinada a receber outra personalidade, sendo que da área da comunicação, como acordado anteriormente. $\mathrm{O}$ então ministro Antonio Carlos Magalhães protagonizou uma das reuniões mais difíceis, com muitos debates e troca de ofensas entre os presentes. Destacaram-se nesses embates os constituintes Artur da Távola - que abordou a questão das concessões de rádio e televisões -, Joaci Góes e Hermes Zaneti, sendo que este chegou a dizer que sabia que a presença do ministro em nada contribuiria para o avanço dos trabalhos da comissão.

$\mathrm{Na}$ mesma data foi convocada uma reunião extraordinária a pedido de Artur da Távola, que foi finalizada rapidamente, posto haver entendimento sobre a viabilidade da solicitação realizada, a respeito dos prazos. A solicitação da presidência foi a extensão do prazo do relator, conforme mostra o texto seguinte:

Estivemos examinando estes prazos, espremendo daqui e dali e chegamos à conclusão de que isto será possível desde que o Relator se comprometa a nos entregar o parecer e o substitutivo ainda que informalmente na véspera, isto é, na segunda-feira, para que a Comissão tenha tempo de rodar os avulsos e, quando o dia amanhecer, na terça-feira, tenhamos feito a distribuição perante os Srs. Constituintes. Assim, a terça e a quarta-feiras, integralmente, poderiam ser usadas para a formulação de emendas pelos Srs. Constituintes (CÂMARA, 2017c, p. 157). 
A sessão seguinte foi realizada no dia nove daquele mês, com a evocação da proteção de Deus pelo presidente e com a proposta da leitura, apresentação e discussão do parecer do relator com seu substitutivo. Todavia, ao iniciar sua fala, Marcondes Gadelha informou alguns problemas com o calendário combinado na sessão anterior. Houve um problema com o prazo anteriormente combinado, posto que o presidente Ulysses Guimarães solicitou a entrega do texto dos relatores no dia 07 de junho, antes, porém, de sua apresentação na comissão. Todavia, o presidente Marcondes garantira que cumpriria os demais prazos, inclusive os dois dias dedicados às emendas e os demais, à discussão. Alguns constituintes apresentaram suas considerações, cabendo um aparte ao deputado Arolde de Oliveira, que afirmou haver uma "ditadura dos relatores", ao apresentar seu receio do tempo disponível não ser suficiente para sistematizar todos os debates, vindo a prevalecer a versão por ele organizada. Sobre esse ponto, obteve a seguinte resposta do presidente, que fez a leitura do regimento interno:

"Na hipótese de alguma Comissão não apresentar o seu trabalho no prazo estipulado,
no parágrafo anterior - ou seja, até o dia 15 - caberá ao Relator da Comissão
de Sistematização a elaboração do mesmo, obedecido o prazo estabelecido no
caput do art. 19". Então, o Relator da Comissão de Sistematização é quem passa
a fazer... (IDEM, p. 159).

Em réplica à observação do presidente, Arolde de Oliveira disse conhecer o teor do regimento, mas que também sabia que, na prática, o relator da subcomissão de sistematização, no caso acima descrito, entraria em contato com o texto mais sistematizado possível que, indubitavelmente, seria o do relator da comissão temática. Foi então proposta a redução do prazo para as emendas, por alguns constituintes. A princípio a parlamentar Márcia Kubitschek resistiu, mas aceitou a proposta. Desta forma, a votação teria início no dia 12 , às quatorze horas.

Após o debate, passou-se à apresentação do referido relatório a ser emendado e votado. Sobre ele, apresentaremos os principais temas defendidos pelo relator. Este, em seu turno, iniciou sua fala com uma observação oportuna sobre o difícil processo de relatoria que é o de "juntar tendências" - posto que leu e emitiu parecer sobre 1.047 emendas - e tentar romper com o maniqueísmo, que vinha dividindo os parlamentares em lados opostos:

[...] o relatório não é obra deste Relator, que apenas procurou realizar um trabalho de síntese do que havia chegado às suas mãos. É evidente que o Relator não pode se eximir de ter uma definição doutrinária no momento em que ele acolhe uma emenda e rejeita outra, isso é fora de dúvida. Mas, eu gostaria de deixar aqui, com os Srs. Constituintes, o apelo para que procurem verificar o trabalho do Relator, em cada caso, ao invés de encapsulá-lo em rótulos de direita, de esquerda, como 
vem sendo comum nesta Constituinte. Ou nós vamos ser capazes de superar este maniqueísmo, que pertence talvez a uma linguagem do princípio do século e não à complexidade da sociedade contemporânea, ou vamos ficar nos enredando em pequenas disputas que invalidam o esforço de obter um ponto comum. Se esta Constituição for a vitória esmagadora de um grupo sobre o outro, ela não representará a pluralidade do pensamento brasileiro. Temos que encontrar um ponto comum, ainda que sejamos originariamente divergentes (IBIDEM, p. 160).

Neste capítulo abordaremos de forma sucinta as alterações propostas pelo relator, focando mais nos debates e nos grupos que o sustentavam. No capítulo seguinte, como lembramos exaustivas vezes, voltaremos ao debate específico do conteúdo das propostas.

O relator iniciou sua leitura já com uma proposta de mudança no artigo primeiro, retirando a formulação da educação como "direito de todos", para a de "direito de cada um". A defesa desta alteração foi feita com base na ideia de que a educação seria um direito individual, e não coletivo. Afirmou ainda que a formulação anterior buscava oferecer um conceito de educação deveras amplo, que não caberia à Constituição fazer. No que se refere ao segundo artigo, defendeu que o mesmo seria uma espécie de detalhamento do anterior, por meio da vinculação da educação como direito individual ao compromisso do Estado. Essa formulação nos é bastante cara, pois ela que nos oferece as bases para o nosso entendimento da educação como direito e, inclusive, auxiliou-nos na formulação das categorias específicas deste trabalho de pesquisa. Aqui entram os incisos que abordam a democratização do acesso e permanência; a liberdade do ensino, entendida de diferentes formas; a gratuidade do ensino público em todos os níveis; a valorização dos profissionais da educação; a superação das desigualdades regionais; e a superação de qualquer tipo de discriminação.

$\mathrm{O}$ artigo terceiro tratava da efetivação do direito à educação, por meio da obrigatoriedade do Estado, que se materializaria com o ensino fundamental a partir dos sete anos de idade, com duração mínima de oito anos e, também, aos que não tiveram acesso na idade regular, sendo essa a principal alteração em relação ao texto que lhe antecedera. A extensão dessa obrigatoriedade ao ensino médio foi mantida, além da sinalização para a importância da educação da faixa etária dos 0 aos 6 anos. Sobre esse aspecto, o relator chamou a atenção do constituinte Álvaro Valle, devido ao fato dele desconhecer a discussão acumulada sobre a temática, por não ter suficientemente frequentado as sessões. Cabe ressaltar que a ideia da educação como direito público subjetivo já apareceu aqui.

Os artigos subsequentes tratavam da língua nacional em que seria ministrado o ensino; do currículo e das universidades, sobre os quais não nos aprofundaremos. $\mathrm{O}$ artigo $7^{\circ}$ trouxe, segundo o relator, a consagração do princípio da municipalização do ensino, estabelecendo 
a presença supletiva do Estado e da União. O artigo seguinte, amplamente debatido, incorporou o fundamento da emenda Calmon, ampliando a vinculação orçamentária de 13 para 18\%, no que se referia à contribuição da União. A mudança significativa nesse artigo se deveu à alteração da quantificação dos recursos destinados ao ensino fundamental $50 \%$, para a priorização deste, na redação de seu texto.

Passando pelos padrões de eficácia, chegamos novamente à polêmica da liberdade de ensino, no artigo décimo, assunto o qual o relator disse carecer de melhor reflexão e análise. Sendo assim, resgatou o histórico da aplicação de recursos públicos no Brasil, considerando que o mesmo sempre se deu de forma insuficiente e que, contraditoriamente, “[...] Em toda a órbita privada, apenas a órbita do ensino recebe diretamente verba pública. Isto passa, no Brasil, como se fosse algo natural, numa evidente preferência, diante de toda a outra atividade privada" (CÂMARA, 2017c, p. 164). Mais além, o relator colocou que a construção de uma sociedade democrática no Brasil somente seria possível mediante investimento público em educação pública, e exclusivamente nela. Por sua vez, esclareceu que tal exclusividade não inviabilizaria o funcionamento de escolas privadas, que deveriam se valer de recursos próprios à sua manutenção. No entanto, em uma perspectiva conciliatória, buscou trazer ao texto uma versão que contemplaria as instituições confessionais e filantrópicas, da seguinte forma: “[...] esse caso foi abrangido aqui, porque, evidentemente, onde o poder público não chega, escolas de natureza filantrópica, confessional ou comunitárias devem merecer também o abrigo do poder público" (IDEM, p. 164-165). Desta forma, caso seguissem as especificações constantes no artigo onze, as instituições supracitadas fariam jus ao recebimento de verbas públicas.

Os demais artigos - quatorze ao todo - tratavam do PNE, do salário-educação e da capacitação profissional de trabalhadores. Suspensa a sessão, ao final da leitura da matéria educacional, a mesma foi retomada à tarde, para a continuidade dos trabalhos, com a leitura do texto pertinente às áreas do desporto, da família, do menor e do idoso.

A $11^{\mathrm{a}}$ sessão ordinária aconteceu no dia seguinte, com a presença do ministro da Previdência Social à época, Raphael de Almeida Magalhães, que abordou, dentre outros temas, as políticas compensatórias e as políticas de geração de renda. Destacou a necessidade do consensualismo na redação de um texto constitucional e que, por tal motivo, dever-se-ia evitar o detalhamento excessivo das matérias, haja vista que quanto mais detalhe, menos possibilidade de acordos. Na continuidade dessa sessão à tarde, o relator informou que já havia recebido oitocentas e setenta e três emendas, o que nos mostra a dificuldade de se atingir o tão desejado consenso. 
Após a realização de uma reunião para esclarecimento de dúvidas sobre o processo de votação, no dia 11/06/1987, o dia seguinte anunciou a sessão de votação do substitutivo do relator. Esta sessão teria início, podendo ser suspensa quantas vezes necessárias, porém, só se encerraria após a votação e apresentação da versão final do anteprojeto a ser encaminhado à comissão de sistematização. Após o ritual inicial de explicação da dinâmica a ser adotada no dia, o constituinte Hermes Zaneti solicitou a palavra para tecer uma crítica a respeito da conduta do colega Álvaro Valle, presidente do PL, que teria comparecido a um programa de televisão e feito críticas, segundo ele, infundadas quanto ao processo de elaboração da Constituição. Cabe, pois, destacar um trecho de sua participação, uma vez que trouxe à público a ausência repetida daquele constituinte às sessões das quais deveria ser parte:

Presidi, como V. Ex. ${ }^{\text {a }}$ sabe, a Comissão de Educação. Aquele Parlamentar, Presidente do PL, Constituinte Álvaro Valle, compareceu uma pequena parte da primeira reunião e nunca mais foi à Subcomissão, nem para a votação. Não o vi, em nenhuma reunião aqui, nesta Comissão. Respeito todos quantos aqui vieram e sustentaram os seus pontos de vista, mesmo que não concorde com o conteúdo. Agora, ir a um programa de televisão, de forma irresponsável e leviana, dizer coisas que não são verdadeiras, denigre o trabalho da Assembléia Nacional Constituinte [...] (IBIDEM, p. 206).

Destacou os debates que tomaram assento naqueles espaços - subcomissão $8 \mathrm{a}$ e a própria comissão 8 - a respeito do ensino religioso, das creches e das escolas privadas, que o constituinte afirmou não ter sido contemplado pelo texto do relator. Sobre esta última temática, inclusive, afirmou não ter acordo sobre o texto consignado, posto que defendeu a exclusividade da aplicação de recursos públicos para o ensino público, mas que entendeu ser este o caminho possível para a elaboração de uma CF. Por fim, lamentou-se pelo fato do constituinte não estar, mais uma vez, presente à sessão para explicar suas falas.

Outros dois constituintes fizeram exposições em relação às observações do colega Álvaro Valle, até que o mesmo chegou à sessão. Rebatendo as críticas sobre sua ausência, o mesmo disse já conhecer o que as entidades convidadas tinham a apresentar e que, portanto, ocupou-se de outros afazeres. Apresentou considerações aos pontos que julgou não serem contemplados no texto, tal como já apresentado acima.

Durante a polêmica inicial, o presidente Marcondes Gadelha fez a leitura do regimento interno, especificamente em seu artigo 43, que abordava a questão do público presente nas galerias, informando-o que não existe a possibilidade de manifestações de repúdio ou aprovação, e que estas poderiam redundar na evacuação da área. Com a chegada do relator, 
o mesmo apresentou a dificuldade vivida nos últimos dias, para conseguir responder e incorporar as sugestões recebidas, via emendas. Outrossim, informou que o dispositivo que considerava ser o mais problemático - referente à destinação dos recursos - acreditava ter resolvido, posto que o texto "[...] não abre mão da disposição fundamental da destinação da verba pública para a escola pública e não dificulta o funcionamento de escolas comunitárias ou filantrópicas" (IBIDEM, p. 210). Resgatou, pois, em sua argumentação o sentido de CF como pactuação.

Após a reunião ser suspensa e retomada pouco tempo depois, o primeiro questionamento da sessão foi feito pela constituinte Cristina Tavares, sobre o fato do texto apresentado pelo relator ser um novo substitutivo, ao qual não caberia apresentação de emendas, mas aprovação ou não. Ratificando a fala da deputada, o presidente encaminhou os trabalhos, mesmo sob as reclamações de que então, tratava-se de um decreto-lei, e não de um anteprojeto. Desta forma, Marcondes Gadelha recorreu ao regimento interno, em seu artigo 18, e relembrou que a matéria já entrara em fase de votação, não cabendo novas emendas, mas votação ou rejeição do texto.

Superada a polêmica inicial sobre a possibilidade de emendar ou não o substitutivo, o constituinte Jorge Hage solicitou que o quórum fosse novamente verificado, pois não via presença no plenário que justificasse o início da sessão. O presidente, então, respondeu que fora registrada a presença de 29 titulares e 14 suplentes, o que viabilizaria a realização dos trabalhos do dia. Foi reiniciada a verificação de presença e constatado o número mínimo para início dos trabalhos. O presidente, pois, passou a informar detalhadamente como se daria o processo de votação, de maneira a esclarecer os constituintes. Apesar de longo, julgamos pertinente transcrever todo o trecho, tendo em vista que o resultado dos encaminhamentos finais da comissão 8 foi resultante do que estava previsto desde o início da sessão de votação:

Srs. Constituintes, antes de suspender a reunião para recebimento oficial dos destaques, a Mesa gostaria de dar uma informação sobre o processo de votação. Inicialmente, quando for reaberta a reunião, a Presidência procederá à leitura dos requerimentos de destaques para votação, em separado, do Substitutivo. Estes destaques serão deferidos pela Presidência. Em seguida, passaremos à votação em globo do Substitutivo do Relator, sem prejuízo das emendas e dos destaques. Neste ponto duas alternativas podem acontecer; o Substitutivo é aprovado, salvo os destaques e as emendas, ou o Substitutivo é rejeitado em bloco. Na primeira hipótese, isto é, aprovado o Substitutivo, fica prejudicado o primeiro Substitutivo do Relator, ressalvado os destaques; em seguida, passa-se a votação dos artigos destacados do Substitutivo, pois a ele cabem também destaques, de parte. Rejeitado determinado artigo, ficam prejudicadas as emendas supressivas, modificativas, e aditivas a ele referentes. A emenda substitutiva ao mesmo artigo será votada 
na fase própria. Em seguida, passa-se à leitura dos requerimentos de destaques para votação em separado das emendas. Requerimentos, são automaticamente deferidos pela Presidência. Passa-se, então, à votação em globo das emendas que receberam parecer contrário, ressalvados os destaques. Depois, passa-se à votação das emendas destacadas, que serão votadas uma a uma, obedecendo a ordem dos artigos do substitutivo. As emendas são classificadas em supressivas, substitutivas, modificativas, e aditivas; finalmente, serão votadas as emendas destacadas que contenham a expressão "onde couber". Aquelas emendas de lugar incerto e não sabido serão votadas ao final, sob esta epígrafe de "onde couber". A segunda vertente, a segunda hipótese, é de que haja rejeição em bloco do Substitutivo do Relator. Neste caso, se o Substitutivo do Relator for rejeitado em bloco, a Mesa colocará em votação o primeiro Substitutivo do relator. Se este também for rejeitado em bloco, nós passamos à votação das emendas que passarão à constituir as partes componentes de um novo e futuro substitutivo. Concluída a votação destas emendas, a Mesa pedirá ao Relator Artur da Távola que faça a redação final desse último Substitutivo. Se S. Ex ${ }^{\mathrm{a}}$ se recusar, a Mesa designará um novo relator. Eram informações preliminares que gostaríamos de prestar (CÂMARA, 2017c, p. 221).

A complexidade do processo que ora se iniciava era grande e, portanto, havia de ser bem explicado, uma vez que as dúvidas, como a trazida por Cristina Tavares, já pululavam na abertura da sessão. Antes, todavia, da suspensão das atividades para o recebimento dos destaques, que deveriam ser preenchidos em formulários próprios pelos constituintes, novo debate se estabeleceu. Desta vez, trazido por Hermes Zaneti, sobre o afastamento de representantes da comissão; no caso, do constituinte Pedro Canedo (PFL). Desta forma, o presidente explicou que recebera um documento enviado pelo líder daquele partido em que suprimia um de seus filiados, a pedido da presidência da ANC, uma vez que o partido somente dispunha de 15 assentos e usava, até então, 16. Assim sendo, optou-se por transferir Pedro Canedo para outra comissão. Tal fato causou indignação em alguns constituintes, inclusive no próprio, que julgavam esta ser uma forma de diminuição dos votos a favor da destinação exclusiva dos recursos públicos para as escolas públicas, bandeira defendida por Pedro, diferentemente da maioria de seu partido. Ao fazer a defesa da permanência do colega, Hermes Zaneti foi interrompido por Marcondes Gadelha, pois este julgara que o mesmo solicitou uma questão de ordem e não estava cumprindo a finalidade de sua fala:

Quero pronunciar-me sobre a questão do eminente Constituinte Pedro Canedo. E afirmo, para iniciar, que é manobra, manobra no sentido de destituir do Constituinte Pedro Canedo a sua livre expressão e a sua livre manifestação. Pedro Canedo foi Segundo-VicePresidente da minha Subcomissão, da qual eu fui o Presidente. Foi um brilhante Constituinte e teve a coragem de defender as posições que a sua consciência lhe ditava e por isto venho a este microfone dizer a V. $\mathrm{Ex}^{\mathrm{a}}$ que [interrupção do presidente, solicitando que se atenha às questões de ordem]. 
Obrigado a V. Exa ${ }^{\mathrm{a}}$ É manobra, Sr. Presidente, porque Pedro Canedo votou em favor da escola pública e as manobras do Líder do PFL, neste momento, destinamse a impedir que tenhamos aqui maioria para aprovar aquilo que a maioria do povo brasileiro e que os interesses do povo brasileiro exigem. É manobra para assegurar, Sr. Presidente, que esta Constituição que estamos aqui a aprovar resguarde os interesses de meia dúzia de pessoas que pretendem manter o status quo (IDEM, p. 221).

Diante o desenrolar dos fatos, o deputado Arolde de Oliveira acusou Hermes Zaneti de tentar tumultuar a sessão para inviabilizar o processo de discussão e votação do substitutivo, assim como Cristina Tavares. Solicitou ao presidente que evacuasse as galerias, caso os presentes continuassem com suas manifestações de apreço ou reprovação à avaliação dos constituintes sobre as questões discutidas. Na linha oposta ao deputado, outros constituintes declararam apoio a Pedro Canedo e repulsa a decisão autoritária do partido, a saber: Octávio Elísio, Joaci Góes, entre outros. Fausto Rocha disse acreditar que o tumulto era proposital, para procrastinar os trabalhos previstos. Pedro Canedo, por fim, explicou o que acontecera nos últimos dias, a respeito de sua exclusão da comissão:

[...] o Líder me informou que me procurou por estes dias e não me conseguindo encontrar, não tendo nenhuma notícia a meu respeito, $\mathrm{S}$. Ex $x^{\mathrm{a}}$ houve por bem atender a uma designação do Presidente da Assembléia Nacional Constituinte, substituindo ou retirando um dos 16 membros do PFL que fazem parte desta Comissão. Como eu estava no exterior, em missão oficial da Câmara dos Deputados, assinada pelo Presidente da Câmara dos Deputados e Presidente da Assembléia Nacional Constituinte, fui procurá-lo. Não encontrando, falei com o Secretário Geral da Mesa, Dr. Paulo Afonso, que me informou que esta Comissão tem apenas sessenta e dois membros, conforme V. Ex acabou de ratificar, e que o PC do B tinha uma vaga e que o PTB estava ocupando uma das vagas do PDT, por acordo de lideranças firmado. Perfeitamente. Voltei ao Líder do meu Partido e informei ao Líder do meu Partido que já havia encontrado o caminho. Como tinha a plena certeza e conviç̧ão de que pela forma democrática, já que o PC do B não tem membros suficientes para colocar, também, nesta Comissão, tinha plena certeza e convicção de que não me faltaria apoio no PC do B para integrar esta Comissão ou qualquer outra, mas mesmo antes de consultar o PC do B eu fui até o Líder do meu Partido quando, então, entreguei-lhe a solução do caso. Surpreendentemente, talvez, o Líder do meu Partido respondeu-me que faria acordo com qualquer Partido democrático, mas que não faria acordo com o $\mathrm{PC}$ do $\mathrm{B}$, nem para manter um membro do seu Partido numa Comissão que trabalhou, que dedica e que pretende continuar dedicando a esta Comissão. De modo, Sr. Presidente, gostaria de deixar registrado que não foi pelo fato de o Líder do meu Partido não ter me localizado que eu deixei ou que estou deixando esta Comissão. Outros motivos fizeram, e os motivos foram simplesmente por não abaixar, por não agachar a esta direita que querem conduzir o Partido da Frente Liberal (IBIDEM, p. 229). 
Assim, mesmo diante o interesse de outros partidos manterem o constituinte no âmbito da comissão 8 - como o caso do constituinte Aldo Arantes do PC do B - o presidente não acatou e informou que a solicitação deveria ser enviada ao presidente Ulysses Guimarães, posto que só estaria cumprindo uma decisão maior. Em meio à discussão de vagas ocupadas ou não pelos partidos ${ }^{56}$, quórum e outras questões, a sessão foi suspensa para que se buscasse entendimento sobre a situação do constituinte Pedro Canedo, já indicado por seu partido ${ }^{57}$ para outra subcomissão, à qual prontamente ele renunciou. Foi recomendada pelo presidente a indicação de uma comissão suprapartidária para acompanhamento da questão.

Desta forma, a sessão que deveria estar suspensa até às 9 horas da manhã, foi retomada somente às 11 horas e 05 minutos com a leitura do regimento interno, sobre o significado das questões de ordem, e também com um despacho do presidente da ANC, que informava que somente o líder do partido teria competência para indicar um membro para ocupar a vaga da comissão. Portanto, não caberia ao PCdoB indicar um constituinte do PFL para sua vaga ociosa.

Continuavam as questões de ordem solicitando explicações quanto a precedência do processo de votação, razão pela qual não se iniciaram efetivamente as votações até aquele momento. Os constituintes Cristina Tavares e Octávio Elísio inscreveram-se para discursar em defesa ao substitutivo do relator; Mendes Ribeiro e Rita Furtado para argumentarem contra o mesmo. Foi feita uma nova solicitação de questão de ordem por Haroldo Lima, do PCdoB, para proceder a indicação de Gumercindo Milhomem (PT) para a vaga que estava ociosa. O mesmo se deu com o PDT, que indicou Brandão Monteiro. Novo tumulto teve início no plenário, pois o presidente começara o processo de votação sem a indicação do PT estar devidamente assinada por Ulysses Guimarães. Sanada a situação, apresentou-se os votos a favor (26) e contra (37) o substitutivo do relator, que por tal razão, foi rejeitado ${ }^{58}$.

56 PMDB: 34; PFL: 15; PDS: 4; PDT: 3 (estava com 1 vaga ociosa); PTB: 2; PT: 2; PDC: 1 (cedeu ao PTB, que passou a contar com 3 vagas); PCdoB: 1 (não ocupada).

57 Respondiam pelo PFL naquela sessão José Lourenço, líder do partido, e Eraldo Tinoco.

58 Votaram à favor: Antônio Gaspar - Artur da Távola - Carlos Alberto Caó - Cássio Cunha Lima - Cristina Tavares - Fernando Cunha - Flávio Palmier da Veiga - Florestan Fernandes - França Teixeira - Hermes Zaneti Joaci Góes - Koyu lha - Louremberg Nunes Rocha - Márcia Kubitschek - Maria Lúcia - Nelson Aguiar - Octávio Elísio - Olívio Dutra - Paulo Silva - Pompeu de Souza - Rita Camata - Sólon Borges dos Reis - Tadeu França Ubiratan Aguiar - José Maurício - Gumercindo Milhomem. Votaram contra: Aécio de Borba - Agripino de Oliveira Lima - Álvaro Valle - Ângelo Magalhães - Antônio de Jesus - Arnold Fioravante - Arolde de Oliveira - Átila Lira - Bezerra de Melo - Cláudio Ávila - Dionísio Hage - Eliel Rodrigues - Eraldo Tinoco - Ervin Bonkoski Eunice Michiles - Fausto Rocha - Francisco Diógenes - lberê Ferreira - João Calmon - João de Deus - José Carlos Martinez - José Elias - José Moura - Marcondes Gadelha - Matheus lensen Mendes Ribeiro - Onofre Corrêa Osvaldo Sobrinho - Paulo Marques - Rita Furtado - Roberto Augusto - Roberto Vital - Vingt Rosado - Rodrigues Palma - Ruberval Pilotto - Renato Jonhsson - Luís Eduardo. 
Devido ao tumulto e ao barulho das galerias - que foram advertidas pelo presidente - a sessão foi novamente suspensa, sendo reaberta uma hora depois. Em sua reabertura, um ofício fora entregue à presidência da comissão por alguns constituintes, no qual estes se responsabilizavam pela presença de convidados: Hermes Zaneti, Florestan Fernandes, Joaci Góes, Ubiratan Aguiar e Gumercindo Milhomem. Sabendo do teor do ofício, a constituinte Cristina Tavares também solicitou a inclusão de sua assinatura, à qual se seguiram mais onze constituintes.

As polêmicas continuavam a se desenrolar, e duas questões de ordem são interessantes destacar: uma de Olívio Dutra, ao apresentar sua posição de líder do PT e as posições por ele defendidas, e outra de Arolde de Oliveira, que refutou o colega:

Eu, particularmente, não sou proprietário de nenhum canal de televisão ou rádio; sou um modesto ouvinte, como a maioria do povo brasileiro, do rádio e assistente eventual - quando posso - de programas de televisão. Mas, sabemos concretamente que existem, dentro desta Comissão - como estavam dentro da Subcomissão de Ciência, Tecnologia e Comunicação vários companheiros, que não estão aqui na condição de meros representantes do povo brasileiro, mas também - e isso é preciso que se diga - representando interesses de sua empresa, uma vez que são proprietários, ou concessionários, de canais de rádio e de televisão, ou, então, são prepostos e acho que isso é natural. Quero registrar aqui que a sociedade brasileira é composta de proprietários de rádio e televisão, concessionários de rádio e de canais de televisão e ondas de rádio e, também, de ouvintes. Sou um representante da maioria do povo, pois sou apenas um mero, um modesto e talvez um inabitual ouvinte de rádio e assistente de televisão, mas sabemos que há aqueles que, concretamente, têm o direito de estar aqui representando canais de televisão e de rádio [...] Agora, quero ouvir daqueles que são proprietários de canais de televisão ou de ondas de rádios ou são seus prepostos, que estão aqui defendendo os interesses da Associação Brasileira das Empresas de Telecomunicações, que digam: "Estou aqui representando esses interesses" (CÂMARA, 2017c, p. 247).

[...] eu os desafio a provar que eu, ou qualquer membro da minha família, possui qualquer participação em alguma emissora de rádio ou televisão dentro do território brasileiro. Deixo aqui este desafio. Tenho ouvido, neste plenário e em outros lugares, essas mesmas afirmações mentirosas que visam a desacreditar as pessoas. Deixo-as passar, até porque, se eu fosse proprietário, Sr. Presidente, dentro do modelo de livre mercado, de livre iniciativa, de democracia representativa, que defendo e que meu Partido defende nesta Casa - não estaria cometendo nenhum crime (IDEM, p. 247). 
$\mathrm{Na}$ sequência dos debates, foi apresentada uma questão pelo constituinte Carlos Alberto Caó ocorrida na subcomissão 8b, para a qual o presidente considerou não haver nenhuma solução a oferecer. Tal discussão rendeu muito tempo, postergando o tempo destinado ao debate e angariando críticas à conduta do presidente. Em um momento, a constituinte Cristina Tavares chegou a pedir que o presidente solicitasse "[...] que se retirem deste plenário os proprietários de rádio e televisão que aqui estão representando empresas de rádio e televisão e estão sentados indevidamente" (IDEM, p. 249), como forma de terminar o problema. Assim, o presidente solicitou que os microfones fosses desligados com o objetivo de dar início ao processo de votação do primeiro substitutivo do relator, já que o segundo fora rejeitado. Houve solicitação de encaminhamento de votação, da parte do constituinte Fausto Rocha, o que foi negado pelo presidente. O relator solicitou que a presidência tivesse respeito para com ele e seu trabalho, solicitando que pudesse prestar esclarecimento quanto aos diferentes pontos constantes no $1^{\circ}$ texto:

Sr. Presidente, agradeço a gentileza de V. $\mathrm{Ex}^{\mathrm{a}}$ e peço que compreenda que não podemos entrar num processo de votação de um novo substitutivo sem encaminhamento de votação. Há alterações substanciais do primeiro para o segundo substitutivo, e me sinto no dever de dizer aos Srs. Constituintes quais são os pontos de diferença entre os dois substitutivos (IBIDEM, p. 250).

Desta forma, o presidente concedeu aos apelos dos constituintes, permitindo o encaminhamento da votação a Aécio de Borba, contrariamente, e a Octávio Elíseo, favoravelmente. Porém, quem apresentou a fala foi o constituinte Nelson Aguiar, citando um trecho da bíblia para criticar a ausência de regulamentações no texto do relator, que garantissem os direitos do menor, e, na sequência, Fausto Rocha fez a defesa do pagamento da escola pelos menos necessitados, de maneira que estes pudessem garantir o direito dos que não tivessem condições de fazê-lo.

Foi então passada a palavra ao relator, que iniciou uma leitura pausada do primeiro substitutivo, que afirmou ser menos elaborado que o segundo, e foi citando nominalmente os constituintes e suas posições contrárias, de forma que nos pareceu irônica. Destacamos o seguinte trecho que ilustra nossa afirmação:

“Art. 10. O ensino é livre à iniciativa privada, que o ministrará sem ingerência do Poder Público, salvo para fins de autorização, reconhecimento e credenciamento de cursos e supervisão da qualidade." O Constituinte Oliveira de Melo, que é 
dono de colégio, e que defende a idéia de que o ensino privado se liberte da tutela arbitrária do Estado, seguramente poderá falar com muita clareza sobre este texto, mas também seguramente votará contra o mesmo. "Art. 11. É assegurada a exclusividade de utilização das verbas públicas para o ensino público." Quem quiser, vote contra este princípio, que não pertence à esquerda ou direita, ou ao partido tal ou qual, mas é um ideal republicano que este País já teve e do qual se afastou (IBIDEM, p.252).

Passou-se à votação do substitutivo, que foi rejeitado por 37 votos contra $26^{59}$. Após a suspensão da reunião por três horas, a mesma foi retomada em um local diferente de onde acontecia antes. Vários constituintes reclamam do novo espaço que sediava as discussões, que Octávio Elísio disse ser devido à "uma crise de 'galeritite aguda' " dos parlamentares (IBIDEM, p. 253). Com a prerrogativa de manutenção da ordem, o presidente disse que usaria a força policial contra as pessoas presentes à audiência caso elas oferecessem algum tipo de ameaça aos parlamentares.

Muitos solicitaram questão de ordem para reivindicar a transferência da sessão para um local apropriado, e também buscavam oferecer saídas ao impasse que fora criado, com a rejeição dos dois textos apresentados pelo relator. O mesmo se prontificou a escrever novo relatório, o que foi negado, pois, como apresentado nas páginas anteriores, deveriam ser votadas as emendas e, depois desse percurso, o relator poderia optar por escrever ou não um novo documento. Novo impasse se estabeleceu, posto que muitos, inclusive o relator, consideravam ser impossível emendar um texto que ainda não existia. Após o debate acalorado sobre votação de emendas, encaminhamento ou não de relatório à subcomissão de sistematização, sobretudo com a intervenção do constituinte Gumercindo Milhomem junto ao presidente, no sentido de pressioná-lo a oferecer uma resposta quanto a inviabilidade de envio de documento por falta de tempo hábil, o mesmo optou por suspender a sessão faltando apenas sete minutos para a meia-noite.

\footnotetext{
59 Votaram "sim” os constituintes: Antônio Gaspar - Artur da Távola - Carlos Alberto Caó - Cássio Cunha Lima - Cristina Tavares - Fernando Cunha - Flávio Palmier da Veiga - Florestan Fernandes - França Teixeira Hermes Zaneti - Joaci Góes - Louremberg Nunes Rocha - Koyu lha - Márcia Kubitschek - Maria Lúcia - Nelson Aguiar - Octávio Elísio - Olívio Dutra - Paulo Silva - Pompeu de Souza - Rita Camata - Sólon Borges dos Reis - Tadeu França - Ubiratan Aguiar - José Maurício - Gumercindo Milhomen. Votaram "não" os constituintes: Aécio de Borba - Agripino de Oliveira Lima - Álvaro Valle - Ângelo Magalhães - Antônio de Jesus - Arnold Fioravante - Arolde de Oliveira - Átila Lira - Bezerra de Mello - Cláudio Ávila - Dionísio Hage - Eliel Rodrigues - Ervin Bonkoski - Eunice Michiles - Fausto Rocha - Francisco Diógenes - Iberê Ferreira - João Calmon - João de Deus Antunes - José Carlos Martinez - José Elias - José Moura - Marcondes Gadelha - Matheus Iensen - Mendes Ribeiro - Onofre Corrêa - Osvaldo Sobrinho - Paulo Marques - Rita Furtado - Roberto Augusto - Roberto Vital Vingt Rosado - Eraldo Tinoco - Rodrigues Palma - Ruberval Pilotto - Renato Jonhsson - Luís Eduardo.
} 
No início da tarde do dia seguinte foi retomada a sessão, para a qual o presidente chamou os constituintes ao entendimento, uma vez que a "Constituição é [seria] apenas a ata de um pacto social" (CÂMARA, 2017c, p. 262). Na sequência a reunião foi novamente suspensa pelo período de uma hora, em respeito ao falecimento do senador Fábio Lucena, do PMDB. No retorno, o presidente leu um pedido de 32 parlamentares para que as galerias fossem evacuadas e o aprovou, gerando a crítica de alguns constituintes, como Cristina Tavares, que fez uso do microfone para registrá-la, assim como vários outros presentes, ao que respondeu Marcondes Gadelha:

Srs. Constituintes, V. Exas me pediram para permitir o acesso do público às galerias. Se aqui dentro o clima é de tal emocionalidade, o que é que teremos com uma galeria acionada para vaiar, aplaudir ou rir, quando se julga conveniente dentro do plenário, para gritar e perturbar a ordem? Se V. Ex ${ }^{\mathrm{a}}$ não se responsabilizam sequer pela tranqüilidade aqui dentro, como vão se responsabilizar pela galeria? (IDEM, p. 269).

Brandão Monteiro, do PDT, solicitou que os representantes dos lobbies de canais de televisão também fossem retirados do plenário, já que a população em geral não poderia ocupar aquele espaço. Desta forma, novamente os trabalhos foram suspensos, sendo retomados com a tentativa de votação das emendas. O presidente foi então informado que um grupo de constituintes tentava formalizar um acordo, de maneira a viabilizar o trabalho na comissão. Compunha o grupo os seguintes parlamentares: Hermes Zaneti, Florestan Fernandes, Carlos Alberto Caó, Eraldo Tinoco, João Calmon e Mendes Ribeiro. Novamente a sessão foi suspensa para que o grupo pudesse avançar nas negociações. Após meia hora, foram retomados os trabalhos, sendo que as negociações ainda precisariam ter mais tempo para avançar. Sobre este processo de entendimento, relatou Hermes Zaneti que, apesar do esforço, percebia que apenas um grupo estava cedendo nos pontos nos quais inexistia o consenso:

Estou explicando que havia divergências, também, do nosso grupo com o substitutivo e nenhuma delas foi levada em conta, nenhuma foi contemplada. Partimos das divergências do outro grupo, de tal sorte que fomos cedendo do ponto zero; qualquer coisa, a partir daquele momento, estávamos cedendo para um grupo! E o que quero explicar a V. Ex a , até que os Anais da Assembléia Nacional Constituinte registrem também este esforço para o entendimento (IBIDEM, p. 271). 
Na mesma linha do que argumentara Zaneti, Mendes Ribeiro também já sinalizava para a possibilidade da comissão não fechar um relatório, deixando tal tarefa para a comissão de sistematização:

Sr. Presidente, avançamos muito. A Constituição não termina aqui, e a Constituinte não se exaure nesse esforço. É apenas uma etapa da caminhada. Chegamos a uma grande conclusão: nenhum de nós vai lucrar com a exacerbação de ânimos. Podemos estar separados em alguns pontos hoje, mas estaremos juntos amanhã. Para a tranqüilidade do público que nos prestigia e de quem nos questiona, é preciso ficar bem claro que, se esta Comissão não tiver um relatório, a Comissão de Sistematização receberá todo o material e fará o seu papel. Isto está previsto, $\mathrm{Sr}$. Presidente, no próprio Regimento da Assembléia Nacional Constituinte (IBIDEM, p. 271).

Destarte os entendimentos que começaram a ser encaminhados, mas não chegaram a termo, o presidente continuou o processo de votação do recurso, a pedido do deputado Arolde de Oliveira, para que se pudesse iniciar a votação dos destaques feitos ao corpo do substitutivo, que fora rejeitado. A mesa entendeu que não era possível tal votação, uma vez que não existia mais o texto mencionado. Cabe ressaltar que a votação não era desejada por muitos dos presentes. Diante do impasse, muitos constituintes se recusaram a votar por considerar a proposta contrária ao regimento. Assim, a maioria absoluta - 33 votos foi contra a votação proposta por Arolde de Oliveira, sendo que apenas seis constituintes votaram a favor e 24 se abstiveram.

O relator solicitou a palavra para fazer mais um apelo ao consenso da comissão, posto que, segundo ele, haveria apenas 5 pontos de dissenso. Tentou, pois, explicitar em quais temas haveria maior relutância e concluiu que o grupo teria apenas duas horas para tentar chegar a um texto que pudesse seguir as etapas previstas no processo constituinte:

Estou convencido - e preciso dizê-lo com franqueza - que na área da educação ainda não estão esgotadas, a meu juízo, as possibilidades de entendimento; que na área da ciência e tecnologia há, praticamente, um consenso; que na área da cultura podemos aprovar, praticamente, todo o capítulo; que na área da família poderemos aprovar todo o capítulo; que na área do menor não há dissensões; que na área do idoso apenas uma pequena passagem de sugestão para artigo com a qual até, eventualmente, o Relator não concorda, mas abre mão, que nos permitiria sair daqui com um belo projeto e uma sólida demonstração do penoso, sofrido e honrado trabalho que fizeram os Srs. Constituintes ao longo desse tempo (IBIDEM, p. 272). 
Alguns encaminhamentos ainda foram propostos, no sentido que a comissão temática fizesse uso dos textos oriundos das três subcomissões para envio à comissão de sistematização. Todavia, o presidente respondeu que este não seria o entendimento da mesa diretora da ANC, posto que, segundo parecer já emitido, os textos das subcomissões deixaram de existir quando se iniciaram as atividades das oito comissões. Desta forma, suspendeu novamente a sessão por trinta minutos na busca de uma última oportunidade de entendimento.

No retorno da sessão, Marcondes Gadelha começou a verificar a ordem de precedência para a votação; e, novamente, foi solicitada uma questão de ordem para se questionar a insanidade que seria votar termos acessórios de um conjunto que não mais existia. Álvaro Valle falou sobre a inviabilidade de se votar qualquer proposta em uma hora (já era 23 horas) e entregou ao presidente o que ele chamou de um documento que viria a expressar as concepções da maioria dos constituintes do plenário. Da mesma forma, Aldo Rabelo reafirmou os princípios de seu partido, ressaltando o compromisso com a educação pública e com a democratização dos meios de comunicação, pontos extremamente polêmicos do debate. Foi adiante, proclamando sua preocupação com o rumo tomado nos debates e nas posições que começavam a despontar no processo constituinte:

[...] o Partido Comunista do Brasil está extremamente preocupado com os rumos da Assembléia Nacional Constituinte: infelizmente, o que estamos vendo aqui prevaleceré a influência do Poder Executivo, a influência dos militares, a influência de grupos econômicos e a nossa esperança é que os relatórios conservadores vão chegar ao conhecimento do povo brasileiro (CÂMARA, 2017c, p. 274).

Continuando a ordem das falas, o líder do PFL, José Lourenço, afirmou que “[...] os representantes do diversos Partidos com assento nesta Casa, PFL, PMDB, PDT, PL, PTB, PDS, entregaram a V. Exa um documento que representa 2/3 da Comissão" (IDEM, p. 274), ratificando o que já mencionara Álvaro Valle. Antônio Brito, líder do PMDB, afirmou que “[...] aqueles que pensam que a Constituinte poderá gerar um texto que faça praça apenas de algumas idéias poderão ganhar aqui e perder na História" (IBIDEM, p. 274). Recebendo tempo do líder de seu partido, Hermes Zaneti afirmou que a comissão vivia um estelionato, pois o documento mencionado pelo líder do PFL não representava nenhum consenso, mas apenas as concepções de um grupo. Acusou, inclusive, o ministro Antônio Carlos Magalhães de intrometer-se nos entendimentos que estavam em curso naquela sessão, 
inviabilizando-os. Brandão Monteiro, líder do PDT, também defendeu o compromisso de seu partido com a escola pública e afirmou desconhecer o documento que o líder do PFL disse ter sido também consignado pelo PDT. Sólon Borges, vice-líder do PTB também fez uso da palavra, demonstrando apoio ao trabalho de relatoria de Artur da Távola; Florestan Fernandes falou em nome do PT. Dele destacamos um trecho do discurso, uma vez que resgatou aspectos de sua vida e sua obra para explicar as posições adotadas pelo seu partido na comissão temática:

Represento aqui o homem pobre do povo, aquele homem pobre do povo que chegou à universidade, e que, além de chegar à universidade, chegou também ao Parlamento, para dizer aqui que o Brasil não pode continuar a viver na situação em que se encontra, sob uma ditadura militar disfarçada, sob uma tirania política e sob um regime educacional em escombros, apodrecido, mercantilizado. Nós tentamos, nesta Comissão, durante vários dias, transformar o sistema de ensino brasileiro. No entanto, nós não tivemos êxito. Não tivemos êxito por quê? Porque realmente esta Casa bafeja os interesses dos poderosos. Encontramos pessoas que pretendem, através do ensino, controlar as consciências; pessoas que através do ensino pretendem aumentar suas fortunas. Encontramos poucas pessoas que queriam se devotar realmente à solução dos nossos problemas educacionais. Em nome do PT, represento aquele setor da sociedade brasileira que são os oprimidos, que são os famintos, que são os analfabetos, milhões de analfabetos. Por eles nós devíamos fazer uma revolução educacional (IBIDEM, p. 276).

Retomou ainda os debates dos anos de 1960, quando da aprovação da LDBEN de 1961, diferenciando os momentos históricos, posto que acreditava que ainda havia espaço para luta nas etapas subsequentes da ANC. Em continuidade, Aécio de Borba agradeceu ao presidente e constituintes que com sucesso conseguiram obstruir o trabalho da maioria, que objetivava finalizar o relatório. Por fim, o presidente passou o tempo disponível ao relator, que fez uma crítica aos partidos majoritários - PFL e PMDB, que não conseguiram uma unidade no trabalho constituinte. Em resposta às críticas ao seu partido, José Lourenço afirmou que o relator não representava a maioria, mas era a figura que buscava materializar os interesses "radicais" na elaboração da nova carta magna. Finalizou afirmando que o plano destes radicais era a estatização da educação, como observamos no trecho abaixo:

E o que se pretendeu fazer aqui hoje, senão estatizar tudo, estatizar o ensino, estatizar as comunicações, estatizar tudo. Pretendeu-se entrar hoje aqui na contramão da História, pretenderam jogar o Brasil na contra-mão da História, mas nós que somos a maioria iremos com o Brasil na mão da História (IBIDEM, p. 278). 
O presidente passou à leitura do documento que lhe foi entregue, que citava, entre outras questões, o plano de grupos de constituintes que desejavam boicotar a elaboração do texto na comissão. Após a leitura, concedeu a palavra rapidamente ao líder do PMDB, senador Mário Covas, posto que o partido já havia recebido seu tempo de fala; tendo o mesmo recusado tal concessão e argumentado contra a postura do presidente. Por fim, Marcondes Gadelha elaborou sua argumentação final, destacando o esforço no cumprimento do regimento e a retidão de suas ações na condução dos trabalhos, que foram finalizados às uma hora e sete minutos.

Cunha (2009) e Pinheiro (2005) concordam em suas análises ao relatarem que a comissão 8 teve um perfil centro-conservador, tendo o grupo progressista sido derrotado em suas propostas. Também afirmaram que as questões mais problemáticas do debate ali estabelecido não eram propriamente oriundas do campo educacional, mas já haviam se iniciado nas outras subcomissões, e diziam respeito ao controle dos meios de comunicação - como observamos claramente no material apresentado anteriormente, e mesmo no início deste capítulo - e à questão da condenação do controle da natalidade, entre outros aspectos. Ambos também destacaram que os constituintes evangélicos se filiaram ao grupo conservador, ou seja, aos parlamentares ligados aos setores da telecomunicação e aos representantes das empresas de ensino, para rejeitar os dois textos apresentados pelo relator, com vistas a aprovação de suas emendas, isoladamente. Todavia, a obstrução dos trabalhos não permitiu que lograssem total êxito, ficando para a comissão de sistematização tal responsabilidade, como veremos no item seguinte.

Segue, abaixo, a exemplo do que fizemos no subcapítulo anterior, um quadro com a posição dos constituintes neste espaço da ANC: 
QUADRO II - Espaço da Comissão 8

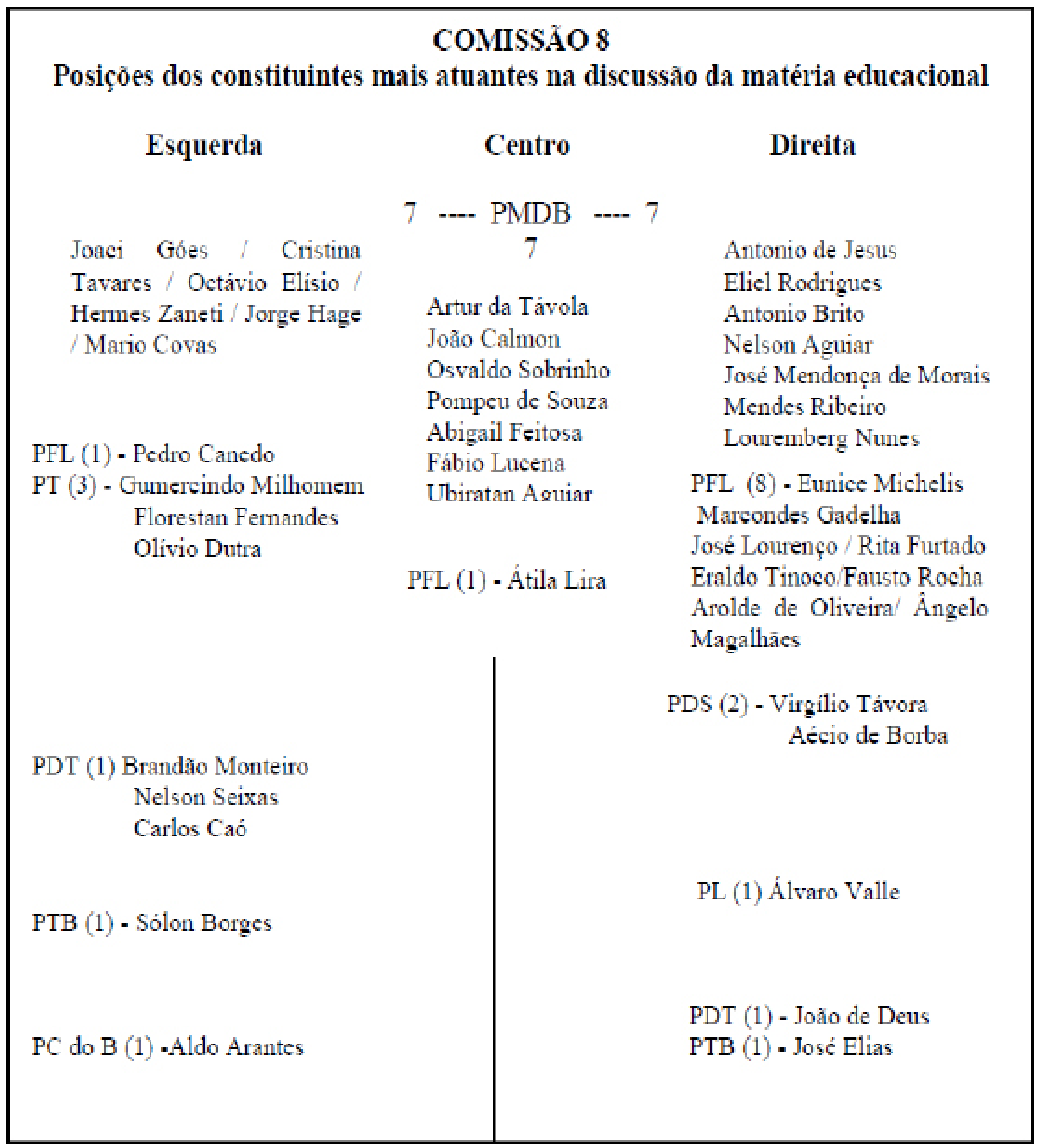

Cabe ainda um destaque para a atuação da sociedade civil nesta etapa da ANC, que se deu de forma diferenciada, como até então apresentamos. Na subcomissão 8a, em todas as sessões estiveram presentes representantes de setores organizados do campo educacional; neste momento, tal participação direta se deu em momentos isolados e se concentrou mais na formação de lobbies com os constituintes, o que também ficou evidenciado nas colocações e discussões que transcrevemos. Nas palavras de Pinheiro (2005, p. 271- 272): 
A tática empregada foi a de procurar influenciar os votos dos parlamentares. A caça aos votos assumiu formas distintas: o trabalho de convencimento [...]; os grupos de pressão [...]; e os lobbies [...] A movimentação na Constituinte também assumiu novos aspectos. Ao invés de salas repletas de pessoas, onde se discutia e aprofundava determinados temas, passou-se a privilegiar os corredores e as visitas aos gabinetes. A mobilização foi substituída pelos conchavos e pelas pressões nas galerias.

Sobre as galerias, percebeu-se o forte incômodo que geraram nos constituintes mais ligados ao campo conservador, que insistentemente buscaram afastar a presença popular daquele espaço, conseguindo tal feito na última e mais difícil sessão.

\subsection{O TRABALHO NA COMISSÃO DE SISTEMATIZAÇÃO - AGENTES, PARTIDOS, ASPECTOS GERAIS E DA EDUCAÇÃO}

Após o desgastante trabalho da comissão 8, que teve fim sem lograr êxito - ou sem ter produzido um relatório final, o que por si só pode ser considerado uma vitória frente às condições colocadas - a comissão de sistematização iniciou sua dinâmica no dia nove de abril de 1987, com a eleição de seus membros. Foram realizadas reuniões entre os dias 24/04/1987 e 24/11/1987, ou seja, por sete meses, até a aprovação de um texto que serviu de base para a última instância que deveria percorrer - a comissão de redação final ${ }^{60}$ - até virar, finalmente, a Constituição Federal que foi promulgada.

Diferentemente dos outros itens deste capítulo, nos quais fizemos a leitura das atas pertinentes à cada sessão, neste momento utilizamos um filtro de busca para selecionarmos o material de nossa análise, uma vez que as atas da comissão de sistematização são constituídas por um vasto material. Desta forma, utilizamos a palavra educação na ferramenta de busca do programa adobe acrobate reader para ter acesso apenas às ocorrências que nos ligassem ao tema de estudo. As atas resultantes dos debates da comissão de sistematização se encontram divididas em quatro documentos: 9a, com 816 páginas, nas quais encontramos 402 ocorrências do termo procurado; 9b, com 1.058 páginas e 79 ocorrências encontradas; 9c, com 519 páginas e 138 ocorrências da palavra buscada; e $9 \mathrm{~d}$, com apenas 4 páginas, que trata da entrega do texto final à comissão de redação, sem nenhuma ocorrência específica

60 A primeira sessão realizada na comissão de redação final foi no dia 20/04/1988, na qual instalou-se. No dia 20/09/1988 aconteceu a última sessão de debates, sendo a versão final da Constituição Federal finalmente apresentada no dia 05/10/1988. As atas da comissão de redação estão agrupadas em 235 páginas e, segundo a metodologia adotada para a leitura das atas da comissão de sistematização, descrita no corpo do texto, encontramos 15 ocorrências do termo educação. No entanto, tal comissão não será abordada nesse estudo, por não compor nosso objeto de pesquisa. O texto que lá chegou já fora acordado anteriormente, não havendo questões significativas a serem analisadas, pertinentes aos grupos políticos que a discutiram naquele espaço. 
ao vocábulo em questão.

Nos trechos pertinentes à matéria educacional, que estudamos e que serão descritos nas próximas linhas, aparecem recorrentemente no debate vinte e nove constituintes, e deles buscamos alguns dados biográficos para sustentar algumas de nossas sínteses. Dentre estes, seis ${ }^{61}$ participaram dos debates nos três espaços analisados; outros seis ${ }^{62}$ constituintes participaram de mais um espaço, além desta comissão; e, por fim, dezessete ${ }^{63}$ participaram efetivamente no debate educacional apenas na comissão ora apresentada.

Voltemos, pois, à sessão de instalação da comissão, na qual foram apresentados os nomes que seriam votados para ocupação dos lugares de destaque naquele espaço. Presidiu a abertura dos trabalhos o constituinte Afonso Arinos, redator do texto na Comissão dos Notáveis. Logo após o começo da sessão, assumiu a presidência provisória o constituinte Nelson Carneiro, devido ao interesse de Arinos na ocupação efetiva da presidência, que seria votada em seguida. Logo no início dos debates os constituintes José Genuíno, Luís Inácio Lula da Silva e Gerson Peres apresentaram questões de ordem para questionar a composição da comissão, pois estava com um número maior do que o previsto no regimento. Notou-se a preocupação na seguinte fala do constituinte José Genoíno:

Ao concluir minha questão de ordem, Sr. Presidente, reafirmo minha posição no
sentido de que não podemos, numa questão tão significante, tão importante, alterar
o regimento interno num ponto que é claro, isto é: são 49 membros, e a lista
da Comissão de Sistematização está composta por 53 , nesta fase inicial. Com
mais 40 , teremos, portanto, 93 membros, quando o Regimento Interno é claro ao
estabelecer (CÂMARA, 2017d, p. 2).

Seguiram-se à sua intervenção a dos demais constituintes listados. A presidência responsabilizou-se por confirmar tal número, porém afirmou que isto não influenciaria na eleição da mesa diretora da comissão. Sobre os nomes indicados, passou à fala o líder do PMDB, senador Mário Covas, que encaminhou a proposta, com base nos acordos previamente delineados:

\footnotetext{
$61 \quad$ Florestan Fernandes (PT), Hermes Zaneti (PMDB), Artur da Távola (PMDB), Octávio Elísio (PMDB), Gumercindo Milhomem (PT) e Sólon Borges dos Reis (PTB).

62 Osvaldo Sobrinho (PMDB), Nelson Seixas (PDT), José Mendonça de Morais (PMDB), Jorge Hage (PMDB), Eraldo Tinoco (PFL), e Bezerra de Melo (PMDB).

63 Afonso Arinos (PFL), Nelson Carneiro (PMDB), José Genuíno (PT), Lula (PT), Gerson Peres (PDS), Sandra Cavalcanti (PFL), Bernardo Cabral (PMDB), Carlos Sant'Ana (PMDB), Celso Dourado (PMDB), José Tavares (PMDB), Lysâneas Maciel (PDT), Jamil Haddad (PMDB), Mario Lima (PMDB), Virgildásio de Sena (PMDB), José Maurício (PDT), Mozarildo Cavalcanti (PFL) e Victor Faccioni (PDS).
} 
Sr. Presidente, para esta Comissão a Presidência, como em todas as demais, nos acordos feitos, e por intermédio desses acordos, caberá ao Partido da Frente Liberal, e o PMDB votará em seu candidato. A $2^{\text {a }}$ Vice-Presidência pertencerá

ao PDT, e o PMDB votará no candidato do PDT. No caso da $1^{\text {a }}$ Vice-Presidência, efetivamente o partido optou, hoje, por uma decisão, através da sua bancada. Isto é um problema de sua economia doméstica - e, ao final, de certa forma, referendado pela própria bancada -, e solicitou o partido ao ilustre Constituinte Pimenta da Veiga que aceitasse ocupar, em nome do PMDB, a $1^{\text {a }}$ Vice-Presidência. Sabemos e sabíamos do pleito do ilustre e honrado companheiro Aluízio Campos. Nada nos deixa em situação tão intranqüila quanto a de termos, em certas circunstancias, de optar, quando existe mais de um companheiro disputando, com igualdade de condições e com igual potencial, a mesma posição. Todavia, não apenas a bancada, como de resto a própria bancada do PMDB na Constituinte, com um documento com quarenta assinaturas, demanda-nos que o candidato à $1^{\text {a }}$ Vice-Presidência - sem que isso represente qualquer desprestígio à ilustre figura que toda a Casa aprendeu a respeitar e que certamente tem um excepcional trabalho a oferecer a esta Comissão e, mais do que isso, à consolidação da nova Constituição, sem embargo disso - o candidato decorrente da vontade não apenas da bancada, como de resto da própria bancada do PMDB, dentro desta Comissão, é o Constituinte Pimenta da Veiga (IDEM, p.5).

Como vimos também na abertura do presente capítulo, interessavam-se pelo lugar da relatoria os constituintes Fernando Henrique Cardoso (PMDB), Pimenta da Veiga (PMDB) e Bernardo Cabral, também do PMDB. Sobre os acordos partidários para ocupação dos espaços, Aluízio Campos teceu a seguinte crítica:

Não concordo com o nobre Líder Mário Covas sobre que o partido deva indicar nomes aos lugares que, por acordo político, pertençam a essa ou àquela agremiação. O acordo político versa sobre posições constitutivas da Mesa. Reservou-se ao PFL a indicação de Presidente; ao PMDB, a indicação da $1^{\text {a }}$ Vice-Presidência; ao PDT, nesta Comissão, a indicação da $2^{\text {a }}$ Vice-Presidência. Mas a eleição para preenchimento desses cargos não se faz na órbita exclusiva de nenhum partido. O Regimento determina que a eleição é procedida pelos elementos integrantes da Comissão, que é constituída pela representação proporcional de todas as agremiações partidárias. Então, não é somente com os votos do PMDB que será eleito o $1^{\circ}$ Vice-Presidente; ao PDT, nesta Comissão. Quando mais de um candidato do mesmo partido deseja concorrer ao cargo, o que se faz democraticamente é deixar a questão em aberto, para que todos os componentes da Comissão possam manifestar-se livremente sobre a escolha (IBIDEM, p. 6).

Após o debate, foram eleitos para a mesa os seguintes nomes, após a verificação da presença de 86 votantes: Afonso Arinos: 74 votos e doze em branco; 48 votos para 
Aluízio Campos contra 35 votos de Pimenta da Veiga e três em branco, para a vaga de primeiro vice-presidente; e 70 votos para Brandão Monteiro e dezesseis em branco, para a vaga de $2^{\circ}$ vice-presidente. No que se refere à relatoria, o líder do PMDB fez a seguinte declaração, ratificando uma observação realizada no início deste capítulo e também no livro de Carvalho (2017), no qual diversos atores narraram tal fato:

Sr. Presidente, antes de mais nada, quero congratular-me com aqueles que neste instante acabam de ser guindados às difíceis e trabalhosas tarefas de Presidente, $1^{\circ}$ e $2^{\circ}$ Vice-Presidentes da Comissão de Sistematização, processo que se completa com a designação do Relator, que neste instante, em nome do PMDB, aponto na figura do Deputado Bernardo Cabral (CÂMARA, 2017d, p.7).

Passemos à biografia dos membros da mesa, tal como fizemos nos subcapítulos anteriores. O presidente Afonso Arinos de Melo Franco (CPDOC, 2017p) é oriundo de uma tradicional família de políticos, intelectuais e diplomatas. Seu pai foi ministro no governo Delfim Moreira, embaixador do Brasil na Liga das Nações e ministro das relações exteriores de Getúlio Vargas. Seu tio foi escritor, e um de seus irmãos, Virgílio de Melo Franco, foi importante líder civil da Revolução de 1930. Bacharel em direito e atuante no meio jornalístico, participou da Aliança Liberal e, nos anos de 1930, dirigiu importantes jornais no país. No período do Estado Novo, dedicou-se à vida acadêmica. Foi oposição à Vargas, líder da UDN. Foi um dos fundadores da ARENA, após a deposição de Jango e, mais tarde, tornou-se crítico ao regime, retornando às atividades acadêmicas. Em 1986 elegeu-se senador pelo PFL, sendo que em 1988 migrou para o PSDB.

O primeiro vice-presidente Aluísio Afonso Campos (CPDOC, 2017q), administrador de empresa, advogado e pecuarista, bacharelou-se em ciências jurídicas e sociais. Foi deputado estadual em 1934 pelo PP. Com a redemocratização em 1946, filiou-se ao PSB, e, mais tarde, com a ditadura empresarial-militar, filiou-se à ARENA. Em 1982 passou a ser do PMDB. Foi eleito deputado em 1983, votando favoravelmente à emenda Dante de Oliveira. Em 1986 foi reeleito deputado federal pelo mesmo partido.

O segundo vice-presidente José Carlos Brandão Monteiro (CPDOC, 2017r) começou a vida política cedo, militando no movimento estudantil. Durante o curso de direito, foi vicepresidente da UNE, em 1963. Com direitos políticos suspensos e cassado de seu emprego no banco do Brasil em 1964, dedicou-se à carreira de advocacia, sendo preso mais de uma vez e torturado pelo regime. Após a extinção do bipartidarismo, foi um dos fundadores do 
PDT, sendo eleito deputado em 1982. Durante o mandato, votou a favor de eleições diretas e, vencida essa possibilidade, apoiou Tancredo Neves à presidência; todavia, foi contra o mandato de cinco anos para o presidente José Sarney.

O relator José Bernardo Cabral (CPDOC, 2017s), bacharel em direito e ciências contábeis, foi aprovado promotor em 1956, mas retornou ao exercício da advocacia. Em 1958 se formou em serviço social e psicologia. Em 1962 foi eleito deputado pelo PTB. Após o golpe de Estado, filiou-se ao MDB, sendo novamente eleito deputado federal em 1966. Com a cassação de seus direitos políticos, em 1966, atuou na OAB, sendo, inclusive, seu presidente. Posteriormente, filiou-se ao PMDB, onde concorreu ao mandato de deputado federal, em 1986, para o qual foi eleito com o apoio do governador do Amazonas, mantendo, inclusive "um gabinete no palácio do governo, onde seu filho atendia aos eleitores". Teve uma atuação muito criticada na ANC: primeiramente objetivou a presidência da mesma; apoiou Mário Covas à liderança do $\mathrm{PMDB}$, recebendo, em seguida, sua indicação para a relatoria da presente comissão, como vimos anteriormente. Considerado como um parlamentar de atuação mais ao centro, ao mesmo tempo que se intitulava "isento", foi acusado de ligações com a máfia dos jogos. Sua atuação política foi vinculada à barganha, como afirmaram quase todos os entrevistados do livro de Luiz Maklouf Carvalho (2017), a começar pela sua indicação com o apoio do ministro do Exército do governo Sarney - general Leônidas Pires (IDEM, p.64), e pela redação do texto constitucional em congruência com o desejo do governo, conforme narrou o presidente Sarney (IBIDEM, p.51). Segundo o Centro de Pesquisa e Documentação de História Contemporânea do Brasil (2017s), existia ligações do parlamentar e a busca por favorecimento de grupos, como foi o caso da UDR. Respondeu a críticas também pela super valorização do regimento interno da comissão e pelos anteprojetos por ele organizados:

Refutando as críticas de que teria cedido às facções políticas na redação de seu substitutivo e de que teria traído o acordo feito com os militares, afirmou que o governo estaria procurando usá-lo como "bode expiatório" do agravamento da crise e do fracasso das medidas oficiais para reduzir o déficit público. Haveria, segundo ele, uma "trama" para desmoralizar seu trabalho, com o objetivo de desviar a atenção da opinião pública do grave quadro nacional. Tanto no Senado como na Câmara recebeu apoio dos parlamentares em relação ao episódio. Ainda na primeira fase da Constituinte, chamou de fantasioso o artigo que incluía entre os direitos sociais a jornada de trabalho de 40 horas semanais e a estabilidade no emprego, que, em sua opinião, não deveriam constar do texto constitucional. Em julho de 1988, entregou o texto para o segundo turno das votações na ANC, sendo novamente acusado de alterar seu conteúdo. Nessa segunda fase, porém, 
deu parecer contrário às emendas supressivas aos direitos individuais e sociais aprovados anteriormente (IDEM, p.1).

Voltemos às atas. Não as acompanharemos por datas e sessões, mas apenas com base na temática educacional, conforme já explicamos anteriormente. A primeira aparição da palavra educação se deu vinculada a uma proposta de emenda modificativa, na qual se trocaria o termo direito por acesso. A constituinte Sandra Cavalcanti falou sobre a falta de legitimidade que a comissão 8 passou a ter, por não ter sido capaz de gerar um produto de seu trabalho, tal como as demais. Assim sendo, sugeriu que essa discussão tivesse prioridade sobre as demais, solicitação que foi atendida.

Afonso Arinos informou que Ulysses Guimarães respondeu ao questionamento que lhe fora enviado, sobre a possibilidade de emendar o anteprojeto, o que foi confirmado. Desta forma, Sandra Cavalcanti questionou se feito o destaque à discussão preliminar do capítulo da educação, ao final este já poderia ser incorporado ao anteprojeto. O relator então respondeu afirmativamente a tal questionamento. Mais adiante, a constituinte afirmou que o texto apresentado por Bernardo Cabral, que teve a tarefa regimental de elaborar um documento, já que a comissão não o fizera, buscava resgatar o substitutivo rejeitado naquele espaço. Acusou-o de privilegiar o texto de seu correligionário, desconsiderando o histórico da situação, que fez questão de relembrar:

[...] durante os seus trabalhos tivesse sido organizados dois projetos e, ao final, o Presidente da Comissão tivesse enviado ao Presidente da Comissão de Sistematização relatório contendo substitutivo que logo na primeira fase de apresentação, foi rejeitado; igualmente na segunda fase de apresentação foi rejeitado, acompanhou-o um documento assinado pela maioria dos integrantes daquela comissão, onde se consubstanciava a opinião daquela eventual maioria. $\mathrm{O}$ trabalho em si esbarrou em alguns pontos conflitantes. Tenho a impressão de que o Relator Bernardo Cabral tentou - ao elaborar o texto nos termos do Regimento Interno - conciliar, da forma mais adequada, as duas correntes de opinião e os dois grupos que, na Comissão, não chegaram a se entender (CÂMARA, 2017d, p. 172-173).

Assim sendo, a parlamentar do PFL considerou como vontade da maioria o documento entregue pelo líder do seu partido, expressando, desta forma, como vontade coletiva, as decisões de uma parcela daquele grupo. Assim, prosseguiu deferindo sugestões quanto a redação do artigo $1^{\circ}$, que deveria ser mais completa, de acordo com sua visão; falou sobre o auxílio suplementar aos estudantes; as verbas, entre outras questões. Carlos 
Sant'Ana mencionou a problemática do salário educação e a diferença entre a educação e a cultura, no que é pertinente a diferenciação para a restrição do uso de verba pública nestes espaços. Voltando a fala à Sandra Cavalcanti, a mesma propôs também a eliminação de alguns artigos, especificamente dos que se referem à exclusividade de aplicação dos recursos públicos nas entidades públicas (seriam os artigos 342, 495 e 496). Ainda sobre os recursos públicos, disse que a comissão de tributos derrubou a discussão sobre vinculação constitucional obrigatória, e, portanto, tal seria a lógica ao pensar na proposição defendida por parte dos parlamentares da comissão temática.

Octávio Elísio trouxe a questão da vinculação orçamentária, do salário educação, do estabelecimento de prazos para criar uma LDBEN. Artur da Távola falou sobre a educação e a escola pública como formas de atingir democraticamente parcelas mais significativas da população. Eraldo Tinoco mais uma vez abordou a questão da exclusividade da aplicação dos recursos públicos em escolas públicas, que ele considera que enquanto não houver escolas dignas para todos, não existirá a possibilidade de cumprir tal princípio. Solicitou, pois, uma exceção no texto, para contemplar em um período transitório outras instituições, não públicas. Por fim, considerou que o texto constitucional precisaria ser "o mais claro possível e deva ser destinado ao entendimento de uma pessoa de inteligência e conhecimento médios" (IDEM, p. 179).

Somente mais adiante apareceu nova menção ao vocábulo que utilizamos como filtro. João Botelho, orador convidado para a sessão, representando a Associação Nacional dos Funcionários do banco do Brasil, destacou que na redação final da Constituição deveria se optar por um meio termo entre os constituintes. Mais adiante, Chico Humberto mencionou a questão da educação especial e da necessidade da utilização de métodos especiais de educação. Nelson Seixas resgatou a discussão da vinculação, presente na emenda Calmon. Outras questões também foram levantadas: a educação como direito universal em contraponto ao ingresso prematuro de jovens no mercado de trabalho; a obrigação deste mesmo Estado no oferecimento de educação especializada e gratuita. $\mathrm{Na}$ apresentação de Deodato Riviera, em defesa dos direitos das crianças, a gratuidade apareceu como forma das crianças das classes populares terem acesso e garantia de permanência na escola. Vidal Didonet, especialista em educação infantil, destacou o direito ao futuro via educação, tendo esta uma função equalizadora e compensadora das diferenças de nascimento e 
das ocasionadas pelas diferentes oportunidades oferecidas a cada agente. Desta forma, no substitutivo deveria, pois, constar a obrigatoriedade da pré-escola. Dom Cândido de Padim - coordenador da comissão da CNBB de acompanhamento da Constituinte e Bispo de Bauru - defendeu a emenda número 10, de autoria da CNBB, AEC e ABESC, que abordava a destinação dos recursos por meio de uma crítica ao "estatismo" que, segundo o interlocutor, prejudicava a maneira de ordenar a educação.

Sólon Borges trouxe também uma reflexão sobre a qualidade educacional e citou, inclusive, a necessidade de elaboração de uma nova LDBEN. Houve um breve debate entre Artur da Távola e Dom Cândido, posto que o primeiro entendeu que na abertura do capítulo da educação deveria ter uma definição do conceito, enquanto aquele defendeu que não tivesse. Celso Dourado tratou a educação como uma atividade fracassada, sendo que Dom Cândido considerou tal fracasso como resultado da perspectiva intervencionista do Estado, que inviabiliza uma real liberdade de ensino.

Hermes Zaneti citou uma cartilha publicada pela FENEN, que incitava a agressão da população aos constituintes no processo de votação do texto na comissão temática 8 . Sobre o referido material, encontramos uma publicação da página 2 do Jornal do Brasil, do dia 23 de julho de 1987, cujo título da matéria era Cartilha diz que vale até ameaças. Nela se afirmava que a Federação distribuíra uma circular, que virou um cartilha, aos diretores de escolas, incitando-os à ocupar as galerias e mesmo agredir os constituintes e demais participantes. Destacamos o trecho que, inclusive, classifica os parlamentares em "amigos" e "cubanos":

Precisamos de muita gente para encher galerias. Além de diretores, esperamos que cada sindicato traga uns seis funcionários para a "tropa de ocupação". Na terceira página, há uma lista dos constituintes "amigos", acompanhada da observação: "Votaram com a escola particular e com as empresas de comunicação através de aliança ou por convicção pessoal". Amigos — A lista dos "amigos" inclui 45 parlamentares do PMDB, PDS, PFL, PTB e PL. Estão, por exemplo, o líder do PFL, José Lourenço (BA), Mendes Ribeiro (PMDB-RS), Álvaro Valle (PL-RJ), Rita Furtado (PFL-RO), Fausto Rocha (PFL SP), Marcondes Gadelha (PFL PB). Na página seguinte estão os constituintes"cubanos". - Votaram e se manifestaram contra a escola particular, por motivos ideológicos ou político-partidários —, diz a cartilha logo na abertura da lista de "cubanos". Rita Camata (PMDB ES), Cristina Tavares (PMDB-PE), Otávio Elísio (PMDB-MG), Hermes Zanetti (PMDB-RS) e Joaci Góes (PMDB-BA) são alguns dos "cubanos", cuja relação traz ainda António Salim Curiati (PDS-SP) e José Queiroz (PFL-SE). Entre os "cubanos" estão ainda "todos os líderes do PT, PDT, PCB, PC do B. 
Desta forma, o acirrado debate pertinente à destinação dos recursos, que atravessou as três esferas da ANC por nós estudadas, continuava acalorado neste momento. Enquanto Dom Cândido defendia que todos os estabelecimentos de ensino que ministrassem educação gratuita tivessem acesso aos recursos públicos, a emenda popular $n^{\circ} 49$, da UNE, ANDES e da Confederação de Professores do Brasil, apresentada por Tomaz Wonghon, defendia o ensino público e gratuito, bem como a destinação exclusiva destes recursos às instituições públicas. Outra questão levantada foi a diferença entre a necessária laicidade do ensino, que difere do ateísmo, questão também veiculada pelos meios de comunicação de forma inverídica e apressada, o que acabava por criar certa confusão na opinião pública. Apresentou, pois, a ideia de que " $O$ cidadão tem o direito de optar por religião, o que não pode ser confundido com que o Estado ministre essa religião, que o ensino público desse Estado - o Estado republicano não pode conviver com isto" (CÂMARA, 2017d, p.472).

Gumercindo Milhomem rememorou o trabalho da comissão 8, ressentindo-se pelo grupo não ter a oportunidade de ter deixado um produto do trabalho desenvolvido naquele espaço. Hermes Zaneti retomou a fala, para questionar Dom Cândido a respeito das orientações da cartilha supracitada, sobre a qual ele negou ter participado. Tomaz Wonghon, ao retomar a palavra, destacou sua perspectiva a respeito da exclusividade da aplicação de recursos públicos na escola pública, descartando, inclusive, as instituições filantrópicas:

A filantropia, Srs. Constituintes, se faz com o excesso. Há organizações que fazem: Lions, Rotary etc. É impossível se querer mascarar com a questão da filantropia a oferta de um produto, cobrando do Estado um preço alto por esse produto e tendo um lucro muito alto com a questão que é da educação (IDEM, p. 471).

Aproveitou ainda a tribuna para fazer uma denúncia quanto à atividade do MEC junto à aquisição e distribuição da Revista Nova Escola nas escolas públicas, o que, segundo sua argumentação, favorecia ao grupo empresarial Abril Cultural, ocasionando o dispêndio de recursos públicos. Mais uma vez, Hermes Zaneti retomou o falso dilema existente entre a ideia de liberdade de ensino, assim como a relação entre escolas públicas e privadas, a saber:

Liberdade de educação existirá no momento em que tivermos construído uma estrutura de escola pública de qualidade nacional, capaz de atender a toda a demanda de educação deste País. Não será com os lucros exorbitantes, que uma CPI do ensino pago, da Câmara dos Deputados provou, que vamos construir a liberdade de educação e muito menos iremos construir a educação que a Nação 
democrática, que queremos, precisa! É evidente que V. Ex. ${ }^{\text {a }}$, aqui, hoje, está representando os interesses daquelas grandes empresas de educação que lidam com uma mercadoria, porque assim é vista por essas instituições, chamada ensino e cujo objetivo, evidentemente, não é a qualidade de ensino, é o lucro que possam auferir desta atividade (IBIDEM, p. 473).

Ainda na mesma discussão, o presidente da FENEN, Roberto Geraldo de Paiva Dornas, defendeu que o dinheiro fosse dado ao aluno para que ele escolhesse em qual escola estudar, por meio de pagamento de bolsas de estudos. Tal questão foi contraposta, novamente, por Hermes Zaneti. Gumercindo Milhomem destacou em sua fala que na cartilha da FENEN foi descrito como "cubano", por também defender o ensino público.

Assim, Dornas afirmou acreditar que os encaminhamentos propostos pelos "cubanos" seriam uma forma de legitimar a defesa do ponto de vista coletivo em detrimento do direito individual. Considerou, pois, que a estatização da educação por meio de uma escola única seria uma forma de controlar a escola. Seguindo a mesma linha de raciocínio, o constituinte José Mendonça de Morais afirmou que as esquerdas que se constituíram na ANC tinham a intenção de implantar uma ditadura "para o povo que paga verbas enormes para manter uma escola falida, que corrompe a liberdade do aluno de escolher" (CÂMARA, 2017d, p. 475). Cabe ressaltar que tal parlamentar iniciou sua vida política na ARENA, tendo migrado para o PDS e, posteriormente, para o PFL. Defendeu a censura ampliada, a realização de eleições indiretas para a presidência da República, e a pena de morte, entre diversos outros aspectos (CPDOC, 2017u). Ainda na defesa deste tema, o constituinte Bezerra de Melo também se colocou favorável à concessão de ajuda do Estado aos alunos carentes, por meio de bolsas de estudo.

Voltando ao ensino religioso, o pastor Elias Abrahão, que fez a defesa da emenda 004, que se dedicava ao ensino religioso, propôs a garantia da educação religiosa pelo Estado no ensino de $1^{\circ}$ e $2^{\circ}$ graus, de acordo com a pluralidade religiosa de nosso país, e como componente curricular obrigatório. Neste sentido, o constituinte Osvaldo Sobrinho colocou-se na defesa da obrigatoriedade da oferta deste ensino por parte do Estado, mas na garantia da frequência ser facultativa ao aluno. Já o constituinte Celso Dourado afirmou que tal emenda caminhava na direção da defesa da fé, e não do ensino de uma religião em detrimento da outra, na mesma perspectiva de José Mendonça, que se apresentou como 
católico e defendeu que a "escola não pode omitir-se numa faceta importantíssima, qual seja, a formação do caráter, da consciência crítica, que a religião tem o papel preponderante" (IDEM, p. 478). Debate semelhante se estabeleceu com a emenda $\mathrm{n}^{\circ} 012$, defendida por Dom Raymundo Damasceno de Assis, sob o patrocínio da CNBB, AEC e Cáritas Brasileira. O significado da laicidade ficou esquecido neste debate.

Ainda como parte das discussões das emendas populares, o plenário recebeu Carlos Eduardo Moreira, que tratou da emenda n ${ }^{\circ} 36$, que objetivava a preservação do Sistema "S" de ensino (SESI, SESC, SENAI, SENAC), apoiada pelo constituinte Eraldo Tinoco. Outros temas que também apareceram neste documento foram o ensino superior; a importância do trabalho com pessoas deficientes; a defesa da importância do mandato de injunção; o entendimento da criança como sujeito de direitos; a aposentadoria diferenciada para a mulher; e, novamente, a defesa da vinculação de percentual mínimo no orçamento para a educação.

O segundo conjunto de atas da comissão de sistematização analisado foi o agrupado sob o título Sistematização $9 b$. A primeira aparição do termo educação se deu na fala do constituinte José Genoíno, que solicitou a votação de todas as emendas populares. Alguns parlamentares teceram críticas ao texto que estava em processo de elaboração: Lysâneas Maciel, do PDT, falou que o grupo estaria fazendo um "estatuto da classe dominante" (CÂMARA, 2017e, p. 44); Jamil Haddad afirmou que não adiantaria ter uma CF com temas sociais se a ordem econômica e financeira não propiciasse as reformas necessárias; Celso Dourado disse que a instituição escolar estaria falhando em seu papel social. Seguiu, defendendo o Sistema "S", a democratização da escola e a escola pública.

As outras duas vezes que apareceram a temática educacional, foram relacionadas à importância do mandato de injunção e à notificação da mudança do ministro da Educação, cadeira que passou a ser ocupada pelo senador do PFL, Hugo Napoleão.

O terceiro documento da etapa de sistematização iniciou a discussão educacional com o constituinte Mario Lima, que abordou a necessidade do fim das isenções fiscais, inclusive para as universidades privadas. Virgildásio de Sena voltou ao assunto da vinculação orçamentária apenas para a educação. Na sessão do dia 14/11/1987, a votação da matéria educacional teve início. 
Foi proposta e votada uma emenda que previa o apoio suplementar do poder público aos CIEP (Centros Integrados de Educação Pública) pelo constituinte José Maurício, do PDT. Octávio Elísio solicitou a retirada da proposta, tendo em vista que ações como esta amarrariam o apoio da União apenas a tais instituições. Desta forma, o destaque foi rejeitado. O próximo destaque feito dizia respeito à autonomia universitária, defendido por Jorge Hage e aprovado. Um dos destaques que abordavam um tema arenoso, foi apresentado por Florestan Fernandes, propondo nova redação ao artigo 381, sobre a destinação de recursos públicos, que ficaria apenas com a formulação seguinte, suprimindo a especificação de instituições que também seriam passíveis de recebimento dos recursos: "Art. 381 - As verbas públicas serão destinadas, com exclusividade, às escolas públicas" (CÂMARA, 2017e, p. 355). Cabe destacar a argumentação do constituinte, que relembrou que a mesma discussão fora encampada nos anos de 1950-60, e que as posições privatistas lograram êxito:

O pluralismo democrático na Educação envolve a filosofia e a prática segundo as quais diferentes tipos de escola concorrem para resolver o problema fundamental das necessidades básicas do ensino. Por isto, escolas confessionais, escolas privadas a pagamento e escolas públicas gratuitas, todas concorrem para o mesmo objetivo e, naturalmente, com recursos diferentes. Se o Estado tiver de patrocinar todos três tipos de escolas, então, não há razão nenhuma para a existência de um pluralismo; o que existiria seria um parasitismo dos tipos de escolas que não fossem estatais sobre os recursos públicos postos à disposição da Educação. Ocorre que, no Brasil, temos problemas fundamentais. Há desigualdades que nascem de diferenças de riquezas entre regiões, entre classes, entre etnias, e somos um País com uma população jovem muito numerosa. Por isto, a concorrência de vários tipos de recursos para desenvolver o sistema educacional vem a ser fundamental para o País. Por aí se somariam esforços no sentido de criar um processo de crescimento educacional mais amplo, contínuo e profundo. Seria preciso lembrar, aqui, algo que já é conhecido: de 1960 para cá, especialmente depois da promulgação da Lei de Diretrizes e Bases da Educação Nacional, que levou a uma predominância das correntes privatistas, o Estado tomou a si responsabilidades, na área do ensino, que deveriam caber a entidades confessionais e a estabelecimentos comerciais de ensino [...] Vejo-me, agora, diante de Sandra Cavalcanti, de quem fui adversário num combate em que se colocaram frente a frente os que defendiam a escola pública e os que defendiam a escola privada. Espero que, hoje, a situação não seja a mesma (IDEM, p. 355).

No sentido de rebater Florestan Fernandes na defesa da rejeição à emenda, o constituinte Eraldo Tinoco abordou que a importância deveria ser dada ao destino da 
ação educacional - o estudante - e não ao "veículo" desta ação. Desta forma, defendeu a manutenção dos incisos que colocavam a possibilidade do recebimento dos recursos públicos pelas entidades filantrópicas e confessionais. Alegou, ainda, que a situação dos CNEC, por exemplo, ficaria insustentável sem tais recursos. Destacamos a seguir parte do encaminhamento de voto, feito pelo constituinte:

Se aprovarmos esta emenda, estaremos condenando à marginalidade milhões de brasileiros que freqüentam escolas confessionais e comunitárias e que, por isso, essas escolas, sem finalidade lucrativa necessitam do apoio do setor público, para que complementem o seu trabalho e ofereçam oportunidade educacional. Isto, sim é mais que necessário em um país tão deficiente em termos educacionais (IBIDEM, p. 356).

A essa altura do debate, foi necessária a intervenção do segundo vice-presidente, em exercício na sessão, para solicitar o silêncio das galerias. Em continuidade aos debates, Sólon Borges defendeu a emenda proposta por Florestan, enquanto Sandra Cavalcanti se colocou a favor da manutenção do texto original e da defesa realizada por Eraldo Tinoco. Em uma das votações mais difíceis, devido à pressão das galerias, expressa sob a forma de aplausos e vaias, o destaque foi rejeitado por 57 votos contra 27.

Solicitou-se novamente o controle das galerias antes da discussão de novo destaque, ainda sobre o mesmo assunto. Mozarildo Cavalcante, do PFL, propôs a alteração da indicação de repasse dos recursos públicos para as instituições filantrópicas e/ou confessionais, para as instituições em geral. Sobre o destaque, contrapôs-se José Genoíno, e o mesmo foi rejeitado, por 71 a 15 votos. Ainda sobre a mesma matéria, Victor Faccioni, do PDS, propôs um destaque incluindo a possibilidade de distribuição de bolsas de estudo, estratégia criticada por Octávio Elísio, como vemos no trecho transcrito:

A intenção do Constituinte Victor Faccioni, com a sua emenda, é bastante louvável, na medida em que a sua preocupação é a garantia do acesso à escola. A filosofia que marcou todo o trabalho desde a Subcomissão, foi no sentido de que: "garante-se escola aumentando-se vagas na escola. E aqueles que estão fora da escola precisam de uma escola pública". Por causa disso é que um projeto de educação democrático exige a garantia dos recursos públicos na expansão das vagas de escolas públicas para aqueles que estão fora da escola. Esse projeto, 
entretanto, abriu a oportunidade de garantir, dentro de determinadas condições - como já foi dito aqui - o uso do recurso público para escolas comunitárias, confessionais ou filantrópicas. Ora, o Constituinte Victor Faccioni propõe um mecanismo de bolsas de estudo para se garantir escola àqueles onde não exista escola pública. Mas, o que é lamentável é que a sua emenda não faz referência à regulamentação em lei e, muito menos, ao fato de que só se dirige aos alunos nessas condições específicas. Deixarmos generalizado desse modo, meus caros colegas Constituintes, é incorrermos no que há de pior em termos de transferência de recurso público (IBIDEM, p. 361).

Nova defesa do pagamento de bolsas de estudo foi feita pelo parlamentar Mario Assad (PFL) e contraposta por Jorge Hage. Em nome da relatoria, José Fogaça afirmou que não via a necessidade de inclusão de um dispositivo constitucional com este tom, já que tal estratégia se constituiria em uma ação de governo, não necessitando, portanto, ser regulamentada em um texto constitucional. Desta forma, a votação foi muito próxima, sendo o destaque rejeitado por 49 votos contra 43. A última votação pertinente à educação foi referente ao PNE, encaminhada por Octávio Elísio e tendo parecer favorável.

A seguir, o quadro síntese, com a posição dos constituintes na comissão 9: 


\section{COMISSÃO DE SISTEMATIZAÇÃO (9)}

Posições dos constituintes mais atuantes na discussão da matéria educacional

Esquerda

Jamil Haddad

Hermes Zeneti

Artur da Távola

Octávio Elísio

PT (2) - Gumercindo Milhomem

Florestan Femandes

PDT (3) - Lysâneas Maciel

Chico Humberto

Brandão Monteiro

PTB (1) - Sólon Borges
Direita

4 --- PMDB ----3

$\begin{array}{cl}2 & \text { Celso Dourado } \\ \text { Osvaldo Sobrinho } & \text { José Mendonça de Morais } \\ \text { Nelson Seixas } & \text { Bezerra de Melo }\end{array}$

PFL (4) - Sandra Cavalcanti

Mario Assad

Eraldo Tinoco

Mozarildo Cavalcanti

PDS (1) - Victor Faccionni

\section{CENTRO}

Como podemos observar, diferentemente dos outros quadros, neste o constituinte Artur da Távola teve uma atuação mais à esquerda, no que se refere à defesa da destinação de recursos públicos, cabendo-nos salientar esta alteração.

O último dos quatro documentos da comissão de sistematização foi a sessão de entrega do texto final à mesa da $\mathrm{ANC}$, realizada em vinte e quatro de novembro de 1987. $\mathrm{Na}$ ocasião o senador Afonso Arinos fez um resumo do trabalho: foram votados 2.612 dos 8.377 destaques apresentados, sendo que a definição dos assuntos prioritários para elencarem o painel de votação foram definidos pelas lideranças partidárias. Segue o quadro síntese das votações, constante nos anais da ANC (CÂMARA, 2017e, p.512). 


\section{QUADRO IV - Demonstrativo do processo de votação}

Quadro demonstrativo a que se refere o Sr. Presidente:

ASSEMBLÉIA NACIONAL CONSTITUINTE

VOTAÇÃO DOS DESTAQUES

COMISSÃO DE SISTEMATIZAÇÃO

MAPA DEMONSTRATIVO

SECRETARIA

\section{PROJETO DE CONSTITUIÇÃO}

\begin{tabular}{|c|c|c|c|c|c|c|c|c|c|c|c|c|}
\hline \multirow{2}{*}{\multicolumn{2}{|c|}{ DESTAQUES }} & \multicolumn{10}{|c|}{ TÍTULOS } & \multirow{2}{*}{$\begin{array}{c}\text { TOTAL } \\
\text { ATÉ } \\
18-11-87\end{array}$} \\
\hline & & \multirow{2}{*}{$\begin{array}{l}\text { PREAM- } \\
\text { BULO } \\
01\end{array}$} & \multirow{2}{*}{$\begin{array}{l}\mathrm{I} \\
04\end{array}$} & \multirow{2}{*}{ II } & \multirow{2}{*}{$\begin{array}{l}\text { III } \\
35\end{array}$} & \multirow{2}{*}{$\frac{\text { IV }}{33}$} & \multirow{2}{*}{$\begin{array}{l}\mathrm{V} \\
04\end{array}$} & \multirow{2}{*}{$\frac{\mathrm{VI}}{15}$} & \multirow{2}{*}{$\frac{\text { VII }}{19}$} & \multirow{2}{*}{$\begin{array}{c}\text { VIII } \\
18\end{array}$} & \multirow{2}{*}{$\frac{\text { IX }}{27}$} & \\
\hline \multirow{4}{*}{$\begin{array}{l}\mathrm{V} \\
\mathrm{O} \\
\mathrm{T} \\
\mathrm{A} \\
\mathrm{D} \\
\mathrm{O} \\
\mathrm{S}\end{array}$} & APROVADOS & & & & & & & & & & & 214 \\
\hline & REJEITADOS & 04 & 11 & 80 & 42 & 25 & 06 & 17 & 14 & 20 & 13 & 234 \\
\hline & $\begin{array}{l}\text { PREJUDICADOS } \\
\text { (QUORUM) }\end{array}$ & - & - & 25 & 11 & 10 & - & 01 & 08 & 01 & 05 & 61 \\
\hline & $\begin{array}{l}\text { TOTAL DE } \\
\text { VOTAÇÕES }\end{array}$ & 05 & 15 & 163 & 88 & 68 & 12 & 33 & 41 & 39 & 45 & 509 \\
\hline \multirow{5}{*}{$\begin{array}{l}\mathrm{N} \\
\tilde{A} \\
\mathrm{O} \\
\\
\mathrm{V} \\
\mathrm{O} \\
\mathrm{T} \\
\mathrm{A} \\
\mathrm{D} \\
\mathrm{O} \\
\mathrm{S}\end{array}$} & RETIRADOS & 06 & 30 & 571 & 161 & 24 & 10 & 31 & 16 & 13 & 12 & 874 \\
\hline & $\begin{array}{l}\text { PREJUDICADOS } \\
\text { (Ausência, } \\
\text { matéria idêntica ou } \\
\text { já acolhida) }\end{array}$ & 08 & 56 & 746 & 340 & 22 & 04 & 10 & 27 & 13 & 03 & 1229 \\
\hline & $\begin{array}{c}\text { TOTAL DE } \\
\text { DESTAQUES }\end{array}$ & 19 & 101 & 1480 & 589 & 114 & 26 & 74 & 84 & 65 & 60 & 2612 \\
\hline & $\begin{array}{l}\text { Substitutivo e } \\
\text { Redação Final }\end{array}$ & 01 & 01 & 02 & 02 & 02 & 02 & 02 & 02 & 02 & 02 & 18 \\
\hline & $\begin{array}{l}\text { Requerimento } \\
\text { de Preferência }\end{array}$ & 01 & 02 & 02 & 01 & 01 & - & - & - & 01 & - & 08 \\
\hline
\end{tabular}

(*) 1 Substitutivo do Relator (Títutlo II) e 1 Redação Final (Preâmbulo, Títulos I e II). 
De uma forma geral, o balanço feito pelos analistas apontam que o texto resultante do trabalho de sistematização resguardou boa parte dos debates que hegemonizaram as etapas anteriores, sendo, portanto, desinteressante para o governo, uma vez que encaminhava questões importantes na garantia de direitos da população, via educação pública e gratuita em todos os níveis. Desta forma, como vimos na abertura deste capítulo, houve uma reação dos setores conservadores, no sentido de garantir que o anteprojeto de Bernardo Cabral não fosse aprovado no plenário. Entrou em ação, pois, a atividade do Centrão.

A extensa retomada dos aspectos históricos e as disputas políticas que constituíram a ideia de educação como direito no Brasil realizadas nos capítulos 2 e 3 servirão como pano de fundo às discussões que empreenderemos no próximo capítulo, no qual analisaremos especificamente as categorias que dela são decorrentes, nas disputas ocorridas nas diferentes etapas do processo constituinte. Para tanto, basearemo-nos no desenho do campo político delineado nos espaços estudados, como vimos ao final de cada subcapítulo. 


\section{DEMOCRATIZAÇÃO DAS OPORTUNIDADES}

EDUCACIONAIS E LIBERDADE DE ENSINO NAS DISCUSSÕES DO PROCESSO CONSTITUINTE: DIREITO PARA QUEM? 
Este capítulo tem por objetivo analisar a evolução do texto legal referente à ideia de direito à educação na ANC, desde o início dos debates na subcomissão 8a, em abril de 1987, até a votação do texto final no plenário e sua posterior promulgação, em outubro de 1988. Enquanto no capítulo anterior nos dedicamos a analisar a dinâmica de funcionamento dos espaços de discussão percorridos pelo texto constitucional, neste momento retomaremos o material produzido e centraremos nossas análises a partir de dois recortes: as versões preliminares do que viria a ser a $\mathrm{CF}$, produzidas no percurso da $\mathrm{ANC}$, assim como o texto finalmente promulgado; e as duas categorias específicas de análise que apresentamos no início da presente tese - democratização das oportunidades educacionais e liberdade de ensino.

Sobre as versões preliminares, trabalharemos com os artigos, incisos e alíneas que dizem respeito às categorias acima apresentadas dos seguintes documentos:

$\checkmark$ Texto produzido pela Comissão dos Notáveis;

$\checkmark$ Textos produzidos na Subcomissão 8a:

- apresentados pelas principais instituições que foram ouvidas na subcomissão 8 a (entre eles: a Carta de Goiânia, na qual se baseou o FNDEP; o da FENEN; e o da AEC, ABESC, CNEC e CNBB; além de outras entidades);

- Fase A: Anteprojeto do relator da subcomissão;

- Fase C: Anteprojeto da subcomissão;

$\checkmark$ Textos produzidos na Comissão 8:

- Fase F: Substitutivo do relator da Comissão;

- Fase H: Anteprojeto da Comissão ( $2^{\circ}$ substitutivo do relator);

$\checkmark$ Textos da Comissão de Sistematização (Comissão 9):

- Fase I: Anteprojeto de Constituição;

- Fase I: Anteprojeto de Constituição - erratas;

-Fase P: Substitutivo às emendas de Plenário aprovado pela Comissão de Sistematização;

$\checkmark$ Textos do Plenário:

- Fase Q: Projeto de sistematização(A) da Comissão de Sistematização - quadro comparativo; - Fase V: Projeto de sistematização (C) da Comissão de Sistematização - redação final.

Para melhor explicar a organização dos documentos em "fases" e a escolha das que viriam a compor o objeto de estudo desta tese, reproduzimos o quadro disponível na página eletrônica da Câmara dos Deputados ${ }^{64}$, no qual podemos encontrar a explicação da metodologia utilizada para a separação dos textos legais:

64 Disponível em: http://www2.camara.leg.br/atividade-legislativa/legislacao/Constituicoes_Brasileiras/ constituicao-cidada/o-processo-constituinte/o-processo-constituinte. Acesso em 17.out.2017. 
QUADRO V - Fases do texto legal na ANC

\begin{tabular}{|c|c|}
\hline Etapas & Fases \\
\hline \multirow{2}{*}{ 1. Preliminar } & - Definição do Regimento Interno da ANC \\
\hline & - $\quad$ Sugestões: Cidadãos, Constituintes e Entidades \\
\hline \multirow{4}{*}{ 2. Subcomisso Temáticas } & - A: Anteprojeto do Relator \\
\hline & - B: Emenda ao Anteprojeto do Relator \\
\hline & - C: Anteprojeto da Subcomissão \\
\hline & - E: Emenda ao Anteprojeto da Subcomissão na Comissão \\
\hline \multirow{6}{*}{ 3. Comissões Temáticas } & - F: Substitutivo do Relator \\
\hline & - G: Emenda ao Substitutivo \\
\hline & - H: Anteprojeto da Comissão \\
\hline & - I: Anteprojeto de Constituição \\
\hline & - $\mathrm{J} / \mathrm{K}$ : Emendas de Mérito e de Adequação ao Anteprojeto \\
\hline & - L: Projeto de Constituição \\
\hline \multirow{7}{*}{$\begin{array}{l}\text { 4. Comissões de } \\
\text { Sistematização }\end{array}$} & - $\quad \mathrm{M}$ : Emendas (1P) de Plenário e Populares \\
\hline & - N: Substitutivo 1 do Relator \\
\hline & - O: Emenda (ES) ao substitutivo 1 \\
\hline & - P: Substitutivo 2 do Relator \\
\hline & - Q: Projeto A (início $1^{\circ}$ turno) \\
\hline & - R: Ato das Disposições Transitórias \\
\hline & - S: Emenda (2P) de Plenário e Emendas do Centrão \\
\hline \multirow{4}{*}{ 5. Plenário } & - $\quad \mathrm{T}$ : Projeto B (fim do $1^{\circ} ;$ início $2^{\circ}$ turno) \\
\hline & - U: Emenda (2T) ao Projeto B \\
\hline & - V: Projeto $\mathrm{C}\left(\right.$ fim $2^{\circ}$ turno) \\
\hline & - W: Proposta exclusivamente de redação \\
\hline 6. Comissão de Redação & - X: Projeto D - redação final \\
\hline 7. Epílogo & - Y: Promulgação \\
\hline
\end{tabular}

Assim sendo, a seleção que adotamos se baseou no critério de análise do primeiro e do último texto (fase) da etapa em tela. Só foi feita uma exceção para a etapa 3, pois nela optamos pela análise do documento da fase $\mathrm{F}$, e não da fase $\mathrm{E}$, posto que desejávamos observar um texto mais sistematizado, e não apenas o agrupamento de emendas que chegaram à comissão 8 . Desta forma, faremos uma análise comparativa do material de acordo com a seguinte dinâmica: fase A - fase C; fase C - fase F; fase F - fase $\mathrm{H}$; fase $\mathrm{H}$ fase I; fase I - fase P; fase P - fase Q; fase Q - Fase V - Texto aprovado.

O documento da fase A (ANC, 2017a, p.7) teve início com um breve resgate das Constituições brasileiras, de forma a traçar os avanços obtidos no campo educacional ao 
longo da história do nosso país. Logo após, apresentou a dinâmica estabelecida para os trabalhos constituintes e as principais questões abordadas, que foram assim divididas: vinculação de recursos; ensino fundamental e gratuito nas escolas públicas; fiscalização do ensino pela comunidade; aposentadoria especial para profissionais da área do ensino; intervenção federal nos estados que não cumprirem a determinação constitucional da aplicação de um percentual mínimo em educação; além de outras, que fizeram parte do debate das demais áreas que foram abrangidas pela competência da subcomissão (família, cultura, esporte, lazer, turismo, ciência e tecnologia, e comunicação). Apresentou o nome dos constituintes que fizeram parte daquele campo, assim como das instituições ouvidas, fazendo um balanço das discussões.

Na continuidade do texto, vemos cada um dos temas que foram esmiuçados nos artigos propostos, que já foram explicados no capítulo anterior, quando apresentamos os debates da subcomissão. Junto aos temas, o relator correlacionou o nome de cada constituinte que votou a favor de uma ou outra forma de redação. Sabemos da dificuldade para separá-los, devido à proximidade das discussões que abrigam, mas faremos um esforço no sentido de nos concentrarmos nos que mais se aproximam das categorias contempladas por este estudo, que são os selecionados em negrito:

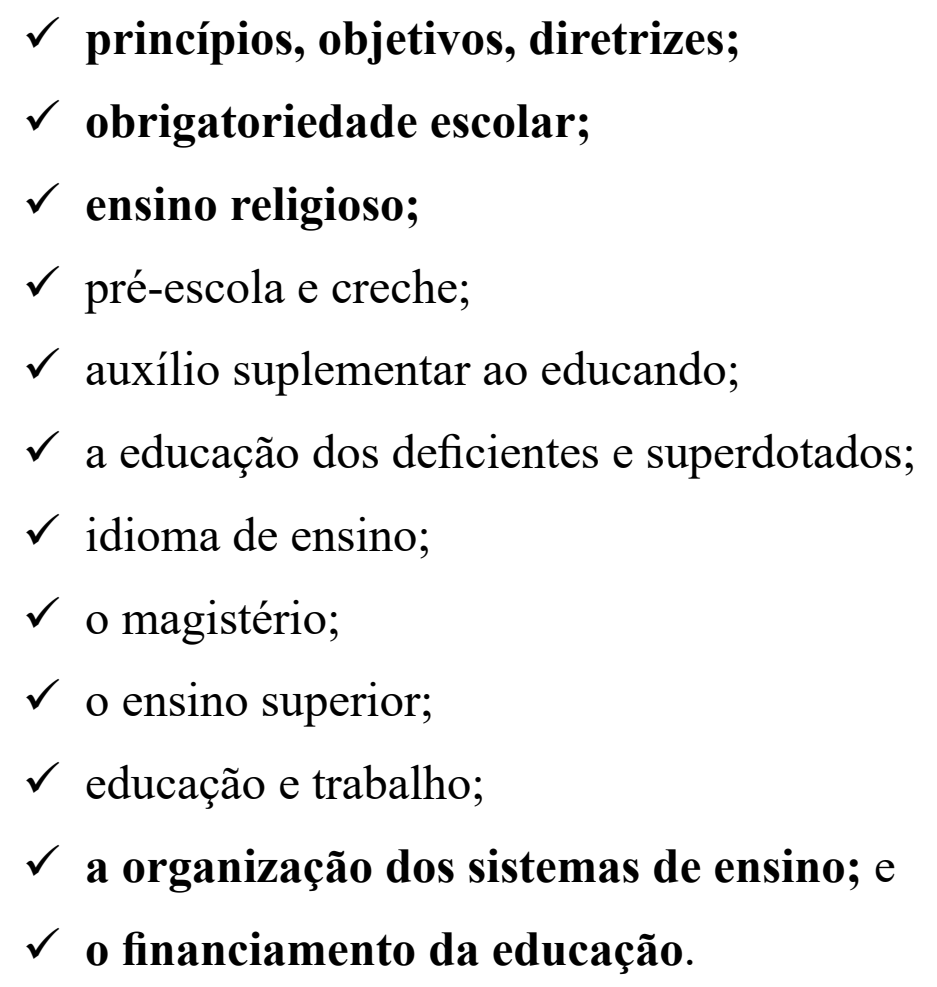

O documento da fase C (ANC, 2017b) trouxe apenas o texto legal, sem discussões prévias. O mesmo aconteceu com os documentos das fases F, I, Pe V. O da fase H trouxe uma peculiaridade, que foi a explicação da razão do encaminhamento do segundo substitutivo 
do relator da comissão 8 à comissão de sistematização, uma vez que não houve texto final oficial para ser encaminhado, devido ao fato de não ter se alcançado uma posição consensual no grupo. É importante também destacar que nesse documento constava uma carta assinada por um grupo de constituintes que se autodenominou "a maioria da comissão", que chamou o relator Artur da Távola de antidemocrático e demagógico, e expressou seu compromisso com a sociedade brasileira, a qual, em suas palavras, poderia ficar tranquila, pois "[...] a maioria de seus representantes, de diferentes correntes partidárias, está coerente e fiel àquelas que são suas maiores aspirações" (ANC, 2017d, p. 6). E, pelo teor do referido documento, tais aspirações seriam:

Não aceitamos a elitização da Escola Brasileira, criando escolas para ricos e
escolas para pobres. Não queremos fechar a escola privada de excelência para as
crianças carentes. Defendemos os direitos que têm as famílias pobres de também
terem seus filhos em escolas confessionais, se assim o desejarem. Por essas
razões, não aceitamos que tais escolas sejam marginalizadas quando se utilizam
verbas públicas. Queremos os veículos livres para que a opinião pública seja bem
informada em uma democracia pluralista. Recusamos a censura em qualquer
de suas formas, mas defendemos o direito que têm as famílias de bem educar
seus filhos, devendo-se por isso, exercer vigilância sobre programas de televisão
(IDEM, p.5-6).

Discutiremos mais adiante a ideia de democratização e de liberdade aqui destacadas. O documento da etapa 5 , fase $\mathrm{Q}$, ou seja, o texto inicial da discussão em plenário, foi apresentado em um formato diferenciado, em uma tabela. Nele pudemos observar a última versão oriunda da comissão de sistematização, as emendas do Centrão, as emendas coletivas e individuais, artigo por artigo, com destaques de incisos, alíneas e parágrafos, além dos nomes dos constituintes que as propuseram.

Face ao exposto, nos subcapítulos seguintes passaremos a uma breve discussão conceitual sobre a democratização das oportunidades educacionais e a liberdade de ensino, sempre antecedendo a análise do material empírico. Cabe destacar que a separação que pretendemos estabelecer entre as categorias é meramente esquemática, posto que em diversos momentos existe uma intersecção entre elas, sobretudo quando abordamos a questão da origem dos recursos que devem manter as instituições de ensino. 


\subsection{A CONCEPÇÃO DE DEMOCRATIZAÇÃO DAS OPORTUNIDADES EDUCACIONAIS NO TEXTO CONSTITUCIONAL DE 1988}

A categoria que ora analisamos emergiu quando nos dispusemos a fazer a revisão bibliográfica inicial para a presente tese. Naquele momento, percebemos que todas as vezes que diferentes autores buscavam explicar o que e como se elaborou a perspectiva do direito à educação, no mundo em geral e, mais especificamente no Brasil, esses estudos vinham permeados pela ideia de democratização das oportunidades educacionais.

Retomaremos um pouco a discussão que iniciou o segundo capítulo, quando historicizamos a ideia de educação como direito. Horta (1998, p. 7), no texto Direito à educação e obrigatoriedade escolar destaca, em consonância com Bobbio, que a maior dificuldade não é fundamentar os direitos do homem, mas sim, protegê-los. Desta forma, podemos afirmar que foi com o surgimento do Estado de direito que a relação entre súditos e príncipe foi substituída pela relação entre os cidadãos. Assim, foi somente com o nascimento dos direitos públicos subjetivos, ou seja, aqueles que já nasceram com as pessoas, que se rompeu com a ideia principal do Estado despótico, no qual à população só cabiam deveres.

Cury (2010, p.180-181) afirma que com a estruturação e o avanço do capitalismo, o surgimento das políticas sociais se fez como resposta às demandas das classes trabalhadoras, como vimos no primeiro capítulo. Destacamos ainda que o Estado de bem-estar social se estruturou na Europa como resposta a uma das grandes crises de acumulação capitalista, uma vez que o acesso aos direitos sociais básicos auxiliava na contenção da massa e, consequentemente, barravam o avanço da ameaça socialista, em um momento que o mundo era ainda polarizado. Desta forma, para que se pudesse garantir a execução dos direitos sociais, havia a necessidade do Estado se apresentar como ente responsável por tal garantia, tendo nos dispositivos legais o melhor meio de fazê-lo. No caso específico da educação, além da garantia do direito, era preciso também o estabelecimento do dever, uma vez que quem deve usufruir do mesmo, muitas vezes não é capaz de reivindicá-lo. Concordamos com Cury (1988, p. 10-11), portanto, quando ele afirma que

[...] direito à educação e obrigatoriedade escolar, embora não tenham surgido de forma concomitante no processo histórico, estão historicamente relacionados e devem ser estudados conjuntamente [...] ao direito de educar por parte do Estado correspondeu a obrigatoriedade escolar como imposição ao indivíduo. Só muito recentemente, ao direito à educação, por parte do indivíduo, correspondeu a obrigatoriedade de oferecer educação, por parte do Estado. 
A educação, tida como um pré-requisito à formação do cidadão, e, consequentemente, necessária a estruturação da sociedade, tem o terreno da liberdade invadido pela obrigatoriedade, na medida em que não é possível que crianças e suas famílias se eduquem sozinhas, sem o apoio e a defesa do Estado. Assim, concordamos com Cury (2010, p.111), quando afirma que

A magnitude da importância da educação é assim reconhecida por envolver todas as dimensões do ser humano: o singulus, o civis, e o socius. O singulus por pertencer ao indivíduo como tal, o civis por envolver a participação nos destinos de sua comunidade e o socius por significar a igualdade básica entre todos os homens.

Como afirmamos anteriormente, a educação é diferente de outros direitos, pois a ela vincula-se um dever, que é a garantia de sua execução. Por tal motivo, apesar de historicamente direito e obrigatoriedade não caminharem juntos na educação brasileira, como mencionamos anteriormente, cabe-nos a análise conjunta das duas ideias. Assim sendo, Baia Horta (1998, p. 11-21) faz uma pesquisa sobre a relação entre estes conceitos no império, em que aparece de forma clara a figura da gratuidade; na primeira república a ideia de laicidade aparece, ficando a gratuidade e a obrigatoriedade previstas apenas em alguns estados; somente na Constituição de 1934 que tais perspectivas assumem contornos legais. Todavia, a CF de 1946 não apresenta a educação como dever do Estado, deixando vaga a perspectiva de obrigatoriedade, portanto.

O direito à educação só passou a ser reconhecido como direito público subjetivo entendido como a "[...] faculdade que tem o particular de exigir do Estado o cumprimento de diversas prestações" (CRETELLA JÚNIOR, 1977, p. 338) - muito recentemente, na Constituição de 1988, mesmo sendo reivindicado desde os anos de 1930. A educação vista como direito público subjetivo abre caminho para a ampliação do acesso à educação por partes significativas da população, que até então estavam segregadas deste sistema. A partir daí poderiam formalmente exigir do Estado o cumprimento de seu dever de se fazer educador. Concordamos com Cury (1996, p. 26) quando afirma que

[...] a assunção da educação como direito público subjetivo amplia a dimensão democrática da educação, sobretudo quando ela é declarada, exigida e protegida para todo o ensino fundamental e em todo território nacional. Isto, sem dúvida, pode cooperar com a universalização do direito à educação fundamental e gratuita. $\mathrm{O}$ direito público subjetivo auxilia e traz um instrumento jurídico institucional capaz de transformar este direito num caminho real de efetivação de uma democracia educacional. 
Diferentemente dos países centrais, no Brasil, como em outros países de capitalismo tardio, tais políticas foram induzidas pelo Estado, com base em uma perspectiva de alteridade social, o que levou a educação a ser, por longos anos, caracterizada como privilégio de um grupo restrito, como bem disse Anísio Teixeira (1957). Foi ainda Anísio Teixeira quem, baseado no princípio do liberalismo igualitarista de John Dewey, propôs uma escola nova, “[...] capaz de produzir indivíduos orientados para a democracia, e não para a dominação/ subordinação; para a cooperação, em vez da competição; para a igualdade, e não para a diferença" (2007, p. 13). Tal tarefa só seria possível na medida em que a escola pudesse estar aberta a todos, e não somente a uma pequena elite. Era preciso, pois, criar as condições para que tal espaço fosse ampliado, para alcançar parcela da população que historicamente dele se viu excluído, por razão de sua origem de classe.

A obra "Educação para a democracia", datada de 1936, contemporânea, portanto, do Manifesto de 1932, está profundamente entremeada pelo princípio da escola única, pública, gratuita e laica para todos, capaz de - na visão de seu autor - viabilizar a reconstrução da sociedade por meio desta instituição. Sobre o referido documento e a efervescência por ele gerado nesse período, Florestan Fernandes (1989, p.34) destacou que o mesmo representou uma "[...] tomada de posição na tentativa de incorporar o Brasil nas correntes modernas da democratização do ensino". Escritos no contexto da Constituinte de 1933/1934, os textos do Manifesto e de Anísio permanecem atual para o estudo da ANC de 1987/1988, uma vez que a ideia de democratização do ensino é um dos principais vieses da efetivação do direito à educação na política brasileira.

Neste sentido, para endossar o quadro que pretendemos delinear, trabalharemos com o conceito de democracia e de democratização, com embasamento principal em Luiz Antônio Cunha. O autor, no primeiro capítulo do livro Educação, Estado e democracia no Brasil (2009, p.19), inicia sua argumentação afirmando que em nossa realidade é mais comum pensar a democracia como esperança do que como realização. Desta forma, faz uma passagem pela história do país desde o período imperial até a CF de 1988, analisando a ação dos partidos políticos e dos movimentos sociais no sentido de impulsionar a democracia, que ele define primeiramente como a forma de participação mais ampla, pautada nas decisões coletivas, elaboradas a partir de regras e procedimentos (IDEM, 2009, p.20). Todavia, acredita que, com a complexificação das sociedades, é mais pertinente se falar em um processo de democratização, que se direciona do Estado à sociedade. Ainda com 
Bobbio, define o processo de democratização como a passagem das relações políticas, ou seja, as relações que se desenrolam na esfera da vida cidadã, às relações sociais, que se referem aos diferentes papéis que assumimos em nosso cotidiano. Assim sendo, devido aos momentos de supressão das liberdades no Brasil, o sistema partidário ainda não estaria tão consolidado, o que levou a uma proeminência de grupos corporativos e de defensores de interesses particulares - profissionais, religiosos, econômicos, entre outros, promovendo uma "corporativização da vida política" (IBIDEM, 2009, p. 21), de forma que o governo tenha se tornado o responsável pela intermediação dos interesses das entidades que passou a representar.

Cabe, pois, intrincar ainda mais este olhar, uma vez que para compreender a elaboração da educação como direito na história brasileira, é importante lembrar que o ponto de partida de cada indivíduo que chega ao espaço escolar nunca será o mesmo, sabendo-se que existem as "histórias individuais", que são forjadas diferentemente, de acordo com a origem social, econômica e cultural de cada grupo. Destacamos que Anísio, neste sentido, conseguiu avançar em relação aos demais signatários do Manifesto, pois atentou para a incorporação "[...] de todos os indivíduos em condições de igualdade e não de forma seletiva [...] que resgata a noção de individualidade sem separar o homem do cidadão" (TEIXEIRA, 1968, p. 202). A escola pública, pois, ratificando Barros, em obra datada de 1960 (p.31), deveria "[...] receber a todos sem qualquer discriminação de classe, raça, política ou religião [...] o melhor instrumento de iniciação social e de cultura democrática”. Falar de democratização requer que pensemos no que clamamos como liberdade e como diferença. A igualdade nos conduz pelo caminho da eliminação dos privilégios, da discriminação, da luta contra as desigualdades de naturezas diversas. Todavia, é importante também considerar que na materialidade do cotidiano, as pessoas são diferentes, e tais diferenças devem ser consideradas, sem prejuízo da igualdade como princípio.

Cabe lembrar que, grosso modo, a democratização do ensino pode ser compreendida como ampliação do acesso e zelo pela permanência dos estudantes na escola; também como garantia do direito individual e ao mesmo tempo, como direito público e subjetivo à educação; e ainda, como a obrigatoriedade do Estado garantir tal direito de forma a universalizá-lo, tendo a gratuidade como ferramenta crucial. Cabe ainda problematizar a própria ideia de oportunidades educacionais com a de igualdade de condições, fundamentais ao entendimento do que se construiu em termos de política educacional. 
A palavra oportunidade nos remete à perspectiva liberal, na qual se acredita que todos os cidadãos tem possibilidade de acessar os bens disponíveis na sociedade, cabendo-lhes sua parcela de esforço para obter sucesso. Desconsidera-se, pois, a desigualdade existente entre as pessoas, o que se agrava sobremaneira em realidades complexas e com um abismo sócio-econômico entre as classes sociais, que, no caso brasileiro, refere-se, por exemplo, a uma discrepância salarial na qual o salário dos $10 \%$ mais ricos é quase 30 vezes maior que o dos 10\% mais pobres (PNAD, 2014). Não podemos, assim sendo, afirmar que uma criança oriunda de um lar que possui o salário trinta vezes maior do que o da outra, trinta vezes menor, terá as mesmas oportunidades que a mais pobre. Inexiste possibilidade de mérito em tal situação; inexiste liberdade na necessidade. O que existe são privilégios.

De posse deste pensamento, a classe detentora do capital entra na vida em sociedade com vantagens decisivas em relação às classes menos favorecidas, que dependem dos primeiros para poder participar da produção social e, consequentemente, do sistema escolar. A meritocracia busca camuflar a falta de equidade sob o discurso da igualdade acima exposto, garantindo que se existem as mesmas oportunidades, os que obtém sucesso o fazem porque se esforçaram mais. Pode-se, pois, afirmar que a meritocracia acaba por colocar sobre os indivíduos a responsabilidade por seu sucesso ou fracasso, dissimulando as questões que são fundamentais para a sua colocação nos diferentes espaços sociais por onde transitam.

Por conseguinte, falar de democratizar as oportunidades educacionais também nos leva a crer que basta inscrever tal conceito em lei, abrir vagas nas escolas e matricular os alunos para que o direito à educação venha a ser mecanicamente efetivado. Desconsiderase, nesta perspectiva, todas as questões que historicamente levaram parte da população a não frequentar tal espaço, ou mesmo o fato de não lograrem êxito na tarefa de se educarem e concluírem o período escolar com resultados satisfatórios. Concordamos com Cury (2010, p. 114) quando afirma que

As consequências da colonização e da escravatura, associadas às múltiplas formas de não acesso à propriedade da terra, a ausência de um sistema contratual de mercado e uma fraca intervenção do Estado no sistema de estratificação social produzirão sociedades cheias de contrastes, gritantes diferenças próprias da desigualdade social [...] Isso explica o enorme número de pessoas que sequer possuem educação primária, sendo ainda grande o número de pessoas que possuem poucos anos de escolaridade. A pirâmide educacional acompanha muito de perto a pirâmide da distribuição da renda e da riqueza. 
Neste sentido, a defesa da escola pública como forma de promover a sociedade democrática começa a fazer sentido, pois seria ela uma das instituições responsáveis pela equalização do acesso à educação, na medida em que pode oferecer o mesmo ponto de partida para todos, mesmo que os caminhos de cada qual tenham se desenhado de forma diferente até ali. Destacamos ainda que não é possível desconsiderar que as diferentes trajetórias influenciam no maior ou menor sucesso que os agentes terão na escola e nas etapas que a sucedem. Duas palavras são apresentadas por Anísio para ilustrar esse momento: direito e continuidade. Destaca que o sistema de educação deveria ser organizado para que todos “[...] em igualdade de condições, possam dele participar e nele continuar até os níveis mais altos" (IBIDEM, p. 61). Neste sentido, o autor afirma que a CF de 1946 consagrou o direito individual à educação e apresentou o dever do Estado para com o ensino primário, todavia não cuidou da promoção da educação como ferramenta de mudança social. Continuava, pois, a educação se constituindo uma vantagem, uma vez que apenas deveria instrumentalizar parte da população para vida social.

Não basta, portanto, conforme vimos anteriormente, ampliar o acesso à escola e entender que tal ação, por si só, caracteriza-se como democratização do ensino. Há que se considerar outras posições e vertentes para que venhamos a alcançar efetivamente uma abordagem mais social deste processo, retirando do indivíduo a responsabilidade pelo seu sucesso ou fracasso. Os estudos de Beisiegel (2005, p. 8) partem essencialmente do questionamento do que viria a ser a qualidade, vinculado ao processo de extensão das oportunidades educacionais à população em geral. $\mathrm{O}$ autor afirma que a expansão do número de matrículas não garante efetivamente o direito à educação, posto que por vezes se trata de estratégia político-eleitoral, que condiciona a oferta de vagas a determinadas regiões/níveis de ensino, sem se pautar em um efetivo estudo de demanda e de impacto, que deveriam ser feitos por planos de educação, como a muito tempo já se discute no campo educacional.

Em entrevista realizada para esta tese, Luiz Antônio Cunha ponderou sobre outros aspectos a serem observados quando se fala a respeito das dimensões que compõem o direito à educação, contemplando, por exemplo, a questão do acesso em condição conveniente e a gestão democrática da escola:

Se eu pensar em dimensões [...] eu posso pensar que o acesso à escola seja uma dessas dimensões. Escola próxima de casa, por exemplo. Não adianta ter vaga em uma escola que eu demore 2 horas para chegar lá. E é muito comum, os sistemas escolares, e aí não depende da LDB, depende da prática política da administração 
educacional. Viajando por aí, eu vejo uma escola na frente da outra, uma estadual e a outra municipal, claro que as duas com capacidade ociosa. Mas do outro lado do rio, do outro lado da estrada, de uma estrada, uma BR cheia de carro, ali tem um monte de gente morando sem escola. Então, é, se você for olhar do ponto de vista das médias, não tem escola para todo mundo, mas se você baixa as vagas, você vai ver que sobra vaga lá. Então o direito é isso, de ter acesso à escola em condições convenientes. Eu acho que essa é uma questão, uma das dimensões. Isso a LDB não responde, essa é uma questão de política prática. Bom, outra questão, a questão do acesso a uma escola democrática. Está cada vez mais claro para mim que a escola democrática inclui a laicidade não só do seu currículo, mas do seu currículo no sentido amplo, isso significa a maneira, a sua vida dentro da escola, as relações com as pessoas e tudo.

Mais uma vez se mistura a democratização com a liberdade de ensino. Segundo Cunha, não é possível se pensar em garantia do direito à educação em uma escola que não é democrática, e que, por conseguinte, não é laica. Voltaremos à questão da laicidade no próximo item, mas é importante mais uma vez destacar que tais aspectos não se dão em separado, posto que são dialéticos. Destacou também, ratificando Beisiegel (2005), que a mera ampliação do número de vagas não garante o direito ao acesso de todos à escola, uma vez que a oferta desordenada e irregular não viabiliza a frequência dos alunos ao espaço escolar. Acrescentaríamos ainda aqui a rotina e os currículos escolares como comprometedores da permanência (ou responsáveis pela evasão) de parcela significativa dos alunos que nela ingressam, por desconsiderarem a vivência e os conhecimentos prévios de alguns grupos, sobretudo os oriundos das classes populares.

Outro aspecto que vale destacar se refere às condições objetivas da vida de crianças, adolescentes, jovens e adultos que têm acesso à educação, sobretudo via escola pública. Muitas vezes tais condições não permitem sua continuidade nos bancos escolares, uma vez que a demanda econômica requer a saída prematura destes agentes desse espaço, ocasionando o fenômeno da evasão e do abandono escolar, muito familiares à discussão educacional brasileira. Cabe, pois, destacar um trecho que resume bem estas outras esferas, que compõem a complexa teia de significados do que vem a se constituir como democratização do ensino na realidade brasileira:

O ensino democrático não é só aquele que permite o acesso de todos que o procuram, mas, também, oferece a qualidade que não pode ser privilégio de minorias econômicas e sociais. O ensino democrático é aquele que, sendo estatal, não está subordinado ao mandonismo de castas burocráticas, nem sujeito às oscilações dos administradores do momento. Tem isto sim, currículo, condições de ingresso, 
promoção e certificação, bem como métodos e materiais discutidos amplamente com a sociedade, de modo que os interesses da maioria, em termos pedagógicos, sejam efetivamente respeitados. $\mathrm{O}$ ensino democrático é, também, aquele cuja gestão é exercida pelos interessados, seja indiretamente, pela intermediação do Estado (que precisamos fazer democrático), seja diretamente, pelo princípio da representação e da administração colegiada (CUNHA, 1987, p. 6).

Voltemos ao objeto deste estudo. Resgatamos a entrevista realizada com Carlos Roberto Jamil Cury, na qual ele cita a mudança de concepção que a aprovação de uma CF com uma linha social tão clara promoveu no que tange à compreensão da mesma. Apesar de ser um trecho longo, a resposta do entrevistado foi extremamente relevante para ratificarmos a nossa perspectiva da ANC como campo político, na qual as disputas se estabeleceram para que uma tendência viesse a se evidenciar e conseguisse, nos embates internos a este campo, galgar degraus no que se refere à sua aprovação com força de lei.

[...] as leis são um campo de disputas, não é? [...] É... um campo de tensões, um campo de disputa, quem é legítimo para afirmar isso, quem é legítimo, quem tem legitimidade para dizer isso... é, enfim. [...] a Constituição de 46 e ao próprio clima que o Brasil viveu na época, ela tem um tom mais liberal [...] sempre que você tem um tom mais liberal, a tendência é você enfatizar o indivíduo... o empenho, a força do indivíduo. A vontade do indivíduo, né. Ele não enfatiza tanto a questão grupal, a questão de classe, entendeu? A questão do coletivo, né. Não é que ela não tenha, mas o interesse, vamos dizer assim, esse pano de fundo mais liberal, liberal democrático na verdade, não é, ela tende a deixar determinadas coisas por conta da força do indivíduo, o indivíduo tem que ir atrás. Tá? Claro que tem a obrigatoriedade do ensino primário, aí foge, porque aí você tem uma invasão da liberdade. Sai a liberdade, entra a obrigatoriedade. E neste sentido então, quando você tem uma perspectiva social democrata, avulta o dever do Estado e a necessidade das garantias. Quando você tem uma dimensão liberal democrata, o que avulta é a força do indivíduo, diminui, portanto, a dimensão social [...] A igualdade de oportunidades ela certamente é o que marca uma constituição para a educação de caráter liberal democrático. É oportunidade. Mas, na verdade quem assume o risco da oportunidade é o indivíduo. Tá? A Constituição de 88 ela associa a igualdade de oportunidades com igualdade de condições. São as filigranas que estão na Constituição de 88 . A igualdade de condições, ela tende por social democrata. Então ela tende a fazer uma negociação entre igualdade de oportunidades e igualdade de condições. Do ponto de vista específico, acho que eu já toquei nisso, a Constituição de 46 ela gera a igualdade de oportunidades de uma forma isonômica, para o primário. Mas não para além. [...] É, já a Constituição de 88, ela, é, amplia a igualdade de oportunidades ao tipificar, ao tipificar toda educação pública como gratuita, ao, antes da emenda 14, portanto, na versão original da Constituição, indicar que o ensino médio deveria ser progressivamente obrigatório, então já está lá em 88 o que só veio a se consubstanciar com a emenda 
59 [...] seja a Constituição de 46, seja a 4.024, elas são mais limitadas à igualdade de oportunidades. O que fica muito claro, por exemplo, na 5.692. Como você sabe, a 5.692 rigorosamente, no direito a gente diz, é a lei 4.024 com a redação dada pela 5.692. E ali é muito claro, né, a gratuidade é só para aqueles que comprovem insuficiência de recursos. Então, você tem uma limitação de igualdade de oportunidade, tem uma limitação, que é a limitação da gratuidade. Que vai cair com a Constituição de 88. A gratuidade se amplia, a obrigatoriedade é anunciada para além do ensino fundamental, né, e, é, além disso, a Constituição de $88,[\ldots]$ vai abrir-se para o direito à diversidade, que é naquela linha do Bobbio, né, que é o direito à especificação. É, são as pessoas com deficiência, é, as comunidades afrodescendentes. [...] a democracia tem haver com a noção de igualdade. Há uma democratização. Em 46 volta a haver uma democratização porque, porque em 37 você praticamente, na Constituição de 37, você substitui a força do direito à educação pelo dever de família. Em 46 volta o Estado a ser o protagonista. Tá? E ele ficou secundarizado no texto de 37 , que na prática não foi exatamente isso, mas ele ficou secundarizado no texto de 37, então o Estado volta a ser o garantidor da igualdade, da democratização de oportunidades, abrindo de novo, explicitamente, a gratuidade do ensino primário, não é, e a obrigatoriedade do ensino primário como dever do Estado, não é, e, também, volta a vinculação. Então, isso você pode dizer que há uma democratização de oportunidades, tranquilamente. Agora, a Constituição de 88, ela junto com essa democratização, ela vai colocar a democratização, no caso a igualdade de condições, é um pouco diferente do que oportunidade.

Considerando a fala acima transcrita, a discussão trazida pela CF de 1988 ampliou a perspectiva inicial de democratização das oportunidades educacionais, uma vez que as oportunidades extrapolam a esfera individual e ganham materialidade na igualdade de condições, com o viés da social democracia, que passa a alcançar parte significativa da educação básica - mais tarde, quando a lei consegue abarcar este nível de ensino, com o FUNDEB e, ainda, com a aprovação da EC $n^{\circ} 59 / 2009$, que ampliou a obrigatoriedade da educação, passando a contemplar a faixa etária de quatro aos dezessete anos de idade (deixando de fora apenas parte da educação infantil, dos 0 aos 3 anos de idade).

Destaca-se ainda que a ideia de liberdade mais uma vez se mescla à da democratização, posto que várias vezes foi mencionada e problematizada acima. $\mathrm{Na}$ linha defendida pelo texto constitucional de 1988, diferentemente do texto de 1946, a liberdade aparece de uma forma não restrita à esfera individual, que envolve as questões da meritocracia, trazida à baila nos anos de 1930, e principalmente alavancada pelos intelectuais envolvidos com a publicação do Manifesto. Destacamos, mais uma vez, Anísio Teixeira para elucidar esta questão quando tratou, primeiramente, da educação capaz de promover a democracia, 
em texto dos anos de 1936, e, em um segundo momento, quando analisou mais tarde a revolução industrial e a mudança que esta começou a promover no campo educacional, em um texto de 1968:

A escola deve fornecer a cada indivíduo os meios para participar, plenamente, de acordo com as suas capacidades naturais, na vida social e econômica da civilização moderna, aparelhando-o, simultaneamente, para compreender e orientar-se dentro do ambiente em perpétua mudança que caracteriza esta civilização (TEIXEIRA, 1936, p. 87-88).

O que prometia o século XVIII era a libertação do indivíduo em uma nova sociedade, organizada na base de um novo saber [...] Estado moderno, com o sufrágio universal, o mandato temporário e a tácita responsabilidade dos eleitos perante os eleitores [...] Mas não se compreendera, em toda a extensão, a dependência de um regime de um novo nível educacional da humanidade. Muito pelo contrário, não faltaram teoristas do novo individualismo para julgar a oferta de oportunidades iguais de educação a todos como algo completamente insensato. Como o alimento, a casa e a roupa, a educação era algo a ser conseguido pela iniciativa individual e à custa do próprio indivíduo (TEIXEIRA, 1968, p. 34).

De acordo com Singer (1996, p.7), existe uma tendência a minimizar as diferenças entre liberalismo e democracia, que se reflete no uso da expressão liberal-democracia ou democracia liberal. Como vimos anteriormente, o liberalismo clássico se aproximou da perspectiva democrática, angariando suas principais características, dentre elas a educação como direito. Nesse contexto, a instituição escolar foi entendida como instrumento capaz de promover a democratização da sociedade, que se materializou no Estado de bem-estar social. Aqui, no entanto, os efeitos desse processo não foram tão sentidos, como também já mencionamos, uma vez que a imensa desigualdade social não nos permitiu incorporar efetivamente aquela grande parcela que sempre fora excluída de todo processo social.

Zaia Brandão (2017, p. 1) tece uma crítica à instituição escolar e à escolarização, na medida em que considera que só há democratização do ensino quando esta “ [...] implica em padrões de escolaridade que permitem de fato se fazer presente em condições de igualdade no espaço público: é condição de equidade cidadã". Considera, pois, que o nosso sistema escolar, mesmo diante da aprovação de leis no campo educacional, ainda não foi capaz de operar os mesmos padrões de qualidade entre as diferentes classes sociais “"...] garantido a manutenção de distância simbólica e real entre a escola pública dos pobres e as das 'elites escolares"”. 
À vista disso, passaremos a analisar as diferentes versões propostas na abertura deste capítulo, a partir da concepção multifacetada de democratização, que além das especificações colocadas, resgata a concepção de democracia trazida por Wacquant (2005, p.19-20), com inspiração em Pierre Bourdieu, quando a apresenta

[...] definida em termos gerais com o Estado social em que todos possuiriam a inclinação quanto a capacidade de tomar nas próprias mãos as questões políticas e de detectar as armadilhas e possibilidades das lutas propiciadoras de seu avanço nos diferentes domínios da vida.

São essas lutas no âmbito da ANC de 1987-1988 que passaremos a analisar. Levemos a advertência de Florestan Fernandes feita no texto A reforma educacional (1989, p.130131), em que ele afirma ser necessário cumprir algumas tarefas na elaboração de um texto constitucional. Já apresentamos parte desta concepção anteriormente, mas resgatamos o trecho completo na obra consultada:

Não se pode fazer um projeto ou um anteprojeto na área de educação sem perguntar quais são as tarefas educacionais na situação brasileira e qual é a posição que a Assembleia Nacional Constituinte deve ter diante dessas tarefas. Não se trata de entrar num terreno tão complexo como se estivesse dando um mergulho numa piscina [...] Era preciso fazer uma revolução no topo, através da educação, para acabar com essa mentalidade de privilégio, e fazer uma revolução na base, de maneira a ter uma situação diferente dessa que prevalece até hoje, de modo que toda a massa pobre da população tenha acesso ao sistema de ensino. Era preciso articular essas duas transformações - esse é o dilema geral. A ele se juntam três conjuntos de prioridades pedagógicas. A mais importante diz respeito à garantia da igualdade de oportunidades educacionais - garantia de fato, não em termos de retórica. A segunda diz respeito ao enfoque dado à escola, visto como valor social, e a uma nova visão do professor, do aluno, e do funcionário [...] A terceira tarefa prioritária consiste na auto-emancipação pedagógica. $\mathrm{O}$ repúdio à colonização de nossa cabeça.

Na mesma linha descrita acima, além do dispositivo legal, é preciso conferir materialidade ao discurso da democratização do ensino. Este só seria possível por meio da radicalização do sentido da escola pública, ou seja, quando ela não somente incorporar os historicamente excluídos em número, via matrícula. É urgente e necessário que o faça com qualidade, com estratégias que os permitam não só acessar, mas permanecer e ter sucesso no trabalho escolar, como ratificamos no trecho seguinte: 
Se a escola pública quiser ser fiel à sua origem e vocação democrática, ela terá de se ajustar ao novo papel de educadora universal e principalmente das crianças de famílias socialmente excluídas. O que significa repensar-se por inteira e recolocar o conteúdo da instrução, a metodologia didática, a formulação de regras de conduta e o disciplinamento dos participantes do processo educativo. Chego a pensar que a reforma requerida pode beirar uma revolução, à medida que exige de professores, que provavelmente sempre se enxergaram como diferenciadores, a conquista de uma nova identidade (SINGER, 1995, p. 14).

\subsubsection{A democratização das oportunidades educacionais: do texto da Comissão dos Notáveis à aprovação da CF de 1988}

Nossa análise se inicia com o texto apresentado pela comissão formada pelo governo, capitaneada por Afonso Arinos, antes do início dos trabalhos da Assembleia Nacional Constituinte. $\mathrm{O}$ texto da referida comissão trouxe, logo no artigo $5^{\circ}$, uma menção aos princípios defendidos no Brasil a partir de convenções internacionais, sendo que, dentre eles, aparece primeiramente os direitos humanos. O capítulo dois apresentou os direitos e garantias individuais, sendo nele enunciado o direito à educação, especificamente no artigo 25, conforme o que se segue:

Art. 25 - É assegurado o direito à educação, como iniciativa da comunidade e
dever do Estado, e o do livre acesso ao patrimônio cultural. Parágrafo único - O
direito de aprender e ensinar, na forma da lei, não fica sujeito a qualquer diretriz
de caráter religioso, filosófico, político partidário ou ideológico, sendo facultada a
livre escolha de instituição escolar (CÂMARA, 2017, p. 20).

O artigo 75 trouxe a responsabilidade da União e dos Estados para com a legislação comum referente aos direitos em diferentes níveis, estando elencado no inciso XV a educação. O mesmo se deu no artigo 128, quando a educação foi apresentada como serviço de interesse das cidades. O título IV trouxe a ordem social com a finalidade de realização da justiça social, por meio do cumprimento de alguns princípios, dentre os quais a educação também foi lembrada. Passemos ao título V, que se destinou a organizar os princípios da educação, da cultura, da comunicação social, da ciência e da tecnologia a serem respeitados no Brasil. Vimos que, mais tarde, quando da divisão dos temas constantes nas comissões, todos esses passaram a compor a comissão 8, objeto de nosso estudo.

$\mathrm{O}$ capítulo I do título $\mathrm{V}$, diz respeito especificamente à educação. Como em todo texto legal, o primeiro artigo buscou definir o que o legislador entende por educação. 
Como já vimos a redação do artigo 384 no início do capítulo anterior, cabe-nos apenas alguns destaques adicionais: ligada à cidadania, a educação foi defendida pela Comissão na perspectiva liberal, tendo no Estado a garantia da efetivação do direito individual. Mais adiante, no artigo 386, incluiu os pais como co-responsáveis na garantia do direito à educação. Defendeu-se, ainda no parágrafo único, a educação na perspectiva dos acordos internacionais que deram origem à moderna concepção de direitos humanos, no qual o direito à especificação - já mencionado anteriormente - foi apresentado de forma explícita.

O artigo 385 incumbiu-se de elencar as diretrizes da educação no país. Foram relevantes para nossa análise neste momento os incisos I, III, IV, VI e VIII, abarcados pela perspectiva da democratização das oportunidades educacionais - inclusive o inciso IV se aproximou muito da fala de Luiz Antônio Cunha em sua entrevista, quando apresentou a necessidade de democratização das relações no interior da escola.

Art. 385-O sistema de educação obedece às seguintes diretrizes: I-democratização do acesso de toda coletividade aos benefícios da educação; II - pluralismo de idéias e de instituições públicas e privadas; III - descentralização da educação pública, cabendo, prioritariamente, aos Estados e Municípios o ensino básico obrigatório, nos termos do art. 387 deste Capitulo; IV - participação adequada, na forma da lei, de todos os integrantes do processo educacional nas suas decisões; $\mathrm{V}$ - adequação aos valores e às condições regionais e locais; VI - garantia da educação permanente, supletiva, e de alfabetização para todos; VII - valorização do magistério em todos os níveis, com garantia de padrões mínimos de remuneração fixados em lei federal; VIII - superação da marginalidade social e econômica (IDEM, p. 66).

O artigo 387 apresentou a obrigatoriedade da educação dos seis aos dezesseis anos de idade, buscando materializar o dever do Estado para com a educação das crianças e adolescentes. É interessante destacar que neste anteprojeto a obrigatoriedade foi delineada abarcando uma extensa faixa etária, diferentemente do que foi aprovado mais tarde. Aqui ela perpassaria o que hoje entendemos por ensino fundamental, cobrindo, inclusive, a educação profissional. Todavia, não se fez menção ao ensino médio como obrigatório.

Um debate caro à ANC, colocado nos termos da emenda Calmon, encontrou expressão no artigo 388. Apresentou-se os valores de $13 \%$ e $25 \%$ dos recursos que seriam vinculados constitucionalmente pela União, pelos estados e municípios, respectivamente. Veremos, mais tarde, que após um extenso debate tal percentual melhorou de forma significativa, no que se refere à aplicação da União. 
O artigo 390 pode ser destacado aqui e no item concernente à liberdade de ensino. Ele trouxe a discussão do acesso à educação, por nós classificado na categoria democratização das oportunidades educacionais, mas também tratou da concessão de bolsas de estudo, que afeta a categoria que analisaremos posteriormente.

\begin{abstract}
Art. 390 - O acesso ao processo educacional é assegurado: I - pela gratuidade do ensino público em todos os níveis; II - pela adoção de um sistema de admissão nos estabelecimentos de ensino público que, na forma da lei, confira a candidatos economicamente carentes, desde que habilitados, prioridade de acesso até o limite de cinqüenta por cento das vagas; III - pela expansão desta gratuidade, mediante sistema de bolsas de estudos, sempre dentro da prova de carência econômica de seus beneficiários; IV - pelo auxílio suplementar ao estudante para alimentação, transporte e vestuário, caso a simples gratuidade de ensino não permita, comprovadamente, que venha a continuar seu aprendizado; V - pela manutenção da obrigatoriedade de as empresas comerciais, industriais e agrícolas garantirem ensino gratuito para os seus empregados, e filhos destes, entre os seis e dezesseis anos de idade, ou concorrer para esse fim, mediante a contribuição do salário educacional na forma estabelecida pela lei; VI - pela criação complementar à rede municipal de escolas de promoção popular, capazes de assegurar efetivas condições de acesso à educação de toda coletividade (IBIDEM, p. 66).
\end{abstract}

O dispositivo é contraditório, pois ao mesmo tempo em que apresentou a educação como gratuita em todos os níveis, tal gratuidade não alcançou a todos, assim como o direito se enunciou anteriormente. Além de propor uma espécie de credenciamento dos alunos carentes, fez-nos subentender que o acesso à escola pública deveria se dar após algum exame de admissão ou prova seletiva, ao mencionar que tal credenciamento seria realizado "[...] desde que habilitados". Questiona-se, pois, que educação para todos é essa que restringe a entrada por meio de seleção e novamente apura os alunos passíveis de serem contemplados pela gratuidade ou pela concessão de bolsas, devido à sua origem sócioeconômica. Novamente o viés econômico foi evocado quando se abordou a necessidade de se pensar e garantir não só o acesso, como também a permanência dos estudantes, por meio de auxílio suplementar. O inciso VI apresentou a "criação complementar à rede municipal de escolas de promoção popular"; sobre esta questão não ficou claro se as escolas citadas seriam propriamente parte das redes municipais que viriam a se estabelecer, que deveriam ser enraizadas na comunidade com a qual dialogam e com a cultura popular para o estabelecimento de seu currículo; ou se as redes municipais deveriam dialogar com espaços outros de cultura popular, como ONG, por exemplo. 
Por fim, o artigo 394 exibiu a necessidade do currículo escolar contemplar o ensino dos direitos, deveres e garantias do cidadão e os do Estado democrático de direito. Tal fato também dialoga com a perspectiva anunciada por Luiz Antônio Cunha no trecho transcrito da entrevista realizada, quando o mesmo abordou a necessária revisão curricular.

O conjunto de versões que passaremos agora a analisar é composto pelos textos apresentados pelas principais instituições que foram ouvidas na subcomissão 8a. Começaremos com a Carta de Goiânia, que foi citada por muitas das entidades ouvidas no período em que se desenrolaram os trabalhos das subcomissões. Já apresentada nos capítulos precedentes, a Carta, fruto da IV Conferência Brasileira de Educação, organizada pela ANDE, ANPEd e CEDES - realizada no início do mês de setembro de 1986 - objetivou debater os principais problemas da educação brasileira e oferecer propostas para a CF a ser elaborada.

Desta forma, partiu do diagnóstico da educação brasileira, apresentando seus principais problemas, dentre eles a dificuldade na universalização e na efetivação da qualidade do ensino, a viabilização da gratuidade escolar, as condições de trabalho do magistério, além da escassez e má distribuição das verbas públicas. Após a apresentação de um texto explicando as principais reflexões feitas pelo grupo, elencou 21 princípios que deveriam ser inscritos no texto da nova Constituição. Discutiremos os que dizem respeito à categoria estudada neste item.

O primeiro ponto tratou da educação como direito de todos os brasileiros, que deveria ser gratuita e laica em todos os estabelecimentos e em todos os níveis de ensino. Tal princípio foi especificado na passagem seguinte, que agregou muitos outros adjetivos à educação pública para todos: "básica comum, gratuita e de igual qualidade, independentemente de sexo, cor, idade, confissão religiosa e filiação política, assim como da classe social ou da riqueza regional, estadual ou local" (CÂMARA, 2017b, p. 70). Cabe ressaltar que tal proposição em muito se distanciou do texto apresentado pela Comissão Afonso Arinos, analisado anteriormente.

O item 3 tratou da obrigatoriedade de 8 anos de duração do ensino, sendo facultada a matrícula a partir dos 6 anos de idade; obrigatoriedade esta que seria garantida pelo Estado, tal como previsto no princípio seguinte, que ainda agregou a duração do período escolar. As propostas seguintes $(5,6,7$ e 8$)$ estenderam a oferta de escolarização com qualidade a outros grupos de estudantes, a saber: aos que ingressaram no sistema escolar na faixa etária 
dos 0 aos 6 anos; aos deficientes; aos jovens e adultos que foram excluídos do processo de escolarização formal na idade própria; e aos jovens que precisavam compatibilizar estudo e trabalho, mediante a criação de bolsas de estudo a serem distribuídas para estudantes de escolas públicas. Contemplou-se nesta discussão o direito à especificação, mencionado anteriormente.

O item 9 trouxe o ensino de $2^{\circ}$ grau, ou de nível médio, como segunda etapa do ensino básico, sendo também indicado como forma de materializar o direito à educação, percebido para além do ensino elementar. Quando o décimo princípio abordou o direito de alfabetização na língua materna aos indígenas, cremos que tal perspectiva viria também para viabilizar um maior comprometimento com a ampliação dos limites do conceito de democratização das oportunidades educacionais, no sentido de conferir a igualdade de condições.

Os itens 12 e 13 trataram da gestão das universidades, entendidas em seu compromisso na manutenção de um ambiente autônomo e democrático. Já o 14 trouxe, ainda na perspectiva de garantia do direito, a necessidade de regulamentação da responsabilidade de estados e municípios na tarefa educacional, com a participação da União. Acreditamos que aqui se encontravam as bases do que na lei veio a ser chamado de regime de colaboração entre os entes federados. Cabe ressaltar que este princípio ainda consagrou a questão da qualidade do ensino como um elemento que precisa ser garantido, junto à ampliação do acesso. Sobre tal aspecto, é importante transcrever a fala de Jarbas Barato, quando de sua participação na subcomissão 8a, como tesoureiro da ANDE, ao discutir os princípios da Carta no que foi concernente à educação de jovens e adultos, mas que se aplicava perfeitamente à ideia de direito, tal como deveria ser visto e reclamado:

\footnotetext{
Parece que, muitas vezes, confundimos o direito à educação como uma das formas de atendimento a esse direito, que é a escola de $1^{\circ}$ grau, dos 7 aos 14 anos. O direito à educação não é o direito de apenas estar na escola, mas é o direito que as pessoas têm de terem acesso a um patrimônio cultural comum, construído por esta Nação - esse patrimônio cultural com relação ao domínio da língua nacional, com relação aos conhecimentos no campo das Ciências Sociais, das Ciências Físicas, da Matemática, etc. (CÂMARA, 2017b, p. 46).
}

A presidenta da ANDE, Elba Siqueira, iniciou sua participação na subcomissão 8a, colocando-se alinhada aos princípios da Carta de Goiânia e às orientações do FNDEP. 
Pôs-se a elaborar um diagnóstico da educação no Brasil, que pode ser resumido no trecho seguinte, que muito se aproxima das discussões que iniciaram o presente capítulo, e que se repetem no Brasil desde, pelo menos, os anos de 1930:

O direito à educação tem sido escamoteado justamente à maioria da população. E, neste sentido, o baixo nível educacional tem a ver muito com a iníqua distribuição de renda deste País, que é a mais injusta do mundo e que tem privado a maioria da população da assistência aos direitos fundamentais de moradia, de saúde e de educação (IDEM, p. 45).

Sobre a questão da assistência anunciada por Elba, havia dois princípios expressos na Carta. Um tratava da responsabilidade do setor de saúde pública na garantia deste serviço para os estudantes, e outro abordava a merenda escolar e programas assistenciais afins, afirmando que os mesmos deveriam existir e serem gerenciados pela educação, mas que, todavia, deveriam dispor de recursos próprios, para que não viessem a camuflar os gastos efetivos com os processos de ensinar e aprender.

Os princípios 19 e 20 tratavam da gestão democrática do ensino, que vão ao encontro da fala do professor Luiz Antônio Cunha, já exposta anteriormente. Anunciavam a necessidade de criação de espaços colegiados, nos quais a participação acontecesse de forma ampliada e direta, com vistas "[a]o cumprimento e [a]o controle social efetivo das suas obrigações referentes à educação pública, gratuita e de boa qualidade em todos os níveis de ensino" (IBIDEM, p. 70).

Por fim, o último princípio tratava da vinculação orçamentária, destacando a proposta da emenda Calmon. Buscou-se, neste sentido, garantir a aplicação mínima de recursos na educação em todas as esferas de governo, de maneira a minimizar a falta de compromisso com os problemas educacionais.

Na mesma ata da subcomissão 8a em que constava a Carta de Goiânia, estavam também anexados os documentos com as propostas da ANDES, da SBPC e da Federação Brasileira de Associações de Professores de Educação Física (FBAPEF). Abordaremos brevemente cada um deles. O documento da ANDES começava com a apresentação dos seguintes princípios:

Originária das grandes mobilizações de trabalhadores do século XX, a luta pelo ensino público e gratuito no Brasil representa, com clareza, um exemplo da divergência existente entre os interesses da maioria da população brasileira em obter serviços públicos de boa qualidade e aqueles das classes mais privilegiadas que controlam o Estado e suas políticas. Lutamos por uma educação pública, gratuita, crítica, democrática e competente (CÂMARA, 2017b, p. 70). 
Partindo da crítica à seletividade do sistema educacional brasileiro e de seu compromisso com o ensino privado, a ANDES propôs um compromisso social com o saber crítico para todos, colocando como pontos inegociáveis: “[...] a democracia, a qualidade, a gratuidade, o interesse público e a autonomia" (IDEM, p. 71). Assim sendo, apresentou uma plataforma, cujo primeiro elemento dizia respeito ao direito à educação, especificamente no sentido de democratização das oportunidades educacionais:

1.2.1 - A educação é um dos agentes promotores da capacitação ao trabalho, à sustentação da vida e dos meios de elaboração e reflexão crítica da realidade social em que vivemos, sendo dever do Estado prover ensino público, gratuito e laico para todos, em todos os níveis, inclusive o pré-escolar (IBIDEM, p. 71).

Além de propor o princípio, apontou a metodologia a ser realizada para a efetivação do mesmo. Expôs a necessidade de elaboração de um Plano Nacional de Educação como forma de prever e articular as ações necessárias à melhoria da educação no país, com base em um diagnóstico prévio. Para tanto, aprofundou alguns aspectos já trazidos pela Carta de Goiânia, buscando tornar mais concreta a possibilidade de sua realização, sobretudo no que se referia à democratização das oportunidades educacionais via escola pública de qualidade:

Neste Plano cabe ao Estado garantir na escola pública um número de vagas suficiente para atender a demanda da população escolar potencial. O Estado garantirá a todos a realização desse direito através de outros programas sociais devidamente orçamentados no seu setor específico, tais como transporte, alimentação, material escolar e assistência à saúde (CÂMARA, 2017b, p. 72).

Ratificando a proposta escrita, o Sr. Newton Lima Neto, presente na subcomissão, apresentou da seguinte forma a proposta da associação ora representada na condição de seu presidente:

Em primeiro lugar, nós entendemos que a educação é um direito de todo cidadão, sendo dever do Estado oferecer ensino público gratuito e laico para todos e em todos os níveis. Isso não significa a extinção da escola particular, evidentemente, mas significa que cabe ao Estado, em função do recolhimento dos impostos gerados pelo trabalho e pela riqueza desta Nação, devolver à população brasileira, ao povo brasileiro, na forma do benefício social da educação, em todos os níveis, o ensino de qualidade laico e gratuito (IDEM, p. 51). 
Ainda constavam no documento da ANDES a defesa da gestão democrática e da autonomia das instituições de ensino. Cabe um destaque para o fato do documento detalhar alguns dos principais princípios expostos na Carta. Passemos ao documento da SBPC. Como mencionamos no capítulo anterior, a SBPC contou na subcomissão com Luiz Antônio Cunha para a apresentação de suas propostas. $\mathrm{O}$ documento exibido àquele espaço, iniciava-se com uma justificação que resgatou a necessária democratização das oportunidades educacionais, também a partir do diagnóstico das mazelas de nosso país nessa área:

A questão educacional tem estado presente em todos os momentos decisivos do País, no nosso período de modernidade. Sua discussão ampliou-se para todos os setores sociais, e pode-se dizer que a educação é um anseio social generalizado. Como resultado, o Estado tem sido chamado a criar escolas, formar e contratar professores, ampliar as matrículas em todos os níveis e, não obstante, a educação ainda constitui um problema nacional. Temos uma taxa decrescente, mas ainda alta de analfabetismo (quase 20\%) (IBIDEM, p. 72).

Seguiu, trazendo outros dados que demonstraram a exclusão historicamente promovida pelo sistema educacional no Brasil, que teria trabalhado em favor da "comercialização" (IBIDEM, p. 72) do ensino, nos seus diferentes níveis. Não avançamos na exposição dos demais itens constantes na proposta da referida Sociedade, por se aproximarem sobremaneira da Carta de Goiânia.

No que se refere à proposta da FBAPEF, ela estabeleceu quatro artigos que deveriam constar na nova Constituição. O primeiro, mais geral, bem próximo ao apresentado na Carta, e os demais, mais específicos, abordavam a educação física como direito de todo brasileiro, a ser garantida nos estabelecimentos de ensino do $1^{\circ}$ ao $3^{\circ}$ graus.

Cabe um destaque para a extensa discussão que tomou lugar na $12^{\mathrm{a}}$ sessão, de 23/04/1987, em que as instituições supracitadas estiveram presentes e defenderam suas propostas. Aliou-se a este grupo a representante da ANPAE, que trouxe a democratização das oportunidades educacionais nos mesmos termos das instituições que lhe antecederam. $\mathrm{Na}$ ocasião, como já vimos no capítulo anterior, Miriam Limoeiro respondeu a alguns constituintes - como Louremberg Nunes e Sólon Borges - destacando a urgência de se pensar o direito à educação, garantido a todos os níveis, sem priorizar a educação básica/ ensino fundamental em detrimento dos demais. Sendo que, para tal proeza, citou a criação do FNDEP como forma de agregar posições de diferentes instituições com vistas a consecução de tal objetivo: 
É importante salientarmos que às vezes esse argumento que acaba jogando o gasto que estaria sendo feito com a Universidade como um tanto supérfluo, porque há uma carência muito grande, esconde uma questão básica, que é a de que nossa luta é uma luta pela elevação do padrão de qualidade e pela democratização do acesso - portanto, pela ampliação quantitativa da rede pública escolar em todos os graus. Os três graus são interdependentes. O caminhar do nosso movimento leva para que a nossa luta se torne uma luta conjunta. Não é à toa que no momento da Constituinte nós formamos um Fórum de entidades ligadas à Educação e de entidades que de uma forma ou de outra têm algum tipo de vínculo com a Educação, porque ela diz respeito aos nossos filhos, aos filhos de todos nós e, portanto, às entidades dos trabalhadores estão profundamente interessadas na educação. Não é à toa que as entidades de $1^{\circ}, 2^{\circ}$ e $3^{\circ}$ graus se juntam numa ação comum, neste momento. É necessário que tenhamos a clareza de que formação de $3^{\circ}$ grau é tão imprescindível num país atrasado, tão carente e tão dependente como o nosso, como a educação de $1^{\circ}$ grau. É uma luta para conjugar os três graus e conseguir, isto sim, mais verbas para a Educação como um todo (IBIDEM, p. 54-55).

Neste ponto retomamos a proposta do FNDEP. Como já mencionado anteriormente, o Fórum apresentou sua proposta à nova Constituição sob a forma de emenda popular. Nela constava os principais pontos da Carta de Goiânia e reivindicações de alguns setores específicos, como as entidades sindicais. Foi considerada por alguns autores como "[...] a plataforma mais avançada até então formulada no país” (CUNHA, 2009, p. 433). Ressaltou em seus pontos os dispositivos da emenda Calmon, sobre a vinculação orçamentária; a preocupação com a gestão democrática, por meio da criação de órgãos de controle das ações governamentais, a partir da participação da chamada sociedade civil. A formulação do direito à educação, de uma forma geral, explicitou-se de forma semelhante ao primeiro e segundo princípios da Carta de Goiânia, agregando, porém, um pouco da perspectiva que embasava a ideia de direito:

Art. $1^{\circ}$ A Educação, baseada nos princípios da democracia, da liberdade de expressão, da soberania nacional e do respeito aos direitos humanos é um dos agentes do desenvolvimento da capacidade de elaboração e reflexão crítica da realidade, visando a preparação para o trabalho e a sustentação da vida. Art. $2^{\circ}$ O ensino público, gratuito e laico em todos os níveis de escolaridade é direito de todos os cidadãos brasileiros, sem distinção de sexo, raça, idade, confissão religiosa, filiação política ou classe social. Parágrafo único. É dever do Estado o provimento em todo o território nacional de vagas em número suficiente para atender à demanda (CÂMARA, 2017b, p. 147-148).

Desta forma, ressaltou-se a defesa do ensino público, laico e gratuito como forma de organização da educação nacional, sem discriminação econômica, política ou religiosa; 
a necessidade de democratização do acesso, permanência e gestão da educação como responsabilidade do Estado. Sobre essa questão, houve uma melhor definição dos objetivos do ensino secundário, assim como uma tentativa de organização de sua oferta, que passou a ser designado como segunda etapa do ensino obrigatório e, portanto, também como direito de todos:

\begin{abstract}
Art. $5 \mathrm{O}$ ensino de segundo grau constitui a segunda etapa do ensino básico e é direito de todos. Visa assegurar formação humanística, científica e tecnológica voltada para o desenvolvimento de uma consciência em todas as modalidades de ensino em que se apresentar. No segundo grau serão oferecidos cursos de: I- formação geral; II- caráter profissionalizante, em que a formação geral seja articulada com formação técnica de qualidade; III- formação de professores para as séries iniciais do $1^{\circ}$ grau e da pré-escola (IDEM, p. 148).
\end{abstract}

A questão da qualidade foi colocada como responsabilidade das instituições de ensino e pesquisa do país, com a tarefa de garantir “[...] um padrão [...] indispensável para que sejam capazes de cumprir seu papel de agente da soberania cultural, científica, artística e tecnológica [...] contribuindo para a melhoria das condições de vida, trabalho e participação da população brasileira" (IBIDEM, p. 148). Desta forma, contemplou-se na referida proposta tanto o aspecto quantitativo - ampliação do número de vagas para o atendimento à demanda pelo ensino à toda população em idade escolar, sem transferência de recursos públicos ao setor privado - quanto o aspecto qualitativo - ou seja, as ações que visavam estabelecer um nível de ensino que possibilitasse aos estudantes uma efetiva inserção na sociedade. Sobre esse aspecto cabe também destacar a seguinte crítica, constante no relatório que seguia as propostas de artigos para o texto constitucional, intitulado "Política Educacional do Governo" ${ }^{\text {, }}$, no qual se tensionou a relação quantidade/qualidade:

No Brasil, o ensino fundamental assumiu características de violenta elitização. A obrigatoriedade convencionada pela Constituição (ensino gratuito e obrigatório entre os 7 e 14 anos) não é suficiente para garantir a todas as crianças o ensino de $1^{\circ}$ grau. E também de nada adianta oferecer o número de vagas correspondentes ao total da população em idade escolarizável, que se procure compreender a paupérrima escolarização de nossas crianças à luz da situação atual da sociedade brasileira. Tendo em vista a especificação do modo de produção capitalista na formação social brasileira, a escola transmite determinado saber visando os interesses da sociedade: a produção (CÂMARA, 2017b, p. 151).

65 Os temas constantes na parte do relatório foram assim dividos: 2- Educação e Constituinte; 2.1 Política Educacional do Governo; 2.2 Ensino Público e Gratuito; 2.3 Reforma Universitária; 2.3.1 Reforma Universitária e as Propostas dos Servidores. 
No que se refere à gestão democrática, a eleição de diretores se encontrava prevista como estratégia de garantia da participação da comunidade nos rumos da instituição. $\mathrm{O}$ apoio assistencial aos alunos matriculados na rede pública também foi lembrado no artigo oitavo, devendo ser orçado dentro de rubrica específica e não como despesa com educação. Cabe destaque para o inciso II, que especificou o artigo em tela, no qual a figura das "bolsas de estudo" surgiu como estratégia de democratização das oportunidades educacionais, paralelamente à ideia de liberdade: “[...] II - bolsas de estudo a estudantes matriculados na rede oficial pública, quando a simples gratuidade não permitir que continuem seu aprendizado" (IDEM, p. 148).

Após a apresentação dos artigos, como já foi mencionado, o texto do FNDEP trouxe um relatório, no qual retomou temas significativos da história da educação no Brasil, como forma de contextualizar as propostas que deveriam virar lei, segundo seus signatários. A própria evolução da perspectiva de direito foi ali colocada, a partir da análise dos textos constitucionais até então existentes:

Na questão da Educação, a gratuidade, em todos os níveis, deve ter um tratamento
prioritário do Governo. Sem essa pedra de toque repetimos a velha dicotomia, os
que podem e os que não podem, consolidando assim a divisão de classes daqueles
privilegiados e não-privilegiados. Em toda a história da educação brasileira
verificamos o quanto foi restrito o tratamento dado pelo poder público a essa
questão. Se nos reportarmos às seis principais Constituições que tivemos, vamos
perceber que os avanços foram muito pequenos nesses campos (IBIDEM, p. 149).

Quatro diretrizes estavam expostas no manifesto do FNDEP, a saber: a educação como direito de todo o cidadão e como dever do Estado, efetivando-se a partir do oferecimento do ensino público, gratuito e laico para todos; a questão da vinculação orçamentária prevista na emenda Calmon, para manutenção e desenvolvimento do ensino público e gratuito; a exclusividade das verbas públicas às escolas públicas (que veremos no próximo item); e a democratização da escola em todos os níveis, compreendida quanto ao acesso, permanência e gestão, conforme já discutimos anteriormente. Colocou a questão que a limitação da transição democrática - lenta e gradual - impôs ao processo de democratização e à própria elaboração do texto constituinte. Destacou ainda o papel da educação neste percurso, de uma forma bastante clara e com base na perspectiva de equidade, apresentada no início deste subcapítulo:

Para que essa dominação ocorra, as frações dominantes buscam consolidar sua hegemonia; para dirigir politicamente a sociedade, precisam, para isso, conquistar a direção intelectual e moral do conjunto da sociedade, o que exige a ampliação do espaço político dentro do qual consigam impor sua dominação com legitimidade. 


\begin{abstract}
Neste contexto, podemos avaliar o quanto deverá a sociedade se mobilizar para arrancar algum avanço nas grandes questões que o povo brasileiro tem a merecer para melhores condições de sobrevivência num Estado que ainda tem muito a percorrer para conseguir um verdadeiro estágio de democratização. Consideramos essenciais quanto às questões sociais para sobrevivência de qualquer povo num estado democrático três aspectos fundamentais: educação, saúde e trabalho com acesso a todos de igual maneira (IBIDEM, p. 149).
\end{abstract}

Mais algumas especificações estavam previstas na referida emenda popular, que foi apoiada por 279 mil pessoas, no período de dois meses até sua apresentação, conforme afirma Cunha (2009, p. 434).

Na reunião seguinte da subcomissão, estiveram presentes o CFE, o Fórum Nacional de Secretários de Educação e o Grupo de Trabalho Educação e Constituinte do MEC. Sobre este último, é importante afirmar que contou com a influência de alguns grupos e documentos, a saber: AEC, CNBB, CBE, Carta de Goiânia, Congresso Nacional de Estabelecimentos Particulares de Ensino, ANPEd, ANPAE, ANDES, Conselho Nacional de Defesa dos Direitos da Mulher, UNE, CFE, dentre outros. Sobre a concepção do CFE a respeito do direito à educação, cabe transcrever o trecho em que se evidenciou tal questão:

Parece-me que o fundamental é definir o conteúdo do direito à educação e do dever do Estado. Há uma contrapartida do dever do Estado em relação ao direito. E eu diria mais: temos que tomar consciência de que o País, a Nação ainda não assumiu o desafio da educação nacional. Muitas vezes, quixotes, como o Constituinte João Calmon, na opinião de alguns, andam sozinho, cutucando, despertando a consciência nacional. Eu diria mais, se me perdoassem, parafraseando Xerxes: "Acho que a educação é um assunto muito sério para ser resolvido somente pelos educadores. Acho que a Nação inteira deve ser convocada, a Nação inteira deve ser mobilizada". Pediria a V. Ex.as, na área da educação, na elaboração do texto constitucional, vamos fazê-la enxuta, seca, mas firme para que não precise sofrer plásticas mutiladoras (CÂMARA, 2017b, p. 79).

Ao apresentar um princípio amplo, o CFE acabou por não exemplificar como se poderia viabilizar, por meio de um texto constitucional, a efetivação do direito proclamado. Outras instituições estiveram presentes na $15^{\mathrm{a}}$ sessão, tendo, ao final desta ata, algumas propostas anexadas. Passaremos a uma breve análise dos documentos, fazendo uma correlação às discussões daquela ocasião.

A primeira foi a proposta do FNDEP, já explicitada anteriormente, que não voltaremos a mencionar. A segunda foi da SEAF - Sociedade de Estudos e Atividades Filosóficas, que 
iniciou a justificativa de seu documento com um alinhamento às propostas do referido Fórum, agregando a ele apenas quatro propostas, que objetivavam, em grande parte, o enaltecimento da educação pública; a prioridade do ensino de $1^{\circ}$ grau e o atendimento às diferentes áreas do conhecimento no ensino de $2^{\circ}$ grau; e, por fim, o investimento público em "[...] pesquisa científica, filosófica e cultural, essa última desde manifestações culturais do povo às elaborações eruditas" (IDEM, p.154).

Na sequência, indica-se o documento do CRUB. A proposta de texto constitucional acompanhava a Carta de Goiânia e o FNDEP no tocante às suas principais reivindicações. Todavia, apresentou uma justificação mais pautada na história do ensino superior no Brasil, no caráter elitista por ele assumido, e na questão da tensão entre as instituições públicas e privadas, que veremos mais à frente. Por fim, tem-se a proposta da UBES, que caminhou na mesma direção das anteriores, reafirmando a importância do ensino público, laico e gratuito, por meio da articulação entre os artigos $1^{\circ}$ e $2^{\circ}$ das versões dos textos supracitados, garantindo o acesso e protagonismo da juventude brasileira na educação do país:

Por isso defendemos que seja incluído o item que defina na Constituição que "O
ensino público, gratuito e laico em todos os níveis de escolaridade, é direito de
todos os cidadãos brasileiros, sem distinção de sexo, raça, cor, idade, confissão
religiosa, filiação política ou classe social", além de afirmar que "será dever do
Estado a garantia de todas as vagas necessárias, a nível nacional" (IBIDEM,
p.160).

A sessão seguinte trouxe novos grupos à participação e outros documentos anexados à ata. Os primeiros trataram do conjunto das instituições que abordaram a questão indígena, bem como a especificidade de sua educação. Desta forma, compreendeu-se que "Os povos indígenas têm direito a uma educação específica que lhes assegure e fortaleça a própria identidade e possa fornecer-lhes respostas satisfatórias para o processo histórico que vivem" (CÂMARA, 2017b, p. 195). A compreensão da educação indígena como direito, a ser exigido pela sociedade em geral e cada vez mais diretamente pelas próprias comunidades indígenas, foi historicamente negada e negligenciada, embora consolidada em convenções internacionais e mesmo em leis próprias. Havia preocupações específicas que também foram apresentadas, no conjunto de documentos que abordaram tal causa: a metodologia e o conteúdo do ensino, a partir de uma educação bilíngue, são umas delas. 
Passemos aos documentos das instituições que expressaram visão contrária ou apenas dissonante em relação às que foram até então descritas. AABESC apresentou um documento enxuto, com cinco pontos, no qual defendeu a liberdade de ensino como decorrência do regime democrático. Desta forma, colocou que o maior interesse da família era o acesso à educação de qualidade, com prioridade para a obrigatoriedade do ensino de $1^{\circ}$ grau para todos, sob a responsabilidade do Estado. Caberia ao mesmo Estado, portanto, garantir o acesso também ao ensino de $2^{\circ}$ e $3^{\circ}$ graus aos estudantes carentes de recursos, como forma de democratização do acesso à escolarização. Todavia, o texto descreveu caminhos distintos dos propostos pelas instituições que a antecederam, como veremos no próximo item. No mesmo sentido caminhou o documento da PUC de Campinas e do Rio Grande do Sul, nos quais se evidenciou a necessidade de tais instituições agarrarem-se à defesa da liberdade do ensino, traçando algumas considerações, primeiramente, a partir do diálogo da realidade da área com a educação brasileira, e, em um segundo momento, a partir da necessidade de interação entre os diferentes níveis, algo a ser alcançado por meio de amplo diálogo e investimento. Teremos muitos destaques a fazer sobre a questão do investimento público em tais instituições, como reclamam em seus respectivos documentos.

A CNEC iniciou seu documento com uma queixa do poder público, por considerálo como "seu pior algoz" (IDEM, p. 211) por desconsiderar seu esforço em apoiar "[...] o lado pobre e sofrido do povo brasileiro" (IBIDEM, p. 211). Assim, o documento tratou do compromisso da rede cenecista com a liberdade - entendida como disposição do homem em relação ao seu próprio destino; com a consolidação da paz social, vista como fruto da justiça social, da ordem e da solidariedade; com a democratização das oportunidades; com a formação de democratas, a ser realizada no cotidiano da instituição; com a escola de cidadania, que exigia características como liderança, competência e equilíbrio, por exemplo; com a escola de serviço público, que destacava a capacidade de gerência da instituição para o bem comum; e, por fim, com a escola do povo, por estar afincada nas comunidades e por serem por elas geridas, em sentido mais geral. Vemos o que o documento abordou especificamente a respeito da democratização, que já antecipamos se aproximar da perspectiva meritocrática:

A educação oferece um campo considerável de oportunidades para doações altruísticas, destituídas de caráter estritamente profissional ou de natureza mercenária. A história dos povos está repleta de exemplos de educadores que foram mais filantropos do que profissionais da educação. Cabe ao Estado oferecer a todos os cidadãos as oportunidades e os estímulos para que exerçam os papéis sociais que lhes possam propiciar sua auto-realização, contribuindo ao mesmo tempo para o esforço de educação permanente de velhas e novas gerações (CÂMARA, 2017b, p. 212). 
Sessão conturbada, permeada por muitas discussões, trouxe ainda a presença de outras instituições que se prestaram à defesa de um papel diferenciado para o Estado frente à educação. Passemos à proposta da FENEN. A Federação dividiu seu documento em partes, que visavam explicar os artigos que foram listados na sequência do texto: I Representatividade e aprovação; II - O problema educacional e a instrução; III - Educação e democracia; IV - A proposta da FENEN; V-Direito da família, liberdade de ensino e garantia do direito de escolha; VI- Ensino obrigatório, pré-escolar e ensino religioso; VIIVerba para educação; VIII- Imunidade Tributária; e IX- Salário-Educação e Contribuição das Empresas. Comentaremos alguns deles. Logo no começo, posicionou-se no cenário nacional - única entidade de representação nacional do ensino privado. Na segunda parte, apresentou sua concepção de educação e instrução, bem como a do papel do Estado nessa área:

\begin{abstract}
Muitos misturam instrução com educação e pregam meios e medidas de se obter apenas a primeira. A instrução pode construir um Estado e ordenar a população que o habita; mas não cria um povo, uma nação, uma pátria, pois estes somente serão constituídos mediante a educação, que envolve mais formação e menos instrução. O Estado, sozinho e por si, não forma, mesmo porque não tem filosofia ou crença; apenas instrui. O pai sempre se reservou o direito de educar: orientar e criar o filho de acordo com seus valores, suas crenças, seus anseios, seus conceitos, sua visão, sua filosofia e sua religião. E ninguém abre mão desse direito, que é natural. Com o desenvolvimento das ciências, dos conhecimentos a da própria dificuldade dos pais, a tarefa de educar foi delegada à escola. Assim, deve haver tantas escolas quantas forem as religiões, as crenças, as filosofias, os ideais e os valores existentes. E esta pluralidade o estado não consegue oferecer sozinho, em seus próprios estabelecimentos (IDEM, p. 212).
\end{abstract}

Explicitaremos melhor a questão da liberdade na sequência do texto. Todavia, é importante considerar que a redação acima transcrita atribuiu primeiramente à família o dever e o direito à educação, compreendido como "natural". À escola caberia primeiramente instruir, mas, como a família não conseguia mais se responsabilizar sozinha pela educação de seus filhos, a escola passou a assumir tal responsabilidade, porém de forma subserviente aos interesses desta família. A perspectiva de direito à educação como bem coletivo se perdeu nessa posição, prevalecendo o direito individual. Ainda destacou que o Estado não seria capaz de responder às demandas familiares, sendo necessário que a rede de escolas privadas o fizesse. Tal perspectiva nega a ideia de formação de uma escola única, capaz de buscar a promoção da redução das desigualdades sociais tão abissais em nosso país. No terceiro item aprofundou tal idealização, colocando o esforço pelo fortalecimento da escola pública como característica dos Estados totalitários, que tenderam a negar a diversidade. 
Desta forma, apresentou como proposta "[...] garantir a todos o efetivo direito à educação e à consecução da sociedade mais justa, dentro dos princípios democráticos e do respeito à individualidade de cada ser humano" (IBIDEM, p. 213).

A parte 5 deveria ser discutida na sessão pertinente à categoria liberdade de ensino, mas, antes da perspectiva de liberdade, trouxe alguns tópicos que chamou de "princípios democráticos" que deveriam orientar a educação. A formulação entendida pela FENEN como forma de materializar tais princípios se encontrava expressa no que viria a ser o artigo primeiro de sua sugestão de texto legal:

Art. A educação, inspirada nos princípios da unidade nacional, igualdade, liberdade e nos ideais de solidariedade humana, cívicos e de responsabilidade social, é direito natural de todos, inalienável e efetivo da família, e será assegurada pelo Estado e livre à iniciativa privada nos diferentes graus de ensino. $\S 1^{\circ}$ A educação será ministrada no lar, na escola e por todos os meios capazes de promover sua universalidade. $\S 2^{\circ}$ É dever do Estado assegurar a igualdade de oportunidades educacionais, garantindo a todos, independentemente das condições sociais e econômicas, o acesso à educação, cabendo à família a escolha do gênero de educação a ser ministrada a seus filhos. $\S 3^{\circ}$ Os poderes públicos garantirão a gratuidade do ensino a todos os que provarem insuficiência de recursos para sua manutenção. $\S 4^{\circ}$ No ensino de $2^{\circ}$ e $3^{\circ}$ graus, a gratuidade será retribuída pelos beneficiários mediante a prestação de serviços de interesse público, durante o curso ou após a sua conclusão (CÂMARA, 2017b, p. 213-214).

Mais uma vez o dever de educar vem associado à família, que deveria ter o Estado apenas como instrumento para prover a educação. Este provimento se daria por meio da garantia da gratuidade dos estudos aos que não possuíssem recursos, em qualquer nível de ensino, sendo que nos níveis ulteriores ao fundamental o beneficiado deveria ressarcir ao Estado, por meio da prestação de serviços públicos. Mais uma vez, pudemos perceber uma ênfase na ideia do direito individual, em detrimento da educação como garantia social. No que se refere à assistência estudantil, houve também a proposta de sua garantia, com critérios vinculados à renda do estudante, que não foram bem definidos.

Passemos ao texto da AEC, que foi introduzido com a apresentação de si mesma enquanto Associação, mostrando sua capilaridade no país. Trouxe ainda sua perspectiva de democratização do ensino, entendida como "[...] uma educação de qualidade para todos e a possibilidade de grupos culturais e religiosos organizarem escolas próprias, a partir de seus valores e de sua concepção de vida, dentro das exigências legais, com acesso a elas em igualdade de condições" (IDEM, p. 216). 
Foram definidos os pressupostos que sustentam a defesa de sua proposta educacional. Dentre eles, destacamos dois: o Estado visto como "instrumento a serviço da sociedade, subordinado e controlado por ela"; e a "prioridade da pessoa humana, respeitados e garantidos os seus direitos fundamentais" (IBIDEM, p. 218). Assim como no texto da FENEN, o indivíduo foi considerado mais importante do que a esfera coletiva. Ressaltou o Estado como ente capaz de zelar por tal liberdade de organização individual, sendo a educação apenas um serviço que ele deveria prestar, em atendimento às diferentes demandas das famílias.

$\mathrm{O}$ atendimento das exigências educacionais por parte do Estado deveria se processar a partir do entendimento da instituição sobre o direito à educação. Dividiu, pois, seu texto em partes explicativas que antecederam a proposta de redação da lei, e nele incluiu o item III, no qual delimitou suas ideias centrais para a educação no país:

1. - Em primeiro lugar e com absoluta prioridade, defendemos o direito de todos a uma educação fundamental de qualidade, sem qualquer tipo de discriminação [...] 1.2 - Desse direito de todos a uma educação fundamental de qualidade decorre também o direito de todos a um ensino fundamental gratuito. 2. - O slogan “dinheiro público para a escola pública", ideologicamente repetido, tenta tornar inseparáveis os qualificativos: pública, estatal, gratuita e laica atribuídos à escola. Defendemos o direito de todos a um ensino fundamental gratuito e de qualidade, mas excluímos, por coerência, os outros adjetivos (CÂMARA, 2017b, p. 218).

Evidenciou-se a preocupação em retirar do Estado a responsabilidade para com a educação entendida como direito coletivo, para sobrepor a perspectiva de instrumento, chamando de pública toda educação, e não aquela ministrada pelo viés estatal, gratuito, laico, que deveria acompanhar a formação das novas gerações na escola pública. Público passava a ser o serviço, a ser prestado por qualquer instituição que se dissesse educacional. Tal perspectiva ganhou muito espaço nas discussões da constituinte, como vimos no capítulo anterior, tornando-se uma marca das escolas confessionais e comunitárias, que insistiram em dissociar sua imagem das escolas não-confessionais privadas. Retomaremos em breve a contenda sobre a dicotomia público-privado, tão antiga na discussão educacional brasileira - pois nos acompanha desde os anos que dividiram a aprovação da Constituição de 1946 e os debates estabelecidos para a promulgação da LDBEN de 1961, até a ANC de 1987-1988 - e ao mesmo tempo tão atual, chegando ainda ao tempo presente. 
Destacamos, por fim, como se organizaram tais metas na proposta defendida pela AEC. É importante também observar que ela colocou a educação fundamental a ser distribuída em 11 anos, contudo trouxe a obrigatoriedade apenas para os oito primeiros anos, como na maioria das demais propostas:

Art. $1^{\circ}$ A educação é instrumento indispensável para o pleno desenvolvimento pessoal e social; para o exercício livre e consciente da cidadania; para a capacitação ao trabalho e a sustentação da vida; para a garantia da igualdade de direitos; para a convivência solidária; para possibilitar a reflexão crítica e a ação eficaz a serviço da sociedade justa e livre. Art. $2^{\circ}$ Todos têm igual direito a uma educação escolar fundamental de qualidade, sem discriminação de qualquer ordem. Parágrafo único. Entende-se por educação escolar de qualidade a descrita no art. $1^{\circ}$. Art. $3^{\circ}$ A educação escolar fundamental será gratuita e compreende onze anos de escolaridade, sendo os oito primeiros obrigatórios para todos [...] Art. $6^{\mathbf{o}}$ Cabe a toda a sociedade o dever de garantir a educação escolar fundamental de igual qualidade para todos. Art. $7^{\circ} \mathrm{O}$ Estado, em suas escolas, tem obrigação de oferecer gratuitamente a todos as condições necessárias de acesso e permanência na educação escolar fundamental, e de garantir os recursos necessários àqueles grupos que se dispuserem a ministrar, gratuitamente, a educação escolar fundamental (IDEM, p. 218-219).

Ainda anexadas a ata, temos duas propostas: a da UNE e a da Comissão Paulista para Defesa dos Direitos dos Surdos - COPADIS. Analisaremos a primeira delas, tendo em vista que a segunda não participou efetivamente do debate na subcomissão.

A UNE trouxe a situação da universidade brasileira por meio de dados, para contextualizar o que chamou de política privatizante do governo nos anos que precederam a ANC, posto que o mesmo pouco investiu na abertura de vagas em universidades públicas, tendo se multiplicado, sobretudo durante a ditadura, instituições de ensino superior privadas. Assim, propôs que a Constituinte resgatasse a dívida educacional que possuía com a nação, por meio de “[...] formação geral para que o indivíduo possa tornar-se sujeito consciente do contexto social, político e econômico onde vive, segundo os princípios da democracia e da soberania nacional" (IBIDEM, p. 215). Ressaltou também a necessidade da indissociabilidade entre o ensino, a pesquisa e a extensão, como forma de estabelecer a pesquisa e o desenvolvimento científico do país. Resgatou a garantia do ensino público, gratuito, universal e laico para todos, em todos os níveis.

$\mathrm{Na} 17^{\mathrm{a}}$ sessão foi ouvido mais um conjunto de instituições, sendo que apenas algumas apresentaram textos escritos a serem anexados à ata daquela reunião. Assim sendo, 
deteremo-nos apenas nestes. O primeiro documento foi o do Sindicato dos Professores do Estado de Minas Gerais, que transcreveu na íntegra o manifesto do FNDEP. O segundo foi de autoria da UDEMO - União dos Diretores de Escola do Magistério Oficial, que seguiu, em grande medida, as diretrizes constantes na Carta de Goiânia e no FNDEP. O FITEE apresentou, logo no início de sua exposição de motivos, o que entendia por democratização e seu objetivo:

[...] democratização do acesso à Educação, como meio de criar oportunidade à todos de terem uma vida digna, assegurando um ensino voltado para atender os interesses do povo trabalhador. É necessário levar em consideração também, o fato de que a solução dos problemas educacionais não esgotam em si mesmo, mas estão indissoluvelmente ligados a necessidade de distribuição da renda e melhoria das condições de vida da população nas várias áreas sociais, como saúde, habitação, cultura, lazer, transportes, etc. (CÂMARA, 2017b, p. 247).

A Federação reconheceu e destacou a importância de se pensar a relação da educação com as demais esferas da vida social, não supervalorizando seu papel, colocando-a como redentora das mazelas sociais. Resgatou-se também o protagonismo do trabalhador e a necessidade do entendimento de suas demandas, quando da formulação de propostas educacionais. Desta forma, elencou princípios, dentre os quais destacamos alguns, pelo fato de se apresentarem como inovadores em relação às propostas que discutimos até o presente momento:

1 - Assegurar o ensino público, gratuito e laico em todos os níveis, a partir de zero ano. Não será permitido nenhum tipo de discriminação por motivos econômicos, sociais, ideológicos, raciais e religiosos; [...] 6 - Currículos voltados para aos problemas do povo e do país, elaborados com a participação da sociedade, através de suas entidades representativas, no planejamento e execução da política educacional. Ensino voltado para o desenvolvimento independente e para o progresso social e científico.[...] 9 - Ensino profissionalizante como responsabilidade do Estado, garantindo a participação das entidades representativas dos trabalhadores na elaboração e definição dos rumos do mesmo; [...]12 - Piso salarial aos trabalhadores em estabelecimentos de ensino que possibilite aos mesmos remuneração condigna, que permita sua formação e qualificação profissional; 13 - Fixação do número máximo de alunos por sala de aula, estabelecendo-se de forma democrática por série e faixa etária dos alunos, através de comissões estaduais com participação das entidades sindicais representativas dos trabalhadores em estabelecimentos de ensino;[...] 15 - Estabilidade no emprego a partir da contratação, para os trabalhadores em estabelecimentos de ensino; 16 - Amplas garantias para pais e alunos organizarem-se em associações e grêmios por escola (IDEM, p. 247). 
A formulação do primeiro item se aproximou das instituições anteriormente apresentadas, no rol da defesa do ensino público. Todavia, como inovação, garantiuse o ensino público e gratuito desde o início da educação infantil, ou seja, no que hoje conhecemos como creche (na faixa etária que vai de 0 a 3 anos). Apareceram neste documento a preocupação com um currículo voltado para os problemas cotidianos da população e baseado na realidade da classe trabalhadora; a responsabilidade do Estado com o ensino profissionalizante, que deveria contar com a participação das entidades sindicais na elaboração de seus currículos, o que se constituiu em um avanço na relação educação e trabalho; a qualidade do ensino pensada a partir da valorização dos profissionais da educação, que se refletiu tanto por meio da remuneração quanto da estabilidade do emprego; e, por fim, a gestão democrática da escola seria pensada a partir da organização das bases que constituem a comunidade escolar.

Os próximos textos foram do Conselho Federal de Farmácia, da Organização das Cooperativas Brasileiras, da Comissão Pró-federação de Arte-educadores do Brasil, dos Arte-educadores de São Paulo, bem como um texto intitulado "A síntese do pensamento de educadores e parlamentares sobre a Resolução CFE nº 6/86 e o Parecer CFE n 785/86". Estes últimos se caracterizaram como uma espécie de reação dos setores ligados à arte e à educação artística aos instrumentos legais supracitados, que retiraram, dentre outras coisas, a educação artística da área de linguagens.

Consta ainda, em anexo, o documento do Centro de Estudos Afro-Brasileiro (CEAB), que trouxe um histórico da inserção do negro no Brasil, por meio do resgate do papel subalterno que lhe fora destinado, cabendo à educação a "[...] superação da marginalidade social e econômica" (IBIDEM, p. 251). Abordou também a questão da profissionalização, ao colocar a idade obrigatória entre 6 e 16 anos de idade; a responsabilidade dos pais, primeiramente, e depois do Estado; a necessidade de criação de escolas de promoção popular; a questão curricular, na qual propôs a inclusão da discussão da "História dos Povos Africanos e a História do Negro e do Índio no Brasil” (IBIDEM, p. 252); entre outras questões.

Outro documento foi o da Associação Nacional dos Professores de Prática de Trabalho, que teve início a partir da explicitação de seu princípio fundamental, ou seja, a percepção do trabalho como elemento de formação integral do indivíduo, que buscava romper com a dicotomia entre intelecto e físico. Para tanto, indicou que o texto constitucional 
contemplasse

[...] o trabalho como um conjunto de normas educativas, organizado de forma sistemática com condições de desenvolvimento contínuo a ser iniciado concomitantemente com o aprendizado de ler e escrever, com fundamentação científico-técnica e prática. A preparação para o trabalho deve progredir acompanhando as fases evolutivas do educando, nos diversos níveis de ensino até uma educação permanente (CÂMARA, 2017b, p. 254).

Nos demais aspectos o texto se aproximou das concepções anunciadas pelo Fórum, cabendo um destaque para a proposta de ampliação dos percentuais de vinculação de recursos constitucionais, de 13 para $20 \%$, no caso da União; e de 25 para $30 \%$, no caso dos estados e municípios (IDEM, p. 254).

Defronte às análise das propostas apresentadas, às quais se agregaram as contribuições trazidas pelo ministro da Educação e de presenças renomadas como Paulo Freire e Moacir Gadotti - já apresentados no capítulo 3 -, além de um outro texto anexado à ata, de autoria do Conselho Nacional de Seringueiros (entregue depois do prazo dedicado à audição das entidades da sociedade civil), ratificou-se a dicotomia já anunciada desde o início do presente trabalho, que colocou como principal problema a ser resolvido na subcomissão a conjugação de duas principais perspectivas que trouxeram a democratização das oportunidades educacionais como forma:

$\checkmark$ de promoção do direito coletivo, por meio da ampliação das vagas na escola pública, gratuita, laica, que zela pela qualidade e garantia da permanência dos estudantes por meio de uma política assistencial;

$\checkmark$ de promoção do direito individual, tendo o Estado apenas como ferramenta para assegurar a responsabilidade da família na educação de seus filhos.

Houve ainda as propostas que caminharam no sentido de agregar ao Estado a responsabilidade para com grupos que historicamente foram negligenciados do processo educacional, a saber: negros, índios, pessoas com deficiência, jovens e adultos, além de temáticas específicas, como forma de conferir materialidade ao sentido de "para todos", que deveria caracterizar a escola pública.

Doravante, passaremos à análise do conjunto de documentos expostos no começo deste capítulo, de acordo com a metodologia já explicitada (A-C; C-F; F-H; H-I; I-P; P-Q; Q-V-Texto final). Trabalharemos de forma comparativa, no que é pertinente à análise dos 
artigos, um a um, discorrendo sobre a mudança processada após as contribuições e debates que se estabeleceram em cada momento.

Passemos, pois, ao estudo do primeiro artigo, que estava subscrito no tema princípios, objetivos, diretrizes, posto que tipifica a concepção de educação e direito a ser adotada na CF. Inspirado na perspectiva liberal, porém com um viés mais coletivista do que individual, ratificando as palavras de Jamil Cury na entrevista que nos foi concedida e já mencionada anteriormente, o artigo foi mantido nas duas primeiras versões, sendo assim apresentada sua redação:

Art. $1^{\circ}$ A educação, direito de todos e dever do Estado, será promovida e incentivada por todos os meios, com o colaboração da família e da comunidade, visando ao pleno desenvolvimento da pessoa e ao compromisso do ensino com os princípios da liberdade, da democracia, do bem comum e do repúdio a todos as formas de preconceito e de discriminação.

Ao tramitar da subcomissão à etapa seguinte, o artigo $1^{\circ}$ foi simplificado, como foi dito pelo próprio relator da comissão, Artur da Távola, passando a contar com a seguinte redação "A educação, direito de cada um, e dever do Estado" (CÂMARA, 2017c, p.2). Todavia, com a rejeição dos dois substitutivos elaborados pelo relator, a redação que foi repassada à comissão de sistematização voltou a ser a dos documentos anteriores. Já na fase I, com nova numeração, percebemos que o relator Bernardo Cabral buscou fazer uma composição entre as duas propostas, sendo que o texto ficou com a seguinte redação:

Art. 377 - A educação, direito de cada um, é dever do Estado. Parágrafo único - A educação será promovida e incentivada por todos os meios, com a colaboração da família e da comunidade, visando ao pleno desenvolvimento da pessoa e ao compromisso do Ensino com os princípios da liberdade, da democracia, do bem comum e do repúdio a todas as formas de preconceito e de discriminação (ANC, 2017e, p.42).

Na fase P, etapa final da comissão de sistematização, buscou-se simplificar a redação do artigo 377, que passou a ser o 240. Suprimiu-se o trecho "do Ensino com os princípios da liberdade, da democracia, do bem comum" do caput do artigo, levando-o, de forma mais detalhada, para a forma de incisos, uma vez que sob a forma de parágrafo único foi abrigada a redação que nas versões anteriores compunha o caput artigo $2^{\circ}$. (ANC, 2017f). Cabe ressaltar que na fase $Q$ este artigo sofreu emendas do Centrão, que voltou a simplificá- 
lo, assim como emendas individuais, dos constituintes Jorge Bornhausen (PFL) e Sólon Borges (PTB).

Na fase V, já como artigo 205, o texto foi redigido de uma forma próxima à original, com algumas modificações, a saber: "A educação, direito de todos e dever do Estado e da família, será promovida e incentivada com a colaboração da sociedade, visando ao pleno desenvolvimento da pessoa, seu preparo para o exercício da cidadania e sua qualificação para o trabalho" (ANC, 2017h, p. 108). Percebemos a alteração na ideia de direito, que passou de uma visão mais individual (de cada um) à esfera coletiva (de todos). Ressaltamos que há idas e vindas nesta perspectiva - alterou-se a redação entre as fases I e P, que depois retornou à forma anterior. A concepção de formação cidadã e para o trabalho apareceu pela primeira vez neste momento, ocupando o lugar da discussão a respeito do combate à discriminação, tão cara à defesa dos direitos humanos. Este foi o texto promulgado em 1988.

Já o artigo $2^{\circ}$ teve o seu caput alterado. No texto inicial foi apresentado como as diretrizes do sistema de educação, quando na segunda versão foi trazido como estratégia de materialização do processo educacional. Percebemos que a alteração foi conceitual, na medida em que a ideia de um sistema de educação é algo muito amplo e ainda não delimitado pela legislação até o presente momento. Lembramos Nelson Piletti (2002), na introdução desse texto, quando nos apresentou os significados e níveis de abrangência de sistema de educação, sistema de ensino e sistema escolar. Seria, portanto, mais plausível o uso do termo sistema de ensino, por transpor a educação para um nível mais restrito, posto que deveria se referir às instituições que se dedicam sistematicamente a tal ofício. De toda forma, o que houve de mais importante neste artigo, foram os incisos que o acompanham. Vejamos, pois, a redação da fase C:

Art. $2^{\circ}$. Para a execução do previsto no artigo anterior, serão obedecidos os seguintes princípios: I - democratização do acesso, permanência e gestão da educação escolar; II - pluralismo de ideias e de instituições de ensino, públicas e privadas; III - liberdade de aprender, ensinar, pesquisar e divulgar as descobertas feitas; IV - adequação dos valores universais da pedagogia às condições concretas da sociedade brasileira, em sua unidade e diferenciação; V- garantia de ensino fundamental para todos; VI - gratuidade de ensino público em todos os níveis; VII - valorização do magistério em todos os níveis, garantindo-se aos docentes: estruturação de carreira nacional; provimento dos cursos iniciais e finais da carreira, no ensino oficial mediante concurso público de provas e títulos; condições condignas de trabalho; padrões adequados de remuneração; aposentadoria aos 
vinte e cinco anos de exercício em função do magistério, com proventos integrais, equivalentes aos vencimentos que, em qualquer época, venham a perceber os profissionais de educação da mesma categoria, padrões, postos ou graduação, direito de greve e sindicalização; VIII - eliminação progressiva dos efeitos das desigualdades e das discriminações de raça, de etnia, de classe e de região (ANC, 2017b, p. 3).

Da fase A à C, houve alteração nos seguintes incisos: I, III, IV, V, VI, VII e VIII. $\mathrm{Na}$ primeira versão tínhamos nove incisos, tendo sido retirado na fase $\mathrm{C}$ os incisos IV, que abordava a descentralização da educação pública, e VIII, que tratava da gestão democrática, que foi absorvido pelo I. Aqui nos importa especificamente o inciso I, que retratou a democratização do acesso, a permanência e a gestão da educação; o II, que defendeu a diversidade de pensamento e a existência de instituições públicas e privadas; o V, que versava sobre a garantia do ensino fundamental; e o VIII, que abordou a questão da eliminação dos efeitos das desigualdades e da discriminação, que compunha o caput do artigo anterior. $\mathrm{Na}$ passagem do texto da fase $\mathrm{C}$ para a $\mathrm{F}$, percebemos algumas alterações na redação e ordem dos incisos, porém sem muito impacto para nosso estudo. Todavia, é importante registrar que não houve alterações no texto que saiu da comissão 8 . Na fase I também não houve variação nos incisos estudados neste momento; o que cabe destacar foi a substituição da numeração dos artigos - passou a ser o número 378. Como vimos anteriormente, na fase $\mathrm{P}$, o artigo se fundiu novamente ao primeiro da matéria educacional. Houve também algumas modificações importantes nos incisos mencionados: o inciso I foi acrescido da seguinte especificação "[...] com participação de docentes, alunos, funcionários e representantes da comunidade" (ANC, 2017f, p. 7). Foi eliminado o inciso VI, que abordava as desigualdades e a discriminação.

Na passagem pela fase $\mathrm{Q}$, no plenário, o texto dos incisos sofreram algumas propostas de emenda, das quais destacamos as seguintes: a proposta de supressão da divulgação do pensamento, constante no inciso II, pelo Centrão; a de autoria de Farabulini Júnior (PTB), que sugeria a criação de novo inciso que obrigasse o regime de semi-internato para os alunos que estivessem cursando as quatro primeiras séries do ensino fundamental, no ensino oficial; e a do Florestan Fernandes (PT), que visava a criação de estratégias de equalização das oportunidades educacionais, sobretudo para crianças e jovens carentes, negros e indígenas, de forma que estes conseguissem se manter na escola (ANC, 2017g). Na fase V resgatamos tal artigo sob a numeração 206, com a redação seguinte:

Art. 206. O ensino será ministrado com base nos seguintes princípios: I- igualdade de condições para o acesso e permanência na escola; II- liberdade de aprender, 
ensinar, pesquisar e divulgar o pensamento, a arte e o saber; III- pluralismo de idéias e de concepções pedagógicas, e coexistência de instituições públicas e privadas de ensino; IV - gratuidade do ensino público em estabelecimentos oficiais; V- valorização dos profissionais do ensino, garantido, na forma da lei, planos de carreira para o magistério público, com piso salarial profissional e ingresso exclusivamente por concurso público de provas e títulos, assegurado regime jurídico único para todas as instituições mantidas pela União; VI - gestão democrática do ensino público, na forma da lei; VII - autonomia didático-científica, administrativa e de gestão financeira e patrimonial, com indissociabilidade entre ensino, pesquisa e extensão, nas universidades; VIII - garantia de padrão de qualidade (ANC, 2017h, p. 108).

Nesta versão, a democratização das oportunidades foi substituída pela "igualdade de condições para o acesso e permanência na escola" (ANC, 2017h, p. 108). Lembramos neste ponto da entrevista com o professor Jamil Cury, na qual ele aponta a diferença entre estas duas expressões:

A igualdade de oportunidades ela certamente é o que marca uma constituição para a educação de caráter liberal democrático. É oportunidade. Mas, na verdade, quem assume o risco da oportunidade é o indivíduo. A igualdade de condições, ela tende por social democrata. Então ela tende a fazer uma negociação entre igualdade de oportunidades e igualdade de condições.

Neste momento os constituintes mais progressistas conseguiram obter um ganho - na correlação entre as forças que disputavam a hegemonia do campo educacional posto que a perspectiva social democrata se sobrepôs. No inciso II também se conseguiu preservar a liberdade de divulgação do pensamento, assim como o inciso III, que envolveu as concepções pedagógicas, o pluralismo de ideias e a coexistência de instituições públicas e privadas. Permaneceu a gestão democrática, a autonomia universitária e a perspectiva de um padrão de qualidade, algo subjetivo, porém, desejado e também destacado nas entrevistas com Jamil Cury e Luiz Antônio Cunha. O texto final da CF manteve a mesma redação, exceto na questão relativa à autonomia universitária, que virou um artigo próprio, o de número 207.

$\mathrm{O}$ artigo $3^{\circ}$ do anteprojeto da subcomissão 8 a trouxe a seguinte redação para delimitar o dever do Estado com a educação, inclusive mediante a inclusão de um parágrafo único, que abordava uma grande inovação no campo educacional, o mandato de injunção:

Art. 30. - O dever do Estado para com a educação pública de todos os brasileiros efetivar-se-á prevalentemente pelas seguintes ações: I- garantia de ensino fundamental, com duração mínima de oito anos, obrigatório e gratuito para todos, 
permitida a matrícula a partir dos seis anos de idade; II- oferta de vagas em creches e pré-escolas para as crianças até seis anos de idade; III- atendimento oficializado e gratuito aos portadores de deficiência e aos superdotados, em todos os níveis de ensino; IV- garantia de auxílio suplementar ao aluno do ensino fundamental, através de programas sociais que assegurem condições de aproveitamento e continuidade dos seus estudos. Parágrafo Único- O acesso de todos os brasileiros à educação fundamental gratuita é um direito público subjetivo, acionável contra o Estado mediante mandado de injunção (ANC, 2017a, p. 25).

Apesar da inovação mencionada, incomoda-nos o emprego da palavra "prevalentemente". Seria mais legítimo o uso da palavra "obrigatoriamente", que delimita a esfera da garantia do direito e, consequentemente, do dever do Estado. Assim, a redação do mesmo artigo na fase $\mathrm{C}$ trouxe a alteração, logo no caput, da palavra “ações" para "obrigações", o que foi algo interessante, pois o Estado passaria a poder ser responsabilizado pelo não cumprimento das metas que traçara nos incisos. Estes sofreram algumas modificações, sendo as mais significativas as seguintes: o inciso I aprofundou um pouco mais a explicação sobre a faixa etária obrigatória - oito anos, obrigatório a partir dos sete, facultando a matrícula aos 6 anos de idade -; houve a inclusão de um novo texto para o inciso II, que passou a tratar da continuidade da obrigatoriedade para o ensino médio, especificando-se as suas áreas (formação geral ou de caráter profissionalizante); o inciso III passou a fazer referência às creches e pré-escolas, com a substituição da palavra "oferta" para "garantia"; o inciso VI, sobre o auxílio suplementar, retirou o corte de renda, aumentando, por conseguinte, sua abrangência.

$\mathrm{Na}$ versão da fase $\mathrm{F}$, outras alterações foram feitas no artigo $3^{\circ}$, começando por uma nova troca de palavras: "garantia" substituiu "obrigações"; já nos incisos é relevante informar que a problemática dos alunos que não tiveram acesso ao ensino na idade regular passou a ser mencionada - no inciso I, já existente e ampliado; e com a inclusão de um novo inciso VI: "Oferta de ensino noturno adequado às condições dos discentes, observada a qualidade do ensino e as situações sociais do educando" (ANC, 2017c, p.2). Ampliouse, pois, o espectro da democratização do acesso para além da faixa etária obrigatória. Houve também a inclusão de um novo inciso V, que tratava da possibilidade de acesso aos níveis mais elevados de ensino, de acordo com o mérito de cada um, com uma evidente menção aos direitos individuais. Por fim, cabe destacar a separação do parágrafo único em dois, ratificando ainda mais a responsabilidade do Estado no cumprimento de seus deveres constitucionais. 
Passemos à fase $\mathrm{I}$, já que o texto $\mathrm{H}$ manteve a mesma redação anterior. Fez-se uma pequena modificação no inciso IV do artigo 379, que agregou a inclusão dos alunos deficientes sempre que possível em classes regulares, primeiro passo para a eliminação das escolas especiais. Tal detalhe possibilitaria uma real democratização, posto que se ampliaria a possibilidade de acesso e de integração entre todos os alunos, sem distinção. A versão que saiu da comissão de sistematização observou outras alterações no artigo 241, com destaque para a duração da obrigatoriedade do ensino fundamental, que foi suprimida; a ampliação do apoio suplementar a todos os educandos, posto que o recorte do ensino fundamental também foi abortado; e a simplificação do parágrafo segundo, que colocou a questão da responsabilização pelo não cumprimento das obrigações do Estado sob as "autoridades competentes". A inclusão do parágrafo terceiro, que trouxe a competência do Estado para com a chamada pública dos educandos em idade escolar, assim como a responsabilização das famílias que não zelassem pela frequência, caracterizaram-se como importante inovação na garantia dos direitos individuais e coletivos (ANC, 2017f, p. 7-8).

No que é pertinente ao processo de votação em plenário, algumas emendas foram feitas, sendo que as de caráter aditivo previam a inclusão de incisos que tratariam da concessão de bolsas de estudo, as quais faremos menção mais à diante. Por ora é importante destacar uma proposta do Centrão, de trazer novamente ao inciso VII a delimitação do apoio suplementar ao ensino fundamental, perspectiva esta que acabou permanecendo na versão final da Constituição. Cabe ainda o destaque de algumas propostas aditivas que visavam ampliar a responsabilidade do Estado: uma de autoria do constituinte Florestan Fernandes, que versava sobre o incentivo às práticas de lazer social; uma de Louremberg Nunes (PMDB), que colocava a obrigatoriedade do atendimento aos alunos deficientes em todos os níveis de ensino; a questão da educação integral, trazida por Vivaldo Barbosa (PDT); entre outras. Desta forma, no documento final temos o artigo 208 com a seguinte redação:

Art. 208. O dever do Estado com a educação será efetivado mediante a garantia de: I - ensino fundamental, obrigatório e gratuito, inclusive para os que a ele não tiveram acesso na idade própria; II - progressiva extensão da obrigatoriedade e gratuidade ao ensino médio; III - atendimento educacional especializado aos portadores de deficiência, preferencialmente na rede regular de ensino; IV atendimento em creche e pré-escola às crianças de zero a seis anos de idade; $\mathrm{V}$ - acesso aos níveis mais elevados do ensino, da pesquisa e da criação artística, segundo a capacidade de cada um; VI - oferta de ensino noturno regular, adequado às condições do educando; VII - atendimento ao educando, no ensino fundamental, através de programas suplementares de material didático-escolar, transporte, alimentação e assistência à saúde. $\S 1^{\circ} \mathrm{O}$ acesso ao ensino obrigatório e gratuito 
é direito público subjetivo. $\S 2^{\circ} \mathrm{O}$ não-oferecimento do ensino obrigatório pelo Poder Público, ou sua oferta irregular, importa responsabilidade da autoridade competente. $\S 3^{\circ}$ Compete ao Poder Público recensear os educandos no ensino fundamental, fazer-lhes a chamada e zelar, junto aos pais ou responsáveis, pela freqüência à escola (ANC, 2017i, p. 1).

O artigo que trouxe a obrigatoriedade do ensino em língua portuguesa e a possibilidade de alfabetização dos índios em sua língua nativa - artigo $4^{\circ}$ na versão original e parte do artigo 209 (parágrafo segundo), não teve sua redação alterada significativamente; apenas sua localização no texto constituinte.

No que se refere à organização dos sistemas de ensino, três temas tiveram grande repercussão ao longo dos debates nos diferentes espaços, mas de certa forma contaram com algum consenso entre os constituintes: a distribuição das competências entre os entes federados; a questão da vinculação orçamentária para a educação; e o recolhimento e aplicação do salário-educação. $\mathrm{O}$ artigo 10 tratou do primeiro tema, não tendo sofrido alterações significativas da fase $\mathrm{Aà} C$, a não ser no que se referia à necessidade de organização de conselhos de educação em municípios com mais de cinquenta mil habitantes (parágrafos quinto e sexto). Na versão $\mathrm{F}$, a redação do artigo já apareceu totalmente mudada, com o caput praticamente transcrito no parágrafo terceiro, mas sem perda de sentido. Cumpre apresentar que a versão H retomou o número de habitantes, inserindo, inclusive, um novo parágrafo que abordava o número de conselheiros nos CME (neste momento tratava-se do artigo $7^{\circ}$ ). Na versão final do artigo 211 não constaram alterações significativas no sentido, exceto tal detalhamento, que foi suprimido do texto.

As mesmas observações cabem ao artigo 11, que trouxe a discussão da conhecida emenda Calmon. Nele constava, além dos percentuais já amplamente discutidos, a priorização dos recursos para o ensino formal - alterando-se na versão C para "programas de educação pré-escolar e de ensino" (ANC, 2017b, p. 5). Em três parágrafos se reafirmou a perspectiva da aplicação dos recursos no ensino obrigatório. Ainda na versão $C$ houve a inclusão de um percentual para este investimento - 50\%, além da proibição de cobrança de taxas nas escolas públicas. Na versão $\mathrm{F}$ esta discussão foi realocada no artigo $8^{\circ}$, tendo-se agregado o adjetivo "público" ao substantivo ensino, na redação do caput, e sendo retirado o inciso que tratava da proibição da cobrança de taxas. Cabe ressaltar que, devido aos enormes embates sobre a destinação dos recursos que tomaram parte na comissão 8, a versão 
encaminhada à sistematização (fase $\mathrm{H}$ ), oriunda do segundo substitutivo do relator, teve novamente a palavra "público" suprimida. Foi também retirada a necessidade de elaboração de um PNE que viesse a organizar a repartição dos recursos; e foram introduzidos novos parágrafos, que viabilizavam o repasse de recursos públicos às instituições comunitárias, filantrópicas ou confessionais, questões às quais voltaremos no próximo subcapítulo. $\mathrm{Na}$ fase I, contabilizado como artigo 384, saíram os novos incisos que tratavam de tais recursos, além do parágrafo $3^{\circ}$, que estabelecia sanções jurídicas e administrativas aos entes que não aplicassem a verba devida em cada área do ensino. Na fase final da comissão de sistematização, o artigo 384 passou a ser o 245, sendo que nele foi incluído um novo inciso, que abordava a arrecadação de impostos e sua aplicação. Na versão da fase Q, percebese que poucas emendas foram propostas, que não vieram a alterar significativamente o conteúdo de todo o artigo, o mesmo se repetindo no artigo 211, número que passou a ter na versão V; e no artigo 212, no texto final.

A discussão pertinente ao salário educação foi um pouco alterada, desde o início, no artigo 16 da versão da subcomissão, até sua aprovação. A alteração mais significativa se fez na fase $\mathrm{H}$, na qual o grupo privatista lograra êxito significativo com a redação seguinte:

\begin{abstract}
Art. 11 - As autarquias, fundações e empresas comerciais, industriais e agrícolas, que não mantiverem escolas próprias ou não concederem bolsas de estudo para matrícula de seus empregados e respectivos dependentes no pré-escolar e no primeiro grau, deverão recolher o salário educação, na forma da lei. $\S 1^{\circ}$ - Os recursos a que se referem o caput deste artigo destinar-se-ão à expansão da oferta do ensino público e, em casos especiais de escolas comunitárias, filantrópicas ou confessionais, nos termos do artigo $8^{\circ}$ e seus parágrafos. $\S 2^{\circ}-$ As empresas que mantiverem escolas, ou custearem sob qualquer forma os estudos de seus empregados ou de seus filhos, poderão descontar as despesas de recolhimento do salário-educação, na forma da lei (ANC, 2017d, p. 13).
\end{abstract}

Ao chegar na comissão de sistematização, a versão a ser considerada foi a anterior, sem menção às escolas comunitárias, filantrópicas ou confessionais, e sem a dispensa de aplicação de recursos por parte das empresas. Na fase $\mathrm{P}$ houve uma redução significativa do texto do artigo, que passou a ser numerado como 249 e a contar com a seguinte redação: "O ensino público federal terá como fonte adicional de financiamento a contribuição social do salário-educação, a ser recolhida pelas empresas, na forma da lei” (ANC, 2017f, p. 9). Durante a votação em plenário, sofreu uma proposta de emenda por parte do constituinte Bocayuva Cunha, do PDT, que previa uma contribuição a partir dos lucros mensais da 
empresa, na proporção de $1 / 10$. No que é pertinente ao texto que saiu da votação e ao que foi finalmente aprovado como o artigo 211 da CF, a redação pertinente ao salário-educação concentrou-se no parágrafo $5^{\circ}$, sem a proporção prevista, tampouco as especificações colocadas na versão da comissão 8. Permaneceu a versão que ocupou a maior parte dos espaços constituintes, em uma espécie de conciliação entre as posições privatistas e publicistas, como a sinalizada anteriormente na fase $\mathrm{P}$, com o acréscimo do trecho "que dela poderão deduzir a aplicação realizada no ensino fundamental de seus empregados e dependentes" (ANC, 2017i, p. 2).

Ainda no que concerne à organização dos sistemas de ensino, havia no projeto final da subcomissão 8a um artigo (artigo 14) que versava sobre o Plano Nacional de Educação, a ser definido por lei complementar, com vistas à universalização do atendimento escolar, entre outras propostas. Manteve-se na fase F, foi suprimido na fase H, voltou na fase I como artigo 387 - e continuou na fase P (artigo 248). Já na votação em plenário, sofreu uma proposta de emenda pelo constituinte Francisco Diógenes (PDS), que sugeriu sua supressão, com nova redação do $\S 3^{\circ}$ do artigo 245 , que tratava da distribuição dos recursos vinculados constitucionalmente. Sendo assim, o texto foi redigido da seguinte forma na versão da fase V: “Art. 211 [...] $3^{\circ}$ A distribuição dos recursos públicos assegurará prioridade ao atendimento das necessidades do ensino obrigatório, nos termos do plano nacional de educação" (ANC, 2017h, p. 109). Passou, por fim, a fazer parte do artigo 212 no texto final, da mesma forma que apresentado anteriormente.

Sobre essa discussão, Florestan Fernandes (1989, p. 125) fez uma análise da sua proposição, à época, que visava a implantação de um órgão de controle do PNE para efetivação de um planejamento democrático. O constituinte lembrou que nossa sociedade capitalista tem prioridades outras que não a fiscalização e a gestão coletiva dos recursos públicos, posto que

Planejamento democrático na área da educação implicaria em controles racionais institucionalizados de aplicação e avaliação dos recursos públicos, o que não interessa aos que comandam o sistema educacional brasileiro a partir de posições estratégicas “oficiais" ou "privadas" [...] Na verdade, as contradições existentes são fatores de aceleração da acumulação de capital. Precisam ser mantidas intocadas.

Traçando um panorama geral a respeito da carta magna de 1988, podemos dizer que em meio a disputas de diferentes naturezas, o capítulo II, intitulado Dos direitos 
sociais, apresentou originalmente a educação como um dos direitos sociais, ao lado da saúde, do lazer, da segurança, da previdência social, da proteção à maternidade, à infância e aos desamparados. Anos depois, a EC 26 de 2010 incluiu o direito à moradia no rol dos direitos sociais a serem garantidos pelo dispositivo constitucional. O artigo 22 trouxe a competência da União em legislar sobre as diretrizes e bases da educação nacional, aspecto importante a ser destacado. O capítulo III concerne à educação, à cultura e ao desporto. $\mathrm{Na}$ seção I deste capítulo se encontram descritos os princípios da educação nacional, que não cabem exclusivamente ao Estado, mas também à família, que deveria escolher qual a educação de seus filhos. Segundo Cunha (2009, p.445), trazer a família e a sociedade para compartilhar com o Estado a obrigatoriedade da educação, serviu para atenuar o seu dever de se fazer um Estado educador, abrindo caminho para outros grupos compartilharem de tal responsabilidade, ou seja, os setores privados.

No que é pertinente à democratização das oportunidades educacionais, apresentouse no artigo 208 o ensino fundamental como obrigatório e gratuito, a ser oferecido pelas escolas oficiais, com a extensão progressiva da obrigatoriedade para o ensino médio - fato que somente se efetivou muito recentemente em um dispositivo legal, em 200966. Um aspecto que cabe destacar é o acesso ao ensino obrigatório e gratuito ser garantido como direito público subjetivo, tal como já apresentamos anteriormente.

\subsection{A CONCEPÇÃO DE LIBERDADE DE ENSINO NO TEXTO CONSTITUCIONAL DE 1988}

A discussão sobre a liberdade de ensino não é atual na educação brasileira. Se pegarmos como referência o Manifesto de 1932, veremos que a demanda por uma escola única - pública, laica, gratuita - já era colocada como forma se superação do atraso educacional aqui vivido, fruto de um projeto de país que buscava manter em lugares distintos cidadãos distintos, cuja origem social e econômica cuidava de separar, desde o nascimento.

Sobre este aspecto, é importante retomar o trabalho de Jessé Souza, a respeito da justificação da desigualdade no Brasil (2011, p. 43), no qual ele historiciza a difundida ideia de que alcançam os níveis mais importantes da vida em sociedade aqueles que se esforçam, ou seja, por mérito, individualmente. Desta forma, os poderes dominantes se encarregam de reproduzir os privilégios de determinados grupos, por meio da difusão do senso comum, que constrói a ilusão de que somos realmente todos iguais e livres. A esfera 
social é diluída no indivíduo, responsabilizado pelo seu sucesso ou fracasso. Assim, as famílias de classe média ensinam seus valores como "naturais" e, portanto, "universais".

Quando as camadas populares começaram a ter acesso ao espaço escolar, lá chegaram sem possuir uma gama de pré-requisitos, valores, aprendizados. Desta forma, os elementos "que faltam à ralé" são os mesmos que permitem "às crianças de classe média o acesso às características emocionais e cognitivas que irão, mais tarde, separar aqueles que terão sucesso escolar e, consequentemente, sucesso no mercado de trabalho" (IDEM, p. 46). Cabe-nos, como educadores, não desconsiderar, tampouco subestimar a diferenciação que a origem de classe é capaz de promover na colocação social de cada pessoa. Percebe-se a distinção de gostos (BOURDIEU, 2007, p. 318), da linguagem, das visões de mundo, que, consequentemente, irão se desdobrar nas diferenciações no tocante ao rendimento escolar. Concordamos mais uma vez com Jessé Souza (2010, p. 21-22), quando ele afirma que

Como é o pertencimento às classes sociais que predetermina todo o acesso privilegiado a todos os bens e recursos escassos que são o fulcro da vida de todos nós 24 horas por dia, encobrir a existência das classes é encobrir também o núcleo mesmo que permite a reprodução e legitimação de todo tipo de privilégio injusto.

A escola única seria, para os reformadores de 1932, a instituição capaz de iniciar um processo de diminuição do abismo historicamente existente entre as diferentes classes, pois as colocaria para conviver em um mesmo espaço - a escola pública. Igual para todos, com o mesmo conteúdo, laica, tal instituição seria capaz de colocar todos os alunos em situação de equidade, rompendo com a perspectiva de educação como vantagem de uns sobre os outros, alçando-a à categoria de direito, como vimos anteriormente.

As reações à proposta do Manifesto, visto por Florestan Fernandes como um avanço para a realidade elitista e excludente brasileira - mesmo que distanciado dos valores socialistas, e caracterizando-se por um ideal liberal - já denotavam que alguns setores da sociedade desejavam perpetuar as distinções entre os grupos, oferecendo educações diferentes para pessoas diferentes, colocando sob a égide da família a "escolha" pelo modelo educacional a adotar para seus filhos. A palavra liberdade ganhou um sentido mais específico, passando a se referir à possibilidade de escolha da família, e não mais à perspectiva mais ampla de liberdade, aquela gestada na autonomia do sistema escolar e dos agentes que dele fazem parte. 
Em entrevista para este trabalho, quando questionado sobre o que efetivamente viria a ser liberdade de ensino, Carlos Roberto Jamil Cury considerou que

\begin{abstract}
Aliberdade do ensino, ela nunca foi contestada no Brasil. Contestada assim, eu estou falando do ponto de vista jurídico. Tanto do ordenamento jurídico. A liberdade de ensino é a liberdade das escolas privadas. E as escolas privadas, elas são ligadas à iniciativa privada. E neste sentido elas são diretamente sustentadas pelas famílias. A liberdade de ensino, como o próprio nome diz, representa uma opção, por uma diferença que hipoteticamente a escola pública não dá. Por exemplo, o que cai a vista assim diretamente é a questão religiosa. Então, o Estado é laico, tem lá o ensino religioso, de oferta obrigatória, mas de matrícula facultativa, tá, então se eu não quiser não inscrevo meu filho, tá, porém a escola privada ela diz, não, eu quero acentuar essa diferença. Então, a liberdade de ensino, ela nem é propriamente da família, etc. Ela se articula com empresa. Ela tem haver com o privado.
\end{abstract}

Ainda de acordo com Cury (2010, p. 63), este problema atravessa toda história republicana, colocando em lados opostos católicos e positivistas. De 1890 até os dias atuais tal conflito sempre esteve presente, alternando seus agentes, mas colocando o debate entre as seguintes díades: ensino público/privado - oficial/livre - laico/religioso, ora colocando maior ênfase em um aspecto, ora em outro. Todavia, o autor reconhece que, à medida que o papel do Estado foi crescendo, por volta dos anos de 1930, tais conflitos também se intensificaram no interior do debate sobre a elaboração das leis do país.

A aprovação da Constituição Federal de 1946 e o início do processo de tramitação da primeira LDBEN trouxeram à tona esse conflito de concepções. Baseado no artigo 166 daquela Constituição, a educação nacional deveria se pautar na liberdade e nos ideais de solidariedade (DAVIES, 2004, p. 23). A ênfase que antes residia nas divergências entre os grupos que debatiam a centralização ou a descentralização das políticas educacionais, passou a se concentrar em dois polos antagônicos: o conflito que colocava em campos distintos os publicistas e os privatistas; e também os que defendiam os interesses das escolas confessionais dos que se levantavam à favor das escolas laicas.

Ester Buffa, em seu livro Ideologias em conflito: escola pública e escola privada (1979) bem coloca esta questão, por meio da retomada dos principais aspectos que geraram o longo processo de tramitação da primeira LDBEN, em que havia um grande movimento - parlamentar e social - para barrar a ameaça de "estatização" do ensino, por meio de uma escola para todos. Ao agregar ao termo "pública" também o adjetivo "laica", mais um grupo se contrapôs à tal reivindicação - o religioso, naquele momento composto predominantemente por escolas confessionais católicas. 
Como já apresentamos, vários ataques foram feitos a Anísio Teixeira, considerado como defensor de "elementos agnósticos e cripto-comunistas" (BUFFA, 1979, p. 21). As disputas acirradas na elaboração da LDBEN, levaram a formulações que colocavam a liberdade de ensino contra o monopólio estatal, defendendo-se “[...] o direito paterno de promover, com prioridade absoluta, a educação dos filhos; e dos particulares, de comunicarem a outros seus conhecimentos", conforme constava no substitutivo Lacerda (IDEM, p. 37).

A obra Diretrizes e bases da educação nacional, organizado por Barros (1960) reúne vários textos de diferentes autores daquele período, inclusive textos do jornal O Estado de São Paulo. Retomamos alguns dos que tratam mais diretamente do conceito de liberdade, a começar pelo Estado Educador (1960, p. 25). Ele defende que o fato do Estado se fazer presente nos assuntos educacionais não contraria os princípios liberais, ao contrário, percebe a educação como meio de realizar sua filosofia política. Do mesmo modo, o artigo seguinte, intitulado Ainda a liberdade de ensino (IDEM, p. 28), apresenta a perspectiva constante na encíclica do Papa Pio XI, na qual ele examina a questão educacional, colocando-a como obra social, sob a responsabilidade de três ordens: a família, a sociedade civil e a Igreja. Desta forma, a família seria considerada a "sociedade imperfeita, porque não possui em si todos os meios para o próprio aperfeiçoamento"; a sociedade civil, por sua vez, teria a "preeminência sobre a família [...] a sua conveniente perfeição temporal". Assim sendo, a educação deveria considerar as três ordens, a fim de que o homem fosse também considerado individual e socialmente. A partir daí tece a crítica aos debates que buscavam deslegitimar a reivindicação por escolas públicas, recolocando a liberdade como possibilidade de criação de pessoas críticas e autônomas. Liberdade de ensino seria, portanto, uma conquista histórica, um avanço no direito positivo.

Catani (1960, p.124-125) faz uma excelente distinção entre a proposta da escola pública e a dos defensores do ensino religioso e privado. Afirma que a primeira se pauta em princípios abertos, de verdades mutáveis, posto que humanas e históricas. Neste sentido, o conteúdo da escola pública deveria ser essencialmente laico e democrático, viabilizando o máximo grau de consciência, necessário ao desenvolvimento científico e, por conseguinte, capaz de gerar a liberdade. Em contrapartida, o ensino religioso e privado limitaria a liberdade de consciência, visto que se encontra restrito a um sistema dogmático, seja ele pautado por uma religião específica ou por apenas uma corrente filosófica. Desta forma, a 
função pública da educação é conectada ao Estado laico, moderno, dissociado da Igreja. $\mathrm{E}$, diferentemente do que propugnava alguns, isso não é socialismo. Destacamos a fala do autor, que elucida muito bem esta posição:

A escola pública não é neutra perante o problema da liberdade, pois a transforma no princípio moral e instrumental básico de sua existência. Apenas quer a liberdade completa e integral, liberdade para todos e para todas as investigações do espírito humano e não a liberdade para um grupo, uma seita, uma raça, uma classe, imporem suas convicções, por mais respeitáveis que sejam para a consciência desses grupos, eliminando assim a própria liberdade, liberdade como direito comum e democrático. Já foi afirmado que os adversários da escola pública querem a liberdade da escola porque não a querem na escola ${ }^{67}$.

Seja com Florestan Fernandes na Campanha em defesa da escola pública dos anos 1960, como vimos no capítulo 2, seja nos debates que permearam a Assembleia Nacional Constituinte de 1987-1988, percebemos que os grupos - devidamente representados por alguns constituintes - e suas reivindicações por liberdade não se alteraram. Os conteúdos apenas se complexificaram mais um pouco, pois tais grupos passaram a agregar novos agentes - o setor evangélico, que começava a crescer no país; e os representantes das escolas não-confessionais, sobretudo do ensino superior, que proliferaram no período da ditadura empresarial-militar.

Luiz Antônio Cunha (2009, p. 324) explica o fenômeno a partir de dois vieses: as facilidades abertas às escolas privadas, a partir da instituição da obrigatoriedade do recolhimento do salário-educação por empresas, que poderia deixar de ser descontado caso a empresa com mais de 100 funcionários passasse a distribuir bolsas de estudo ou abrisse escolas próprias. Tal situação viabilizou a realização de fraudes $^{68}$, que favoreceram ainda mais estas instituições, posto que, em sua maioria, gozavam da presença de vários alunos bolsistas. Outro fator foi o período do milagre econômico, que aumentou a renda da classe média, levando-a às escolas privadas, o que se agravava com a difusão do discurso da baixa qualidade do ensino público. Com a reformulação do sistema tributário nacional, em 1965, as instituições privadas passaram a desfrutar de verdadeira imunidade fiscal, fazendo com que entidades antes precárias viessem a se tornar grandes redes. Outros fatores destacados

$67 \quad$ Grifos do autor.

68 Segundo Velloso apud Cunha (2009, p. 326)"[...] Em 1981, as bolsas e as indenizações de gastos propiciadas por recursos do salário-educação correspondiam a 70\% das vagas das escolas privadas [...] Em pelo menos três estados (Rio Grande do Sul, Santa Catarina e Rio de Janeiro), o número de bolsas ultrapassava o de alunos das escolas privadas". 
pelo autor foram a criação do FNDE - Fundo Nacional de Desenvolvimento da Educação, administrado por um conselho deliberativo que tinha em sua composição empresários do ensino, até 1985; e o Programa de Bolsas de Estudo no Ensino Médio, criado em 1956 com a justificativa da não existência de vagas no setor público, e que serviu como fonte de recursos públicos para instituições privadas. Cabe destacar que as bolsas em 1970 passaram a ser distribuídas pelos senadores e deputados federais, o que nos mostra as reais razões para este ser um tema tão polêmico e interessante no cenário educacional do país.

Em 1973, com a promulgação do Decreto $n^{0} 72.495$, foram estabelecidas normas para a concessão de amparo técnico e financeiro às escolas privadas. Desta forma, elas passaram a ter novas formas de suprir as perdas que se deram a partir da crise da economia: a concessão de empréstimos por parte da União; a utilização de seus prédios para suprir a demanda por escolarização onde não houvesse escolas públicas; a utilização das escolas técnicas públicas para que os alunos das instituições privadas tivessem a parte do currículo destinada ao ensino técnico; e o aproveitamento das escolas privadas, de forma que se evitasse a construção de escolas públicas próximas para que estas não viessem a atrapalhar o "mercado", cabendo ao Estado, nesses casos, o oferecimento de bolsas de estudo (IDEM, p. 334).

Diante o panorama traçado, temos clareza que o problema não era a ameaça de estatização do ensino; na verdade, a preocupação era o fim das regalias que estas empresas que se dedicavam ao ramo educacional recebiam. A questão da laicidade entra nesse debate mais pelo viés econômico do que religioso propriamente, visto que muitas escolas confessionais se valiam de tais incentivos. Daí a necessidade de aliarem seu discurso aos benefícios sociais que promoviam, por se autoproclamarem instituições sem fins lucrativos e, portanto, públicas não estatais.

Concordamos ainda com Cunha (IBIDEM, p. 344-345) que a liberdade de culto faz parte da perspectiva democrática, porém “O que não faz parte desse ideário é a existência de práticas religiosas na escola pública, nem o ensino da religião (qualquer religião), já que esta é uma questão da esfera privada”. Neste sentido, Maria Francisca Pinheiro (2005, p.255) complementa o autor, afirmando que o conflito entre as esferas públicas e privadas no Brasil é, ao mesmo tempo, antigo e atual, pois se coaduna com as relações entre o Estado e a sociedade, bem como os limites entre eles. Resgata a origem grega das categorias, na qual “[...] público e privado foram utilizadas para distinguir a esfera da política da esfera das 
necessidades básicas" (IDEM, p. 356). Desta forma, a religião passa a ser mais uma forma de uso do direito à educação entendido como liberdade de ensino, em uma tentativa de transformar o dever da família para com a educação de seus filhos em um poder de escolha, quer sobre a natureza do ensino (público/privado), quer sobre o conteúdo do mesmo (laico/ religioso).

Segundo Cury (2010, p. 66), nos anos de 1970, também se agregou ao discurso da “escolha”, o da "relação custo/benefício". Por seu intermédio, a alegação era que o ensino público acabava por ser muito mais custoso aos cofres públicos do que o privado. Vimos isso em vários argumentos de alguns constituintes, ao longo da ANC de 1987-1988, como demonstrado no terceiro capítulo.

Outro fator relevante se refere às diferentes esferas que o termo liberdade de ensino abrange. Luiz Antônio Cunha evidenciou essa polissemia na entrevista que nos foi concedida, na qual partiu da ideia de escolha, já mencionada anteriormente e protagonizada em grande medida pelas escolas católicas, para afirmar que

Para que isso se efetivasse era preciso que as famílias fossem detentoras, mais uma
vez famílias entre aspas, detentoras desse direito de educar os filhos. E ao Estado
corresponderia, correlativamente, o dever de criar condições para que esse direito
fosse exercido de fato. Não adianta só ter o direito de poder por o filho na escola
que quiser se não tiver esse dinheiro [...] Então, o Estado teria que prover recursos,
direta ou indiretamente, para que eu exercesse esse direito de botar meus filhos
na escola que eu quisesse, conforme a minha orientação religiosa, ideológica, sei
lá, moral, qualquer coisa desse tipo. [...] Então eu quero escolher a escola que
seja adequada aos meus filhos, então vocês têm que me dar bolsa de estudos, ou
permitir que eu abata no imposto de renda. Sobretudo essa gente de classe média,
que paga imposto de renda, coisa e tal, permitir que eu abata no imposto de renda,
que eu receba de volta de você, governo, o dinheiro que eu paguei. Pode ser que
isso retorne. Então, essa expressão liberdade de ensino, se você for ver no plano
institucional, estou chamando isso de plano institucional. Agora tem mais, tem
outros planos. Tem o plano do professor, que é o plano do magistério. Aí a coisa
é bem outra, né? Aí o assunto é bem outro. A Constituição determina a liberdade
do pensamento, de concepções pedagógicas. Os professores teriam o direito de
exercer no âmbito da sua atividade.

Não nos deteremos neste momento às demais esferas que o polissêmico conceito de liberdade de ensino nos remete, como a liberdade de pensamento e de difusão do mesmo, pertinente ao trabalho do professor; assim como a seleção do que vem a compor o que comumente chamamos de currículo escolar. Sobre este último aspecto, é importante 
destacar a experiência com a disciplina de Moral e Cívica, instituída no período da ditadura empresarial-militar, como maneira de viabilizar a formação de "[...] apreço à pátria, de respeito às instituições, de fortalecimento da família, de obediência à Lei [...] cidadãos sinceros, convictos e fiéis no cumprimento de seus deveres" (CUNHA, 2000, p.74). Desta forma, ressalta-se que o conteúdo do que vinha a ser ensinado nos bancos escolares não era "livre"; ao contrário, estava profundamente vinculado aos interesses dos grupos que detinham a hegemonia do processo sócio-econômico e, consequentemente, do habitus e capital necessários ao seu desenvolvimento profissional.

Contudo, é significativo lembrar que a invasão da liberdade pela obrigação do Estado não permite, sob hipótese alguma, que a família deixe de garantir a educação de seus filhos. No caso da nossa legislação, constitui-se como direito e dever a educação escolar, não cabendo, portanto, ações que permitam que os sujeitos estejam fora de tal instituição.

Partimos, pois, ao exame dos documentos e propostas de textos legais para analisar que concepção/concepções venceu/venceram a disputa no campo político, na tentativa de tornar-se/tornarem-se hegemônica(s) na aprovação de uma nova carta constitucional.

\subsubsection{A liberdade de ensino: do texto da Comissão dos Notáveis à aprovação da CF de 1988}

Tal como fizemos no subcapítulo anterior, iniciaremos com a análise do anteprojeto oriundo da comissão formada pelo governo. Evidenciou-se, já no preâmbulo, uma grande contradição - evocou-se a proteção de Deus em um espaço público, presumidamente, laico: "Nós, representantes do Povo Brasileiro, reunidos sob a proteção de Deus em Assembléia Nacional Constituinte, proclamamos a necessidade de oferecer ao nosso País uma Constituição [...]" (CÂMARA, 2017, p. 18).

No parágrafo único do artigo 25 se enunciou a necessidade da educação laica, tema que se fez bastante controverso na discussão desenvolvida por todos os meses que durou a ANC. Outro tema que gerou muitas divergências também foi logo posto em pauta: a garantia da liberdade da escolha da instituição de ensino na qual a família poderia matricular seus filhos. Vale um destaque para o fato de ainda não aparecer aqui a destinação dos recursos que financiariam a educação, tampouco os critérios que viabilizariam a escolha familiar. 
Outra menção à liberdade de ensino sob a forma da coexistência de instituições públicas e privada foi feita no inciso II do artigo 385. Além disso, nele também se agregou o reconhecimento à pluralidade de ideias, portanto, à liberdade de pensamento. $\mathrm{O}$ artigo 385 trouxe a responsabilidade conjunta dos pais e do Estado para com a educação dos filhos. Todavia, pela redação do mesmo, percebemos que havia uma ênfase no papel da família diante desta tarefa.

Mais uma vez a perspectiva de pluralismo no campo da educação foi registrada no texto do artigo 389, a saber: “A prestação pluralista do ensino é assegurada pela autonomia institucional e a auto organização do ensino público e pela livre organização da iniciativa privada" (IDEM, p. 66). Os artigos seguintes serviram para organizar a liberdade da iniciativa privada, na medida em que ofereceram a metodologia de seu funcionamento: pela expansão da gratuidade do ensino, conforme sistema de bolsas de estudos já existente à época, conforme prevê o inciso III; e pelo recolhimento do salário-educação ou investimento em escolas próprias, para atendimento aos seus funcionários e filhos deles. Na sequência, o artigo 391 trata diretamente da transferência de recursos públicos à iniciativa particular, destacando a precedência em relação ao que chamou de "interesse comunitário" - que mais tarde veio a ser chamado de filantropia e/ou de escolas públicas não estatais -, como vemos a seguir:

Art. 391 - A lei regulará a transferência de recursos públicos ao ensino privado a todos que a solicitem, dentro de quantitativos previamente estabelecidos, e obedecendo a processo classificatório, tendo em vista: I - a contribuição inovadora da instituição para o ensino e pesquisa; II - o suprimento de deficiências qualitativas ou quantitativas do ensino público; III - a participação de representantes da comunidade nas decisões da instituição beneficiada; IV - o interesse comunitário da sua atividade. Parágrafo único - Têm prioridade na atribuição desses recursos as instituições de interesse social, reconhecidas pelos poderes públicos, e capazes de compensar, progressivamente, com recursos alternativos, o auxílio recebido pelo Estado (IBIDEM, p. 67).

Outro aspecto aqui destacado foi a exigência do cumprimento de padrões de qualidade como condicionante para o recebimento de recursos. Contudo, não se especificou com que critérios as instituições seriam avaliadas. A questão do ensino religioso novamente apareceu no artigo 393, como componente curricular - facultativo aos alunos - porém, como direito destes, que deveria ser cumprido pelas escolas. O grande problema que se colocava, à época, era o fato de tal ensino ser pouco viável, devido à toda complexidade que 
envolvia facultá-lo à escolha dos alunos e suas famílias, sem antes dispor de professores de diferentes confissões religiosas para ministrarem suas aulas:

Art. 393 - Será facultativo o ensino religioso nas escolas oficiais, sem constituir matéria do currículo.Parágrafoúnico-Defere-se aos alunos, ou a seus representantes legais, o direito de exigir a prestação daquele ensino, horário e programa escolar, de acordo com a confissão religiosa dos interessados (CÂMARA, 2017, p. 67).

Passemos à Carta de Goiânia, já apresentada anteriormente. O primeiro ponto da Carta, além da ideia da educação como direito, enunciava a laicidade do ensino nos estabelecimentos públicos. Apresentava-se, pois, esta como uma necessidade prioritária, junto à gratuidade, para que de fato a educação fosse destinada a todos. Tal princípio, como vimos, foi ratificado no ponto seguinte. $\mathrm{O}$ texto voltou a mencionar a perspectiva de liberdade de ensino, como aqui a definimos, no seguinte trecho: “15. Os recursos públicos destinados à educação serão aplicados exclusivamente nos sistemas de ensino criados e mantidos pela União, Estados e Municípios” (IDEM, p. 70). Aqui temos a questão da transferência de recursos, que envolve a discussão mais recorrente e difícil da ANC, que foi o entendimento sobre em que consiste a liberdade: na ampliação da rede de escolas públicas, que atendessem aos alunos com qualidade, para que todos fossem capazes dela saírem com uma formação crítica e potente, decorrendo daí a necessidade da escola pública receber exclusivamente os recursos do Estado; ou a destinação de recursos para todas as escolas, por meio de incentivos fiscais ou por intermédio de bolsas de estudo, de maneira que a família contemplada tivesse a liberdade de escolher em qual instituição deveria matricular seu responsabilizado. A perspectiva trazida pela Carta era a que defende a exclusividade de recursos para o ensino público, que, além de explícito no princípio 15 , foi ratificado no 18: "É permitida a existência de estabelecimentos de ensino privado, desde que atendam às exigências legais e não necessitem de recursos públicos para sua manutenção" (IBIDEM, p. 70).

O documento da ANDES trouxe a mesma afirmação, corroborando ambos os pontos destacados: "Lutamos por uma educação pública, gratuita, crítica, democrática e competente. Uma luta já antiga e hoje, mais do que nunca, necessária. Uma luta, portanto, para a transformação da realidade que temos entre nós" (IBIDEM, p. 70). Na sequência do texto da apresentação do seu documento, a ANDES teceu uma severa crítica à privatização do ensino no Brasil, que se evidenciaria 
[...] na falta de vagas nas escolas públicas com mais de 10 milhões de crianças que estão sem escolas e na existência de turnos curtos, entre tantos outros exemplos. Significa ainda o tratamento do ensino como mercadoria, com a própria política educacional favorecendo a que empresas privadas de ensino se tomem negócio altamente rentável. Assistimos ao lobby privatista controlar uma fatia lucrativa do mercado ao mesmo tempo em que controla a própria política educacional com sua presença ou representação em comissões, no CFE e no Congresso Nacional.

Assim, já vimos no item anterior que o primeiro ponto da plataforma da ANDES destacou o ensino público, que foi mais uma vez confirmado na descrição que o ponto 1.2.4. da plataforma trouxe, quando explicitou os critérios que deveriam ser obedecidos para que uma escola privada pudesse funcionar:

1.2.4 - É permitida a existência de escolas particulares desde que não recebam verbas públicas, estejam organizadas segundo os padrões unitários de qualidade e não tenham fins lucrativos e sejam subordinadas às normas mínimas ordenadoras da estrutura educacional nacional. $\S 1^{\circ}$ A existência da escola privada estará condicionada à observância das normas previstas no caput deste artigo, à garantia da participação dos professores e funcionários nos órgãos deliberativos da instituição, bem como à garantia de que a entidade mantenedora sustentará de forma integral, econômica e financeiramente, o funcionamento da instituição. $\S$ $2^{\circ}$ Cabe ao Estado garantir, através da fiscalização, a observância permanente dessas normas e condições, sob pena de cassação da permissão de funcionamento e intervenção administrativa na instituição. $\S 3^{\circ}$ Ficam proibidas isenções tributárias às mantenedoras e aos proprietários de empresas particulares de ensino (CÂMARA, 2017b, p. 71).

A proposta do artigo clarificou que toda instituição privada deveria se manter com recursos próprios sem auxílio financeiro do Estado, seja por meio de isenções, seja por bolsas ou outra forma de destinação direta de recursos. Porém, no que se referia à sua fiscalização, o Estado deveria se fazer presente. Outro aspecto que chamou a atenção foi a existência de um colegiado para gerir a instituição, posto que na tradição das entidades privadas - que possuem um mantenedor - não era algo comum e bem aceito. Em complemento ao item 1.2.4, os pontos 1.2.5 e 1.2.6 mais uma vez definiram a destinação dos recursos públicos, sendo que o primeiro tópico tratou da vinculação orçamentária constitucional, nos termos da emenda Calmon, porém, evidenciando que "[...] Fica o Estado obrigado a alocar ao ensino público e gratuito uma parcela fixa da receita tributária", e, depois, divide a porcentagem de tal destinação. No ponto seguinte, novamente se destacou o ensino público 
como caminho para alcançar efetivamente a liberdade de ensino e, por conseguinte, como destinatário exclusivo dos recursos do governo:

As verbas públicas destinam-se exclusivamente às escolas públicas criadas e mantidas pela União, Estados e Municípios. 1.2.7 - A União se responsabilizará pela criação de mecanismos de controle e fiscalização da arrecadação e aplicação das verbas destinadas à Educação, com ampla participação da comunidade escolar, acadêmica, científica e das entidades da classe trabalhadora (IDEM, p. 71).

Cabe-nos ainda mencionar o item 1.2.3, que tratou da liberdade de expressão, diretriz que deveria ser garantida nas instituições de ensino. Tratava-se, pois, da ideia de liberdade associada ao conteúdo do que era ensinado, que envolvia tanto o currículo, quanto a prática pedagógica dos professores - liberdade associada ao plano do magistério, como afirmou Luiz Antônio Cunha, em entrevista -, assim como a proposta da própria unidade escolar (ou de uma rede de escolas), em todos os níveis:

É livre a manifestação pública de pensamento e de informação, proibida toda e qualquer forma de censura. $\mathrm{O}$ ensino, a pesquisa e a extensão serão organizados e exercidos em todo o território nacional de forma a garantir, plenamente, a sua autonomia, sem quaisquer imposições ou restrições de natureza filosófica, ideológica, religiosa ou política (IBIDEM, p. 71).

Por fim, trouxe a necessidade de criação de um "órgão colegiado superior de educação", que teria como principal tarefa a indução de normas mínimas para a estrutura do ensino. Observamos que tal órgão seria uma alternativa ao CFE, amplamente criticado como espaço de interesses privatistas, na apresentação do documento. Ratificou-se muito o caráter público e permanente deste órgão, que deveria estar ligado à um "Conselho Interuniversitário", autônomo perante o Estado. Ainda zelando por mecanismos mais democráticos e livres da influência privatista, houve uma sinalização para a avaliação dos materiais didáticos adquiridos, por parte da comunidade, de forma que não se tornasse comum a compra de livros e/ou outros materiais de grupos empresariais que muito lucravam com esta parcela do mercado ${ }^{69}$.

69 Sobre esse aspecto, cabe destacar novamente um trecho da entrevista do professor Luiz Antônio Cunha, no qual ele analisa a situação atual do ensino no país, fazendo uma crítica ao material didático adotado: "É muita gente interessada... Então nenhum desses protagonistas tem a condição de determinar sozinho o rumo da escola. O futuro da escola vai ser uma resultante de forças, um polígono de forças da física. Eu preferia que não fossem os vendedores de apostilados os protagonistas. Em SP eles estão fortíssimos. Olha, o que tem de rede escolar municipal [...] um colégio católico antiquíssimo de classe média, não é nenhum nome de santo desses [...]. $\mathrm{Na}$ educação pública e privada. Está até no ensino superior". 
Na mesma linha, o documento da SBPC iniciou sua justificação com uma crítica ao processo que denominou de "comercialização" do ensino, pela omissão do Estado, que gerou a "morte cívica de gerações e gerações de brasileiros" (CÂMARA, 2017b, p. 72). Como vimos anteriormente, todos os pontos que abordavam a questão da responsabilidade na manutenção do ensino pelo Estado nas instituições públicas - que poderia ser evidenciado com o parágrafo único do artigo 12 e na proposta expressa no artigo $15^{70}$ - e a questão da laicidade, expressa nas propostas dos artigos $1^{\circ}$ e $2^{\circ}$, foram basicamente uma reprodução dos princípios apresentados na Carta de Goiânia. Já a tese defendida pela FBAPEF apenas mencionou a laicidade em seu primeiro tópico, no clássico artigo que caracterizava que a educação deveria ser "gratuita e laica", em termos gerais.

A ANPAE trouxe um documento semelhante aos seus antecessores, a respeito do qual cabe destacar uma diferença, expressa no artigo 13, no qual constava que "Os recursos orçamentários serão aplicados prioritariamente no ensino público de $1^{\circ}$ grau” (IDEM, p. 72). Neste caso, a palavra "prioritariamente" substituiu a palavra "exclusivamente", conferindo-lhe, portanto, outro caráter. Todavia, a proposta da Associação entrou um pouco em contradição, quando mais adiante, no artigo 15, afirmou que não deveria ser permitido o provimento de recursos públicos para a criação, manutenção e desenvolvimento do ensino privado, embora este ficasse sob o âmbito de fiscalização do Estado.

O documento apresentado pelo FNDEP, como vimos no subcapítulo anterior, também estava muito baseado na Carta de Goiânia. Na parte do texto que continha um relatório sobre a educação e a constituinte, criticou-se o lobby do ensino privado no país, que viria a comprometer o próprio processo de elaboração da $\mathrm{CF}$, devido ao fato de não contarmos com uma constituinte exclusiva, mas congressual. Assim sendo, destacamos o artigo $2^{\circ}$, que foi o primeiro a fazer menção à perspectiva da laicidade. Já o artigo $3^{\circ}$ proibiu toda forma de censura, em seu parágrafo único, prezando pela liberdade do pensamento e das informações, fundamentais à formação da autonomia e da criticidade, tão elementar para qualquer educação que se pretendesse democrática e progressista. $\mathrm{O}$ artigo 15 abordou de forma mais completa a questão da liberdade de coexistência entre instituições públicas e privadas, mas reafirmou a necessidade dos recursos públicos serem exclusivos à educação pública:

$\overline{70 \text { "Art. } 12}$ [...] Parágrafo único. Os recursos públicos destinados à educação serão aplicados exclusivamente nos sistemas de ensino criados e mantidos pela União, Estados e Municípios. [...] Art 15. É permitida a existência de estabelecimento de ensino privado, desde que atendam às exigências legais e não necessitem de recursos públicos para sua manutenção" (CÂMARA, 2017b, p. 72). 
Art. 15. O Estado autorizará a existência de escolas particulares, desde que não recebam verbas públicas, que estejam, segundo padrões de qualidade, e que sejam

subordinadas às normas ordenadoras da educação nacional. $\S 1^{\circ} \mathrm{A}$ existência de escolas privadas estará condicionada à observância daquelas normas, à garantia aos professores e funcionários da estabilidade no emprego, de remuneração adequada, de carreira docente e técnico funcional e da participação de alunos, professores e funcionários nos organismos de deliberação da instituição, bem como a garantia de que a instituição sustentará econômica e financeiramente o funcionamento da escola. $\S 2^{\circ}$ Cabe aos Poderes Públicos assegurar, através da fiscalização, a observância permanente dessas normas e condições, sob pena de suspensão da autorização para o funcionamento, sem prejuízo das sanções cabíveis, na forma da lei. $\S 3^{\circ}$ Os estabelecimentos de ensino privado, em funcionamento na data de promulgação deste Ato, deverão ajustar-se aos dispositivos legais ou terão sua autorização de funcionamento suspensa, na forma da lei (IBIDEM, p. 148).

No artigo $2^{\circ}$ da sessão que tratou do sistema tributário, do orçamento e das finanças, o documento do Fórum estabeleceu que "Os estabelecimentos privados de ensino não serão beneficiados por isenção fiscal de qualquer natureza, ficando sujeitos aos mesmos impostos que incidam sobre as atividades das demais empresas privadas" (IBIDEM, p. 149).

Ainda na parte do relatório, o documento apresentou a gratuidade em todos os níveis de ensino como forma de materializar a equidade das oportunidades educacionais, pois "Sem essa pedra de toque repetimos a velha dicotomia, os que podem e os que não podem, consolidando assim a divisão de classes daqueles privilegiados e não-privilegiados" (IBIDEM, p. 149). Desta forma, resgatou todos os dispositivos constitucionais para justificar a afirmação de que historicamente não houve o compromisso dos governos brasileiros com tal princípio. Foi além, afirmando que caberia ao Estado restituir toda a população pelo grande estrago que a proporcionou, com seus altos tributos, retribuindo-a sob a forma de bens materiais e culturais, como vemos no trecho seguinte:

Numa sociedade democrática os tributos devem ser geridos publicamente por um governo representativo o qual aplicará também publicamente os seus recursos em áreas consideradas prioritárias para todos os cidadãos. Na realidade, a escola dita "gratuita" acessível a todos, baseia-se no pressuposto de que todos já estão pagando proporcionalmente, via Estado, para o bem de todos e de cada um. Cada cidadão deve merecer redistribuição constante e sistemática do bem público, principalmente em setores vitais que empenham a pessoas e a sociedade por um longo tempo, como é o ensino de $2^{\circ}$ e $3^{\circ}$ graus (CÂMARA, 2017b, p. 150-151). 
Trouxe, um pouco mais adiante, a necessidade de se garantir a liberdade de ensinar e aprender, resumida na perspectiva de liberdade do pensamento, à qual já fizemos referência. Na parte do texto intitulada de "propostas alternativas", residiam alguns pontos interessantes: a questão curricular se fez presente em alguns momentos - damos destaque à proposta de substituição das disciplinas de Organização Social e Política Brasileira (OSPB) e Moral e Cívica, pelas de Sociologia e Filosofia -; a necessidade de ampliação da rede pública gratuita, incluindo uma rede de escolas supletivas - para os que a ela não tiveram acesso na idade própria. O documento do FNDEP trouxe ainda um tópico bastante específico, referente ao ensino público e gratuito, que propôs que o Estado tornasse todas as escolas estatais, radicalizando toda a discussão até então colocada. Destaca-se que não se tratava de uma estatização imediata, a partir da aprovação da nova $\mathrm{CF}$, mas de um processo anunciado e gerido de transição. Mesmo se tratando de um longo trecho, pensamos ser necessário seu destaque na íntegra:

\section{2 - Ensino Público e Gratuito}

Formar uma frente com os constituintes comprometidos com a classe trabalhadora para que se garanta na Constituição: - ensino público e gratuito para todos, em todos os níveis, inclusive o pré-escolar, com garantia de funcionamento também em horário noturno; - dotação automática de recursos para o ensino como determina a Emenda Constitucional $n^{\circ} 24$ (Emenda João Calmon), cabendo à União aplicar nunca menos de $13 \%$ e aos estados e municípios nunca menos de $25 \%$, da arrecadação tributária ao ensino público e gratuito, não incluindo escolas militares, formação de diplomatas, treinamento de funcionários de bancos etc.; criação de mecanismos de controle e fiscalização da arrecadação e aplicação das verbas destinadas à educação, com ampla participação da comunidade escolar, acadêmica, científica e das entidades de classe; - aumento gradativo do número de vagas na escola pública e gratuita até que sejam suficientes para atender toda a demanda; - fim dos subsídios para as escolas particulares; - fim do crédito educativo e das bolsas de estudos para as universidades particulares, revertendo estes recursos para aumento de vagas nas universidades públicas; - estatização das instituições de ensino de $1^{\circ}, 2^{\circ}$ e $3^{\circ}$ graus, sem indenização ou absorção das dívidas de seus proprietários; - No processo de estatização, toda verba que for repassada pelo Estado deve ser aplicada sob o controle da comunidade escolar; - regulamentação do funcionamento das escolas particulares (até que sejam estatizadas), fiscalização do seu funcionamento a partir de comissões oficializadas, amplas, formadas por sindicatos de professores, funcionários, associações de pais (nas escolas de $1^{\circ}$ grau) e entidades estudantis, a nível federal, estadual e em cada escola; - o Estado deve também garantir material escolar, uniforme, assistência médica e odontológica, alimentação, transporte ao estudante em todos os níveis; democratização do ensino de $1^{\circ}, 2^{\circ}$ e $3^{\circ}$ graus com a participação de professores, 
funcionários e alunos na escolha de Reitores e Diretores (através da eleição direta) e dos pais nas escolas de $1^{\circ}$ grau; - a edição de livros didáticos pelo poder público deve ser submetida ao controle social e democrático da comunidade dos educadores, garantindo-se a representatividade dos diferentes pontos de vista; criação de um imposto educacional aplicado junto às multinacionais de 5\% do lucro total da empresa; - aplicação anual de pelo menos $2 \%$ do PIB em pesquisa científica e tecnológica (IDEM, p. 152).

Chamamos tal proposta de radical, no sentido de buscar a eliminação de todas as formas de repasse direto e indireto de recursos públicos para as instituições privadas, e ainda por trazer à baila o sentido primeiro da educação em uma sociedade, que seria o aprimoramento do ser humano, único, que só seria possível de se formar em uma escola também única. Acreditamos, pois, que tal posição veio a acirrar os ânimos nos debates da subcomissão $8 \mathrm{a}$, da comissão 8 e da comissão de sistematização, sobretudo à medida em que elementos progressistas foram sendo agregados e aprovados, chegando a compor, mesmo que em parte, o novo texto constitucional. Para barrar tal avanço, fez-se necessária a atuação decisiva do Centrão, como veremos mais adiante.

Passemos às demais instituições que elaboraram propostas de textos à subcomissão 8a. A SEAF apontou um item que dizia respeito exclusivamente à inviabilização do mecanismo de distribuição de bolsas de estudo, de forma que as vagas escolares viessem a ser oferecidas em escolas públicas, iguais para todos. Já o CRUB, como congrega reitores de diferentes instituições, não se colocou de forma direta em sua proposta, mas sim buscando uma alternativa intermediária para a distribuição de recursos, como vemos na passagem em destaque:

Art. É assegurada a liberdade de ensino. Art. O Poder Público assegurará, sem exclusividade, ensino gratuito em todos os níveis. Art. As verbas públicas serão aplicadas exclusivamente no ensino público. Parágrafo único. Em caráter excepcional, o Poder Público poderá destinar recursos a instituições privadas que, pela sua atividade, contribuam relevantemente para a cultura, o ensino ou a pesquisa no País, na forma regulamentada por lei (IBIDEM, p. 155).

Também na parte de sua justificação das propostas, historicizou o processo de ampliação das vagas no ensino superior, no período pós 1968, trazendo o contexto do mundo e do Brasil. Afirmou ainda que a crise no modelo até então existente resultou na multiplicação de "imitações pobres de verdadeiras universidades”. Mais adiante também 
defendeu a existência de padrões que não seriam exclusivamente os universitários para o ensino superior, o que chamou de "diversificação". Desta forma, entendemos que o CRUB

defendeu o repasse de verbas para entidades filantrópicas ou confessionais, que não tinham objetivo de lucro, baseados nos seguintes aspectos, para além dos já transcritos:

\begin{abstract}
O sistema particular é altamente diversificado e compreende, ao lado das empresas de ensino, escolas de bom nível, cujos custos de instalação e manutenção foram parcialmente cobertos através de doações de entidades filantrópicas, de empresas privadas ou de comunidades confessionais [...] O que não pode se permitir é que, uma vez criadas, os custos de sua manutenção sejam repassados para o Estado, através da federalização do estabelecimento ou da exigência de subvenções vultosas e permanentes. Nesse último caso, o que ocorre é uma verdadeira apropriação privada de fundos públicos [...] e promover, por outro lado, um criterioso processo de incentivos e controles, que elimine as empresas de ensino e permita a sobrevivência daquelas escolas apoiadas em iniciativas comunitárias, confessionais ou de grupos empresariais que oferecem uma formação adequada e uma opção pedagógica válida (CÂMARA, 2017b, p. 157).
\end{abstract}

A UBES ratificou os princípios da Carta de Goiânia e do FNDEP, destacando a proposta da centralidade dos investimentos em educação serem feitos exclusivamente na rede pública “[...] pois, não é cabível o Estado transferir recursos para instituições privadas, instituições essas que se deslocam para a área da educação exatamente com o objetivo da obtenção de lucros" (IDEM, p. 160). Desta forma, avançaram na perspectiva de que as escolas profissionais que pertenciam a outros ministérios, como as militares, por exemplo, não deveriam receber recursos oriundos da educação, devido à natureza e à finalidade da formação oferecida.

Os documentos oriundos do grupo que reuniu as instituições indigenistas não modificaram as questões pertinentes à categoria aqui estudada, em relação às propostas da Carta e do FNDEP. Passemos, pois, às contribuições que contradizem as proposições até aqui colocadas. Comecemos pela ABESC. Após explicitar os caminhos para a democratização das oportunidades educacionais, afirmou o direito à liberdade como coexistência de instituições públicas e privadas, defendendo a destinação de recursos públicos para além da manutenção das escolas estatais, o que deveria abranger as instituições "[...] que pela sua atividade, contribuam relevantemente para a cultura, o ensino ou a pesquisa no País, na forma regulamentada por lei” (IBIDEM, p.200). Tratam, pois, das instituições filantrópicas e confessionais, ao que tentam ainda, por meio de dados de 1986, fazer crer que tal subsídio não implicaria na diminuição de gastos com a esfera pública, posto que seriam irrisórios. 
Os documentos das PUC de Campinas e do Rio Grande do Sul, mais uma vez, foram similares em suas proposituras: distanciaram-se das instituições superiores "comerciais", ressaltando sua vocação para o serviço público, o que se evidenciava na seguinte passagem:

[...] propõe a destinação de verbas a determinado conjunto de IES, que embora criadas e submetidas ao controle jurídico privado, volta-se expressa e efetivamente para os interesses da sociedade, deslocando a conceituação de "público" de sua feição meramente jurídico burocrática e resgatando o caráter comunitário e coletivo de seus serviços. Esses recursos, por isso mesmo, não devem ser estendidos a todo e qualquer tipo de IES particular e nem tampouco canalizados para o pagamento de dívidas financeiras, mas para a consecução de atividades ligadas ao escopo fundamental da instituição, que se submeterá aos mecanismos de controle do uso das verbas públicas e se proporá a realizar a necessária contrapartida interna ao esforço governamental (CÂMARA, 2017b, p. 202).

O CNEC, entidade comunitária, também resgatou em seu documento o viés de instituição pública não oficial. Como já apresentamos a composição do documento anteriormente, na qual o texto foi subdividido de acordo com os valores que a instituição preza, resgatamos aqui apenas o "compromisso com a liberdade", que mais se aproxima da categoria que ora analisamos. Tratava-se, pois, do compromisso cenecista com o saber, que, segundo o documento, seria a única forma de condução à liberdade.

A FENEN trouxe sua concepção de liberdade permeada pela visão do Estado como um ente que deveria servir aos interesses privados, na medida em que deveria garantir a gratuidade do ensino para qualquer pessoa desprovida de recursos, sendo que não se mencionou a escola pública como principal destinatária de tais recursos, ao contrário, qualquer escola estaria apta a recebê-los, desde que cumprisse a legislação vigente. Segundo a Federação, tal forma de financiamento viabilizaria a pluralidade, que é desejável na vida democrática. Observa-se que se associa o sentido de pluralidade ao de muitas instituições, diferentemente da perspectiva que trouxe a escola pública como local privilegiado de vivência da pluralidade, por congregar diferentes agentes em um mesmo espaço.

Ainda em seus pressupostos, o documento apresentou a educação como direito da família, dever do Estado e não como "direito do Estado criar o cidadão conforme sua vontade" (IDEM, p. 213). Justificou tal afirmação com base na ideia de que o Estado não viabiliza às famílias sua liberdade, por não lhes facultar escolhas ao estabelecer uma escola pública, igual para todos: 
Hoje, quem tem meios, embora pagando imposto e tendo direito a ensino gratuito, pode escolher uma escola batista, metodista, católica, leiga, marxista ou nazista, conforme sua preferência; ao pobre não se permite o direito de crença, de religião, de filosofia, de ideal, de opção, porque só tem - querendo ou não - a escola pública. Confunde-se gratuidade de ensino com escola oficial, que não é gratuita, porque é paga regiamente pelo imposto de todos, dela usufruindo apenas alguns (IBIDEM, p. 213).

Foi além, afirmando que os que usufruem da gratuidade sem necessitar deveriam ressarcir ao Estado. Colocou, mais a frente no texto, que a concessão de verbas a todas as instituições de ensino, indiscriminadamente, seria uma questão óbvia, de "consciência nacional", por se constituir em atividade social, para a qual, além da destinação de recursos diretos, caberia também outras fórmulas, como a imunidade tributária, já "que está poupando aos poderes públicos investir" (IBIDEM, p. 213). Ainda sobre a questão da liberdade, resgatou a importância da obrigatoriedade do ensino religioso nas escolas públicas, facultativo aos alunos - ressaltou que nas escolas particulares já o seria -, de forma, mais uma vez, a atender aos desejos das famílias. Acrescentou que o ensino desta natureza seria imprescindível à formação do ser humano, e que sua ausência se reduziria à mera instrução.

Na parte do texto destinada à formulação dos artigos, foi incluído como inciso $\mathrm{V}$ em um possível artigo $2^{\circ}$, que tratava dos princípios e normas da educação nacional, a seguinte redação: "V - é garantida a liberdade de comunicação no exercício do magistério, exceto quando constituir abuso de direito individual ou político" (CÂMARA, 2017b, p. 214). Este dispositivo versava sobre a censura parcial à liberdade dos professores no âmbito de sua prática profissional, uma vez que seria deveras subjetivo definir o que se constitui como abuso. Tal definição depende dos critérios definidos e dos avaliadores.

Passemos às proposições da AEC. A associação procurou se dissociar da imagem de escola privada e buscou se inscrever no texto constitucional como instituição pública, devido à natureza de sua atividade. Desta forma, colocou o Estado na posição de servidor da sociedade, devendo zelar pelos seus interesses. Ratificando esta posição, afirmou, pois, que "Com a mesma ênfase com que rejeitamos o monopólio estatal do ensino ou da educação, rejeitamos, igualmente, a mercantilização que subordina a educação a objetivos meramente lucrativos" (IDEM, p. 218). 
Colocou ainda como uma de suas ideias centrais o direito de todos ao ensino fundamental, associado ao direito dos pais escolherem a educação que desejam para seus filhos. Tal premissa era permeada tanto pela discussão público/privada, quanto pela discussão laico/religiosa. Como se sabe, a AEC tentou viabilizar os princípios defendidos pela CNBB no campo educacional e, assim sendo, a educação religiosa seria fundamental para materializar tais pressupostos. Esse seria o papel do artigo 10, que trouxe a necessidade de respeito à religião da família e a garantia do ensino religioso como componente curricular obrigatório nas escolas públicas.

No que se refere à liberdade como autonomia do pensamento, a AEC apresentou um tom um pouco mais progressista em relação à FENEN ao expressar, em seu artigo $9^{\circ}$, a garantia “[...] da característica democrática dos conteúdos ministrados, a participação da comunidade, o respeito à liberdade de opinião e consciência”. Todavia, ao mesmo tempo, busca-se livrar da gerência do Estado na composição de seus quadros, assim como na definição de seus currículos ao, no parágrafo único, reclamar às escolas não estatais “[...] o direito de preservar a filosofia e a proposta pedagógica próprias e, conseqüentemente, gozar de autonomia na composição de seu quadro de pessoal, respeitadas as exigências legais" (IBIDEM, p. 219).

Cabe um destaque para o fato do aspecto religioso ter se delineado como grande adversário das emendas mais progressistas. A Declaração de Florianópolis, aprovada pelo XX Congresso Nacional dos Estabelecimentos Particulares de Ensino em 1985, que se apresentava contra o monopólio da educação por parte do Estado e pela liberdade de escolha das famílias, serviu como base para uma nova e importante emenda, promovida pela CNBB, pela AEC e pela ABESC. Nela foram fundidas duas reivindicações: o ensino religioso nas escolas públicas e o direcionamento de subsídios governamentais para as instituições que não apresentassem fins lucrativos (CUNHA, 2009, p. 436).

Entretanto, a Federação Nacional dos Estabelecimentos de Ensino e o Sindicato dos Estabelecimentos de Ensino do Estado de Minas Gerais e do Município de Duque de Caxias (RJ), apresentaram uma outra emenda, aproximando a ideia de democratização das oportunidades educacionais ao pagamento de bolsas pelo governo para alunos pobres em escolas privadas (CUNHA, 2009, p. 434). É notório que os interesses particularistas se sobrepunham à necessidade de se pensar uma educação que pudesse efetivamente atender a todos. 
O texto seguinte foi da UNE. A representação estudantil se colocou em defesa do ensino público e do privado, desde que este último não recebesse subvenções do Estado. Ao historicizar o ensino superior no Brasil, apresentou a necessidade de resgate da dívida para com a educação pública, tendo em vista a tendência privatizante no setor, sobretudo a partir do período da ditadura. Colocou como forma de iniciar esse resgate, a vinculação orçamentária nos termos da emenda Calmon, assim como a garantia e o respeito à autonomia universitária.

Passaremos diretamente à análise do tex to da FITEE, pois os que os antecedem como anexo nas atas não trazem novas considerações ao debate, como exposto anteriormente. Os itens 1,2 e 3 de sua proposta são os que tocam na discussão sobre a liberdade. O primeiro, de forma geral, em consonância com todos os dispositivos já estudados - ensino público, gratuito e laico. Os outros dois contemplam a questão da liberdade de pensamento, que deve ser caracterizada pela ausência de imposições de natureza religiosa, política, entre outros aspectos; e, também sobre a autonomia universitária, temas estes já discutidos aqui.

O Conselho Federal de Farmácia, por sua vez, trouxe aspectos interessantes, que se aproximaram da Carta de Goiânia e da proposta do Fórum. Destacamos alguns pontos de seu texto, que, de forma muito objetiva, trouxeram problemas gerais e comuns na história da educação brasileira que afetaram a formação de profissionais desta área específica, mas não somente eles:

1 - O ensino público será assegurado e gratuito em todos os níveis [...] 3 - As verbas públicas para a educação deverão ser exclusivamente utilizadas na rede pública. 4 - O poder público fixará métodos para um controle mais eficaz e ostensivo sobre a rede privada de ensino. 5 - A educação compreenderá a formação global do indivíduo, não limitando-se apenas à simples instrução. 6 - A pesquisa científica e seu incentivo fará parte integrante do processo educacional. 7 - Os currículos deverão voltar-se para a identificação e solução dos problemas que afligem o povo e o País, buscando com isso seu desenvolvimento independente e o progresso científico, tecnológico e cultural. 8 - A composição dos órgãos públicos da educação deverá ter garantida a representação da comunidade educacional organizada [...]10 - Assegurar-se-á a autonomia universitária em todos os sentidos. 11 - O ensino público deverá ter caráter leigo, garantindo-se a opção pelo ensino religioso àqueles que assim o desejarem (CÂMARA, 2017b, p. 248).

Não somente reafirmaram a importância da educação pública e da necessidade da destinação exclusiva de recursos públicos à sua causa, como também solicitaram a criação de estratégias de fiscalização e controle da educação privada. Tal ideia era vista como 
"estatismo" ou "totalitarismo" por alguns setores, como já apresentamos anteriormente, nos debates da subcomissão 8a e comissão 8, assim como em documentos que analisamos. A discussão curricular se fez presente algumas vezes: ao propor uma formação integral, que não se limitasse à instrução (conforme item 5); o estímulo à pesquisa em todo período de escolarização, posto que a formação científica não era comumente valorizada em nossa tradição pedagógica; a necessidade de se pensar o currículo escolar a partir das demandas sociais, rompendo com o enciclopedismo ao qual estávamos submetidos desde a ratio studiorum.

Sobre a questão do ensino religioso vale um registro especial, porque além do documento estabelecer uma crítica, ele propôs uma alteração de sentido no que comumente era apresentado: não seria obrigatório ao Estado o oferecimento do ensino religioso, desta forma garantir-se-ia a laicidade das escolas públicas. Por outro lado, também não seria proibido que ele existisse, cabendo às famílias tal opção. Subentende-se, pois, que estas teriam que procurar escolas confessionais. Por fim, assim como os documentos no qual se inspirou, o CFF fez uma crítica velada à composição do CFE, ao propor uma renovação nos seus critérios. Sobre a liberdade de pensamento, estaria também prevista a autonomia universitária.

O conjunto de documentos dos arte-educadores apresentados anteriormente trouxe uma crítica contundente à política curricular do CFE, que desconsiderou os setores que se dedicavam ao estudo das diferentes áreas de conhecimento, propondo mudanças sem discussão prévia. Cabe um destaque para o trecho seguinte, que era um dos fundamentos que precedeu a Carta Protesto de Brasília:

[...] seja o CFE impedido de continuar sua política autocrática, com a emissão de Pareceres e Resoluções e o encaminhamento de Leis sem consulta às bases, instituições e entidades representativas dos diversos segmentos educacionais numa linha totalmente contrária ao processo de democratização que o Brasil a duras penas vem tentando implantar (IDEM, p. 250).

Por fim, antes de passar aos textos formalizados pela subcomissão $8 \mathrm{a}$, veremos os textos do CEAB e da ANPPT. Logo na parte expositiva do primeiro documento, justificouse a razão de se lutar por um currículo que contemplasse a questão do negro, uma vez que “[...] é de caráter didático, pedagógico. Não adianta apenas criminalizar o racista. É fundamental, sobretudo, impedir o surgimento do racismo! É através de um processo 
educativo que se reverte o machismo e o racismo" (IBIDEM, p. 251). Na parte dedicada às propostas de redação dos artigos, colocava a responsabilidade da educação primeiro como sendo dos pais e, em um segundo momento, como do Estado. Acreditamos que esta troca de palavras muito significou para a sobreposição das responsabilidades e para a relação entre as esferas pública/privada. Tal perspectiva se confirmaria mais adiante no texto, quando se propôs a estratégia do pagamento de bolsas de estudo por parte do Estado, como forma de ampliação das oportunidades educacionais e como materialização da liberdade de ensino:

Art. O acesso ao processo educacional é assegurado: I - pela gratuidade do
ensino público em todos os níveis; II - pela adoção de um sistema de admissão
nos estabelecimentos de ensino público que, na forma da lei, confira a candidatos
economicamente carentes, desde que habilitados, prioridade de acesso, até o limite
de $50 \%$ das vagas; III - pela expansão desta gratuidade, mediante sistema de bolsas
de estudo, sempre dentro da prova de carência econômica de seus beneficiários
[...] (CÂMARA, 2017b, p. 252).

Por fim, passemos ao texto da ANPPT. A Associação frisou muito a questão curricular, que deveria ter na categoria trabalho seu eixo de articulação, como exposto anteriormente. No que se refere especificamente ao debate aqui posto, trouxe o item 6 , no qual se apresentou favorável à exclusividade dos recursos públicos para as instituições públicas.

Ao termos um panorama das propostas oriundas das instituições que dialogaram com os constituintes na subcomissão 8a, pudemos perceber que os principais debates estavam mesmo em torno dos temas que abriram este capítulo: a relação entre educação pública/ privada e a relação entre a educação laica/religiosa, de forma preponderante; e as questões pertinentes ao currículo e à autonomia docente.

Iniciaremos neste momento a análise dos textos formalizados nos diferentes espaços por onde tramitou o capítulo da educação na ANC. Lembramos que neste momento nos dedicamos aos artigos que agregaram questões pertinentes ao debate que envolve a possibilidade de uso dos recursos públicos por instituições públicas e/ou privadas; a questão da organização curricular e, por fim, a inclusão ou não do ensino religioso na grade curricular oficial, como componente obrigatório.

O texto da fase A trouxe basicamente dois artigos que abordavam a questão da transferência de recursos para a iniciativa privada, na perspectiva da garantia da liberdade 
de escolha da família. Inicialmente, o artigo $6^{\circ}$ apresentou a liberdade do ensino como garantia de existência da iniciativa privada. Mais à frente, no artigo 15, tratou-se mais diretamente desta questão:

Art. 15. - A lei regulará a transferência de recursos públicos a instituições educacionais privadas que prestem relevantes serviços públicos. Parágrafo Único: As instituições a que se referem o caput deste artigo: a) serão organizadas por comunidades e grupos de caráter social, religioso e cultural; b) comprovarão a não distribuição de lucros, a reaplicação de eventuais excedentes em educação e apresentarão contabilidade aberta e verificável pela comunidade e pelo Poder Público (ANC, 2017a, p. 26).

Na passagem do texto pela fase $\mathrm{C}$, o artigo $6^{\circ}$ passou a ser o $7^{\circ}$ e agregou o trecho "[...] sendo proibido o repasse de verbas públicas para criação e manutenção de entidades de ensino particular" (ANC, 2017b, p. 4). O artigo 15, seu parágrafo único e as alíneas correspondentes foram suprimidos da fase final da subcomissão. Acredita-se que esta mudança seria resultado dos debates que já foram aqui recontados, assim como da pressão das instituições e do público presente nesta etapa da ANC. Ao chegar na comissão 8, fase F, os artigos 10 e 11, acabaram por trazer novamente tal redação, em uma tentativa de conciliação entre as duas posições que buscavam ser hegemônicas. Destaca-se a redação deles:

Art. 10 - O ensino é livre à iniciativa privada, que o ministrará sem ingerência do Poder Público, salvo para fins de autorização, reconhecimento e credenciamento de cursos e supervisão da qualidade. Art. 11 - É assegurada a exclusividade de utilização das verbas públicas para o ensino público.§ $1^{\circ}$ - $\mathrm{Na}$ insuficiência de ofertas na rede pública, as escolas comunitárias, filantrópicas ou confessionais poderão receber, na forma da lei, auxílio do Poder Público; $§ 2^{\circ}$ - As escolas mencionadas no parágrafo anterior merecerão o estímulo financeiro do Poder Público se: a - aprovarem finalidade não lucrativa e reaplicarem eventuais excedentes financeiros em educação; b - previrem a destinação de seu patrimônio a outra escola comunitária, filantrópica ou confessional ou ao Poder Público, no caso de encerramento de suas atividades; c - forem administradas, em regime de participação, pelos integrantes do processo educacional e pela comunidade (ANC, 2017c, p. 2).

Ao mesmo tempo em que previu a exclusividade da aplicação dos recursos públicos nas escolas públicas, propôs uma exceção, disponibilizando-os às instituições de caráter público não estatal, como tais instituições fizeram-se conhecer. Sabemos, pois, que a exceção se faria regra, devido à precariedade da oferta de vagas na rede pública de ensino 
superior. No que era pertinente à versão final da comissão 8, a redação foi modificada mais uma vez. Desta vez, ela apareceu em outros artigos: no oitavo, por dentro da discussão da vinculação constitucional, especificamente nos parágrafos quinto e sexto, com a seguinte composição:

$\S 5^{\circ}$ - As escolas comunitárias, filantrópicas ou confessionais, sem finalidades lucrativas, poderão receber, na forma da lei, verbas do poder público e de entidades públicas e da iniciativa privada. $\S 6^{\circ}$ - As escolas mencionadas no parágrafo anterior merecerão estímulo financeiro do Poder Público se: a- administradas, em regime de participação, pelos integrantes do processo educacional e pela comunidade; b- comprovarem finalidade não lucrativa e reaplicarem eventuais excedentes na Educação; c - previrem a destinação de seu patrimônio a outra escola comunitária, filantrópica ou confessional ou ao Poder Público, no caso de encerramento de suas atividades (ANC, 2017d, p.12).

$\mathrm{O}$ artigo dez apresentou a liberdade da iniciativa privada, que afirmou, inclusive, que caberia ao Estado apenas a tarefa de fiscalização das atividades das instituições de ensino da rede particular. Já o artigo onze reafirmou, por dentro do texto que versava sobre o salário-educação, a possibilidade de distribuição de recursos públicos entre as diferentes instituições, com a possibilidade de oferta de bolsas de estudo e a transferência de recursos para instituições da natureza descrita na citação acima.

Sobre esta etapa da ANC, Florestan Fernandes teceu severa crítica em um texto publicado em 1987, na Folha de São Paulo. Nele, disse que a versão que chegara à comissão de sistematização deveria ser mexida com muito cuidado, pois compatibilizava textos díspares, e que os avanços conquistados estavam ameaçados por concessões espúrias. Cabe destacar um trecho, no qual ele sinalizou os principais problemas vivenciados até ali, bem como a interferência explícita dos grupos que disputavam os recursos públicos:

As entidades representativas do ensino privado movimentaram-se no sentido de resguardar suas posições e interesses, e contam com aliados decisivos (no caso da Comissão de Educação, Ciência e Tecnologia, Família etc., uma maioria que se manteve na relação de 27 para 36 em todas as votações). Não perdemos a batalha porque o projeto e o substitutivo de Artur da Távola não chegaram à votação final. Agora, nos novos trâmites, essas forças "conservadoras" voltam à carga, atuando como grupos de interesse e como grupos de pressão. [...] Partia com a vantagem de contar com um relator serviçal, o probo senador João Calmon, que sempre foi um denodado defensor das verbas públicas para o ensino (esclareçase não para o ensino ${ }^{71}$ público, o que o exime de qualquer crítica). A escolha do relator já indicava que o PMDB e o Governo haviam "negociado" o ensino com a Igreja Católica. Todavia, na subcomissão, o páreo foi duro, porque os constituintes 
perfilhavam, sem subterfúgios, a causa do ensino público [...] A Igreja Católica contou com os constituintes engajados explícita ou dissimuladamente no reforço e ampliação de suas posições [...] Alguns desempenharam esse papel lealmente, como fica notório no caso de Sandra Cavalcanti. Outros, porém, sucumbiram à

tentação como caçadores de votos ou por espírito reacionário (o que se patenteou nas votações dos líderes evangélicos "conservadores"). [...] a Igreja Católica recorreu a uma tática direta de recrutamento de lealdades. O deputado Nelson Aguiar recebeu uma carta, escrita à mão e assinada por D. Luciano Mendes de Almeida, na qualidade de presidente da CNBB (1989, p. 120-122).

Confirmando a versão exposta acima, vemos as assinaturas dos constituintes, no Anexo I deste trabalho, que se proclamaram como o grupo majoritário, e, por sua vez, assinaram o texto do segundo substitutivo do relator, encaminhando-o à comissão de sistematização.

A versão inicial da comissão de sistematização obedeceu ao que havia sido proposto no início dos debates da comissão 8, em uma perspectiva conciliatória, com algumas alterações na redação dos textos de ambos os artigos. Neste momento, o antigo artigo 10 virou parágrafo único do atual artigo 386, que era o 11 . Na fase $\mathrm{P}$, já como artigo 247, o parágrafo único foi retirado, assim como as expressões "nas condições da lei” e "em casos excepcionais" também saíram do caput do artigo, em uma tentativa de simplificação de um debate que foi deveras polêmico.

Passemos, pois, à fase de discussão em plenário. Havia uma proposta de emenda do Centrão, que não foi aprovada, na qual o artigo 247 passaria a contar com a seguinte composição em seu parágrafo primeiro "O poder público não subvencionará o ensino privado, salvo em caso de instituições sem fins lucrativos” (ANC, 2017g, p. 140). Duas propostas de emendas substitutivas foram apresentadas, porém não lograram êxito. Uma de autoria do constituinte Bezerra de Melo (PMDB), que objetivava suprimir os incisos I e II do artigo 247, cuja redação também seria alterada: no lugar de “escolas comunitárias, confessionais ou filantrópicas" entraria "escolas privadas sem fins lucrativos, nos termos da lei" (IDEM, p. 140). Lembramos que tal constituinte tinha muito interesse na aprovação de um texto que privilegiasse a flexibilização da destinação de recursos públicos para instituições privadas, visto que dirigia uma delas. A outra emenda, de autoria do constituinte Roberto Torres (PTB) propunha uma redação diferenciada, nos seguintes termos: “As 
verbas públicas, salvo bolsas de estudo, serão destinadas às escolas públicas, podendo em casos excepcionais e na forma da lei, ser aplicadas em benefício de entidades de ensino sem fins lucrativos, devidamente cadastradas como utilidade pública" (IBIDEM, p. 140). Da mesma forma que a versão do PMDB, esta buscava atender mais diretamente aos interesses privatistas.

Ainda no que é pertinente ao caput do artigo 247, houve uma proposição de emenda modificativa, de autoria da constituinte Lídice da Mata, do PCdoB, na qual a redação passaria ser a seguinte: "As verbas públicas serão destinadas exclusivamente às escolas públicas, criadas e mantidas pelo Governo Federal, pelos Estados, Distrito Federal e Municípios" (IBIDEM, p. 140). Percebe-se um texto bem alinhado às propostas dos grupos mais à esquerda, progressistas, ou, como disse a FENEN, dos cubanos (JORNAL DO BRASIL, 1987, p. 2).

No que concerne ao inciso I do mesmo artigo, houve uma proposta do Centrão, de inclusão de um texto com a previsão de termo de cooperação entre o poder público e as instituições privadas de ensino. Cabe destacar que não foi aprovado. Por fim, mais duas propostas foram feitas ao inciso II, uma aditiva - de autoria de Saulo Queiroz (PFL) e outra modificativa, de Ruy Nedel (PMDB). A primeira previa a inclusão de um parágrafo único, com a seguinte formulação:

O estudante de nível superior, comprovadamente carente, demonstrando efetivo aproveitamento, terá direito à gratuidade de ensino, quando matriculado em escola particular, ressarcindo o Estado os valores correspondentes, nos termos em que a lei dispuser (ANC, 2017g, p. 141).

Tratava-se, mais uma vez, de tentativa de transferência de recursos públicos, sob a forma de bolsa de estudos. Já a segunda emenda buscava alterar a redação do referido inciso, no qual a destinação do patrimônio foi substituída pela "[...] dedução de custos e estudantes, bibliotecas e/ou museus" (IDEM, p. 141).

$A$ versão da fase $\mathrm{V}$ foi a mesma que constou no texto publicado ao final de todo processo, salvo uma pequena diferença na numeração dos artigos. Sob o caput do artigo 209, o ensino foi apresentado como livre à iniciativa privada, porém, com dois condicionantes: o cumprimento das normas da educação nacional e a autorização e avaliação por parte dos poderes públicos. O artigo 213 manteve o espírito das últimas versões que lhe precederam, 
com uma redação um pouco diferenciada, como vemos a seguir:

Art. 213. Os recursos públicos serão destinados às escolas públicas, podendo ser dirigidos a escolas comunitárias, confessionais ou filantrópicas, definidas em lei, que: I - comprovem finalidade não lucrativa e apliquem seus excedentes financeiros em educação; II - assegurem a destinação de seu patrimônio a outra escola comunitária, filantrópica ou confessional, ou ao Poder Público, no caso de encerramento de suas atividades. $\S 1^{\circ}$ Os recursos de que trata este artigo poderão ser destinados a bolsas de estudo para o ensino fundamental e médio, na forma da lei, para os que demonstrarem insuficiência de recursos, quando houver falta de vagas e cursos regulares da rede pública na localidade da residência do educando, ficando o Poder Público obrigado a investir prioritariamente na expansão de sua rede na localidade. $\S 2^{\circ}$ As atividades universitárias de pesquisa e extensão poderão receber apoio financeiro do poder público (ANC, 2017i, p. 2).

Observa-se que a formulação dos parágrafos abria precedentes para a remuneração de atividades de instituições privadas de uma forma geral, visto que passou a existir uma exceção, devido à carência de instituições públicas na proximidade. Desta forma, os dois setores que defendiam a não exclusividade da aplicação dos recursos públicos na escola pública saíram vencedores nesta disputa, daí a crítica de alguns parlamentares ao produto que se originou dos debates da ANC. Destacamos a seguinte, do constituinte Florestan Fernandes (1989, p. 273):

Os vários poderes constituídos sufocaram o processo constituinte e reduziram seu espaço criativo, acompanhando pari passu a evolução dos vários estratos das classes dominantes [...] Os constituintes "liberais" e "conservadores" vergaram sob essa pressão, deixando o centro mais firme ao desamparo e combatendo-o através da estimatização ideológica, identificando-o com a esquerda e com o radicalismo extremado. Apesar disso, o processo caminhou com oscilações, até a Comissão de Sistematização. Daí em diante, a direita e a ultradireita inventaram as fórmulas pelas quais se saltaria de uma constituição avançada" para uma "constituição feita na marra".

O segundo tópico que analisaremos neste subcapítulo faz referência à questão curricular, de uma forma mais ampla. Iniciamos no texto da fase A, com os artigos $4^{\circ}$ e 14 . Como vimos anteriormente, o artigo $4^{\circ}$ - que abordava a língua portuguesa como o padrão do ensino a ser ministrado no nível fundamental, garantindo-se a especificidade dos grupos indígenas - não sofreu muitas alterações, a não ser por ter sido incluído como parágrafo do artigo 243, já na fase $\mathrm{P}$, com a seguinte redação:

Art. 243. A lei fixará conteúdo mínimo para o ensino fundamental, de maneira a assegurar a formação comum e o respeito aos valores culturais e artísticos e às especificidades regionais. $\S 1^{\circ} \mathrm{O}$ ensino, em qualquer nível, será ministrado na língua portuguesa, assegurado às comunidades indígenas o uso também de suas 
línguas maternas e processos próprios de aprendizagem. $\S 2^{\circ} \mathrm{O}$ ensino religioso, de matricula facultativa, constituirá disciplina dos horários normais das escolas públicas de ensino fundamental (ANC, 2017f, p. 8).

Este artigo passou a reunir em si tanto a questão da língua quanto a questão do ensino religioso, que veremos adiante. Todavia, o conteúdo não foi alterado, somente a localização no texto constituinte. Ressalta-se que na fase Q propôs-se pelo Centrão a alteração na ordem dos parágrafos, que foi aprovada e que também passou ao texto final, sob o número 209.

No que concerne ao artigo 14, o mesmo versava sobre a concessão de incentivos fiscais para o desenvolvimento da educação, da cultura, da ciência e da pesquisa. Tal orientação não permaneceu na fase $\mathrm{C}$, que passou a contar com um novo artigo $5^{\circ}$, que buscava agregar a discussão curricular, como transcrevemos abaixo:

Art. 5 . Lei complementar fixará o conteúdo mínimo obrigatório para o ensino fundamental, no qual se assegure a formação essencial comum e o respeito aos valores culturais e regionais, nela se prevendo a importância pedagógica do ensino intelectual, da educação física, da aprendizagem do trabalho, do lazer e da cultura (ANC, 2017b, p. 4).

Ressalta-se que os incentivos fiscais foram suprimidos desta versão, assim como a perspectiva de uma política curricular ficou mais evidente. Na fase F, a mesma formulação permaneceu, exceto pelo fato da expressão "conteúdo mínimo" dar lugar à "conteúdo básico". Uma alteração significativa se processou na fase $\mathrm{H}$, na qual a prerrogativa de uma lei complementar organizar a questão curricular cedeu espaço à organização da escola, em uma clara investida dos grupos privatistas para se libertarem da gerência estatal. Desta forma, além de passar à escola tal tarefa, ainda trouxe a figura dos conselhos, órgãos historicamente hegemonizados por representantes das grandes instituições privadas, como podemos destacar: "A escola fixará os conteúdos mínimos, respeitada, se a lei assim o determinar, a orientação dos conselhos de educação" (ANC, 2017d, p.11).

A fase I trouxe parte da redação anterior à fase $\mathrm{H}$, de forma mais sucinta. Desta forma, o artigo 381 tratou da fixação de conteúdo mínimo no ensino fundamental "que assegurem a formação comum e o respeito aos valores culturais e artísticos e suas especificidades regionais"(ANC, 2017e, p. 43). Como vimos nos parágrafos anteriores, este artigo, ao 
avançar para a fase P com o número 243, passou a abrigar a discussão sobre a língua e o ensino religioso, não sendo seu caput alterado nas versões subsequentes.

Por fim, passemos ao ensino religioso nas propostas que tramitaram na ANC. Assunto arenoso, que assim como a destinação dos recursos ocupou muito tempo nos debates ocorridos nos diferentes espaços. Aparece primeiramente como o artigo $5^{\circ}$, com a seguinte redação: "O ensino religioso, como parte da educação integral, constituirá disciplina de matricula facultativa, nas escolas oficiais de ensino fundamental e médio" (ANC, 2017a, p. 25). Podemos dizer que não houve mudança significativa na passagem para a fase $C$ onde passou a ser o artigo $6^{\circ}$-, exceto pelo fato de se retirar todo trecho que sucedeu a palavra "oficial". Ao chegar na comissão 8 , tal artigo passou a ser o parágrafo único do texto que contemplava a questão curricular, de forma bastante simplificada, como se pode ver: "O ensino religioso, sem distinção de credo, constituirá disciplina facultativa" (ANC, 2017c, p. 2). Com a obrigatoriedade do ensino mencionada no caput do artigo, de forma mais geral, trouxe a perspectiva ecumênica, posto que não tratava de ensino confessional, facultando-se ao aluno a escolha de frequentá-lo ou não. Com a mesma redação seguiu à comissão de sistematização, ressaltando-se a alteração no caput que evidenciamos anteriormente, quando analisamos os currículos. O mesmo ocorreu com as fases I e P, nos quais as mudanças se deram na lógica já explicitada. É importante trazer a fase $Q$, pois que apresentou uma proposta de emenda supressiva de autoria de Afonso Arinos, que solicitava a exclusão de todo o parágrafo segundo do artigo 243, não tendo sido aprovada. Apesar de se constituir como um tema árido nos debates, não houve problemas na aprovação deste artigo, uma vez que ele não deixou de fazer parte de nenhuma das versões do texto constitucional. Isso mostra o quanto o lobby das escolas católicas foi importante neste momento, sendo a eles agregado os representantes das demais religiões e, inclusive, os constituintes mais conservadores.

Desta forma, em uma tentativa de avaliação mais ampla sobre a destinação dos recursos públicos, como afirmamos anteriormente, prevaleceu a versão das alas conservadoras da política nacional, que se manifestou oficialmente na discussão educacional desde a década de 1940, quando se iniciaram os debates da primeira LDBEN. Não houve, pois, a garantia do uso dos recursos públicos exclusivamente para os estabelecimentos oficiais de ensino, conforme a muito reclamavam os setores mais progressistas da sociedade, tampouco do Estado laico, sem a obrigatoriedade do ensino religioso ser ministrado nas escolas públicas. 
Os debates problematizados ao longo do terceiro e quarto capítulos evidenciaram os conflitos que já disputavam espaço na sociedade brasileira a muitas décadas, e aqui intentamos trazer um pouco do recorte que dizia respeito ao campo educacional. A importância deste dentre os demais campos é notória, posto que a fala do presidente Ulysses Guimarães no encerramento de todo o processo, mais uma vez o evidencia, como vemos na transcrição do áudio constante nos anais da ANC:

É só cidadão quem ganha justo e suficiente salário; lê e escreve, mora, tem hospital e remédio; lazer quando descansam. Num país de trinta milhões, quatrocentos e um mil analfabetos, afrontosos $25 \%$ da população, cabe advertir: a cidadania começa com o alfabeto. 


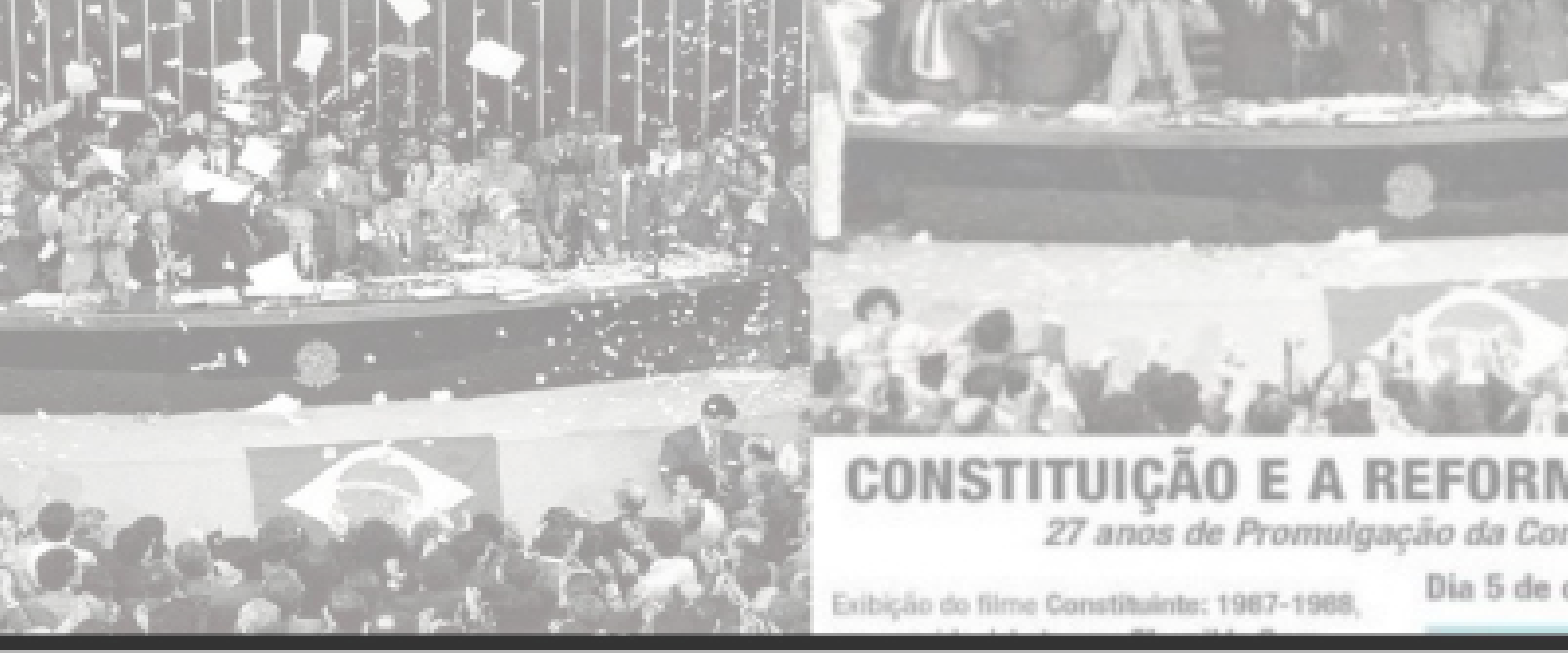

\section{CONSIDERAÇÕES FINAIS}

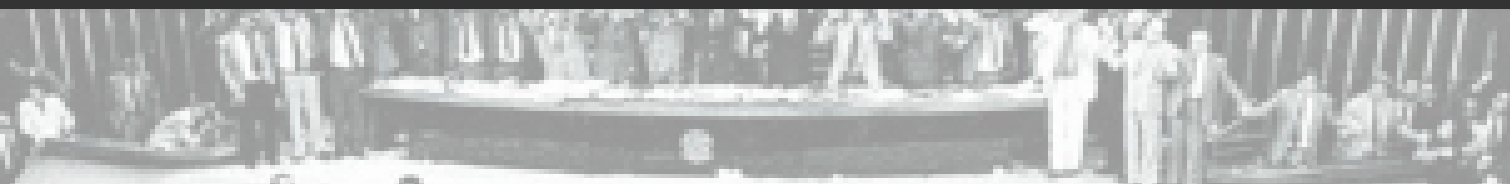

a)

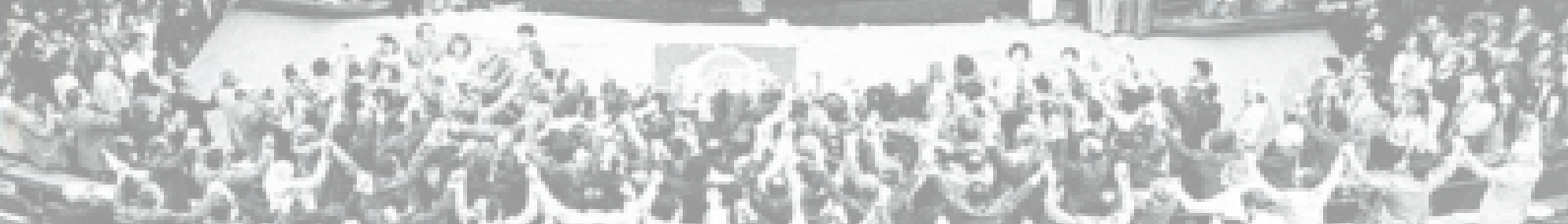

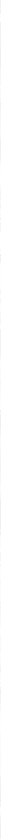


Concluir um estudo que tem o campo educacional como objeto é, no mínimo, pretensa ousadia. Em virtude dos fatos apresentados nesta tese, buscaremos, neste momento, articular algumas reflexões que nos auxiliem a sistematizar a discussão sobre o direito à educação na história brasileira, assim como as disputas travadas no campo político, especificamente no que é concernente à Assembleia Nacional Constituinte de 1987-1988. Desta forma, além da síntese proposta, acreditamos ser relevante indicar alguns paralelos entre as vivências do período em pauta com os dias atuais, tendo em vista a complexidade e os desafios do tempo presente.

Ainda na introdução do texto, resgatamos alguns conceitos basilares à pesquisa a ser empreendida. Tais conceitos seriam o substrato capaz de conferir corporeidade aos debates que alimentaram o período estudado, além de nos fornecer as lentes para que pudéssemos olhar o recorte da realidade escolhido, para, posteriormente, aprofundá-lo. Desta forma, entender a educação a partir da concepção de Anísio Teixeira, Dermeval Saviani, por exemplo, é resgatar a perspectiva que envolve o contínuo processo de humanização do ser humano, que é histórico e, consequentemente, diferente, devido às marcas da cultura e do período sobre cada um. O próprio conceito de história assume, portanto, novos contornos, na medida em que não se esgota na percepção do passado como fonte de saber, mas, sobretudo, na interlocução contínua deste passado com o tempo presente, marcando-o e reestruturando suas relações.

Tendo a dialética como forma de apreensão da realidade, tomamos a ANC como espaço no qual os conflitos sociais se evidenciaram e produziram as condições objetivas e subjetivas para a elaboração de um novo texto constitucional. A tarefa tornou-se ainda mais complexa ao sermos colocados diante de interlocutores que viveram o momento estudado, $\mathrm{o}$ que permitiu um confronto entre as possíveis e diferentes leituras que uma mesma situação poderia ter, posto que dependente das disputas ideológicas entre os grupos que buscavam a hegemonia no campo político, assim como do lugar que tais grupos ou agentes ocupavam na dinâmica da vida em sociedade. No caso específico deste trabalho, das vinculações que cada constituinte possuía com grupos, associações, partidos, formando lobbies que tinham interesse na concepção de um determinado tipo de homem e que, portanto, viam na definição da política educacional do país, expressa em sua carta magna, uma forma de manter seu status quo. Para tanto, sustentavam uma perspectiva de direito à educação que 
se aproximava da defesa da democratização das oportunidades educacionais e da liberdade de ensino em um caminho mais progressista, ou à esquerda; ou em uma vertente mais conservadora (à direita).

A compreensão do campo político como espaço no qual os agentes que dele fazem parte reforçam sua autoridade por meio do reconhecimento do seu próprio discurso e na identificação dele com o de outros pares, e também como lugar de disputa por posições hegemônicas, que visam angariar o consenso por meio da modificação das representações do público alcançado por estes agentes, que objetivam, em última instância, a modificação (ou a manutenção) da realidade social, ajudou-nos a perceber as nuances das posições ocupadas por cada constituinte, assim como as defesas e propostas que fizeram em cada etapa do processo. É importante destacar a ideia de disposição dos agentes no campo, uma vez que tal análise confere um diferencial à obra bourdiesiana, na medida em que podemos perceber que, sobretudo na questão política, nada simplesmente é; está. As articulações, os interesses necessários a cada momento podem movimentar os agentes no campo: um bom exemplo é a modificação que percebemos na postura adotada pelo constituinte Artur da Távola, na passagem dos trabalhos na comissão 8 - da qual foi relator - para a comissão de sistematização, onde assumiu uma postura mais combativa, em defesa de uma visão mais radical da matéria educacional a ser aprovada na nova CF. Neste sentido, concordamos com Bourdieu (1981, p. 69) quando afirma que "L'action proprement politique est possible parce que les agents, qui font partie du monde social, ont une connaissance (plus ou moins adéquate) de ce monde et que l'on peut agir sur le monde social en agissant sur leur connaissance de ce monde ${ }^{72}$ ".

Antes de aprofundar as conclusões da dinâmica do processo constituinte, que foram realizadas por meio de três principais vieses - levantamento bibliográfico; análise documental, por meio da leitura de fontes primárias, ou seja, das atas pertinentes às etapas do processo constituinte e das diferentes versões que o texto constitucional assumiu nas diferentes etapas pelas quais passou; e entrevistas, realizadas com intelectuais e constituintes envolvidos com a elaboração do texto de 1988 - retomaremos algumas questões dos capítulos precedentes. Passando brevemente pela difícil construção da ideia de educação

72 Tradução: “A ação propriamente política é possível porque os agentes, que fazem parte do mundo social, têm um conhecimento (mais ou menos adequado) deste mundo e que podemos agir no mundo social, agindo em seu conhecimento deste mundo". 
como direito nos séculos XVII e XVIII, chegando ao Brasil dos anos de 1930, traçamos um panorama que serviu como pano de fundo para o entendimento de um dos principais embates do campo educacional que resgatamos nesta tese. Apesar das muitas mudanças observadas no país a partir deste período, não logramos rápido êxito na consolidação da escola pública gratuita e de qualidade para todos, tendo ainda um sistema educacional dual, composto por escolas que abrigavam uma pequena elite e escolas para a população em geral, e, ainda, um grande efetivo que nem a este espaço conseguia chegar. A redemocratização do país nos permitiu imaginar uma outra estrutura educacional possível de ser elaborada, por meio de uma ANC que viesse a se comprometer com a ampliação dos direitos sociais.

O primeiro componente da ANC que nos chamou a atenção foi a primazia de dois partidos na composição das subcomissões e comissões, sobretudo nos locais de destaque, como a presidência e a relatoria de tais espaços. Praticamente hegemonizaram estes lugares o PMDB - partido da situação, complexo, que abrigava três outros partidos em si, sendo que um deles promovia ampla defesa das instituições privadas e confessionais - e o PFL, que abrigava dissidentes do PDS, e carregava a defesa dos setores católico e liberal. Outros partidos se mostraram bastante comprometidos com a elaboração de um texto que desse voz às populações comumente excluídas das preocupações governamentais e, por conseguinte, das políticas públicas formuladas. Foram eles: PT, PCdoB, PCB, PDT e o constituinte Sólon Borges, do PTB, que fez parte de todas as arenas que estudamos neste trabalho. Cabe ressaltar que os partidos abrigam pessoas e que, portanto, as pessoas são diferentes, assim como as posições que acabam por assumir. Desta forma, pudemos perceber que um mesmo partido apresentou posições contrárias em diferentes momentos, sendo o caso do constituinte Pedro Canedo, do PFL, emblemático, posto que acabou por ser afastado da comissão 8 , devido sua defesa da destinação exclusiva de recursos públicos à escola pública, gratuita e laica. As entrevistas realizadas com os constituintes que participaram como deputados da ANC - Paulo Ramos e Arolde de Oliveira - confirmaram muitas das afirmações aqui feitas, seja pela postura que adotaram em algumas votações, ou mesmo pelo conteúdo das respostas que deram às perguntas, nas quais rememoraram a recente história que ajudaram a construir.

As entrevistas semiestruturadas objetivaram averiguar fatos, opiniões, sentimentos, planos de ação, condutas atuais ou mesmo as do passado, de forma a nos oferecer pistas 
para a reconstrução da história que os documentos sozinhos não são capazes de fazer. A memória, ferramenta fundamental para possibilitar o encaixe de informações que muitas vezes não conseguimos organizar, traz o protagonismo dos agentes ao processo de elaboração das leis, que nos faz lembrar o poeta Carlos Drummond de Andrade no poema Nosso tempo: “Os homens pedem carne. Fogo. Sapatos. As leis não bastam. Os lírios não nascem da lei. Meu nome é tumulto, e escreve-se na pedra. Visito os fatos, não te encontro. Onde te ocultas, precária síntese, penhor de meu sono, luz dormindo acesa na varanda?".

Conjuntamente às entrevistas, analisamos os documentos já apresentados anteriormente. Como produções que não são neutras, nem tampouco ingênuas, trazem a público diferentes modos de interpretação do vivido por um determinado grupo de pessoas, que nos são contemporâneas. Esses interlocutores nos possibilitaram melhor compreender a complexa trama que se estabeleceu nas etapas e fases em que o texto constitucional caminhou e foi aprovado, bem como as nuances que fizeram uma ou outra palavra sair ou permanecer na redação dos artigos, alinhavando concepções e sentidos do que se convencionou chamar de direito à educação no Brasil do final dos anos de 1980.

A análise das atas no terceiro capítulo nos permitiu elaborar uma espécie de mapeamento dos espaços estudados na ANC. Desta forma, alinhamos a postura dos constituintes que mais se pronunciaram naquelas arenas, de forma que pudéssemos perceber em que sentido se direcionava sua atuação e a defesa que faziam de uma perspectiva ou outra de direito à educação.

$\mathrm{Na}$ subcomissão $8 \mathrm{a}$, local em que os debates foram mais longos, posto que contemplaram a participação de diferentes setores da sociedade civil organizada, abrigando a fala e o posicionamento de diversas instituições, dividimos nossa análise nas propostas mais à esquerda, ou seja, que se aproximavam da defesa da escola pública, laica e gratuita, cujos recursos provenientes do Estado lhe fossem exclusivos; e à direita, que entendiam a liberdade de ensino como a possibilidade das famílias escolherem a escola na qual matriculariam seus filhos, preferencialmente com os recursos do Estado para custeá-la, por meio de bolsas de estudo. Nesse campo ainda se defendia o ensino religioso como parte da educação integral, dentre outras questões. Consideramos ainda os constituintes e instituições que se colocaram mais ao centro, posto que admitiam a transferência de recursos públicos para escolas confessionais e filantrópicas, e ainda consignavam a perspectiva do 
ensino religioso como importante à formação integral, desde que a frequência às aulas fosse facultativa aos alunos. Os partidos mais expressivos da ANC mostraram-se divididos neste momento, confirmando a perspectiva apontada anteriormente, da existência de ao menos três frações do PMDB. No que se refere à postura dos constituintes do PFL, apenas pendeu à esquerda Pedro Canedo. Os representantes do PL e PDS adotaram defesas à direita; os do PT estiveram sempre mais à esquerda, assim como Sólon Borges, do PTB. Os dois constituintes do PDT tiveram posturas distintas, sobretudo devido à defesa da esfera religiosa feita por João de Deus.

No que se refere às instituições ouvidas, a maior parte delas apresentou propostas mais progressistas, alinhadas à defesa da escola pública, gratuita e laica, para todos, em todos os níveis. Apenas as instituições que estavam ligadas aos grupos religiosos, com primazia do setor católico; e também a FENEN, que abrigava as instituições privadas de ensino,

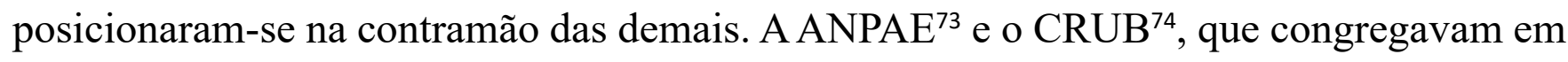
suas fileiras tanto instituições públicas quanto privadas, mantiveram-se ao centro. Com base nas análises realizadas e também com a leitura de diferentes comentaristas, observamos que o produto oriundo deste momento de debates foi um texto mais avançado (Fase C), que foi devidamente estudado no quarto capítulo.

Ao passarmos para a análise da comissão 8, percebemos que o cenário até então colocado se complexificou. Para além deste espaço contar com a participação de um maior número de constituintes, aglutinou temas que trouxeram debates também inconclusos das outras subcomissões para serem aqui resolvidos - destaca-se a questão da comunicação, por exemplo. Como na subcomissão 8a, o PMDB se encontrou dividido nas três posições já apresentadas; o PFL manteve-se à direita do processo, agora com a participação de um maior número de constituintes envolvidos nos debates, inclusive um dos nossos entrevistados, o deputado Arolde de Oliveira. Mais uma vez Pedro Canedo se manteve à

$73 \quad$ Segundo o estatuto da ANPAE (2018, p. 2-3): “Art. $5^{\circ} \mathrm{O}$ quadro associativo [...] é integrado pelos seguintes grupos de referência: I - pesquisadores, docentes e dirigentes de educação superior; II - dirigentes e técnicos dos sistemas educacionais; III - professores e diretores de educação básica e de instituições congêneres; IV - estudantes de cursos de graduação e pós-graduação; $\mathrm{V}$ - profissionais de outras áreas do conhecimento e da atividade humana, interessados ou engajados no objeto de estudo e campo de atuação da Associação".

$74 \quad$ Segundo o estatuto do CRUB (2018, p. 3): “Art. $4^{\circ}$ Constituem o CRUB: I - como associados efetivos, as universidades e os centros universitários brasileiros, atendido o disposto no art. $5^{\circ}$, representados por seus reitores ou por seu substituto legal, segundo estabelecido no Estatuto da respectiva instituição universitária; II - como associados honorários, os ex-reitores que tiverem integrado o CRUB e dele desejarem participar, devendo sua admissão ser aprovada pelo Conselho Deliberativo". 
esquerda, contrapondo claramente a orientação de seu partido, sendo devidamente punido por tal atitude, como já mencionamos acima. A posição do PT foi à esquerda, assim como a do PCdoB e da ampla maioria do PDT. Cabe destacar que, como havia um número maior de constituintes com posturas conservadoras, a estratégia adotada pela esquerda foi de inviabilizar o processo de votação neste espaço, para que a comissão de sistematização pudesse recompor os textos anteriores e produzir sua síntese. Cabe ressaltar que tal estratégia se ancorou no perfil da comissão 9, que, como vimos no início do terceiro capítulo, tinha um contorno mais "avançado", posto que escolhida por Mário Covas, líder do PMDB à época, para que a Constituição produzida pudesse incorporar avanços nas diferentes áreas. Foi então encaminhado, com a assinatura dos constituintes que se sentiram lesados com a falta de votação e de produção de um texto da comissão 8 , o texto da fase $\mathrm{H}$, que reconstituiu o segundo substitutivo do relator, que, por sua vez, incorporou demandas caras ao setor privatista e, sobretudo, às escolas confessionais e filantrópicas.

Na comissão de sistematização percebemos a influência de parlamentares mais à esquerda, como vimos na distribuição do Quadro III, também no terceiro capítulo. Cabe ressaltar que o texto da Fase $\mathrm{P}$, que seguiu para o plenário, conciliou a questão da destinação dos recursos públicos, que deveria ser para manutenção das escolas públicas, mas que também permitia que instituições que comprovassem finalidade não lucrativa viessem a se beneficiar dos mesmos. No que se refere ao ensino religioso, outro ponto nevrálgico, trouxe a obrigatoriedade da disciplina, mas a matrícula facultativa aos alunos. Desta forma, percebemos que muito pouco da matéria educacional foi alterada pelo Centrão nas negociações que ocorreram na etapa posterior, ou seja, no plenário, embora algumas propostas neste sentido tenham sido encaminhadas, como vimos no quarto capítulo.

De uma forma bem geral, concluímos que o produto final, a Constituição aprovada em outubro de 1988, embora não tenha sido tão progressista quanto sua primeira versão sinalizou que poderia ser, incorporou algumas demandas caras aos movimentos, instituições e partidos que reclamavam por uma educação pública e gratuita em todos os níveis. Apesar da obrigatoriedade (tema identificado com a categoria democratização das oportunidades educacionais) ter sido restringida apenas à idade do ensino fundamental regular - à época dos 7 aos 14 anos, que veio a ser ampliada em um ano em 2006 e, posteriormente, para a 
faixa etária que vai dos 4 aos 17 anos de idade, abrangendo a educação básica, com exceção da creche - o texto original já contemplava a necessidade de ampliação de tal preceito, incluindo, inclusive, os jovens e adultos que a ela não tiveram acesso na idade regular. A vinculação constitucional do orçamento destinado à educação também foi um ganho significativo, assim como o fato dos constituintes não terem definido uma porcentagem específica para aplicação no ensino fundamental, como era desejado por alguns, já que acreditavam que o ensino superior consumia mais recursos do que devia; o que gerava a defesa, inclusive, da necessidade deste nível de ensino não ser alcançado pela gratuidade.

A questão da laicidade da escola pública, identificada com a categoria liberdade de ensino, ficou a desejar, posto que mesmo sendo o ensino religioso de matrícula facultativa, delegar à escola pública a tarefa de trazer a religião como disciplina obrigatória fere a separação entre as esferas pública e privada, tão necessária à configuração do Estado democrático.

Assim sendo, percebemos que os grandes nós da educação brasileira, em pauta desde os anos de 1930, não foram realmente desfeitos, posto que a influência dos grupos conservadores, sobretudo dos empresários da educação e dos grupos ligados à Igreja católica, fez-se presente em todas as etapas do processo constituinte, logrando êxito em pautas relevantes, como a destinação dos recursos públicos e a da laicidade, como vimos acima. Diante desta constatação, lembramos da tese defendida por Dermeval Saviani (2008, p. 5) - já apresentada no início deste texto, mas que cabe relembrar - quando estudou a influência do Congresso Nacional na legislação pertinente ao ensino e destacou que as estratégias adotadas

[...] reduzem-se a quatro modalidades que são as seguintes: "conciliação", "autoritarismo desmobilizador", "autoritarismo mobilizador" e "liberalismo". Entre elas destaca-se a "conciliação", que vem se revezando no poder com o "autoritarismo desmobilizador", reduzindo-se o "autoritarismo mobilizador" a débeis ensaios episódicos, enquanto o "liberalismo" geralmente não tem ultrapassado o plano dos "valores proclamados".

Desta forma, para além das categorias acima citadas, o autor trouxe ao debate também a ideia de "democracia restrita" e "democracia excludente", para exemplificar as estratégias de sustentação da política brasileira. Posto isso, entendendo que apenas uma parcela da 
sociedade realmente seria chamada à participação, ratificando a exclusão sistemática de amplos setores do debate, podemos dizer que tais análises não se distanciam do caso da ANC de 1987-1988. Este processo teve início com a ampla participação da sociedade civil nas subcomissões; estreitou-se na fase das comissões, passando a contemplar debates setorizados e a troca de influências, por meio da formação de lobbies; passou aos acordos detalhados pelo relator da comissão de sistematização, numa clara demonstração de quem efetivamente define os rumos da política brasileira; e desaguou, por fim, na manobra em defesa dos interesses representados por alguns parlamentares e, sob a supervisão do presidente José Sarney. Formou-se o Centrão, que viabilizou a mudança no processo de votação previamente definido no regimento da $\mathrm{ANC}$, que veio a mudar os rumos desse documento.

Cabe, inclusive, a problematização do conceito de sociedade civil aplicado ao caso brasileiro. Virgínia Fontes (2006) faz um estudo, com base na perspectiva gramsciana, no qual resgata as lutas sociais e teóricas na década de 1980. Desta forma, aborda a complexidade da estruturação e atuação das esferas públicas e privadas na realidade brasileira, destacando a multiplicidade dos movimentos sociais que resistiram à ditadura de 1964, assim como os novos agentes que começam a surgir ao longo do processo de democratização - como as ONG, por exemplo. Destaca a heterogeneidade e a atuação do empresariado brasileiro, especificamente no período que abrange nosso estudo, afirmando que

Suas entidades, corporativas ou associativas (aparelhos privados de hegemonia), foram especialmente agressivas ao longo do processo constituinte (entre $1985 \mathrm{e}$ 1988), tanto no sentido de reafirmar o seu papel quanto no de impedir (ou reduzir) as conquistas de cunho universalizante no âmbito da nova Constituição, na qual o "antiestatismo funcionou como proposta aglutinadora do empresariado e dos conservadores" (IDEM, p. 226).

Coutinho (2006, p.183) ao analisar a gênese do Estado brasileiro também reafirma que este sempre esteve a serviço de interesses privados, devido às suas fortes características patrimonialistas que vieram a redundar em práticas de clientelismo, corrupção, nepotismo, entre outros males que persistem ainda nos dias atuais. Jessé Souza (2016, p. 39) faz uma crítica a esta análise que, segundo ele, é resultante da assimilação do mito freyreano da 
cultura da mistura do povo brasileiro por Sérgio Buarque de Holanda, que, por sua vez, produziu uma versão oficial da nossa sociedade, na qual

A pecha do Estado patrimonial - e, portanto, corrupto - serve para dois propósitos básicos: tornar invisível a corrupção legal e ilegal no mercado dominado pela elite do dinheiro e permitir a deslegitimação de todo governo comprometido com o uso do orçamento público para a maioria da população.

Assim, todo o debate que vimos na ANC contra a "estatização da escola pública", materializado nas propostas das famílias terem liberdade na escolha da escola na qual matricular seus filhos, visto que o recurso público é de todos, encontrou muito eco devido à própria origem de nossa formação enquanto Estado, assim como na percepção que temos dos papéis que este deve assumir para com seus cidadãos. Como não tivemos estruturado o Estado de bem-estar social, acabamos por ter políticas sociais muito frágeis, que sempre estiveram tensionadas entre os interesses da elite e da população em geral, ou, como prefere Jessé Souza (2011), da ralé.

Este ano a Constituição faz trinta anos. Ela ainda carrega em si todos os sonhos e expectativas nela depositados? Ainda defende os direitos sociais com toda a força que desejávamos? Nós ainda desejamos? Nós, quem? Mais do que respostas, a tese nos apresentou novos questionamentos. Diante de um novo golpe, desta vez empresarialmidiático-jurídico ${ }^{75}$, o ano de 2016 e o de 2017 trouxeram antigas reflexões à tona, embrulhadas em nova roupagem.

\section{SOMBRIAS PERSPECTIVAS DIANTE DO ATAQUE À DEMOCRACIA E À CONSTITUIÇÃO}

Sem entrar no mérito dos governos dos presidentes Lula e Dilma - que abrangeu o período de 2003 à 2016 - percebemos que houve um processo significativo de inclusão

$75 \quad$ Baseamo-nos em alguns autores e obras para fazermos tal afirmação, dentre eles Jessé Souza na obra "A radiografia do golpe" (2016), na qual ele explica o papel de cada um destes elementos na estruturação do golpe que promoveu o impeachment da Presidenta Dilma. Destacamos o seguinte trecho, no qual tal perspectiva é evidenciada: "A articulação entre mídia - como braço dos endinheirados que cuida da violência simbólica -, comandando e estimulando as manifestações de rua da fração mais conservadora da classe média, e a facção mais conservadora e corporativa da casta jurídica formou a linha de frente do golpe reacionário" (2016, p. 122-123). Em outro momento, está a seguinte afirmação: "A elite financeira, a mídia - sob comando da TV Globo-, o parlamento comprado e a casta jurídica se unem e decretam o fim do governo eleito" (IDEM, p. 131). Valemo-nos ainda da leitura do livro organizado pela Editora Boitempo, intitulado "Por que gritamos golpe?" (2016) - especificamente do texto do Marcelo Samer (2016, p. 109), no qual ele afirma que "Em um golpe sem armas, sem tanques ou baionetas, judiciário e imprensa são de fato os principais instrumentos de legitimação" -, e da obra "A boa política. Ensaios sobre a democracia na Era da Internet”, de Renato Janine Ribeiro (2017). 
social, mudando, inclusive o tradicional gráfico da "pirâmide" de distribuição de classes sociais, para um "losango":
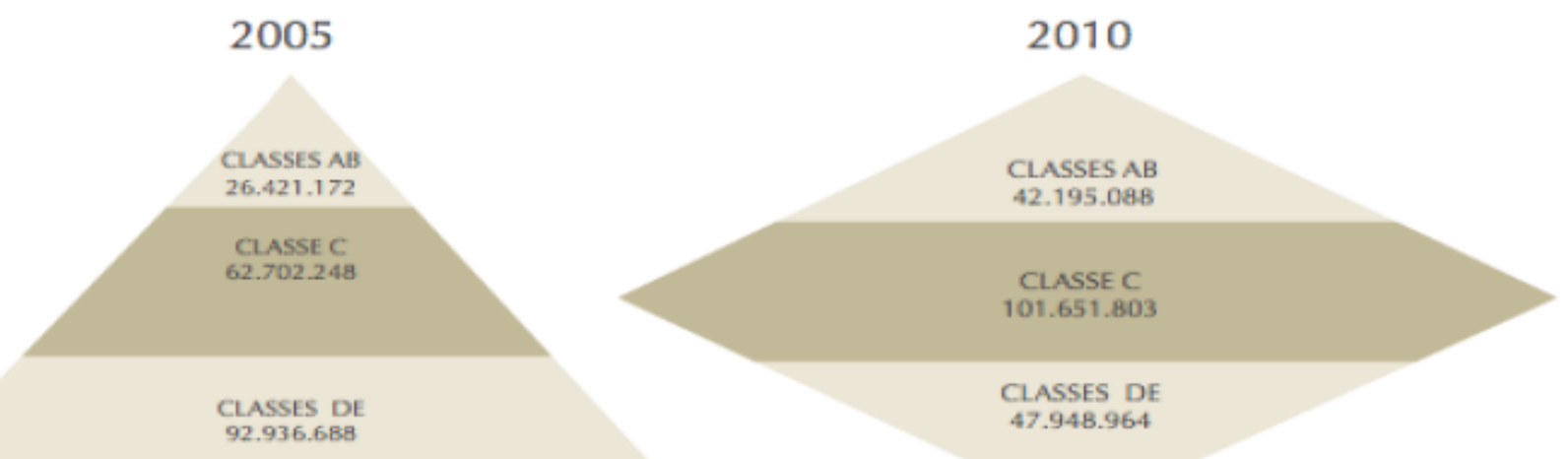

Fonte: Isto É Dinheiro, 22 mar.2011

Lembramos que, em 2003, o país saía de um período de oito anos do PSDB à frente da política nacional, no comando de um processo de minimalização do Estado, como vimos no segundo capítulo, logo após a aprovação de uma Constituição que ampliara as responsabilidades Estatais, sobretudo no que se refere às políticas sociais. Os treze anos do PT no cargo principal do executivo brasileiro trouxeram à tona uma série de conflitos, de diferentes naturezas: para chegar ao poder, o partido se baseou em uma política conciliatória, de forma que as elites tradicionais brasileiras - as mesmas, que sempre estiveram presentes nos espaços de poder, no campo político, garantindo seus privilégios - foram incorporadas ao seu projeto. Buscou-se, nas palavras de Miguel (2016, p. 32), acomodar e não afrontar. Mesmo diante desta realidade, tal grupo se viu ameaçado e teve em mais um golpe a saída para a recolocação do país - e das classes - em seus devidos lugares. Concordamos ainda com o autor, quando afirma que existiram dois principais componentes para a insatisfação da elite para com os rumos do país, que corroboram o gráfico anterior:

É possível identificar, então, um componente material e outro "simbólico" para a inconformidade com os governos petistas. A redução da miséria afeta uma vulnerabilidade social que é funcional para largos setores do capital [...] E já atingia as classes médias - a massa de manobra da direita -, privadas do trabalho doméstico de que sempre desfrutaram a preço vil. O outro componente, "simbólico", não é, na verdade, desprovido de materialidade. Os anos petistas foram acompanhados de uma sensação de que hierarquias seculares estavam sob ameaça [...] grupos em posição subalterna passaram a reivindicar cada vez mais o direito de falar com sua própria voz, a questionar sua exclusão de muitos espaços, 
a reagir à violência estrutural que os atinge [...] Os privilegiados perderam a sensação de que sua superioridade social era natural, logo inconteste, e perderam também a exclusividade na ocupação de posições de prestígio. Para eles, o risco

da democracia é esse: ela abre uma brecha para que se ouçam vozes silenciadas, para que o jogo das elites seja bagunçado (IDEM, p. 34).

A mesma análise é compartilhada por Jessé Souza (2016, p. 48), quando ele apresenta o papel cumprido pelos principais partidos políticos no contexto dos anos supracitados. Coloca o PMDB como partido que trabalha como coadjuvante de quem está no comando do executivo; o PSDB como regionalizado demais e cego às demandas da população mais pobre, não tendo, por tal motivo, capilaridade; e, por fim, o PT como articulador de uma política de aliança entre o que convencionou chamar de "elite do dinheiro" e os setores mais pobres, que conseguiram emergir e melhorar sua condição econômica, social e cultural.

E foi justamente o constrangimento com a passagem dos setores mais pobres para outra esfera da vida social que incomodou os "endinheirados" (IDEM, p. 59) e os diversos setores da classe média. Cabe aqui um destaque para o entendimento de classe social como relação social, e não como local estrutural, como definiu Ellen Wood (2006, p. 73), posto que nosso foco de estudo está na dinâmica da relação entre apropriadores e produtores, nas contradições e nos conflitos que se dão no mundo do trabalho, que explicam os processos históricos e sociais. Desta forma, resgata-se o papel da educação neste processo, na medida em que as classes trabalhadora e excluída não possuem o capital social que as distingue das demais - capital econômico, que é muito destacado na classe endinheirada; e capital cultural, que é o destaque da(s) classe(s) média(s). Assim, concordamos com Jessé Souza (2016, p. 64), quando afirma que "A linha fluida entre classe trabalhadora e classe excluída é construída a partir da maior ou menor possibilidade de incorporação dos pressupostos afetivos e emocionais que permitem evitar, em alguma medida, o total fracasso escolar".

Para explicar as condições que possibilitaram o golpe de 2016, o autor volta ainda mais no tempo, resgatando as manifestações de junho de 2013, que se iniciaram em São Paulo, com a proposta de redução nas tarifas das passagens, portanto, que atingia a esfera municipal. Contudo, percebeu a federalização das reivindicações, que passaram a ser incorporadas pelo discurso da mídia e transformadas em uma forma de abalar a popularidade da presidenta Dilma, já que as ruas começaram a trazer questões que diziam 
respeito à qualidade dos serviços de educação e saúde, e também à corrupção. Criadas as condições e com a associação dos agentes que se dispuseram a reclamar a hegemonia do Estado brasileiro - os empresários, a mídia e o aparelho jurídico - em 2016, Michel Temer assumiu a presidência, tratando de implantar o projeto de governo que fora rejeitado no pleito do ano anterior.

Uma Ponte para o futuro foi um documento elaborado em outubro de 2015 pelo PMDB, como base de discussão do Congresso da Fundação Ulysses Guimarães, centro de estudos da sigla, com o objetivo de "[...] buscar a união dos brasileiros de boa vontade. O país clama por pacificação, pois o aprofundamento das divisões e a disseminação do ódio e dos ressentimentos estão inviabilizando os consensos políticos sem os quais nossas crises se tornarão cada vez maiores" $(2015$, p. 2). Segundo Cleto (2016, p. 45), ele serviu para mostrar ao empresariado a necessidade deste se associar de vez ao processo de deposição do governo recém-eleito. Desta forma, ao assumir a presidência após o questionável processo de impeachment da presidenta Dilma, Michel Temer aproveitou sua impopularidade para implantar uma agenda que nos levou de volta aos anos de 1990. A crítica contundente às vinculações constitucionais orçamentárias redundou na PEC 241 e, posteriormente na EC 95/2016, que alterou o ato das disposições constitucionais transitórias da CF de 1988, para instituir o novo regime fiscal, com a seguinte justificativa:

O orçamento é a peça mais importante de uma legislatura. Para este fim é que os parlamentos foram criados no moderno Estado de direito. E assim continua sendo na maioria das grandes democracias modernas. Se quisermos atingir o equilíbrio das contas públicas, sem aumento de impostos, não há outra saída a não ser devolver ao orçamento anual a sua autonomia. A cada ano a sociedade e o parlamento elegem suas prioridades, conforme os recursos e as necessidades. Para isso é necessário em primeiro lugar acabar com as vinculações constitucionais estabelecidas, como no caso dos gastos com saúde e com educação, em razão do receio de que o Executivo pudesse contingenciar, ou mesmo cortar esses gastos em caso de necessidade, porque no Brasil o orçamento não é impositivo e o Poder Executivo pode ou não executar a despesa orçada $(2015$, p. 8).

Estava aberto o caminho para que as pautas da ralé, da classe dos trabalhadores, dos excluídos estivesse de vez soterrada. O parlamento eleito no último pleito foi um dos mais conservadores desde $1964^{76}$, conivente com todo tipo de negociata, tal como estamos

76 Conforme afirma a matéria de 05/01/2015, do Valor Econômico. Disponível em http://www.valor.com.br/ politica/3843910/nova-composicao-do-congresso-e-mais-conservadora-desde-1964. 
assistindo nos últimos tempos. Assim, a emergência do pensamento conservador trouxe à ordem do dia alguns temas que mostram claramente como retrocedemos na garantia dos direitos, especificamente do direito à educação. $O$ fato do ministro da Educação que assumiu a pasta ter recebido membros do Movimento Brasil Livre e do Movimento Revoltados Online logo no início de seu trabalho, denota o tratamento a ser dado à educação, que passou a ser do DEM, partido que "[...] exige que o Estado sirva à sociedade e não a sociedade sirva ao Estado", preocupado com "[...] o crescimento descontrolado da atividade empresarial do Estado, que, em muitas áreas, transborda dos limites aceitos num regime econômico, social e político, de livre competição"77. Concordamos com Ribeiro (2017, p. 13) quando ele rememora sua experiência como ministro da Educação no ano de 2015 e afirma que

[...] o Ministério da Educação (MEC) tem uma característica relevante: é a educação que mais pode formar as pessoas na direção de maior liberdade e responsabilidade. $\mathrm{Na}$ Saúde e em parte na Inclusão Social, as medidas que melhoram a vida das pessoas podem ser adotadas sem que delas nem sequer tenham consciência, sem que as percebam ou as tornem valores seus: digamos, o saneamento de córregos, o investimento na qualidade da água ou dos alimentos. Já na Educação - e na parte autossustentável da Saúde e da Inclusão Social -, essa consciência é indispensável. É o que constitui a emancipação, o trabalho pelo qual alguém que é cativo, dependente, subordinado se torna sujeito, livre, cidadão.

Desta forma, o ataque ostensivo à liberdade docente, sobretudo por meio do Programa Escola sem partido ${ }^{78}$ e o que vem sendo chamado de "ideologia de gênero" - que buscam eliminar a possibilidade de acesso das classes menos favorecidas à plenitude do conhecimento historicamente acumulado, classificando alguns conteúdos como "ideológicos" e que, portanto, não devem ser ensinados na escola e discutidos pelos professores, chamados agora de doutrinadores - são uns dos capítulos que temos que enfrentar nesse momento. Resgatamos a entrevista de Luiz Antônio Cunha, na qual ele afirma que percebe estas propostas como “[...] uma reação à presença do Estado na educação. Porque o Estado está acolhendo demandas seculares da sociedade". Ora, então nada melhor do que tomar de volta o Estado e propor o que e como se deve ensinar, com os recursos congelados pelos próximos vinte exercícios fiscais.

77 Propostas constantes na página eletrônica do Democratas. Disponível em: http://www.dem.org.br/wpcontent /uploads/2011/01/Ideario-do-Democratas.pdf. Acesso em 22.nov.2017.

78 Para um aprofundamento desse debate, sugerimos a leitura do livro "Escola 'sem' partido. Esfinge que ameaça a educação e a sociedade brasileira", organizado por Gaudêncio Frigotto (2017). Ressaltamos que o projeto de lei 867/2015, que visa instituir o Programa Escola sem partido nas diretrizes e bases da educação nacional foi retirado do Senado no dia 20/11/2017, devido às chances de rejeição do mesmo por aquela Casa. Ressalta-se que há um processo semelhante em tramitação na Câmara, com maiores chances de ser aprovado. 
Outro ponto que denota o tamanho retrocesso vivido é a recente - datada de setembro de 2017 - decisão do Supremo Tribunal Federal que determina que a aula de uma religião não constitui ataque à laicidade do ensino ${ }^{79}$ nem ao previsto na Constituição de 1988 , que pressupunha o ensino de caráter confessional e facultativo. Mais uma vez a tênue linha que separa a esfera privada da pública é rompida, com base nos votos da maioria dos ministros. Ainda na tensão entre o que é público e privado, caminha a questão do homeschooling, proposta que vem ganhando espaço nas discussões educacionais no Brasil - embora a lei ainda não permita este formato de escolarização. A possibilidade das famílias educarem seus filhos em casa, fora do espaço escolar, visa radicalizar a sua liberdade neste processo, livrando as crianças e adolescentes da influência dos professores e escolas, considerados, como vimos anteriormente, instituição e agentes "doutrinadores".

Cabe também ressaltar que a reforma do ensino médio foi iniciada com a Medida Provisória $n^{\circ} 746 / 2016$, ou seja, no ano em que esta etapa da educação básica se tornou efetivamente obrigatória, ampliando a perspectiva do direito à educação. Tornada lei no ano seguinte, com sua aprovação sob o número 13.415, sem debate prévio com a comunidade educacional, assistimos à "flexibilização" e "modernização", que mais consiste em uma estratégia de aligeiramento e precarização da formação a ser oferecida às classes populares ${ }^{80}$. Da mesma forma vem se processando a aprovação da Base Nacional Comum Curricular (BNCC), documento normativo que busca definiros conteúdos essenciais à aprendizagem em cada etapa de escolaridade, elaborado sem participação efetiva da sociedade e amplamente questionado pela comunidade acadêmica. Sobre este ponto, voltamos à um questionamento colocado na introdução desta tese, formulado por Florestan Fernandes (1989, p. 235) “A liberdade é do professor, a liberdade é da escola, a liberdade é da família?”. Atrevemo-nos a responder: a liberdade, certamente, não é da população que comumente tem acesso aos serviços públicos. Ela cotidianamente é alijada dos seus direitos básicos, posto que não tem o capital necessário para disputar o campo político. E tudo isso se torna um doloroso ciclo de servidão.

O debate sobre a gratuidade do ensino superior também caminha em tal direção. Debate antigo, como pudemos perceber com a leitura das atas da ANC, analisadas no terceiro e quarto capítulos. Realocado no discurso de muitos parlamentares - como no do deputado Nelson Marquezelli (PTB-SP), ao defender a proposta de emenda à Constituição

\footnotetext{
79 Ver a matéria: "STF decide que escola pública pode promover crença específica em aula de religião". Disponível em: https://brasil.elpais.com/brasil/2017/08/31/politica/1504132332_350482.html. Acesso em 22.nov.2017.

80 Sugerimos a leitura do texto "O nome é Retrocesso", de Waldeck Carneiro (2017), no qual ele discute como tal reforma se insere no contexto do governo do presidente Michel Temer.
} 
que limita os gastos públicos - e também no de parte da sociedade, que defende que somente tenha acesso ao ensino superior quem pode pagá-lo, tendo em vista que muitas pessoas que ocupam as universidades federais teriam recursos para custeá-lo. Desmonta-se, mais uma vez, a defesa da necessidade da educação pública e gratuita em todos os níveis, para todos.

Diante do cenário atual, poderíamos ainda elencar outras questões que atingem o campo educacional brasileiro, no sentido de estabelecerem uma nova (ou antiga?) direção ao que foi duramente construído como direito à educação, via o entendimento do que consideramos a democratização das oportunidades educacionais e a liberdade de ensino. Resta-nos a luta e a certeza que o passado ajuda a explicar o presente e que o presente é também importante para ressignificar o passado. Entender, portanto, a história como ferramenta de ação nos dá o poder de tentar elaborar um novo futuro. Que aprendamos as lições e disputemos novamente o campo político. 


\section{POSFÁCIO}

A oportunidade de publicar a tese resultante de meu processo de doutoramento se deu agora, três anos e cinco meses após sua defesa. Ao reler o trabalho escrito naquela ocasião, penso ser preciso revisitar algumas reflexões tecidas à época, valendo-me de uma advertência que eu mesma fiz no último parágrafo das considerações finais do texto:

Resta-nos a luta e a certeza que o passado ajuda a explicar o presente e que o presente é também importante para ressignificar o passado. Entender, portanto, a história como ferramenta de ação nos dá o poder de tentar elaborar um novo futuro. Que aprendamos as lições e disputemos novamente o campo político.

Na ocasião, julguei ser importante escrever, para além da formatação convencional de uma conclusão de texto acadêmico, uma espécie de releitura do processo da ANC de 19871988, bem como do produto dela resultante, à luz dos acontecimentos que movimentaram a história do país no ano em que a apresentei à banca. Para tanto, ousei escrever uma segunda parte, com uma breve análise daquele tempo, no qual, sombrias perspectivas diante do ataque à democracia e à Constituição estavam em curso. O golpe de $2016 \mathrm{e}$ seu embasamento empresarial-midiático-jurídico trouxeram as primeiras ações regressivas apresentadas na "pinguela para o passado" (ANTUNES, 2016) de Michel Temer, que se aprofundou com a eleição de Jair Messias Bolsonaro, em novembro de 2018, nove meses após a realização da minha banca de defesa.

Mais uma vez retomo a análise bourdiesiana que realizei no processo da pesquisa de doutorado, atentando que "[...] na questão política, nada simplesmente é; está. As articulações, os interesses necessários a cada momento podem movimentar os agentes no campo $^{81 " .}$. Retomo também os conceitos de "democracia restrita" e "democracia excludente" de Saviani (2008), que utilizei anteriormente para caracterizar os processos de formulação e implementação das políticas públicas de educação no Brasil. Os mesmos partidos ora alinhados mais à esquerda, à direita ou ao centro, não alteraram suas posições. Todavia, se hoje utilizasse tal forma de análise para compreender a articulação dos agentes no processo de aprovação de textos legais no Congresso Nacional, teria que inserir um novo campo, a ser chamado de extrema direita ou protofascista.

Se havia clareza que a Constituição aprovada em 1988 não representou os setores progressistas da forma como prometera em seu processo inicial, seus avanços foram

Análise constante nas Considerações Finais do presente livro. 
fortemente atacados pela facção que hegemoniza a condução dos rumos do país desde então. Os grupos que à época chamei de conservadores, hoje chamo de reacionários; os lobbies foram incrementados com o apoio de grupos ligados às milícias, com assento, inclusive, nos poderes legislativo e executivo dos três entes da federação; o Centrão continua vivo e atuante, encaminhando projetos que buscam reafirmar suas próprias demandas, e não os interesses públicos republicanos e democráticos que os elegeram.

Desde a fatídica aprovação da EC 95/2016, o direito à educação, a liberdade e a laicidade do ensino só sofreram mais ataques, com a continuidade de processos já em curso naquele cenário: projetos de lei em tramitação que visam implantar as prerrogativas do movimento Escola sem Partido e da educação domiciliar (homeschooling); a decisão do STF, que permitiu o ensino religioso confessional em escolas públicas e acabou por recrudescer a perseguição de algumas religiões - sobretudo as de matrizes afro-brasileiras - , manifestações culturais e mesmo das discussões de gênero e sexualidades, alocadas sob a deturpada e falaciosa ideologia de gênero; a reforma do ensino médio, assim como a BNCC, que vêm sendo implementadas sem o devido aprofundamento democrático de seus debates, contribuindo ainda mais para a precarização da educação das classes populares; a gratuidade do ensino superior público, sempre questionada, é continuamente posta à prova por meio do contingenciamento e da diminuição dos recursos destinados às universidades públicas. Corroborando a expressão popular de que "nada é tão ruim que não possa piorar", o primeiro ato do atual governo foi incentivar a disseminação de escolas cívico-militares, criando uma estrutura administrativa e de fomento para os estados que ampliassem tal rede, com base em um discurso de criminalização da pobreza, que atribui a baixa qualidade da escola pública à pouca (ou má) qualificação docente, à indisciplina dos estudantes $\mathrm{e}$ à falta de respeito à hierarquia, em diferentes relações; as fake news - notícias falsas tornaram-se o padrão utilizado para veicular informações inverídicas em todos os níveis, desde o processo eleitoral até o momento atual, na qual assistimos cotidianamente a defesa de argumentos que negam a ciência e o conhecimento historicamente produzido pela humanidade.

Se no momento em que a CF fazia 30 anos, as considerações trazidas ao final da tese traziam perguntas sobre sua atualidade, tais como: "Ela ainda carrega em si todos os sonhos e expectativas nela depositados? Ainda defende os direitos sociais com toda a força que desejávamos? Nós ainda desejamos? Nós, quem?”, hoje afirmo que não. Não temos mais expectativas diante do cenário que se descortina sob os nossos olhos: até o momento da escrita deste texto temos mais de 500 mil mortos em decorrência de dois vírus que assolam 
nosso país: a COVID-19 e uma gestão irresponsável e genocida, que aprofundaram as desigualdades sociais já históricas e imensas, fazendo com que aquele losango apresentado anteriormente - como representação das frações de classe ao final da primeira década dos anos 2000 - se tornasse quase um planisfério, dada a junção das crises sanitária, política e econômica que levaram milhões de brasileiros ao desemprego, à miséria, à desesperança. Isso se refletiu diretamente na agudização das desigualdades educacionais: segundo dados do Instituto de Pesquisa Econômica Aplicada (IPEA, 2020, p. 8) aproximadamente 12\% da população entre a pré-escola e a pós-graduação - 6 milhões de pessoas, sendo que 5,8 milhões estão matriculadas em instituições públicas - não tem acesso à internet e, por conseguinte, não conseguiu acompanhar as aulas em formato remoto, modelo alternativo emergencial oferecido como resposta dos sistemas de ensino ao fechamento de escolas, em decorrência da pandemia do coronavírus. Este triste dado serviu para dar fôlego à tramitação do $P L n^{0} 5.595 / 2020$, que visa estabelecer a educação como serviço essencial, ratificando a lógica empresarial que trata um direito constitucional da população e um dever Estatal - a educação pública, gratuita, laica e de qualidade para todos - como mercadoria a ser comercializada sob quaisquer circunstâncias: pandemias, desastres, inviabilizando o direito de greve, reduzindo a autonomia dos sistemas de ensino e dos profissionais da educação, bem como permitindo sua inserção entre os serviços negociáveis pelos países membros da Organização Mundial do Comércio (OMC), a partir do entendimento da educação sob um viés produtivista, próximo aos interesses dos empresários e do capital financeiro que domina e lucra com este campo.

Mais uma vez faço, com Florestan Fernandes, a pergunta: “A liberdade é do professor, a liberdade é da escola, a liberdade é da família?” (1989, p. 235). Com Marx (1985), respondo: não há liberdade sem considerarmos a base concreta das relações materiais, ou seja, não podemos ser livres se não conseguimos suprir nossas necessidades básicas à sobrevivência. Não há liberdade na fome, no caos, em meio ao genocídio, à necropolítica.

Retomando a conhecida frase do artista de rua Eduardo Marinho, podemos considerar que "quem chega no fundo do poço precisa lembrar que o fundo é o melhor do poço para se tomar impulso". Espero que não tenhamos mais para onde afundar e que a união das forças progressistas deste país possa fazê-lo ressurgir das cinzas, tal como a fênix. 


\section{REFERÊNCIAS BIBLIOGRÁFICAS}

ALTHUSSER, L. P. Aparelhos ideológicos de Estado. $7^{\mathrm{a}}$ ed. Rio de Janeiro: Graal, 1998.

ANC. Fase A. Anteprojeto do relator. Disponível em: http://www2.camara.leg.br/ atividade-legislativa/legislacao/Constituicoes_Brasileiras/constituicao-cidada/o-processoconstituinte/o-processo-constituinte. Acesso em 23.set.2017a.

. Fase C. Anteprojeto do subcomissão. Disponível em: http://www2.camara.leg.br/ atividade-legislativa/legislacao/Constituicoes_Brasileiras/constituicao-cidada/o-processoconstituinte/o-processo-constituinte. Acesso em 23.set.2017b.

- Fase F. Substitutivo do relator. Disponível em: http://www2.camara.leg.br/ atividade-legislativa/legislacao/Constituicoes_Brasileiras/constituicao-cidada/o-processoconstituinte/o-processo-constituinte. Acesso em 23.set.2017c.

. Fase H. Anteprojeto do comissão. Disponível em: http://www2.camara.leg.br/ atividade-legislativa/legislacao/Constituicoes_Brasileiras/constituicao-cidada/o-processoconstituinte/o-processo-constituinte. Acesso em 23.set.2017d.

. Fase I. Anteprojeto de Constituição. Disponível em: http://www2.camara.leg.br/ atividade-legislativa/legislacao/Constituicoes_Brasileiras/constituicao-cidada/o-processoconstituinte/o-processo-constituinte. Acesso em 23.set.2017e.

. Fase P. Substitutivo 2 do relator. Disponível em: http://www2.camara.leg.br/ atividade-legislativa/legislacao/Constituicoes_Brasileiras/constituicao-cidada/o-processoconstituinte/o-processo-constituinte. Acesso em 23.set.2017f.

. Fase Q. Projeto A: início do $1^{\circ}$ turno. Disponível em: http://www2.camara.leg.br/ atividade-legislativa/legislacao/Constituicoes_Brasileiras/constituicao-cidada/o-processoconstituinte/o-processo-constituinte. Acesso em 23.set.2017g.

. Fase V. Projeto C: fim do $2^{\circ}$ turno. Disponível em: http://www2.camara.leg.br/ atividade-legislativa/legislacao/Constituicoes_Brasileiras/constituicao-cidada/o-processoconstituinte/o-processo-constituinte. Acesso em 23.set.2017h.

- Promulgação da Constituição. Disponível em: http://www2.camara.leg.br/ atividade-legislativa/legislacao/Constituicoes_Brasileiras/constituicao-cidada/o-processoconstituinte/o-processo-constituinte. Acesso em 23.set.2017i.

ANDRADE, C. D. de. Nosso tempo. Disponível em: https://www.letras.com.br/carlosdrummond-de-andrade/nosso-tempo. Acesso em: 10.jan.2018. 
ANPAE. Estatuto social da Associação Nacional de Política e Administração da Educação. Disponível em: http://www.anpae.org.br/website/downloads/Documentos/Estatuto,\%20 Planos\%20e\%20Relat\%C3\%B3rios/portal_2010_-_8_documentos_1_1estatuto_da_ anpae.pdf. Acesso em: 02.jan.2018.

ANTUNES, Marcello. A ponte para o futuro é, na verdade, uma pinguela rumo ao atraso do Brasil. PT Senado, 2016. Disponível em: https://ptnosenado.org.br/a-ponte-para-o-futuroe-na-verdade-uma-pinguela-rumo-ao-atraso/. Acesso em: 25.set. 2020.

ARAUJO, F.M. de B., ALVES, E.M. e CRUZ, M.P. Algumas reflexões em torno dos conceitos de campo e de habitus na obra de Pierre Boudieu. Revista Perspectivas da ciência e tecnologia.v.1, n.1, jan-jun 2009.

ARROYO, M. Educação e exclusão da cidadania. In: BUFFA, E., ARROYO, M. e NOSELLA, P. Educação e cidadania: quem educa o cidadão. São Paulo: Cortez, 1987. p.31- 79 .

ASSUMPÇÃO, R.P.S. e KERBAUY, M. Redes sociais e capital político: uma proposta teórico-metodológica para análise das organizações partidárias brasileiras. Política e Sociedade. Abril de 2011, v.10, nº 18, pp. 301-332.

AZEVEDO, Dermi. A Igreja Católica e seu papel político no Brasil. Estud. av., São Paulo, v. 18, n. 52, p. 109-120, Dez. 2004. Disponível em: http://www.scielo.br/scielo. php?script $=$ sci_arttext\&pid=S0103-40142004000300009\&lng=en\&nrm=iso. Acesso em: 06.dez.2017.

AZEVEDO, J.M.L. A educação como política pública. Campinas, SP: Autores Associados, 2001.

BARROS, R.S.M. de. Diretrizes e bases da educação nacional. São Paulo: Livraria Pioneira Editora, 1960.

BEISIEGEL, C.de R. A qualidade do ensino na escola pública. Brasília: Liber Livro Editora, 2005.

BOBBIO, Norberto. A era dos direitos. Tradução Carlos Nelson Coutinho. 7 ed. Rio de Janeiro: Elsevier, 2004.

. Direita e esquerda. Razões e significados de uma distinção política.

São Paulo: Editora UNESP, 1995. 
BOURDIEU, P. Décrire et prescrire. IN: Actes de la recherche en sciences sociales. vol.38, mai.1981, pp. 69-73.

. Coisas ditas. São Paulo: Editora Brasiliense, 1990.

. Razões práticas. Sobre a teoria da ação. Campinas, SP: Papirus, 1996.

. O poder simbólico.7 ed. Rio de Janeiro: Bertrand, 2004.

. A distinção: crítica social do julgamento. São Paulo: Edusp; Porto Alegre:

Zouk, 2007.

. O campo político. Rev. Bras. Ciênc. Polit. [online]. 2011, n.5. pp.193216. Disponível em $<$ http://www.scielo.br/scielo.php?script=sci_arttext\&pid=S0103$33522011000100008 \& \operatorname{lng}=$ en\&nrm=iso $>$. ISSN 2178-4884. http://dx.doi.org/10.1590/ S0103-33522011000100008.

BRANDÃO, Z. Direito à educação e cidadania escolar. Disponível em: http://www.cis.pucrio.br/cis/cedes/bn/janeiro_marco_2014/Artigo\%20-\%20Zaia\%20Brandao.pdf. Acesso em: 8.dez.2017.

BUFFA, E. Ideologias em conflito: Escola pública e escola privada. São Paulo: Cortez \& Moraes, 1979.

BURAWOY, M. O marxismo encontra Bourdieu. Campinas, SP: Editora UNICAMP, 2010.

CÂMARA. Regimento interno da Assembleia Nacional Constituinte. Disponível em: $\quad$ http://www2.camara.leg.br/atividade-legislativa/legislacao/Constituicoes Brasileiras/ constituicao-cidada/publicacoes/regimento-interno-da-assembleia-nacional/ resolucao-2-1987. Acesso em 09.ago.2017a.

. Atas da Subcomissão 8a. Disponível em: http://www2.camara.leg.br/atividadelegislativa/legislacao/Constituicoes_Brasileiras/constituicao-cidada/publicacoes/anais-daassembleia-nacional-constituinte. Acesso em 02.jan.2017b.

. Atas da Comissão 8. Disponível em: http://www2.camara.leg.br/atividadelegislativa/legislacao/Constituicoes_Brasileiras/constituicao-cidada/publicacoes/anais-daassembleia-nacional-constituinte. Acesso em 02.jan.2017c.

. Atas da Comissão de Sistematização 9a. Disponível em: http://www.senado. leg.br/publicacoes/anais/constituinte/sistema.pdf. Acesso em: 15.nov.2017d. 
. Atas da Comissão de Sistematização 9b. Disponível em: http://www.senado. leg.br/publicacoes/anais/constituinte/sistema.pdf. Acesso em: 15.nov.2017e.

. Atas da Comissão de Sistematização 9c. Disponível em: http://www.senado. leg.br/publicacoes/anais/constituinte/sistema.pdf. Acesso em: 15.nov.2017f.

CANTONI, W. Querem a liberdade da escola porque não a querem na escola. IN: BARROS, R.S.M. de. Diretrizes e bases da educação nacional. São Paulo: Livraria Pioneira Editora, 1960. pp. 123-126.

CARNEIRO, W. O nome é retrocesso. Reforma do ensino médio no Brasil: ofensiva da elite golpista contra a ampliação do direito à educação. IN: Esquerda Petista, n.8, nov.2017. Disponível em: https://www.pagina13.org.br/2017/11/16/saiu-a-revista-esquerdapetista-n-8/. Acesso em 5.dez.2017.

CARVALHO, J.M. Cidadania no Brasil. O longo caminho. Rio de Janeiro: Civilização Brasileira, 2001.

CARVALHO, L.M. 1988: segredos da constituinte. Os vinte meses que agitaram e mudaram o Brasil. São Paulo: Ed. Record, 2017.

CARVALHO, M. A. R. e VIANNA, L. W. República e civilização brasileira. IN: Estudos de Sociologia. v.5, n.8 (2000). Disponível em: http://seer.fclar.unesp.br/estudos/issue/ view/127. Acesso em 4.ago.2015.

CEDES. Carta de Goiânia. IN: Educação \& Sociedade. v. 25 (1986). Disponível em: http:// http://www.gppege.org.br/ArquivosUpload/1/file/Carta\%20de\%20Goi\%C3\%A2nia\%20 2\%20a\%205\%20de\%20Setembro\%20de\%201986.pdf. Acesso em: 04.dez.2017.

CLETO, M. O triunfo da antipolítica. IN: SINGER, A. [et.al.] Por que gritamos golpe? Para entender o impeachment e a crise política no Brasil. São Paulo: Boitempo, 2016. pp. 43-48.

CHINELLI, F. Florestan Fernandes: educação e compromisso com a mudança. IN: FÁVERO, O. (org.) Democracia e educação em Florestan Fernandes. Niterói: EDUFF, 2005, pp. 55-78.

COUTINHO. C. N. O estado brasileiro: gênese, crise, alternativas. IN:LIMA, J.C.F. e NEVES, L.M.W. Fundamentos da educação escolar do Brasil contemporâneo. Rio de Janeiro: Ed. FIOCRUZ, 2006. p.173-200. 
CPDOC. Reformas educacionais. Disponível em: https://cpdoc.fgv.br/producao/dossies/ AEraVargas1/anos20/QuestaoSocial/ReformasEducacionais. Acesso em 08dez.2015a

.PlanoCohen.Disponívelem:https://cpdoc.fgv.br/producao/dossies/AEraVargas1/ anos30-37/GolpeEstadoNovo/PlanoCohen. Acesso em 08.dez.2015b.

. João Goulart. Disponível em: https://cpdoc.fgv.br/producao/dossies/Jango/ biografias/joao_goulart. Acesso em 08.dez.2015c.

. Hermes Zaneti. Disponível em: http://www.fgv.br/cpdoc/acervo/dicionarios/ verbete-biografico/zaneti-hermes. Acesso em 06.set.2017a.

. Aécio de Borba. Disponível em: http://www.fgv.br/cpdoc/acervo/dicionarios/ verbete-biografico/aecio-de-borba-vasconcelos. Acesso em 06.set.2017b.

- Pedro Canedo. Disponível em: http://www.fgv.br/cpdoc/acervo/dicionarios/ verbete-biografico/pedro-chaves-canedo. Acesso em 06.set.2017c.

- João Calmon. Disponível em: http://www.fgv.br/cpdoc/acervo/dicionarios/ verbete-biografico/joao-de-medeiros-calmon. Acesso em 06.set. $2017 \mathrm{~d}$.

. Ubiratan Aguiar. Disponível em: http://www.fgv.br/cpdoc/acervo/dicionarios/ verbete-biografico/ubiratan-diniz-de-aguiar. Acesso em 06.set. $2017 \mathrm{e}$.

. Louremberg Nunes. Disponível em: http://www.fgv.br/cpdoc/acervo/dicionarios/ verbete-biografico/rocha-louremberg-nunes. Acesso em 06.set. $2017 \mathrm{f}$.

. Antônio de Jesus. Disponível em: http://www.fgv.br/cpdoc/acervo/dicionarios/ verbete-biografico/antonio-de-jesus-dias. Acesso em 06.set. 2017g.

. Bezerra de Melo. Disponível em: http://www.fgv.br/cpdoc/acervo/dicionarios/ verbete-biografico/melo-manuel-bezerra-de. Acesso em 06.set. 2017h.

. Octávio Elíseo. Disponível em: http://www.fgv.br/cpdoc/acervo/dicionarios/ verbete-biografico/otavio-elisio-alves-de-brito. 7.set.2017i.

. Marcondes Gadelha. Disponível em: http://www.fgv.br/cpdoc/acervo/dicionarios/ verbete-biografico/marcondes-iran-benevides-gadelha. Acesso em 7.set.2017j.

. José Elias. Disponível em: http://www.fgv.br/cpdoc/acervo/dicionarios/verbetebiografico/jose-elias-moreira. Acesso em 06.set.20171. 
. Osvaldo Sobrinho. Disponível em: http://www.fgv.br/cpdoc/acervo/dicionarios/ verbete-biografico/osvaldo-roberto-sobrinho. Acesso em 06.set.2017m.

. Artur da Távola. Disponível em: http://www.fgv.br/cpdoc/acervo/dicionarios/ verbete-biografico/paulo-alberto-artur-da-tavola-m-m-de-barros. Acesso em 06.set.2017n.

. Sólon Borges. Disponível em: http://www.fgv.br/cpdoc/acervo/dicionarios/ verbete-biografico/reis-solon-borges-dos. Acesso em: 28.set.2017o.

.Afonso Arinos. Disponível em:http://cpdoc.fgv.br/producao/dossies/AEraVargas1/ biografias/afonso_arinos. Acesso em 13.set.2017. Acesso em 14.set.2017p.

- Aluísio Afonso Campos. Disponível em: http://www.fgv.br/cpdoc/acervo/ dicionarios/verbete-biografico/aluisio-afonso-campos-1. Acesso em 14.set.2017q.

. José Carlos Brandão. Disponível em: http://www.fgv.br/cpdoc/acervo/dicionarios/ verbete-biografico/jose-carlos-brandao-monteiro. Acesso em 14.set.2017r.

. Mendes Ribeiro. Disponível em: http://www.fgv.br/cpdoc/acervo/dicionarios/ verbete-biografico/jorge-alberto-mendes-ribeiro. Acesso em 14.set.2017t

. José Mendonça de Morais. Disponível em: http://www.fgv.br/cpdoc/acervo/ dicionarios/verbete-biografico/bezerra-jose-mendonca. Acesso em 14.set.2017u

CRETELLAJUNIOR, J. Direito subjetivo público. IN: FRANÇA, R.L. (org.). Enciclopédia Saraiva de Direito. São Paulo: Saraiva, 1977, v.28, pp.338-339.

CRUB. Estatuto do CRUB. Disponível em: http://www.crub.org.br/wp-content/ uploads/2015/06/estatuto_final.pdf. Acesso em: 01.jan.2018.

CRUZ, Mariano da. Vinte anos a serviço da educação. Rio de Janeiro: AEC, 1966.

CRUZ, Verônica. Estado regulador e políticas públicas. IN: Alejandra Pastorini, Andrea Moraes Alves, Silvina V. Galizia (org.). Estado e cidadania: reflexões sobre as politicas públicas no Brasil contemporâneo. Rio de Janeiro: Editora FGV, 2012. pp. 73-102.

CUNHA, Luiz Antônio. Diretrizes para o estudo histórico do ensino superior no Brasil. Em aberto. Brasília, ano 3, n. 23, set/out. 1984.

. A educação na nova Constituição. Revista da Ande, São Paulo, v.

6, n. 12, 1987. 
. Educação, Estado e democracia no Brasil. São Paulo: Cortez;

Niterói, RJ: Ed. da Universidade Federal Fluminense; Brasília, DF: FLACSO do Brasil, 2009.

Editora, 2000.

; GÓES, M. de. O golpe na educação. Rio de Janeiro: Zahar

CURY, C.R.J.; HORTA, José Silvério Bahia; FÁVERO, Osmar. A Relação EducaçãoSociedade-Estado pela mediação jurídico-constitucional. IN: FÁVERO, Osmar (Org.). A educação nas Constituintes Brasileiras: 1823-1988. Campinas: Autores Associados, 1996. pp. 5-30.

. Direito à educação: direito à igualdade, direito à diferença. Cadernos de Pesquisa. n. 116, julho/ 2002. p. 245-262.

- Carlos Roberto Jamil Cury, intelectual e educador. Organização e introdução Cynthia Greive Veiga. Belo Horizonte: Autêntica Editora, 2010 (Coleção Perfis da Educação).

DAVIES, N. Legislação educacional federal básica. São Paulo: Cortez, 2004. . FUNDEB: a redenção da educação básica? Niterói: Edição do autor, 2007.

DEBRUN, M.A. A conciliação e outras estratégias. São Paulo: Brasiliense, 1983.

DEMO, P. Metodologia científica em ciências sociais. 3 ed. São Paulo: Atlas, 2012.

DEMOCRATAS. Disponível em: http://www.dem.org.br/. Acesso em 12.nov.2017.

DIAS, A. A. Da educação como direito humano aos direitos humanos como princípio educativo. Disponível em: http://www.dhnet.org.br/dados/livros/edh/br /fundamentos/26_ cap_3_artigo_04.pdf. Acesso em: 03 ago. 2014.

DRAIBE, S. Rumos e Metamorfoses: Estado e industrialização no Brasil: 1930-1960. Rio de Janeiro, Paz e Terra, 1985.

DURANTE, L. Gramsci e os perigos do cosmopolitismo. In: Educação em foco. Revista de Educação. Juiz de Fora: UFJF, v.5, n.2, set/fev - 2000 /2001, pp.81 -94.

FARIA, C.A.P. Idéias, conhecimento e políticas públicas. Um inventário sucinto das principais vertentes analíticas recentes. Revista Brasileira de Ciências Sociais. v. 18, n.51, fev/2003. pp.21-29. 
FAUSTO, B. A Revolução de 1930: historiografia e história, Companhia das Letras, 1997.

. História do Brasil.6 ed. São Paulo: Edusp: Fundação do Desenvolvimento da Educação, 1998.

FERNANDES, Florestan. Objetivos da Campanha em defesa da escola pública. In: BARROS, Roque Spencer Maciel de. BARROS, Roque Spencer de. Diretrizes e Bases da Educação. São Paulo, Pioneira, 1960.

. Educação e Sociedade no Brasil. São Paulo, 1966.

. Universidade brasileira: reforma ou revolução? São Paulo:

Alfa- ômega, 1975.

. Que tipo de república? São Paulo: Ed. Brasileiense, 1986.

. O renascimento da universidade. In: D'INCAO, Maria Angela

(org.). O saber militante: ensaios sobre Florestan Fernandes. Rio de Janeiro: Paz e Terra; SãoPaulo: Unesp, 1987. p. 309-317.

. O desafio educacional. São Paulo: Cortez/Autores Associados,

1989.

. Florestan Fernandes na Constituinte. Leituras para a reforma política. São Paulo: Editora Fundação Perseu Abramo Expressão Popular, 2014.

FERREIRA, Marieta de Moraes. História do tempo presente: desafios. Cultura Vozes, Petrópolis, v.94, nº 3, p.111-124, maio/jun., 2000.

FICO, C. História do tempo presente, eventos traumáticos e documentos sensíveis.In: Varia Historia, Belo Horizonte, vol. 28, nº 47, p.43-59, jan/jun 2012.

FNE. Plano Nacional de Educação. O planejamento educacional no Brasil. Brasília. Jun/2011. Disponível em: http://fne.mec.gov.br/images/pdf/planejamento_educacional_ brasil.pdf

FONTES, V. Sociedade civil no Brasil contemporâneo:lutas sociais e luta teórica na década de 1980. IN:LIMA, J.C.F. e NEVES, L.M.W. Fundamentos da educação escolar do Brasil contemporâneo. Rio de Janeiro: Ed.

FIOCRUZ, 2006. p. 201-240.

FRIGOTTO, G. (org.) Escola sem partido. Esfinge que ameaça a educação e a sociedade brasileira. Rio de Janeiro: LPP/UERJ, 2017. 
FUNDAÇÃO ULYSSES GUIMARÃES. Uma ponte para o futuro (2015). Disponível em: http://pmdb.org.br/wp-content/uploads/2015/10/RELEASE-TEMER_A4-28.10.15Online.pdf. Acesso em 14.nov.2017.

GRAMSCI, A. Cadernos do Cárcere. Maquiavel. Notas sobre o Estado e a política. Tradução por Carlos Nelson Coutinho. Rio de Janeiro: Civilização Brasileira, 2004, V.III.

HORTA, J.S.B. Direito à educação e obrigatoriedade escolar. IN: Cadernos de Pesquisa. Fundação Carlos Chagas, n.104. jul.1998. pp. 5-34.

IELGESKI, F. O olhar de Claude Lévi-Strauss sobre as ciências. Disponível em: http:// www.sbhc.org.br/resources/anais/10/1345086010_ARQUIVO_O olhardeClaudeLevi.pdf Acesso em: 8.fev.2014.

IPEA. Nota técnica. Acesso domiciliar à internet e ensino remoto durante a pandemia. Brasília: Ministério da Economia, n. 88, agosto/ 2020. Disponível em: https://www.ipea. gov.br/portal/images/stories/PDFs/nota_tecnica/200902_nt_disoc_n_88.pdf. Acesso em: 26.jun. 2021.

KONDER, L. O que é dialética. São Paulo: Brasiliense, 2008.

LAHIRE, B. Patrimónios individuais de disposições. Para uma sociologia à escala individual. In: Sociologia, problemas e práticas, n. ${ }^{\circ}$ 49, 2005, pp. 11-42. Disponível em: http://www.scielo.mec.pt/pdf/spp/n49/n49a02.pdf. Acesso em 30 jan 2016.

LDBEN. Lei de Diretrizes e Bases da Educação Nacional: Lei no 9.394 de 20.12.1996. Disponível em: http://www.planalto.gov.br/ccivil_03/Leis/L9394.htm. Acesso em 23.dez.2015.

LE GOFF. História e memória. Tradução por Bernardo Leitão[et al.]. Campinas: SP Editora da UNICAMP, 1990.

MARANGONI, G. Anos 1980, década perdida ou ganha? IPEA, Ano 9 . Edição 72, 2012. Disponível em: http://www.ipea.gov.br/desafios/index.php?option=com content\&id=2759: catid $=28 \&$ Itemid $=23$. Acesso em 20.dez. 2015 .

MARCELINO, D.A. Tempo presente e usos do passado: qual o lugar da epistemologia? In: Historia e historiografia. Ouro Preto, n. 14, abril 2014, p. 162-169. Disponível em: http:// www.historiadahistoriografia.com.br/revista/article/viewFile/658/455 Acesso em 30 jan 2016. 
MARCONI, M. de A. e LAKATOS, E.M. Fundamentos de metodologia cientifica. 7 ed. São Paulo: Atlas, 2010.

MARX, Karl. Manuscritos econômico-filosóficos e outros textos escolhidos. 3.ed. São Paulo: Abril Cultural, 1985. 407p. (Os Pensadores).

MATTOS, I. R. de. O tempo Saquarema. São Paulo: Editora Hucitec, 1987.

MEC. Manifestos dos pioneiros da Educação Nova (1932) e dos educadores 1959. Recife: Fundação Joaquim Nabuco, Editora Massangana. (Coleção Educadores), 2010.

MIGUEL, L. F. A democracia na encruzilhada. IN: : SINGER, A. [et.al.] Por que gritamos golpe? Para entender o impeachment e a crise política no Brasil. São Paulo: Boitempo, 2016. pp. 31-38.

MINAYO, M.C.de S. O desafio do conhecimento: pesquisa qualitativa em saúde. 3 ed. Rio de Janeiro: Abrasco, 1996.

MONTALVÃO, Sérgio. Liberdade de ensino versus totalitarismo: a semântica política dos substitutivos de Carlos Lacerda durante a tramitação da Lei de Diretrizes e Bases (19581959).IN: Revista de História. São Paulo, no 169, p. 293-322, jul/dez 2013. Disponível em: http://www.scielo.br/pdf/rh/n169/0034-8309-rh-169-00293.pdf. Acesso em 07.dez.2017.

NEVES, Lucia M. W. Educação: um caminhar para o mesmo lugar. IN: $O$ desmonte $d a$ nação: balanço do governo FHC. Rio de Janeiro: Vozes, 1999. p 133- 152.

. (org.) A nova pedagogia da hegemonia. Estratégias do capital para educar o consenso. São Paulo: Xamã, 2005.

NOGUEIRA, M.A. Gramsci desembalsamado: em torno dos abusos do conceito de sociedade civil. In: Educação em foco. Revista de Educação. Juiz de Fora: UFJF, v.5, n.2, set/fev - $2000 / 2001$, p.115 - 130.

NUNES, Clarisse. Anísio Teixeira: a poesia da ação. São Paulo: EDUSF, 2000.

OLIVEIRA, M. M. O articulista Florestan: ciência e política como base de uma pedagogia socialista. TESE. (Pós-Graduação em Educação) - Universidade Federal Fluminense; Orientador: Giovanni Semeraro; 2006.

. Florestan Fernandes. Recife: Fundação Joaquim Nabuco, Editora Massangana. (Coleção Educadores), 2010. 
OLIVEIRA, Marcos Aurélio Guedes de Oliveira (org.). O Comintern e a Aliança Nacional Libertadora. Recife, Edições Bagaço, 1996.

OTRANTO, C. R. A nova LDB da Educação Nacional: seu trâmite no Congresso e as principais propostas de mudança. Disponível em $<$ http://paginas.terra.com.br/educacao/ celiaotranto/pasta1/trabalho3..htm>. Acesso em: 16.abr. 2007.

PASINATO, D. A concepção de público no Manifesto de 1959. IN: Anais Eletrônicos do II Congresso Internacional de História Regional (2013). Disponível em: http:// www.upf.br/ historiaregional/index.php ?...gid... Acesso em: 08 jul. 2014.

PILETTI, Nelson. Estrutura e Funcionamento do Ensino Fundamental.26aEd. São Paulo: Ática, 2002.

PINHEIRO, M.F. O público e o privado na educação: um conflito fora de moda? IN: FÁVERO, O. (org.). A educação nas constituintes brasileiras 1823-1988. 3a ed. Campinas,SP: Autores Associados, 2005. pp.255-292.

PNAD. Pesquisa Nacional por Amostra de Domicílios. Disponível em: https://biblioteca. ibge.gov.br/visualizacao/livros/liv94935.pdf. Acesso em 8.dez.2017.

PRADO, A. A. Notas sobre movimentos em defesa da escola pública no Brasil. IN: Movimentos instituintes em educação: políticas e práticas. Niterói: Intertexto, 2010. p.3346.

REIS, D. A. Ditadura e democracia no Brasil. Do golpe de 1964 à Constituição de 1988. Rio de Janeiro: Zahar, 2014.

RIBEIRO, M. L. História da Educação Brasileira. A Organização Escolar. Campinas, Autores Associados, 2003.

RIBEIRO, R.J. A boa política. Ensaios sobre a democracia na era da internet. São Paulo: Companhia das Letras, 2017.

ROMANELLI, O. História da educação brasileira. 28 ed. Petrópolis: Vozes, 2003.

RUA, M.G. Gestão pública municipal. Florianópolis: UFSC; CAPES: UAB, 2009.

SÁ-SILVA, J. R; ALMEIDA, C.D. de e GUINDANI, J.F. Pesquisa documental: pistas teóricas e metodológicas. In: Revista Brasileira de História \& Ciências Sociais, ano I, n. I, Julho de 2009. Disponível em: www.rbhcs.com 
SANTOS, Daniella Miranda. Memória, Igreja e Educação: Dom Azeredo Coutinho e o Seminário de Olinda como precursor dos Cursos Jurídicos no Brasil. Dissertação (Mestrado em Memória: Linguagem e Sociedade da Universidade Estadual do Sudoeste da Bahia UESB). Orientadora: Professora Dra. Ana Palmira Bittencourt Santos Casimiro; 2012.

SANTOS, R.O. Florestan Fernandes: A campanha de defesa da escola pública como um ato cívico. IN: $2^{\circ}$ CIEPG. Paraná, 2010. Disponível em: http://www.isapg.com.br/2010/ ciepg/download.php?id=168. Acesso em: 30 jul. 2014.

SANTOS, W.G. Cidadania e justiça. A política social na ordem brasileira. Rio de Janeiro: Campus, 1979.

SAVIANI, Dermeval. A nova lei da educação. LDB trajetória, limites, perspectivas. Campinas: Autores Associados, 1997.

. Escola e democracia. Teorias da educação. Curvatura da vara. Onze teses sobre educação e política. 38 ed. São Paulo: Cortez, 2006.

. Cidadania e educação. Disponível em < http:// www.adunicamp. org.br/publicacoes/revista1/saviani.htm>. Acesso em: 16 abr. 2007.

. Política e educação no Brasil: o papel do Congresso Nacional na legislação do ensino. 6 ed. Campinas, SP: Autores Associados, 2008.

SEMERARO, Giovanni. Recriar o público pela democracia popular. In: FÁVERO e SEMERARO (orgs.). Democracia e construção do público no pensamento educacional brasileiro.Petrópolis: Vozes, 2002. pp. 213-223.

SENRA, A. de O. Vinte Anos a Serviço da Educação: as lutas pela educação vistas pelo "outro lado". Disponível em: http://docplayer.com.br/64580257-Vinte-anos-a-servicoda-educacao-as-lutas-pela-educacao-vistas-pelo-outro-lado-i-a-relevancia-da-obra.html. Acesso em: 07.dez.2017.

SILVA, L. e LIMA, R. de. Jacques Le Goff: estudo de conceitos em história da educação. Disponível em: http://www.pucpr.br/eventos/educere/educere2009/anais/pdf/3122_1893. pdf. Acesso em 30.jan.2016a.

SILVA, L. R. C. da; DAMASCENO, A.D.; MARTINS, M.da C. R.; SOBRAL, K.M.; FARIAS, I.M.S de. Pesquisa documental: alternativa investigativa na formação docente. Disponível em: http://www.pucpr.br/eventos/educere/educere2009/anais/pdf/3124_1712. pdf. Acesso em 30.jan.2016b. 
SGUISSARDI, V. (org.) Educação superior: velhos e novos desafios. São Paulo: Xamã, 2000. pp.103-130.

SILVA, A. F. Florestan Fernandes e a educação brasileira nas décadas de 1950 e 1960. IN: FÁVERO, Osmar (org.). Democracia e educação em Florestan Fernandes. Campinas: Autores Associados e Niterói: EDUFF, 2005.

SILVA, Artur de Morais. Voluntariado e responsabilidade social, direitos da cidadania e serviços públicos: as políticas sociais de Estado no Brasil pós 1995. In Educação se faz (na) politica. Nadjjar, Jorge e Camargo, Sueli (Orgs.). Série Práxis Educativas. Niterói: EdUFF, 2006, p 169-198.

SINGER, P. Poder, política e educação. IN: Revista Brasileira de Educação. Conferência de abertura da XVIII Reunião Anual da ANPEd. Caxambu, out. 1995. Disponível em: http://www.ia.ufrrj.br/ppgea/conteudo/T2-1SF/Sandra/Poder,\%20pol\%EDtica\%20e\%20 educa\%E7\%E3o.pdf. Acesso em: 8.dez.2017.

SMITH, A. A Riqueza das nações: investigação sobre sua natureza e suas causas. São Paulo: Abril Cultural, 1983, v. II.

SPOSATI, A. et.all. Assistência na trajetória das políticas sociais brasileiras. Uma questão em análise. 7 ed. São Paulo: Cortez, 1998.

SOUZA, Celina. Políticas públicas: uma revisão da literatura. Sociologias. Ano 8, n.16, jul/dez 2006. pp. 20-45.

SOUZA, Jessé. Os batalhadores brasileiros: nova classe média ou nova classe trabalhadora? Belo Horizonte: Editora UFMG, 2010.

. A ralé brasileira: quem é e como vive. Belo Horizonte: UFMG, 2011.

- A construção social da subcidadania. Para uma sociologia política da modernidade periférica. 2 ed. Belo Horizonte: Editora UFMG, 2012.

. A radiografia do golpe. Entenda como e por que você foi enganado. Rio de Janeiro: LeYa, 2016.

. A elite do atraso: da escravidão à Lava Jato. Rio de Janeiro: LeYa, 2017.

SOUZA, D.B e FARIA, L.C.M. O processo de construção da educação municipal pós LDB 9.394/96: políticas de financiamento e gestão. IN: SOUZA, D.B e FARIA, L.C.M. (orgs). Desafios da educação municipal. Rio de Janeiro: DPeA, 2003. p. 45 - 86. 
TEIXEIRA, Anísio. Educação progressiva. Uma introdução à filosofia da educação. 2 ed. São Paulo: Companhia Editora Nacional, 1934.

.Educação para a democracia. Introdução à administração educacional. 3 ed. Rio de Janeiro: Editora UFRJ, 2007 (coleção Anísio Teixeira; v. 4; 1936).

. A educação e a crise brasileira. Rio de Janeiro: Editora UFRJ, 2005 (coleção Anísio Teixeira; v. 5; 1956).

. Educação não é privilégio. 6 ed. Rio de Janeiro: Editora UFRJ, 1994 (1957).

. Educação é um direito. 4 ed. Rio de Janeiro: Editora UFRJ (coleção Anísio Teixeira; v.7; 1968).

THIRY-CHERQUES, H. R. Pierre Bourdieu: a teoria na prática. In: RAP. Rio de Janeiro 40(1):27-55, Jan./Fev. 2006. Disponível em: http://www.scielo.br/pdf/rap/v40n1/v40n1a03. pdf. Acesso em 30.jan.2016.

TOSI, G. Algumas questões acerca da história dos direitos humanos. IN: Contemporaneidade e educação.Revista semanal de ciências sociais e educação. Ano V, n.8. Rio de Janeiro: IEC, 2000. p.35 - 55 .

VALLE, I.R. A obra do sociólogo Pierre Bourdieu: uma irradiação incontestável. IN: Educação e Pesquisa. v. 33, n.1. São Paulo, jan-abr.2007.p.117-134.

VILLELA, Viviane Merlim Moraes. As representações sociais da disciplina entre professores das escolas públicas e privadas de São Gonçalo/R.J. Monografia (Graduação em Pedagogia) - Universidade Federal Fluminense; Orientadora: Adonia Antunes Prado; 2000 .

A formação de educadores / intelectuais no curso de pedagogia da Faculdade de Educação da Universidade Federal Fluminense. Monografia (Aperfeiçoamento/Especialização em Educação Superior no Brasil) - Universidade Federal Fluminense; Orientador: Giovanni Semeraro; 2003.

O conceito de cidadania na definição de políticas públicas educacionais. Debates e impasses na elaboração do Plano Municipal de Educação de Niterói/ RJ. Dissertação (Pós-Graduação em Educação) - Universidade Federal Fluminense; Orientadora: Adonia Antunes Prado; 2008. 
WACQUANT, L. Esclarecer o habitus. Educação\& Linguagem. ano 10, n 16, jul.-dez. 2007, p. 63-71.

WOOD, E.M. Democracia contra capitalismo. A renovação do materialismo histórico. Tradução por Paulo Cezar Castanheira. São Paulo: Boitempo, 1995. 


\section{BIBLIOGRAFIA}

OBRAS CONSULTADAS PARA COMPOSIÇÃO DO ESTADO DA ARTE DO TEMA DE PESQUISA

$\checkmark$ Direito à educação nas Constituições Federais e Leis de Diretrizes e Bases foram encontrados 13 artigos, todos acessados em 10 de dezembro de 2015:

BOMENY, H. Moral, bons costumes e limites à participação cívica. Desigualdade \& Diversidade - Revista de Ciências Sociais da PUC-Rio, no 9, ago/dez, 2011, pp. 181192. Disponível em: http://desigualdadediversidade.soc.puc-rio.br/media/17\%20DeD\%20 _\%20n.\%209\%20-\%20artigo\%2012\%20-\%20JALLES.pdf

BOMENY, H. Novos talentos, vícios antigos. Os renovadores e a política educacional. Estudos históricos. Rio de Janeiro, v. 6, n.11, 1993, p. 24-39. Disponível em: http:// bibliotecadigital.fgv.br/ojs/index.php/reh/article/view/1955/1094

BRAGA, V.L.F. Intelectuais escolanovistas e a construção do estado nacional. Disponível em: http://www.ufjf.br/virtu/files/2010/05/artigo-7a11.pdf

HUMENHUK, H. Federalismo e educação na Constituição de 1988. Disponível em:http:// egov.ufsc.br/portal/sites/default/files/anexos/16597-16598-1-PB.pdf

KULESZA, W. A. História da educação popular no Brasil: uma interpretação. Disponível em: http://www.sbhe.org.br/novo/congressos/cbhe1/anais/166_wojciech.pdf

LIMA, A. B. Manifesto dos pioneiros da educação (1932): leituras de seus 80 anos. Disponível em: http://www.histedbr.fe.unicamp.br/acer_histedbr/seminario/seminario9/ PDFs/2.20.pdf

MARTINS, M.A.C. A participação católica brasileira na constituição da modernidade educacional nos anos de 1920. Disponível em: http://sbhe.org.br/novo/congressos/cbhe3/ Documentos/Individ/Eixo3/234.pdf

MEINERZ, C.B. e CAREGNATO, C.E. Educação e processos de escolarização no Brasil: perspectivas históricas e desafios contemporâneos Ciências \& Letras, Porto Alegre, n. 49, p. 43-62, jan./jun. 2011. Disponível em: <http://seer1.fapa.com.br/index.php/arquivos>

MONTALVÃO, S. Educação e democracia no Brasil: reflexões a partir da Lei de Diretrizes e Bases de 1961. Disponível em: http://www.historiapolitica.com/datos/biblioteca/ montalvao.pdf 
MOTTA, I.D. e KOEHLER, R.O.L. A Constituição Federal de 1988 e o direito à educação. Revista Jurídica Cesumar - Mestrado, v. 12, n. 1, p.49-74, jan./jun. 2012. Disponível em: http://periodicos.unicesumar.edu.br/index.php/revjuridica/article/view/2268

VIEIRA, E. Política e bases do direito educacional. Cadernos Cedes, ano XXI, $\mathrm{n}^{\circ}$ 55, novembro/2001. Disponível em: http://www.scielo.br/pdf/ccedes/v21n55/5538

WINCKLER, C. R. O contexto das velhas e (não tão) novas reformas educacionais no Brasil . Disponível em: http://revistas.fee.tche.br/index.php/indicadores/article/view/694/939

XAVIER, M. do C. Manifesto dos Pioneiros da Educação: um legado educacional em debate. Disponível em: http://www.rbhe.sbhe.org.br/index.php/rbhe/article/view/189/197

Direito à educação no Brasil de 1930 à 1996 - foram encontrados 30 textos, todos consultados nos dias 10 e 11 de dezembro de 2015:

ARAUJO, Gilda Cardoso de. Estado, política educacional e direito à educação no Brasil: "o problema maior é o de estudar”. Educ. rev. [online]. 2011, n.39, pp. 279-292. Disponível em: http://www.scielo.br/ scielo.php?script=sci_pdf\&pid=S0104-40602011000100018\&lng= pt\&nrm=iso\&tlng=pt

ARELARO, Lisete Regina Gomes; JACOMINI, Márcia Aparecida e KLEIN, Sylvie Bonifácio. O ensino fundamental de nove anos e o direito à educação. Educ. Pesqui. [online]. v. 37, n.1, 220p. 35-51, jan./abr. 2011. Disponível em:http://www.scielo.br/scielo. php?script $=$ sci_pdf\&pid=S1517-97022011000100003\&lng=pt\&nrm= iso\&tlng=pt

BARBOSA, L.M.R. Estado e educação em Martinho Lutero: a origem do direito à educação. Disponível em: http://www.scielo.br/pdf/cp/v41n144/v41n144a12.p

CANDAU, V.M.F. Direito à educação, diversidade e educação em direitos humanos. Educ. Soc., Campinas, v. 33, n. 120, p. 715-726, jul.-set. 2012. Disponível em: http://www.scielo. br/pdf/es/v33n120/04.pdf

CARVALHO, J.P.F. A origem do Manifesto dos educadores mais uma vez convocados, de 1959, na correspondência de alguns de seus signatários. Disponível em: http://www.sbhe. org.br/novo/congressos/cbhe5/pdf/827.pdf

CERQUEIRA, A. G. A trajetória da $L D B$ : um olhar crítico frente à realidade brasileira. Disponível em: http://www.uesc.br/eventos/cicloshistoricos/anais/aliana_georgia_ carvalho_cerqueira 
CONSED. A discussão nacional sobre a nova Lei de Diretrizes e Bases da Educação: contribuição do conselho nacional de secretários de educação. Em Aberto, Brasília, ano 7, n. 38, abr./jun. 1988. Disponível em: http://emaberto.inep.gov.br/index.php/emaberto/ article/viewFile/657/584

CURY, C.R.J. A constituição de Weimar: Um capítulo para a educação. Educ. Soc. v.19, n. 63, Campinas. Ago. 1998. Disponível em: http://www.scielo.br/scielo.php?script=sci_ arttext\&pid $=$ S0101-73301998000200006\&lng $=$ pt\&nrm $=$ iso

FERRARO, A. R. Direito à Educação no Brasil e dívida educacional: e se o povo cobrasse? Educação e Pesquisa, São Paulo, v.34, n.2, p. 273-289, maio/ago. 2008. Disponível em: http://www.scielo.br/pdf/ep/v34n2/05.pdf

FLACH, S. de F. O direito à educação e sua relação com a ampliação da escolaridade obrigatória no Brasil. Ensaio: aval. pol. públ. Educ., Rio de Janeiro, v. 17, n. 64, p. 495-520, jul./set. 2009. Disponível em: http://www.scielo.br/scielo.php?script=sci_pdf\&pid=S0104$40362009000300006 \& \operatorname{lng}=$ pt\&nrm=iso\&tlng $=$ pt

FREITAS, D. N. T. de. Ação reguladora da União e qualidade do ensino obrigatório (Brasil 1988-2007). Disponível em: http://www.scielo.br/readcube/epdf.php?doi=10.1590/ S0104-40602008000100004\&pid=S0104-40602008000100004\&pdf_path=er/n31/ n31a04.pdf\&lang=pt

GENTILI, P. O direito à educação e as dinâmicas de exclusão na América Latina. Educ. Soc., Campinas, vol. 30, n. 109, p. 1059-1079, set./dez. 2009. Disponível em:http://www. scielo.br/pdf/es/v30n109/v30n109a07.pdf

MACHADO, M.C.G. O debate acerca do ensino público nas discussões sobre a Lei de Diretrizes e Bases da Educação Nacional (1961). Educação e Fronteiras On-Line, Dourados/ MS, v.2, n.4, p.62-79, jan/abr. 2012. Disponível em: http://www.periodicos.ufgd.edu.br/ index.php/educacao/article/viewFile/1558/pdf_111

McCOWAN, T. O direito humano à aprendizagem e a aprendizagem dos direitos humanos. Educ. rev. no.55 Curitiba jan./mar. 2015. Disponível em: http://www.scielo.br/scielo. php?script $=$ sci_arttext\&pid $=\mathrm{S} 0104-40602015000100025 \& \operatorname{lng}=\mathrm{pt} \& \mathrm{nrm}=\mathrm{iso}$

MÉLO, C. S. Estado e educação pela imprensa: o debate de Florestan Fernandes ante a Lei de Diretrizes e Bases da Educação Nacional (1959 - 1961). DISSERTAÇÃO. (Pósgraduação em Educação) Universidade Estadual de Maringá. Orientadora:Maria Cristina Gomes Machado. 2009. Disponível em: http://www.ppe.uem.br/dissertacoes/2009_ cristiane_melo.pdf 
MONTALVÃO, S. A LDB de 1961: apontamentos para uma história política da educação. Disponívelem:http://cpdoc.fgv.br/mosaico/?q=printpdf/artigo/ldb-de-1961-apontamentospara-uma-hist $\% \mathrm{C} 3 \% \mathrm{~B} 3$ ria-pol\%C3\%ADtica-da-educa $\% \mathrm{C3} \% \mathrm{~A} 7 \% \mathrm{C} 3 \% \mathrm{~A} 3 \mathrm{o}$

MONTEIRO, A. dos R. O pão do direito à educação... Educ. Soc., Campinas, vol. 24, n. 84, p. 763-789, setembro 2003. Disponível em: http://www.scielo.br/pdf/es/v24n84/ a03v2484.pdf

MONTEIRO, R. A. C. Lei de Diretrizes e Bases da Educação Nacional: o porquê e seu contexto histórico. Revista Eletrônica de Educação, v.5, n.2, nov.2011. Disponível em: Ahttp://www.reveduc.ufscar.br/index.php/reveduc/article/viewFile/225/142

NASCIMENTO, M.N.M. Educação e nacional-desenvolvimentismo no Brasil. Disponível em: http://www.histedbr.fe.unicamp.br/navegando/periodo_nacional_desenvolvimentista_ intro.html

OLIVEIRA, D. A. Nova gestão pública e governos democrático-populares: contradições entre a busca da eficiência e a ampliação do direito à educação. Educ. Soc., Campinas, v. 36, no . 132, p. 625-646, jul.-set., 2015. Disponível em:http://www.scielo.br/pdf/es/ v36n132/1678-4626-es-36-132-00625.pdf

OLIVEIRA, M. M. de. Elementos para a constituição de uma pedagogia socialista a partir dos escritos "jornalísticos” de Florestan Fernandes. Disponível em: http://www.histedbr. fe.unicamp.br/ acer_histedbr/seminario/seminario7/TRABALHOS/M/Marcos\%20 Marques\%20de\%20Oliveira.pdf

OLIVEIRA, R.P. de. Qualidade do ensino: uma nova dimensão da luta pelo direito à educação. Rev. Bras. Educ. n. 28 Rio de Janeiro jan./abr. 2005. Disponível em: http:// www.scielo.br/scielo.php? script $=$ sci_arttext\&pid $=$ S1413-24782005000100002\&lng $=$ pt\& nrm $=$ iso

SANFELICE, J.L. O Manifesto dos educadores (1959) à luz da história. Educ. Soc., Campinas, vol. 28, n. 99, p. 542-557, maio/ago. 2007. Disponível em: http://www.scielo. br/pdf/es/v28n99/a13v2899.pdf

SANTOS, I.S.F. Brasil, 1930 - 1961: escola nova, LDB e disputa entre escola pública e escola privada. Revista HISTEDBR On-line, Campinas, n.22, p.131-149, jun. 2006. Disponível em: http://www.histedbr.fe.unicamp.br/revista/edicoes/22/art10_22.pdf 
SAVIANI, D. Vicissitudes e perspectivas do direito à educação no Brasil: abordagem histórica e situação atual. Educ. Soc., Campinas, v. 34, n. 124, p. 743-760, jul.-set. 2013. Disponível em: http://www.scielo.br/pdf/es/v34n124/06.pdf

SCUARCIALUPI, L. O que é a Lei de Diretrizes e Bases, quais os principais ganhos para os cidadãos e a história até sua aprovação em 1996. Disponível em: http:// educarparacrescer.abril.com.br/politica-publica/lei-diretrizes-bases-349321.shtml

SILVA, R. L. da. O público e o privado na educação brasileira: do debate intelectual ao texto legal. DISSERTAÇÃO. (Pós-graduação em Educação) Universidade Federal do Rio de Janeiro. Orientadora: Libânea

Nacif Xavier. 2008. Disponível em: http://www.educacao.ufrj.br/ppge/dissertacoes/ dissertacao_rosane_lima_da_silva_pinto.pdf

SILVEIRA, A.D. Conflitos e consensos na exigibilidade judicial do direito à educação básica. Educ. Soc., Campinas, v. 34, n. 123, p. 371-387, abr.-jun. 2013. Disponível em: http://www.scielo.br/pdf/es/v34n123/03.pdf

XIMENES, S.B. O conteúdo jurídico do princípio constitucional da garantia de padrão de qualidade do ensino: uma contribuição desde a teoria dos direitos fundamentais. Educ. Soc., Campinas, v. 35, no. 129, p. 1027-1051, out.-dez., 2014. Disponível em: http://www. scielo.br/pdf/es/v35n129/0101-7330-es-35-129-01027.pdf

XIMENES, S.B. Responsabilidade educacional: concepções diferentes e riscos iminentes ao direito à educação. Educ. Soc., Campinas, v. 33, n. 119, p. 353-377, abr.-jun. 2012. Disponível em: http://www.scielo.br/pdf/es/v33n119/a03v33n119.pdf

$\checkmark$ Caminhos e descaminhos do direito à educação no campo político brasileiro: Disputas ideológicas nas constituições federais e leis de diretrizes e bases da educação nacional (título desta tese) - apenas 1 texto, consultado no dia 11 de dezembro de 2015:

SANTOS, K. S. Políticas públicas educacionais no Brasil: tecendo fios. Disponível em: http://www.anpae.org.br /simposio2011/cdrom2011/PDFs/trabalhosCompletos/ comunicacoesRelatos/0271.pdf 


\section{Viviane Merlim Moraes}

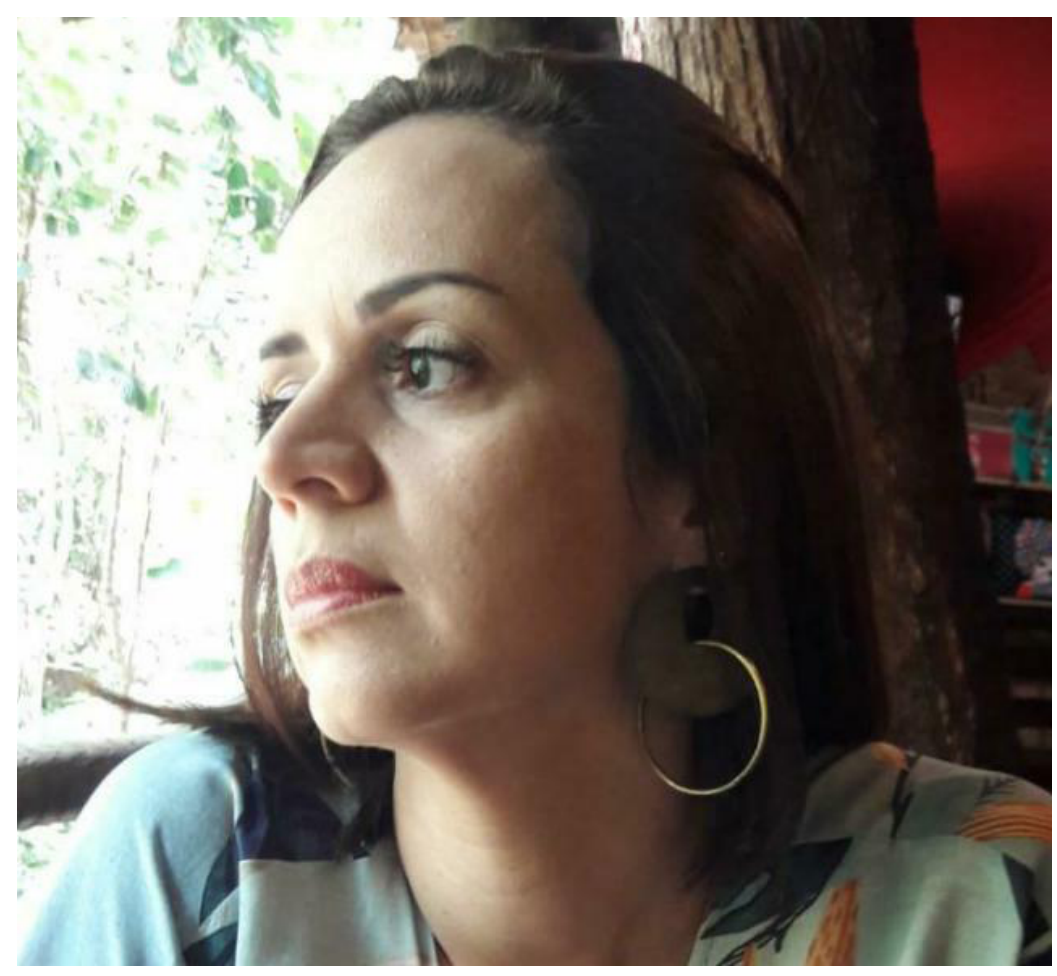

Possui graduação em Pedagogia (2000) e especialização em Educação Superior pela Universidade Federal Fluminense (2002). Concluiu em 2008 o curso de mestrado em Educação, e em janeiro de 2018 o curso de doutorado em Educação, ambos na Universidade já citada. Atuou na rede pública estadual do Rio de Janeiro como professora dos anos iniciais do ensino fundamental e do Curso Normal (2000-2004), na Secretaria de Educação de São Gonçalo /RJ, como orientadora educacional (2004-2008), e na Fundação Municipal de Educação de Niterói/RJ, como orientadora educacional/pedagoga e professora dos anos iniciais do ensino fundamental; exerceu os cargos de superintendente de desenvolvimento de ensino (2013 e 2014) e de diretora geral da Escola Municipal Professor André Trouche (2008 - 2009) e da Escola Municipal Professor Dario de Souza Castello (2015-2020). Atuou na Marinha do Brasil, no quadro técnico, como Pedagoga RM2 (entre 2010 e janeiro/2012). No ensino superior, atuou como professora do curso de graduação em Pedagogia da UniLaSalle (2012-2014); como professora visitante do ISAT, atuou no curso de graduação em Pedagogia e nos cursos de pós-graduação lato sensu (2008-2012). No Centro de Estudos de Pessoal e Forte Duque de Caxias, atuou como professora do curso de Psicopedagogia Escolar, nos anos de 2012, 2014 e 2016. Atualmente é professora adjunta no Departamento de Sociedade, Educação e Conhecimento da Faculdade de Educação da UFF, na área de conhecimento Organização do Trabalho na Escola, em regime de dedicação exclusiva. É pesquisadora do GRUPPE - Grupo de Políticas Públicas de Educação e do NUARTTE - Núcleo de Articulação do Trabalho Educativo. Tem experiência na área da educação, com ênfase em orientação, supervisão e administração/gestão educacional. 


\section{$A R C O$}

(f) @arcoeditores
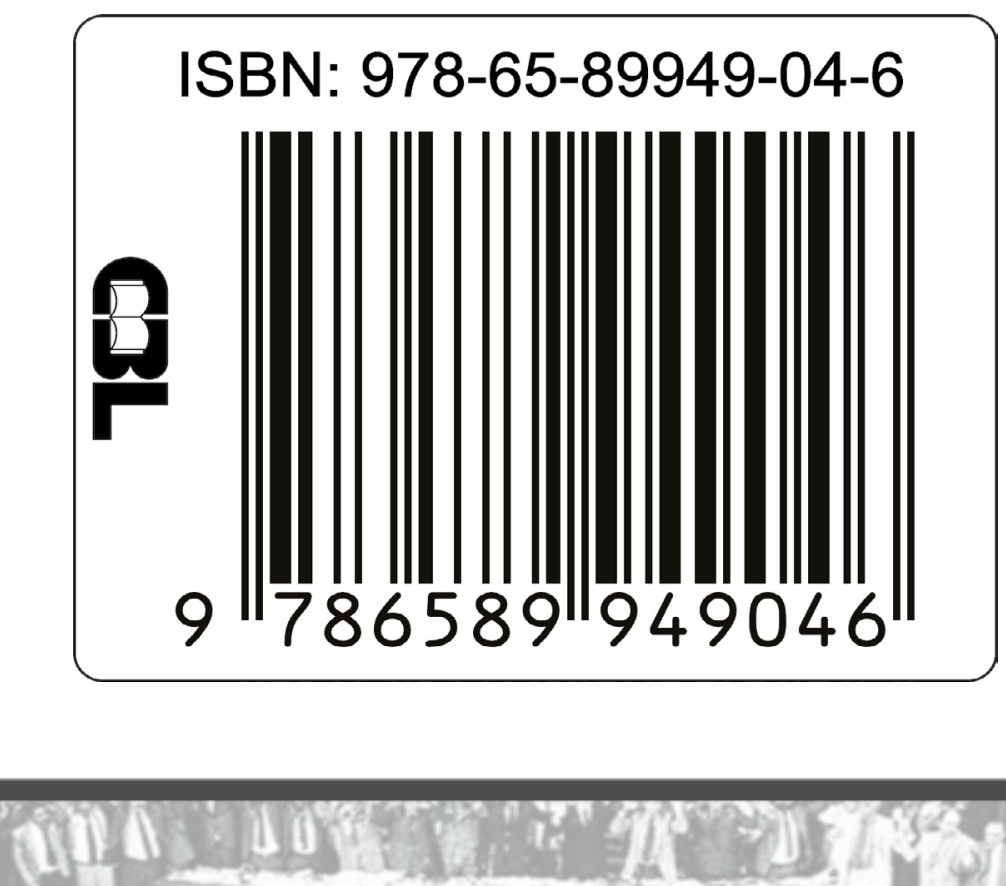